CINARA PALHARES

A TUTELA DO CONSUMIDOR EXCESSIVAMENTE ENDIVIDADO COMO FORMA DE PRESERVAÇÃO DOS DIREITOS FUNDAMENTAIS DA PESSOA HUMANA

DISSERTAÇÃO DE MESTRADO

ORIENTADOR: PROFESSOR CLAUDIO LUIZ BUENO DE GODOY

FACULDADE DE DIREITO DA UNIVERSIDADE DE SÃO PAULO São Paulo

2010 
UNIVERSIDADE DE SÃO PAULO - USP

FACULDADE DE DIREITO

\section{A TUTELA DO CONSUMIDOR EXCESSIVAMENTE ENDIVIDADO COMO FORMA DE PRESERVAÇÃO DOS DIREITOS FUNDAMENTAIS DA PESSOA HUMANA}

Dissertação apresentada à Faculdade de Direito da Universidade de São Paulo como requisito para a obtenção do título de Mestre em Direito Civil, sob a orientação do Professor Cláudio Luiz Bueno de Godoy.

São Paulo

2010 
Dedico esse trabalho a meu mestre, o Professor Antonio Junqueira de Azevedo, que deixou a todos saudosos de sua genialidade, simpatia e humor surpreendente.

Suas lições marcaram a minha vida e a de todas as pessoas que tiveram o privilégio de receber os seus ensinamentos $e$ especialmente a sua orientação.

Obrigado por ter me acolhido na comunidade cientifica da Universidade de São Paulo, por ter acreditado nas idéias defendidas neste trabalho e por ter confiado na minha capacidade e dedicação. 
Agradeço ao meu pai, Joaquim Ernesto Palhares, que sempre acreditou na minha capacidade e que tornou tudo isso possível.

À minha família, por todo apoio e pela compreensão das ausências, especialmente à minha mãe e ao meu marido que, além disso, me auxiliaram com a troca de idéias ou com a revisão do trabalho.

Ao Professor Cláudio Luiz Bueno de Godoy, por ter me aceitado como sua orientanda, mesmo sabendo das dificuldades que encontraria para concluir a orientação num curto espaço de tempo, e, mesmo assim, cumpriu nobremente esse mister, contribuindo de forma decisiva para os aspectos mais relevantes desse trabalho. $O$ seu vasto saber jurídico e a sua rapidez de pensamento certamente foram os fatores que tornaram possível essa difícil missão.

Ao Professor João Alberto Shützer Del Nero, meu supervisor de estágio em docência, pelos conselhos e ensinamentos transmitidos que muito contribuíram para o enriquecimento das idéias aqui desenvolvidas, em razão do contraponto gentilmente efetuado.

Ao Professor Renan Lotufo, com quem formei a base do meu conhecimento em Direito Civil, e a quem devo o aprendizado da língua francesa, necessária para freqüentar as suas aulas na Pontifícia Universidade Católica de São Paulo.

À Universidade de São Paulo e aos gentis funcionários da sua biblioteca, por terem viabilizado a pesquisa.

A todos aqueles que contribuíram com a troca de idéias e com o empréstimo de material, especialmente Márcio Mello Casado, Francisco Marino e Luiz Philipi Cardoso. 


\section{RESUMO}

O endividamento excessivo dos indivíduos e das famílias é um fenômeno recente que tem sua origem na necessidade da economia de mercado conferir poder aquisitivo imediato a seu principal agente econômico: o consumidor. Desde o final do século XX, o crédito se tornou o motor propulsor da sociedade de consumo, de maneira que o endividamento se tornou uma situação desejada, mas que, por outro lado, apresenta riscos aos consumidores, que ficaram sujeitos ao superendividamento.

A "democratização do crédito" chegou ao Brasil apenas no século XXI, apresentando-se como a principal ameaça à integridade financeira do consumidor. $\mathrm{O}$ incentivo governamental para tornar o crédito mais acessível e a criação de novos instrumentos de crédito foram os principais fatores responsáveis pela guinada do crédito ao consumo. Contudo, a ausência de uma rede eficaz de proteção ao consumidor pode trazer graves problemas sociais e a violação de direitos fundamentais dos tomadores de crédito.

Esse cenário já se verificou em muitos países que tiveram a sua "revolução do crédito ao consumo", gerando uma multidão de superendividados passivos, que passou a viver à margem da sociedade, ocasionando um forte problema de exclusão social. Nesses países, que tem a França como exemplo, foi adotada uma lei específica para a prevenção e tratamento do sobreendividamento, reconhecendo-se que essa situação não é prejudicial apenas para o consumidor, mas também para todo o mercado de consumo, podendo dar origem a uma grave crise financeira generalizada.

No Brasil não existe uma lei específica para o tratamento das situações de sobreendividamento, de forma a proporcionar a recuperação financeira global do consumidor; contudo, o ordenamento jurídico brasileiro contém diversas normas, por meio das quais incidem os direitos fundamentais da pessoa humana, que são capazes de tutelar os direitos dos consumidores de crédito, inclusive nas situações de superendividamento.

Este trabalho pretende, num primeiro momento, demonstrar a necessidade de uma lei específica para o tratamento global da situação do consumidor superendividado, e, num segundo momento, desenvolver a tutela jurídica de lege lata para a proteção do consumidor de crédito em geral e para a solução dos casos de endividamento excessivo em que esteja ameaçado o núcleo dos direitos fundamentais decorrentes da dignidade da pessoa humana. 


\section{ABSTRACT}

The over-indebtedness of households is a recent phenomenon which has its origins in the need of market economies to confer purchasing power to its main economic agent: the consumer. Since the end of the $20^{\text {th }}$ Century, credit has become the main propeller of consumer societies, making indebtedness a desirable situation. Such a situation, though, presents risks to consumers, who became subjected to over-indebtedness.

The credit democratization has reached Brazil only in the $21^{\text {st }}$ Century, presenting itself as the main threat to the consumer's financial integrity. The governmental incentive to make credit affordable and the creation of new instruments of credit were the main factors responsible for the growth of consumer credit. However, the lack of an effective consumer protection net may bring about serious social problems and the violation of borrowers fundamental rights.

This context took place in many countries where the credit revolution has happened generating a multitude of passive over-indebted people, which are living on the margins of society, causing a serious problem of social exclusion. In these countries, as France for example, a specific law was adopted for the prevention and handling of over-indebtedness, in recognition that this situation is prejudicial not only to the consumer, but also to the whole market, being able to cause even a severe generalized financial crisis.

Brazil doesn't have a specific bankruptcy law to provide financial rehabilitation for the over-indebted consumer. However, Brazilian law has many rules through which fundamental rights are applied providing consumers judicial protection, including situations of over-indebtedness.

This essay intends, firstly, to demonstrate the necessity of a specific bankruptcy law for the global handling of over-indebtedness situations and, secondly, to develop the judicial treatment de lege lata for the protection of the consumer credit in general and for over-indebtedness situations where the core of fundamental rights is threatened. 
SUMÁRIO:

INTRODUÇÃO

\section{PARTE I - OS FUNDAMENTOS DA TUTELA DO CONSUMIDOR EXCESSIVAMENTE ENDIVIDADO}

CAPÍTULO 1 - A CULTURA DO ENDIVIDAMENTO NA SOCIEDADE DE CONSUMO PÓS-MODERNA: GÊNESE DO PROBLEMA DO ENDIVIDAMENTO

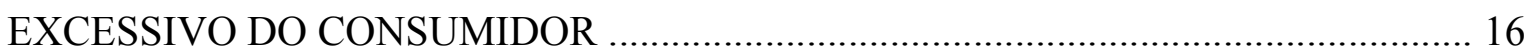

Seção 1.1 A sociedade pós-moderna e a alteração de paradigmas jurídicos ...................... 16

1.1.1 A modernidade e o paradigma do Estado Liberal ......................................... 16

1.1.2 O paradigma do Estado Social ................................................................... 19

1.1.3 Globalização: sociedade de consumo e o papel do direito social ................. 24

1.1.4 A pós-modernidade e a nova mudança de paradigma jurídico: do juiz ao caso concreto 28

Seção $1.2 \mathrm{O}$ crescimento do crédito no mercado de consumo pós-moderno 32

1.2.1 A desregulamentação do crédito, o "boom" dos cartões de crédito e a sua influência no sobreendividamento das famílias nos Estados Unidos 37 1.2.2 A desregulamentação do crédito e o surgimento do sobreendividamento na Europa 40

1.2.3 O crescimento na demanda pelo crédito: o papel da tecnologia, da publicidade e dos meios de comunicação 42

1.2.4 O empréstimo predatório 44

1.2.5 Acidentes da vida que ocasionam o sobreendividamento passivo 50

CAPÍTULO $2-\mathrm{O}$ PROBLEMA DO ENDIVIDAMENTO EXCESSIVO NA REALIDADE SÓCIO-ECONÔMICA BRASILEIRA …................................................... 53

Seção 2.1 O crescimento da demanda pelo crédito no Brasil ............................................. 54

Seção 2.2 A situação do endividamento no Brasil ............................................................... 60

Seção $2.3 \mathrm{O}$ crédito consignado no pagamento de salários e aposentadorias ..................... 64

Seção 2.4 Evolução das normas que regem a concessão do crédito ao consumo e alterações

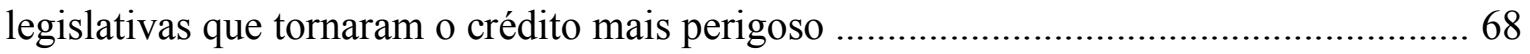

Seção 2.5 A insuficiência do argumento utilitarista ......................................................... 79 
Seção 2.6 - A oportunidade de uma lei específica para tratamento e prevenção das situações de endividamento excessivo do consumidor no Brasil

CAPÍtUlO 3 - MODELOS DE TUTELA DO ENDIVIDAMENTO EXCESSIVO A PARTIR DO SEU FUNDAMENTO

Seção 3.1. Os modelos de tutela existentes no direito comparado 92

3.1.1 Modelo tradicional: insolvência civil como forma de tutelar o direito dos credores e como resposta a desvios de conduta do devedor 94 3.1.2 Modelo liberal: falência pessoal como instrumento de regulação do mercado e de tutela do consumidor de crédito 96

3.1.3 Modelo social: tutela do indivíduo excessivamente endividado como forma de preservação dos direitos fundamentais da pessoa humana 100

Seção 3.2 O modelo de tutela compatível com o ordenamento jurídico brasileiro: proteção dos direitos fundamentais da pessoa humana

3.2.1 O princípio da dignidade da pessoa humana

3.2.2 O princípio da solidariedade social 116

3.2.3 A incidência dos direitos fundamentais nas relações privadas 122

\section{PARTE II - A TUTELA DO CONSUMIDOR DE CRÉDITO NO ORDENAMENTO JURÍDICO BRASILEIRO}

\section{CAPÍTULO 1 - IRRADIAÇÃO DOS VALORES SOCIAIS NOS MECANISMOS DE}

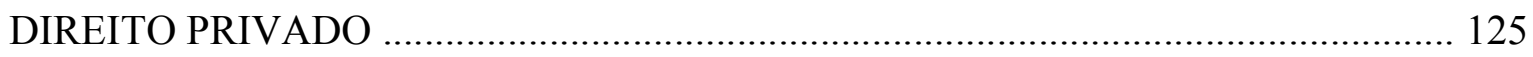

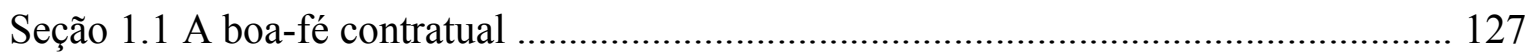

1.1.1 Imposição de deveres de conduta ........................................................... 130

a) Dever de informação e de aconselhamento ....................................... 132

b) Dever de lealdade e de cooperação ................................................... 136

c) Dever de Cuidado: cobrança de dividas, cadastros de restrição ao crédito e dever de cuidado na concessão do crédito e no desenvolvimento de contratos de longa duração

1.1.2 Limitação de direitos subjetivos e faculdades jurídicas

a) Proibição das cláusulas abusivas

b) O problema da capitalização de juros 155 
c) Vedação ao abuso de direito ............................................................ 160

d) Adimplemento substancial do contrato ............................................... 164

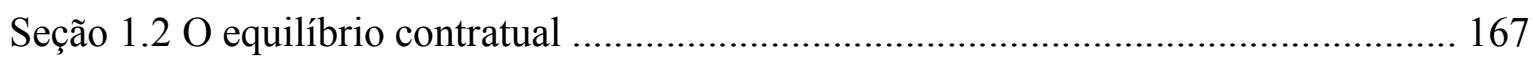

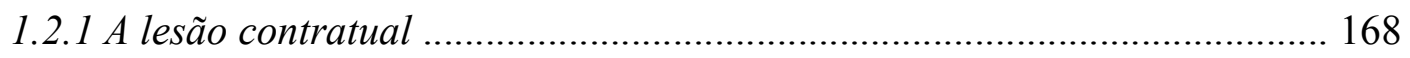

1.2.2 Onerosidade excessiva em razão de fatos supervenientes ........................... 177

Seção 1.3 A função social do contrato ………………………………………………... 186

Seção 1.4 A proteção à parte mais fraca ........................................................................ 195

CAPÍTULO 2 - TUTELA DO CONSUMIDOR EXCESSIVAMENTE ENDIVIDADO..... 202

Seção 2.1 Pressupostos para a tutela do consumidor excessivamente endividado .......... 204

2.1.1 Situação de vulnerabilidade do devedor .................................................... 204

2.1.2 Boa-fé do devedor: ausência de culpa pela alteração das condições pessoais ou pelo agravamento da sua situação financeira .............................................. 207

2.1.3 Situação de urgência social (força maior social) ....................................... 210

Seção 2.2 Responsabilidade pela má concessão do crédito .............................................. 212

Seção 2.3 Tutela do consumidor excessivamente endividado em face da alteração das circunstâncias subjetivas ......................................................................................... 220

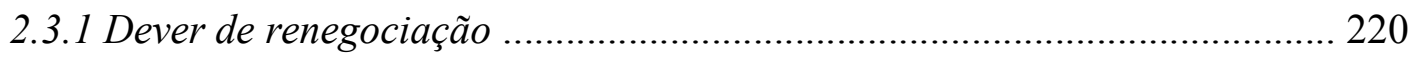

2.3.2 Adaptação do contrato em razão da alteração das circunstâncias relativas à

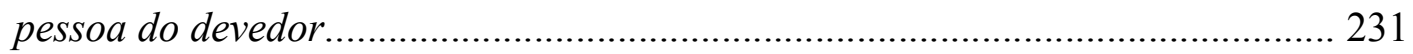

2.3.3 Resolução do contrato que se tornou excessivamente oneroso ................... 241

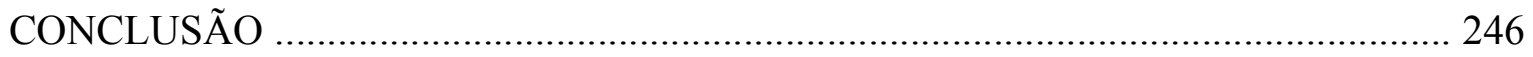

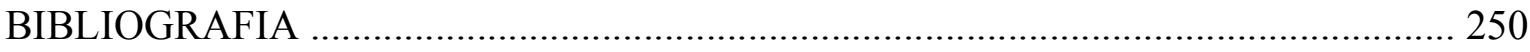




\section{INTRODUÇÃO}

O endividamento excessivo dos indivíduos e das famílias é um fenômeno característico da sociedade de consumo pós-moderna, marcada pela globalização da economia, pela massificação do consumo e pela desregulamentação das atividades privadas. A economia de mercado da atualidade depende do crédito para o fomento da produção e para a circulação das mercadorias, pois este instrumento negocial permite a obtenção dos recursos necessários para o financiamento das atividades econômicas, bem como para o acesso imediato do consumidor aos bens produzidos, tornando-o ativo e capaz de manter a economia aquecida. O crédito tornou-se, dessa forma, o motor propulsor da atividade econômica. ${ }^{1}$

O apelo ao consumo passa necessariamente pela facilitação do crédito. O que se tem observado nos países que aderem à economia de mercado é o crescimento do endividamento excessivo do consumidor, tendo em vista a sua exposição às forças produtivas, que necessitam da sua capacidade econômica para assimilar a produção, e, por esse motivo, empregam todos os artifícios possíveis, por meio da publicidade, para a indução ao consumo e ao endividamento.

O crédito é, em si, um bem essencial, pois é por meio dele que se obtém acesso aos bens necessários à sobrevivência digna (crédito ao consumo, financiamento habitacional, crédito educativo, seguro-saúde, etc.). Mas existe também a outra face desse bem essencial: assim como possibilita a inclusão do indivíduo no mercado de consumo, proporcionando o acesso aos bens essenciais, a sua utilização desmedida pode resultar no fenômeno do sobreendividamento, ${ }^{2}$ cujo efeito é exatamente o oposto, qual seja, o de gerar a exclusão social do indivíduo excessivamente endividado. ${ }^{3}$

O sobreendividamento, em geral conceituado como a incapacidade manifesta do indivíduo fazer frente ao conjunto de suas dívidas vencidas e a vencer, ${ }^{4}$ tornou-se um

\footnotetext{
${ }^{1}$ Termo usado, dentre outros, por BIHL, L. Le surendettement : apparition d'un fléau social, In : GARDAZ, M. (dir.). Le surendettement de particuliers. Paris: Anthropos, 1997. p. 3.

2 O termo "sobreendividamento" será utilizado como sinônimo de endividamento excessivo por ser a tradução mais adequada dos termos equivalentes em inglês (over-indebtedness) e em francês (surendettement), além do que, é essa a expressão utilizada no direito português. Por vezes, contudo, será utilizada a expressão "superendividamento", como expressão de linguagem para dar ênfase ao caráter manifestamente excessivo do endividamento.

${ }^{3}$ Conforme Luc Bihil, « ... le crédit présenté comme une possibilité pour tous les consommateurs d'accéder aux bienfaits de la société de consommation, se transforme alors en son inverse, c'est-à-dire en un mécanisme d'exclusion ». (BIHIL, L. Le surendettement: apparition d'un fléau social. cit. p. 7).

${ }^{4}$ Ver, por exemplo: PAISANT, Gilles. A reforma do procedimento de Tratamento do Superendividamento pela Lei de 29.07.1998 relativa à luta contra as exclusões. In: CAVALLAZZI, R. L.; MARQUES, C. L.
} 
problema crônico na atual sociedade de consumo, na qual o crédito é oferecido de forma generalizada e profissional, seja por instituições financeiras oficiais, seja por meio de financiamentos obtidos junto aos próprios fornecedores de bens ou de serviços. $\mathrm{O}$ crédito tornou-se, dessa maneira, um produto que oferece riscos aos consumidores. Primeiramente, porque a falta de informação, as altas taxas de juros e as condutas abusivas por parte dos fornecedores o tornam um produto potencialmente causador de onerosidade excessiva. Some-se a isso o fato de que as pessoas que utilizam o crédito estão sujeitas à externalidades, como o desemprego, a doença e a ruptura familiar (separação e divórcio), que afetam a sua capacidade financeira, impossibilitando-as de cumprir com os contratos firmados. Esses riscos, em geral, não são calculados pelos indivíduos, sendo apontados pelo direito comparado como causa de sobreendividamento passivo.

A tutela do sobreendividamento, apesar de não ter ainda chamado a atenção do legislador brasileiro, é uma preocupação crescente nos países desenvolvidos, nos quais têm se dedicado estudos aprofundados sobre a questão. Muitos países adotaram uma tutela legislativa completa das situações de superendividamento, tal como nos Estados Unidos, ${ }^{5}$ na França, ${ }^{6}$ na Bélgica ${ }^{7}$ e na Alemanha. ${ }^{8}$ Mas o que se tem percebido é uma preocupação geral, mesmo daqueles países que ainda não possuem uma tutela legislativa específica. Exemplo disso é o Relatório Conjunto sobre a Inclusão Social, elaborado pela Comissão das Comunidades Européias, em 12.12.2003, na cidade de Bruxelas, onde a questão do sobreendividamento é tratada como causa de exclusão social. ${ }^{9}$

(coord.). Direitos do Consumidor Endividado - Superendividamento e crédito. São Paulo: Editora Revista dos Tribunais, 2006.

${ }^{5}$ Nos EUA, o Bankruptcy Act é de 1898, e sofreu significativa reforma em 1978. A partir daí, sofreu diversas emendas, como recentemente em 2005, com o Bankruptcy Abuse Prevention and Consumer Protection Act.

${ }^{6} \mathrm{Na}$ França, o tratamento foi conferido, no âmbito do Code de la Consommation, originalmente pela Lei de 31.12.1989, sofrendo reformas em 1998 e 2003.

${ }^{7} \mathrm{Na}$ Bélgica, o tratamento é conferido pela Lei de 08 de dezembro de 2000.

${ }^{8} \mathrm{Na}$ Alemanha, o tratamento é conferido pelo Insolvency Act (Insolvenzordnung) de 5.10.1994, em vigor a partir de janeiro de 1999, e emendado diversas vezes: disponível em <http://www.bmj.bund.de/enid/2064dc4c727930724a953b4e06af2cba,8ccef75f7472636964092d0933303335 /Publications/Insolvency_Statute_19v.html>. Acesso em: 13 de outubro de 2009.

9 O projeto definitivamente aprovado está disponível no site pelo endereço < $\underline{\text { http://eur- }}$ lex.europa.eu/LexUriServ/site/pt/com/2003/com2003 0773pt01.pdf>. Acesso em: 13 de outubro de 2009. Do relatório: "A prevenção e o tratamento do endividamento excessivo são considerados um elemento essencial da luta contra a exclusão social e a pobreza na maior parte dos PAN/incl. Alguns sublinham que as consequências do sobreendividamento são graves para os indivíduos e para as famílias, na medida em que dificultam a participação na vida econômica e social (Alemanha). O sobreendividamento obsta à liberdade de circulação e dificulta a saída de situações de pobreza (Bélgica), ao ponto de engendrar a perda de habitação, fenômeno que frequentemente está na origem do aumento do número dos sem-abrigo (Portugal), forma extrema de exclusão social. Constitui uma barreira considerável à obtenção de um emprego, em razão designadamente do carácter dissuasivo para os empregadores dos procedimentos legais e administrativos de penhora sobre salários de que deverão assumir a responsabilidade (Áustria)". 
No Brasil, são ainda tímidos os estudos sobre a questão e não há uma lei específica que confira à pessoa física um mecanismo global para a sua recuperação financeira, a exemplo do que ocorre com as empresas, que atualmente dispõem da Lei 11.101/05, a qual prevê um mecanismo de recuperação judicial e extrajudicial com o intuito de evitar a falência. A única solução jurídica disponível para os não empresários é o procedimento de execução por quantia certa contra devedor insolvente, a chamada insolvência civil, prevista nos artigos 748 a 782 do Código de Processo Civil, a qual visa unicamente ao pagamento dos credores, por concurso universal. Ou seja, trata-se de procedimento previsto em benefício do credor, sem qualquer preocupação com a pessoa do devedor, com a sua recuperação financeira e conseqüente reinclusão social, nem mesmo com a manutenção de uma condição mínima de sobrevivência ou com a celeridade de um processo tão depreciativo e vexatório, como é a decretação da falência pessoal.

Trata-se, em verdade, de um paradoxo característico do capitalismo periférico: enquanto o empresário possui uma legislação que lhe permite uma recuperação financeira, e a sua reinclusão no mercado, a pessoa física, cuja dignidade, segundo os ditames constitucionais, deveria ser colocada em primeiro lugar, não possui mecanismo análogo de proteção, evidenciando-se que a legislação não evoluiu de maneira isonômica para as empresas e para as pessoas físicas. O que ocorreu, de fato, no Brasil, foi um aproveitamento do sistema norte-americano sobre falências apenas na parte do Bankruptcy Code relativa à empresa (regulamentada pelo capítulo 11), deixando-se de lado o tratamento da falência pessoal (capítulos 7 e 13).

No entanto, a ausência de uma legislação específica que regulamente de maneira global a recuperação financeira do consumidor não significa a ausência de proteção jurídica ao indivíduo que se encontre numa situação de endividamento capaz de pôr em risco o núcleo dos seus direitos fundamentais. O ordenamento jurídico brasileiro possui diversos mecanismos aptos a conferir uma tutela adequada para determinadas situações de endividamento excessivo, a começar pela Constituição da República Federativa do Brasil, repleta de valores sociais e que tem como fundamento a dignidade da pessoa humana (CF, art. $1^{\circ}$, III e 170), a solidariedade social (CF, art. $3^{\circ}$, I), a proteção do consumidor (art. 170, V), e a redução das desigualdades sociais (art. 170, VII), garantindo uma série de direitos sociais, tais como a educação, a saúde, o trabalho, a moradia, o lazer, a segurança, a previdência social, a proteção à maternidade e à infância e a assistência aos desamparados (CF, art. $6^{\circ}$ e 196 e seguintes). Mas não é só. O direito privado possui mecanismos próprios aptos a dar maior concreção à tutela do sobreendividamento, positivados pelo Código de 
Defesa do Consumidor, que impõe deveres de informação, de lealdade e de cooperação aos fornecedores de produtos e serviços e protege o consumidor contra as cláusulas e práticas abusivas, bem como contra eventos supervenientes que torne a relação contratual excessivamente onerosa (CDC, arts. $6^{\circ}$, inciso V, 39, V e Capítulo IV, da proteção contratual, especialmente os artigos 51, IV e 52). Também o Código Civil é permeado por valores sociais, contendo diversos dispositivos que asseguram a boa-fé e a função social dos contratos, bem como regras que permitem o reequilíbrio da relação contratual seja na sua formação (CC, arts. 156 e 157), seja em razão de fato superveniente que ocasione onerosidade excessiva (CC, arts. 478 a 480).

O objetivo deste trabalho será, portanto, o de buscar, a partir dos mecanismos existentes no ordenamento jurídico brasileiro, as soluções adequadas para os casos concretos, nos quais os direitos fundamentais da pessoa humana devem ser tutelados frente a uma situação de endividamento excessivo.

Para cumprir com o objetivo proposto, o trabalho será dividido em duas partes. A primeira parte será dedicada exclusivamente aos fundamentos jurídicos da tutela das situações de superendividamento e a sua contextualização no paradigma da pósmodernidade. No Capítulo 1, será abordada a evolução dos paradigmas jurídicos até a formação de uma nova dogmática do Direito das Obrigações, na qual se permitiu a penetração dos valores sociais nas relações contratuais, com a admissão das cláusulas gerais da boa-fé objetiva, da função social do contrato e da justiça contratual, que integram a moldura jurídica das declarações de vontade, e conferem os parâmetros para a interpretação e aplicação do direito nas situações concretas, permitindo a incidência dos direitos fundamentais nas relações privadas. Essa mudança de paradigmas jurídicos foi conseqüência da alteração das relações econômicas e sociais, dentre elas o surgimento da sociedade de consumo de massas, que impôs uma nova forma de contratação por meio de contratos com cláusulas predispostas, tornando-se necessário proteger a parte mais fraca nas relações de consumo. Nesta nova realidade, o crédito passou a exercer papel fundamental, e o endividamento do consumidor passou a ser uma situação desejada, já que a sociedade de consumo necessita do poder aquisitivo dos seus principais agentes econômicos para absorver a produção. A conseqüência negativa desse fenômeno foi o superendividamento do consumidor, que se apresentou como causa de exclusão social, por impedir o exercício pleno dos direitos fundamentais, além de acarretar sérios problemas para toda a coletividade, na medida em que o consumidor excessivamente endividado não cumpre com o papel exigido pelo mercado, de ser um agente fomentador da economia, 
podendo, num nível mais acentuado de endividamento em massa, ocasionar uma grave e generalizada crise econômico-financeira. Ainda neste Capítulo, será identificada a origem do problema do superendividamento, que, além de ser uma conseqüência do crescimento do mercado de crédito, conta outros fatores, tais como a desregulamentação das taxas de juros, o desenvolvimento tecnológico e dos meios de comunicação, e a forma predatória pela qual o crédito passou a ser oferecido no mercado de consumo. Por outro lado, a redução do Estado social garantista contribuiu, juntamente com os outros fatores conjunturais, para o surgimento da categoria dos "superendividados passivos", que são aqueles indivíduos atingidos por fatos adversos da vida, como o desemprego, a doença ou a ruptura familiar, e que por isso tiveram a sua capacidade econômica reduzida.

No Capítulo 2, serão analisados o crescimento do mercado de crédito e a situação do endividamento no Brasil, especialmente em relação a algumas modalidades de crédito, como o cartão de crédito e o crédito com reembolso consignado no pagamento de salários e aposentadorias, oferecidas a consumidores com elevado grau de vulnerabilidade, sendo potencialmente causadores de endividamento excessivo. Por outro lado, será demonstrado que, nos últimos anos, a legislação brasileira foi alterada, sendo retirados alguns direitos dos consumidores, de forma a tornar o crédito um produto mais perigoso. Em conclusão, será feita uma comparação entre a realidade socioeconômica dos países que dispõem de uma legislação específica a respeito da recuperação financeira do consumidor e a realidade socioeconômica brasileira, a fim de verificar se o ordenamento jurídico brasileiro carece de uma legislação semelhante.

Em seguida (Capítulo 3), serão analisados os modelos de tutela existentes no direito comparado, que foram classificados, segundo os fundamentos da tutela, em modelo tradicional, liberal e social. A partir das constatações feitas ao longo do Capítulo 1, chegarse-á a uma conclusão a respeito de qual modelo de tutela melhor se ajusta ao ordenamento jurídico brasileiro, evidenciando-se as características essenciais que uma futura lei sobre prevenção e tratamento o superendividamento deve conter. Ademais, essa análise também servirá para orientar a aplicação do direito vigente, no intuito de oferecer uma resposta jurídica adequada aos valores supremos expressamente consagrados pela Constituição da República Federativa do Brasil.

Na segunda parte, serão abordados os mecanismos de direito privado que permitem a permeação dos valores sociais e dos direitos fundamentais previstos constitucionalmente nas relações contratuais, analisando-se as conseqüências da incidência dos princípios da boa-fé objetiva, da função social do contrato e da justiça contratual na tutela do 
consumidor de crédito em geral, inclusive nas situações de superendividamento (Capítulo 1). Em seguida (Capítulo 2), o estudo dedicar-se-á à tutela do consumidor excessivamente endividado, que ocorre em dois momentos: primeiramente, considerar-se-á o sobreendividamento causado pelo descumprimento dos deveres anexos à boa-fé na fase pré-contratual e no momento da contratação, o que enseja a responsabilidade civil do credor pela má concessão do crédito (seção 2.2); posteriormente, analisar-se-á o sobreendividamento causado pela alteração das circunstâncias relativas à pessoa do devedor, que tenham tornado o contrato excessivamente oneroso, de forma a impossibilitar o seu cumprimento sem violação dos direitos fundamentais do devedor (seção 2.3). Mas antes, para atender ao paradigma do caso concreto, serão estabelecidos pressupostos para identificação das situações efetivamente merecedoras de uma tutela especial à luz do princípio da proteção da parte mais fraca nas relações contratuais, atentando-se para as situações em que o núcleo dos direitos fundamentais decorrentes do princípio da dignidade da pessoa humana corra grave risco de violação (seção 2.1). 


\section{PARTE I - OS FUNDAMENTOS DA TUTELA DO CONSUMIDOR EXCESSIVAMENTE ENDIVIDADO}

\section{CAPÍTULO 1 - A CULTURA DO ENDIVIDAMENTO NA SOCIEDADE DE CONSUMO PÓS-MODERNA: GÊNESE DO PROBLEMA DO ENDIVIDAMENTO EXCESSIVO}

\section{Seção 1.1 - A sociedade pós-moderna e a alteração de paradigmas jurídicos}

A compreensão da evolução histórica das instituições sociais, sobretudo a partir da ruptura com o modelo do Estado Absoluto, bem como da influência dessas transformações nos paradigmas jurídicos, são de fundamental importância para o estabelecimento das premissas contemporâneas que regem a construção e a interpretação do direito.

Com relação ao nosso objeto de estudo, importa saber em que medida a alteração do paradigma jurídico estabelece uma nova disciplina para a tutela da parte mais fraca numa relação contratual, especialmente quando essa parte se encontre numa situação de endividamento excessivo. Ademais, importa saber de que maneira a nova configuração da sociedade contemporânea, caracterizada pela economia de mercado globalizada e de consumo de massas, interfere no surgimento e no agravamento das situações de endividamento excessivo, e, conseqüentemente, das patologias sócio-jurídicas dele decorrentes.

Para isso será analisada, ainda que brevemente, a evolução dos paradigmas jurídicos da era moderna, partindo da formação da ciência jurídica do século XIX, passando pela crise do modelo do Estado Liberal e pela formação do Estado Social, chegando, finalmente, ao paradigma da globalização e seus efeitos no campo do direito. Essa análise facilitará a compreensão da nova dogmática contratual contemporânea e da tutela que se entende possível em matéria de endividamento excessivo do consumidor.

\subsubsection{A modernidade e o paradigma do Estado Liberal}

A modernidade é o período histórico que se caracteriza, no plano político, pela passagem do Estado Absoluto para o Estado Liberal, com a ascensão da burguesia e a queda dos monarcas; no plano filosófico, pelo surgimento das concepções racionalistas e 
iluministas, em contraposição às concepções teológicas e outras ligadas à natureza; no plano econômico, pela consolidação do modelo liberal, que se baseava na confiança de que a atuação livre do mercado seria capaz de promover a justiça e a igualdade social (laissezfaire), ${ }^{10}$ e na defesa da propriedade privada e da economia de mercado, baseada na livre iniciativa e na livre competição. ${ }^{11}$

A ascensão da burguesia fez surgir a necessidade de reação ao ancien régime, ${ }^{12}$ urgindo a proteção dos interesses mercantis e a formação de uma racionalidade capaz de pôr fim ao poder divino dos monarcas. Como resultado desse processo, chamado pelos filósofos de movimento da Ilustração, ocorreu a separação entre o público e o privado, de maneira que a interferência do Estado nas atividades econômicas (tipicamente privadas) e na esfera de liberdade individual passou a ser repudiada. Foi assim que, no plano jurídico, foram reconhecidos os primeiros direitos fundamentais do homem, os chamados "direitos de liberdade", que inicialmente objetivaram a proteção do indivíduo, da sua propriedade e das relações de troca (o contrato) contra as arbitrariedades do Estado Absoluto. ${ }^{13}$

\footnotetext{
${ }^{10}$ Segundo Sérgio Paulo Rouanet, "de um modo geral, os economistas setecentistas achavam que para se chegar à autonomia, na acepção acima [com uma ordem de igualdade relativa em que, segundo Rousseau, 'ninguém fosse tão pobre que precisasse vender-se nem tão rico que pudesse comprar os outros'], era necessário partir da autonomia na acepção de liberdade para os agentes. Era um caminho individualista e antiestatizante. Foi o caso dos fisocratas, que defendiam a ausência de toda regulamentação governamental a fórmula do laissez faire foi uma invenção do fisiocrata Quesnay (ou de Gournay, outro fisiocrata)". Contudo, esclarece que outros autores, como é o caso de Adam Smith, defendiam soluções não tão individualistas, entendendo possível a intervenção do Estado para mitigar algumas desigualdades sociais. (ROUANET, S. P. Mal-estar na Modernidade. $2^{\text {a }}$ ed. São Paulo: Companhia das Letras, 2003. p. 18-19).

${ }^{11}$ Nesse trecho da obra $O$ Discurso Filosófico da Modernidade, Habermas conceitua modernização como "um conjunto de processos cumulativos e de reforço mútuo: à formação de capital e mobilização de recursos; ao desenvolvimento das forças produtivas e ao aumento da produtividade do trabalho; ao estabelecimento do poder político centralizado e à formação de identidades nacionais; à expansão dos direitos de participação política, das formas urbanas de vida e da formação escolar formal; à secularização de valores e normas, etc". (HABERMAS, J. O Discurso Filosófico da Modernidade. São Paulo: Martins Fontes, 2002. p. 5)

${ }^{12}$ Após a Revolução Francesa, a burguesia necessitava afirmar-se como classe social dominante, de maneira que os juízes, indicados pela nobreza, foram reduzido a meros aplicadores da lei, sem margem de interpretação que poderia favorecer a nobreza. Segundo Renan Lotufo, "diante da pretensão de edificação de uma nova justiça legalista, evitando-se a livre interpretação judicial, deu-se a verdadeira sacralização da lei, como expressão da vontade geral, consagrado tal pensamento no art. $6^{\circ}$ da Declaração de Direitos. Da história fica claro que se buscava o primado da lei, evitando-se a discricionariedade do Rei, como do Judiciário, a ponto de a Constituição da França, de 3 de setembro de 1791 ter disposto, no dizer de tradutores espanhóis: No hay em Francia autoridad superior a la de la ley" (texto de apresentação da obra Direito Civil Constitucional - Cadernos I. São Paulo: Max Limonad, 1999. p. 8).

${ }^{13}$ Os direitos fundamentais sugiram, dessa forma, tanto para evitar interferências indevidas do Estado nas liberdades individuais, como a de pensamento e de expressão, na vida privada, no direito à vida, etc., quanto para proteger a liberdade das relações mercantis, como a propriedade privada, o contrato e a autonomia da vontade. Como ensina Paulo Bonavides, "foi assim - da oposição histórica e secular, na Idade Moderna, entre liberdade do indivíduo e o absolutismo do monarca - que nasceu a primeira noção de Estado de Direito, mediante um ciclo de evolução teórica e decantação conceitual, que se completa com a filosofia política de Kant”. (BONAVIDES, P. Do Estado Liberal ao Estado Social. $7^{\text {a }}$ ed. São Paulo: Malheiros editores, 2004. p. 41).
} 
Neste contexto é que foram elaborados os princípios clássicos do direito contratual, como a força obrigatória e a relatividade dos efeitos dos contratos, o consensualismo e a autonomia da vontade. A vontade foi equiparada à lei, imperando o voluntarismo e a proteção exacerbada do vínculo contratual, que somente poderia ser desfeito diante da ocorrência de um vício da vontade, o que revela ainda mais o caráter voluntarista da concepção jurídica moderna. Segundo Judith Martins-Costa, a idéia era a de que "se o indivíduo, no Estado da Natureza, é livre, nada o pode obrigar, salvo o seu consentimento. Por conseqüência, a origem única das normas jurídicas - por definição obrigatória - é o acordo de vontades". ${ }^{14}$

Para proteger a intangibilidade da autonomia da vontade, era necessário retirar dos magistrados a margem de discricionariedade de suas decisões, tendo em vista o seu comprometimento com a nobreza que até então estava no poder. Nesse intuito, o Estado Liberal inaugurou a "era das codificações" ", na qual a certeza e a segurança jurídica eram essenciais para a afirmação da burguesia no poder. A pretensão era a plenitude do ordenamento jurídico, que deveria regular de maneira exaustiva os atos da vida civil. A atividade do juiz deveria ser reduzida ao mero silogismo da aplicação da lei ao caso concreto. ${ }^{16}$

\footnotetext{
${ }^{14}$ MARTINS-COSTA, J. Crise e modificação da idéia de contrato no direito brasileiro. Revista do Direito do Consumidor, ${ }^{0}$ 3, São Paulo, set-dez/1992. pág. 127.

${ }^{15}$ Como herança desse período tem-se o Código Civil Napoleônico (Code Civile, de 1804) e Código Civil Alemão (BGB, de 1896). Com o Código Napoleônico, surge a escola da exegese, que se dedicou à tarefa de interpretar e explicar o Código Civil Napoleônico. Na Alemanha, a pandectística sistematizou o direito das obrigações, criou a noção de negócio jurídico e formulou as bases para uma Teoria Geral do Direito. Ver a respeito em: CALASSO, F. Il negozio giuridico - lezioni di storia Del diritto italiano. Milano: Giuffrè, 1967. p. 13 e ss., principalmente lezioni prima e seconda.

${ }^{16}$ Segundo Antonio Junqueira de Azevedo: "Ora, sem remontarmos a épocas muito mais remotas, qual era o paradigma até aproximadamente a Primeira Grande Guerra? Era o paradigma da lei. Vindos dos traumas do absolutismo, os juristas de então viam, na lei, o direito. Para dar segurança, a norma devia ser clara, precisa nas suas hipóteses de incidência (fattispecie), abstrata, universal. Como garantia de impessoalidade, o papel do juiz, por isso mesmo, era visto como passivo (o juiz era somente boca da lei, la bouche de la loi Montesquieu); a sentença, um mero silogismo, cuja premissa maior era o imperativo hipotético do texto legal ("se A é, segue-se B" - se matar, pena de prisão); a premissa menor, o fato ("A é", ou seja, fulano matou) e a conclusão a decisão (logo, "segue-se B") - fulano deve ser preso). A função do juiz era de um autômato; bastava verificar se havia ocorrido o fato previsto na lei e, se sim, impor a conseqüência. As preocupações lógico-formais sobre a lei eram, então, tão grandes que, na vida acadêmica, a "apoteose final" das teses consistia na apresentação de impecável definição de um instituto jurídico (muitas vezes, seguida da sugestão de um projeto de lei)"'. (JUNQUEIRA DE AZEVEDO, A. O direito pós-moderno e a codificação. Revista do Direito do Consumidor, $\mathrm{n}^{\mathrm{o}}$ 33, São Paulo, jan-mar/2000, p. 125). Ainda, Francisco do Amaral: "Do positivismo decorre ainda o raciocínio lógico dedutivo na aplicação do direito, deduzindo-se as normas dos conceitos e dos princípios da ciência jurídica, sem recurso a valores extrajurídicos, considerando-se que a aplicação do direito leva, necessariamente, a uma decisão justa. A norma seria justa só pelo fato de ser válida. Além disso, considerando o direito um sistema fechado e pleno, nega a existência de lacunas do sistema. É o dogma da plenitude da ordem jurídica, hoje superado". (AMARAL, F. Direito Civil Introdução. Rio de Janeiro: Renovar, 2006. p. 47)
} 
Indiscutível, que a modernidade trouxe importantes avanços para a humanidade nas áreas da economia, da política, da ciência (inclusive a jurídica) e da cultura. No entanto, com o passar do tempo, muitos dos pilares sobre os quais se sustentou a modernidade passaram a ruir. A razão se mostrou instrumental, servindo aos interesses da classe dominante, transformando-se em dominação, exploração e maximização de lucros. A “mão invisível" do mercado não foi capaz de evitar as injustiças sociais. Muito pelo contrário, a lógica do mercado favorecia a prevalência dos mais fortes sobre os mais fracos, evidenciando-se, como constata Bittar, que as injustiças de origem (falta de escolaridade, precárias condições de trabalho) pré-determinam a condição socioeconômica de cada pessoa $^{17}$ e corroboram não só com a manutenção, mas com o agravamento das desigualdades sociais. Os ideais de racionalidade humana, ordem e progresso, mostraramse falhos diante das turbulências verificadas durante os séculos XIX e XX. Diante disso, correntes filosóficas e movimentos sociais passaram a defender necessidade de combater as desigualdades com uma maior atuação do Estado para corrigir as deficiências do modelo liberal, dando origem a um novo paradigma, o do Estado Social.

\subsubsection{O paradigma do Estado Social}

A descrença nos valores erigidos ao longo da modernidade fez surgir, ao longo do século XIX, movimentos de crítica e de oposição ao Estado Liberal, uma vez que o ideal revolucionário da liberdade revelou-se instrumento de dominação econômica, gerador de desigualdades sociais. Surgiram os movimentos socialistas, calcados no primado da igualdade substancial, que pregavam uma maior atuação do Estado na prevenção e repressão às desigualdades sociais. ${ }^{18}$

Diante da realidade que se apresentava, o próprio pensamento liberal foi compelido a rever as suas balizas. Conforme constatação de Menezes Cordeiro, "o funcionamento livre da autonomia privada, mesmo em períodos históricos anteriores onde esse princípio não ocupava, no sistema jurídico-privado, o papel primordial que lhe atribuiu o

\footnotetext{
${ }^{17}$ BITTAR, E. C. B.. O Direito na Pós-Modernidade. Rio de Janeiro: Forense Universitária, 2005. p. 140141.

${ }^{18}$ Assim Rouanet retrata esse movimento: "Desde sempre o socialismo criticou o conceito burguês de autonomia política: privada de uma base material e dissociada das outras dimensões da autonomia, ela era uma fraude para a maioria da população". E prossegue: "Quanto à autonomia econômica, a principal contribuição do socialismo foi ter transitado do conceito de autonomia como liberdade para o conceito de autonomia como segurança: autônomo não é quem tem o direito abstrato de atuar como agente econômico mas quem tem o poder efetivo de obter pelo trabalho os bens necessários à própria sobrevivência" (ROUANET, S. P. Mal-estar na Modernidade. cit., p. 16-18).
} 
liberalismo, sempre conduzira a injustiças potenciais". ${ }^{19}$ Em verdade, o próprio Adam Smith já reconhecia que, em certas circunstâncias econômicas, poderiam ser impostas restrições ao mercado pela intervenção estatal. ${ }^{20}$

Sérgio Paulo Rouanet esclarece que "por volta de 1880, alguns filósofos idealistas de Oxford passaram a defender um liberalismo 'organicista', segundo o qual a liberdade era redefinida como potencial de cada indivíduo de crescer e desenvolver-se - 'to make the best and most of himself' - e não apenas negativamente, como ausência de coação. Para assegurar o exercício dessa liberdade orgânica, o Estado deveria intervir sempre que necessário". Nesse contexto foi que o Estado Alemão de Bismarck, na década de 1880, como forma de auto-preservação, reconheceu uma série de direitos sociais.

No primeiro pós-guerra, a necessidade de intervenção estatal para garantir a reconstrução dos países envolvidos acelerou o processo de positivação do Estado Social. A Constituição Mexicana de $1917^{21}$ e a Alemã de Weimar de 1919 foram as primeiras a contemplar os direitos sociais, trabalhistas e previdenciários, chamados direitos de igualdade, ao lado dos direitos individuais conquistados com o Estado Liberal. No Brasil, o primeiro reflexo dessa mudança de paradigma manifestou-se com a Constituição de $1934 .^{22}$

${ }^{19}$ MENEZES CORDEIRO, A. M. R.. Da Boa-fé no Direito Civil. Coimbra: Livraria Almedina. 1984. p. 652.

${ }^{20}$ Amartya Sen, ao defender a necessidade de exame crítico do papel dos mercados, recorda a análise de Smith, que toma o exemplo dos empresários imprudentes e dos perdulários para demonstrar que, por vezes, as motivações do lucro privado poderiam ser contrárias ao interesse social, sendo necessária a atuação do Estado para corrigir estes desvios e diminuir as desigualdades sociais. Segundo o autor: "Na lógica intervencionista de Smith, o argumento básico é que os sinais de mercado podem ser enganosos, e as conseqüências do livre mercado podem ser um grande desperdício de capital, efeito do empenho privado em empreendimentos mal orientados ou míopes, ou do desperdício privado de recursos sociais. Jeremy Bentham criticou Smith em uma longa carta que lhe escreveu em março de 1787, defendendo a não-intervenção no mercado. Esse é um episódio notável na história do pensamento econômico, com o principal intervencionista utilitarista fazendo preleção para o guru pioneiro da economia de mercado sobre as virtudes da alocação de mercado" (p. 136). Lembra, ainda, da preocupação de Smith com os abismos sociais existentes e com os interesses dos pobres (SEN, A. Desenvolvimento como Liberdade. São Paulo: Companhia das letras, 2000. p. 115)

${ }^{21}$ Sobre a importância da Constituição Mexicana de 1917, Fábio Konder Comparato aduz que: " $A$ Carta Política mexicana de 1917 foi a primeira a atribuir aos direitos trabalhistas a qualidade de direitos fundamentais, juntamente com as liberdades individuais e os direitos políticos (arts. $5^{\circ}$ e 123). A importância desse precedente histórico deve ser salientada, pois na Europa a consciência de que os direitos humanos têm também um dimensão social só veio a se afirmar após a grande guerra de 1914-1918, que encerrou de fato o 'longo século XIX'” (COMPARATO, F. K. A Afirmação Histórica dos Direitos Humanos. 2. ed. São Paulo: Saraiva, 2001. p. 184).

${ }^{22}$ Conforme Paulo Bonavides: "Com a Constituição de 1934 chega-se à fase que de perto nos interessa, porquanto nela se insere a penetração de uma nova corrente de princípios, até então ignorados do direito constitucional positivo vigente no país. Esses princípios consagravam um pensamento diferente em matéria de direitos fundamentais da pessoa humana, a saber, faziam ressaltar o aspecto social, sem dúvida grandemente descurado pelas Constituições precedentes. O social aí assinalava a presença e a influência do modelo de Weimar numa variação substancial de orientação e de rumos para o constitucionalismo brasileiro". (BONAVIDES, P. Curso de Direito Constitucional. São Paulo: Malheiros Editores, 2008. p. 366) 
Após a Segunda Guerra Mundial, as desigualdades sociais foram acirradas, fazendo crescer o sentimento de desencanto nos padrões liberais. O nazi-fascismo, que também pode ser apontado como uma patologia da modernidade, ${ }^{23}$ fez o mundo repensar os seus valores, retomando a posição do homem ao centro, mas não segundo uma razão instrumental dominante de mercado, mas para valorizar a dignidade da pessoa humana. $\mathrm{O}$ fim da Segunda Guerra mundial é considerado o marco da reconstrução e internacionalização dos direitos humanos, ${ }^{24}$ da consolidação do Estado Social (welfare state) e da positivação dos direitos humanos econômicos, sociais e culturais. ${ }^{25}$ Verificou-se que a simples garantia dos direitos de liberdade não assegurava a justiça social, tornandose cada vez mais necessária a intervenção efetiva do Estado para a garantia das condições mínimas de sobrevivência do ser humano. ${ }^{26}$

A Constituição da República Federativa do Brasil de 1988 é um exemplo de Constituição Democrática e Social, seguindo a linha de diversas outras constituições do pós-guerra, pois, além de uma larga lista de direitos fundamentais individuais (concentrados no seu artigo $5^{\circ}$ ), consagra também direitos sociais trabalhistas (arts. $7^{\circ}$ ao 11) e não trabalhistas (art. $6^{\circ}$ ), políticos (arts. 14 ao 16), econômicos (arts. 170 ao 192), além de uma série de direitos sociais e transindividuais específicos previstos a partir do seu artigo 193, no Título VIII "Da Ordem Social”. Além da consagração expressa desses direitos, a Constituição de 1988 é caracterizada por ser repleta de valores sociais e humanitários, como a dignidade da pessoa humana $\left(\mathrm{CF}\right.$, art. $1^{\circ}$. III), a igualdade e a

\footnotetext{
${ }^{23}$ BAUMAN, Z. Modernidade e ambivalência. Rio de Janeiro: Jorge Zahar Editor, 1999. p. 38.

${ }^{24} \mathrm{O}$ direito positivo e a soberania nacional mostraram-se incapazes de conter as graves violações à dignidade humana, de maneira que esses conceitos passaram a ser repensados e relativizados, com o processo de internacionalização dos direitos humanos. Ver a respeito: PIOVESAN, F. Direitos Humanos e o Direito Constitucional Internacional. São Paulo: Saraiva, 2007. pág. 118.

${ }^{25}$ Mais do que uma distinção relativa à época do seu surgimento, os direitos sociais e os individuais distinguiam-se em razão dos seus mecanismos de efetivação. Entendeu-se que os direitos individuais (liberdade de expressão, direito à privacidade, etc.), por envolverem uma abstenção (ausência de impedimento no livre exercício desses direitos), eram auto-aplicáveis, enquanto que os direitos econômicos, sociais e culturais, por envolverem uma prestação, eram normas programáticas, que dependiam de certas condições factuais para a sua plena realização. Entretanto, apesar das dificuldades de implementação, atualmente se reconhece que os direitos sociais não são desprovidos de eficácia, podendo ser exigidos judicialmente em determinadas circunstâncias de urgência social. Ver, de minha autoria, "Ensaio sobre a eficácia dos direitos sociais". Disponível em < http://www.conpedi.org/manaus/arquivos/ anais/salvador/cinara palhares.pdf. $>$. Acessado em: 20 de outubro de 2009.

${ }^{26}$ No escólio de Paulo Luiz Neto Lobo, "o Estado Social (welfare state) caracteriza-se justamente pela função oposta à cometida ao Estado liberal mínimo. O Estado não é mais apenas o garantidor da liberdade e da autonomia contratual dos indivíduos; vai além, intervindo profundamente nas relações contratuais, ultrapassando os limites da justiça comutativa para prover não apenas a justiça distributiva mas a justiça social” (LÔBO, P. L. N. Contrato e mudança social. Revista dos Tribunais, $\mathrm{n}^{0}$ 722. São Paulo: Editora Revista dos Tribunais, dez 1995. p. 42).
} 
solidariedade social, postos como fundamento e objetivos fundamentais da República (CF, art. $3^{\circ}$, I e III).

O paradigma do welfare state é marcado, portanto, pelo surgimento de novos valores decorrentes do revisionismo crítico do paradigma do Estado liberal. Esses novos valores estão ligados a uma onda de preocupação social, de retomada da moral, da justiça e da dignidade humana, que, em época de forte crise social, econômica e institucional, ganhou importância e espalhou-se nos mais diversos campos do saber. O mercado passa a ser visto não mais como "terra de ninguém", e as operações econômicas deixam de interessar unicamente às partes envolvidas, passando a ter uma função econômica e social relevante, que passou a ser reconhecida pelos ordenamentos jurídicos.

Consolida-se, assim, o modelo do estado intervencionista, que surtirá seus reflexos também no Direito Privado, com o dirigismo estatal no âmbito dos contratos, que é sentido não só em razão da tríplice limitação da liberdade de contratar (com quem contratar, qual tipo contratual utilizar e determinação do conteúdo do contrato), citada por Paulo Luiz Neto Lobo, ${ }^{27}$ mas pela previsão de cláusulas gerais que permitem a interferência do juiz para a garantia da justiça contratual.

Os valores sociais e econômicos passam a ser incorporados no direito das obrigações. Fala-se em crise das fontes, seja devido à inflação legislativa, seja devido à admissão de deveres decorrentes dos novos valores, anexos à boa-fé objetiva (informação, cuidado e lealdade), de maneira que a vontade perde seu posto de única fonte capaz de obrigar os indivíduos. O modelo contratual do estado liberal não mais atendia às exigências do Estado Social, pois o seu pressuposto de igualdade formal revelou-se contrário à realidade. Paulo Bonavides, citando Vierkandt, destaca que a liberdade formal do liberalismo encobre um mundo de desigualdades de fato, transformando "a apregoada liberdade, como Bismarck já o notara, numa real liberdade de oprimir os fracos, restando a estes, afinal de contas, tão-somente a liberdade de morrer de fome", ${ }^{28}$ ou, na conhecida fala de Henri Lacordaire, "entre o forte e o fraco é a liberdade que oprime e a lei que liberta”.

\footnotetext{
${ }^{27}$ Segundo o autor: "O avanço maior deu-se pelo crescente dirigismo jurídico do contrato, intervindo o legislador em vários setores da atividade negocial, utilizando-se principalmente de uma tríplice técnica de limitação da liberdade contratual, a saber: I) limitação da liberdade de escolha do outro contratante, sobretudo nos setores de fornecimento de serviços públicos (água, luz, telefone, transporte etc.), ou monopolizados; II) limitação da liberdade de escolha do tipo contratual, quando a lei estabelece os tipos contratuais exclusivos em determinados setores, a exemplo dos contratos de parceria e arrendamento no âmbito do direito agrário; III) limitação da liberdade de determinação do conteúdo do contrato, parcial ou totalmente, quando a lei define o que ele deve conter de forma cogente, como no exemplo do inquilinato, dos contratos imobiliários, do contrato de turismo, do contrato de seguro". (LÔBO, P. L. N. Contrato e mudança social. Revista dos Tribunais. $\mathrm{n}^{0}$ 722. São Paulo: Editora Revista dos Tribunais, dez 1995. p. 43).

${ }^{28}$ BONAVIDES, P. Do Estado Liberal ao Estado Social. São Paulo: Malheiros, 7 a . Ed., 2004. p. 61.
} 
Entretanto, a modernidade fincou raízes e continuou gerando frutos no mundo contemporâneo, persistindo ainda fortes os seus valores, os seus princípios e as suas instituições. Em relação ao direito das obrigações, os princípios tradicionais da força obrigatória dos contratos, da relatividade dos efeitos dos contratos e da liberdade contratual $^{29}$, que refletem os ideais liberais e individualistas da modernidade, ainda se mostram presentes e fortes, mas passaram a conviver com os novos princípios contratuais da boa-fé objetiva, da função social dos contratos e do equilíbrio contratual. Nesse sentido é a lição de Antônio Junqueira de Azevedo:

Estamos em época de hipercomplexidade, os dados se acrescentam, sem se eliminarem, de tal forma que, aos três princípios que gravitam em volta da autonomia da vontade e, se admitido como princípio, ao da ordem pública, somam-se outros três - os anteriores não devem ser considerados abolidos pelos novos tempos mas, certamente, devese dizer que viram seu número aumentado pelos três novos princípios. Quais são esses novos princípios? A boa-fé objetiva, o equilíbrio econômico do contrato e a função social do contrato. ${ }^{30}$

O direito passou a viver uma época de incertezas, acompanhando as tendências pósmodernas. As legislações passaram a prever cláusulas gerais, que abriram o sistema para a incorporação dos novos valores sociais. O papel dos juízes na interpretação e aplicação dos conceitos abertos de boa-fé, equilíbrio contratual e função social do contrato passa a ser crucial nessa nova feição do ordenamento jurídico, numa época de transição paradigmática marcada pela insegurança, pela incerteza do direito e pela forte e rápida oscilação de tendências. Com isso, restou caracterizada uma mudança no paradigma jurídico: $d o$ paradigma da lei para o paradigma do juiz. ${ }^{31}$

\footnotetext{
${ }^{29}$ De acordo com Antonio Junqueira de Azevedo, "são três os princípios do direito contratual que vêm do século passado; giram em torno da autonomia da vontade e assim se formulam: a) as partes podem convencionar o que querem, e como querem, dentro dos limites da lei - princípio da liberdade contratual lato sensu; b) o contrato faz lei entre as partes (art. 1134 do Código Civil francês), pacta sunt servanda princípio da obrigatoriedade dos efeitos contratuais; c) o contrato somente vincula as partes, não beneficiando nem prejudicando terceiros, res inrter alios acta tertio neque nocet neque prodest - princípio da relatividade dos efeitos contratuais. Os grandes movimentos sociais do final do século passado e da primeira metade do século XX obrigaram os juristas a reconhecer o papel da ordem pública, acrescentando-se, pois, segundo alguns, um quarto princípio, dito 'princípio da supremacia da ordem pública' (na verdade antes um limite do que um princípio)". (JUNQUEIRA DE AZEVEDO, A. Princípios do novo direito contratual e desregulamentação do mercado. (parecer). Revista dos Tribunais, v. 87, n.750, São Paulo, p. 113-120. abr. 1998p. 115).

${ }^{30}$ JUNQUEIRA DE AZEVEDO, A. Princípios do novo direito contratual..., cit. 115-116.

${ }^{31}$ Antonio Junqueira de Azevedo assim expressou a mudança do paradigma jurídico da lei para o juiz: "O paradigma termina, pois, por mudar; os juristas deixaram de examinar as questões pelo ângulo da lei e passaram a tomar, nos seus modelos de solução, com centro, a figura do juiz (encarado como um representante do Estado). Introduziram-se, assim, nos textos normativos, os conceitos jurídicos indeterminados, a serem concretizados pelo julgador no caso a decidir, e as cláusulas gerais, como a de boafé (falou-se até mesmo de fuga para as cláusulas gerais, ou seja, fuga da lei para o juiz). Noções vagas, como ordem pública, interesse público, função social, tornaram-se moeda corrente no mundo jurídico, servindo a
} 


\subsubsection{Globalização: sociedade de consumo e o papel do direito social}

A globalização é o fenômeno que se iniciou com a reconstrução e expansão da economia de mercado após a segunda guerra mundial, quando surgiram as empresas multinacionais e as grandes instituições financeiras, que foram aos poucos superando as fronteiras dos estados nacionais, desterritorializando a produção industrial e criando mecanismos de controle das cadeias produtivas por esses grandes conglomerados econômicos. Este fenômeno não se limitou à economia, passando a determinar culturalmente os hábitos da comunidade internacional, já que a economia globalizada fundamenta a sua estrutura num mercado de consumo de massas capaz de absorver ao máximo a produção em escala mundial, sendo imperiosa a determinação do comportamento cultural de cada agente econômico (consumidor) de acordo com os interesses mercantilistas. ${ }^{32}$

Foi assim que a globalização passou a ser sentida nas artes, na música, no cinema, nas ciências, nos meios de produção e nos hábitos de consumo, de forma que a sociedade de consumo de massa surgiu como imposição dessa nova ordem econômica. Zigmunt Bauman esclarece que, diferentemente da sociedade de nossos avós, que era considerada de produtores, a sociedade atual precisa engajar seus membros pela condição de consumidores: "a norma que nossa sociedade coloca para seus membros é a da capacidade de desempenhar esse papel". ${ }^{33} \mathrm{O}$ agente econômico e social deixou, portanto, de ser primordialmente o trabalhador (o produtor), passando para a figura do consumidor, de forma que a necessidade de consumir é incutida nas mentes das pessoas, que passam a acreditar na indispensabilidade dos produtos e serviços oferecidos no mercado, tornando-se vítimas da ilusão da liberdade de escolha. Nas palavras de Bauman:

Agir assim é uma compulsão, um must, para os consumidores amadurecidos, formados; mas esse must, essa pressão internalizada, essa impossibilidade de viver a vida

\footnotetext{
torto e a direito para as autoridades de plantão. Multiplicaram-se, na doutrina, os trabalhos sobre o papel do juiz, sua função, sua independência, sobre o modo como deve interpretar, etc. Diante do novo paradigma, é claro que alguns permaneceram aferrados ao paradigma antigo, tal e qual, hoje, outros tantos, por seu turno, continuam presos a este paradigma que ora estamos descrevendo e que podemos chamar de paradigma da modernidade (por oposição ao atual, da pós-modernidade)". (JUNQUEIRA DE AZEVEDO, A. O direito pós-moderno e a codificação. cit. p. 125)

32 "Para aumentar sua capacidade de consumo, os consumidores não devem nunca ter descanso. Precisam ser mantidos acordados e em alerta sempre, continuamente expostos a novas tentações, num estado de excitação incessante - e também, com efeito, em estado de perpétua suspeita e pronta insatisfação. As iscas que os levam a desviar a atenção precisam confirmar a suspeita prometendo uma saída para a insatisfação: "Você acha que já viu tudo? Você ainda não viu nada!" (BAUMAN, Z. Globalização - as conseqüências humanas. Rio de Janeiro: Jorge Zahar Editor, 1999. p. 91- 92).

${ }^{33}$ Idem, ibidem, p. 88.
} 
de qualquer outra forma, revela-se para esses consumidores sob o disfarce de um livre exercício da vontade. O mercado pode já tê-los selecionado como consumidores e assim retirado sua liberdade de ignorar as lisonjas; mas a cada visita a um ponto de compra os consumidores encontram todas as razões para se sentir como se estivessem - talvez só eles apenas - no comando. Eles são os juízes, os críticos e os que escolhem. Eles podem, afinal, recusar fidelidade a qualquer das infinitas opções em exposição. Exceto a opção de escolher entre uma delas, isto é, essa opção que não parece ser uma opção. ${ }^{34}$

Nesse modelo, a condição social passou a ser medida pela capacidade de ter e de consumir, de maneira que o excluído do mercado de consumo passou a ser também o excluído socialmente. ${ }^{35}$ Como afirma Bauman, aqueles que pretendem ser admitidos pela sociedade pós-moderna devem passar por um "teste de pureza", qual seja, o "mostrar-se capaz de ser seduzido pela infinita possibilidade e constante renovação promovida pelo mercado consumidor". 36

Esses novos valores são estabelecidos por um novo centro de dominação supranacional formado pelos grandes conglomerados econômicos e instituições financeiras internacionais. Ensina José Eduardo Faria que atualmente existe uma "sociedade das organizações", caracterizada, sobretudo, pela descentralização das decisões em matéria de investimentos (o que acaba afetando o mercado de trabalho e de consumo, bem como a própria política interna, limitando, desta forma, a atuação do Estado-nação) e pela autoregulamentação. ${ }^{37} \mathrm{~A}$ interferência do Estado na economia, nesse contexto, volta a ser indesejada pelos detentores do poder econômico, retornando o primado da desregulamentação do mercado com o chamado neoliberalismo. ${ }^{38}$

${ }^{34}$ BAUMAN, Z. Globalização - as conseqüências humanas. cit. p. 92 .
${ }^{35}$ A realização pessoal fica condicionada à capacidade de consumir, e o indivíduo que não conseguir
comportar-se dessa maneira sofrerá com a exclusão social. A constatação é de Gilberto Dupas: "De fato, a
sociedade contemporânea criou um sério problema ao centrar no consumo diferenciado boa parte da
realização pessoal e social. Tal possibilidade de consumo transformou-se num principal sinal exterior de
sucesso individual, o que faz com que o sentimento de exclusão possa ter um teor puramente relativo, ou
seja, o de estar excluído não de necessidades consideradas básicas, mas daquilo que outras pessoas têm. Essa
sensação pode, com efeito, ocorrer em qualquer faixa de renda" (DUPAS, G. Economia Global e Exclusão
Social: pobreza, emprego, estado e o futuro do capitalismo. São Paulo: Paz e Terra, 1999. p. 17).
${ }^{36}$ E prossegue o autor: "Uma vez que o critério da pureza é a aptidão de participar do jogo consumista, os
deixados fora como um "problema", como a "sujeira" que precisa ser removida, são consumidores falhos -
pessoas incapazes de responder aos atrativos do mercado consumidor porque lhes faltam os recursos
requeridos, pessoas incapazes de ser "indivíduos livres" conforme o senso de "liberdade" definido em função
do poder de escolha do consumidor. São eles os novos "impuros", que não se ajustam ao novo esquema de
pureza. Encarados a partir da nova perspectiva do mercado consumidor, eles são redundantes -
verdadeiramente 'objetos fora do lugar"” (BAUMAN, Z. O mal-estar da pós-modernidade. Rio de Janeiro:
Jorge Zaher Editor, 1998 . p. 23 e 24 ).
37 FARIA, J. E. O direito na economia globalizada. São Paulo: Malheiros Editores, 2005. p. 219 .
${ }^{38}$ Segundo Faria, a doutrina do "direito reflexivo", acreditando na capacidade das "organizações complexas"
de tomar consciência das situações-limite, a partir das quais todos os grupos passariam a perder com a
deflagração de uma competição predatória e com a tomada de decisões irresponsáveis, vislumbra o
surgimento de um novo tipo de democracia, a democracia organizacional, que é uma alternativa à democracia 
Como, então, impedir que o domínio econômico supra-Estatal das corporações econômicas e financeiras redunde em autodestruição e violação de direitos fundamentais? Muito recentemente, a interferência do Estado para a regulamentação do mercado revelouse mais uma vez indispensável. A atual crise financeira mundial mostrou que os agentes econômicos atuando sem a orientação e a fiscalização do Estado podem ser prejudiciais a si próprios e trazer conseqüências desastrosas aos indivíduos que dependem das riquezas produzidas pelo mercado. Entra em cena novamente a importância do Estado para assegurar o bem-estar social e o respeito aos direitos fundamentais, promovendo valores como a solidariedade e a dignidade humana.

Atualmente já se reconhece que a mera produção de riquezas é insuficiente para garantir o desenvolvimento de uma sociedade. Amartya Sen defende que o desenvolvimento não deve ser medido apenas pelas riquezas e pelas rendas que uma comunidade produz, mas, sim, pela capacidade que as pessoas dessa comunidade efetivamente têm de realizar as liberdades substantivas. Nas palavras do autor, "a utilidade da riqueza está nas coisas que ela nos permite fazer - as liberdades substantivas que ela nos ajuda a obter". 39 Em outras palavras, só há desenvolvimento onde os direitos

participativa, restrita aos limites territoriais do Estado-nação. Para essa doutrina, somente a democracia organizacional teria condições de canalizar as diversidades em direções construtivas. Entretanto, explica José Eduardo Faria que essa democracia situa-se no espaço da produção, e não da cidadania. "Seu princípio não está assentado num valor considerado universal, porém, no pragmatismo das instituições financeiras e das incorporações empresariais, que dependem do 'equilíbrio ecológico' do sistema econômico para poderem continuar atuando sem obstáculos e incidentes de percurso". E prossegue: "A integração sistêmica no plano econômico é responsável, desta maneira, por um crescente processo de ruptura das redes de solidariedade e de desagregação nos planos social e nacional. No plano social porque, dada a já mencionada substituição da 'sociedade de homens' pela 'sociedade de organizações', quem não pertence formal ou informalmente a uma delas, não dispõe de uma corporate citizenship e, por conseqüência, numa situação-limite, acabaria não fazendo parte da sociedade"... "No plano nacional porque, dado o alcance transnacionalizado da atuação das 'organizações complexas', cujas regras, critérios e procedimentos de inclusão são acessíveis apenas aos mais qualificados, elas também acabam exercendo impacto corrosivo sobre a própria identidade nacional, pois os que foram por elas empregados ou contratados acabam sendo levados a assumir sua 'cultura organizacional' como "cultura cívica'”. (FARIA, J. E. O direito na economia globalizada. cit. p. 222, 247 e 248).

${ }^{39}$ SEN, A.. Desenvolvimento como liberdade. São Paulo: Companhia das letras, 2000. p. 28. Amartya Sen, numa construção complexa, critica as concepções utilitaristas da economia (tanto a liberal quanto a welferista) para defender um enfoque mais amplo, que considere como base avaliatória a capacidade que as pessoas efetivamente têm de realizar as liberdades substantivas (enquanto capacidade para levar uma vida que a pessoa tem razão para valorizar). Segundo o autor, as principais fontes de privação de liberdade são a pobreza econômica, a carência de oportunidades econômicas e destituição social sistemática (referindo-se aos grupos discriminados sistematicamente, como as mulheres, os negros, etc.), a negligência dos serviços públicos, e a negação de liberdades políticas e civis por regimes autoritários (p. 18, e 29 a 32). Destaca que a livre condição do agente (conforme pregado pelo liberalismo) é a parte constitutiva do desenvolvimento, mas “a ligação entre liberdade individual e realização de desenvolvimento social vai muito além da relação constitutiva - por mais importante que ela seja. O que as pessoas conseguem positivamente realizar é influenciado por oportunidades econômicas, liberdades políticas, poderes sociais e por condições habilitadoras como boa saúde, educação básica e incentivo e aperfeiçoamento de iniciativas. As disposições institucionais que proporcionam essas oportunidades são ainda influenciadas pelo exercício das liberdades das pessoas, mediante a liberdade para participar da escolha social e da tomada de decisões públicas que 
substantivos (individuais, políticos e sociais) são respeitados, e onde as estruturas econômicas, políticas e sociais proporcionam às pessoas a efetiva possibilidade (capacidade) para realizar esses direitos.

O papel do Estado em garantir a real existência dessas capacidades é primordial, e se manifesta seja por meio da realização de políticas públicas, seja pela garantia aos direitos fundamentais e pela regulamentação do mercado de acordo com os interesses sociais, e não para atender a determinados grupos de interesse. Nesse sentido, a atuação do direito privado mostra-se importante não apenas para garantir a justiça comutativa nas contratações, mas também para promover a justiça distributiva através dos entes privados. $^{40} \mathrm{O}$ ordenamento jurídico, ao impor padrões éticos às contratações (boa-fé, equilíbrio e função social) transforma os sujeitos privados em agentes implementadores da justiça econômica, necessária para proporcionar a redução das desigualdades sociais.

Sendo a pós-modernidade uma época de hipercomplexidade, na qual valores novos e velhos convivem, acredita-se que é preciso aprender com os erros do passado e encontrar um equilíbrio capaz de reduzir os altos e baixos pelos quais tem passado a humanidade. Não se deve abandonar o papel do Estado na promoção da igualdade social, sobretudo nos países em desenvolvimento, também chamados de países de modernidade tardia, nos quais o Estado Social não cumpriu com a tarefa de redução das desigualdades sociais e mostrouse incapaz de prestar os direitos sociais. ${ }^{41}$ Mas, por outro lado, não se deve levar essa função às últimas conseqüências, a ponto de entrar em choque com a economia de mercado que aí está. Esse equilíbrio é necessário à própria manutenção do sistema, e parece ilusório acreditar que as "organizações complexas" o conquistem por si só.

Outra característica da atual economia globalizada é a alteração na forma de contratação, que numa sociedade de consumo em massa passou a ser cada vez mais constante a utilização dos contratos por adesão, consistentes em instrumentos padronizados, com cláusulas pré-estabelecidas pelos fornecedores de produtos e de serviços, aos quais o consumidor simplesmente adere. Essa forma de contratação favorece

\footnotetext{
impelem o progresso dessas oportunidades. Essas inter-relações também são investigadas neste livro”. (p. 19) Prossegue em outra passagem esclarecendo que "cinco tipos distintos de liberdade vistos de uma perspectiva 'instrumental', são investigados particularmente nos estudos empíricos a seguir. São eles: (1) liberdades políticas, (2) facilidades econômicas, (3) oportunidades sociais, (4) garantias de transparência e (5) segurança protetora". (p. 25 e 55 a 57).

${ }^{40}$ Macpherson sugere que a justiça distributiva pode ser realizada através dos mercados, e não pelos mercados (MACPHERSON, C. B. Ascensão e queda da justiça econômica. Rio de Janeiro: Paz e Terra, 1991, p. 27).

${ }^{41}$ Daniel Sarmento destaca que o paradigma da globalização (neoliberal) "pegou no contrapé" a Constituição Federal de 1988, que segue um modelo social que jamais logrou ser concretizado (SARMENTO, D. Direitos Fundamentais e Relações Privadas. Rio de Janeiro: Lúmen Júris, 2004. Pág. 49).
} 
a prática de abusos, já que o estipulante formulará o contrato da forma que mais lhe favoreça, incluindo cláusulas abusivas que por vezes sequer são conhecidas pelo consumidor, e, quando são, ele nada pode fazer, porque as condições não são negociáveis. Nessa situação, tornou-se necessária a intervenção do Estado, por meio dos poderes Legislativo, Executivo e Judiciário, para corrigir as injustiças resultantes dessa nova forma de contratação, o que se verificou pela edição do Código de Defesa do Consumidor, pela regulação de algumas atividades essenciais pelas entidades governamentais e pela intervenção judicial no âmbito dos contratos para corrigir ilegalidades.

Nesse contexto cumpre, revigorar o papel dos direitos sociais e da atuação estatal como fator essencial de equilíbrio do sistema. Se a fluidez dos conceitos e a delegação da sua concretização exclusivamente ao juiz mostrou-se desastrosa do ponto de vista da dogmática contratual, como será analisado a seguir, é preciso buscar novos paradigmas que permitam a correta aplicação das cláusulas gerais, e assim, não afastar do campo do direito os valores de justiça, solidariedade social e dignidade da pessoa humana, essenciais no mundo contemporâneo. Nesse intuito, a busca de padrões mais objetivos e a atenção às peculiaridades do caso concreto, quando a objetividade não se mostrar possível, parecem ser a saída para a solução das questões jurídicas que necessitem de uma apreciação a partir dos valores ligados à justiça, à dignidade e à solidariedade.

\subsubsection{A pós-modernidade e a nova mudança de paradigma jurídico: do juiz ao caso concreto}

Fala-se atualmente em pós-modernidade como referência a um período histórico no qual se verifica um paradoxo de ruptura e de continuidade com a modernidade, período histórico que a antecede. ${ }^{42}$ Ruptura porque os "tempos pós-modernos" caracterizam-se pelo questionamento, crítica e superação dos valores erigidos durante a modernidade. Continuidade porque, apesar do revisionismo crítico, os valores da modernidade não desaparecem. O que ocorre é uma mescla gradual com novos valores decorrentes da constatação de que as idéias, os valores e as diretrizes da modernidade são insuficientes para oferecer as respostas adequadas à nova realidade sócio-econômica em direção a qual se desenvolveu a humanidade. Trata-se, em verdade, de uma característica própria de um

\footnotetext{
${ }^{42}$ De acordo com Eduardo C. Bianca Bittar, “a pós-modernidade, na acepção que se entende cabível, é o estado reflexivo da sociedade ante as suas próprias mazelas, capaz de gerar um revisionismo completo de seu modus actuandi et faciendi, especialmente considerada a condição de superação do modelo moderno de organização da vida e da sociedade" (BITTAR, E. C. B.. cit. p. 120).
} 
período de transição, marcado pelo questionamento dos antigos valores e por transformações nas concepções fillosóficas, ideológicas e culturais. Segundo Rouanet, "resta o projeto de uma civilização neomoderna, capaz de manter o que existe de positivo na modernidade, corrigindo suas patologias". 43

Como resultado de um processo que se iniciou no paradigma do Estado Social, o direito privado passou a admitir cláusulas gerais que se tornaram uma "ponte" para a assimilação dos valores sociais no direito privado. Aos poucos, essas cláusula gerais foram positivadas pela legislação infra-constitucional, o que ocorreu no Brasil com a cláusula da boa-fé objetiva (CC, arts. 113, 187 e 422; CDC, arts. $4^{\circ}$, III e 51, IV), da função social do contrato (CC, art. 421) e do equilíbrio contratual (CC, arts. 156, 157, 317, 478 e 480; CDC, arts. $6^{\circ}, \mathrm{V}, 39, \mathrm{~V}$ e $\left.51, \S 1^{\circ}, \mathrm{III}\right)$. Esses novos princípios passaram a conviver com os princípios tradicionais dos contratos (força obrigatória, relatividade e liberdade contratual), num movimento característico do revisionismo crítico da pós-modernidade. Por trazerem conceitos abertos, exaltou-se o papel do juiz na concreção dos valores carregados pelas cláusulas gerais, o que se convencionou chamar de paradigma do juiz em oposição ao paradigma da lei que se estabeleceu com o surgimento do Estado Liberal.

Fala-se hoje de uma nova crise do contrato, ${ }^{44}$ ocasionada pela hipertrofia na utilização das cláusulas gerais da boa-fé, da função social do contrato e do equilíbrio contratual, e pela delegação de sua concreção única e exclusivamente à figura do juiz, o que trouxe muita insegurança e incerteza para as relações jurídicas privadas. Para Antonio Junqueira de Azevedo, atualmente existe uma crise de segurança nas relações jurídicas privadas, de maneira que "as noções vagas estão ultrapassadas e, nisto, pode-se até mesmo vislumbrar uma certa volta a aspectos do paradigma da pré-modernidade; há, hoje, outra vez, muita preocupação com a segurança jurídica". ${ }^{45}$ No entanto, o ilustre jurista não nega a necessidade de se interpretar as relações jurídicas contratuais de acordo com os valores sociais conquistados desde a primeira metade do século passado. Muito pelo contrário. Em parecer, cuja hipótese era a de aplicação do princípio da função social do contrato, e o seu reflexo na mitigação do princípio da relatividade dos contratos, assim se manifestou:

Não é possível que, ao final do século XX, os princípios do direito contratual se limitem àqueles da survival of the fittest, ao gosto de Spencer, no ápice do liberalismo sem peias; seria fazer tabula rasa de tudo que ocorreu nos últimos cem anos. A atual

\footnotetext{
${ }^{43}$ ROUANET, S. P.. cit., p. 13.

${ }^{44}$ MARQUES, C. L. O novo modelo de direito privado brasileiro e os contratos: entre interesses individuais, sociais e direitos fundamentais. In: A nova crise do contrato. São Paulo: Editora Revista dos Tribunais, 2007. p. 20.

${ }^{45}$ JUNQUEIRA DE AZEVEDO, A. O direito pós-moderno e a codificação. cit. p. 127.
} 
diminuição do campo de atuação do Estado não pode significar a perda da noção, conquistada com tanto sofrimento, de tantos povos e de tantas revoluções, de harmonia social. O alvo, hoje, é o equilíbrio entre sociedade, Estado e indivíduo. O contrato não pode ser considerado como um ato que somente diz respeito às partes; do contrário, voltaríamos a um capitalismo selvagem, em que a vitória é dada justamente ao menos escrupuloso. Reduzido o Estado, é preciso, agora, saber harmonizar a liberdade individual e a solidariedade social. É grande, nessa função, o papel do Poder Judiciário; por isso, devem ser atuados, com a habilidade dos prudentes, os novos princípios do direito contratual - o da boa-fé e o da economia contratual entre as partes, e o da função social, em relação à coletividade e aos terceiros. ${ }^{46}$

A questão, portanto, não diz respeito à incorporação ou não dos valores sociais no direito privado, mas, sim, à maneira como as cláusulas gerais estão sendo aplicadas. ${ }^{47} \mathrm{Com}$ efeito, não se deve abandonar a interpretação do direito de acordo com os valores sociais e econômicos próprios do mundo contemporâneo, pois essa é uma exigência do ordenamento jurídico brasileiro, considerando o atual estágio de nossa sociedade, cuja Constituição Federal reconhece expressamente esses valores com fundamento na solidariedade social e na dignidade da pessoa humana.

Mas como conciliar, então, a necessidade de acolhimento dos valores sociais com o reclame de segurança das relações jurídicas privadas? A solução parece estar, como já adiantado, na busca de critérios mais objetivos para a aplicação das cláusulas gerais e quando a objetividade não se mostrar mais possível, em razão das peculiaridades do caso concreto, buscar-se uma decisão que melhor se coadune com os valores insculpidos no ordenamento jurídico brasileiro, construídos e assimilados pela nossa cultura, e positivados na Carta Constitucional.

Como afirma Antonio Junqueira de Azevedo, o eixo em torno do qual deve girar o paradigma jurídico atual é a centralidade do caso. "O novo paradigma exige vetores materiais, diretrizes, e não fórmulas vazias, próprias de uma axiologia formal, cujo 'recheio' é posto arbitrariamente pela autoridade (juiz ou membro do Poder Executivo)". ${ }^{48}$ Verifica-se, portanto, uma nova alteração de paradigma jurídico: do juiz para o caso concreto. $^{49}$

\footnotetext{
${ }^{46}$ JUNQUEIRA DE AZEVEDO, A. Princípios do novo direito contratual e desregulamentação do mercado. cit. p. 119-120.

${ }^{47}$ Para Cláudia Lima Marques, esta nova crise deve-se a fatores externos à dogmática contratual, e que pode ser solucionada pela correta utilização das novas cláusulas gerais (MARQUES, C. L. O novo modelo de direito privado brasileiro e os contratos... cit. p. 20).

${ }^{48}$ JUNQUEIRA DE AZEVEDO, A. O direito pós-moderno e a codificação. cit. p. 127.

${ }^{49}$ Segundo Luis Roberto Barroso, "as fórmulas abstratas da lei e a discrição judicial já não trazem todas as respostas. $\mathrm{O}$ paradigma jurídico, que já passara, na modernidade, da lei para o juiz, transfere-se agora para o
} 
A análise do caso concreto deve não só ser dirigida aos elementos objetivos do contrato, como a verificação do equilíbrio entre as prestações, ou o cumprimento de deveres anexos à boa-fé objetiva, mas também deve atentar para a condição pessoal ou status das partes envolvidas. No direito das obrigações, a interpretação jurídica deve considerar a situação da parte mais fraca, seja essa fraqueza decorrente de uma presunção legal, como é o caso dos consumidores e dos trabalhadores, seja em decorrência de uma condição privilegiada constitucionalmente, como é o caso dos idosos, das crianças e dos adolescentes, seja, ainda, em razão de uma situação específica de urgência social, na qual a dignidade humana e os direitos fundamentais corram grave risco de violação.

Observa-se que essa nova crise do contrato está mais ligada a um problema operacional relativo à dogmática jurídica do que a uma mudança axiológica na interpretação do direito. Como concretizar as cláusulas gerais que permitem o ingresso de valores tradicionalmente considerados extrajurídicos é o grande dilema do direito na atualidade. O papel do juiz não pode ser abandonado, pois diante de um conflito de interesses é ele que realizará a interpretação jurídica escolhendo, dentre as diversas soluções compatíveis com o ordenamento jurídico, qual a que melhor representa a síntese dos valores vigentes.

Contudo, a atuação do juiz não pode ser arbitrária: deve pautar-se por algumas diretrizes delineadas pelo ordenamento jurídico. No que respeita ao objeto desde trabalho, adianta-se, desde logo, duas diretrizes para a atuação do juiz na concreção das cláusulas gerais, que resultarão numa interpretação diferenciada: i) a necessidade de proteção da parte mais fraca nas relações contratuais; ii) a necessidade de proteção da pessoa física quanto ao mínimo existencial, para preservação do núcleo dos seus direitos fundamentais decorrentes da dignidade humana. Essas premissas serão retomadas na Parte II, quando será defendida a imposição de um dever de renegociação à parte mais forte da relação contratual em razão da alteração das circunstâncias subjetivas da parte mais fraca.

caso concreto, para a melhor solução, singular ao problema a ser resolvido". (BARROSO, L. R. Fundamentos teóricos e filosóficos do novo direito constitucional brasileiro. Revista Diálogo Jurídico, ano 1, v. $1, \mathrm{n}^{\mathrm{o}}$ 6. Salvador: CAJ - Centro de Atualização Jurídica, set. 2001). 


\section{Seção 1.2 - O crescimento do crédito no mercado de consumo pós-moderno}

O crédito ao consumo, oferecido de maneira generalizada e massificada, é um fenômeno típico da sociedade pós-moderna. No paradigma da globalização, sob o qual o desenvolvimento tecnológico e logístico permitiu o crescimento vertiginoso da produção, as atenções foram desviadas para o mercado de consumo, que deveria ser capaz de absorver os bens produzidos em larga escala. Conforme dito anteriormente, o agente econômico transferiu-se do trabalhador para o consumidor, que deveria não só ser estimulado a consumir - função essa desempenhada pela publicidade e propaganda -, mas também ter poder aquisitivo para assimilar a produção, e assim ser útil à sociedade de consumo. Nesse contexto, o crédito tornou-se um bem essencial, pois forneceu ao mercado o instrumento adequado para permitir que o seu agente econômico cumprisse com o papel que lhe era esperado, qual seja, o de assimilar a produção mundial, conferindo-lhe poder aquisitivo imediato. O crédito tornou-se, assim, o verdadeiro "motor da sociedade de consumo". 50

No período medieval, o empréstimo de dinheiro a juros era condenado pela Igreja Católica, que exercia forte domínio sobre os hábitos, a política e assim também sobre a economia. ${ }^{51}$ Dessa forma, o crédito oferecido no intuito de obtenção de lucro era praticamente inexistente, sendo uma atividade desempenhada, sobretudo, pelos judeus, ${ }^{52}$ que não se sujeitavam aos cânones do cristianismo. As leis sobre usura eram rigorosas, limitando o lucro que poderia ser obtido na concessão do crédito. ${ }^{53}$

$\mathrm{Na}$ era moderna, o domínio religioso foi substituído pela racionalidade iluminista, rompendo-se com a barreira da Igreja Católica para o desenvolvimento da atividade de intermediação financeira, mediante a cobrança de juros. No entanto, o crédito somente era concedido a quem já detinha alto poder aquisitivo, com a finalidade de financiar a produção, de maneira que era restrito a uma pequena parcela da população. ${ }^{54}$ Foi somente no século XX que o crédito passou a ser acessível à parcela da população com menor

\footnotetext{
${ }^{50}$ Nesse sentido, Luc Bihl: «Le crédit allait se révéler comme le véritable moteur de la société de consommation. Le problème, lorsque les besoins élémentaires sont satisfaits, n'est plus tant de produire que d'écouler la production, c'est-à-dire de vendre. Or, pour vendre, il faut des acheteurs, c'est-à-dire des consommateurs ayant les moyens de payer » (BIHL, L. Le surendettement ..., cit. p. 3).

${ }^{51}$ Bihl, L. op. cit. p. 2.

${ }^{52}$ MARQUES, M. M. L. e FRADE, C.. Searching For an Over-indebtedness Regulatory System for Portugal and the European Union. In: NIEMI-KIESILÄINEN, J.; RAMSAY, I. e WHITFORD, W. Consumer Bankruptcy in Global Perspective. Oxford and Portland, Oregon: Hart Publishing, 2003, p. 122-123.

${ }^{53}$ PEREIRA, C. M. S. Lesão nos contratos. 6.ed. Rio de Janeiro: Forense, 1994. p. 45.

${ }^{54}$ BIHL, L. Le surendettement : apparition d'un fléau social, cit., p. 2.
} 
poder aquisitivo, e ainda assim a sua concessão passava por uma forte seleção dos tomadores.

Após a Segunda Guerra Mundial, com o desenvolvimento da economia globalizada, a concessão do crédito começou a popularizar-se, por uma necessidade da economia de mercado. Mechele Dickerson analisa o crescimento da disponibilidade de crédito no mercado de consumo norte-americano, constatando que, na década de 60 , não era fácil obter um crédito de baixo custo, exigindo-se para tanto documentação que comprovasse a existência de bens passíveis de penhora ou de renda compatível. ${ }^{55}$

Não era diferente a situação da Europa, esclarecendo Luc Bihl, com relação à França, que, após a segunda guerra, o crédito era escasso e muito regulamentado, de maneira que, para obter um empréstimo, era necessário fornecer um aporte pessoal em montante estabelecido pelo poder público, no intuito de controlar a inflação, o que restringia a concessão do crédito a uma categoria social economicamente favorecida. ${ }^{56}$ Segundo o autor, a sabedoria popular dizia que somente se deveria emprestar aos ricos («on ne prête qu'aux ruches »). ${ }^{57}$

A partir da década de 70 nos Estados Unidos, e da década de 80 na Europa, a situação foi sendo modificada, com o crescimento da importância do crédito como elemento essencial para a alimentação e estimulação do mercado de consumo: junto com a sociedade de consumo surge a sociedade do endividamento. ${ }^{58} \mathrm{O}$ crédito tornou-se um verdadeiro fator de inclusão social, pois, na economia globalizada, os padrões culturais requerem que os indivíduos consumam constantemente, sendo que o crédito confere o poder aquisitivo imediato para esta finalidade. Nessa perspectiva, o crédito é considerado

\footnotetext{
${ }^{55}$ Esclarece a autora que, naquela época, existiam duas formas de concessão de crédito nos Estados Unidos: a primeira era o crédito a longo prazo concedido pelo governo ou por bancos comerciais, garantido por hipoteca; a segunda consistia em empréstimos parcelados por instituições financeiras locais ou uniões de crédito que eram concedidos apenas se após a análise detalhada da renda e do patrimônio do tomador concluía-se que este era merecedor do crédito ("Over-indebtedness, the subprime mortgage crisis and the effect on US Cities", unpublished work paper). No mesmo sentido é a análise de Michelle White (WHITE, M. Bankruptcy reform and credit cards. Journal of Economic Perspectives, volume 21, number 4, fall 2007, p. 175-199).

${ }^{56}$ Nesse sentido, ver Luc Bihl: « Ce n'est donc que très récemment, après la seconde guerre mondiale, que le crédit à la consommation est apparu. Timidement d'ailleurs et très réglementé. Pour obtenir un crédit il faut nécessairement fournir un apport personnel dont le montant est fixé par les pouvoirs publics de manière notamment à contrôler l'inflation. Ainsi, le consommateur désireux d'obtenir un crédit pour acheter une voiture, devra fournir, de sa poche, un apport personnel de $30 \%$. Cet encadrement au crédit conserve à celuici un aspect semi-concret et le limite à une certaine catégorie sociale». (BIHL, L. Le surendettement : apparition d'un fléau social, cit., p. 3).

${ }^{57}$ Idem, ibidem, p.2.

${ }^{58}$ DERRUPÉ, J. Rapport de Synthese. L'endettement - Travaux de L'Association Henri Capitant - Journées argentines, Tome XLVI, 1995, p. 23.
} 
um bem essencial para o indivíduo. ${ }^{59}$

Por outro lado, o crédito também é considerado um bem de interesse coletivo, tendo em vista a sua vocação para proporcionar o controle da economia, por meio da política monetária, e, assim, implementar a justiça social. ${ }^{60}$ Mesmo que o crédito seja fornecido e utilizado por entidades privadas, carrega ínsito um interesse público que justifica a sua regulamentação. Dessa forma, afirma José Reinaldo de Lima Lopes que o crédito deve ser visto como um bem coletivo ou público que deve cair naturalmente sob a vigilância das autoridades públicas. ${ }^{61}$ Isso se torna evidente ao constatar-se que a disponibilidade do crédito ao consumo, bem como o seu preço (taxa de juros), é fator de controle da inflação e da economia, sendo que a concessão de crédito de maneira irresponsável pode ocasionar uma crise econômica de proporção mundial, como a atual crise financeira norte-americana, que se espalhou pelo mundo afora.

Um outro fator que reforça o caráter distributivo do crédito é a atual passagem do Estado Social para a Sociedade do Crédito, ${ }^{62}$ na qual o crédito passou a ser utilizado para suprir as deficiências do Estado Social (crédito à educação, crédito habitacional, seguro saúde privado, crédito ao consumo, etc.). ${ }^{63}$ Fala-se hoje em privatização do seguro social, ${ }^{64}$ o que ocorre seja por meio de seguros privados (previdência privada, planos de saúde privados), seja por meio do crédito, do qual se socorrem os indivíduos que não têm outros meios para prover as suas necessidades. ${ }^{65}$

\footnotetext{
${ }^{59}$ Nesse sentido, Jean Derrupé, cit., p. 25: “Comprendre l'endettement, c'est avant tout constater qu'il n'est pas toujours mauvais. L'endettement peut être une vertu (Jean Stouflet). Il est une condition de la croissance et du développement. Celui qui ne s'endette pas végète. L'endettement n'est mauvais que par ses conséquences. Distinguer le bon endettement du mauvais est primordial. Où commence l'endettement nocif et dangereux? Telle est la première question qui appelait une réponse".

${ }^{60}$ José Reinaldo de Lima Lopes defende a tese de que o crédito, e em especial o crédito ao consumidor, é um mecanismo de realização da justiça distributiva, citando doutrina segundo a qual o dinheiro não é um bem como os outros, pois a alteração do seu valor é sempre um instrumento de distribuição ou de concentração. (KEYNES, J. M. Conseqüências das alterações no valor da moeda para a sociedade. In: T SZMRECSÁNYI (ed), São Paulo: Ática, 1978, apud LOPES, J. R. L.. Consumer Bankruptcy and Over-indebtedness in Brazil. In: NIEMI-KIESILÄINEN, RAMSAY e WHITFORD. Consumer Bankruptcy in Global Perspective. Oxford and Portland, Oregon: Hart Publishing, 2003. p. 90).

${ }^{61}$ LOPES, J. R. L. op. cit. p. 91.

${ }^{62}$ REIFNER, U. 'Thou shalt pay thy debts' - Personal Bankruptcy Law and Inclusive Contract Law. In: NIEMI-KIESILÄINEN, J; RAMSAY, I. e WHITFORD, W. Consumer Bankruptcy in Global Perspective. Oxford and Portland, Oregon: Hart Publishing, 2003. p. 143.

${ }^{63}$ Ver: RAMSAY, I. Consumer Credit Society and Consumer Bankruptcy: Reflections on Credit Cards and Bankruptcy in the Informal Economy, p. 23-25 e JACOBY, M. B. Generosity Versus Accessibility: Bankruptcy, Consumer Credit, and Health Care Finance in the US, p. 283-300, ambos em: NIEMIKIESILÄINEN, J.; RAMSAY, I. e WHITFORD, W.. Consumer Bankruptcy in Global Perspective. Oxford and Portland, Oregon: Hart Publishing, 2003.

${ }^{64}$ NIEMI-KIESILÄINEN, J.; RAMSAY, I. e WHITFORD, W.. Introduction. Consumer Bankruptcy in Global Perspective. Oxford and Portland, Oregon: Hart Publishing, 2003. p. 4.

${ }^{65}$ Como afirma José Reinaldo de Lima Lopes, o crédito ao consumo tem sido utilizado para substituir um sistema de seguridade social ineficiente. (LOPES, J. R. L. op. cit., p. 98).
} 
Dessa forma, observa-se que o crédito exerce um papel central na sociedade de consumo globalizada, seja por permitir ao indivíduo a inclusão social, que vai desde o atendimento às necessidades básicas até a fruição de bens de consumo supérfluos, que proporcionam bem-estar e contentamento, seja em razão do interesse público que ele representa, como fator de regulação monetária e controle da economia, sendo, desta maneira, elemento de efetivação de políticas econômicas capazes de realizar a justiça distributiva.

Nesse contexto, o oferecimento do crédito experimentou um crescimento vertiginoso a partir de meados da década de 70 nos Estados Unidos e, no resto do mundo, a partir dos anos 80. As causas para esse fenômeno, que passou a ser chamado democratização ou revolução do crédito, são várias. Niemi-Kiesiläinen, Ramsay e Whitford identificam algumas das causas, sendo a desregulamentação do mercado financeiro a principal delas, à qual se soma o desenvolvimento da tecnologia dos bancos de dados para a classificação do crédito, que facilitou a administração do risco e possibilitou o fornecimento de crédito a um grande número de consumidores. ${ }^{66}$ Outros estudos apontam o desenvolvimento dos meios de comunicação, que possibilitaram uma publicidade mais abrangente e agressiva, como fator de crescimento na demanda pelo crédito. ${ }^{67}$

Entretanto, a própria desregulamentação do crédito foi ocasionada por uma demanda anterior, decorrente da sociedade pós-industrial, que necessitava do poder aquisitivo do consumidor para escoar a produção e manter a economia aquecida. Como observa Luc Bihil, "para permitir a sobrevivência da sociedade de consumo, o crédito se tornou essencial... e o governo suprimiu em 1984 todas as medidas de limitação (inclusive as limitações da necessidade de aporte pessoal". ${ }^{68}$ Em razão da demanda pelo crédito, os

${ }^{66}$ NIEMI-KIESILÄINEN, J.; RAMSAY, I. e WHITFORD, W.. cit. p. 2. Ver na mesma publicação: RAMSAY, I. Consumer Credit Society and Consumer Bankruptcy: Reflections on Credit Cards and Bankruptcy in the Informal Economy, p. 17; REIFNER, U. 'Thou shalt pay thy debts' - Personal Bankruptcy Law and Inclusive Contract Law; MARQUES, M. M. L. e FRADE, C.. Searching For an Over-indebtedness Regulatory System for Portugal and the European Union, p. 123; Ver ainda: FAY, S.; HURST, E.; WHITE, M. J. The Household Bankruptcy Decision. The American Economic Review, Vol. 92, No. 3. (Jun., 2002), pp. 706-718; GROSS, D. B.; SOULELES, N. S. An Empirical Analysis of Personal Bankruptcy and Delinquency. The Review of Financial Studies, Vol. 15, No. 1. (Spring, 2002), pp. 319-347.

${ }^{67}$ Susan Burhouse identifica cinco fatores responsáveis pelo que ela chama de "revolução do crédito ao consumo": 1) a desregulamentação do crédito; 2) o crescimento na oferta de cartões de crédito; 3) avanços na tecnologia da informação que permitiu uma melhor e mais ampla classificação dos consumidores para efeito de concessão de crédito (credit scoring); 4) o preço do crédito baseado no risco; 5) a securitização, que permite a negociação das dívidas para investidores em todo o mundo. (BURHOUSE, S. Evaluating the Consumer Lending Revolution. Federal Deposit Insurance Corporation. September 17, 2003. Disponível em: <http:/www.fdic.gov/bank/analytical/fyi/2003/091703fyi.html>. Acessado em: 10 de janeiro de 2009).

${ }^{68}$ Do original: « pour permettre la survie de la société de consommation, le crédit devenait essentiel. Et le gouvernement supprimait en 1984, toutes les mesures d'encadrement (avec lui les limites de la nécessité de l'apport personnel) ». (BIHIL, L. Le surendettement : apparition d'un fléau social..., cit., p. 4). 
governos foram forçados a desregulamentar o mercado financeiro e, partir daí, houve a explosão do oferecimento do crédito. $\mathrm{O}$ crédito passou a financiar não apenas a produção, como ocorria majoritariamente antes de meados dos anos 70 , passando a ser oferecido em larga escala também ao consumidor pessoa física de baixa renda, no intuito de torná-lo um agente fomentador da economia.

Evidentemente, com o crescimento do volume de crédito disponível no mercado, sobretudo o crédito ao consumo, crescem também os problemas dele decorrentes. $\mathrm{O}$ crédito é um produto que apresenta riscos, sendo que o principal deles é o sobreendividamento, que pode levar à escravidão contratual, à exclusão social e à submissão dos indivíduos aos mais diversos tratamentos vexatórios. Sob o aspecto social, o endividamento excessivo da massa de consumidores gera uma crise de inadimplência, que pode levar à paralisação da economia, tal como se verificou com a crise de crédito mundial deflagrada nos Estados Unidos em 2009. ${ }^{69}$

Facilmente se observa que as causas do endividamento excessivo do consumidor estão relacionadas com o crescimento da disponibilidade e da oferta do crédito no mercado de maneira generalizada e massificada. No entanto, não é somente o crescimento da oferta do crédito que leva ao sobreendividamento. A forma como o crédito é concedido e a ocorrência de fatos imprevistos que alterem a capacidade financeira do devedor também têm relação direta com este fenômeno.

Nos tópicos subseqüentes serão abordadas as principais causas do crescimento da oferta do crédito, que indiretamente se relacionam com o surgimento do fenômeno do sobreendividamento, quais sejam, a desregulamentação do mercado de crédito e o crescimento da oferta e da demanda pelo crédito sob a influência do desenvolvimento tecnológico, da publicidade e dos meios de comunicação. Ao lado desses fatores, serão analisadas outras duas questões que estão diretamente relacionadas com o sobreendividamento. A primeira delas é o empréstimo predatório (predatory lending), ou seja, a concessão de crédito em condições abusivas a pessoas que notoriamente não terão a

\footnotetext{
${ }^{69}$ Luc Bihil assim retrata a importância do crédito, mas também os perigos que lhe são ínsitos, ressaltando a ilusão que ele provoca no consumidor: Certes, le crédit à la consommation joue un rôle positif qu'il ne saurait être question de nier. Il permet à tous, dit-on, d'accéder à un niveau de vie supérieur, de se procurer sans attendre, des biens dont il a (ou croit avoir) besoin. L'automobile, la chaîne haute fidélité, l'ordinateur, ne sont plus un luxe réservé à quelques privilégiés. Grâce au crédit, ces biens sont accessibles à tous. Est-ce aussi vrai qu'on l'affirme ? Le crédit permet certes de se procurer ces biens, tout de suite. Mais il ne fait que déplacer les problèmes. Le crédit n'augmente pas les revenues. Bien au contraire, il les diminue. C'est beaucoup plus une impression, voire une illusion d'augmentation du niveau de vie, qu'une réalité. Non seulement le crédit ne résout pas les problèmes sociaux, mais il en créé de nouveaux. (« Le surendettement : apparition d'un fléau social», cit., p. 5).
} 
capacidade de cumprir o contrato. A segunda questão é o chamado sobreendividamento passivo, cujas causas estão nos acidentes da vida, como o desemprego, ruptura familiar e doença, que alteram as condições pessoais do devedor, agravando a sua situação de endividamento.

\subsubsection{A desregulamentação do crédito, o "boom" dos cartões de crédito e a sua influência no sobreendividamento das famílias nos Estados Unidos}

Conforme já mencionado, a desregulamentação das taxas de juros iniciou-se nos Estados Unidos a partir do final da década de 70, em razão de uma crescente demanda por crédito decorrente da sociedade de consumo pós-industrial. Estudos norte-americanos demonstram que a guinada na oferta de crédito teve como marco a decisão da Suprema Corte em 1978 no caso "Marquette" (Marquette National Bank of Mineapolis vs. First Omaha Service Corp) ${ }^{70}$ que impulsionou a abolição das leis estaduais contra a usura pecuniária, liberalizando as taxas de juros cobradas pelas instituições financeiras. Nos Estados Unidos, desde a era colonial, existiam leis de usura estabelecendo limites para a cobrança de juros, que eram editadas por cada Estado. No caso "Marquette", a Suprema Corte decidiu que legislar sobre usura era de competência do Congresso, sendo que o artigo 85 do National Bank $A c t^{71}$ permitia ao fornecedor cobrar a maior taxa de juros permitida no seu Estado sede, a despeito do limite estabelecido na residência do consumidor. Segundo Diane Ellis, o efeito desta decisão foi a desregulamentação das taxas de juros em todo o país, com a abolição das leis estatuais contra a usura, pois os Estados que ainda mantinham as restrições passaram a ser pressionados pelas instituições financeiras, que ameaçavam se mudar para Estados onde as taxas eram mais flexíveis. Ellis apresenta dados que comprovam que a partir da decisão do caso Marquette o volume de operações de crédito aumentou bruscamente, já que a existência de restrições para a cobrança de taxas de juros limitava o volume de operações de crédito, pois os fornecedores não se sentiam incentivados a emprestar dinheiro para a massa de consumidores de baixa

\footnotetext{
${ }^{70}$ ELLIS, D. The Effect of Consumer Interest Rate Deregulation on Credit Card Volumes, Cherge-Offs, and the Personal Bankruptcy Rate. Bank Trends - Analysis of Emerging Risks in Banking, n 98-05, 1998.

${ }^{71}$ Section 85, National Bank Act: "Any association may take, receive, reserve, and charge on any loan or discount made, or upon any notes, bills of exchange, or other evidence of debt, interest at the rate allowed by the laws of the State, Territory, or District where the bank is located, or at a rate of 1 per centum in excess of the discount rate on ninety-day commercial paper in effect at the Federal reserve bank in the Federal reserve district where the bank is located, whichever may be the greater, and no more, except that where the laws of any State a different rate is limited for banks organized under state laws, the rate so limited shall be allowed for associations organized or existing in any such State under this chapter [title 62 of the Revised Statutes]".
} 
renda, em razão do alto risco que esses empréstimos representam. ${ }^{72} \mathrm{Com}$ a liberação das taxas de juros, os bancos puderam cobrar taxas mais altas e assim embutir no custo do dinheiro o alto risco. ${ }^{73}$ Em outras palavras, o alto risco assumido não só por emprestar a consumidores de baixa renda, mas também pela diminuição da burocracia na análise do crédito, era compensado com a cobrança de taxas de juros mais elevadas. Para a autora, as operações com cartão de crédito foram as que experimentaram maior suscetibilidade à liberação da taxa de juros, sendo as principais responsáveis pelo crescimento do volume de crédito entre a população, inclusive a de baixa renda. ${ }^{74}{ }^{75}$

\footnotetext{
${ }^{72}$ Sobre o tema, ver também: DICKERSON, M. op. cit. p. 3.

${ }^{73}$ Sobre a influência da liberação da taxa de juros no volume de operações de crédito, ver: VILLEGAS, D. J. 1989. The impact of usury ceilings on consumer credit. Southern Economic Journal, 56, $\mathrm{n}^{\circ} 1$. Ver também: HYNES, R.; POSNER, E. A. The Law and Economics of Consumer Finance. American Law and Economics Review. V. 4, $\mathrm{n}^{\circ} 1,2002$, p. 168-207.

${ }^{74} \mathrm{Um}$ outro fator pode ter contribuído para o crescimento dos pedidos de falência pessoal nos Estados Unidos. É que, em 1978, o Bankruptcy Code (Código de Falências) foi significativamente alterado, tornando o procedimento de falência pessoal mais atraente para o indivíduo. As alterações nesta lei Federal seguiram as orientações da Bankruptcy Laws Comission, que emitiu um relatório em 1973 declarando que o crédito era visto como uma instituição social benéfica tanto para o indivíduo quanto para a sociedade, pois proporciona crescimento econômico e bem-estar pessoal (Bankruptcy Laws Commission, Report of the Commission on the Bankruptcy Laws of the United States, H. R. Doc. No. 93-173 (1973), apud NIEMI-KIESILÄINEN, J. op. cit., 1999, p. 476), de forma que o consumidor deveria ser incentivado a tomar empréstimos para ser capaz de aumentar o consumo pessoal. Por outro lado, a Comissão reconheceu que a contratação de empréstimos envolve riscos, e, para incentivar o consumidor a assumir esses riscos, a lei de falências deveria ser alterada para servir como uma "válvula de escape", oferecendo a possibilidade de recuperação financeira pelo mecanismo do fresh start, ou seja, um procedimento que permite a extinção das dívidas do consumidor (discharge) e a sua re-inserção no mercado de consumo com um novo começo. A lei de falências passou a ser encarada como um seguro de consumo e as taxas de juros mais altas como uma espécie de prêmio pago pelos usuários do crédito. Portanto, as alterações na lei de falências, que passou a ser considerada "debtor friendly", podem ter contribuído para o crescimento no número de pedidos. Diversos estudos discordam do argumento de que as alterações na lei de falências foram responsáveis pelo crescimento do endividamento do consumidor, argumentando que o principal fator foi o desenvolvimento do mercado de cartões de crédito, que também elevou o número de pedidos de falência. Pelas próprias características do cartão de crédito, essa é uma possibilidade bastante provável: trata-se de um empréstimo sem garantia (observe-se que somente os débitos sem garantia podem ser extintos de acordo com o Bankruptcy Code), oferecido e concedido de maneira generalizada, inclusive à população de baixa renda, com altas taxas de juros para compensar os riscos, e de fácil utilização, camuflando o real custo das mercadorias. Susan Burhouse apresenta dados que comprovam a relação direta entre a taxa de inadimplência dos cartões de crédito e o número de pedidos de falência pessoal nos Estados Unidos. (BURHOUSE, S.. op. cit., 2003, p. 4).

${ }^{75}$ Michelle White também defende a tese de que a principal razão para o crescimento dos pedidos de falência pessoal é o aumento do crédito renovável (revolving debt), cuja principal modalidade é o cartão de crédito, demonstrando que as alterações na lei de falência não interferiram no volume de endividamento do consumidor, e só aparentemente reduzem o problema do sobreendividamento. (WHITE, M. Bankruptcy reform and credit cards. cit. p. 175-199). A autora demonstra que o endividamento do consumidor, que tem aumentado desde 1980, não parou de crescer mesmo após o Bankruptcy Abuse Prevention and Consumer Protection Act de 2005, que tornou o procedimento menos atrativo para o consumidor, muito embora os pedidos de falência tenham diminuído. Segundo os dados apresentados pela autora, o percentual de comprometimento da renda familiar com os débitos rotativos cresceu de 3,2 para $12,5 \%$, do período de 1980 para 2004. A autora demonstra que a partir de 1980 o montante de débito decorrente de crédito rotativo por pessoa era de \$1.664, passando para \$ 5.927 em 1995 e não parou de crescer até atingir a soma de \$ 7.544 em 2005, ano da edição do BAPCPA. A quantidade de pedidos de falência pessoal também vinha acompanhando esse crescimento, passando de 287.000 casos em 1980 para 874.000 casos em 1995, até atingir a incrível soma de 2.039.000 casos em 2005. Para comprovar sua tese de que o volume de endividamento do consumidor não guarda relação com o rigor da lei de falências, Michelle White demonstra
} 
O crédito hipotecário subprime ${ }^{76}$ foi outro produto que teve o seu crescimento acelerado a partir da década de 70, interferindo também na quantidade de requerimentos de falência. ${ }^{77}$ Em três décadas, os Estados Unidos acumularam o maior nível de endividamento do consumidor do mundo, ${ }^{78}$ cujo descontrole levou à crise financeira de 2009, que surtiu reflexos, em maior ou menor grau, em diversos outros países. O crédito hipotecário subprime, securitizado e negociado nas bolsas de todo o mundo, foi o pivô da crise.

Em virtude disso, fala-se atualmente num movimento de regulamentação do mercado financeiro, contrário ao que ocorreu anos atrás, e de exigências de fornecimento responsável do crédito, a fim de proteger o mercado de uma crise generalizada e os indivíduos contra o risco do sobreendividamento e de todos o males que o acompanham. Mesmo o procedimento de falência pessoal, antes considerado o mais benéfico ao consumidor, tem sido criticado por não prever medidas efetivas de prevenção do endividamento e de proteção da economia familiar, e por permitir que as pessoas simplesmente percam suas casas, sem que o governo tome qualquer medida para evitar essa drástica conseqüência.

que após o BAPCPA o número de requerimentos de falência caiu para 598.000, mas o endividamento do consumidor continuou subindo, passando para \$7.694 em 2006. Portanto, o fato da lei de falências ser mais ou menos "debtor friendly" não explica o porquê dos consumidores estarem se endividando excessivamente. Para a autora, existem muitos consumidores que podem ser classificados como hyperbolic discounters (consumidores contumazes), que gastam de maneira irracional, sendo que um tratamento mais rigoroso por parte da lei, impedindo-lhes o acesso aos procedimentos de recuperação financeira, não interfere nas causas do endividamento excessivo. A autora defende que, enquanto os "rational consumers" usam os cartões de crédito apenas para realizar transações, os "hyperbolic discounters" efetuam empréstimos por meio dos cartões, tendo a opção de pagar valores menores mensalmente e assim acumular débitos nos cartões de crédito (WHITE, M J., op. cit. 2007, p. 182). No mesmo sentido, Mechele Dickerson esclarece que ao efetuar apenas o pagamento mínimo do cartão de crédito, o consumidor acaba usando este instrumento para financiar o consumo, e não apenas para administrar despesas, pagando por isso juros extremamente elevados. (DICKERSON, M. Over-indebtedness, the subprime mortgage crisis and the effect on US Cities, unpublished work paper).

${ }^{76}$ Crédito concedido a consumidores com "crédito ruim" seja por não possuírem histórico, seja em razão da baixa renda, ou ambos.

${ }^{77}$ Para Michelle White, ainda que o crédito hipotecário não possa ser extinto nos termos do Bankruptcy Code - pois não pode ser concedido o discharge -, o seu crescimento interfere no volume de requerimentos de falência, pois, para manter em dia as obrigações decorrentes do crédito hipotecário, e assim não perder as suas casas, os consumidores deixam de cumprir com as demais obrigações (WHITE, M., op. cit., 2007, p. 180).

${ }^{78}$ De acordo com os dados disponíveis no Federal Reserve, em 1980, o volume total de débitos em aberto era de U\$351920,05 milhões, sendo que atualmente atingiu a quantia de U\$2588074,19 milhões. Os números relativos ao crédito rotativo (cartões de crédito, cheque especial) passaram a ser registrados em 1968, e a cada ano se duplicavam, passando de U\$1316,77 milhões em 1968 para U\$36924,59 milhões uma década mais tarde, montando atualmente a quantia de \$971408,28 milhões. Disponível em: $<$ http://www.federalreserve.gov/releases/g19/hist/cc_hist_as.txt $>$. Acessado em 26 de outubro de 2009. 


\subsubsection{A desregulamentação do crédito e o surgimento do sobreendividamento na}

\section{Europa}

A desregulamentação e o conseqüente crescimento no volume de crédito oferecido no mercado foi uma tendência seguida pela Europa nos anos 80. Conforme pode ser observado no relatório de informação $\mathrm{n}^{0} 60$ do Senado Francês, a taxa de crescimento anual do crédito ao consumo, que era de $6 \%$ em 1980, passou para $21 \%$ em 1985 e para $39 \%$ em $1986 .^{79}$ Essa guinada no crescimento do crédito ao consumo resultou da supressão das medidas de regulamentação em $1984,{ }^{80}$ do surgimento de novos instrumentos de crédito, como o crédito renovável sob a forma de cartões de crédito e dos incentivos governamentais para a aquisição da propriedade. ${ }^{81}$ Para Vincent Vigneau e GuillaumeXavier Bourdin, outro fator que contribuiu foi a abertura do capital das empresas e a conseqüente possibilidade de obtenção de outras formas de financiamento que não o bancário forçaram os bancos a substituir a clientela empresarial pelos particulares. Esclarecem os autores que, se antes o crédito era limitado às empresas e ao financiamento de imóveis, "o recurso ao crédito se tornou para os franceses um modo normal de gestão de seu orçamento lhes permitindo de satisfazer os encargos imediatos da vida corrente". 82

$\mathrm{Na}$ Inglaterra, a desregulamentação começou já no final da década de 70, quando o mercado financeiro foi aberto para competir com instituições estrangeiras (sobretudo as norte-americanas). ${ }^{83}$ Também Niemi-Kiesiläinen, Ramsay e Whitford afirmam que o crescimento e expansão do crédito foram causados pela redução do controle pelos bancos centrais e pela abolição dos limites das taxas de juros em diversos países. ${ }^{84}$ No entanto, o crédito não evoluiu da mesma forma em todos os países da Europa. Em Portugal, por exemplo, o crescimento iniciou-se a partir de 1990, tendo sua verdadeira guinada a partir

\footnotetext{
${ }^{79}$ Disponível em http://www.senat.fr/rap/r97-060 mono.html\#fn2. Acessado em 10 de janeiro de 2009. Este relatório oferece inúmeras estatísticas, conceitos, e conclusões a respeito da evolução do sobreendividamento na França.

${ }^{80}$ Loi Bancaire, 84-46 de 24/01/1984.

${ }^{81}$ O Relatório do Senado $n^{\circ} 60$ fornece dados a respeito da evolução da concessão do crédito à habitação, que acelerou o crescimento a partir da Lei de 3 de janeiro de 1977, chamada "reforma Barre", que criou o empréstimo de acessão à propriedade.

${ }^{82}$ Do original: « le recours au crédit est devenu pour les Français un mode normal de gestion de leur budget leur permettant de satisfaire les charges immédiates de la vie courante ». (Tradução livre. VIGNEAU,V. e BOURDIN, G. X.. Droit du surendettement des particuliers. Paris: Litec, 2007. p. 3).

${ }^{83}$ Fernandez-Corugedo e Muellbauer analisam a liberalização do mercado de crédito inglês no contexto mundial, afirmando que na década de 80 a redução do controle e a eliminação de limites máximos de taxas de juros, e de outras restrições, foi uma tendência seguida por diversos países. (FERNANDEZ-CORUGEDO, E.; MUELlBAUER, J. Consumer credit conditions in the United Kingdom. Disponível em: www.bankofengland.co.uk/publications/workingpapers/index.htm. Acessado em 5 de novembro de 2009).

${ }^{84}$ NIEMI-KIESILÄINEN, J.; RAMSAY, I. e WHITFORD, W. Introduction. cit. p. 2.
} 
de 1995. Isso porque apenas nesse período é que ocorreu a desregulamentação do crédito e o incentivo para aquisição da casa própria coma utilização do crédito hipotecário, ambos fatores influenciados pela inclusão de Portugal na Comunidade Européia. ${ }^{85} \mathrm{Na}$ Itália, a desregulamentação também foi tardia, em razão do forte controle tradicionalmente exercido sobre o crédito. ${ }^{86}$

Entretanto, diferentemente dos Estados Unidos, a revolução do crédito na Europa não foi acompanhada por uma legislação que assegurasse os indivíduos contra os riscos do endividamento excessivo. Em alguns países, como na França, o procedimento de falência era previsto apenas para comerciantes. A única exceção era a região de Alsace-Moselle, que em virtude de uma lei local (lei de $1^{\circ}$ de junho de 1924), combinada com o artigo L. 670 do Código Comercial, previa um procedimento de falência civil, no qual os particulares de boa-fé e em estado notório de insolvência poderiam beneficiar-se dos procedimentos de recuperação e liquidação judicial previstos para as empresas. No restante do país, a única alternativa para o devedor em grave dificuldade financeira, mais precisamente em crise de liquidez, era o requerimento do prazo de prorrogação do vencimento em até 2 anos, para que pudesse liquidar seus bens e obter os recursos necessários para pagar a dívida, nos termos do art. 1244, alínea 2 do Código Civil. ${ }^{87}$ Nos demais países europeus, segundo informam Vigneau e Bourdin, o procedimento de falência civil era praticamente inexistente antes dos anos 80, exceção feita à Alemanha (Insolvency Statute de 1877) e à Inglaterra (Bankruptcy Act de 1861), cujas legislações tratavam as pessoas físicas da mesma maneira que as empresas, sem atentar para as especificidades próprias da condição humana. ${ }^{88}$

Dessa maneira, com a desregulamentação e o conseqüente crescimento da oferta de crédito, alguns países da Europa começaram rapidamente a perceber os problemas decorrentes do sobreendividamento do consumidor e das famílias. A resposta legislativa foi a edição, em diversos países, de leis que vieram em socorro desses indivíduos com

\footnotetext{
${ }^{85}$ Sobre as causas e diversas estatísticas a respeito do endividamento em Portugal ver MARQUES, M. M. L. M. e FRADE, C. An Over-indebtedness Regulatory System for Portugal and the EU, cit.

${ }^{86}$ Ver: EFRAT, R.. Global Trends in Personal Bankruptcy. American Bankruptcy Law Journal, vol 76:81109, 2002.p. 94.

${ }^{87}$ Essa norma foi introduzida pela lei de 25 de março e 20 de agosto de 1936, como resposta à crise de 1929 , que gerou uma forte crise de inadimplência.

${ }^{88}$ Ver: VIGNEAU, V. e BOURDIN, G. X.. Droit du surendettement des particuliers. cit. p. 6. ; MUIR WATT, Horatia. Personal insolvency en droit anglais : un autre découpage. Gaz. Pal, 27 févr. 2003, n⿳ 58, p. 21 ; SORTAIS, J. P.. Le surendettement des particuliers en droit comparé. $L P A, 21$ mai 1999, $\mathrm{n}^{\circ} 101$, p. 16. ; MERLE, W.. Le droit allemand à travers l'Insolvenzordnung. Gaz. Pal., 27 févr. 2003, n ${ }^{\circ}$ 58, p. 17 ; VALLENS, J. L.. L'universalité de la faillite : le droit allemand de l'insolvabilité reconnait les procédures de redressement judiciaire. $L P A, 17$ mars $1999, \mathrm{n}^{\circ} 54$, p. 6.
} 
sérios problemas financeiros: na Dinamarca em 1984, na França em 1989, na Noruega em 1993, na Finlândia em 1993, na Suécia em 1994, na Áustria em 1995, na Bélgica em 1998, na Holanda em 1998 e na Alemanha em 1999.

Essas legislações possuem as suas especificidades, mas o importante neste momento é salientar o fundamento distinto do tratamento do endividamento excessivo no sistema predominante na Europa e no sistema norte-americano. Enquanto que nos Estados Unidos a lei de falências é vista como um instrumento de regulação do mercado, oferecendo ao consumir uma espécie de seguro para o consumo e incentivando o endividamento, na Europa, o sobreendividamento é visto como um problema social, que leva à exclusão e à escravidão contratual. Desta maneira, no sistema europeu, há uma preocupação com a prevenção do sobreendividamento e com os atributos morais do devedor (como a sua boa-fé), além da previsão de mecanismos de aconselhamento dos indivíduos para que não reincidam nesta situação. Ademais, há o tratamento diverso do sobreendividamento ativo e do passivo, sendo que o tratamento deste último é considerado uma questão de justiça social, devendo pautar-se pelos deveres de solidariedade e de dignidade da pessoa humana.

\subsubsection{O crescimento na demanda pelo crédito: o papel da tecnologia, da publicidade e dos meios de comunicação}

Outro fator apontado como responsável pelo crescimento da oferta generalizada do crédito foi o desenvolvimento da tecnologia da informação, que permitiu o aperfeiçoamento dos mecanismos de classificação dos consumidores para efeito de concessão do crédito. ${ }^{89}$ A criação de computadores com capacidade para armazenar e processar uma imensa quantidade de dados possibilitou às agências de classificação do crédito e às próprias instituições financeiras dividirem os consumidores em classes conforme o histórico de crédito existente, a renda pessoal e familiar, as preferências de consumo, etc.. Os dados são obtidos das mais variadas formas (preenchimento de fichas mediante promessa de retribuição, venda de bancos de dados, cuja legalidade é questionada, utilização dos próprios cadastros de clientes dos bancos, cadastros de devedores inadimplentes, etc.), e o resultado é a obtenção do perfil de cada consumidor

\footnotetext{
${ }^{89}$ Susan Burhouse informa que os mecanismos de classificação do crédito existem nos EUA desde 1950, mas que os avanços nas comunicações e tecnologia da informação apenas automatizaram completamente os empréstimos ao consumo em 1990. (BURHOUSE, S. op. cit.).
} 
residente em determinada localidade e a sua classificação (credit scoring), que vai desde o crédito ruim (poor credit, classificados entre os clientes subprime), até o consumidor merecedor de crédito (credit worthy ou clientes prime).

Essa tecnologia permitiu a estipulação de taxas de juros diferenciadas conforme a categoria do crédito e os riscos que ela representa (risk-based pricing). Para os consumidores com crédito ruim as taxas são mais elevadas, pois os riscos de inadimplência são incluídos como forma de compensação para o fornecedor. Ademais, os consumidores com crédito ruim têm menos opções de crédito, até mesmo em função da prática generalizada e padronizada por parte das instituições financeiras, de maneira que acabam aceitando pagar taxas mais altas. ${ }^{90}$ Assim, tanto a oferta de cartões de crédito, quanto de empréstimos pessoais, passaram a abranger uma quantidade cada vez maior de consumidores, ${ }^{91}$ bastando elevar as taxas de juros conforme o risco apresentado. $\mathrm{O}$ procedimento de aprovação do crédito também foi simplificado, o que permitiu o aumento significativo da clientela dos bancos. Por outro lado, os clientes com alto potencial de investimento (clientes prime) continuaram recebendo um tratamento diferenciado, sendo que quanto mais alta a classificação, mais baixos os juros pagos.

Por sua vez, o desenvolvimento da tecnologia dos meios de comunicação permitiu que o crédito fosse oferecido de maneira mais abrangente e por diversos meios: não apenas correio convencional, mas também correio eletrônico, mensagens nos aparelhos celulares, ampliação das vendas por telemarketing e a própria televisão que se tornou acessível à maior parte da população.

O desenvolvimento tecnológico também contribuiu para a sofisticação das estratégias de marketing envolvendo a publicidade e propaganda. Essas práticas comerciais influenciam o crescimento do endividamento de duas maneiras: a) indiretamente quando são a respeito dos bens de consumo, incutindo na mente do consumidor a necessidade de adquirir os produtos e serviços disponíveis no mercado; b) diretamente, quando são a respeito do próprio crédito, incitando o consumidor a contrair o empréstimo, ainda que ele não precise do dinheiro ou que não tenha capacidade para cumprir as obrigações assumidas.

\footnotetext{
${ }^{90}$ ELLIS, Diane. The Effect of Consumer Interest Rate Deregulation on Credit Card Volumes, Cherge-Offs, and the Personal Bankruptcy Rate. cit., p. 6

${ }^{91}$ JOHNSON, K. W. Recent Developments in the Credit Card Market and the Financial Obligations Ratio. 91 Federal Reserve Bulletin, 473, 2005.
} 


\subsubsection{O empréstimo predatório}

Até o momento o fenômeno do sobreendividamento foi abordado como conseqüência lógica do crescimento do mercado de crédito, evidenciando-se que juntamente com a democratização ou revolução do crédito cresceram também os problemas dele decorrentes. Entretanto, não foi o simples crescimento do volume de crédito que disseminou o sobreendividamento em diversos países. A forma como o crédito passou a ser concedido influenciou de maneira decisiva o agravamento dos problemas financeiros do consumidor e das famílias.

Com a desregulamentação do crédito, a prática do empréstimo predatório (predatory lending), também chamado de crédito irresponsável ou negligente (irresponsible or reckless credit), tornou-se cada vez mais comum e institucionalizada, deixando muitos consumidores em sérias dificuldades financeiras, sendo que, em alguns países, a saída foi beneficiar-se das leis de falência ou de recuperação financeira e, em outros, a única alternativa era manter-se à margem da sociedade, aguardando que os credores desistissem de recuperar o crédito ou que as obrigações prescrevessem. ${ }^{92}$

Não há consenso na definição de empréstimo predatório, tendo em vista a necessidade de conjunção de uma série de fatores. Como afirmam Carr e Kolluri ${ }^{93}$, o empréstimo predatório é geralmente caracterizado pela cobrança de uma taxa de juros excessivamente alta, mas, dependendo do caso, essa cobrança pode ser justificada, sendo necessária a conjugação de outros fatores, quais sejam:

a) Estratégias de marketing que visam atingir pessoas cultural, econômica ou socialmente vulneráveis. Os fornecedores que agem de maneira predatória, se utilizando das estratégias de marketing (telemarketing, mala-direta, solicitação de porta em porta, abordagem nas ruas) para atrair consumidores incapazes de compreender os termos da oferta, seja por possuírem educação limitada, seja por não estarem acostumados a lidar com o mercado financeiro. Os idosos, os jovens e as pessoas de baixa renda são, em geral, alvos fáceis. Segundo Carr e Kolluri, “fornecedores de crédito predatório usam estratégias de marketing não para ir de

\footnotetext{
${ }^{92}$ NIEMI-KIESILAINEN, J. Consumer Bankruptcy in Comparison: Do We Cure a Market Failure or a Social Problem? Osgoode Hall Law Journal, vol. 37, nº 1 e 2, 1999, p. 473-503.

${ }^{93}$ CARR, J. H. e KOLLURI, L. Predatory Lending: an overview. Fannie Mae Foundation Report, 2001. Disponível em: $<$ http://www.knowledgeplex.org/showdoc.html?id=1325> Acesso em 04 de março de 2010.
} 
encontro às necessidades dos seus clientes, mas para identificar consumidores mais vulneráveis". 94

b) Condições contratuais abusivas. Os empréstimos predatórios são formulados de forma a extrair do consumidor o máximo lucro possível. A primeira característica é a alta taxa de juros, que os fornecedores cobram com fundamento no alto risco assumido. No entanto, mesmo não se verificando o risco, a cobrança de altas taxas permanece, pois como o consumidor de baixa renda não tem outras opções ou não tem a exata compreensão dos termos contratuais, ele contrairá o empréstimo de qualquer maneira. Como afirmam Carr e Kolluri, o empréstimo predatório geralmente se desenvolve em meio de baixa competitividade. Além das altas taxas de juros, outras práticas abusivas também podem ser verificadas, como aportes iniciais sem a devida compensação com redução nas taxas de juros, cobrança excessiva de taxas, capitalização de juros, cláusula de arbitragem obrigatória, refinanciamentos sucessivos do débito a taxas mais elevadas, dentre outras. Observe-se, por fim, que o fornecimento do crédito em condições abusivas em geral ocorre com o aproveitamento da situação de vulnerabilidade da pessoa, o que torna ainda mais evidente a atividade predatória do fornecedor.

c) Comportamento fraudulento do fornecedor. Carr e Kolluri identificam cinco atitudes que caracterizam o comportamento ilícito do fornecedor, quais sejam, 1) falha na explicação dos termos do empréstimo ou prestar informações obscuras; 2) utilização de táticas de alta pressão para forçar um consumidor a continuar o processo de concessão do empréstimo mesmo contra a sua vontade; 3) omissão de explicações sobre condições abusivas (no caso brasileiro o melhor exemplo é a omissão sobre os efeitos da capitalização de juros); 4) desencorajar os tomadores a buscar opções de menor custo; 5) iniciar empréstimo sem considerar a capacidade do consumidor de cumprir o contrato. ${ }^{95}$ Ademais, os autores identificam um comportamento discriminatório com relação à população negra americana, demonstrando, por meio de dados apresentados pelo US Department of Housing and Urban Development (HUD), que os negros não só são mais visados pelos fornecedores, como também recebem crédito em condições mais abusivas que o restante da população.

\footnotetext{
${ }^{94}$ Do original: "predatory lenders use target marketing not to meet the needs of their costumers, but rather to identify households most vulnerable to the lenders' aggressive or fraudulent behavior". (Tradução de CARR, J. H. e KOLLURI, L. Predatory Lending: an overview. cit.)

${ }_{95}$ Este último comportamento foi extraído do contexto apresentado pelos autores.
} 
Em todos esses casos, resta claro que o fornecedor é responsável pelo endividamento do consumidor. Jean Derrupé indica o comportamento dos credores como uma das causas do sobreendividamento, devido à falta de vigilância e de rigor na concessão de crédito. Para o autor, a atitude dos credores explica-se pela busca do lucro, pois o volume de negócios depende do volume de operações de crédito. Se algum devedor deixa de pagar ocorre uma compensação com o lucro que eles obtiveram nas demais operações. Ademais, a inadimplência é previamente calculada (cálculo atuarial) e incluída no preço de todos os empréstimos. Há uma transferência de riscos ao conjunto dos devedores, que se justifica, segundo o autor, pelo princípio da solidariedade. ${ }^{96}$

O crédito predatório é fornecido em geral no mercado dos clientes denominados no jargão financeiro de subprime, que podem ser definidos como os consumidores com histórico de crédito ruim (ausência de dados ou histórico negativo) e/ou sem documentação suficiente para demonstrar que possuem bens ou recursos financeiros que possam responder pelas suas dívidas. Essas características podem fazer crer que esse cliente seria indesejado, em razão do alto risco que ele representa. Contudo, tendo em vista a ausência de limitação da taxa de juros, as instituições financeiras podem impor taxas extremamente elevadas, capazes não só de compensar os riscos, como também obter grande lucratividade, de forma que o mercado dos clientes subprime mostrou-se altamente atrativo nos últimos anos, até mesmo porque os riscos são superestimados, e, na medida em que ele não se verifica, automaticamente converte-se em lucro para a instituição financeira.

O mercado dos cartões de crédito é um ambiente bastante favorável à prática de abusos, pois, por meio deste instrumento, os grupos mais vulneráveis (jovens, idosos, pessoas de baixa renda ou com educação deficiente) são facilmente atingidos. Conforme já analisado, nos Estados Unidos essa modalidade de crédito é a responsável pela maior parte dos pedidos de falência pessoal, pois trata-se de um instrumento de crédito distribuído indiscriminadamente à massa de consumidores, que disponibiliza um crédito sem garantias e com altas taxas de juros. ${ }^{97}$

\footnotetext{
${ }^{96}$ DERRUPÉ, J. Rapport de Synthese. L'endettement, Travaux de L'Association Henri Capitant - Journées argentines, Tome XLVI, 1995. P. 34.

${ }_{97}$ Cabe destacar que existem dois tipos de usuários de cartões de crédito: os convencionais, que utilizam o cartão predominantemente para realizar transações cotidianas, sem efetuar empréstimos, e os que utilizam o cartão como forma de financiamento ao consumo, o que ocorre sempre que o usuário efetua apenas o pagamento do valor mínimo do cartão ou quando conclui uma compra parcelada a juros pela administradora do cartão. Aqueles se identificam com os rational consumers (consumidores racionais), e estes com os hyperbolic discounters (consumidores contumazes). Sobre a classificação dos consumidores em "rational consumers" (consumidores racionais) vs. "hyperbolic discounters" (consumidores que preferem consumir do que poupar), ver: LAIBSON, D. Golden Eggs and Hyperbolic Discounting. Quarterly Journal of Economics, May, 1997, p. 443-477; e LAIBSON, D; REPETTO, A. e TOBACMAN, J. A Debt Puzzle, NBER Working
} 
Iain Ramsay ilustra os efeitos dos abusos praticados no mercado de cartões de crédito citando o debate ocorrido no Parlamento Inglês, durante a discussão de reformas na Lei de Empresas (Enterprise Act), o qual se transcreve:

These days, [credit cards] are enabling young people to accumulate massive debts in the hope that something will turn up to anable them to pay them off. I am aware of one young man who managed to run up debts of \& 250.000. Surely it is impossible for any credit company - or series of credit companies; I think that about 20 credit card companies were involved - to allow a debt of $\& 250.000$ to be run up in that way. There is great danger unless we seriously consider that matter. Borrowing has become a habit, and the use of easy access to credit is creating a penalty that many of the young will have to face in years to come (UK HL Parliamentary Debates, second reading, Enterprise Bill col 161 (2 July 2 2002) - Lord Boardmanhttp://www.publications.parliament.uk/pa/ld199900/ldhansrd/pdvn/lds02/text/2070 2-04.htm\#20702-04 head0). ${ }^{98}$

Os abusos praticados no mercado subprime no âmbito das operações de crédito com garantia hipotecária também são motivo de preocupação, pois o comportamento negligente dos fornecedores que concederam indiscriminadamente empréstimos a condições abusivas e securitizaram os títulos para negociação nas bolsas de valores está na origem da crise financeira norte-americana que se espalhou por todo o mundo. Os sinais da crise já eram anunciados por algumas entidades de defesa do consumidor no mercado financeiro, e atualmente é motivo de grandes debates mundiais. ${ }^{99}$

Atualmente existe forte clamor pela regulamentação do mercado financeiro, pois a partir da crise financeira e de crédito norte-americana, em 2009, ficou evidente que os efeitos da falta de regras rígidas para impedir práticas lesivas ao consumidor de crédito não são sentidos apenas individualmente pelo consumidor prejudicado, mas, sim, por toda a sociedade. A atuação desenfreada de agentes despreocupados com o interesse social neste

Paper, 2000; e ANGEletos, G. M.;LAIBSON, D.; REPETTO, A e TOBACMAN, J. The Hyperbolic Consumption Model: Calibration, Simulation and Empirical Evaluation. Journal of Economic Perspectives, 2001, p. 47-68. É este segundo tipo de consumidor (hyperbolic discounters) que proporciona as maiores margens de lucro para as empresas administradoras de cartões de crédito, ainda que nesta categoria estejam incluídos aqueles consumidores com as mais altas quantias inadimplidas, e que, pela legislação norteamericana, recebem o perdão pelas dívidas em virtude do procedimento de falência. A despeito disso, portanto, as empresas continuam a praticar os abusos porque continuam obtendo lucros. Ronald Mann comprova que as empresas de cartão de crédito auferem grandes lucros com os clientes inadimplentes, pois esses não deixam de fazer pagamentos, muito embora estejam em débito. Entretanto, a partir do deferimento do requerimento de falência, esses clientes deixam de ser rentáveis. Dessa forma, retardando a decisão do consumidor sobre o requerimento, o período de alta rentabilidade do credor aumenta. (MANN, R. J. Bankruptcy reform and the "sweat box" of credit card debt. University of Illinois Law Review, vol. 2007, p. 375-403).

${ }^{98}$ RAMSAY, I. Consumer Credit Society and Consumer Bankruptcy..., cit., 2003.

${ }^{99}$ Como o que ocorreu na $8^{\text {th }}$ International Conference on Financial Services, London, November/2008. 
setor representa um perigo tanto para a saúde e segurança do consumidor, quanto para o bom funcionamento do mercado. ${ }^{100}$

Em face do novo cenário mundial, o sobreendividamento tem sido uma preocupação constante dentre as entidades de defesa do consumidor, pois muito se fala em salvar empresas e instituições financeiras em crise, mas pouco se fala sobre a situação dos indivíduos e famílias que perderam suas casas e estão superendividados. ${ }^{101}$ Em vista disso, assim como no final do século XIX e início do século XX a doutrina liberal passou a ser fortemente questionada, pois a livre competição na sociedade moderna industrial mostrouse injusta e autodestrutiva, demandando uma maior regulamentação do mercado, o mesmo movimento volta a acontecer na sociedade do crédito pós-moderna. Mesmo diante da existência de regulamentação interna do mercado financeiro, como defendem muitos economistas e juristas, existe pouco controle no que tange à relação entre o mercado financeiro e o consumidor de crédito, e a permissão de abusos nas relações de consumo revelou-se prejudicial ao mercado como um todo.

Em termos de direito comparado, são escassas as leis que procuram responsabilizar expressamente as instituições financeiras pela má concessão do crédito. Argumenta-se que a própria existência de um procedimento que permita a extinção dos débitos do consumidor excessivamente endividado já é uma forma de imposição de um comportamento mais diligente às instituições financeiras, que, em tese, não concederão empréstimo a quem não tiver condições de restituir os valores. Kazuhiko Yamamoto esclarece que, no Japão, não há uma responsabilização legal dos fornecedores de crédito pelo descuido na relação com seus devedores, mas que os credores que emprestam com muita facilidade podem ser criticados sob o plano moral e estarão sujeitos a perder seus créditos em razão do procedimento da falência civil, que existe naquele país desde 1952,

\footnotetext{
${ }^{100}$ A crise financeira originada nos Estados Unidos foi uma prova concreta de que Adam Smith estava certo ao preocupar-se com a atuação dos empresários imprudentes e perdulários, defendendo a regulamentação do mercado financeiro. Smith defendia a restrição legal das taxas de juros (existência de leis contra a usura), mas, como destaca Amartya Sen, muito embora essa questão da limitação da taxa de juros esteja fora dos interesses contemporâneos, "o argumento dos perdulários e empresários imprudentes mostra a possibilidade de que, em certas circunstâncias, as motivações do lucro privado podem realmente ser contrários aos interesses sociais". (SEN, A.. Desenvolvimento como liberdade. cit. p. 150).

${ }^{101}$ A fim de viabilizar os debates, a European Coalision for Responsible Credit elaborou sete princípios que devem orientar a concessão de empréstimos responsáveis, conforme segue: 1) o crédito acessível e responsável deve ser fornecido para todos; 2) as relações de crédito devem ser transparentes e compreensíveis; 3) o empréstimo deve a todo o tempo ser cauteloso, responsável e justo; 4) a adaptação deve ser preferida ao cancelamento do crédito; 5) a proteção legal deve ser efetiva; 6) o sobreendividamento deve ser uma preocupação pública; 7) os tomadores devem ter meios adequados para defender seus direitos e manifestar suas preocupações. Disponível em: <http://www.responsible-credit.net/index.php?id=2516> . Acessado em 10 de novembro de 2008.
} 
mas que, seguindo a tendência mundial, passou apenas a ser utilizado em larga escala a partir da década de $70 .^{102}$

Na Bélgica, a sanção ao fornecimento de crédito irresponsável decorre não só da existência do procedimento de recuperação financeira, mas também da imposição para que os credores colaborem para o Fundo de Controle do Sobreendividamento, que arcará subsidiariamente com pagamento do mediador no processo de insolvência, sob o fundamento de que eles são também responsáveis pelo endividamento excessivo do consumidor. ${ }^{103}$ Também na legislação francesa, existe uma norma que impõe uma forma de responsabilização dos credores além da simples extinção dos débitos no procedimento de rétablissement personnel. O artigo L. 331-7, alínea 6, do Code de la Consommation, determina que, para a aplicação das medidas de recuperação pessoal (re-escalonamento da dívida, redução dos juros, etc.), a Comissão de análise do sobreendividamento deverá levar em consideração o conhecimento que cada fornecedor de crédito poderia ter, no momento da conclusão do contrato, a respeito da situação de endividamento do devedor. ${ }^{104}$ Dessa maneira, é possível sancionar de maneira diversa cada credor, na medida da sua contribuição para o endividamento do devedor.

Por fim, cumpre mencionar o National Credit Act da África do Sul, que contém um capítulo sobre a política do crédito ao consumo, no qual consta uma seção que dispõe expressamente sobre o empréstimo negligente (reckless credit) e o sobreendividamento. $\mathrm{O}$ diploma sul-africano impõe algumas obrigações aos fornecedores para prevenir o empréstimo negligente, quais sejam: a proibição de firmar o contrato sem antes tomar as medidas razoáveis (i) para se certificar de que o consumidor tem a necessária compreensão dos riscos e dos custos do crédito oferecido, bem como de seus direitos e obrigações, além do que deverá (ii) analisar o histórico de crédito do consumidor e (iii) verificar a existência de meios para cumprimento do contrato (art. 81, 2 do NCA). Dessa forma, se o fornecedor descumprir uma destas obrigações, ou se, de qualquer maneira, conceder o crédito mesmo que todas as informações obtidas indiquem que o consumidor (i) não compreendeu os riscos, custos ou obrigações do contrato ou (ii) que será levado ao sobreendividamento, a concessão do crédito será caracterizada como negligente (art. 80, 1 do NCA). Uma vez

\footnotetext{
102 YAMAMOTO, K.. Rapport Japonais. L'endettement, Travaux de L'Association Henri Capitant Journées argentines, Tome XLVI, 1995. P. 160.

103 GROOTE, B.. Citizenship and Consumer Insolvency under Belgian Law. Paper apresentado na "Conference on Consumer Law", África do Sul, Cidade do Cabo, abril/ 2007.

${ }^{104}$ Redação original do artigo L. 331-7, alínea 6, do Code de la Consommation: "Pour l'application du présent article, la commission prend en compte la connaissance que pouvait avoir chacun des créanciers, lors de la conclusion des différents contrats, de la situation d'endettement du débiteur. Elle peut également vérifier que le contrat a été consenti avec le sérieux qu'imposent les usages professionnels ».
} 
declarado negligente, o crédito poderá ser suspenso, reestruturado ou extinto, de acordo com o procedimento de reorganização em caso de sobreendividamento (art. 87 do NCA).

\subsubsection{Acidentes da vida que ocasionam o sobreendividamento passivo}

Em razão do aumento da oferta do crédito, bem como do incentivo para a utilização do crédito ao consumo, muitos indivíduos, consciente ou inconscientemente, acabaram entrando em sérias dificuldades financeiras e ficando manifestamente impossibilitados de reembolsar as quantias emprestadas. A esse tipo de endividamento a doutrina francesa deu o nome de "sobreendividamento ativo" (surendettement active). Outros, contudo, não sofriam necessariamente de um excesso de débitos, mas sim, da falta de recursos para adimplir as suas obrigações, em razão do acontecimento de um fato que alterou a sua capacidade financeira. Ou seja, em razão de um acidente da vida, como o desemprego, a ruptura familiar, a doença ou qualquer outra forma de diminuição da renda, o indivíduo teve a sua capacidade econômica reduzida ou o seu custo de vida encarecido, de maneira a impossibilitar o cumprimento das obrigações assumidas. Essa situação foi chamada pela doutrina francesa de sobreendividamento passivo (surendettement passive).

De acordo com o relatório $\mathrm{n}^{0} 60$ do Senado francês, as comissões de sobreendividamento indicaram que as principais causas do sobreendividamento entre os anos de 1994 e 1996 eram os acidentes da vida, como o desemprego (38\%), a doença (17\%), a separação ou morte de familiar (21\%). Ademais, constatou-se que os planos de reorganização de dívidas, que impunham o pagamento de prestações periódicas, não estavam sendo cumpridos, pois os sobreendividados passivos não tinham recursos disponíveis para tanto, de maneira que de nada adiantava os esforços das comissões de sobreendividamento no sentido de conciliar os interesses dos credores com as possibilidades dos devedores. ${ }^{105}$ Esses fatores levaram à edição da lei de 29 de julho de 1998, que alterou o procedimento de tratamento do sobreendividamento pra atender os indivíduos que não tinham meios de cumprir o plano de pagamento, permitindo a concessão de uma moratória ao devedor insolvente e, em último caso, a extinção parcial ou total das dívidas. Posteriormente, a lei de $1^{\circ}$ de agosto de 2003 veio em socorro dos indivíduos com a situação financeira irremediavelmente comprometida, possibilitando a

${ }^{105}$ WHITE, M. J. Bankruptcy reform and credit cards. cit. p. 175-199. 
rápida extinção das dívidas pelo procedimento do restabelecimento pessoal (rétablissement personnel).

Nos Estados Unidos, as estatísticas não são precisas, de maneira que existe uma divergência a respeito da contribuição dos acidentes da vida no número de requerimentos de falência pessoal. Sullivan, Warren e Westbrook apresentam dados segundo os quais $67 \%$ dos pedidos são decorrência do desemprego. ${ }^{106}$ Por outro lado, Michelle White coloca em dúvida essa estatística e argumenta que a ocorrência de fatos adversos não explica o porquê do aumento nos pedidos de falência, pois esses eventos não se tornaram mais freqüentes ao longo dos anos. ${ }^{107}$ Como visto anteriormente, a autora defende que o aumento nos pedidos de falência ocorre em razão da oferta indiscriminada de crédito, sobretudo por meio dos cartões de crédito, que fez aumentar o endividamento do consumidor. De qualquer forma, mesmo nos Estados Unidos, os acidentes da vida continuam dentre as principais razões para o agravamento da situação financeira do indivíduo.

Um outro fator, contudo, deve ser considerado. Foi dito anteriormente que, na atual sociedade neoliberal, a atuação do Estado na prestação dos direitos sociais, como educação, saúde, esporte e cultura, bem como na garantia do seguro social, em caso de acidentes da vida como desemprego ou doença, vem sendo paulatinamente reduzida, sendo que o crédito passou a ser utilizado para suprir as deficiências do Estado Social (crédito à educação, crédito habitacional, seguro saúde privado, etc). ${ }^{108}$ Essa "privatização do bemestar social" interfere no endividamento de duas maneiras: a) primeiramente, obriga o particular a pagar por serviços que pela sua natureza deveriam ser custeados pelo Estado, encarecendo o custo de vida, como ocorre com a educação e a saúde; ${ }^{109}$ b) ademais, caso ocorra um evento adverso, como o desemprego, a morte na família ou o divórcio, o indivíduo fica desprotegido, já que o Estado reduziu as garantias sociais, ou estas se tornaram insuficientes. Portanto, ainda que os acidentes da vida não tenham se tornado mais freqüentes ao longo do tempo (o que, na verdade, vai depender da realidade sócioeconômica de cada país), a redução do Estado social tornou os indivíduos mais suscetíveis ao endividamento em virtude desses acontecimentos.

\footnotetext{
${ }^{106}$ SUlliVAN, T. A.; WARREN, E.; WESTBROOK, J. L.. The Fragile Middle Class: Americans in Debt. Yale University Press, 2000. Apud WHITE, M. J. Bankruptcy reform and credit cards. cit..

${ }^{107}$ WHITE, M. J. Bankruptcy reform and credit cards. cit..

${ }^{108}$ Ver supra notas 62 a 65.

${ }^{109}$ Nesse sentido, Iain Ramsay questiona se na Europa o crescimento dos casos de superendividamento tem relação direta com o declínio na prestação dos direitos sociais pelo Estado. Ver em: RAMSAY, I. Models of Consumer Bankruptcy: Implications for Research an Policy. Journal of Consumer Policy 20: 269-287, 1997
} 
Assim, se na passagem do Estado Social para o Estado Neoliberal globalizado, o papel do Estado foi sendo reduzido e ocupado pela iniciativa privada, passou-se a discutir não só a transferência dos direitos, mas também dos deveres e dos princípios do Estado Social para os entes privados que o substituíram. Surge o conceito de "poderes sociais" (que será novamente abordado quando for tratada a incidência dos direitos fundamentais nas relações privadas) que se refere aos grandes conglomerados e empresas multinacionais, inclusive instituições financeiras e concessionárias de serviços públicos, que vêm substituindo o papel do Estado na prestação de serviços essenciais. Os valores sociais, de dignidade e de solidariedade, que já tinham sido incorporados nas relações privadas desde meados do século passado, servem de fundamento para a legislação protetiva do consumidor sobreendividado. Johanna Niemi-Kiesiläinen argumenta que os benefícios tradicionais do desemprego são insuficientes e inadequados para ajudar as pessoas excessivamente endividadas, de maneira que as leis de reorganização financeira são vistas na Europa como parte da proteção do Estado Social. ${ }^{110}$

Por fim, deve ser mencionada a doutrina de Thomas Wilhelmsson a respeito do princípio da força maior social, ou social force majeure, pela qual um indivíduo em dificuldades financeiras por causa do desemprego, doença, divórcio ou situação análoga, não deveria ser considerado culpado pelo atraso no cumprimento de uma obrigação. ${ }^{111}$ De acordo com Johanna Niemi-Kiesiläinen, esta doutrina representa a introdução dos valores do Estado Social no âmbito das relações privadas, o que já vinha ocorrendo no direito privado com a compreensão de que a parte mais fraca deve ser protegida, exemplificando com o direito do consumidor e o direito laboral. ${ }^{112}$

O conceito de força maior social, combinado com o princípio da proteção da parte mais fraca e da boa-fé contratual, será indispensável para as conclusões finais acerca da tutela do endividamento excessivo à luz do direito brasileiro, pois defende-se que esses acidentes da vida, responsáveis pela alteração da condição pessoal da parte mais fraca na relação contratual, poderão fundamentar o dever de renegociação do contrato por alteração de circunstâncias subjetivas, desde que concorram outros requisitos que serão analisados na Parte II deste trabalho.

\footnotetext{
${ }^{110}$ NIEMI-KIESILAINEN, J. Consumer Bankruptcy in Comparison: Do We Cure a Market Failure or a Social Problem? cit., p. 481.

111 WILHELMSSON,T. Social Force Majeure - A New Concept in Nordic Consumer Law. Journal of Consumer Policy 13: 1-14, 1990, p. 1 - 14

${ }^{112}$ NIEMI-KIESILÄINEN, J.. Collective or Individual? Constructions of Debtors and Creditors in Consumer Bankruptcy. In: RAMSAY, I.; WHITFORD, W. e NIEMI-KIESILÄINEN, J. (editors), Consumer Bankruptcy in Global Perspective, Hart Publishing UK, 2003.
} 


\section{CAPÍTULO 2 - O PROBLEMA DO ENDIVIDAMENTO EXCESSIVO NA REALIDADE SÓCIO-ECONÔMICA BRASILEIRA}

Na seção anterior foi abordado o surgimento do sobreendividamento nos países desenvolvidos, especialmente nos Estados Unidos e na França, indicando-se os seguintes fatores que contribuíram para este fenômeno:

1) Desregulamentação do mercado financeiro, que levou ao aumento da disponibilidade do crédito para a população em geral, inclusive a de baixa renda, em razão da possibilidade de compensar os riscos com taxas de juros mais altas;

2) Desenvolvimento tecnológico, que permitiu o aperfeiçoamento dos sistemas de cadastro e de classificação do crédito, viabilizando o fornecimento de crédito em larga escala para os consumidores a taxas diferenciadas;

3) Publicidade mais abrangente e agressiva para estimular o consumo tanto dos bens e serviços disponíveis no mercado, quanto do próprio crédito;

4) Concessão de crédito de maneira predatória, ou seja, em condições abusivas a indivíduos que manifestamente não terão capacidade de reembolsar as quantias;

5) Redução da atuação do Estado Social que deixou os indivíduos mais suscetíveis aos acidentes da vida que alteram a sua capacidade econômica, seja reduzindo a renda, seja aumentando o custo de vida. Resta saber em que medida esses fatores podem ser verificados na realidade social, econômica e jurídica brasileira.

Nas seções seguintes serão analisados o crescimento da demanda pelo crédito e a situação do endividamento no Brasil, com especial destaque para a extensão da modalidade do crédito consignado para aposentados e pensionistas do INSS, pessoas que merecem tratamento diferenciado pelo ordenamento jurídico em razão de sua condição especial reconhecida constitucionalmente. Por fim, será feita uma abordagem geral a respeito da legislação sobre crédito ao consumo, com uma análise crítica a respeito das recentes alterações que deixaram o crédito mais perigoso, e da ausência de legislação que confira um tratamento global às situações de endividamento excessivo. 


\section{Seção 2.1 - O crescimento da demanda pelo crédito no Brasil}

Diferentemente do que ocorreu nos Estados Unidos e na Europa, o crescimento da demanda pelo crédito no Brasil não guardou relação direta com a desregulamentação das taxas de juros. A abolição dos limites de juros cobrados pelas instituições financeiras no Brasil ocorreu, seguindo a tendência mundial, a partir da década de 70, com a consolidação da jurisprudência do Supremo Tribunal Federal sobre a interpretação do Decreto 22.626 de 1933 (lei do mútuo) e da lei 4.595 de 1964 (lei da reforma bancária), que culminou na edição da súmula 596 na seção plenária de 15 de dezembro de 1976. Já o crescimento da demanda pelo crédito é um fenômeno recentíssimo, que teve o seu "boom" a partir de 2005, conforme será analisado a seguir. Primeiramente, entretanto, trataremos da abolição dos limites das taxas de juros praticadas pelas instituições financeiras.

No Brasil, a livre estipulação de juros foi instituída, sob influência da ideologia liberal, por uma lei de 24 de outubro de 1832, orientação que também foi seguida pelo Código Comercial de 1850 (art. 248) e pelo Código Civil de 1916 (art. 1262). Com a crise do café de 1920, que acarretou uma série de pedidos de falência, seguida da crise de wall street em 1929, iniciou-se um período de dirigismo contratual, que no Brasil teve como marco a Era Vargas, durante a qual foi editado o Decreto 22.626 de 1933, que estabeleceu o limite de juros nos empréstimos em dinheiro ao dobro da taxa legal (6\% ao ano, nos termos do artigo 1.062 do Código Civil de 1916), de maneira que a taxa de juros máxima permitida no território nacional passou a ser de $12 \%$ ao ano. Dessa forma, se, num contrato qualquer, fosse estipulada taxa de juros superior a esse patamar, não só era cominada a sanção de nulidade contratual (art. 11 do Decreto 22.626), como também o mutuante cometia crime contra a economia popular, previsto pelo art. $4^{\mathrm{o}}, a$, do Decreto-Lei 869 de 1938 e posteriormente pelo art. $4^{\circ}, a$, da Lei 1.521 de 1951.

Em 1964 foi editada a lei n ${ }^{\circ}$ 4.595/64 (lei da reforma bancária), que assim estabeleceu em seu art. $4^{\circ}$, inciso IX:

Art. $4^{\circ}$ Compete ao Conselho Monetário Nacional, segundo diretrizes estabelecidas pelo Presidente da República: (...) IX - Limitar, sempre que necessário, as taxas de juros, descontos comissões e qualquer outra forma de remuneração de operações e serviços bancários ou financeiros, inclusive os prestados pelo Banco Central da República do Brasil, assegurando taxas favorecidas aos financiamentos que se destinem a promover;

A partir desta norma, o Supremo Tribunal Federal passou a entender que caberia ao Conselho Monetário Nacional estabelecer limites às taxas de juros praticadas pelas 
instituições oficiais, e, como esse órgão não havia estipulado (como até hoje não estipula) qualquer limite, as instituições financeiras integrantes do sistema financeiro nacional estariam livres para praticar as taxas de juros que entendessem mais adequadas, não estando sujeitas ao limite previsto pelo Decreto 22.626/1933. Esse entendimento foi consolidado na súmula 596 do STF, editada na seção plenária de 15 de dezembro de 1976, segundo a qual "as disposições do decreto 22.626/1933 não se aplicam às taxas de juros e aos outros encargos cobrados nas operações realizadas por instituições públicas ou privadas, que integram o sistema financeiro nacional". Esse entendimento não sofreu qualquer alteração até o presente momento.

Entretanto, a liberação das taxas de juros não teve no Brasil o mesmo efeito imediato no crescimento do crédito ao consumo que teve nos países desenvolvidos, onde a demanda pelo consumo e a necessidade de conferir maior poder aquisitivo ao consumidor foram fatores que pressionaram os governos a incentivar a concessão de crédito, liberando as taxas de juros. No Brasil, a industrialização ocorreu um século mais tarde, de maneira que primeiramente foram desenvolvidos os instrumentos para financiar a produção, e posteriormente começaram a surgir modalidades mais sofisticadas de crédito ao consumo. É bem verdade que a estruturação do mercado financeiro brasileiro para atender o consumidor de bens e serviços iniciou-se a partir da década de 60, com a própria Lei da Reforma Bancária (Lei 4.594/1964), e outros atos legislativos, como a regulamentação do arrendamento mercantil (leasing) pela Lei 6.099/1974 e a criação da garantia de alienação fiduciária pelo Decreto 911/1964. José Reinaldo de Lima Lopes informa que, após a Lei 4.595/1964, as indústrias automobilísticas foram obrigadas a organizar seus próprios bancos, ${ }^{113}$ desenvolvendo o financiamento para aquisição de veículos, que até os dias de hoje ocupa posição de destaque no volume de crédito ao consumo no Brasil.

Todavia, a ausência de condições macroeconômicas favoráveis, em razão da instabilidade monetária (hiperinflação), da insegurança quanto à solvabilidade dos agentes econômicos (risco de inadimplência) e das crises institucionais (golpes de Estado, ditadura militar), bem como a forte regulação do mercado financeiro, ${ }^{114}$ impediram a explosão do crédito ao consumo nos moldes ocorridos nos países desenvolvidos. Apenas após o

\footnotetext{
${ }^{113}$ LOPES, J. R.. op. cit. p. 86.

${ }^{114}$ Apesar das taxas de juros terem sido liberadas a partir da lei 4.565/64, o sistema financeiro era fortemente regulado em função da política monetária, com a pretensão de trazer maior estabilidade à economia. Segundo as avaliações do Banco Central, havia muitas exigências burocráticas, bem como excessiva regulação do crédito subsidiado e direcionado a mercados especiais (crédito rural, crédito habitacional, crédito às microempresas), o que diminuía a possibilidade de desenvolvimento do seguimento do crédito livre. Em razão disso, o BC passou a estudar a possibilidade de flexibilização do mercado de crédito direcionado, o que implica alternativas para os setores da economia beneficiados.
} 
controle da inflação, com o plano real de 1994, e a relativa estabilidade econômica adquirida nos anos que se seguiram, é que foi possível pensar em desenvolvimento do mercado de consumo e de crédito. ${ }^{115}$ A privatização de bancos públicos, a abertura à entrada de instituições financeiras estrangeiras e a melhoria da supervisão e regulação do setor financeiro também são apontados como fatores que deveriam impulsionar o aumento do volume de crédito concedido no país. ${ }^{116}$

Contudo, mesmo após o aumento da confiança e melhoria geral das condições macroeconômicas, decorrentes do controle inflacionário e da estabilidade econômica, a oferta de crédito continuava insatisfatória para os padrões de uma economia de mercado.

Por esse motivo, o Banco Central do Brasil, entendendo que a baixa oferta de crédito em muito se devia ao seu alto custo, implantou, a partir de outubro de 1999, um projeto denominado "Juros e Spread Bancário", com o objetivo de implantar medidas para reduzir o custo do crédito e incentivar o crescimento do mercado financeiro. Tal como consta do relatório de avaliação de 3 anos do projeto, "as medidas que o Banco Central vêm implementando desde 1999, no âmbito desse projeto, estão basicamente voltadas a melhorar e resgatar a cultura de crédito no Brasil, aumentar a segurança jurídica das operações, reduzir os riscos de crédito e as fricções na intermediação financeira, assim como aumentar a transparência e a concorrência". ${ }^{117}$

Dessa forma, com as condições macroeconômicas favoráveis, e com a atuação do Banco Central no sentido de incentivar o crescimento da oferta de crédito a um custo mais acessível, o volume de crédito no Brasil começou a crescer a partir do ano 2000. Com a adoção de medidas como a redução do percentual de recolhimento dos depósitos

\footnotetext{
${ }^{115}$ De acordo com o Relatório de avaliação de 3 anos do projeto do Banco Central "Juros e Spread Bancário no Brasil", de dez de 2002: "O sistema financeiro nacional observou mudanças profundas a partir do Plano Real, com a estabilização dos preços e a maior abertura da economia. A queda da inflação significou o fim do "float" e a maior dependência das instituições financeiras bancárias de fontes mais convencionais de receita (crédito e tarifas). No ambiente de inflação, os bancos "competiam" por depósitos, expandindo redes de atendimento e oferecendo serviços "gratuitos" aos clientes em troca de depósitos e arrecadações, preferencialmente aplicados em títulos públicos sem risco. Com a estabilização, os bancos tiveram que se ajustar, passar a cobrar tarifas pelos serviços e competir de forma mais convencional". (...) "A economia fechada e fortemente protegida pelo Estado explicava a baixa competição no mercado financeiro e a predominância de créditos públicos e direcionados, com a forte participação de bancos públicos e a pequena presença de bancos estrangeiros. A abertura da economia e o reconhecimento das dificuldades financeiras do setor público deram lugar a um modelo mais convencional e menos intervencionista. Nesse novo cenário, ao Estado ficou reservado o papel de promover as condições macroeconômicas favoráveis (estabilidade) ao investimento privado. Com as dificuldades financeiras do Estado, não se poderia esperar que o financiamento de desenvolvimento continuasse liderado por créditos direcionados e de bancos públicos". (Rel. 2001, p. 4)

${ }^{116}$ PINHEIRO, Armando Castelar. "O componente judicial dos spreads bancários", in: Economia Bancária e Crédito - avaliação de 4 anos do projeto Juros e Spread Bancário. Disponível em: $<$ http://www.bcb.gov.br/?SPREAD>. Acessado em 10 de novembro de 2009.

117 "Juros e Spread Bancário no Brasil - avaliação de 3 anos do projeto", Disponível em:

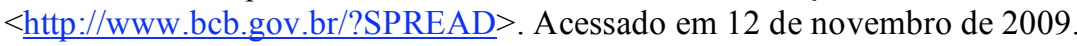


compulsórios e a redução do IOF, as taxas de juros para pessoas físicas, que eram as mais elevadas, experimentaram uma queda sensível já nos primeiros 3 meses do projeto (de $103 \%$ aa para $77,8 \%$ aa - Rel./2000, p. 7), o que gradualmente passou a surtir efeitos no volume de crédito concedido. ${ }^{118}$ Outras medidas como a maior transparência das operações financeiras, ${ }^{119}$ reformulação das Centrais de Risco para melhorar a abrangência e a qualidade das informações sobre o mercado consumidor, bem como a introdução de regras obrigando as instituições financeiras a classificarem as operações por faixa de risco (Resolução 2.682 de 21/12/1999), contribuíram também para o desenvolvimento do mercado de crédito.

$\mathrm{O}$ crédito às pessoas físicas foi a modalidade que mais cresceu nos últimos anos, pois havia ainda muito receio quanto ao risco destas operações, sendo que a melhoria na cultura do crédito estimulou o seu crescimento. Contudo, o volume de crédito à pessoa física teve sua verdadeira guinada a partir de 2005, impulsionada pela disseminação do crédito consignado, que passou a ser uma das principais modalidades de concessão de crédito, como pode ser observado do gráfico a seguir:

\section{Gráfico 4 - Evolução da participação das principais modalidades de pessoa física}

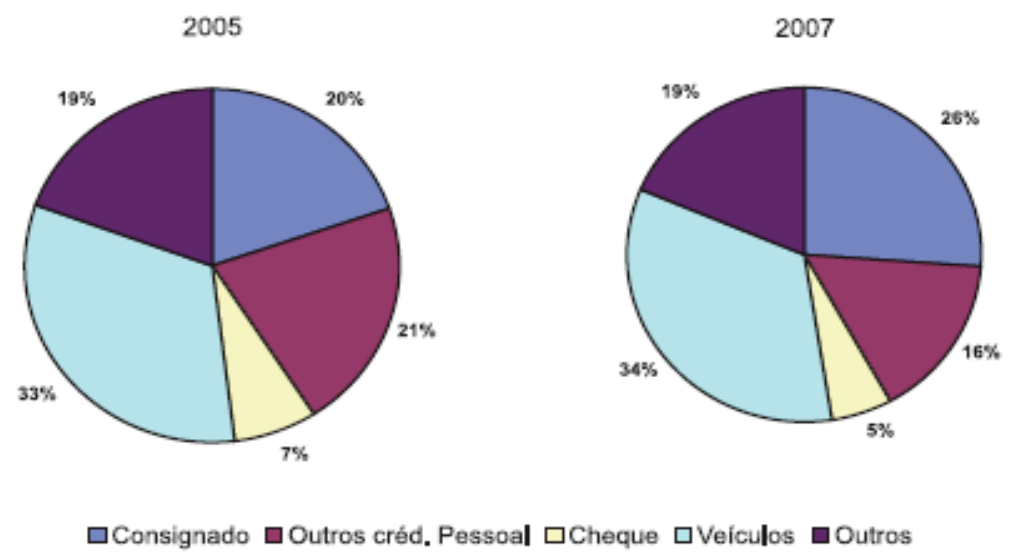

Fonte: Banco Central. Relatório de Economia Bancária e Crédito - 2007, p. 11.

\footnotetext{
${ }^{118}$ No primeiro ano de vigência do projeto, o volume de crédito para as pessoas físicas praticamente dobrou (ver gráficos 5 e 6 do rel. nov/2000 que demonstram, respectivamente, o crescimento das modalidades pessoa jurídica e pessoa física). Por outro lado, à medida que os juros e o spread bancário diminuíam, o volume de crédito livre doméstico crescia (conforme gráfico 1 do Relatório de 2004, p. 9).

${ }^{119}$ O Banco Central passou a disponibilizar, a partir de outubro de 1999, informações básicas sobre os juros nas operações de crédito, incentivando a concorrência nesse seguimento. A partir de 31.05.2000, as instituições financeiras passaram a ser obrigadas a prestar informações diárias mais detalhadas (Circular 2.957/1999 e Comunicado $\left.n^{0} 7.569 / 2000\right)$. Quanto ao cheque especial, medidas específicas foram adotadas, como a obrigatoriedade dos bancos informarem as taxas efetivas, máxima e mínima, praticadas (Circular 2.963/1999) e do fornecimento de informações mais detalhadas sobre encargos financeiros cobrados inclusive nos extratos mensais gratuitos (res. 2.808/2000, atual res. 2.835/2001)
} 
O crescimento das operações com garantia de desconto em folha de pagamento, que foram estendidas aos trabalhadores da iniciativa privada e aos aposentados e pensionistas do INSS pela Lei 10.820/2003, também foi responsável pela redução do spread bancário, já que as taxas praticadas são controladas e o risco da operação é menor.

Segundo consta do Relatório do Banco Central:

Ressalte-se que a expansão das operações de crédito pessoal, bem como a redução significativa da taxa dessa modalidade, refletiu a evolução do crédito consignado em folha de pagamento, acentuada ainda mais após sua extensão a aposentados e pensionistas do Instituto Nacional do Seguro Social (INSS) desde maio de 2004. Em dezembro de 2006, a representatividade desses empréstimos no crédito pessoal atingiu $60 \%$, com saldo de $\mathrm{R} \$$ 48,1 bilhões. Vale observar que essas operações, por apresentarem menor risco de inadimplência, devido 'a garantia de desconto direto das parcelas nas folhas de pagamento, são contratadas a taxas de juros mais baixas, aspecto que contribuiu para a queda verificada no custo médio do crédito pessoal. Assim, enquanto as operações consignadas, ao final de 2006, foram cursadas à taxa média de 33,3\%, as demais operações de crédito pessoal foram contratadas à taxa média de $73,3 \%{ }^{120}$

A guinada do crédito ao consumo a partir de 2005 pode ser constada no gráfico a seguir:

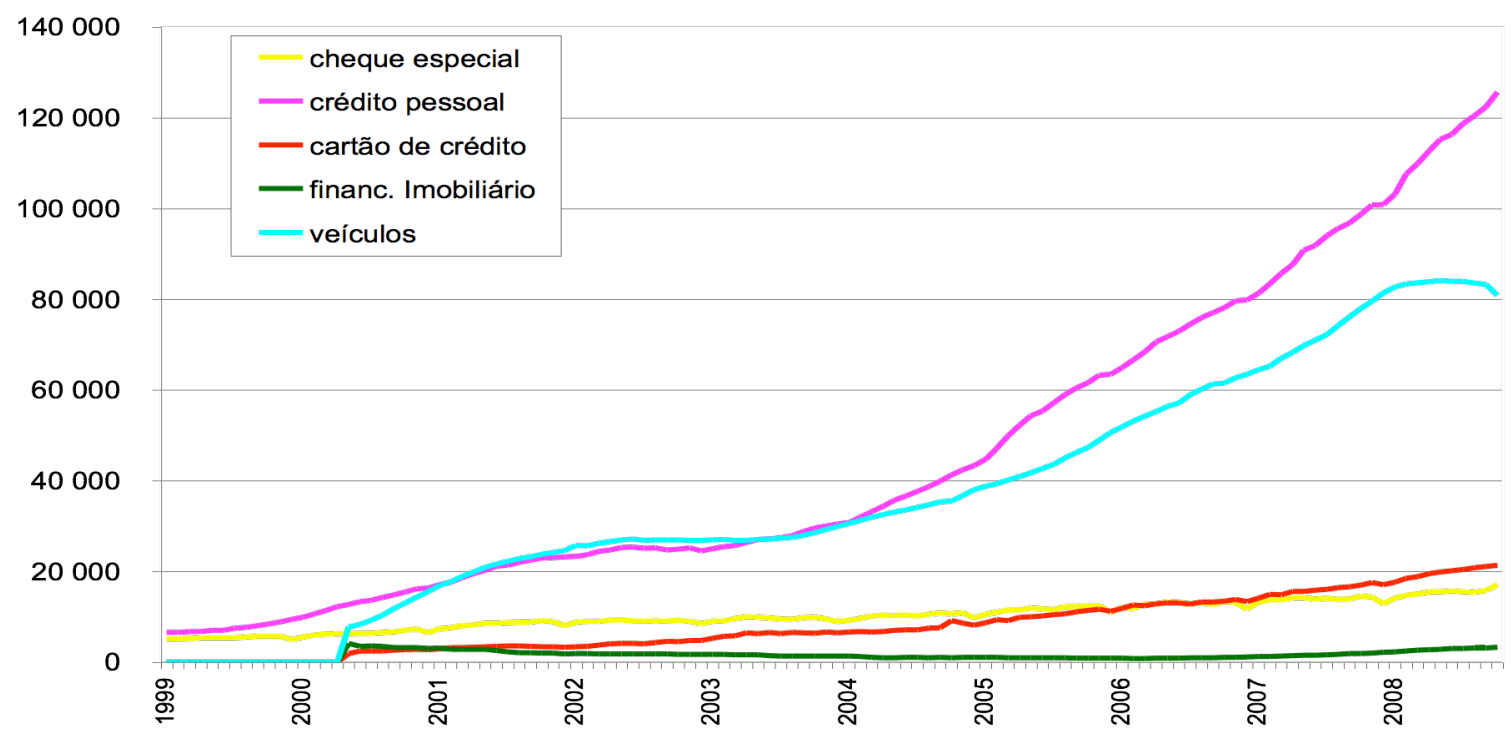

Volume total de crédito por modalidade em milhões de reais - fonte: $\underline{w w w . b c b . g o v . b r}$.

120 Relatório de Economia Bancária e Crédito, BACEN, 2006, p. 10. Disponível em: $<$ http://www.bacen.gov.br/?SPREAD>. Acessado em 12 de novembro de 2009 
Observe-se que o crédito pessoal, que inclui o crédito consignado (tópico 1.3.3), seguido pelo financiamento de veículos, foram as modalidades que mais cresceram nos últimos anos, segundo os dados do Banco Central. As operações realizadas por meio de cartão de crédito tiveram um crescimento mais modesto, de acordo com o Banco Central, mas comparando com os dados fornecidos pela ABECS (Associação Brasileira das Empresas de Cartão de Crédito) o valor negociado é bem superior (ver gráfico abaixo). De qualquer forma, observe-se que também em relação aos cartões de crédito o crescimento acentuou-se a partir de 2005.

Em milhões de reais

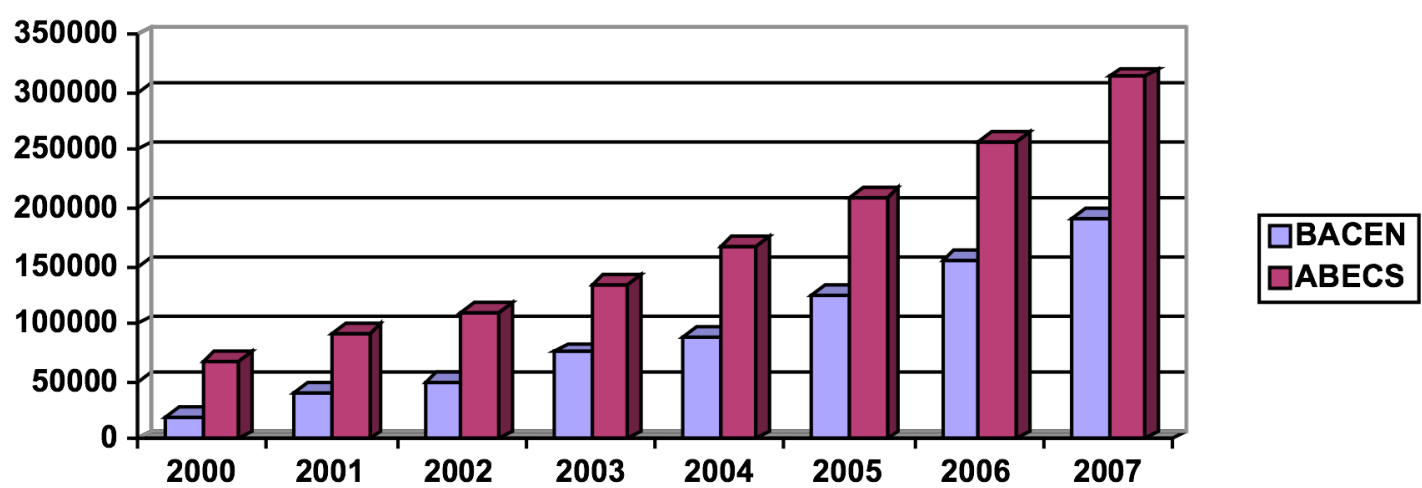

Com a explosão do crédito ao consumo, o endividamento excessivo do consumidor começa a tornar-se um verdadeiro problema social. Antes do fenômeno da explosão do crédito, os casos de endividamento excessivo eram isolados e mais facilmente imputados à má gestão financeira ou à contumácia do indivíduo. Não havia uma questão social ou uma demanda política para tutelar esses indivíduos, que permaneciam endividados até seus credores desistirem de cobrar os créditos por ausência de bens ou de renda penhoráveis, sendo que esta situação persiste até os dias atuais. O procedimento de insolvência civil não serve nem aos propósitos dos devedores, nem aos propósitos dos credores, pois é um procedimento caro, demorado, vexatório e que não preserva os direitos fundamentais mínimos do devedor, e nem mesmo o considera como parte vulnerável da relação jurídica decorrente da sociedade do crédito. 


\section{Seção 2.2 - A situação do endividamento no Brasil}

A sociedade do crédito chegou ao Brasil apenas no século XXI, e com ela surgem também as suas patologias, sendo a principal delas o endividamento excessivo do indivíduo e das famílias, conforme destacou Johanna Niemi-Kiesiläinen. ${ }^{121}$ Nesta sociedade, os consumidores são os principais agentes econômicos, de maneira que as estruturas política, cultural, econômica e jurídica trabalham para que ele cumpra com o seu papel de consumir incessantemente, e, para que isso seja possível, ele precisa endividar-se. Em outras palavras: a atual sociedade de consumo quer que as pessoas endividem-se para sustentar o crescimento econômico.

Os dados oficiais do Banco Central indicavam uma inadimplência em torno de 7\% em 2007, mas que, em novembro de 2008, chegou a 7,8\% ${ }^{122}$ e, em junho de 2009 , a $8,6 \%{ }^{123}$ No entanto, esses dados consideram apenas instituições financeiras oficiais que cumprem com a obrigação de informar corretamente os dados a respeito das suas carteiras de crédito, desconsiderando os estabelecimentos comerciais que financiam diretamente as compras dos consumidores e financeiras que exercem irregularmente a sua atividade, ou prestam informações de maneira irregular. Desconsideram também o endividamento decorrente de relações firmadas fora do Sistema Financeiro, como é o caso das dívidas de consumo de serviços essenciais, como energia elétrica, água, telefone, educação, saúde, dentre outros.

Não existe no Brasil uma fonte que retrate fidedignamente a situação do endividamento no país. Mas algumas entidades realizam pesquisas na tentativa de fornecer um panorama do endividamento. Uma das entidades mais citadas na mídia é a Federação do Comércio (Fecomércio), com sede em várias capitais, que possui um centro de Pesquisas de Endividamento e Inadimplência do Consumidor que apura mensalmente o nível de endividamento do consumidor em diversos Municípios. Apesar de não conter

\footnotetext{
${ }^{121}$ NIEMI-KIESILÄINEN, J. e HENRIKSON, A. S. Report on Legal Solutions to Debt Problems in Credit Societies, CDCJ-BU - Bureau of the European Committee on Legal Co-operation, Strasbourg, 11 Oct, 2005. Disponível em: <http://www.coe.int/T/E/Legal_Affairs/Legal_co- operation/Steering_Committees/CDCJ/ Documents/2005/CDCJ-BU\%20_2005 \%2011EREV.pdf>. Acessado em 15 de janeiro de 2009.

${ }_{122}$ Fonte: Dados BACEN divulgados em 24.12.2008.

123 Fonte: Banco Central $\quad$ - dados divulgados em 24.06.2009. Disponível em $<$ http://www.bcb.gov.br/?ECOIMPOM>. Acessado em 10 de novembro de 2009.
} 
dados oficiais e absolutos, ${ }^{124}$ essas pesquisas fornecem uma boa fonte de informações não só quanto à quantidade de endividamento, mas também quanto a sua qualidade. ${ }^{125}$

A análise dos resultados dessas pesquisas permite concluir um dado preocupante: as classes menos favorecidas (de baixa renda) são as mais atingidas pelo endividamento, o que leva a crer que os fornecedores de crédito no Brasil não estão atentando para a capacidade dos indivíduos de reembolsarem as quantias emprestadas. Esses dados revelam a prática do empréstimo predatório, que, como visto no item 1.2.3, visa a pessoas que manifestamente não têm capacidade de cumprir o contrato. De fato, é cada vez mais comum observarmos anúncios e abordagens nas ruas de promotores de venda oferecendo “crédito fácil", "sem consulta ao SPC", "sem comprovação de renda", "sem necessidade de ter conta bancária ou talão de cheques". Por outro lado, práticas comerciais ilícitas, como o envio de cartão de crédito e outros produtos financeiros sem prévia solicitação, são cada vez mais corriqueiras.

O crescimento do endividamento excessivo fez surgir iniciativas na tentativa de conciliar os interesses dos credores e dos devedores, nessas situações em que dificilmente o credor receberá seu crédito, em virtude da ausência de bens ou de rendimentos

\footnotetext{
${ }^{124}$ De acordo com a nota metodológica, os dados são coletados junto a cerca de 2.200 consumidores no Município de São Paulo.

${ }^{125}$ No último relatório relativo ao Município de São Paulo, publicado em 16 de dezembro de 2008, constatou-se que $50 \%$ dos consumidores entrevistados possuíam alguma dívida, permanecendo estável com relação ao mês anterior (49\%) e também com relação ao mesmo período de 2007 (48\%), com um leve crescimento. No mês de dezembro, o nível de endividamento diminui em razão do recebimento do $13^{\circ}$ salário, que é utilizado para pagar dívidas. No entanto, é comum o registro de percentuais de endividamento de mais de $60 \%$ ao longo do ano. ${ }^{125}$ Demonstrou-se, ainda, que quanto menor a renda dos indivíduos maior é a ocorrência do endividamento e também de inadimplência. Na faixa de renda de até 3 salários mínimos, o percentual de endividamento registrado foi de 53\%, e de inadimplência de $41 \%$. Na faixa entre 4 e 10 salários mínimos, o percentual de endividamento foi também de $53 \%$, mas o de inadimplência foi de $24 \%$. Já na faixa de renda acima de 10 salários mínimos, a situação é bem diferente: o endividamento é de $38 \%$ e a inadimplência é de $21 \%$. De acordo com o relatório, "isso acontece devido a expansão da oferta de crédito verificada nos últimos anos, que proporcionou a entrada das pessoas de baixa renda no mercado consumidor". O cartão de crédito é o principal responsável pelo endividamento dos consumidores entrevistados $\left(45,9 \%\right.$, contra $28,7 \%$ do $2^{\circ}$ colocado, que são as dívidas de carnês, e apenas $7,3 \%$ do crédito pessoal e 3,5\% do cheque especial). Dentre os consumidores que disseram possuir alguma dívida, 31\% disseram estar muito endividados, sendo que $28 \%$ disseram não ter condições de pagar as dívidas. Observamos também dados da FECOMERCIO das cidades de Belo Horizonte-MG, João Pessoa-PB e Maceió-AL sendo que as conclusões são bastante semelhantes. No relatório de Belo Horizonte, registrou-se que $40 \%$ do $13^{\circ}$ salário dos consumidores é utilizado para pagar dívidas, e 19,9\% é utilizado para fazer compras de Natal, enquanto apenas $20 \%$ reservam para poupança. Esses dados sofreram alterações com relação aos anos anteriores, em que a preferência do consumidor era gastar o $13^{\circ}$ salário com compras de Natal, e o percentual daqueles que pretendiam poupar não passava de 5\%, o que revela uma preocupação do consumidor com a atual crise financeira mundial. Em João Pessoa, o nível de endividamento é bem superior ao de São Paulo, atingindo $75 \%$ em setembro de 2008 , mas o percentual de inadimplentes é de $25 \%$. Com relação a Maceió-AL, os dados que mais chamam a atenção são os percentuais de consumidores com contas ou dívidas em atraso em relação à classe social. Os dados analisados de fevereiro de 2007 até o mesmo período de 2008 demonstram que, na classe C, o percentual variou de 49 a $66 \%$, chegando a $68 \%$ nas classes $\mathrm{D}$ e $\mathrm{E}$, sendo que, na classe $\mathrm{A}$, não passou de $52 \%$.
} 
penhoráveis do devedor, e em que o devedor precisa ter um mínimo de dignidade preservada. Essas iniciativas existem atualmente no Rio de Janeiro, organizadas e implementadas por um núcleo especializado da defensoria pública estadual, e no Rio Grande do Sul, que desenvolveu um projeto-piloto ${ }^{126}$ de conciliação por iniciativa de Juizes de Direito, respaldado no projeto "Movimento pela Conciliação" do Conselho Nacional de Justiça.

No Rio Grande do Sul, o projeto vem sendo realizado no núcleo de conciliação da escola da AJURIS, na capital Porto Alegre, e, em algumas comarcas do interior do Estado, perante o Juiz de Direito. O devedor preenche um formulário padronizado no Procon ou na Defensoria Pública indicando os credores, o montante da dívida, o valor dos seus rendimentos, dados sócio-econômicos, dentre outros dados relevantes para se ter a exata noção da capacidade de pagamentos mensais por parte do devedor e, assim, realizar o objetivo de chegar a um acordo sobre um plano de pagamento do conjunto das dívidas, dentro das possibilidades do devedor (manutenção do mínimo existencial), maximizando os interesses de ambas as partes. ${ }^{127}$ É realizada uma audiência para a qual são intimados todos os credores.

O comparecimento é facultativo, mas em verdade, sobretudo os credores sem garantia têm a consciência de que numa situação de endividamento excessivo a única maneira de lograr o recebimento de alguma quantia é chegando a um acordo. Segundo anotam Clarissa Costa de Lima, Káren Bertoncello e Maria Augusta Dall'Agnol, "nesta audiência, o superendividado e os credores são instados a encontrar uma alternativa para que o primeiro consiga saldar suas obrigações, ponderando a suas possibilidades

\footnotetext{
${ }^{126}$ Sobre os dados estatísticos e características do projeto ver: COSTA DE LIMA, C.; BERTONCELLO, K. R.D.; DALL'AGNOL, M. A.. Projeto de Mediação em Superendividamento do Consumidor: a experiência nas comarcas do interior e na capital. In: Multijuris - Primeiro Grau em Ação, ano III, $\mathrm{n}^{\circ}$ 5, junho 2008, p. 815. Sobre a justificativa teórica ver: BERTONCELLO, K. R. D.; COSTA DE LIMA, C.. Adesão ao projeto conciliar é legal - CNJ. Projeto-piloto: tratamento das situações de superendividamento do consumidor. Revista de Direito do Consumidor, $\mathrm{n}^{\circ}$ 63. São Paulo: Editora Revista dos Tribunais, p. 173.

127 "Nestes requerimentos, os requerentes-superendividados a) identificam-se, b) declinam seus dados sócioeconômicos, indicando profissão, número de dependentes, renda mensal, despesas correntes fixas (a título de luz, aluguel, telefone, alimentação, pensão alimentícia, educação, plano de saúde, medicamentos, impostos, entre outras), c) montante total da dívida do superendividamento, d) comprometimento mensal com pagamento de dívidas, e) causas da dívida (gastou mais do que ganha, desemprego, divórcio, separação, dissolução de união estável, doença pessoal ou familiar, redução de renda, morte), f) existência de registro e cadastro de inadimplentes, g) a via do conhecimento do crédito (televisão, meio eletrônico, jornal, revista, mala direta, panfletagem, telefone, telemarketing) e, por fim, procedem à h) enumeração dos credores, declinando um a um, o valor da dívida, se possui processo judicial pendente, se a dívida está vencida, se já houve tentativa de renegociação, se recebeu cópia do contrato e informações sobre juros e conseqüências de falta de pagamento. Dados esses relevantes tanto para fins estatísticos, como, e principalmente, para possibilitar composição das dívidas junto aos credores sempre atento às condições econômicas do superendividado e seu comprometimento econômico" (COSTA DE LIMA, C.; BERTONCELLO, K. R. D.; DALL'AGNOL, M. A.. cit., p. 11).
} 
financeiras, e os segundos recebam os créditos devidos". ${ }^{128}$ Caso as partes cheguem a um denominador comum, o acordo é homologado pelo juiz de direito, tornando-se título executivo judicial. No intuito de evitar dificuldades de ordem prática, os acordos são celebrados individualmente com cada credor.

O projeto-piloto tem logrado êxito, já que o índice de conciliação obtido na capital gaúcha em quatro meses de projeto já é superior ao índice nacional divulgado pelo Conselho Nacional de Justiça. ${ }^{129}$ Em entrevista realizada com Maria Augusta Dall'Agnol, em maio de 2008, ${ }^{130}$ a responsável pela coordenação do projeto em Porto Alegre declarou que eram realizadas cerca de 40 audiências por semana, e que o índice de conciliação era de $66,6 \%$; que os credores que mais se dispunham a conciliar eram as financeiras e grandes lojas; que as propostas eram as mais variadas: parcelamento da dívida, desconto de até $50 \%$, inclusive no principal, e devolução dos bens adquiridos com quitação das dívidas; que observa tanto uma boa vontade do credor, quanto o desejo de pagar do devedor.

No projeto, identificou-se que o desemprego, a doença ou morte na família e a separação ou divórcio estão dentre as principais causas do endividamento, de forma que foi possível concluir que predomina o sobreendividamento passivo. ${ }^{131}$ O Procon de São Paulo chegou a conclusões semelhantes, apurando as seguintes causas do não pagamento das dívidas: desemprego $37 \%$, falta de controle dos gastos 35\%, redução da renda em função de desemprego na família $10 \%$ e problemas de saúde $5 \%$, de maneira que as causas que caracterizam o sobreendividamento passivo chegam a $53 \%{ }^{132}$

Conclui-se, portanto, que o sobreendividamento passivo é uma questão que merece uma tutela especial pelo ordenamento jurídico, sobretudo pelo fato de que o consumidor não concorre para o agravamento da sua situação de endividamento. As circunstâncias que alteram a sua capacidade econômica são fatos alheios à sua vontade (externalidades), os quais a doutrina denominou "força maior social", 133 conceito que será retomado adiante.

\footnotetext{
${ }^{128}$ COSTA DE LiMA, C.; BertonCEllo, K. R. D.; DAll'AGNOL, M. A.. Projeto de Mediação em Superendividamento do Consumidor: a experiência nas comarcas do interior e na capital. cit., p. 11.

${ }^{129}$ Idem, ibidem, p. 10.

${ }^{130}$ A entrevista foi realizada especialmente para a coleta de dados para realização deste trabalho.

${ }^{131}$ As principais causas das dívidas em Porto Alegre: 32\% desemprego, 18\% doença/morte na família, 14\% Redução da renda, 18\% situação com mais de uma opção; e em Sapucaia do Sul e Charqueadas: 29\% desemprego, 20\% separação/divórcio, 19\% gasto maior do que a renda (idem, p. 14).

${ }^{132}$ LOPES, J. R. L., op. cit. p. 97.

133 WILHELMSSON, T. Social Force Majeure - A New Concept in Nordic Consumer Law. Journal of Consumer Policy 13: 1-14, 1990, p. 1 - 14.
} 


\section{Seção 2.3 - O crédito consignado no pagamento de salários e aposentadorias}

Especial referência merece a modalidade de crédito com reembolso (ou desconto) consignado na folha de pagamento ou nas aposentadorias, devido ao potencial comprometimento de renda permanente e risco de endividamento excessivo que pode causar. Esta modalidade já estava disponível para os servidores público, por expressa disposição legal (art. 45 da Lei 8.112, de 22 de dezembro de 1990, atualmente regulamentado pelo Decreto $\mathrm{n}^{\circ} 6.386$ de 29 de fevereiro de 2008), e foi estendido para trabalhadores da iniciativa privada e para aposentados e pensionistas pela Medida Provisória ${ }^{\circ} 130$ de 17 de setembro de 2003, convertida na Lei 10.820 de 17 de dezembro de 2003. Pelo artigo $1^{\circ}$ da Lei 10.820/2003, os empregados regidos pela CLT “poderão autorizar, de forma irrevogável e irretratável, o desconto em folha de pagamento dos valores referentes ao pagamento de empréstimos, financiamentos e operações de arrendamento mercantil concedidos por instituições financeiras e sociedades de arrendamento mercantil, quando previsto nos respectivos contratos". O parágrafo $1^{\circ}$ deste artigo permite que o desconto ocorra também sobre verbas rescisórias, no limite de 30\%.

A Lei estabelece também o limite para descontos em folha, determinando que não poderá ultrapassar $30 \%$, e havendo outras consignações voluntárias, o total delas não poderá ultrapassar $40 \%$. O Decreto $\mathrm{n}^{\circ} 4.840$ de 17 de setembro de 2003, alterado pelo Decreto 5.892 de 12 de setembro de 2006, que regulamenta a lei em questão, estabelece que, para chegar-se à remuneração disponível, para efeito do cálculo do limite para descontos, deve-se deduzir as consignações compulsórias. ${ }^{134} \mathrm{O}$ regulamento também estabelece a possibilidade do empregador e das centrais sindicais realizarem acordos com as instituições consignatárias, estabelecendo as condições gerais dos empréstimos. Se o empregado cumprir os requisitos do acordo, a instituição consignatária não poderá negar o empréstimo, mas o empregado poderá escolher por instituição que firmou acordo com empregador, com sua entidade sindical, ou qualquer outra instituição.

\footnotetext{
${ }^{134}$ Nos termos do artigo $2^{\circ}, \S 2^{\circ}$ do Decreto 4.840/03, são consignações compulsórias: "I - contribuição para a Previdência Social oficial; II - pensão alimentícia judicial; III - imposto sobre rendimentos do trabalho; IV decisão judicial ou administrativa; V - mensalidade e contribuição em favor de entidades sindicais; VI outros descontos compulsórios instituídos por lei ou decorrentes de contrato de trabalho". Ademais, não se consideram incluídos na remuneração básica: "I - diárias; II - ajuda de custo; III - adicional pela prestação de serviço extraordinário; IV - gratificação natalina; V - auxílio-natalidade; VI - auxílio-funeral; VII adicional de férias; VIII - auxílio-alimentação, mesmo se pago em dinheiro; IX - auxílio-transporte, mesmo se pago em dinheiro; e $\mathrm{X}$ - parcelas referentes a antecipação de remuneração de competência futura ou pagamento em caráter retroativo" $\left(\right.$ Art. $\left.2^{\circ} ., \S 1^{\circ}\right)$.
} 
Também foi autorizado pela mesma lei o desconto em benefícios de aposentadoria e pensão, que serão retidos e repassados à instituição consignatária pelo INSS ou pela instituição financeira na qual o benefício é recebido, nas condições estabelecidas em regulamento e observadas as normas editadas pelo INSS. O ato normativo que atualmente regulamenta o empréstimo consignado para aposentados e pensionistas do INSS é a Instrução Normativa ${ }^{\circ} 28$ de 16 de maio de 2008, que determina, dentre outras regras, que a instituição financeira tenha convênio com o INSS/Dataprev; que a autorização para desconto seja expressa; que o limite para o desconto não poderá exceder, após a dedução das consignações obrigatórias e voluntárias, o limite de 30\% para as operações de empréstimo pessoal e $10 \%$ para as operações de cartão de crédito; que as operações realizadas por meio de cartões de crédito não poderão ultrapassar duas vezes o valor mensal do benefício. Atualmente, a taxa de juros máxima permitida para esses empréstimos é de 2,5\% nas operações de crédito pessoal, e de 3,5\% para as operações com cartão de crédito, ${ }^{135}$ já que o governo permitiu um incentivo para essa modalidade, que vinha sendo pouco oferecida pelas instituições financeiras. Inicialmente o prazo do empréstimo era limitado a 36 meses, ${ }^{136}$ mas esse prazo foi elevado para 60 meses. ${ }^{137}$

O empréstimo consignado para aposentados e pensionistas sofreu diversas críticas e reivindicações por parte das entidades de defesa dessa categoria, uma vez que o endividamento dos idosos vinha crescendo assustadoramente, pois essa categoria era a mais visada pelas instituições financeiras. De fato, em razão da certeza do recebimento dos valores emprestados (redução do risco), e da boa remuneração recebida, os Bancos foram incentivados a aumentar o volume de crédito para essa categoria, que, pela sua condição especial, é mais vulnerável do que a média da sociedade.

Em verdade, o crédito consignado foi o maior responsável pelo crescimento da oferta de crédito ao consumo no Brasil, sendo que estudo do Banco Central indica que o crédito consignado para aposentados e pensionistas e para servidores públicos representam a maior parte do crédito concedido, já que as instituições financeiras não vêem vantagens em emprestar para trabalhadores da iniciativa privada, pois o risco do desemprego está sempre presente - e conforme será visto adiante, o desemprego é a principal causa do sobreendividamento.

\footnotetext{
${ }^{135}$ Instrução normativa do INSS n ${ }^{\circ} 28$ de 16 de maio de 2008, alterada pelas INs n 37 de 01/04/2009 e n 39 de $18 / 06 / 2009$.

${ }^{136}$ Instrução normativa do INSS n ${ }^{\circ} 1$ de 29 de setembro de 2005.

${ }^{137}$ Instrução normativa do INSS n ${ }^{\circ} 24$ de 20 de dezembro de 2007.
} 
Quanto aos riscos, em 2006, o Banco Central registrava uma taxa de inadimplência de apenas 2,5\%, de maneira que o único risco era a morte do segurado. No entanto, conforme consta do relatório do Banco Central, os Bancos e Financeiras normalmente "diluem nas parcelas um seguro que quita o empréstimo na hipótese de falecimento do contratante". ${ }^{138}$ Quanto à remuneração, inicialmente as taxas eram liberadas, e variavam de acordo com o prazo do financiamento. ${ }^{139}$ Posteriormente foram limitadas em 2,9\% pela instrução normativa $n^{\circ} 6$ de 31 de maio de 2006, sofrendo outras reduções para 2,86\% em julho de 2006, 2,78\% em outubro de 2006, 2,64\% em junho de 2007, e finalmente em 2,5\%, a partir de 5 de março de 2008 .

O nível de endividamento dos aposentados passou a preocupar o Governo, pois essas pessoas, que possuem necessidades especiais e cuja única fonte de renda, em geral, é o benefício recebido, eram também levadas a tomar empréstimos para ajudar seus filhos, netos e outros familiares, tendo em vista a taxa de juros reduzida. Ademais, essa categoria social, pela sua própria condição fragilizada e compreensão reduzida com relação às inovações tecnológicas, é mais vulnerável à publicidade, que passou a ser agressivamente veiculada pelos meios de comunicação, correspondência, cartazes, telemarketing etc., de maneira que, mesmo sem precisar do empréstimo, os aposentados eram levados a contratar, comprometendo sua renda por um longo prazo e, dessa forma, sendo-lhes imposta uma redução na qualidade de vida. Saliente-se, ademais, que mesmo sendo uma taxa reduzida em relação à média nacional, o percentual de $2,5 \%$ ao mês é ainda muito elevado, inclusive para os padrões internacionais. Outro dado preocupante é o de que os aposentados que mais contratam são aqueles com benefício de até um salário mínimo. ${ }^{140}$

Por outro lado, cresciam também as denúncias pelo Procon e outras entidades de defesa do consumidor e pelo próprio Tribunal de Contas da União de que as instituições financeiras estavam desrespeitando as normas para concessão do crédito consignado. Conforme notícias veiculadas na imprensa, os bancos desrespeitavam tanto os limites de taxa de juros estipulados, ${ }^{141}$ quanto normas como a proibição de oferecimento de crédito

\footnotetext{
${ }^{138}$ Banco Central do Brasil, "Relatório de Economia Bancária e Crédito", 2005, p. 72.

${ }^{139}$ Conforme consta do relatório do Banco Central de 2005, para o empréstimo com prazo de 36 meses o Banco Cacique cobrava 3,5\%, o Banco Cruzeiro do Sul 3\%, o Banco do Brasil com a menor taxa de 2,7\% e a maior taxa do Banco Máxima 3,9\%.

140 Conforme matéria publicada pela Folha On Line de 09.01.2009. Disponível em $<$ http://www1.folha.uol.com.br/folha/dinheiro/ult91u488110.shtml $>$. Acessado em 10 de janeiro de 2009.

${ }^{141}$ Matéria publicada na Folha On Line de 01/11/2006, "Bancos desrespeitam juro máximo estipulado pelo governo a aposentado". Disponível em: <http://www1.folha.uol.com.br/folha/dinheiro/ult91u112088.shtml>. Acessado em 10 de janeiro de 2009.
} 
por telefone. ${ }^{142}$ Quanto ao crédito consignado para servidores públicos, auditoria realizada pelo TCU concluiu que não existem mecanismos de controle suficientes que garantam a legalidade dos descontos. ${ }^{143}$ Por esses motivos, a concessão de empréstimos consignados chegou a ser suspensa por 90 dias no final de 2007, sendo retomada em janeiro de 2008 com uma nova regulamentação.

$\mathrm{Na}$ tentativa de reduzir o endividamento, o INSS editou a instrução normativa $\mathrm{n}^{\circ} 24$ de 20 de dezembro de 2007, elevando o prazo para 60 meses, medida essa questionável, já que quanto maior o prazo, maior os juros pagos e maior o período de comprometimento da renda, sendo que, dependendo do caso, esse prazo pode significar uma dívida para o resto da vida. Além disso, pela instrução normativa $n^{\circ} 1$ de 8 de janeiro de 2008 o limite de desconto mensal passou de 30 para $20 \%$ do valor do benefício, deduzidas as consignações obrigatórias e, nas operações com cartão de crédito, o limite passou para 10\%. Quanto ao percentual de juros, nas operações de crédito pessoal permaneceu em 2,64\%, mas, nas operações com cartão de crédito, passou para 3,7\%, sob o argumento de que essas operações precisavam ser estimuladas. Em março de 2008, as taxas de juros foram novamente reduzidas, passando para $2,5 \%$ nas operações de empréstimo pessoal e 3,5\% nas operações com cartão de crédito. Esse quadro resta inalterado, mesmo com a edição do último regulamento em maio de 2008, que apenas proibiu o saque em dinheiro com o cartão de crédito consignado, proibiu o fornecimento de crédito com carência e reduziu o limite de crédito no cartão para duas vezes o valor do benefício.

\footnotetext{
${ }^{142}$ Matéria publicada na Folha On Line de 27/11/2006, "Bancos desrespeitam lei e oferecem crédito por telefone, diz Procon". Disponível em: <http://www1.folha.uol.com.br/folha/dinheiro/ult91u112688.shtml>. Acessado em 10 de janeiro de 2009.

${ }^{143}$ Matéria publicada na Folha On Line de 19/10/2007, “Governo suspende empréstimo consignado para servidores". Disponível em: $<$ http://www1.folha.uol.com.br/folha/dinheiro/ult91u338024.shtml $>$. Acessado em 10 de janeiro de 2009.
} 


\section{Seção 2.4 - Evolução das normas que regem a concessão do crédito ao consumo e alterações legislativas que tornaram o crédito mais perigoso}

Analisando o ordenamento jurídico brasileiro numa perspectiva histórica, é possível constatar que existe uma tendência de favorecimento aos credores. Com a exceção da edição do Código de Defesa do Consumidor, a ingerência legislativa na atividade financeira em geral ocorre para conceder algum direito aos credores ou para aprimorar as técnicas de cobrança de dívidas, com a criação de novos instrumentos mais ágeis e efetivos, como foi o caso do contrato de leasing e da alienação fiduciária em garantia.

Saliente-se, antes de iniciar o retrospecto da legislação sobre o crédito, que não serão abordadas as normas que dizem respeito à estrutura do sistema financeiro e à regulamentação do funcionamento da atividade financeira, cuja base está na Lei 4.595/94, que confere competência normativa ao Conselho Monetário Nacional. O âmbito legislativo que será objeto de análise é aquele referente às relações entre as instituições financeiras e os consumidores, bem como a concessão de crédito por entidades não oficiais.

Tal como mencionado anteriormente, as taxas de juros foram expressamente liberadas no Brasil em 1832, e assim permaneceram até a edição do Decreto 22.626 de 1933, seguindo-se um período de limitação até o advento da lei 4.594 de 1964, que liberou novamente as taxas de juros cobradas pelas instituições integrantes do sistema financeiro nacional, com entendimento pacificado pela súmula 596 do STF. Assim sendo, as instituições financeiras oficiais não estavam sujeitas ao crime de usura pecuniária, previsto no artigo $4^{\circ}$, 'a', da Lei $1.521 / 51$, e podiam praticar as taxas de juros conforme a conveniência do mercado.

Todavia, mesmo com a liberação das taxas de juros, os demais dispositivos do Decreto 22.626 de 1933 permaneceram aplicáveis às instituições financeiras, inclusive no tocante à proibição da capitalização de juros (anatocismo ou cobrança de juros sobre juros) em períodos inferiores a um ano. A partir do julgamento em 1951 do Recurso Extraordinário $n^{0} 17.785 / \mathrm{DF}$, relator Ministro Orozimbo Nonato, e da subseqüente edição da súmula 121 na seção plenária de $1963,{ }^{144}$ pacificou-se o entendimento de que a capitalização de juros era vedada ainda que expressamente convencionada, pois a norma do artigo $4^{\circ}$ do Decreto 22.626/33 era de ordem pública e não admitia derrogação pela vontade das partes. Neste julgamento, ficou consignado que a lei de 24 de outubro de 1832

\footnotetext{
144 Teor da súmula 121 do STF: "É vedada a capitalização de juros, ainda que expressamente convencionada".
} 
apenas permitiu que as partes fixassem livremente a taxa de juros, mas não permitiu a prática do anatocismo, que, desde aquela época, era vedada, assim permanecendo com a edição do Código Comercial (art. $253^{145}$ ), cujo dispositivo foi repetido pela lei de usura. Mesmo após a Lei 4.595/1964, o STF entendeu que as instituições financeiras não estão excluídas da proibição de cobrar juros sobre juros, pois o teor da súmula 596 (na qual pacificou-se o entendimento acerca da liberação da taxa de juros) não guarda relação com o anatocismo. ${ }^{146}$ Posteriormente, a jurisprudência do Superior Tribunal de Justiça manteve esse mesmo entendimento. ${ }^{147}$

A proibição da capitalização de juros em períodos inferiores a um ano era praticamente a única limitação à autonomia da vontade imposta nos contratos bancários até a edição do Código de Defesa do Consumidor em 1990. É bem verdade que a Constituição Federal de 1988 estipulou um limite de $12 \%$ ao ano para a taxa de juros nas operações realizadas pelo sistema financeiro nacional; no entanto, esta norma foi considerada de eficácia limitada pelo Supremo Tribunal Federal, sendo necessária uma Lei Complementar que dissesse o que significa "taxa de juros real", como consta da ADI $n^{\circ} 4$, entendimento confirmado pela súmula 648 do STF.

O Código de Defesa do Consumidor foi editado com o claro intuito de proteger a parte mais fraca nas relações de consumo, declarando os objetivos de "atendimento das necessidades dos consumidores, o respeito à sua dignidade, saúde e segurança, a proteção de seus interesses econômicos, a melhoria da sua qualidade de vida, bem como a transparência e harmonia das relações de consumo" (art. $4^{\circ}$, caput do CDC) e elencando princípios orientadores da política de defesa do consumidor, tais como o "reconhecimento da vulnerabilidade do consumidor no mercado de consumo" (inciso I); "ação governamental no sentido de proteger efetivamente o consumidor" (inciso II);

\footnotetext{
${ }^{145} \mathrm{CCom}$, art. 253 - "É proibido contar juros de juros; esta proibição não compreende a acumulação de juros vencidos aos saldos liquidados em conta corrente de ano a ano. Depois que em juízo se intenta ação contra o devedor, não pode ter lugar a acumulação de capital e juros".

${ }^{146}$ Tal entendimento pode ser observado na seguinte ementa: "É vedada a capitalização de juros, ainda que expressamente convencionada (súmula 121). Dessa proibição não estão excluídas as instituições financeiras, dado que a súmula 596 não guarda relação com o anatocismo. A capitalização semestral de juros, ao invés da anual, só é permitida nas operações regidas por leis especiais que nela expressamente consentem" (STF, $1^{\text {a }}$ Turma, RE 90.341/PA, Rel. Min. Xavier de Albuquerque, julgado em 26/02/1980). No mesmo sentido: STF, $2^{\text {a }}$ Turma, RE 96.875/RJ, Rel. Min. Djaci Falcão, julgado em 16/09/1983.

147 "Juros. Capitalização. Instituições financeiras. Precedentes. Recurso desacolhido. - A lei 4.595/64 não afastou a vedação contida no art. 4. da lei de usura, mostrando-se defeso o anatocismo mesmo nas operações contratadas por entidades financeiras. - Apenas nos casos em que lei específica a autoriza, a capitalização de juros é admissível, condicionada sua exigibilidade, no entanto, ao pactuado e aos balizamentos legais". (STJ, $4^{\mathrm{a}}$ Turma, REsp 23860/PR, Rel. Min. Sálvio de Figueiredo Teixeira, j. 15/06/1993, DJ 02/08/1993). No mesmo sentido: STJ, $4^{\text {a }}$ Turma, REsp 187499, Rel. Min. Aldir Passarinho Junior, j. 29/02/2000, DJ $22 / 05 / 2000$.
} 
"harmonização dos interesses dos participantes das relações de consumo e compatibilização da proteção do consumidor com a necessidade de desenvolvimento econômico e tecnológico, de modo a viabilizar os princípios nos quais se funda a ordem econômica (art. 170, da Constituição Federal), sempre com base na boa-fé e equilíbrio nas relações entre consumidores e fornecedores" (inciso III).

A atividade bancária foi expressamente mencionada no art. $3^{\circ}, \S 2^{\circ}$ do $\mathrm{CDC}^{148}$, que define o conceito de fornecedor para efeito de aplicação da lei, de forma que todas as normas constantes desse diploma que impõem deveres legais de lealdade e transparência (CDC, art. $6^{\circ}$, III e 31), bem como vedam determinadas práticas comerciais (CDC, art. 39 e 42), protegem contra publicidade enganosa ou abusiva (CDC, arts. $6^{\circ}$, IV e 37), conferem proteção contratual (CDC, art. 46 e 47) e proíbem cláusulas contratuais abusivas (CDC, arts. $6^{\circ}, \mathrm{V}$ e 51 ), passaram a reger a atividade desenvolvida pelas instituições integrantes do sistema financeiro nacional. Especificamente quanto à atividade de concessão de crédito, tem-se o art. 52 do Código de Defesa do Consumidor.

A partir da edição do Código de Defesa do Consumidor, formou-se vasta jurisprudência impondo limites à autonomia da vontade na elaboração e execução dos contratos de financiamento bancário. Os deveres de boa-fé objetiva e de transparência contratual, que já vinham sendo enunciados doutrinariamente, passaram a servir de fundamento para a imposição de obrigações específicas às instituições financeiras quanto aos serviços e produtos ofertados, bem como para a modificação judicial de cláusulas contratuais excessivamente onerosas. Por exemplo, nos contratos em que o consumidor já pagou parte significativa das prestações, não mais se admite a rescisão contratual com devolução do bem, com fundamento na teoria do adimplemento substancial, que tem sua gênese no princípio da boa-fé objetiva. ${ }^{149}$ Também os artigos $6^{\circ}$, inciso $\mathrm{V}$ e 51 , inciso IV do CDC passaram a fundamentar a revisão judicial dos contratos quando fosse demonstrada a abusividade das taxas de juros cobradas pelas instituições financeiras no

\footnotetext{
$148 \mathrm{CDC}$, art. $3^{\circ}, \S 2^{\circ}$. "Serviço é qualquer atividade fornecida no mercado de consumo, mediante remuneração, inclusive as de natureza bancária, financeira, de crédito e securitária, salvo as decorrentes das relações de caráter trabalhista".

149 É esta a jurisprudência do Superior Tribunal de Justiça: “ALIENAÇÃO FIDUCIÁRIA. Busca e apreensão. Falta da última prestação. Adimplemento substancial. O cumprimento do contrato de financiamento, com a falta apenas da última prestação, não autoriza o credor a lançar mão da ação de busca e apreensão, em lugar da cobrança da parcela faltante. $\mathrm{O}$ adimplemento substancial do contrato pelo devedor não autoriza ao credor a propositura de ação para a extinção do contrato, salvo se demonstrada a perda do interesse na continuidade da execução, que não é o caso. Na espécie, ainda houve a consignação judicial do valor da última parcela. Não atende à exigência da boa-fé objetiva a atitude do credor que desconhece esses fatos e promove a busca e apreensão, com pedido liminar de reintegração de posse. Recurso não conhecido". (REsp 272739/MG, Relator Ministro RUY ROSADO DE AGUIAR, Órgão Julgador 4a. TURMA, Julgamento 01/03/2001, DJ 02.04.2001)
} 
caso concreto, sendo que a jurisprudência diverge quanto ao parâmetro a ser utilizado para a verificação da abusividade. Devido a sua complexidade, esta questão será retomada em capítulo próprio.

Com a edição do Código Civil, em 10 de janeiro de 2002, foi reforçada a defesa do consumidor de crédito, pois este diploma consagrou a idéia de que o direito privado é orientado por princípios próprios de um novo paradigma jurídico, que reconhece aos contratos não apenas o valor individual de liberdade, do qual decorrem os princípios da força obrigatória e da relatividade dos efeitos dos contratos, o consensualismo e a autonomia da vontade, mas também valores sociais e econômicos, dos quais decorrem os princípios da boa-fé objetiva, da função social do contrato e do equilíbrio contratual. Com isso, o Código Civil, em diálogo de fontes com o Código de Defesa do Consumidor, reforçou os deveres decorrentes da boa-fé objetiva (CC, arts. 113 e 422), além do que estabeleceu normas que complementaram a tutela das relações jurídicas contratuais, como é o caso do princípio da função social dos contratos $(\mathrm{CC}$, art. 421) e das regras a respeito da manutenção do equilíbrio nos contratos e nos negócios jurídicos em geral, como é o caso da anulabilidade dos negócios jurídicos maculados pelo vício da lesão (CC, art. 157) e da possibilidade de resolução dos contratos por onerosidade excessiva $(\mathrm{CC}$, arts. 478 a 480).

Essas são as normas aplicáveis às instituições financeiras integrantes do sistema financeiro nacional. Com relação a entidades, empresas ou pessoas que não integram o SFN, incidem os artigos 591 e 406 do CC, de maneira que as taxas máximas de juros cobradas não poderão exceder $12 \%$ ao ano, segundo a interpretação que tem prevalecido, estando aquele que violar esta norma sujeito ao crime previsto no artigo $4^{\circ}$ da Lei 1.521/51. Ademais, incide a vedação à capitalização de juros (cobrança de juros sobre juros) em períodos inferiores a um ano (Decreto 22.626/33, art. $4^{\circ}$ e CC, art. 591), e, se a pessoa ou empresa que conceder o crédito enquadrar-se na definição de fornecedor, incidem ainda todas as normas protetivas antes mencionadas.

Retomando a regulamentação da atividade financeira nas relações "banco-cliente", observe-se que antes mesmo da edição do Código Civil, a partir do ano 2000, o panorama jurídico começou a ser transformado para beneficiar as instituições financeiras. Muitas destas alterações, como será a seguir demonstrado, foram resultado das medidas propostas pelo Banco Central no âmbito do projeto "Juros e Spread Bancário". A justificativa dessas medidas normativas, implementadas seja por meio de medidas provisórias, seja por meio de leis ordinárias, era a de que a redução dos riscos da atividade financeira implicaria a 
redução do spread bancário (diferença entre o custo de captação e a taxa cobrada dos tomadores), pois um de seus componentes diz respeito ao risco de inadimplência, e dessa forma as taxas finais de juros seriam também reduzidas.

No entanto, algumas dessas medidas legislativas acabaram por retirar direitos importantes dos consumidores de crédito, tornando o risco de endividamento excessivo ainda mais iminente. Abaixo são referidas algumas das alterações legislativas que são fruto de medidas propostas pelo Banco Central no âmbito do projeto "Juros e Spread Bancário", diretamente relacionadas à tutela das relações de crédito no âmbito do SFN:

a) Capitalização de juros: conforme visto anteriormente, a cobrança de juros sobre juros era prática expressamente vedada pelo ordenamento jurídico brasileiro desde 1832, proibição repetida pelo Código Comercial de 1850 (art. 253), e pela Lei de Usura (Decreto 22.626/33, artigo $4^{\circ}$ ). A jurisprudência dos Tribunais Superiores era pacífica no sentido de que essa vedação aplica-se às instituições financeiras, conforme também já referido anteriormente. ${ }^{150}$ Contudo, o Banco Central do Brasil, entendendo que muitas demandas de consumidores fundamentavam-se na alegação do anatocismo, invocando o artigo $4^{\circ}$ da lei de usura, sugeriu como medida necessária para reduzir os riscos jurídicos das operações de crédito "esclarecer que esse dispositivo da lei da usura não se aplica ao SFN". Para implementar essa medida, o Governo alterou o artigo $5^{\circ}$ da Medida Provisória $n^{\circ} 1963$ na sua $17^{\mathrm{a}}$ edição, em 30.03.2000 (atual MP 2.170-36), que passou a permitir a capitalização de juros "nas operações realizadas pelas instituições integrantes do Sistema Financeiro Nacional". ${ }^{151}$ A constitucionalidade dessa medida provisória está sendo questionada na $\mathrm{ADI} 2316$, questão que será analisada em tópico especifico.

b) Cédula de Crédito Bancário: com o objetivo de criar instrumentos de crédito mais adequados e de fácil execução em caso de inadimplência, o Banco Central sugeriu a criação da Cédula de Crédito Bancário (CCB), o que foi feito pelas MPs 1.925 de 15.10.1999 e $\mathrm{n}^{\mathrm{o}}$ 2.160-25. Posteriormente, foi editada a Lei 10.931 de 02.08.2004, que dispôs sobre a cédula de crédito bancário e certificados de cédula de crédito bancário nos artigos 26 a 45. Destaquem-se duas normas da Lei 10.931/04 que

\footnotetext{
${ }^{150}$ Ver notas 146 e 147.

151 Art. $5^{\circ}$. Nas operações realizadas pelas instituições integrantes do Sistema Financeiro Nacional, é admissível a capitalização de juros com periodicidade inferior a um ano. Parágrafo único. Sempre que necessário ou quando solicitado pelo devedor, a apuração do valor exato da obrigação, ou de seu saldo devedor, será feita pelo credor por meio de planilha de cálculo que evidencie de modo claro, preciso e de fácil entendimento e compreensão, o valor principal da dívida, seus encargos e despesas contratuais, a parcela de juros e os critérios de sua incidência, a parcela correspondente a multas e demais penalidades contratuais.
} 
agravaram a situação do consumidor de crédito: o artigo $28, \S 1^{\circ}$, inciso I permite que seja estipulada a cobrança de juros capitalizados nas CCBs; ademais, o artigo 28 caput e $\S 2^{\circ}$ permitem a constituição de título executivo unilateralmente pela instituição financeira credora, com a apresentação de planilha de cálculo ou extratos da conta corrente. Essa questão ganha especial relevo quando se trata de contrato de abertura de crédito em conta corrente, em relação à qual o STJ já havia firmado entendimento no sentido de que a juntada dos extratos da conta corrente, unilateralmente emitidos pelo credor, não são capazes da conferir liquidez necessária para a formação do título executivo (súmula 233 do STJ ${ }^{152}$ ). Contudo, o art. 28, $\S 1^{\circ}$, inciso II da Lei 10.931/04 estabeleceu que "a Cédula de Crédito Bancário representativa de dívida oriunda de contrato de abertura de crédito bancário em conta corrente será emitida pelo valor total do crédito posto à disposição do emitente, competindo ao credor, nos termos deste parágrafo, discriminar nos extratos da conta corrente ou nas planilhas de cálculo, que serão anexados à Cédula, as parcelas utilizadas do crédito aberto, os aumentos do limite do crédito inicialmente concedido, as eventuais amortizações da dívida e a incidência dos encargos nos vários períodos de utilização do crédito aberto".

c) Contratos e transações eletrônicas: editada a MP 2.200 de 28.06.2001 que instituiu a Infra-estrutura de chaves públicas brasileiras (ICP-Brasil), para garantir a autenticidade a integridade e a validade dos contratos eletrônicos.

d) Alienação fiduciária: com o objetivo de ampliar os instrumentos de crédito, foi ampliado o âmbito de cabimento da alienação fiduciária em garantia, considerada um dos instrumentos mais rápidos e eficazes para a execução de dívidas, para incluir a possibilidade dessa garantia incidir também sobre bens fungíveis e direitos (antes somente bens imóveis - Lei 9.514/97 - e móveis infungíveis - DL 911/64 poderiam constituir essa garantia). Inicialmente esta possibilidade foi incluída pelo art. 22 da MP 2.063-22 de 23.06.2001, que alterou para o $\mathrm{n}^{\circ} 2.160-25$ de 23.08.2001. Posteriormente a Lei 10.931 de 02.08.2004, nos artigos 55 a 57, disciplinou essa e outras alterações com relação à alienação fiduciária em garantia.

e) Crédito consignado no pagamento do salário do trabalhador: a MP 130 de 17.09.2003 instituiu o empréstimo com consignação em folha de pagamento, transformada na Lei 10.820 de 17.12.2003.

\footnotetext{
${ }^{152}$ Súmula 233: "O contrato de abertura de crédito, ainda que acompanhado de extrato da conta-corrente, não é título executivo".
} 
f) Separação da discussão do principal e dos encargos financeiros: a Lei 10.931 de 02.08.2001, no seu art. 50, estabeleceu a obrigatoriedade do devedor que pretender a discussão judicial de obrigação decorrente de empréstimo, financiamento ou alienação imobiliários, discriminar na petição inicial os valores incontroversos, que deverão continuar sendo pagos no tempo e modo contratados. Posteriormente, a lei 11.382/06 introduziu o artigo 739-A no Código de Processo Civil, cujo $§ 5^{\underline{0}}$ estabeleceu uma forma de separar a discussão do principal e dos encargos ${ }^{153}$.

g) Reformas para racionalizar o processo judicial, tornando-o mais célere e eficaz ${ }^{154}$ : reforma do judiciário pela EC 45 de 8.12.2004 e alterações no Código de Processo Civil. $^{155}$

h) Emenda Constitucional n 40 de 2003, que revogou os incisos e parágrafos do artigo 192 da Constituição Federal.

Outro ponto que cabe ser destacado é a propositura pela Confederação Nacional do Sistema Financeiro - CONSIF da ADI n 2.591-1, pela qual requereu a declaração de inconstitucionalidade da expressão "inclusive as de natureza bancária, financeira, de crédito e securitária", contida na parte final do $\S 2^{\circ}$ do artigo $3^{\circ}$ do $\mathrm{CDC}$, pretendendo, dessa forma, afastar a incidência do Código de Defesa do Consumidor com relação às operações de crédito firmadas com as instituições integrantes do Sistema Financeiro Nacional. Segundo consta da petição inicial, a declaração de inconstitucionalidade da expressão impugnada "fará com que nenhuma outra disposição constante desse diploma possa ser aplicada às atividades de natureza bancária, financeira, de crédito e securitária... sem a necessidade de impugnação específica de cada uma das disposições”.

O pedido fundamentou-se no fato de que o artigo 192, caput e incisos II e IV da Constituição Federal (antiga redação) ${ }^{156}$ reservava à lei complementar a regulamentação do

${ }^{153}$ Art. 739-A. §5ํ․ Quando o excesso de execução for fundamento dos embargos, o embargante deverá declarar na petição inicial o valor que entende correto, apresentando memória do cálculo, sob pena de rejeição liminar dos embargos ou de não conhecimento desse fundamento.

${ }^{154}$ A reforma do processo judicial civil no Brasil não se trata de uma demanda exclusiva do setor financeiro, sendo que a reforma já vinha ocorrendo desde 1994.

${ }^{155}$ Lei 11.232 de 22.12.2005 (execução de título judicial) a Lei 11.187 de 19.10.2005 (mudanças nas regras do recurso de agravo); Lei 11.382 de 6.12.2006 (execução extrajudicial); Lei 11.276 de 07.02.2006 (forma de interposição dos recursos, saneamento de nulidades, e súmula impeditiva de recursos), Lei 11.277 de 07.02.2006 (julgamento de casos idênticos), Lei 11.341 de 07.08.2006 (admissibilidade de prova de dissídio por mídia eletrônica), Lei 11.418 de 19.12.2006 (requisito da repercussão geral para conhecimento do recurso especial); Lei 11.419 de 19.12.2006 (informatização do processo judicial); Lei 11.672 de 08.05.2008 (procedimento para julgamento de recursos repetitivos no STJ).

${ }^{156}$ Antes de encerrado o julgamento da ADI 2.591/DF, a EC 40/2003 alterou a redação do artigo 192 da CF, suprimindo-lhe os incisos. Entendeu-se, contudo, que a ADI não restou prejudicada, tendo em vista a relevância das questões discutidas (fronteiras entre relação de consumo e Sistema Financeiro Nacional, além do conflito entre dois valores constitucionais, que é a proteção do consumidor e o fortalecimento da 
Sistema Financeiro, tal como já fora decidido na ADI $n^{\circ}$, além do que a norma impugnada fere o devido processo legal em sentido material (art. $5^{\circ}$, LIV), pois o CDC não é o "meio legislativo adequado para regular tal matéria por não observar as peculiaridades das atividades desenvolvidas pelas instituições integrantes do Sistema Financeiro Nacional a justificar a impossibilidade de equipará-las às atividades de consumo", requerendo, ao final, a suspensão liminar da eficácia da expressão "inclusive as de natureza bancária, financeira, de crédito e securitária" do $\S 2^{\circ}$, do art. $3^{\circ}$ do CDC.

Foram prestadas informações pelo Presidente da República, que requereu que a ação fosse julgada improcedente, mas que se conferisse uma interpretação conforme a Constituição Federal "excluindo da aplicação do Código de Defesa do Consumidor o custo das operações ativas e a remuneração das operações passivas praticadas por instituições financeiras no desempenho da intermediação de dinheiro na economia, de modo a preservar a competência constitucional da lei complementar do Sistema Financeiro Nacional" (fls. 1039/1040). Também o parecer do Procurador-Geral da República foi no mesmo sentido, mas para tanto opinou pela procedência parcial da ação. Nesse sentido, foi também o voto do então relator Carlos Velloso, que julgou parcialmente procedente a ação, conferindo interpretação conforme a Constituição para "afastar a exegese que nela [na expressão impugnada] inclua a taxa de juros das operações bancárias, ou sua fixação em $12 \%$ ao ano, dado que esta questão diz respeito ao Sistema Financeiro Nacional”. Com isso, a CONSIF especificou o seu pedido para constar a concessão de medida liminar para afastar a aplicação do CDC à "remuneração das operações passivas e o custo das operações ativas dos bancos".

O Supremo Tribunal Federal passou a discutir, portanto, se seria necessária a interpretação conforme, com divergência aberta pelo Ministro Néri da Silveira que entendeu a existência de dois planos distintos: o primeiro relativo às matérias que dizem respeito à estrutura do sistema financeiro e ao funcionamento das instituições financeiras, e que a Constituição, no artigo 192, sujeita à Lei Complementar; e outro que diz respeito às relações banco-cliente, que podem ser regidas pelo Código do Consumidor. A maioria dos Ministros, entendendo que o CDC não versava sobre determinação de taxas de juros ou sobre matéria prevista no artigo 192 da CF, julgou a ação improcedente. ${ }^{157}$

economia e o desenvolvimento), considerando-se que a ação direta detém causa de pedir aberta, além do que o artigo 192 conservou a competência legislativa da lei complementar para tratar do SFN (Esses fundamentos constam do voto do Min. Nelson Jobim, às fls. 218 a 221 do acórdão).

${ }^{157}$ Nove Ministros entenderam pela total improcedência e dois pela procedência parcial (Ministros Carlos Velloso e Nelson Jobim), que entenderam pela interpretação do dispositivo conforme a Constituição para 
Muito embora a ação tenha sido julgada improcedente pela maioria dos votos, a ementa do acórdão deu a entender que a procedência teria sido parcial, com a adoção da interpretação conforme. ${ }^{158}$ Foram opostos embargos de declaração nos quais se alegou, em suma, a contradição da ementa, já que a maioria dos Ministros decidiu pela total improcedência da ação, mas a ementa dava a entender que a decisão foi pela procedência parcial, por fazer alusão à interpretação conforme, que foi expressamente afastada pela maioria. Inicialmente o Ministro relator Eros Grau rejeitou os embargos, entendendo não haver a alegada contradição. Mas, após o voto do Ministro Joaquim Barbosa ${ }^{159}$ e dos

afastar a incidência do CDC quanto à regulação dos juros.

${ }^{158}$ EMENTA: CÓDIGO DE DEFESA DO CONSUMIDOR. ART. $5^{\circ}$, XXXII, DA CB/88. ART. 170, V, DA CB/88. INSTITUIÇÕES FINANCEIRAS. SUJEIÇÃO DELAS AO CÓDIGO DE DEFESA DO CONSUMIDOR, EXCLUÍDAS DE SUA ABRANGÊNCIA A DEFINIÇÃO DO CUSTO DAS OPERAÇÕES ATIVAS E A REMUNERAÇÃO DAS OPERAÇÕES PASSIVAS PRATICADAS NA EXPLORAÇÃO DA INTERMEDIAÇÃO DE DINHEIRO NA ECONOMIA [ART. $3^{\circ}$, § $2^{\circ}$, DO CDC]. MOEDA E TAXA DE JUROS. DEVER-PODER DO BANCO CENTRAL DO BRASIL. SUJEIÇÃO AO CÓDIGO CIVIL. 1. As instituições financeiras estão, todas elas, alcançadas pela incidência das normas veiculadas pelo Código de Defesa do Consumidor. 2. "Consumidor", para os efeitos do Código de Defesa do Consumidor, é toda pessoa física ou jurídica que utiliza, como destinatário final, atividade bancária, financeira e de crédito. 3 . O preceito veiculado pelo art. $3^{\circ}, \S 2^{\circ}$, do Código de Defesa do Consumidor deve ser interpretado em coerência com a Constituição, o que importa em que o custo das operações ativas e a remuneração das operações passivas praticadas por instituições financeiras na exploração da intermediação de dinheiro na economia estejam excluídas da sua abrangência. 4. Ao Conselho Monetário Nacional incumbe a fixação, desde a perspectiva macroeconômica, da taxa base de juros praticável no mercado financeiro. 5. O Banco Central do Brasil está vinculado pelo dever-poder de fiscalizar as instituições financeiras, em especial na estipulação contratual das taxas de juros por elas praticadas no desempenho da intermediação de dinheiro na economia. 6. Ação direta julgada improcedente, afastando-se a exegese que submete às normas do Código de Defesa do Consumidor [Lei $n^{0}$ 8.078/90] a definição do custo das operações ativas e da remuneração das operações passivas praticadas por instituições financeiras no desempenho da intermediação de dinheiro na economia, sem prejuízo do controle, pelo Banco Central do Brasil, e do controle e revisão, pelo Poder Judiciário, nos termos do disposto no Código Civil, em cada caso, de eventual abusividade, onerosidade excessiva ou outras distorções na composição contratual da taxa de juros. ART. 192, DA CB/88. NORMAOBJETIVO. EXIGÊNCIA DE LEI COMPLEMENTAR EXCLUSIVAMENTE PARA A REGULAMENTAÇÃO DO SISTEMA FINANCEIRO. 7. O preceito veiculado pelo art. 192 da Constituição do Brasil consubstancia norma-objetivo que estabelece os fins a serem perseguidos pelo sistema financeiro nacional, a promoção do desenvolvimento equilibrado do país e a realização dos interesses da coletividade. 8 . A exigência de lei complementar veiculada pelo art. 192 da Constituição abrange exclusivamente a regulamentação da estrutura do sistema financeiro. CONSELHO MONETÁRIO NACIONAL. ART. $4^{\circ}$, VIII, DA LEI $\mathrm{N}^{\circ}$ 4.595/64. CAPACIDADE NORMATIVA ATINENTE À CONSTITUIÇÃO, FUNCIONAMENTO E FISCALIZAÇÃO DAS INSTITUIÇÕES FINANCEIRAS. ILEGALIDADE DE RESOLUÇÕES QUE EXCEDEM ESSA MATÉRIA. 9. O Conselho Monetário Nacional é titular de capacidade normativa - a chamada capacidade normativa de conjuntura - no exercício da qual lhe incumbe regular, além da constituição e fiscalização, o funcionamento das instituições financeiras, isto é, o desempenho de suas atividades no plano do sistema financeiro. 10. Tudo o quanto exceda esse desempenho não pode ser objeto de regulação por ato normativo produzido pelo Conselho Monetário Nacional. 11. A produção de atos normativos pelo Conselho Monetário Nacional, quando não respeitem ao funcionamento das instituições financeiras, é abusiva, consubstanciando afronta à legalidade.

${ }^{159} \mathrm{O}$ voto do Ministro Joaquim Barbosa assim esclareceu: "Durante os debates, creio que a Corte chegou à conclusão de que o Código do Consumidor não versava diretamente sobre a determinação de taxas de juros e que tal circunstância, aliada à modificação do campo material da reserva de lei complementar previsto no art. 192 da Constituição pela EC 40/2003, para torná-lo mais vago, não permitia que constasse, de forma apriorística, a suposta incompatibilidade entre o Código de Defesa do Consumidor e a Constituição, no que se refere à atividade bancária. (...) Com efeito, a submissão das instituições financeiras ao Código do Consumidor não pressupõe a afirmativa de que tal conjunto de normas efetivamente dispõe sobre juros, ou 
debates realizados, alterou o seu entendimento, e os embargos opostos pela ProcuradoriaGeral da República foram acolhidos parcialmente por unanimidade para reduzir o teor da ementa, excluindo os enunciados em relação aos quais não houve consenso, ficando assim a redação:

ART. $3^{\circ}, \S 2^{\circ}$, DO CDC. CÓDIGO DE DEFESA DO CONSUMIDOR. ART. $5^{\circ}$, XXXII, DA CB/88. ART. 170, V, DA CB/88. INSTITUIÇÕES FINANCEIRAS. SUJEIÇÃO DELAS AO CÓDIGO DE DEFESA DO CONSUMIDOR. AÇÃO DIRETA DE INCONSTITUCIONALIDADE JULGADA IMPROCEDENTE. 1. As instituições financeiras estão, todas elas, alcançadas pela incidência das normas veiculadas pelo Código de Defesa do Consumidor. 2. "Consumidor", para os efeitos do Código de Defesa do Consumidor, é toda pessoa física ou jurídica que utiliza, como destinatário final, atividade bancária, financeira e de crédito. 3. Ação direta julgada improcedente.

No julgamento da ADIN 2.591, complementada pelo julgamento dos embargos, ficou assentado o posicionamento do Supremo Tribunal Federal no sentido de que as relações entre as instituições financeiras e seus clientes, que, conforme afirmou o Ministro Ricardo Lewandowski, são firmadas no plano microeconômico, estão sujeitas às normas do Código de Defesa do Consumidor, inclusive para fundamentar o afastamento de eventuais abusos cometidos ou onerosidade excessiva dos contratos, que deverá ser apreciada caso a caso. Já as questões macroeconômicas, que dizem respeito à política monetária, como a fixação da taxa básica de juros, bem como a regulamentação da estrutura e funcionamento do Sistema Financeiro Nacional, são matérias reservadas à Lei Complementar, e atualmente constam da Lei 4.595/64, que foi recepcionada como tal pela Constituição de 1988.

Muito embora o Supremo Tribunal Federal tenha se manifestado favoravelmente à aplicação do Código de Defesa do Consumidor às relações bancárias, o que tem se verificado na prática é a negativa de vigência desse diploma legal nas ações que têm por objeto os contratos bancários. Isso porque a jurisprudência do Superior Tribunal de Justiça,

ainda de que sirva como fundamento de validade para que os órgãos jurisdicionais modifiquem, arbitrariamente, as taxas de juros. Certamente, o Código do Consumidor não outorga competência para a definição da política financeira e orçamentária. Como demonstrou S. Excelência o ministro-relator, 'essa poderosa capacidade de criação de riqueza abstrata não pode ficar sujeita a administração desde a perspectiva das relações microeconômicas, sob pena de comprometimento dos objetivos que o artigo 192 da Constituição visa a realizar, o desenvolvimento equilibrado do país e a satisfação do interesse da coletividade'. Por outro lado, a ponderação redundaria no emprego da técnica de interpretação conforme a Constituição para o Código de Defesa do Consumidor, expressamente afastada pela maioria da Corte por ocasião do julgamento da ação direta de inconstitucionalidade. Com efeito, entendo que os denominadores comuns a que chegou a orientação majoritária da Corte se reportam à inexistência de conflito apriorístico entre o Código do Consumidor e a Constituição federal, porquanto a Lei 8.078/1990 não versa expressamente sobre estipulação de juros, e é possível conceber a existência de um âmbito próprio das relações de consumo aplicável às instituições financeiras e seus clientes". 
que na década passada reconhecia uma série de direitos aos consumidores de crédito, vem gradativamente retirando as conquistas passadas (muitas delas retiradas pelo próprio legislador) e firmando novos posicionamentos que neutralizam a incidência do Código de Defesa do Consumidor aos bancos. O mais recente deles veio com a edição da súmula 381 , pela qual "nos contratos bancários, é vedado ao julgador conhecer, de ofício, da abusividade das cláusulas". Segundo entendimento aqui manifesto, esta súmula é flagrantemente contra legem, já que o artigo 51 do CDC é expresso ao considerar as cláusulas abusivas "nulas de pleno direito", além do que fere o princípio da isonomia ao restringir a impossibilidade de atuação de ofício exclusivamente aos contratos bancários.

Verifica-se, portanto, que, nos últimos anos, foram retirados direitos importantes dos consumidores de crédito bancário, ao argumento de que o "risco jurídico", traduzido na "incerteza jurisdicional", seria o principal responsável pelas altas taxas de juros no Brasil, e, conseqüentemente, para o baixo volume de crédito no país. Esse argumento será desenvolvido e combatido na seção seguinte. 


\section{Seção 2.5 - A insuficiência do argumento utilitarista}

Na seção 2.1 descreveu-se a atuação do Banco Central do Brasil, por intermédio do projeto "Juros e Spread Bancário", no sentido de incentivar o aumento da demanda pelo crédito no país, tornado esse instrumento mais acessível ao consumidor. Muitas das medidas propostas no âmbito desse projeto envolveram a regulamentação da atividade financeira pelo próprio Banco Central (como a redução do percentual dos depósitos compulsórios), a redução da carga tributária (redução do IOF), o estímulo à concorrência (maior transparência das operações de crédito), e a melhoria na classificação dos clientes para redução dos riscos (aperfeiçoamento da central de risco do Banco Central). No entanto, outras medidas disseram respeito à redução do chamado "risco jurídico", baseando-se numa corrente doutrinária, defendida, sobretudo, por economistas ${ }^{160}$, que coloca a "incerteza jurisdicional" como o principal fator determinante das altas taxas de juros e, conseqüentemente, do baixo volume de crédito doméstico.

Como forma de reduzir o risco jurídico, foram implementadas diversas medidas, analisadas na subseção anterior, tais como: a criação de novos instrumentos de crédito mais eficazes para permitir o reembolso das quantias emprestadas pelos credores; a alteração a legislação processual; finalmente, a subtração de direitos historicamente reconhecidos aos consumidores de crédito, como era o caso da vedação à cobrança de juros sobre juros em períodos inferiores a um ano e a impossibilidade de formação de título executivo unilateralmente pelo credor, que passou a ser permitido por meio da cédula de crédito bancário.

Assim sendo, cumpre analisar mais a fundo esse argumento, que acabou por perpetrar mudanças significativas na legislação sobre o crédito ao consumo no Brasil. Veremos que esse argumento, defendido na sua maioria por autores com formação em law and economics, é tipicamente utilitarista, ${ }^{161}$ já que tem em vista a maximização de

${ }^{160}$ PINHEIRO, A. C. O componente judicial dos spreads bancários. In: Economia Bancária e Crédito avaliação de 4 anos do projeto Juros e Spread Bancário. Ver em: <http://www.bcb.gov.br/?SPREAD>. Acessado em 16 de novembro de 2009.; ARIDA, P.; BACHA, E. L.; LARA-RESENDE, A. Credit, Interest and Jurisdictional Uncertainty: Conjectures on the Case of Brazil. Work-paper apresentado no seminário "Inflation Targeting and Debt: The Case of Brazil"; AFANASIEFF, T. S.; LHACER, P. M. V.; NAKANE, M. The Determinants of Bank Interest Spreads in Brazil. Working Paper Series 46. Central Bank of Brazil, august, 2002.

161 "A doutrina do Utilitarismo foi introduzida no pensamento político pelo inglês John Stuart Mill (18061873). Segundo as concepções dessa corrente, o parâmetro de avaliação da justiça ou da injustiça de determinada conduta repousa na análise das conseqüências do ato em face do montante global de bem-estar social. O princípio elementar de Justiça política, assim, é identificado com a noção de maximização do bemestar de toda a sociedade, considerada como instituição supra-individual. Para a majoração do total de 
riquezas, partindo do pressuposto de que este processo garante o bem-estar e a felicidade geral dos integrantes de uma comunidade, sem se preocupar com eventuais efeitos desastrosos para os direitos de algumas pessoas individualmente consideradas. Esse argumento é também conseqüencialista, na medida em que seu enfoque está nos efeitos que uma decisão judicial equivocada (pelo menos segundo o seu ponto de vista) gera para os agentes econômicos.

A análise tem como ponto de partida o artigo de Armando Castelar Pinheiro, intitulado "O componente judicial dos Spreads Bancários", que é parte integrante do relatório de Economia Bancária e Crédito do BACEN, ${ }^{162}$ bem como o artigo intitulado "Credit, Interest and Jurisdictional Uncertainty: Conjectures on the Case of Brazil", de autoria de Persio Arida, Edmar Lisboa Bacha e André Lara-Resende, que intensificou o debate sobre o tema. Em suma, defendem esses autores que as altas taxas de juros e a inexistência de um mercado de crédito doméstico a longo prazo no Brasil se deve às conseqüências adversas que a incerteza jurisdicional gera nos agentes econômicos. A incerteza jurisdicional, tal como formulado pelos autores, possui duas vertentes: primeiro, diz respeito à morosidade do Poder Judiciário em satisfazer os direitos dos credores; segundo, refere-se às decisões das três esferas de Poder (Executivo, Legislativo e Judiciário) com viés anticredor, ou seja, não se trata simplesmente da incerteza quanto à decisão jurisdicional propriamente dita (enquanto ato do juiz), mas também, dos atos normativos com viés anticredor, e que por isso contrariam as expectativas dos credores. ${ }^{163}$

Não nos ocuparemos da vertente do argumento que critica a morosidade do Poder Judiciário, pois essa discussão foge ao âmbito desse trabalho. ${ }^{164}$ É a segunda vertente do

felicidade social, poderiam ser aceitas limitações aos direitos de um ou de alguns indivíduos. Em uma situação extrema, poder-se-ia até mesmo conceber como justa a miséria de alguns trabalhadores, se com isso se puder perceber crescimento da riqueza total da sociedade. Estas idéias estão em plena consonância com o conceito econômico de Ótimo de Pareto, ainda hoje de grande influência em alguns setores jurídicos, como, por exemplo, no campo da análise antitruste. Também conhecida como Eficiência de Pareto, esta idéia propugna a justeza de situações que redundem em ganhos totais de bem-estar social, conquanto tais práticas possam acarretar efeitos humanitários e distributivos perniciosos". (CASTILHO, R. Justiça Social e Distributiva - desafios para concretizar direitos sociais. São Paulo: Saraiva, 2009. p. 56).

${ }^{162}$ PINHEIRO, A. C. O componente judicial dos spreads bancários... cit.

${ }^{163}$ Arida, Bacha e Lara-Resende assim conceituam incerteza jurisdicional: "Jurisdictional uncertainty may thus be decomposed, in its anti-creditor bias, as the risk of acts of the prince changing the value of contracts before or at the moment of their execution, and as the risk of a unfavorable interpretation of the moment of their execution, and as the risk of a unfavorable interpretation of the contract in case of a court ruling. For our purposes jurisdiction matters as the power of the state consequent upon its sovereignty to issue laws and administer justice, and it is not restricted to the territorial dimension of the contract". (cit. p. 11)

164 Apenas para mencionar o enfoque dado, Pinheiro destaca que a morosidade do Poder Judiciário é prejudicial por três razões: primeiro porque torna a perspectiva de uma ação na justiça menos ameaçadora para o devedor; segundo porque o valor das garantias é reduzido ou perdido com o tempo, em razão da depreciação, de atitudes desleais por parte dos devedores ou do crescimento acelerado da dívida em razão da incidência dos encargos contratuais; terceiro porque os devedores utilizam o Poder Judiciário como forma de 
argumento que será analisada, já que se refere à tutela jurídica do consumidor de crédito. As críticas dizem respeito a uma suposta "politização" das decisões judiciais, em razão de uma tendência anticredores, pois os juízes estariam deixando de cumprir o seu ofício de simplesmente aplicar o direito ao caso concreto para promover "justiça social", com decisões que prejudicam os credores. Aduzem que esse comportamento é, na verdade, prejudicial, já que aumenta a incerteza jurisdicional, representando um obstáculo ao desenvolvimento econômico do país. ${ }^{165}$ Nesse sentido, enfatiza A.C. Pinheiro:

Uma visão que freqüentemente se argumenta ser adotada pelos magistrados é a de que o judiciário não aplica a lei, mas guia suas decisões pelo objetivo de "justiça social". Pinheiro (2001) analisa este comportamento, chamando-o de "politização" das decisões judiciais. Estendendo-se para além dos mercados de crédito, este tipo de comportamento freqüentemente reflete uma intenção de favorecer grupos sociais e/ou econômicos mais fracos, como trabalhadores e pequenos devedores, ou simplesmente as inclinações políticas do magistrado em relação ao conflito em questão.

(...)

Neste sentido, é importante esclarecer e educar os atuais e futuros juízes a respeito do conteúdo econômico das causas em que estão envolvidos, as razões econômicas de algumas cláusulas aparentemente desbalanceadas e as conseqüências macroeconômicas de suas decisões, ocorridas a partir da adaptação dos agentes ao padrão de comportamento dos magistrados. Isso pode ser feito nas faculdades de direito e nas Escolas de Magistratura, mas também pelas empresas na defesa das suas causas, quando apresentadas ao judiciário.

Num estudo que buscou contrapor esse argumento utilitarista, Joaquim Falcão, Luiz Fernando Schuartz e Diego Werneck Arguelhes demonstram que a atuação jurisdicional é muito mais complexa do que supõem os críticos economistas. Sem desprezar a necessidade de aperfeiçoamento das instituições jurídicas brasileiras, aduzem que "o clamor para que os juízes sejam mais 'esclarecidos'... é fruto de desconhecimento quanto à realidade institucional e às restrições de natureza cognitiva que, estruturalmente, afetam o ofício do juiz". Defendem a idéia de que "nem toda decisão judicial que contraria as expectativas dos agentes privados pode ser validamente apontada como algo negativo, em particular, como fator de insegurança jurídica". Afirmam que existem dois tipos de incerteza: a

postergar o pagamento das dívidas, mesmo não reclamando efetivamente nenhum direito a seu favor. PINHEIRO, A. C. O componente judicial dos spreads bancários, in: Economia Bancária e Crédito avaliação de 4 anos do projeto Juros e Spread Bancário. Disponível em: $<$ http://www.bcb.gov.br/?SPREAD>. Acessado em 16 de novembro de 2009.

${ }^{165}$ Esse é também um argumento comumente utilizado para justificar a impropriedade de decisões que favorecem os consumidores em relação a certos contratos, que correm o risco de não mais serem utilizados, como ocorreu em mais de uma ocasião com os contratos de leasing, que foram descaracterizados para meros contratos de compra e venda, e também com relação às decisões sobre a excessiva onerosidade dos contratos indexados pelo dólar, após a desvalorização da moeda nacional. 
estrutural, que diz respeito "ao conjunto não unitário de decisões para o caso concreto que são compatíveis com o direito vigente", e a patológica, que se refere à decisão fora das possibilidades conferidas pelo ordenamento jurídico. Segundo os autores, somente essa última pode ser considerada geradora de insegurança jurídica. ${ }^{166}$

Outra questão levantada por Falcão, Schuartz e Arguelhes, refere-se à incompletude do argumento utilitarista, uma vez que exclui do conceito de "incerteza jurisdicional" qualquer ato dos próprios agentes privados, que são os que realizam as negociações, elaboram os contratos e constroem a realidade sobre a qual deverá incidir o direito. Constatam os autores que, para esse argumento, "o agente econômico privado nunca é coresponsável pelos riscos a que se refere o conceito de incerteza jurisdicional”. O problema dessa concepção, segundo os autores, está em que "a exclusão do que não é público da extensão do conceito de incerteza jurisdicional pressupõe, nos casos de decisão judicial contrária ao interesse do credor, que tal decisão confronta um negócio jurídico cuja licitude está acima de toda suspeita". ${ }^{167}$

Ora, se a "incerteza jurisdicional" deriva tanto de atos propriamente jurisdicionais (decisões do juiz com tendências anticredor), quanto de atos normativos (Lei contrária aos interesses dos credores), e se os agentes privados estão completamente isentos de qualquer responsabilidade pela produção da incerteza, tem-se que a chamada incerteza jurisdicional reside pura e simplesmente no suposto viés anticredor de todo e qualquer ato do Poder Público que venha limitar a autonomia privada. Ao adotar-se indistintamente esta doutrina tem-se a retomada do dogma da vontade que imperava no Estado liberal, sem a consideração da evolução dos paradigmas jurídicos, conforme já foi abordado neste trabalho.

A tese defendida por Falcão, Schuartz e Arguelhes, e com a qual a opinião aqui expressa concorda, é a de que apenas a incerteza patológica, decorrente de decisão judicial contrária ao ordenamento jurídico, é que pode ser considerada como geradora de incerteza jurisdicional. Isso porque a própria atividade jurisdicional é normalmente caracterizada por um certo grau de incerteza, que deriva da existência de um conjunto não unitário de respostas juridicamente possíveis. Por outro lado, o simples fato de uma decisão contrariar as expectativas de uma das partes (ou de um determinado grupo de interesses) não é

\footnotetext{
${ }^{166}$ FALCÃO, J.; SCHUARTZ, L. F. e ARGUELHES, D. W. Jurisdição, Incerteza e Estado de Direito. Revista de Direito Administrativo. Editora Atlas. Set/dez 2006. p. 79-111.

${ }^{167}$ FALCÃO, SCHUARTZ e ARGUELHES. op. cit. p. 83-84.
} 
suficiente para ser considerada equivocada. ${ }^{168}$ Uma outra operação deve ser realizada antes que se conclua pela incorreção da decisão do juiz: a de verificar se a expectativa da parte é legítima, ou seja, se ela é merecedora de tutela pelo direito.

Portanto, se a decisão judicial está de acordo com o ordenamento jurídico vigente, não deve ser considerada geradora de incerteza, sendo inaceitável o argumento de que os atos normativos contrários aos interesses dos credores também produzam incerteza, posto que essa postura é contrária ao Estado Democrático de Direito. Se a lei está posta, e é conforme a ordem constitucional, por mais que seja contrária aos interesses desse ou daquele grupo, não deve gerar qualquer incerteza, uma vez que a ninguém é dado duvidar da aplicabilidade do direito vigente. E o juiz que profere uma decisão de acordo com o ordenamento jurídico não faz mais do que cumprir com o seu ofício. Conforme aduzem Falcão, Schuartz e Arguelhes:

Em outras palavras, e complementando o argumento desenvolvido na primeira seção, o fato de o juiz tomar uma decisão contrária ao credor não significa evidentemente que sua decisão reflita um viés anticredor cuja origem possa ser identificada na "vontade livre do juiz". A fonte primária desse viés pode estar tanto nos atos do Poder Legislativo e do Poder Executivo, enquanto responsáveis pela elaboração das normas que o juiz precisa aplicar, quanto nos atos dos agentes econômicos privados - especificamente, do conjunto de credores e devedores diretamente responsáveis pelo conteúdo das cláusulas contratuais submetidas à apreciação judicial". 169

Assim como importa saber se a incerteza gerada é normal (estrutural) ou patológica, deve ser analisado se o contrato objeto da análise do Poder Judiciário contém um risco normal ou um risco excessivo, gerado por uma "expectativa excessivamente otimista" e possivelmente ilegítima. De acordo com os autores em questão:

Esse cálculo possivelmente contra legem das partes contratantes nasce no momento de celebração do contrato, mas só se revela durante a sua execução. O otimismo excessivo da expectativa da legalidade quanto ao contrato fica oculto até o momento em que, provocado pelas partes, o Judiciário proclama a ilegalidade das cláusulas ou de todo o contrato. Se as partes têm liberdade de contratação apenas nos limites do direito vigente, e se, na maioria dos casos, um uso dessa liberdade que ultrapasse esses limites somente será juridicamente constatada quando o contrato for analisado pela autoridade competente (o juiz de direito), então não se pode afirmar que a decisão judicial que aplique o direito vigente e exclua a aplicação do contrato ilegal expressa algum tipo de viés judicial". ${ }^{170}$

\footnotetext{
168 Considerações de Dworkin sobre o direito refletir os interesses da comunidade enquanto ente personificado.

${ }^{169}$ FALCÃO, SCHUARTZ e ARGUELHES. op. cit. p. 103.

${ }^{170}$ Idem, ibidem, p. 104.
} 
Em parte, o equívoco daqueles que criticam a consideração pelo juiz dos valores sociais ao "aplicar a lei" ao caso concreto deve-se à má compreensão do funcionamento do próprio ordenamento jurídico. É incontroverso atualmente para a Teoria Geral do Direito que a premissa maior do silogismo jurídico (hipótese legal aplicável) não é extraída apenas do texto da lei, já que o ordenamento jurídico é composto também de princípios que regem a interpretação dessas mesmas leis, e que podem ser decisivos diante da necessidade de ponderação de direitos no caso concreto. ${ }^{171}$ Contudo, a obtenção da premissa menor também é problemática, segundo aduz Karl Larenz:

A problemática do procedimento silogístico referido reside principalmente, na correcta constituição das premissas, especialmente da premissa menor. No que respeita à premissa maior, não se pode, decerto, admitir que possa ser retirada simplesmente do texto da lei. Ao invés, toda a lei carece de interpretação e nem toda a proposição jurídica está, de modo algum, contida na lei. Disto tratar-se-á nos capítulos IV e V. A obtenção da premissa menor, ou seja, do enunciado de que $\mathrm{S}$ é um caso de $\mathrm{P}$, denomina-se comumente de processo de "subsunção", cujo núcleo se considera também um silogismo lógico". ${ }^{172}$

Esclarece o jurista que, na aplicação do Direito, não ocorre exatamente um processo de subsunção de conceitos mais restritos para outros mais extensos. São os enunciados sobre os fatos que devem ser confrontados com a hipótese estabelecida na lei, sendo sempre necessário um julgamento sobre a situação de fato enunciada, sendo que os termos constantes da Lei precisam ser explicados para que seja possível o julgamento sobre se a situação de fato corresponde a uma hipótese prevista na lei, produzindo-se novos juízos de subsunção. Ou seja, os fatos não são dados estáticos, mas sim, o resultado de uma construção que se obtém por um movimento de ir e vir dos fatos às normas e das normas aos fatos, num processo caracterizado pela constante presença do ato de julgar. ${ }^{173}$

Resta claro, portanto, que a atividade do juiz comporta valoração do caso concreto, tanto em relação à premissa maior, quanto em relação à premissa menor, de forma que a incerteza é algo inerente à estrutura do Direito. ${ }^{174}$

\footnotetext{
171 Paulo Bonavides concatena diversas posições existentes a respeito da normatividade dos princípios jurídicos. Ver em: BONAVIDES, P.. Curso de Direito Constitucional. cit. cap. 8, "Dos princípios gerais de direito aos princípios constitucionais", p. 255-295.

${ }^{172}$ LARENZ, K. Trad. de José Lamego. Metodologia da Ciência do Direito. Lisboa: Fundação Calouste Gulbenkian, 1997, $3^{\text {a }}$ edição, p. 383.

${ }^{173}$ Larenz aduz que "é problemático qualificar a formação da premissa menor somente como 'subsunção', pois que, com isso, se oblitera a participação decisiva do acto de julgar" (LARENZ, K. Metodologia da Ciência do Direito. cit. p. 386). Junqueira fala em sobresunção, para retratar o movimento "da norma ao fato e do fato à norma”. DWORKIN, R. O Império do Direito. São Paulo: Martins Fontes, 2007.

${ }^{174}$ Por outro lado, muito já se discutiu acerca do conceito de Direito (apenas para citar alguns grandes filósofos do direito: Austin, Hart, Kelsen), sendo conhecida a posição de Ronald Dworkin, para quem diante de um caso difícil (hard case), a solução conferida pelo Direito não resulta de um preceito claro e incontroverso, mas sim, de um conjunto de regras e princípios, que devem ser interpretados sistemática e
} 
Dessa forma, as críticas de Armando C. Pinheiro sobre a politização do Poder Judiciário, cujas decisões estariam guiadas pelo objetivo de "justiça social”, refletindo uma "intenção de favorecer grupos sociais e/ou econômicos mais fracos, como trabalhadores e pequenos devedores", são inócuas a partir do momento em que se compreende que a observância dos valores sociais e de proteção à parte mais fraca decorre do próprio ordenamento jurídico $^{175}$, que reconhece, por exemplo, a função social dos contratos $(\mathrm{CC}$, art. 421), a vulnerabilidade do consumidor (CDC, art. $4^{\circ}$ ) e a justiça nas relações contratuais $\left(\mathrm{CDC}\right.$, art. $\left.6^{\circ}, \mathrm{V}\right)$. Não é sem razão que o resultado da pesquisa de opinião ${ }^{176}$, na qual o autor embasa suas conclusões, demonstrou que a tendência dos juízes de exercer um papel social varia conforme a área do direito a que o caso se refere, sendo mais acentuada nas causas relativas a direito do consumidor, trabalhista, meio ambiente e regulação dos serviços públicos, sendo que nas causas referentes a direito comercial, inquilinato e mercado de crédito a proporção inverte-se, prevalecendo a opinião de que os contratos devem ser sempre ou preferencialmente respeitados. ${ }^{177}$

Afirmou-se, linhas atrás, que o direito atualmente está permeado de valores sociais, sendo que é determinação da própria Constituição Federal que a ordem econômica tenha por fim "assegurar a todos a existência digna, conforme os ditames da justiça social" (CF, art. 170). Para assegurar o equilíbrio das relações jurídicas, o legislador reconheceu a vulnerabilidade de alguns sujeitos de direito, dentre eles os consumidores, além do dever de todas as esferas do Poder Público de tutelar esses indivíduos. Sob o aspecto estritamente

teleologicamente, consoante a moral vigente numa comunidade de princípios. Muito embora Dworkin defenda a existência de uma única resposta correta mesmo nos casos difíceis, no que é muito criticado por diversos autores, não nega a dificuldade do caminho a ser percorrido e a existência de incertezas enquanto não se chega à solução definitiva, tanto que para demonstrar o seu argumento utiliza-se da metáfora do Juiz Hércules. (DWORKIN, R. O Império do Direito. São Paulo: Martins Fontes, 2007).

${ }_{175}$ A respeito do princípio da proteção da parte mais fraca remete-se à seção 2.1 da Parte II deste trabalho.

${ }^{176}$ Ver resultados completos em PINHEIRO, A. C. Judiciário, reforma e economia: a visão dos magistrados. Artigo preparado como parte do projeto de pesquisa "Addressing Judicial Reform in Brazil: Institutions and Constituency Building", realizado pelo Instituto de Estudos Econômicos, Sociais e Políticos de São Paulo (IDESP).

${ }^{177}$ Para essa pesquisa, foi feita a seguinte pergunta: "Na aplicação da lei, existe freqüentemente uma tensão entre contratos, que precisam ser observados, e os interesses de segmentos sociais menos privilegiados, que precisam ser atendidos. Considerando o conflito que surge nesses casos entre esses dois objetivos, duas posições opostas têm sido defendidas: A. Os contratos devem ser sempre respeitados, independentemente de suas repercussões sociais; B. O juiz tem um papel social a cumprir, e a busca da justiça social justifica decisões que violem os contratos. Com qual das duas posições o (a) senhor (a) concorda mais?”. Posteriormente, os juízes foram questionados a respeito dos tipos de causas em que deve prevalecer a posição A ou B, obtendo-se os seguintes resultados: em direito do consumidor, trabalhista e meio ambiente a posição A deve prevalecer, respectivamente, para 16.6, 20.3 e 16.2\% dos magistrados, e a posição B deve prevalecer, respectivamente, para 55.4, 45.8 e 55.6\%; já em direito comercial, inquilinato e mercado de crédito a posição A deve prevalecer, respectivamente, para 49.7, 39.5 e 38.2\% dos magistrados, e a posição B deve prevalecer, respectivamente, para 13.2, 22.7 e $23.5 \%$, sendo mínima a posição de que a resposta $\mathrm{B}$ deve sempre prevalecer (respectivamente $2.7,3.9$ e $6.2 \%$ ). 
jurídico, esse dever impõe a interpretação do direito de acordo com os valores vigentes no ordenamento, além do respeito aos direitos fundamentais da pessoa humana, que não podem ser preteridos em favor da adoção de uma posição meramente utilitarista, que desconhece que o direito é constituído não apenas pelos fatos e pelas normas, mas também pelos valores, que se constituem em princípios orientadores de todo o ordenamento jurídico. Para Mário Júlio de Almeida Costa, "na versão originária da análise econômica do direito está em causa uma absolutização inaceitável de meros critérios pragmáticos, típicos de orientações utilitaristas, com desterro do sentido humano do direito". ${ }^{178}$

$\mathrm{O}$ argumento utilitarista não considera o sacrifício dos direitos de determinados indivíduos, já que pressupõe, por mera abstração, que a felicidade geral da sociedade cresce na medida em que a riqueza gerada é maior. Ora, se nem mesmo dentre os economistas o argumento utilitarista fica isento de críticas, ${ }^{179}$ no campo do direito ele não pode ser acatado sem ressalvas. Evidentemente, as conseqüências econômicas da interpretação do direito devem pesar nas decisões judiciais, já que o direito não pode se afastar da realidade, e a harmonia entre desenvolvimento e proteção de direitos fundamentais é uma exigência legal (não se quer impedir o bom funcionamento do mercado, nem o desaparecimento de um instrumento de crédito que seja salutar para o mercado de consumo). O que não se pode admitir é uma visão unilateral do direito, com a consideração apenas de argumentos econômicos, ou apenas de argumentos sociais. A melhor interpretação do direito é aquela que articula os argumentos econômicos com a necessidade de se tutelar os direitos dos consumidores e o núcleo dos direitos fundamentais, de maneira que a "melhor comunidade futura" não venha a violar direitos fundamentais genuínos, que decorrem diretamente da dignidade humana.

\footnotetext{
${ }^{178}$ ALMEIDA COSTA, M. J. Direito das Obrigações. 9a ed., Coimbra: Almedina, 2001.

179 Nesse sentido, importante é a crítica de Amartya Sen, a qual se transcreve: "Para mencionar apenas algumas, apontamos a seguir o que parecem ser deficiências de uma abordagem utilitarista plena: 1) Indiferença distributiva: o cálculo utilitarista tende a não levar em consideração desigualdades na distribuição da felicidade (importa apenas a soma total, independentemente do quanto sua distribuição seja desigual). Podemos estar interessados na felicidade geral e contudo desejar prestar atenção não apenas nas magnitudes "agregadas", mas também nos graus de desigualdade na felicidade. 2) Descaso com os direitos, liberdades e outras considerações desvinculadas da utilidade: a abordagem utilitarista não atribui importância intrínseca a reivindicações de direitos e liberdades (eles são valorizados apenas indiretamente e somente no grau em que influenciam as utilidades). É sensato levar em consideração a felicidade, mas não necessariamente desejamos escravos felizes ou vassalos delirantes. 3) Adaptação e condicionamento mental: nem mesmo a visão que a abordagem utilitarista tem do bem-estar individual é muito sólida, pois ele pode facilmente ser influenciado por condicionamento mental e atitudes adaptativas". (SEN, A. Desenvolvimento como Liberdade. cit. p. 81)
} 


\section{Seção 2.6 - A oportunidade de uma lei específica para tratamento e prevenção das situações de endividamento excessivo do consumidor no Brasil}

Conforme visto ao longo deste capítulo, a revolução da concessão do crédito ao consumidor é um fenômeno relativamente recente na realidade mundial, e muito recente na realidade brasileira. O crescimento do mercado de crédito foi uma decorrência da economia globalizada, que passou a necessitar do poder aquisitivo dos consumidores para escoar a produção em larga escala. O crédito, que na década de 60 era escasso e utilizado apenas para financiar a produção ou pessoas que demonstrassem capacidade econômica para reembolsar as quantias emprestadas, passou a ser concedido a um número cada vez maior de consumidores, mesmo os de baixa renda, caracterizando o que se convencionou chamar de democratização do crédito.

Nos Estados Unidos, o crescimento do mercado de crédito ao consumo desenvolveu-se rapidamente após a decisão da Suprema Corte em 1978 no caso "Marquette" (Marquette National Bank of Mineapolis vs. First Omaha Service Corp), que impulsionou a abolição das leis estaduais contra a usura pecuniária, liberando, na prática, as taxas de juros cobradas pelas instituições financeiras. $O$ surgimento de novos instrumentos de concessão do crédito, sobretudo dos cartões de crédito, foi outro fator que impulsionou o crescimento do crédito ao consumo. ${ }^{180} \mathrm{Na}$ Europa, o mesmo fenômeno ocorreu na década de 80 . Na França, o relatório $n^{0} 60$ do Senado informa que a taxa de crescimento anual do crédito ao consumo, que era de 6\% em 1980, passou para $21 \%$ em 1985 e para $39 \%$ em 1986.

No Brasil, o crescimento do mercado de crédito ao consumo não se comportou da mesma forma que nos Estados Unidos ou na Europa, onde a revolução do crédito ocorreu respectivamente no final da década de 70 e início da década de 80 . Muito embora a

\footnotetext{
${ }^{180}$ Estudos norte-americanos demonstram a relação direta do crescimento do volume de operações com cartões de crédito com o número crescente de pedidos de falência pessoal Conforme Michelle White: "Comparações internacionais também sugerem uma conexão entre débitos de cartão de crédito e pedidos de falência. Ellis (1998) usa a comparação entre os Estados Unidos e Canadá para argumentar pela importância dos débitos de cartão de crédito na explicação do crescimento dos pedidos de falência. Os primeiros cartões de crédito foram expedidos em 1966 nos Estados Unidos e em 1968 no Canadá. No Canadá, tanto os débitos com cartões de crédito quanto os pedidos de falência cresceram rapidamente a partir de 1969. Mas nos Estados Unidos, as leis de usura em vários Estados limitavam a taxa de juros máxima que os fornecedores poderiam cobrar nos empréstimos, o que diminuía o incentivo para expedir cartões de crédito. Os pedidos de falência nos Estados Unidos mantiveram-se estáveis durante os anos 70. Em 1978, contudo, a Suprema Corte dos Estados Unidos efetivamente aboliu as leis Estaduais contra usura na decisão do caso Marquette, e depois disso, tanto os débitos com cartões de crédito quanto os pedidos de falência cresceram rapidamente nos Estados Unidos. Mann (2006) documenta uma relação similar entre débitos de cartões de crédito e pedidos de falência na Austrália, Japão e no Reino Unido”. (Tradução livre de WHITE, M. J. Bankruptcy reform and credit cards. cit., p. 179.)
} 
desregulamentação das taxas de juros no Brasil tenha ocorrido na década de $70^{181}$, a ausência de condições macroeconômicas favoráveis, bem como a forte regulação do mercado financeiro, impediram a explosão do crédito ao consumo nos moldes ocorridos nos países desenvolvidos. Tal como demonstrado na seção 2.1, desde 1999, com a implantação do projeto "Juros e Spread Bancário no Brasil", o Banco Central vem implementando medidas para elevar o volume de crédito livre ao consumidor, inclusive a redução na regulamentação, sendo que a verdadeira guinada ocorreu a partir de 2005, impulsionada, sobretudo, pelo crescimento do crédito consignado e pelo financiamento de veículos, modalidades com taxas de juros mais acessíveis à população. Por outro lado, constatou-se na seção 2.2 que a situação do endividamento no Brasil, sobretudo das populações de baixa renda, tem se agravado nos últimos anos, tendo em vista o crescimento da oferta de crédito predatório, que tem exatamente por alvo esses indivíduos mais vulneráveis. Ademais, o sobreendividamento passivo mostra-se presente em mais da metade dos casos de endividamento, revelando-se uma situação especialmente preocupante.

Verifica-se, portanto, que o mesmo fenômeno que fez surgir a necessidade de uma lei de tratamento das situações de sobreendividamento na Europa está presentes na atual conjuntura sócio-econômica brasileira. Contudo, no nosso ordenamento jurídico, o único procedimento coletivo disponível para o caso de impossibilidade manifesta de pagamento das dívidas da pessoa física é a insolvência civil, que não é interessante nem para os devedores, nem para os credores. Para o devedor esse procedimento é desvantajoso já que a insolvência produz o vencimento antecipado das dívidas e a arrecadação de todos os seus bens (CPC, art. 751), em relação aos quais perderá imediatamente a administração, que ficará a cargo de um auxiliar do juízo (CPC, art. 752, 761 e 763). Ademais, a lei somente admite a discussão da legitimidade e valor do débito se o devedor depositar a quantia correspondente ao crédito do credor requerente (CPC, art. 757); não há previsão para manutenção do mínimo existencial; o devedor somente readquirirá a capacidade para administrar os próprios bens após a liquidação total da massa (CPC, art. 752), o que poderá levar muitos anos; o devedor ficará "eternamente" obrigado, já que somente após 5 anos, contados da data do encerramento do processo de insolvência, é que as suas obrigações

\footnotetext{
${ }^{181}$ Isso ocorreu com a edição da súmula 596 do STF, em dezembro de 1975 , que afastou do âmbito do Sistema Financeiro Nacional a aplicação dos artigos 1.062 do Código Civil e $1^{\circ}$ do Decreto 22.626/33, que limitavam a taxa de juros a $12 \%$ ao ano, pois, segundo o artigo $4^{\circ}$, inciso IX da Lei $4.595 / 1964$, competia ao Conselho Monetário Nacional limitar as taxas de juros (o que na prática jamais ocorreu).
} 
serão consideradas extintas (CPC, art. 778) ${ }^{182}$, sendo que nesse período qualquer bem que ele vier a adquirir poderá responder pelas obrigações antigas, o que evidentemente significa um desestímulo para que o devedor seja produtivo e o excluirá do mercado de consumo. ${ }^{183}$ Segundo José Reinaldo de Lima Lopes, durante esse período, o devedor será praticamente excluído de algumas transações cotidianas, como obter um cartão de crédito ou abrir conta em bancos. ${ }^{184}$

Por outro lado, para os credores, a insolvência civil também não é interessante, já que, além dos custos com o processo judicial e com a contratação de advogados, que atuarão no processo por longos anos, eles perdem qualquer possibilidade de receber seus créditos fora do procedimento concursal de falência, sendo que atualmente os credores detêm instrumentos de crédito que lhes garantem formas mais ágeis e eficazes para cobrança de dívidas. Mesmo para aqueles credores que não dispõem de instrumentos eficazes é preferível a execução individual, já que nos casos de endividamento excessivo, estando presente a impossibilidade manifesta de pagamento do conjunto das dívidas, dificilmente os credores sem garantia receberão algum valor, sendo que as execuções se eternizam e as dívidas acabam prescrevendo quando os credores desistem de reaver seus créditos. Nas palavras de José Reinaldo de Lima Lopes:

Todos esses fatores indicam que o formato institucional da insolvência civil precisa ser reformado para se tornar mais atrativo aos consumidores. A demora do procedimento, longos períodos de diminuição da capacidade civil, a necessidade de serviços legais profissionais e a noção simbólica cultural de que um caso de insolvência é

\footnotetext{
${ }^{182}$ Lopes prevê uma duração média, 10 anos, considerando 5 anos de duração do processo e cinco anos de prazo para a declaração de extinção das dívidas (LOPES, J. R. L. op. cit., p. 93). No entanto, considerando as diversidades da jurisdição brasileira, que inegavelmente sofre com a demora dos processos judiciais, a duração do processo de insolvência civil pode facilmente superar os 5 anos, sendo freqüente observamos processos no juizado especial que duram esse período, bem como processos de falência que demoram mais de 20 anos. Considerando que a insolvência civil é um procedimento que lida com a vida de um ser humano, apostar numa duração inferior a 5 anos é, no mínimo, temerário.

${ }^{183}$ Muitos estudos em direito comparado buscam demonstrar que um longo período no qual os bens do devedor, especialmente seus rendimentos, estejam sujeitos à penhora ou arrecadação no juízo da falência ou da recuperação, desestimula o devedor a trabalhar. Eva-Maria Steiger e Jochen Bigus defendem que um período fixo de boa conduta (prazo no qual muitas legislações estrangeiras mantém a responsabilidade do devedor, p. ex., 6 anos na legislação alemã) é prejudicial, pois o consumidor pode evitar o desenvolvimento de atividades econômicas nesse período. Dessa forma, entendem que se o Capítulo 7 do Bankruptcy Code é muito benéfico ao devedor, e prejudicial aos credores, a legislação alemã é muito rígida e pode reduzir os incentivos ex-post para o consumidor trabalhar severamente. Por fim, comprovam que um período variável de boa conduta evitaria perda de bem-estar e proporcionaria melhores incentivos para que o consumidor tornasse-se economicamente produtivo, e sugerem que seja fixado um montante que o consumidor seria capaz de pagar, e o restante deveria ser perdoado. (BIGUS, J.; STEIGER, E. M. When it pays to be honest: How a variable period os good conduct can improve incentives in personal bankruptcy. Eur Journal of Law and Economics, 2006, 22: 233-253).
}

${ }^{184}$ LOPES, J. R. L. op. cit. p. 93 
um caso de insucesso pessoal, se adicionam à obsolescência histórica do procedimento de insolvência civil. ${ }^{185}$

Resta claro, portanto, a urgência de uma lei que regulamente um procedimento judicial e extrajudicial de recuperação financeira da pessoa física que contemple o conjunto das dívidas vencidas e a vencer e que concilie os interesses dos credores de receber os valores devidos com a necessidade de se preservar o núcleo dos direitos fundamentais, com base nos princípios da dignidade da pessoa humana e da solidariedade social. Aliás, cabe recordar, esse procedimento de recuperação judicial e extrajudicial já está em vigor para as pessoas jurídicas, sendo inconcebível a inexistência de um procedimento semelhante para as pessoas físicas.

Enquanto não for aprovada uma lei específica, nos moldes do que ocorreu na Europa ou nos Estados Unidos, as situações de endividamento excessivo somente poderão ser tuteladas individualmente e na medida das peculiaridades apresentadas no caso concreto, tendo como parâmetro a preservação do núcleo dos direitos fundamentais da pessoa humana, e, por outro lado, a não violação do núcleo intangível de autonomia privada no qual estão fundamentadas as relações negociais.

Atestada a necessidade de aprovação de uma lei que regule a prevenção e o tratamento das situações de endividamento excessivo no Brasil, cumpre verificar, dentre os modelos de tutela existentes no direito comparado, o que melhor se ajusta ao ordenamento jurídico brasileiro, questão que será abordada no capítulo seguinte.

${ }^{185}$ Tradução livre de LOPES, J. R. L., op. cit., p. 94. 


\section{CAPÍTULO 3 - MODELOS DE TUTELA DO ENDIVIDAMENTO EXCESSIVO A PARTIR DO SEU FUNDAMENTO}

O estudo do direito comparado ganha especial importância em matéria de tutela do endividamento excessivo (ou sobreendividamento) do indivíduo não profissional. Muitos ordenamentos jurídicos, sobretudo na Europa e na América do Norte, regulamentam especificamente a matéria, sendo que a literatura jurídica desses países a respeito do tema, em geral, faz referência aos diferentes modelos de tutela existentes para analisar as divergências e as convergências, e assim buscar as soluções jurídicas mais adequadas para a sua realidade sócio-econômica. A complexidade do assunto, que envolve a tutela dos direitos fundamentais do indivíduo e que acarreta efeitos importantes nas estruturas sociais e econômicas, já fez com que muitos países revisassem os diplomas legais que tutelam o crédito e o endividamento do consumidor, seja para conferir uma proteção mais efetiva, seja para evitar abusos por parte das pessoas beneficiárias. O desafio é sempre o de buscar a tutela na medida certa, ou seja, o exato equilíbrio entre proteção e abuso, através dos mecanismos jurídicos aptos a proteger aqueles que de fato necessitam.

Para os objetivos deste trabalho, o estudo comparativo torna-se fundamental, uma vez que, como já referido, o ordenamento jurídico brasileiro não possui regramento específico que permita uma completa recuperação financeira do indivíduo, considerando o conjunto de suas dívidas, de forma a possibilitar aos credores o recebimento igualitário em concurso universal, sem que isso comprometa o respeito aos direitos fundamentais do devedor. A análise da evolução e do estado atual do direito comparado é indispensável para situar o ordenamento jurídico brasileiro nos modelos jurídicos existentes, e assim estabelecer qual é o mais adequado para inspirar uma tutela de lege ferenda, bem como compreender em que medida é possível conferir a tutela jurídica necessária ao indivíduo excessivamente endividado, nos limites do nosso direito positivo. 


\section{Seção 3.1 - Os modelos de tutela existentes no direito comparado}

A partir da análise das legislações existentes sobre o tema, é possível identificar inicialmente dois modelos de tutela: o modelo norte-americano e o modelo europeu, presente em países como Dinamarca (1984), França (1989), Noruega (1993), Finlândia (1993), Suécia (1994), Áustria (1995), Bélgica (1998), Holanda (1998) e Alemanha (1999). Sem adentrar nos fundamentos ideológicos, é possível identificar diferenças nítidas no tratamento das situações de endividamento excessivo do indivíduo não profissional nesses dois sistemas. São apontados pela doutrina, de uma maneira geral, quatro aspectos que os distinguem: 1) o acesso mais ou menos aberto ao perdão ou extinção das dívidas; 2) a previsão de pagamentos obrigatórios como condição para concessão do perdão das dívidas; 3) a obrigatoriedade de uma fase de conciliação; 4) a previsão de órgãos de aconselhamento e de educação do indivíduo excessivamente endividado.

Avançando para os fundamentos ideológicos desses sistemas, verifica-se que o modelo norte-americano apresenta uma orientação liberal, baseada na livre iniciativa e no livre mercado, de maneira que a legislação a respeito da falência pessoal assume a função de servir ao mercado de consumo. Conforme será melhor explicitado a seguir, no modelo liberal o crédito é considerado um bem essencial tanto para a sociedade quanto para o indivíduo, de maneira que a sua utilização em larga escala deve ser incentivada. A lei sobre falência pessoal serve, nesse contexto, como um incentivo para a utilização do crédito, já que na eventualidade de ocorrerem situações como desemprego, problemas de saúde ou até mesmo má administração do orçamento, o indivíduo poderá valer-se de um procedimento que proporcione o seu reingresso no mercado de consumo. A lei funciona, portanto, como uma espécie de seguro para a utilização do crédito. O sistema tem como base a re-alocação de riscos, partindo do pressuposto de que o fornecedor de crédito está em melhores condições para calcular e redistribuir os riscos.

Já o modelo europeu tem seu fundamento no Estado Social intervencionista, onde a questão do endividamento excessivo é vista como um problema social, que gera a marginalização e a exclusão do indivíduo do bem-estar proporcionado pela vida em sociedade. Assim sendo, a legislação a respeito do endividamento excessivo tem a função de proporcionar o respeito aos direitos humanos fundamentais, mais precisamente aos direitos sociais. Numa abordagem histórica, o que ocorreu foi que, com o crescimento do mercado de crédito, os direitos sociais prestados pelo Estado, como o seguro-desemprego e a rede pública de saúde e de educação, mostraram-se insuficientes para tutelar as situações 
apresentadas pelo sobreendividamento, sendo necessária a atuação do direito privado para dar efetividade aos direitos fundamentais desses indivíduos.

Com base nessas premissas é que se desenvolveram os estudos de direito comparado em matéria de endividamento excessivo do indivíduo não profissional. Johanna Niemi-Kiesiläinen segue a divisão entre modelo liberal e modelo do welfare state, ${ }^{186}$ mas especifica os modelos de comparação adotando uma divisão segundo a função desempenhada pela tutela: reabilitação (modelo Escandinavo), pagamento das dívidas (Europa continental - Alemanha), prevenção (França) ou eficiência (Estados Unidos). Iain Ramsay distingue os modelos também segundo a sua função, mas a sua classificação adota categorias mais genéricas, dividindo-se em: modelo de proteção do consumidor, resposta a desvios de conduta do devedor e modelo do Estado Social. ${ }^{187}$ Udo Reifner apresenta uma classificação ligada à ideologia seguida pela legislação, distinguindo entre: modelo do fresh start, modelo re-educacional e modelo da proteção social. ${ }^{188}$ Por fim, Rafael Efrat divide os modelos de falência pessoal em conservador, moderado e liberal, de acordo com a política adotada para o perdão das dívidas. ${ }^{189}$

Antes de passar ao estudo dos modelos existentes, faz-se necessário um acerto da terminologia que será utilizada, apresentando, ainda, a sua tradução em inglês e francês, pois é freqüente a referência aos termos nesses idiomas. A tutela do endividamento excessivo nos modelos liberal e tradicional é em geral referida como falência (bankruptcy, faillite) ou insolvência (insolvency, insolvabilité); já no modelo social é referida como sobreendividamento (overindebtedness, surendettement), restabelecimento pessoal (personal recovery, rétablissement personnel ou rédressement personnel) ou reorganização das dívidas (debt adjustment). Quanto à pessoa sujeita à tutela pode ser referida como indivíduo não profissional, consumidor ou particular, conforme a tutela conferida pelo ordenamento jurídico em referência. ${ }^{190} \mathrm{O}$ termo discharge (em francês effacement des dettes) refere-se ao perdão ou extinção das dívidas, e o termo fresh start refere-se ao re-

\footnotetext{
${ }^{186}$ NIEMI-KIESILÄINEN, J. Collective or Individual?..., cit. 2003; Idem, Changing directions in consumer bankruptcy law and practice in Europe and USA. Journal of Consumer Policy. Dordrecht: 1997. Vol. 20, Iss. 2; pg. 133, 10 pgs; Idem, Consumer Bankruptcy in Comparison: Do We Cure a Market Failure or a Social Problem? cit. p. 473-503.

${ }^{187}$ RAMSAY, I. Models of Consumer Bankruptcy..., cit., 2007, p. 256-257.

${ }^{188}$ REIFNER, U. Overindebtedness of Consumers in the EC. In: Huls et al. Overindebtedness of Consumers in the EC Member States: Facts and Search for Solutions, 1994.

${ }^{189}$ EFRAT, R. Global Trends in Personal Bankruptcy. cit., 2002.

${ }^{190} \mathrm{Na}$ França, por exemplo, a tutela do surendettement é parte integrante do Code de la Consommation, muito embora não se refira apenas ao consumidor, atingindo dívidas que não se caracterizam como de consumo (CALAIS-AULOY, J.; STEINMETZ, F.. Droit de la consommation. $7^{\mathrm{a}}$ ed. Paris: Dalloz, 2003. p. $611)$.
} 
ingresso do indivíduo no mercado de consumo, ou seja, uma segunda chance concedida ao devedor para recomeçar a sua vida livre de dívidas.

\subsubsection{Modelo tradicional: insolvência civil como forma de tutelar o direito dos credores e como resposta a desvios de conduta do devedor}

O primeiro modelo proposto, de falência como forma de tutelar o direito dos credores e como resposta para desvios de conduta, decorre da origem criminal das leis sobre falência, as quais surgiram para proporcionar ao credor um meio coercitivo para atingir o patrimônio do devedor. O procedimento surgiu, portanto, em favor dos credores, como um método efetivo para alcançar os bens do devedor e permitir uma distribuição igualitária desses bens entre os credores. Esse é o modelo historicamente mais antigo e mais arraigado na cultura popular, de maneira que remanesce até os dias atuais em alguns ordenamentos jurídicos a idéia de que a falência é uma sanção para um comportamento delinqüente do devedor. Nesses sistemas, a imagem do comerciante falido é menos estigmatizada que a do indivíduo falido: este é visto como inábil, incapaz de lidar com os seus negócios domésticos, e de conduta indesejada pela sociedade; já para o comerciante a falência é vista como parte inevitável do mundo dos negócios. ${ }^{191}$ Talvez por isso, em ordenamentos jurídicos como o brasileiro, exista apenas um procedimento de recuperação (judicial ou extrajudicial) para empresários (no caso brasileiro, regrado pela Lei número 11.101/2005), o mesmo não ocorrendo com o indivíduo não profissional.

O procedimento de insolvência civil em vigor no Brasil (CPC, arts. 748 a 786-A) segue esse modelo tradicional, já que foi concebido para proporcionar uma forma de execução coletiva sobre os bens do devedor insolvente, e promover uma distribuição igualitária (concursal) entre os credores do produto obtido com a liquidação desse patrimônio, sem apresentar nenhuma preocupação com os atributos da personalidade humana do devedor e sem considerar que os consumidores de crédito podem ter caído em insolvência por questões alheias a sua vontade, induzidos pelo mercado através da oferta de crédito fácil e da publicidade que incentiva o consumo, e/ou em razão de uma adversidade da vida como o desemprego. Esse procedimento tornou-se inócuo tanto por sacrificar demasiadamente o devedor (v.g. perda da administração dos bens e conseqüente redução da capacidade civil desde o início do procedimento até cinco anos após o término,

${ }^{191}$ RAMSAY, I. op. cit., 1997, p. 274. 
prazo que poderá tornar-se "eterno", conforme a duração do processo), quanto por não atender efetivamente os interesses dos credores, que perdem a possibilidade de negociar individualmente os seus créditos e acabam por não recebê-los, diante da insuficiência dos bens passíveis de penhora e da ineficácia dos meios executivos, já que, com a declaração de insolvência, o devedor torna-se improdutivo e perde qualquer possibilidade de cumprir com as obrigações anteriormente assumidas. Além disso, esse procedimento não é interessante para o mercado de consumo, já que a pessoa insolvente é excluída do mercado, tal como uma "morte civil" ou, como se refere Cláudia Lima Marques, ocorre a morte do homo economicus. ${ }^{192}$

Rafael Efrat denomina esse modelo de conservador, descrevendo-o como aquele no qual os indivíduos não comerciantes não são elegíveis para requerer a proteção da falência, e, portanto, não estão sujeitos a qualquer perdão de dívidas. Nesse grupo, o autor inclui os países da América do Sul e América Central, inclusive o Brasil. ${ }^{193}$ Ainda nesse modelo estão incluídos países que permitem o procedimento de falência para os indivíduos, mas não admitem o perdão de dívidas, tal como ocorre no Chile. ${ }^{194}$

Ramsay indica uma alteração nessa visão do devedor como delinqüente, mencionando os estudos de Teresa Sullivan, Elizabeth Warren e Jay Lawrence Westbrook, ${ }^{195}$ para quem o devedor passa a ser visto como uma pessoa que necessita de tratamento. Daí as atuais reformas possuírem previsões a respeito do aconselhamento e educação do devedor. Passa a existir uma noção de responsabilização dos fornecedores pelo endividamento dos consumidores, surgindo questões como "quem está criando e alimentando o vício no crédito"? Daí o porquê de, no ordenamento francês, haver disposição expressa no sentido de responsabilizar o credor pela má-concessão do crédito $^{196}$, devendo a comissão de sobreendividamento considerar também a conduta do credor ao impor as medidas de reorganização das dívidas para a recuperação do devedor.

\footnotetext{
${ }^{192}$ MARQUES, C. L. Sugestões para uma lei sobre o tratamento do superendividamento de pessoas físicas em contratos de crédito ao consumo: proposições com base em pesquisa empírica de 100 casos no Rio Grande do Sul. In: CAVALLAZZI, R. L.; MARQUES, C. L. (coord.). Direitos do Consumidor Endividado - Superendividamento e crédito. São Paulo: Revista dos Tribunais, 2006, p. 260.

${ }^{193}$ Mesmo existindo no caso brasileiro o procedimento de insolvência civil, o autor não considera esse procedimento como uma forma de tutela para o devedor, pois é mais caracterizado por um concurso de credores, aproximando-se, portanto, do sistema tradicional (EFRAT, R. op. cit. 2002).

${ }^{194}$ EFRAT, R. op. cit., págs. 83-84.

195 SULLIVAN, WARREN e WESTBROOK. As we forgive our debtors: Bankruptcy and Consumer credit in America. New Oxford University Press, 1989.

${ }^{196}$ Assim estabelece o artigo L331-7, alínea 7 do Code de la Consommation: Pour l'application du présent article, la comission prend en compte la connaissance que pouvait avoir chacun des créanciers, lors de la conclusion des différents contrats, de la situation d'endettement du débiteur. Elle peut également vérifier que le contrat a été consenti avec le sérieux qu'imposent les usages professionnels.
} 


\subsubsection{Modelo liberal: falência pessoal como instrumento de regulação do mercado e de tutela do consumidor de crédito}

O modelo liberal de tutela do endividamento excessivo ou falência pessoal tem como fundamento servir de instrumento do mercado de crédito, sendo adotado pelos países de cultura jurídica anglo-saxônica, tendo como representante mais expressivo o sistema norte-americano.

Nos Estados Unidos a lei sobre falência pessoal faz parte do Código de Falências (Bankruptcy Code) de 1898, que, a partir da reforma de 1978, passou a prever o mecanismo do "fresh start", pelo qual o indivíduo excessivamente endividado recebe uma segunda chance para recomeçar a vida livre de dívidas, após a liquidação dos seus bens passíveis de penhora. De acordo com a Bankruptcy Laws Comission, em 1973, o crédito era visto como uma instituição social benéfica tanto para o indivíduo quanto para a sociedade, pois proporciona crescimento econômico e bem-estar pessoal. ${ }^{197}$ Para tanto, o indivíduo deveria ser incentivado a assumir riscos, e a lei de falências serviria como um seguro social para aqueles que se servissem do crédito. E da mesma forma que o acesso ao crédito era facilitado, também deveria sê-lo o acesso ao "fresh start", proporcionado pela lei de falências. ${ }^{198}$ Esse procedimento deveria, portanto, ser rápido e aberto a todos que dele necessitassem para que pudessem retornar ao mercado aptos a continuar consumindo.

Ademais, também era importante proporcionar uma distribuição justa e equânime dos bens do devedor entre os credores. Portanto, a lei sobre falência pessoal dos Estados Unidos surgiu com o claro intuito de servir ao mercado de consumo, sendo que muitos dos estudos existentes sobre esta lei baseiam-se nos preceitos da doutrina "law and economics", que a consideram como uma alocação de riscos. De acordo com Johanna Niemi-Kiesiläinen, para essa doutrina, como os riscos típicos do mercado de consumo de crédito são imprevisíveis, eles devem ser alocados para a parte que está em melhor posição para suportá-los, ou seja, o fornecedor de crédito. E isso ocorre mesmo que o consumidor possua melhores informações sobre o risco (que, por exemplo, não terá capacidade de

\footnotetext{
${ }^{197}$ Bankruptcy Laws Commission, Report of the Commission on the Bankruptcy Laws of the United States, H. R. Doc. No. 93-173 (1973), apud NIEMI-KIESILÄINEN, J. op. cit., 1999, p. 476.

${ }^{198}$ NIEMI-KIESILÄINEN, J. op. cit., 1999, p. 476.
} 
restituir o valor emprestado), pois o fornecedor está igualmente em melhor posição para diversificar e calcular os riscos. ${ }^{199}$

À primeira vista, causa estranheza a afirmação de que o sistema liberal é aquele que mais beneficia o devedor (sendo constantemente referido como debtor friendly), pois proporciona um amplo acesso ao perdão das dívidas (a chamada política do fresh start), enquanto que o sistema do Estado Social permite um acesso mais restrito ao perdão das dívidas. Todavia, cabe observar que quanto maior a rede de direitos sociais prestados pelo Estado, menor será a vulnerabilidade financeira do indivíduo em caso de desemprego, doença ou ruptura familiar, fatores freqüentemente relacionados ao endividamento excessivo, e menor será a necessidade de proteger a pessoa contra os riscos inerentes ao crédito.

Por outro lado, observe-se que é do interesse do mercado de crédito que os indivíduos sejam incentivados a tomar empréstimos, mantendo-se economicamente ativos e aquecendo a economia. Daí porque o ordenamento jurídico oferece uma "válvula de escape", com um regramento benéfico ao devedor. ${ }^{200}$ Assim, mesmo aparentemente contrária aos princípios liberais da não interferência do Estado na economia e da força obrigatória dos contratos, a instituição do fresh start pela legislação norte-americana serviu aos interesses do mercado, e apenas por via reflexa é que acabou por proteger o consumidor de crédito.

Nesse sentido, é também possível falar da tutela do endividamento excessivo enquanto proteção ao consumidor, conforme classificação de Iain Ramsay. Segundo o autor, o consumidor possui uma "racionalidade limitada", seja devido à falta de informações adequadas, seja em razão da tendência natural dos indivíduos de subestimarem os riscos futuros, ${ }^{201}$ tais como desemprego, doença e ruptura familiar. Essas externalidades são apontadas como as mais freqüentes causas de sobreendividamento, sendo que o problema não é apenas a impulsão para o consumo, mas uma falha sistemática na análise dos riscos. ${ }^{202}$ Para essa concepção, o sobreendividamento não possui significado

\footnotetext{
${ }^{199}$ A autora cita estudos da doutrina law and economics a respeito do tema: WESTON, F. Some Economic Fundamentals for an analysis of Bankruptcy (1977) 41 Law and Contemp. Probl. 47 at 56; JACKSON, T. H. The Logic and Limits of Bankruptcy Law (Cambridge, Mass.: Harvard University Press, 1986) at 229; HOWARD, M. A Theory of Discharge in Consumer Bankruptcy (1987) 48 Ohio St. L.J. 1047 at 1064. Ver em NIEMI-KIESILÄINEN, J. op. cit., 1999, nota 13, p. 477.

${ }^{200}$ Report of the Commission on the Bankruptcy Laws of the United States, HR Doc no 93-173, 1973 apud NIEMI-KIESILÄINEN, J. op. cit., 2003, pág. 46.

${ }^{201}$ A esse respeito ver KILBORN, J. J. Behavioral Economics, Overindebtedness \& Comparative Consumer Bankruptcy: Searching For Causes And Evaluating Solutions. Emory Bankruptcy Developments Journal. Atlanta, fall 2005, vol. 22, Iss. 1, pg. 13.

${ }^{202}$ RAMSAY, I. op. cit., 1997, pág. 274.
} 
pejorativo, pois há a compreensão de que qualquer pessoa está sujeita aos riscos inerentes ao mercado de crédito. A política do fresh start nesse modelo é considerada a única forma efetiva de se tutelar o consumidor, devendo os riscos ser absorvidos pelos credores, que em geral estão em melhor posição para calculá-los e suportá-los.

Ramsay ressalta, ainda, que o fato dos custos serem suportados pelos credores cria incentivos para que eles monitorem a inadimplência, reduzindo os problemas de falência. Para o autor, na perspectiva do consumidor, o procedimento deve ser aberto a todos os indivíduos que estiverem em situação de falência. ${ }^{203}$ Como é possível perceber, esse modelo é compatível com o modelo norte-americano, que, como visto anteriormente, foi concebido em função do mercado de crédito, e não apenas em função da proteção da pessoa do consumidor. Conforme destaca Ramsay, nos Estados Unidos e Canadá a lei sobre falência pessoal foi justificada mais em termos de produção do que de valores de consumo. $^{204}$

Em razão do fundamento utilitarista de incentivo ao mercado de consumo, o modelo liberal é marcado pelas seguintes características:

1) Amplo acesso à extinção das dívidas (discharge ou effacement de dette), e do conseqüente fresh start, independentemente de considerações morais a respeito da boa-fé do devedor ou da efetiva possibilidade de pagar a dívida. Originalmente, o sistema norteamericano não previa mecanismos para aferir a boa-fé do devedor. Isso mudou em 2005.

2) Desnecessidade do devedor passar por um plano de pagamento antes da concessão da extinção das dívidas. Nos Estados Unidos, existem dois caminhos para o indivíduo não profissional receber a extinção das dívidas: pelo Capítulo 7 ou pelo Capítulo 13 do Código de Falências. Pelo Capítulo 7, o indivíduo recebe o discharge (extinção das dívidas) por um procedimento rápido e desburocratizado de liquidação, no qual seus bens penhoráveis são arredados, vendidos, e o produto da venda distribuído aos credores. Ocorre que, dependendo das regras sobre impenhorabilidade dos bens e dos rendimentos, que nos Estados Unidos variam conforme o Estado em que a falência é requerida, pode não existir nenhum bem passível de arrecadação, caso em que o devedor é rapidamente liberado de suas dívidas. Já pelo Capítulo 13, o devedor propõe um plano de pagamentos periódicos, com duração de 2 a 3 anos, que será administrado por um trustee, e somente após o término do plano é que ele poderá receber o discharge. Até 2005, a escolha entre os capítulos 7 e 13 era livre, sendo que somente optava pelo capítulo 13 o devedor que

\footnotetext{
${ }^{203}$ RAMSAY, I. op. cit.,1997, pág. 278.

${ }^{204}$ Idem, ibidem, pág. 278.
} 
possuísse uma quantidade razoável de bens passíveis de penhora e desejasse mantê-los. Daí as inúmeras críticas de que, mesmo nos casos em que o devedor tivesse capacidade financeira, com rendimentos mensais regulares, se ele não possuísse muitos bens penhoráveis ele acabaria optando pelo capítulo 7 e receberia o discharge. Mas a partir da reforma de 2005, foi instituído nos Estados Unidos o means testing, ou seja, o estabelecimento de requisitos para determinar qual o procedimento que deverá ser seguido, e assim forçar os devedores que possuem rendimentos regulares acima de um determinado patamar a requererem falência pelo Capítulo 13, e assim, obrigá-los a efetuar um plano de pagamentos antes de receberem o discharge.

3) A maior parte do procedimento se desenvolve administrativamente, perante o U.S. trustee. Nos procedimentos do Capítulo 7, o juiz de falência somente é acionado se alguma das partes formular alguma objeção e, nos casos do Capítulo 13, o juiz pronunciase apenas na audiência de confirmação do plano, sendo todo o restante do procedimento, inclusive a reunião de credores, comandada pelo U.S. trustee. ${ }^{205}$

4) Desnecessidade da existência de agências ou entidades especializadas em oferecer conselhos financeiros (debt counselling). O modelo norte-americano, na sua origem, optou pela não inclusão de esquemas morais na legislação sobre falência pessoal, de maneira que não se pensou inicialmente na reeducação do consumidor de crédito, pois não interessavam as razões sócio-culturais que levavam o indivíduo a requerer a falência. Admitia-se, pura e simplesmente, que os riscos do mercado de consumo de crédito seriam incalculáveis, e que o fornecedor é a parte que está em melhores condições para suportar, calcular e redistribuir esses riscos. Nenhum elemento subjetivo do consumidor, como inabilidade para a gestão das finanças, compulsão para o consumo, dentre outras questões, foi considerado. Na verdade o que se queria era exatamente incentivar o consumo por intermédio da utilização do crédito. Entretanto, mesmo nos Estados Unidos, reconheceu-se a importância das agências de aconselhamento do consumidor. No Canadá, a figura do trustee desempenha um papel importante como conselheiro do devedor, evidenciando que a prática do aconselhamento já vem sendo largamente adotada. ${ }^{206}$

\footnotetext{
${ }^{205}$ Bankruptcy BASICS, Administrative Office of the United States Courts, $3^{\text {rd }}$ edition, April 2006.

${ }^{206}$ RAMSAY, I. op. cit., 1997, p. 270; RAMSAY, I. op. cit., 2006, p. 271.
} 


\subsubsection{Modelo social: tutela do indivíduo excessivamente endividado como forma de preservação dos direitos fundamentais da pessoa humana}

Um terceiro e último modelo a ser analisado é o social, também chamado de modelo da proteção social ${ }^{207}$, o qual é adotado de uma maneira geral pelos países europeus. Ao lado da doutrina "law and economics", surgiu nos Estados Unidos a "sociallegal school", que enfoca seus estudos nos problemas sociais e razões pessoais que levam os indivíduos a requerer falência. Para Johanna Niemi-Kiesiläinen, o pensamento europeu parece estar mais próximo à visão da escola sócio-jurídica americana, pois a tendência é a de enfatizar as causas do sobreendividamento, como a recessão econômica, o desemprego, o fracasso nos negócios, e desventuras pessoais como doenças e má gestão do orçamento doméstico, às quais acrescentamos a constantemente citada ruptura familiar (divórcio ou separação). Segundo a autora, na Europa, o sobreendividamento é visto como um problema social, e não como uma deficiência do mercado, tal como ocorre nos Estados Unidos. ${ }^{208}$

$\mathrm{Na}$ Europa, o crédito não era tão popular antes do final dos anos 70. Portanto, até a década de 80 , os problemas relacionados ao crédito não estavam na agenda política, até mesmo porque, nesta época, o mercado de crédito era severamente regulado e, portanto, não era acessível à massa de consumidores. Dessa forma, problemas isolados não geravam pressão política suficiente para a elaboração de um diploma legal que conferisse uma tutela jurídica adequada para os indivíduos que por uma desventura da vida fossem assolados por um endividamento excessivo. Os devedores passavam a ser prisioneiros das dívidas que, na descrição de Thomas Wilhelmsson, trata-se de "uma situação na qual o débito do consumidor constantemente cresce, apesar dos esforços para pagar, por causa dos juros nas prestações atrasadas, custos das execuções das dívidas, novos e mais caros empréstimos, etc.". ${ }^{209}$ De outra parte, os credores que não conseguiam haver seus créditos acabavam desistindo da cobrança, reconhecendo após muitos anos que os esforços seriam inúteis. ${ }^{210}$

\footnotetext{
${ }^{207}$ REIFNER, U. Overindebtedness of Consumers in the EC. cit., 1994.

${ }^{208}$ NIEMI-KIESILÄINEN, J. Consumer Bankruptcy in Comparison: Do We Cure a Market Failure or a Social Problem? Osgoode Hall Law Journal, vol. 37, nº 1 e 2, 1999, p.

${ }^{209}$ Tradução nossa. Do original: "a situation in which the debt of the consumer constantly grows, in spite of his efforts to pay, because of interest for delayed payments, debt collection costs, new, more expensive loans, etc". (WILHELMSSON, T. Social Force Majeure..., cit, p. 1).

${ }^{210}$ Johanna Niemi-Kiesiläinen assim descreve a situação: "The debt problems of households were not on the political agenda either. Admittedly, some individual debtors had excessive debt loads, mostly arising out of unsuccessful businesses. How these cases were handled has never been properly examined, but creditors may have used several strategies. Credit institutions pursued their claims in due order, sometimes causing formal bankruptcy of the debtor, and wrote off the debts, The legal prescription periods for private debts were long thirty years in Germany, for example, and tem years in many other countries - and could be renewed na
} 
Entretanto, com a gradual desregulamentação do mercado de crédito e o crescimento na demanda por empréstimos, os problemas foram se tornando mais freqüentes, até que, em meados dos anos 80 , as pressões sociais e políticas, sobretudo por parte das famílias de classe média, deram origem aos primeiros diplomas legais a respeito do tratamento do sobreendividamento dos indivíduos e das famílias, ${ }^{211}$ no mais das vezes tratados na condição de consumidores. Essas leis eram também vistas como parte da proteção conferida pelo Estado Social, tendo em vista a noção corrente de que as pessoas deveriam ser protegidas contra eventualidades da vida, como o desemprego e a doença.

De fato, a Europa após a Segunda Guerra Mundial incorporou o modelo do Welfare State, ${ }^{212}$ pelo qual o Estado assumiu o dever de proteger o indivíduo nas situações adversas impostas pela vida, devendo prestar os direitos sociais considerados fundamentais ao ser humano. ${ }^{213}$ Entretanto, a nova realidade do crescimento na demanda por crédito fez surgir um problema novo para o Estado Social: a proteção até então existente não alcançava os indivíduos excessivamente endividados, já que o endividamento tem sua origem nas relações jurídicas de direito privado. Surgiu a necessidade, portanto, do ordenamento jurídico envolver os atores privados na tutela dos direitos fundamentais, sendo editadas as leis de tratamento das situações de sobreendividamento. Dessa forma, é possível identificar na tutela do endividamento excessivo um claro fundamento nos direitos sociais.

Ensina Johanna Niemi-Kiesiläinen que no direito civil é freqüente a influência dos valores sociais, sendo que a proteção à parte mais fraca é de uma maneira geral aceita como princípio de direito privado. ${ }^{214}$ Tal princípio verifica-se, por exemplo, nas leis de proteção do trabalhador, nas que regulam aquisição da casa própria e nas de proteção do

unlimited number of times. It is assumed, however, that many creditors wrote off the debt after recognizing that further enforcement efforts would be futile. Tax authorities and other public or semi-public creditors took the same position, but these debts usually had shorter prescription periods and were not subject to renewal. Even less in known about what happened to debtors. Some resumed their careers or businesses and prospered, while others left the labour force and lived on the margins of society with the help of welfare payments or through illegal activities. Some debtors took up paid work; however, that could be very frustrating for them, since salaries were easy to trace and subject to garnishment, perhaps for the rest of their lives. Nevertheless, the number of these debtors was so small that there was no political pressure to change the debt enforcement legislation before the recession at the beginning of the 1990s.") NIEMIKIESILÄINEN, J. op. cit., 1999, p. 479-480.

${ }_{211}$ O primeiro diploma legal na Europa surgiu na Dinamarca, em 1984, seguido pela França em 1989.

212 Tony Judt constatou as diferenças entre os Estados Unidos e o Modelo Social Europeu, assim descrevendo: "europeus recebiam serviços médicos, aposentadoria adiantada e prodigiosa gama de serviços públicos e sociais. Na escola secundária, eles eram mais bem educados que os Americanos. Eles viviam de maneira mais segura e - em parte por essa razão -, tinham vida mais longa e gozavam de melhor saúde (apesar de gastarem menos) e haviam muito menos pessoas na pobreza. Esse era o 'Modelo Social Europeu"”. (JUDT, T.. Postwar: A History of Europe Since 1945. 2005. apud RAMSAY, I. op. cit. 2006, p. 246.

${ }^{213}$ RAMSAY, I. op. cit., 2006, pág. 246

${ }^{214}$ NIEMI-KIESILÄINEN, J. op. cit., 2003, pág. 48. 
consumidor. Da mesma forma, é possível verificar nos novos princípios do direito contratual, como o da boa-fé, da função social e do equilíbrio contratual, a forte presença do valor social nos contratos. Sendo o endividamento excessivo considerado um problema social e fonte de desrespeito aos direitos fundamentais do indivíduo, a tutela pelo direito privado reflete seu fundamento nos valores do Estado Social, o que já vinha sendo defendido por Thomas Wilhelmsson, ao falar da doutrina da "social force majeure" no direito privado. ${ }^{215}$

Nas últimas três décadas, o tema da proteção da pessoa excessivamente endividada enquanto um problema social, por ser fonte de exclusão social e de desrespeito aos direitos fundamentais do indivíduo, esteve - e ainda está - na ordem do dia das discussões da Comunidade Européia. Essa preocupação fez com que vários países elaborassem ou aperfeiçoassem as suas leis de proteção ao consumidor ou de falência pessoal, sendo que atualmente discute-se a tutela do sobreendividamento pelo Direito Comunitário, tendo em vista que o mercado de crédito ultrapassa as fronteiras dos Estados-Membros Europeus. Os países que ainda não possuem regulamentação própria estão, ao menos, discutindo a elaboração de uma lei semelhante a dos países vizinhos. ${ }^{216}$ Não obstante a identidade na fundamentação ideológica, os diversos países europeus desenvolveram diferentes abordagens legislativas para o problema do endividamento excessivo.

Na França, a lei Neiertz de 31 de dezembro de $1989^{217}$ veio em socorro de famílias sobreendividadas em razão do crescimento acentuado da disponibilidade do crédito e da desregulamentação do setor. ${ }^{218}$ Esta lei teve uma conotação diversa do Bankruptcy Code

\footnotetext{
${ }^{215}$ WILHELMSSON, T. Social Force Majeure..., cit. p. 1 - 14.

${ }^{216}$ Em Portugal existe o Projeto de lei 291/IX/1 sobre a prevenção e tratamento do sobreendividamento das pessoas singulares. Com relação à Itália, ver EFRAT, Rafael. cit..

${ }^{217}$ Foram previstos dois procedimentos para possibilitar a recuperação financeira do devedor de boa-fé: um amigável e extrajudicial, que se desenvolvia perante as comissões de sobreendividamento (réglement amiable), e outro judicial, que era aberto perante o Tribunal de instância do domicílio do devedor (redressement judiciaire civil). Em ambos os casos, era elaborado um plano de recuperação financeira, pelo qual a dívida poderia ser alongada e os juros reduzidos, não havendo previsão para extinção das dívidas, ainda que a condição pessoal do devedor permitisse a conclusão de que ele não teria capacidade de cumprir o plano. Evidentemente, na fase amigável, alguns credores poderiam perdoar total ou parcialmente as dívidas. Em 1995, uma nova lei alterou o procedimento na tentativa de descongestionar o poder judiciário, tendo em vista o crescente número de dossiês que eram apresentados (de acordo com o relatório do senado $\mathrm{n}^{\circ} 60$, em 1990 foram pouco mais de 90 mil dossiês apresentados, e nos anos que se seguiram o número permaneceu constante em pouco mais de 60 mil, acumulando ao final de 1994 o total de 364.550 dossiês). A partir desta lei, o procedimento deveria necessariamente ser iniciado perante as comissões que, uma vez frustrada a conciliação (elaboração do plano convencional), poderiam "recomendar" as medidas que entendessem cabíveis para compor os interesses, podendo os credores contestar as medidas recomendadas perante o juiz da execução, que passou a ter competência para decidir a respeito das contestações e para conferir força executória às medidas, após o julgamento das contestações ou diante da ausência destas.

${ }^{218}$ De acordo com o relatório de informação $\mathrm{n}^{\circ} 60$ do Senado Francês, veio em socorro de aproximadamente 200.000 famílias que se encontravam em situação de urgência social Disponível em:
} 
norte-americano, pois inseriu a regulamentação no âmbito do Code de la Consommation $^{219}$, sob a rubrica traitement des situations de surendettement, evitando o termo pejorativo "falência" 220 , pois havia a compreensão de que o sobreendividamento era decorrência da conjectura econômica, que o favorecia e o incentivava. A primeira situação de "urgência social" que se apresentou foi, portanto, a dos sobreendividados ativos, ou seja, da massa de consumidores que tomou muitos empréstimos, subestimando os riscos capazes de levá-los à inadimplência. Nesse primeiro momento, não se admitia o perdão das dívidas, nem mesmo a sua extinção parcial, exceto se o próprio credor concordasse.

Posteriormente a lei foi reformada pela a lei de 29 de julho de 1998 relativa à luta contra as exclusões sociais, para atender à situação dos sobreendividados passivos, ${ }^{221}$ ou seja, daquelas pessoas que sofrem não de um excesso de dívidas, mas de uma falta de recursos. ${ }^{222}$ A necessidade da reforma deu-se em razão do alto índice de descumprimento dos planos de recuperação por absoluta falta de recursos por parte dos devedores. ${ }^{223} \mathrm{~A}$

$<$ http://www.senat.fr/rap/r97-060 mono.html\#fn2 $>$. Acessado em 17 de novembro de 2009. Ver ainda: PAISANT, G. La réforme de la procédure de traitement du surendettement par la loi du 29 juillet 1998 relative à la lutte contre les exclusion. RTD Com. 1998, p. 743.

${ }^{219}$ Muito embora a tutela tenha sido introduzida no âmbito do Código do Consumidor, entende-se que a tutela não está restrita ao consumidor, o que se denota pela preferência do termo "surendettement des particuliers" em vez de "surendettement des consommateurs". Nesse sentido ver : CALAIS-AULOY, J.; STEINMETZ, F.. Droit de la consommation. cit.. p. 609.

${ }^{220}$ A comissão de elaboração da lei rejeitou a possibilidade de extensão do procedimento existente nos departamentos de Alsace-Moselle, pois o entendimento era o de que o procedimento deveria ser marcado pela conciliação. Como consta no Relatório do Senado $\mathrm{n}^{\circ} 60$, « Mme Véronique Neiertz, secrétaire d'État à la consommation, déclarait à cet égard, lors de l'examen du projet de loi : il faut organiser la prévention, garder toute ses chances à la conciliation, créer en France une procédure collective qui permette aux juges d'alléger l'ensemble des dettes, de quelque nature qu'elles soient et, enfin, répondre absolument à une situation d'urgence. Le caractère à la fois inadapté, onéreux et infamant de la faillite civile et les risques de déresponsabilisation des débiteurs et de surcharge des tribunaux ayant été soulignés, le principe de l'extention de cette procédure, en vigueur dans les trois départements d'Alsace-Moselles, à l'ensemble du territoire a été écarté ».

${ }^{221} \mathrm{O}$ modelo introduzido pela lei Neiertz não tardou a revelar as suas deficiências, pois os planos aprovados, seja amigavelmente, seja por imposição da comissão, não eram condizentes com a capacidade financeira dos devedores, que não raro passavam a descumpri-los. Segundo Gilles Paisant, a lei Neiertz levou em consideração o sobreendividado ativo, que é aquele concernete ao indivíduo que foi buscar o crédito mesmo possuindo recursos próprios sufucientes, e acabou extrapolando os seus limites, embalado pelo forte crescimento na oferta do crédito (PAISANT, G. La réforme de la procédure de traitement du surendettement par la loi du 29 juillet 1998 relative à la lutte contre les exclusions. RTD Com., Dalloz, 1998, p. 743). A lei não considerou o sobreendividado passivo, que é aquele do indivíduo que, em virtude de um acidente da vida, teve a sua capacidade financeira reduzida. Constatou-se que $69 \%$ das situações de sobreendividamento eram causadas por acidentes da vida, como desemprego, divórcio, doenças, dentre outros, sendo que esses devedores estavam com a sua situação financeira de tal forma comprometida que qualquer plano imposto, nos termos permitidos pela lei, seria fatalmente descumprido.

${ }^{222}$ Idem, ibidem.

${ }^{223}$ Segundo informam Vigneau e Bourdin, de acordo com estudo realizado em 2002 pelo Banco da França, $27 \%$ dos devedores sobreendividados não dispunham de qualquer capacidade de reembolso e, em $78 \%$ dos casos, essa capacidade era inferior ou igual ao montante da renda mínima de inserção (valor que a lei francesa entende como necessário para a manutenção das necessidades fundamentais do indivíduo, estando livre de qualquer constrição). Informam, ainda, que, dos 1.100 .000 casos passados pela comissão desde 1989, apenas 300.000 foram considerados em 2002 como verdadeiramente livres da situação de 
partir desta reforma, introduziu-se a possibilidade de extinção total ou parcial das dívidas, mas apenas após um período de 3 anos de moratória, e mediante o preenchimento de uma série de requisitos. ${ }^{224}$ Somente com a reforma de $1^{\circ}$ de agosto de 2003 é que foi previsto um procedimento capaz de extinguir totalmente as dívidas, independentemente de cumprimento de plano de pagamentos ou de período de moratória, o chamado retablissement personnel, por meio do qual o devedor de boa-fé que provar a absoluta incapacidade de cumprir um plano de pagamentos (o que a lei denomina de situação financeira "irremediavelmente comprometida", caracterizada pela impossibilidade manifesta de executar as medidas de tratamento ordinárias ou extraordinárias) poderá requerer a liquidação dos seus bens para receber o perdão das dívidas. ${ }^{225}$

Em verdade, o sistema francês, ao permitir o acesso direto ao procedimento do retablissement personnel, sem nem mesmo exigir uma fase prévia de negociações, por entender que nesses casos tal procedimento seria inútil, aproximou-se do modelo anglosaxão. Entretanto, tendo em vista que esse procedimento é reservado às pessoas profundamente prejudicadas, com a situação financeira irremediavelmente comprometida em longo prazo, mantêm-se os traços das legislações influenciadas pelo welfare satate.

O sistema alemão é considerado mais rígido porque, se o devedor não obtiver a aprovação pelos credores de um plano de reorganização das dívidas, estará sujeito ao processo de insolvência, que abrange todos os seus bens disponíveis, sendo que o perdão das dívidas remanescentes somente será concedido após um período "de boa conduta" de 6 anos, no qual o devedor transfere seus rendimentos para um trustee, que vai redistribuí-los aos credores, ficando sujeito a uma série de obrigações. Ademais, o procedimento inicia-se

sobreendividamento. (VIGNEAU, V. e BOURDIN, G. X.. Droit du surendettement ..., cit. p. 10).

${ }^{224}$ A moratória de até 3 anos para o devedor em estado de insolvência foi prevista como medida extraordinária do procedimento de rédressement personnel. Após esse prazo, a comissão reexaminará a situação do devedor e poderá tomar duas atitudes: ou recomendar as medidas ordinárias, ou, caso a insolvência persista, extinguir total ou parcialmente o débito. Foi, ainda, incluída uma norma pela qual, na elaboração do plano convencional, ou mesmo ao formular as recomendações, a comissão deve assegurar que o devedor mantenha um rendimento mínimo, o denominado reste a vivre.

${ }^{225}$ Por meio deste procedimento, os bens penhoráveis do devedor são liquidados e, se o ativo for insuficiente, o juiz decretará o fechamento do procedimento e a conseqüente extinção dos débitos, o que pode ocorrer de imediato, se a insuficiência de bens for manifesta. Sendo possível o pagamento dos credores, ainda que parcialmente, o juiz procederá nos termos do artigo 332-8 da Lei. Importante frisar que o juiz tem o dever de investigar a presença dos requisitos para a abertura desse procedimento, quais sejam, a situação irremediavelmente comprometida e a boa-fé do devedor. A lei de 2003 manteve a moratória prevista como medida extraordinária do procedimento de rédressement personnel, reduzindo o prazo para dois anos, e permitindo apenas a extinção parcial dos débitos findo esse prazo, pois o devedor continuará cumprindo um plano de recuperação. A extinção total foi reservada ao procedimento de rétablissement personnel. Ademais, a reforma permitiu a inclusão das dívidas fiscais, seja na elaboração do plano de recuperação, seja no procedimento de liquidação, de maneira que apenas as dívidas de caráter alimentar permaneceram imunes à extinção. Foi alargada a definição de sobreendividamento para incluir o fiador ou o devedor solidário pessoa física que garantiu o débito de uma empresa, desde que não ocupe cargo de direção. 
sempre com uma fase de conciliação, e o caso apenas vai para a Corte caso não se chegue a um acordo. ${ }^{226}$

Comparando os modelos liberal e social verifica-se que a diferença de concepção entre eles leva a diferenças estruturais profundas, que até bem pouco tempo marcavam esses dois sistemas. O modelo Europeu, mais preocupado com o problema social decorrente da larga utilização do crédito e com a tutela dos direitos fundamentais da pessoa humana, concebeu um sistema no qual o discharge, ou seja, o perdão das dívidas que possibilita o fresh start, quando admitido, somente pode beneficiar os indivíduos que efetivamente necessitam (os irremediavelmente comprometidos), e em alguns sistemas deve ocorrer somente após uma fase de conciliação extrajudicial ${ }^{227}$ ou um longo plano de pagamentos obrigatórios, ${ }^{228}$ com duração de 3 a 7 anos, possuindo, ainda, uma conotação

$226 \mathrm{Na}$ Alemanha, o Insolvency Statute, na versão de janeiro de 2004, contempla o procedimento de insolvência do consumidor nas seções 304 a 314. A lei determina que primeiramente o consumidor tente um acordo extrajudicial para estabelecimento de um plano de reorganização dos débitos, mas, se isso não for possível, poderá recorrer à Corte de insolvência para tentar aprovar o plano. Para isso, o consumidor deverá apresentar um requerimento contendo todos os seus bens disponíveis e rendimentos, seus credores e ações contra si, bem como o plano de reorganização dos débitos, que deve levar em consideração tanto os interesses dos credores, quanto a sua situação patrimonial, os seus rendimentos e as circunstâncias familiares. Todas as ações relacionadas serão suspensas por três meses, para a aprovação do plano (seção 306). Os credores poderão opor-se ao plano, e, num primeiro momento, o devedor poderá acatar as oposições, efetuando os ajustes. Caso não haja acordo, a Corte poderá suprir a oposição de um ou mais credores, desde que mais da metade dos credores, com mais da metade das quantias envolvidas nas ações, tenham aprovado o plano. Contudo, o(s) credor(es) oponente(s) poderá(ão) fundamentar sua recusa (nos termos da seção 309), e o juiz poderá acolher as suas razões. Não sendo aprovado o plano, a Corte determinará a abertura de um procedimento de insolvência, no qual os bens penhoráveis do devedor estarão sujeitos à satisfação dos credores, sendo que o perdão das dívidas remanescentes somente será concedido após um período de 6 anos "de boa conduta", no qual o devedor transferirá todos os seus rendimentos penhoráveis para um trustee e ficará sujeito a uma série de obrigações, tais como manter ou encontrar um emprego rentável, não recusar nenhuma atividade razoável, transferir ao trustee metade dos bens recebidos em sucessão, informar qualquer alteração de residência, emprego, condição econômica, não esconder rendimentos e bens, dentre outras (seção 295). O perdão também não será concedido se o devedor obteve (ou teve recusado) esse benefício nos 10 anos que antecederam o requerimento de insolvência (ou de aprovação do plano), se prestar declarações falsas ou incompletas, ou se, em qualquer momento do processo de insolvência, faltar com o dever de informação ou cooperação (seção 290). Sobre o sistema alemão ver: KILBORN, J. J. The Innovative German Approach to Consumer Debt Relief: Revolutionary Changes in German Law, and Surprising Lessons for the United States. Northwestern Journal of International Law \& Business; Winter 2004; 24, 2; ABI/INFORM Global. pg. 257-297; MERLE, W. Le droit allemand à travers 1'Insolvenzordnung. Gaz. Pal., 27 févr. 2003, $\mathrm{n}^{\mathrm{o}} 58$, p. 17.

${ }^{227}$ Praticamente todas as legislações européias prevêem uma fase preliminar de negociações, e apenas se houver objeção de algum credor, que em geral deve figurar como um dos "principais credores", é que o caso será levado perante o órgão do Poder Judiciário. Na França, a obrigatoriedade desta fase foi abolida pela reforma de 1995.

${ }^{228}$ Dentro do modelo Europeu, existem diferenças profundas com relação à obrigatoriedade dos planos de pagamentos. Em países como a Dinamarca, Finlândia, Noruega e Suécia, a apresentação de um plano de pagamento é obrigatória. Na Alemanha, a extinção da dívida não ocorre enquanto o devedor não passar pelo período de boa conduta, no qual deverá cumprir um plano de pagamento, alem de outras condições. Na França, a legislação evoluiu de um sistema que apenas admitia a imposição de um plano de pagamentos, com a incorporação de medidas como redução dos juros, consolidação e reescalonamento das dívidas, para um sistema que admite a extinção das dívidas pelo procedimento do rétablissement personnel, do qual apenas podem se beneficiar os indivíduos com a situação financeira irremediavelmente comprometida. 
moralizadora e disciplinadora, lançando mão de recursos como o filtro da boa-fé e a educação financeira do consumidor. Percebe-se que, no modelo europeu, os planos de pagamento não possuem apenas função econômica. É clara a função re-educativa, pois existe a preocupação de que o procedimento não seja apenas um caminho fácil para a liberação das dívidas ("easy way out”), mas um período no qual o devedor deverá cumprir determinadas metas, efetuar uma série de pagamentos e por vezes submeter-se a aconselhamentos. $^{229}$

Não obstante a distinção originalmente existente, o que se tem percebido atualmente é uma aproximação gradativa dos modelos de tutela do sobreendividamento, a partir das reformas que têm sofrido as legislações nacionais. O sistema norte-americano torna-se menos liberal, dificultando o livre acesso ao fresh start com a inclusão do chamado means testing, ou seja, de requisitos para saber se o indivíduo tem capacidade para ser inserido num plano de pagamento aos credores, regulamentado pelo capítulo 13 do Código de Falências, ou se ele pode beneficia-se do procedimento de liquidação pelo capítulo 7, que proporciona um caminho rápido e automático para a extinção das dívidas. $^{230}$ Por sua vez, reconhecendo que em determinados casos o indivíduo sobreendividado está com a sua situação pessoal e financeira irremediavelmente comprometida, alguns sistemas europeus passaram a admitir a concessão direta da extinção das dívidas, prevendo a possibilidade do fresh start. ${ }^{231}$ De qualquer forma, a distinta fundamentação existente nos dois modelos ainda mantém certas características peculiares, conforme destacado anteriormente.

\footnotetext{
${ }^{229}$ As diferenças são de tal forma acentuadas que repercutem na própria referência lingüística dos dois sistemas: a expressão "falência pessoal", utilizada pelo sistema norte-americano, foi rejeitada pelo modelo europeu, tendo em vista a carga pejorativa que contém o termo, preferindo-se os termos sobreendividamento (over-indebtedness, surendettement), recuperação pessoal (redressement personnel) ou reorganização de dívidas (debt adjustment). Essa observação foi feita por NIEMI-KIESILÄINEN, J. op. cit., 1997, que sugeriu a utilização da expressão "consumer debt adjustment". Em nossa tradução, por não encontrarmos correspondência exata, optamos por "reorganização de dívidas do consumidor".

${ }^{230}$ A alteração do sistema americano, com a inclusão do means testing, dentre outras mudanças, ocorreu em 2005, com o Bankruptcy Abuse Prevention and Consumer Protection Act (Lei de Prevenção ao Abuso da Falência e de Proteção do Consumidor).

${ }^{231}$ Na França, um esboço desse sistema foi instituído a partir da reforma do Code de la Consommation pela lei n ${ }^{\circ}$ 98-657 de 29 de julho de 1998, sobre a luta contra as exclusões sociais. O procedimento para concessão direta da extinção das dívidas, chamado rétablissement personnel, foi introduzido pela lei $\mathrm{n}^{\circ}$ 2003-710 de 1 de agosto de 2003, e é reservado para os indivíduos que se encontram em situação irremediavelmente comprometida.
} 


\section{Seção 3.2 - O modelo de tutela compatível com o ordenamento jurídico brasileiro: proteção dos direitos fundamentais da pessoa humana}

Diante de tudo o que foi exposto no capítulo anterior, resta evidente que o modelo de tutela do endividamento excessivo que mais se coaduna com o ordenamento jurídico brasileiro é o modelo social, centrado na necessidade de proteção aos direitos fundamentais da pessoa humana, inclusive nas situações adversas da vida, como o desemprego, a ruptura familiar ou a doença. Na Europa, o tratamento e a prevenção das situações de endividamento excessivo do consumidor e das famílias faz parte do arcabouço jurídico de garantias do Estado Social, diante da percepção de que era necessário expandir a tutela para o direito privado, no intuito de alcançar as relações entre particulares.

No modelo social, os valores dignidade, solidariedade e igualdade se mostram presentes e expressos, em geral, nas Constituições nacionais, irradiando-se para todas as demais normas, inclusive as de direito privado, que os incorporaram ao prever mecanismos para conferir maior equilíbrio (igualdade material) nas relações tuteladas, para promover a cooperação entre os parceiros contratuais, dentre outros deveres de conduta pautados pela boa-fé, e ao estabelecer que os contratos e a propriedade devem cumprir com a função social.

No Brasil, a primeira manifestação do modelo social veio com a Constituição Federal de 1934, inspirada no constitucionalismo alemão do Estado Social, representado pela Constituição de Weimar, e posteriormente pela Lei Fundamental de Bonn, como ensina Paulo Bonavides:

O constitucionalismo dessa terceira época fez brotar no Brasil desde 1934 o modelo fascinante de um Estado social de inspiração alemã, atado politicamente a formas democráticas, em que a Sociedade e o homem-pessoa - não o homem indivíduo - são os valores supremos. Tudo porém indissoluvelmente vinculado a uma concepção reabilitadora e legitimamente do papel do Estado com referência à democracia, à liberdade e à igualdade. $^{232}$

O modelo social inspirou, ainda, a Constituição Federal de 1946, e, por fim, a nossa atual Constituição conforme esclarece Bonavides:

A Constituição de 1988 é basicamente em muitas de suas dimensões essenciais uma Constituição do Estado social. Portanto, os problemas constitucionais referentes a relações de poderes e exercício de direitos subjetivos têm que ser examinados e resolvidos à luz dos conceitos derivados daquela modalidade de ordenamento. Uma coisa é a

${ }^{232}$ BONAVIDES, P. Curso de Direito Constitucional. cit. p. 368. 
Constituição do Estado liberal, outra a Constituição do Estado social. A primeira é uma Constituição antigoverno e anti-Estado; a segunda uma Constituição de valores refratários ao individualismo no Direito e ao absolutismo no Poder. ${ }^{233}$

Aduz o autor que, apesar de muitos dos postulados do Estado social terem permanecido como mera utopia, "não se deve porém diminuir a importância que ele já assumiu como força impulsora de modernização, trazendo às instituições um sopro claramente renovador". ${ }^{234} \mathrm{E}$ de fato, o constitucionalismo brasileiro seguiu a mudança de paradigmas ocorrido do Estado liberal para o Estado social, refletindo a mudança de valores da comunidade, conforme analisado no item 1.1, deixando como herança um ordenamento jurídico repleto de leis com preocupações sociais, que buscam tutelar a situação dos grupos mais vulneráveis, não ficando de fora dessa regulação as relações jurídicas privadas. ${ }^{235}$

Esse é um efeito característico de um Estado social de direito, no qual todas as leis devem respeito aos direitos fundamentais reconhecidos constitucionalmente. Canotilho sistematiza essa questão, afirmando que os direitos fundamentais vinculam tanto as entidades públicas, quanto os agentes privados, sendo que, quanto à vinculação do legislador, esta ocorre tanto num sentido proibitivo, quanto num sentido positivo. No sentido proibitivo, a vinculação "veda às entidades legiferantes a possibilidade de criarem actos legislativos contrários às normas e princípios constitucionais, isto é, proíbe a emanação de leis inconstitucionais lesivas de direitos, liberdades e garantias". No direito brasileiro, as leis anteriores à Constituição Federal de 1988 que violem os preceitos constitucionais não são recepcionadas, sendo que existe um remédio constitucional capaz de declarar a revogação destas leis, qual seja, a argüição de descumprimento de preceito fundamental $\left(\mathrm{CF} \text {, art. 102, } \S 1^{\circ}\right)^{236}$. Quanto à dimensão positiva, assim afirma o constitucionalista português:

A vinculação dos órgãos legislativos significa também o dever de estes conformarem as relações da vida, as relações entre o Estado e os cidadãos e as relações

\footnotetext{
${ }^{233}$ BONAVIDES, P. Curso de Direito Constitucional. cit. p. 371.

${ }^{234}$ BONAVIDES, P. Curso de Direito Constitucional. cit. p. 371.

${ }^{235}$ Este cenário foi bem retratado por Maria Celina Bodin de Moraes: "Neste ambiente, de um renovado humanismo, a vulnerabilidade humana será tutelada, prioritariamente, onde quer que ela se manifeste. De modo que terão precedência os direitos e as prerrogativas de determinados grupos considerados, de uma maneira ou de outra, frágeis e que estão a exigir, por conseguinte, a especial proteção da lei. Nestes casos estão as crianças, os adolescentes, os idosos, os portadores de deficiências físicas e mentais, os nãoproprietários, os consumidores, os contratantes em situação de inferioridade, as vítimas de acidentes anônimos e de atentados a direitos da personalidade, os membros da família, os membros de minorias, dentre outros". (MORAES, M. C. B.. O conceito de dignidade humana: substrato axiológico e conteúdo normativo. In: SARLET, I. W. (org.). Constituição, Direitos Fundamentais e Direito Privado. Porto Alegre: Livraria do Advogado, 2003, p. 116).

${ }^{236}$ Isso ocorreu com a antiga Lei de Imprensa, por meio da ADPF 130.
} 
entre os indivíduos, segundo as medidas e directivas materiais consubstanciadas nas normas garantidoras de direitos, liberdades e garantias. Neste sentido, o legislador deve "realizar" os direitos, liberdades e garantias, optimizando a sua normatividade e actualidade. (...)

Como os direitos, liberdades e garantias possuem também uma dimensão objectiva, eles valem como princípios informadores da ordem jurídica que o legislador deve incorporar e mediatizar ao regular as diferentes relações jurídicas (ex: as leis de imprensa devem concretizar o princípio da liberdade de imprensa; as leis respeitantes às universidades devem plasmar os princípios da autonomia e da liberdade de criação intelectual, artística e científica). ${ }^{237}$

Foi com base nessa dimensão positiva da vinculação aos direitos fundamentais que o legislador brasileiro editou diversas leis que refletem os valores do Estado social, que constituem o seu pressuposto material de constitucionalidade, tais como o Código de Defesa do Consumidor (que em verdade resultou de um mandamento constitucional) e o novo Código Civil, com suas cláusulas gerais e disposições que garantem uma maior justiça contratual, aflorando a nova ideologia que permeia o direito privado, o qual deixou de tutelar apenas valores individuais e patrimoniais, para se preocupar também com valores sociais e com direitos extrapatrimoniais. ${ }^{238}$

Restou caracterizado no item 3.1.1 que o modelo tradicional da insolvência civil, presente do Código de Processo Civil, não é adequado, e por isso foi relegado à obsolescência. Mas a inadequação do procedimento não decorre apenas do seu não uso, mas também, e principalmente, da total desconsideração das peculiaridades inerentes à condição humana do devedor sujeito ao procedimento, o que implica a violação dos seus direitos fundamentais. Por outro lado, um modelo que siga a orientação meramente utilitarista ou pragmática também não seria suficiente, pois despreza direitos individuais em nome da maximização de riquezas, ${ }^{239}$ o que não se ajusta ao ordenamento jurídico brasileiro.

Fazendo um paralelo com a doutrina de Ronald Dworkin, o ordenamento jurídico brasileiro coaduna-se com uma comunidade de princípios, ${ }^{240}$ de maneira que uma

${ }^{237}$ CANOtILHO, J. J. G.. Direito Constitucional e teoria da constituição. Coimbra: Almedina, 4 a edição. p. 432.

${ }^{238}$ Nesse sentido, Miguel Reale destaca três princípios fundamentais que orientaram a elaboração do novo Código Civil: o da eticidade (do qual se destaca a inclusão do princípio da boa-fé objetiva); o da socialidade (do qual se destaca a função social dos contratos, da posse e da propriedade); e o da operabilidade (com destaque para a facilitação da interpretação, em determinados casos, bem como para o papel central do juiz para preencher as cláusulas gerais e os conceitos jurídicos indeterminados). (REALE, M. Visão geral do novo Código Civil. Revista dos Tribunais, $\mathrm{n}^{\circ}$ 808. São Paulo: Editora Revista dos Tribunais, p. 11-19.

${ }^{239}$ Sobre as deficiências da concepção utilitarista ver crítica desenvolvida no item 1.3.5.

240 DWORKIN, R. O Império do Direito. tradução Jefferson Luiz Camargo. São Paulo: Martins Fontes, 
interpretação adequada sobre o direito deve articular as convicções sobre dignidade, solidariedade, justiça e eqüidade, e assim buscar uma concepção mais coerente com a moral política da comunidade enquanto ente personificado. ${ }^{241}$ As concepções que reduzem o direito ao conjunto de regras não satisfazem, porque afastam completamente as idéias sobre moral e justiça presentes numa comunidade. Também as concepções utilitaristas, defendidas na sua maioria pela doutrina law and economics, são inadequadas, pois o cálculo pragmático considera apenas a maximização de riquezas para o alcance da melhor comunidade futura, sem se preocupar se nesse processo os direitos genuínos de alguns indivíduos são preteridos.

Assim sendo, qualquer lei que tenha por objetivo tutelar as situações de endividamento excessivo do consumidor deve pautar-se por uma preocupação social, mantendo as características de um modelo social, tais como: 1) consideração de atributos éticos das partes, ou seja, tanto a boa-fé do consumidor, quanto a retidão no comportamento do credor; 2) necessidade de preservação da dignidade do consumidor, que deve ter meios suficientes para manter uma existência digna; 3) fase extrajudicial para a tentativa de conciliar os interesses das partes, e, caso não seja possível a conciliação, distribuição justa das custas processuais, considerando a capacidade econômica das partes, bem como impondo maior ônus para aqueles que forem considerados culpados pelo endividamento (devedor de má-fé ou credor negligente); 4) elaboração de planos de recuperação financeira que contemplem as mais variadas medidas, tais como a concessão de moratória, reescalonamento da dívida, redução ou exclusão dos juros de mora, devolução de mercadorias com extinção de respectivo débito, dentre outras medidas atípicas capazes de conciliar os interesses dos credores e do consumidor; 5) exigência de conduta ética do consumidor durante o cumprimento do plano de recuperação, inclusive a freqüência em cursos de educação financeira e de elaboração de orçamento familiar; 6) tutela diferenciada para aqueles indivíduos que efetivamente necessitem, a exemplo de que ocorre na França, onde apenas aqueles consumidores de boa-fé que demonstrarem a situação irremediavelmente comprometida é que tem o direito ao perdão das dívidas; 7) não utilização de termos pejorativos, como "falência" ou "insolvência", dando preferência para os termos recuperação financeira ou reorganização de dívidas, em razão do estigma social decorrente daqueles termos.

Têm-se, aí, as diretrizes básicas que constituirão o pressuposto material de 
constitucionalidade de uma lei futura sobre a prevenção e o tratamento das situações de sobreendividamento. Se o endividamento é uma situação desejada na atual sociedade de consumo, não há como recusar a tutela aos cidadãos que, por uma desventura da vida, se tornem impossibilitados de adimplir os contratos firmados. É preciso encarar o crédito como um produto que apresenta riscos para os consumidores, sendo o superendividamento o mais grave deles, e conferir uma oportunidade para que as vítimas desse acidente de consumo recuperem-se financeiramente, e não adotar o caminho mais fácil de relegar esses indivíduos à exclusão social. Aliás, é importante ressaltar que esse caminho não asseguraria nem o desenvolvimento econômico, nem os direitos dos credores, já que o mercado precisa de consumidores ativos para assimilar a produção, e os credores necessitam de meios concretos e possíveis de satisfazer os seus créditos. Contudo, esse pressuposto, que fundamentou a tutela da falência pessoal nos Estados Unidos, também não pode ser tomado numa concepção meramente utilitarista, devendo ser consideradas todas as pretensões merecedoras de tutela jurídica, bem como os pressupostos e os princípios que regem o Estado Social e Democrático de Direito brasileiro, articulando os valores da dignidade humana e da solidariedade social com a necessidade de se garantir o desenvolvimento equilibrado das estruturas econômicas do país.

Mesmo diante da ausência de lei específica, esses valores supremos reconhecidos pelo ordenamento jurídico brasileiro servirão de fundamento para orientar a aplicação do direito vigente às situações de endividamento excessivo. Conforme salientado anteriormente, o direito privado brasileiro contêm diversos instrumentos jurídicos capazes de tutelar o consumidor de crédito, inclusive no caso de alteração das suas condições pessoais, que torne a obrigação excessivamente onerosa. Essa tutela será tratada na Parte II deste trabalho, sendo que, por ora, cumpre abordar, ainda que brevemente, os princípios da dignidade da pessoa humana (3.2.1) e da solidariedade social (3.2.2), que fundamentam e orientam a aplicação do direito às situações concretas, e, em seguida, estabelecer de que forma esses princípios incidem nas relações privadas (3.2.3).

\subsubsection{O princípio da dignidade da pessoa humana}

A proteção da dignidade da pessoa humana, apensar de não ser um conceito ético recente, ganhou importância a partir da primeira metade do século passado, devido às situações extremas às quais o ser humano sujeitou a sua própria dignidade. A origem da 
noção de dignidade humana pode ser atribuída à ideologia cristã ${ }^{242}$, e os seus contornos atuais à filosofia de Immanuel Kant ${ }^{243}$; mas foi com o término da Segunda Guerra Mundial que esse valor tornou-se o centro das discussões mundiais, devido às atrocidades cometidas pelos regimes totalitários nazi-fascistas, que levaram a humanidade a uma profunda reflexão acerca do valor absoluto do ser humano e da necessidade de proteção jurídica da sua dignidade. Foi assim que surgiram diversos documentos internacionais, como a Declaração Universal dos Direitos do Homem da ONU, e muitos países passaram a reconhecer expressamente a dignidade da pessoa humana como valor fundamental em suas Constituições, podendo-se citar a própria Lei Fundamental de Bonn (Alemanha), a Constituição Portuguesa e a Constituição Italiana. Recentemente, a Constituição da República Federativa do Brasil, promulgada em 1988, também reconheceu a dignidade da pessoa humana como valor fundamental do ordenamento jurídico pátrio. ${ }^{244}$

A positivação do princípio da dignidade da pessoa humana nas Constituições representa um importante marco no desenvolvimento da proteção jurídica concedida a esse valor fundamental. Contudo, salienta José Afonso da Silva que a dignidade da pessoa humana não é uma criação constitucional, ${ }^{245}$ mas sim, um conceito preexistente: “A

${ }^{242}$ Ana Paula de Barcellos, destaca o papel do Cristianismo na origem da evolução do conceito de dignidade humana: "A mensagem divulgada por Jesus Cristo e seus sucessores representou um ponto de inflexão no mundo antigo. Pela Primeira vez o homem passou a ser valorizado individualmente, já que a salvação anunciada não só era individual, como dependia de uma decisão pessoal. A conseqüência que se extrairia naturalmente dessa circunstância, mas que foi expressamente verbalizada pelo apóstolo São Paulo e pelos Pais da Igreja, diz respeito à igualdade essencial dos homens. A conhecida declaração 'Nisto não há judeu nem grego; não há servo nem livre; não há macho nem fêmea; porque todos vós sois um em Cristo Jesus', teve um compreensível efeito subversivo no mundo romano" (BARCELLOS, A. P. Normatividade dos princípios e o princípio da dignidade da pessoa humana na Constituição de 1988. Revista de Direito Administrativo $\mathrm{n}^{\circ} 221$; 159-188, Renovar, p. 160).

${ }^{243}$ A concepção Kantiana fundamenta-se na autonomia e na razão, próprios do ser humano, para formular o conceito de dignidade da pessoa humana. Para Kant, "o Homem, e duma maneira geral, todo o ser racional, existe como um fim em si mesmo, não simplesmente como meio para o uso arbitrário desta ou daquela vontade... Os seres cuja existência depende, não em verdade da nossa vontade, mas da natureza, têm contudo, se são seres irracionais, apenas um valor relativo como meios e por isso se chamam coisas, ao passo que os seres racionais se chamam pessoas". Destacando o valor absoluto do ser humano, salienta Kant que "no reino dos fins tudo tem um preço ou uma dignidade. Quando uma coisa tem um preço, pode pôr-se em vez dela qualquer outra como equivalente; mas quando uma coisa está acima de todo o preço, e portanto não permite equivalente, então ela tem dignidade". (KANT, I. Fundamentos da Metafísica dos Costumes. In Os Pensadores, p. 134 e 141, apud SARLET, I. W. Dignidade da Pessoa Humana e Direitos Fundamentais na Constituição Federal de 1988. $3^{\mathrm{a}}$ Edição. Porto Alegre: Livraria do Advogado Editora, 2004. pág. 33).

${ }^{244}$ Constituição da República Federativa do Brasil, artigo 1º, III: "A República Federativa do Brasil, formada pela união indissolúvel dos Estados e Municípios e do Distrito Federal, constitui-se em Estado Democrático de Direito e tem como fundamentos: ... a dignidade da pessoa humana". Artigo 170: "A ordem econômica, fundada na valorização do trabalho humano e na livre iniciativa, tem por fim assegurar a todos existência digna, conforme os ditames da justiça social...".

${ }^{245}$ A respeito da importância do reconhecimento pelo direito da dignidade da pessoa humana, ver Ingo Wolfgang Sarlet: "A dignidade evidentemente não existe apenas onde é reconhecida pelo Direito e na medida que este a reconhece, já que constitui um dado prévio, no sentido de preexistente e anterior a toda experiência especulativa. Todavia, importa não olvidar que o Direito poderá exercer papel crucial na sua proteção e 
Constituição, reconhecendo a sua existência, transformou-a num valor supremo da ordem jurídica, quando a declara como um dos fundamentos da República Federativa do Brasil constituída em Estado Democrático". 246 Trata-se de um valor construído e exaltado ao longo da história, e que recentemente foi consagrado expressamente por diversos ordenamentos jurídicos, recebendo o status jurídico-normativo de um princípio orientador do ordenamento jurídico. ${ }^{247}$

Ingo Wolfgang Sarlet reconhece o status jurídico-normativo do princípio da dignidade da pessoa humana, que servirá não somente como um valor-guia dos direitos fundamentais, mas de toda a ordem jurídica, ${ }^{248}$ orientando a atividade do estado para a proteção e efetivação deste princípio. O jurista gaúcho conceitua o valor em questão como sendo "a qualidade intrínseca e distintiva de cada ser humano que o faz merecedor do mesmo respeito e consideração por parte do Estado e da comunidade, implicando, neste sentido, um complexo de direitos e deveres fundamentais que assegure a pessoa tanto contra todo e qualquer ato de cunho degradante e desumano, como venham a lhe garantir as condições existenciais mínimas para uma vida saudável, além de propiciar e promover sua participação ativa e co-responsável nos destinos da própria existência e da vida em comunhão com os demais seres humanos"249.

Antonio Junqueira de Azevedo defende uma nova concepção de dignidade humana, que tem como pressuposto a intangibilidade da vida humana. Como conseqüência dessa nova concepção, tem-se:

promoção, não sendo, portanto, completamente sem fundamento que se sustentou até mesmo a desnecessidade de uma definição jurídica da dignidade da pessoa humana, na medida em que, em última análise, se cuida do valor próprio, da natureza do ser humano enquanto tal. No entanto, quando se cuida de aferir a existência de ofensas à dignidade, não há como prescindir - na esteira do que leciona González Pérez - de uma clarificação quanto ao que se entende por dignidade da pessoa, justamente para que se possa constatar e, o que é mais importante, coibir eventuais violações". (SARLET I. W., Dignidade da Pessoa Humana e Direitos Fundamentais na Constituição Federal de 1988. cit., pág. 42).

246 SILVA, J. A. A dignidade da pessoa humana como valor supremo da democracia. Revista de Direito Administrativo $\mathrm{n}^{\mathrm{o}}$ 212, Rio de Janeiro, Renovar, p. 91.

${ }^{247}$ Essa idéia é assim traduzida por Maria Celina Bodin de Moraes: "No direito brasileiro, após mais de duas décadas de ditadura sob o regime militar, a Constituição democrática de 1988 explicitou, no artigo $1^{\circ}$, III, a dignidade da pessoa humana como um dos 'fundamentos da República'. A dignidade humana, então, não é criação da ordem constitucional, embora seja por ela respeitada e protegida. A Constituição consagrou o princípio e, considerando a sua eminência, proclamou-o entre os princípios fundamentais, atribuindo-lhe o valor supremo de alicerce da ordem jurídica democrática. Com efeito, da mesma forma que Kant estabelecera para a ordem moral, é na dignidade humana que a ordem jurídica (democrática) se apóia e constitui-se". ("O princípio da dignidade humana", em MORAES, M. C. B. (coord.). Princípios do Direito Civil Contemporâneo. Rio de Janeiro: Renovar, 2006. p. 14).

${ }^{248}$ SARLET, I. W. Alguma notas em torno da relação entre o princípio da dignidade da pessoa humana e os direitos fundamentais na ordem constitucional brasileira. In: Dos Princípios Constitucionais. São Paulo: Malheiros Editores, 2003. p. 216.

${ }^{249}$ SARLET, I. W. Dignidade da pessoa humana e direitos fundamentais na Constituição Federal de 1988. cit., pág. 59/60. 
Além da vida em si e da integridade física e psíquica, a concretização da dignidade da pessoa humana exige também o respeito às condições mínimas de vida ( $2^{\mathrm{a}}$ conseqüência direta do princípio). Trata-se aqui das condições materiais de vida. A obtenção da casa própria e a sua proteção, por exemplo, são decorrências da dignidade humana". 250

Portanto, o princípio jurídico-normativo da dignidade da pessoa humana tem como pressuposto a garantia das condições mínimas de vida, o que se obtém por meio da efetivação dos direitos fundamentais sociais, sendo que atualmente se reconhece que as violações aos direitos fundamentais também podem ser provenientes das relações privadas, de maneira que os particulares também lhe devem observância e efetivação. Daí porque, no campo contratual, tem aplicação o respeito às condições mínimas de vida.

Ricardo Lobo Torres entende que "sem o mínimo necessário à existência cessa a possibilidade de sobrevivência do homem e desaparecem as condições iniciais da liberdade", e "as condições materiais de existência não podem retroceder aquém de um mínimo", ${ }^{251}$ e esclarece que a própria Constituição Federal concretizou o princípio da dignidade, indicando os patamares mínimos e campos a serem desenvolvidos (conteúdo mínimo da dignidade). ${ }^{252}$ Para Ana Paula de Barcelos, ao lado dos direitos individuais, consagrados no artigo $5^{\circ}$ da Constituição Federal, compõe o conteúdo mínimo do princípio da dignidade da pessoa humana o direito à educação (art. 205 e 208 da CF), o direito à saúde (art. 196), que decorre do direito à vida, e o direito à assistência social. Acrescentese a esses o direito à moradia e ao lazer, previstos no artigo $6^{\circ}$ da $\mathrm{CF}$. Desses direitos, extrai-se um conteúdo mínimo de proteção à dignidade, em relação ao qual qualquer violação se mostra intolerável pela própria razão humana e pelo sentimento de alteridade.

$\mathrm{Na}$ esteira da doutrina de Canotilho, esse núcleo dos direitos fundamentais, derivado diretamente do princípio da dignidade da pessoa humana, cumpre duas funções: com relação à atividade legiferante, estabelece o pressuposto material de constitucionalidade das normas de direito privado que refletem os valores sociais (e aí a referência é tanto às normas já existentes ${ }^{253}$, quanto à edição de novas normas, especialmente a sugerida lei de prevenção e tratamento dos indivíduos excessivamente

\footnotetext{
${ }^{250}$ JUNQUEIRA DE AZEVEDO, A. Caracterização jurídica da dignidade da pessoa humana. In: Estudos e Pareceres de Direito Privado. São Paulo: Saraiva, 2004. pág. 18.

${ }^{251}$ TORRES, R. L. Os direitos humanos e a tributação - Imunidades e isonomia, Renovar, pág. 129, apud BARCELLOS, A. P. op. cit., pág. 180.

${ }^{252}$ SARLET, I. W. Algumas notas em torno da relação entre o princípio da dignidade da pessoa humana e os direitos fundamentais. cit. pág. 216.

${ }^{253}$ Por exemplo: Código de Defesa do Consumidor; Lei 8.009/90, que estabeleceu a impenhorabilidade do bem de família; Estatuto do Idoso; Estatuto da Criança e do Adolescente; sistema de impenhorabilidades do Código de Processo Civil.
} 
endividados); com relação à atividade judicante, serve de norte para a aplicação dos instrumentos de direito privado às situações concretamente apresentadas, bem como se constitui no parâmetro para a ponderação de valores no caso concreto, quando ocorrer conflito entre direitos fundamentais.

No direito privado, o princípio da dignidade da pessoa humana tem incidência por intermédio dos novos princípios sociais da boa-fé objetiva, da função social do contrato e do equilíbrio contratual. A boa-fé objetiva exige das partes nas relações contratuais uma conduta ética, impondo os chamados deveres laterais de informação, lealdade, cooperação e cuidado recíproco, impedindo que um contratante abuse da confiança do outro, ou atue de forma a levar o parceiro contratual à ruína econômica ou à escravidão contratual. Além disso, a boa-fé objetiva tem a função de impor limites ao exercício de direitos subjetivos, repudiando a previsão de cláusulas abusivas, bem como servindo de critério, ao lado da função econômica e social, para a caracterização do exercício abusivo de posições jurídicas. O equilíbrio contratual, como corolário da justiça comutativa, impõe a equivalência das prestações, de forma a impedir que uma das partes da relação contratual permaneça em situação de desvantagem exagerada, seja em razão de um vício na formação do contrato (lesão contratual), seja em razão da onerosidade excessiva superveniente. Por fim, a função social do contrato, além de servir de critério para o regular exercício de posições jurídicas (vedação ao abuso do direito), requer que os contratos se coadunem com os valores fundamentais escolhidos pelo ordenamento jurídico, de maneira a não reconhecer tutela aos contratos que violem a dignidade da pessoa humana e a solidariedade social. Dessa forma, abre espaço não só para a justiça comutativa, mas também, para a justiça distributiva no âmbito dos contratos, sobretudo naqueles em que um dos pólos é ocupado por uma pessoa em situação de vulnerabilidade, como será analisado na Parte II, seção 1.4 .

O ponto em comum de todas as questões acima mencionadas está na tutela da dignidade humana, que deverá sempre orientar a incidência dos referidos princípios, e das regras que deles decorrem. Ressalte-se que nos casos concretos, em que os direitos fundamentais da pessoa humana entrarem em conflito com outros direitos, a solução não poderá prescindir da consideração do núcleo do princípio da dignidade da pessoa humana, consistente no respeito às condições mínimas de vida. 


\subsubsection{O princípio da solidariedade social}

A construção filosófica do conceito de solidariedade social iniciou-se com Auguste Comte $^{254}$, que desenvolveu a noção de "dever de assistência", "dever social" e "dívida social". ${ }^{255}$ Contudo, como ensina José Fernando de Castro Farias, "é somente no fim do século XIX que aparece a lógica da solidariedade com um discurso coerente que não se confunde com 'caridade' ou 'filantropia'", 256

O direito de solidariedade surge com o Estado social, como reação ao individualismo exacerbado do Estado liberal. Reconheceu-se que a concepção individualista não era adequada, pois o ser humano não pode ser concebido como um ser isolado e auto-suficiente; vive em sociedade, e somente é capaz de aperfeiçoar a sua existência em razão da solidariedade que o vincula aos seus semelhantes. Dessa forma, assim como a vida em sociedade garante direitos aos seus participantes, também impõe deveres de cooperação recíproca para o fortalecimento de toda a coletividade. O objetivo do Estado social passou ser a criação de redes de solidariedade capazes de amenizar as desigualdades sociais e de distribuir os riscos sociais, a fim de que a desgraça não se abatesse sobre um indivíduo isolado.

Émile Durkheim, um dos maiores representantes do solidarismo sociológico, que influenciou diretamente o solidarismo jurídico, defende que a origem da solidariedade social está na divisão do trabalho, que tem o papel de tornar possíveis sociedades que sem ela não existiriam. ${ }^{257} \mathrm{O}$ sociólogo faz uma distinção entre "solidariedade mecânica", que é aquela que se estabelece por similitude (presente nas sociedades tradicionais ou inferiores), e "solidariedade orgânica", que se estabelece em razão da divisão do trabalho (presente nas sociedades modernas mais complexas). Baseia essa distinção na idéia de uma "consciência coletiva", ${ }^{258}$ que se forma a partir das similitudes sociais e que independe das consciências

${ }^{254}$ COMTE, A. Système de Politique Positive. Paris: Mathias, 1851, Tomo I.

${ }^{255}$ Segundo Durkheim, Comte foi o primeiro sociólogo a assinalar a divisão do trabalho como mais do que algo puramente econômico, mas, sim, como "a condição mais essencial da vida social", pois "leva imediatamente a encarar não apenas os indivíduos e as classes, mas também, sob muitos aspectos, os diferentes povos, como participantes, ao mesmo tempo e de acordo com um modo próprio e um grau especial, exatamente determinados, de uma obra imensa e comum, cujo inevitável desenvolvimento gradual também liga, aliás, os atuais cooperadores à série de seus predecessores e mesmo à série de seus diversos sucessores". COMTE, A. Cours de philosofie positive, IV, 425, apud DURKHEIM, É. Da Divisão do Trabalho Social. São Paulo: Martins Fontes, 2008. p. 29.

${ }^{256}$ CASTRO FARIAS, J. F. A Origem do Direito de Solidariedade. Rio de Janeiro: Renovar, 1998. p. 190.

${ }^{257}$ DURKHEIM, É. Da Divisão do Trabalho Social. cit. p. 27.

${ }^{258}$ Com relação à consciência coletiva, Durkheim assim expressa: "O conjunto das crenças e dos sentimentos comuns à média dos membros de uma mesma sociedade forma um sistema determinado que tem vida própria; podemos chamá-lo de consciência coletiva ou comum. Sem dúvida, ela não tem por substrato um 
individuais dos membros da sociedade, esclarecendo que essa consciência é mais forte nas sociedades tradicionais do que nas sociedades modernas ou complexas. Nas sociedades modernas, em razão do desenvolvimento da individualidade e da especialização das funções desempenhadas, a coesão social é feita pelas partes representativas da sociedade, o que pressupõe a existência de instituições sociais mais complexas. Assim, na medida em que o indivíduo se fortalece, os laços de solidariedade devem também se tornar mais fortes, para que assim a sociedade desenvolva-se. Esclarece Castro Farias que "de um lado, o indivíduo depende cada vez mais da sociedade na medida em que aumenta a divisão do trabalho social; de outro lado, a atividade individual é mais pessoal na medida em que ela é mais especializada". 259

Para Durkheim o direito é o símbolo visível da solidariedade, garantindo a estabilidade e organização dos liames existentes entre os membros da sociedade. ${ }^{260}$ Nas sociedades modernas, em que a divisão do trabalho é mais desenvolvida, resulta o direito cooperativo, ${ }^{261}$ cuja sanção é do tipo restitutiva, ${ }^{262}$ pois, em razão da especialização das

órgão único; ela é, por definição, difusa em toda a extensão da sociedade, mas tem, ainda assim, características específicas que fazem dela uma realidade distinta. De fato, ela é independente das condições particulares em que os indivíduos se encontram: elas passam, ela permanece”. (DURKHEIM, É. Da Divisão do Trabalho Social. cit. p. 50).

${ }^{259}$ CASTRO FARIAS, J. F.. A Origem do Direito de Solidariedade. op.cit., p. 217 e 214.

260 "Quanto mais os membros de uma sociedade são solidários, mais mantêm relações diversas seja uns com os outros, seja com o grupo tomado coletivamente, pois, se seus encontros fossem raros, só dependeriam uns dos outros de maneira intermitente e fraca. Por outro lado, o número dessas relações é necessariamente proporcional ao das regras jurídicas que as determinam. De fato, a vida social, onde quer que exista de maneira duradoura, tende inevitavelmente a tomar uma forma definida e a se organizar e o direito nada mais é que essa mesma organização no que ela tem de mais estável e de mais preciso. A vida geral da sociedade não pode se estender num ponto sem que a vida jurídica nele se estenda ao mesmo tempo e na mesma proporção. Portanto, podemos estar certos de encontrar refletidas no direito todas as variedades essenciais da solidariedade social”. (DURKHEIM, É. Da Divisão do Trabalho Social. op. cit., p. 31-32).

${ }^{261}$ A respeito do direito cooperativo, Durkheim conclui que: "esse direito tem na sociedade um papel análogo ao do sistema nervoso no organismo. De fato, este tem por tarefa regular as diferentes funções do corpo, de maneira a fazê-las concorrer harmonicamente; ele exprime, assim, naturalmente, o estado de concentração a que chegou o organismo, em conseqüência da divisão do trabalho fisiológico. Por isso, pode-se medir, nos diferentes níveis da escala animal, o grau dessa concentração segundo o desenvolvimento do sistema nervoso. Isso quer dizer que se pode igualmente medir o grau de concentração a que chegou uma sociedade, em conseqüência da divisão do trabalho social, segundo o desenvolvimento do direito cooperativo com sanções restitutivas". (DURKHEIM, É. Da Divisão do Trabalho Social. op. cit., p. 105).

262 Durkheim identifica a existência de dois tipos de sanções: a repressiva, própria do direito penal, e que deriva da consciência coletiva, e a restitutiva, própria do direito civil, comercial, processual e administrativo, que não faz parte da consciência coletiva, e que se mostra mais presente nas sociedades modernas. $O$ sociólogo demonstra com exemplos que a consciência coletiva facilmente está de acordo quando se trata de uma sanção de direito penal; mas admite a variabilidade de regras no campo do direito civil, comercial, processual ou administrativo. Declara o autor que esta "é a prova de que as regras com sanção restitutiva ou não fazem parte da consciência coletiva, ou são apenas estados fracos desta". E prossegue: "Enquanto o direito repressivo tende a permanecer difuso na sociedade, o direito restitutivo cria órgãos cada vez mais especiais: tribunais consulares, tribunais trabalhistas, tribunais administrativos de toda sorte...". Destaca o papel essencial que as partes representativas da sociedade exercem na formação desse mecanismo de implementação da solidariedade orgânica, afirmando que "a sociedade não está ausente dessa esfera jurídica... é ela que diz o direito por intermédio de seus representantes”. (DURKHEIM, É. Da Divisão do 
atividades, não há uma consciência coletiva que regule a reciprocidade dos comportamentos. Exemplifica com o contrato, que é o símbolo da troca, a qual, por sua vez, supõe uma divisão do trabalho. Ressalta que a reciprocidade no campo contratual só é possível onde há cooperação.

Contudo, em razão do individualismo exacerbado, as sociedades modernas podem perder essa noção de solidariedade orgânica, que une os seus integrantes e as tornam mais fortes. Léon Duguit critica a doutrina individualista do direito por partir de uma premissa artificial de um homem isolado no estado natural. Duguit parte do pressuposto de que o ser humano não pode ser concebido fora dos agrupamentos sociais. Dessa forma, chega a uma concepção do homem não só enquanto titular de direitos, mas também como sujeito de obrigações essenciais para a manutenção e desenvolvimento da vida coletiva. Afirma que "o ser humano nasce integrando uma coletividade; vive sempre em sociedade e assim considerando só pode viver em sociedade. Nesse sentido, o ponto de partida de qualquer doutrina relativa ao fundamento do direito deve basear-se no homem natural; não naquele isolado e livre que pretendiam os filósofos do século XVIII, mas no indivíduo comprometido com os vínculos da solidariedade social. Não é razoável afirmar que os homens nascem livres e iguais em direito, mas sim que nascem partícipes de uma coletividade e sujeitos, assim, a todas as obrigações que subentendem a manutenção e desenvolvimento da vida coletiva". ${ }^{263}$ Os homens, que vivem em agrupamentos sociais, têm tanto consciência de sua individualidade, quanto dos laços de dependência com os demais, sendo que "a solidariedade social é que constitui os liames que mantêm os homens unidos". 264

A partir daí, Duguit desenvolve a sua ótica funcional do Direito, na qual, segundo Castro Faria, "um ato somente tem valor social e jurídico se for determinado por um fim conforme a 'solidariedade social', e não porque ele tem como sustentação unicamente a vontade do sujeito". ${ }^{265}$ Com isso, Duguit rompe com o dogma da vontade como única fonte de obrigações, ressaltando o papel do Direito fundado na solidariedade social, que se

Trabalho Social. op. cit., p. 85 a 90)

${ }^{263}$ DUGUIT, L.. Fundamentos do Direito. São Paulo: Ícone, 2006. p. 15-16.

${ }^{264}$ Nesse ponto, Duguit relaciona a sua abordagem com o pensamento de Durkheim, assim afirmando: “... consideramos que a solidariedade pode vincular-se a um dos seguintes elementos essenciais: os homens de um mesmo grupo social são solidários entre si - primeiramente porque têm necessidades comuns cuja satisfação reside na vida em comum; e em segundo lugar porque têm anseios e aptidões diferentes cuja satisfação efetiva-se pela troca de serviços recíprocos, relacionados exatamente ao emprego de suas aptidões. Dentro do esboço acima, conceitua-se a primeira como solidariedade 'por semelhança', enquanto a segunda, "por divisão de trabalho"”. (DUGUIT, L. Fundamentos do Direito. op. cit., p. 23)

${ }^{265}$ CASTRO FARIAS, J. F. A Origem do Direito de Solidariedade. op. cit., p. 227. 
expressa como regra de direito objetivo, ${ }^{266}$ capaz de criar deveres dos quais derivam os direitos dos homens que integram determinada comunidade. ${ }^{267}$ Contudo, não deixa de reconhecer a importância dos vínculos criados pela vontade, cujo respeito é também determinado pelo fim da solidariedade social.

Nessa concepção, fundou-se o paradigma jurídico do Estado social, no qual se reconheceu o dever do Estado de prestar os direitos sociais e, aos poucos, reconheceu-se também os deveres de solidariedade entre particulares, e destes para com a sociedade e o Estado. O direito, enquanto símbolo visível da solidariedade, deveria garantir a implementação dos mecanismos necessários à cooperação entre os integrantes da sociedade, e do Estado para com eles, no sentido de reduzir as desigualdades e distribuir os riscos sociais. Ademais, deveria garantir que as normas jurídicas, sobretudo aquelas de direito privado, não concebessem mais os indivíduos como seres auto-suficientes, isolados da sociedade. Era preciso reconhecer que, mesmo nas relações entre particulares, os efeitos não se restringem apenas às partes envolvidas, irradiando-se perante terceiros e perante toda a coletividade.

Foi assim que, a partir da constatação da insuficiência do individualismo do pensamento liberal, passou-se a reconhecer uma série de direitos sociais em busca de uma maior igualdade substancial. Impulsionados pela necessidade de formação de uma consciência coletiva após a Segunda Guerra mundial, vários países positivaram em suas Constituições os direitos fundamentais sociais, enquanto direitos a prestações positivas do Estado. No Brasil, as Constituições de 1934 e 1946 consagraram alguns direitos sociais, mas o princípio da solidariedade social somente foi positivado enquanto tal na Constituição de 1988, que no seu artigo $1^{\circ}$, inciso IV, fixou como fundamento da República o valor social da livre iniciativa, e no seu artigo $3^{\circ}$ estabelece como objetivos

\footnotetext{
266 'Duguit considera o 'direito objetivo' uma 'lei de fim', no sentido da realização da 'solidariedade social'. Para o fundador da escola de Bordeaux, o direito busca a realização de um fim, que é o da 'solidariedade social': 'a lei social é uma lei de fim; todo fim é legítimo quando ele é conforme à lei social, e todo ato feito para atender a esse fim tem um valor social, isto é, jurídico" (CASTRO FARIAS, J. F. A Origem do Direito de Solidariedade. op. cit., p. 226).

${ }^{267}$ Segundo Duguit: "Estabelecido o direito objetivo na solidariedade social, o direito subjetivo daí deriva, direta e logicamente. E sendo todo indivíduo obrigado pelo direito objetivo a cooperar na solidariedade social, resulta que ele tem 'direito' de praticar todos aqueles atos com os quais coopera na solidariedade social, refutando, por outro lado, qualquer obstáculo à realização do papel social que lhe cabe. O homem em sociedade tem direitos; mas esses direitos não são prerrogativas pela sua qualidade de homem; são poderes que lhe pertencem porque, sendo homem social, tem obrigações a cumprir e precisa ter o poder de cumprilas. Esses princípios diferem da concepção do direito individual. Não são os direitos naturais, individuais, imprescritíveis do homem que fundamentam a regra de direito imposta aos homens em sociedade. Mas, ao contrário, porque existe uma regra de direito que obriga cada homem a desempenhar determinado papel social, é que cada homem goza de direitos - direitos que têm assim, por princípio e limites, o desempenho a que estão sujeitos". (DUGUIT, L. Fundamentos do Direito. op. cit., p. 27)
} 
fundamentais da República Federativa do Brasil a construção de uma sociedade livre, justa e solidária (inciso I) e erradicação da pobreza e da marginalização e a redução das desigualdades sociais e regionais (inciso III).

O princípio da solidariedade social passou a informar a aplicação e interpretação da legislação infraconstitucional, a exemplo do que ocorreu com o princípio da dignidade da pessoa humana. Aliás, esses princípios no mais das vezes atuam simultaneamente, a fim de implementar os valores sociais consagrados pelo ordenamento jurídico, uma vez que "pode-se supor que a vida digna de cada um pressuponha a existência minimamente satisfatória de todos os cidadãos, dado que situações de carência de qualquer pessoa podem pôr em risco todo o sistema de cooperação social". ${ }^{268} \mathrm{O}$ significado mesmo de solidariedade pressupõe a cooperação entre os participantes do mesmo ambiente social para se alcançar a vida digna de todos, já que a natureza humana tende a reconhecer no seu semelhante a continuidade do seu próprio ser. É certo que o desenvolvimento da individualidade e a especialização das atividades, decorrentes da divisão do trabalho, fizeram com que esses laços de alteridade distanciassem-se no ser humano moderno, de maneira que cabe ao direito a reconstrução dos liames de solidariedade, a fim de proporcionar a todos o livre exercício dos seus direitos fundamentais, e, assim, alcançar o melhor nível de desenvolvimento humano possível.

Logo se vê que no campo do direito privado o princípio da solidariedade social, juntamente com o da dignidade da pessoa humana, impôs uma nova maneira de compreender as relações jurídicas. A vontade das partes não é mais considerada soberana e única fonte das obrigações, devendo amoldar-se à ordem social na qual está inserida. Não se trata mais de uma autonomia da vontade, enquanto expressão do valor absoluto da liberdade de um homem considerado isolado e auto-suficiente, mas de uma autonomia social, ${ }^{269}$ de um homem que nasce e desenvolve a sua personalidade no ambiente social e retira da sociedade a força obrigatória das relações jurídicas das quais faz parte. Como afirma Durkheim, "é verdade que as obrigações propriamente contratuais podem se fazer

\footnotetext{
${ }^{268}$ CASTILHO, R.. Justiça Social e Distributiva - desafios para concretizar direitos sociais. cit., p. 96

269 Antonio Junqueira de Azevedo prefere o termo "autonomia social" a "autonomia privada". Este último tem sido utilizado por alguns autores contemporâneos para se contrapor ao termo "autonomia da vontade", próprio do paradigma do liberalismo, significando que o acordo de vontades encontra sua força obrigatória no ordenamento jurídico emanado pelo Estado, e não na vontade livre dos contratantes. Contudo, é mais correto falar em autonomia social, posto que mesmo nas sociedades em que não há Estado ou ordenamento jurídico (refere-se às sociedades primitivas) verifica-se que o acordo de vontades surte efeitos, estes provenientes do próprio corpo social que os reconhece e legitima.
} 
e se desfazer pelo simples acordo das vontades. Mas não se deve esquecer que, se o contrato tem o poder de ligar, é a sociedade que lhe confere esse poder". 270

A ótica de socialidade e eticidade, que informou a elaboração do Código Civil de 2002 e do Código de Defesa do Consumidor, também encontra seu fundamento no princípio da solidariedade social, sendo o princípio da boa-fé objetiva e os mecanismos que garantem a justiça contratual corolários dessa nova maneira de encarar as relações contratuais; contudo, como estes já foram tratados no tópico anterior, resta aqui mencionar o princípio da função social do contrato, positivada no artigo 421 do Código Civil. A determinação para que as partes exerçam a liberdade de contratar "em razão e nos limites da função social do contrato" não tem outro significado senão o de harmonizar a autonomia negocial, reconhecida pelo ordenamento jurídico, com a ordem social que confere obrigatoriedade a esse auto-regulamento firmado entre as partes. Segundo Durkheim, "o contrato é o símbolo da troca ... e a troca sempre supõe alguma divisão do trabalho mais ou menos desenvolvida". Assim, o reconhecimento do valor intrínseco dos contratos está na reciprocidade e na cooperação, decorrente da solidariedade orgânica, que deve estar presente entre os contratantes. Mas também existe um valor extrínseco, do contrato em relação ao meio social no qual se insere.

Essa questão será retomada em capítulo próprio (Parte II, seção 1.3), sendo que, por ora, cumpre estabelecer de que forma a solidariedade social opera por meio do princípio da função social dos contratos. Primeiramente, nas relações internas ao vínculo, requer que o contrato cumpra com a finalidade pela qual o ordenamento jurídico the confere tutela, sendo esta ditada tanto pela utilidade proporcionada (permitir as relações de troca e a circulação econômica), quanto pela justiça expressada pelo vínculo ${ }^{271}$, sendo que nas relações entre desiguais a função social requer que seja considerada não só a justiça comutativa, mas também a justiça distributiva (Parte II, seção 1.4). O contrato que se afastar da sua função social, por não representar mais a justiça e a utilidade, não merecerá a tutela que normalmente lhe conferiria o ordenamento jurídico. Com relação aos terceiros, a função social impõe o respeito e a observância aos pactos alheios, gerando uma oponibilidade externa do vínculo contratual, e a conseqüente mitigação do princípio da relatividade dos contratos. ${ }^{272}$ Ademais, requer que os contratos não prejudiquem de forma

\footnotetext{
${ }^{270}$ DURKHEIM, É. Da Divisão do Trabalho Social. op. cit., p. 89

${ }^{271}$ GHESTIN, J. L'utile et le juste dans les contrats. Recueil Dalloz, Sirey, 1982, Chroniques - I, A-3

${ }^{272}$ Ver: JUNQUEIRA DE AZEVEDO, A. Princípios do novo direito contratual e desregulamentação do mercado. Revista dos Tribunais, 750. São Paulo: Editora Revista dos Tribunais, p. 117; e GODOY, C. L. B.. Função Social do Contrato. São Paulo: Saraiva, 2004. p. 131 a 152.
} 
difusa a sociedade, situação que pode ser verificada em contratos de adesão com cláusulas abusivas, que caracterizam a prática de empréstimo predatório.

\subsubsection{A incidência dos direitos fundamentais nas relações privadas}

Sendo a dignidade da pessoa humana e a solidariedade social princípios expressos na Constituição da República Federativa do Brasil (art. $1^{\circ}$, incisos III e IV, e art. $3^{\circ}$, inciso I), resta saber de que maneira eles atuam nas relações privadas. O problema da eficácia dos direitos fundamentais nesse caso decorre do fato de que o particular, contra quem se pretende opor um direito fundamental, ao contrário do Poder Público, também é titular de direitos fundamentais, dentre eles a autonomia privada. A questão é saber em que medida pode-se mitigar o princípio da autonomia privada, que rege as relações entre particulares, para dar efetividade aos direitos fundamentais.

Com a evolução histórica dos direitos fundamentais, surgiram teorias sobre a sua incidência nas relações entre particulares. Pela teoria da eficácia indireta e mediata os direitos fundamentais incidem nas relações privadas pela intermediação do legislador ordinário, seja por previsão expressa nas leis infraconstitucionais, seja pelo estabelecimento de "pontes" entre o direito privado e a Constituição, representadas pelas cláusulas gerais e pelos conceitos jurídicos indeterminados, por meio dos quais seria possível a incidência dos direitos fundamentais. Com isso, os direitos fundamentais irradiam seus valores na legislação ordinária, sendo efetivados através de mecanismos típicos de Direito Privado - ressalvado, ainda, o controle de constitucionalidade das leis por contrariedade aos direitos fundamentais. Pela teoria da eficácia direta e imediata (Drittwirkung) $)^{273}$ os direitos fundamentais não necessitam da intermediação do legislador ordinário para incidir nas relações privadas. Essa posição é criticada por representar um risco para o sistema de Direito Privado, pois entre os particulares existe um grau de desigualdade admitido, em razão da autonomia privada e do poder de dispor sobre os seus interesses, no qual o Estado não deve interferir. ${ }^{274}$

\footnotetext{
${ }^{273}$ Essa teoria foi defendida inicialmente por Hans Carl Nipperdey, para quem certos direitos fundamentais podem ser invocados diretamente nas relações privadas, independentemente de qualquer mediação por parte do legislador. Para o autor, os perigos que ameaçam os direitos fundamentais não provêm apenas do Estado, mas também dos particulares (SARLET, I. W. Direitos Fundamentais e Direito Privado: algumas considerações em torno da vinculação dos particulares aos direito fundamentais. Revista de Direito do Consumidor $\mathrm{n}^{\mathrm{o}}$ 36. São Paulo: Editora Revista dos Tribunais, pág. 66.

${ }^{274}$ No entanto, como afirma Daniel Sarmento, "cumpre destacar ... que os adeptos da teoria da eficácia imediata dos direitos fundamentais nas relações privadas não negam a existência de especificidades nesta incidência, nem a necessidade de ponderar o direito fundamental em jogo com a autonomia privada dos
} 
Entendemos ser mais ponderada a doutrina de Canotilho, para quem a dicotomia entre eficácia mediata e eficácia imediata está superada, em razão da necessidade de soluções diferenciadas em face dos problemas concretos suscitados. ${ }^{275}$ Partindo dessa premissa, o jurista português propõe a divisão dos direitos fundamentais em "constelações de eficácia horizontal", assim caracterizadas: 1) eficácia horizontal expressamente consagrada na Constituição; 2) eficácia horizontal através da mediação do legislador no âmbito da ordem jurídica privada, na qual a incidência ocorre por meio das cláusulas gerais e dos conceitos indeterminados; 3 ) eficácia horizontal imediata e mediação do juiz os direitos fundamentais servem como medidas de decisão ${ }^{276}$; 4) consideração das situações de desigualdade entre as partes para o fim de dar efetividade à função de proteção dos direitos, liberdades e garantias fundamentais ${ }^{277}$, impondo um maior dever de solidariedade quando em um dos pólos da relação jurídica estiver um poder social; 5) consideração de um núcleo irredutível da 'autonomia pessoal' - casos em que os direitos fundamentais não podem exercer força conformadora, sob pena de violação da autonomia pessoal.

Baseando-se nessa doutrina, para garantir a unidade do sistema de direito privado, importa considerar a incidência dos direitos fundamentais decorrentes da dignidade da pessoa humana e da solidariedade social por intermédio das cláusulas gerais da boa-fé contratual e da função social do contrato, bem como dos mecanismos que consagram o equilíbrio nas relações contratuais. Como ensina Judith Martins-Costa:

As cláusulas gerais constituem o meio legislativamente hábil para permitir o ingresso, no ordenamento jurídico, de princípios valorativos, expressos ou ainda inexpressos legislativamente, de standards, máximas de conduta, arquétipos exemplares de comportamento, das normativas constitucionais e de diretivas econômicas, sociais e políticas, viabilizando a sua sistematização no ordenamento positivo. É indiscutível a constatação, hoje, da existência de uma crise na teoria das fontes, que se reflete na

particulares envolvidos no caso. Não se trata, portanto, de uma doutrina radical, que possa conduzir a resultados liberticidas, ao contrário do que sustentam seus opositores, pois ela não prega a desconsideração da liberdade individual no tráfico jurídico-privado" (SARMENTO, D. Direitos Fundamentais e Relações Privadas. Rio de Janeiro: Lúmen Júris, 2004. pág. 246).

275 “Reconhece-se, desde logo, que a problemática da chamada 'eficácia horizontal' se insere no âmbito da função de proteção dos direitos fundamentais, ou seja, as normas consagradoras dos direitos, liberdades e garantias e direitos análogos constituem ou transportam princípios de ordenação objectiva - em especial, deveres de garantia e de proteç̧ão do Estado - que são também eficazes na ordem jurídica privada (K. Hesse). Esta eficácia, para ser compreendida com rigor, deve ter em consideração a multifuncionalidade ou pluralidade de funções dos direitos fundamentais, de forma a possibilitar soluções diferenciadas e adequadas, consoante o 'referente' de direito fundamental que estiver em causa no caso concreto". (CANOTILHO, J.J. G.. op. cit., p. 1246).

${ }^{276}$ CANOTILHO, J.J. G. op. cit., pág. 1249.

${ }^{277}$ Idem, ibidem, pág. 1249. 
metodologia da ciência do direito. Esta crise resulta, segundo Clóvis do Couto e Silva, justamente 'da admissão de princípios tradicionalmente considerados metajurídicos no campo da Ciência do Direito, aluindo-se, assim, o rigor lógico do sistema com fundamento no puro raciocínio dedutivo. ${ }^{278}$

No entanto, não se exclui a possibilidade de interpretação conforme as normas constitucionais, bem como a discussão acerca da constitucionalidade das normas que atentarem contra os direitos fundamentais, o que deverá seguir as formas de controle de constitucionalidade previstas constitucionalmente. Afinal, os direitos consagrados constitucionalmente possuem força normativa, compreensão essa que vem ganhando força na atualidade.

Com relação ao tratamento jurídico das situações de endividamento excessivo, tal como já alertado, o ordenamento jurídico brasileiro não contempla um diploma legal que discipline de forma global a recuperação financeira do consumidor. Contudo, a tutela do consumidor de crédito no ordenamento jurídico brasileiro está presente no Código de Defesa do Consumidor, que contem diversas normas a respeito dos deveres de informação, de cooperação e de lealdade, decorrentes da boa-fé objetiva, bem como a respeito da proibição de cláusulas abusivas e da obtenção de vantagem exagerada, cuja observância visa exatamente inibir o surgimento do endividamento excessivo, conferindo, em grande parte, a tutela necessária para afastar o sobreendividamento nas relações individualmente consideradas. Em outros casos, as cláusulas gerais da boa-fé objetiva, do equilíbrio contratual e da função social do contrato incidirão para tutelar situações que não se subsumem a uma regra específica, exigindo-se um maior esforço interpretativo na ponderação entre os direitos fundamentais, baseados na dignidade da pessoa humana e na solidariedade social, e a autonomia privada.

A tutela do consumidor de crédito será objeto da segunda parte deste trabalho. No Capítulo 1 será apresentada, de forma ampla, a tutela conferida pelo ordenamento jurídico por intermédio das cláusulas gerais da boa-fé, da justiça contratual e da função social do contrato, que será sempre reforçada quando um dos pólos da relação for ocupado por uma parte mais fraca. A tutela apresentada até este momento mostrar-se-á adequada para a prevenção e tratamento de grande parte das situações de endividamento excessivo, sendo que no Capítulo 2 será abordada a situação do consumidor excessivamente endividado seja em virtude do comportamento ilícito do credor, que deverá ser responsabilizado pela má concessão do crédito, seja em virtude da alteração das circunstâncias subjetivas.

${ }^{278}$ MARTINS-COSTA, J. A Boa-fé no Direito Privado. São Paulo: Revista dos Tribunais, 2000. p. 274 


\section{PARTE II - A TUTELA DO CONSUMIDOR DE CRÉDITO NO ORDENAMENTO JURÍDICO BRASILEIRO}

\section{CAPÍTULO 1 - IRRADIAÇÃO DOS VALORES SOCIAIS NOS MECANISMOS DE DIREITO PRIVADO}

Na primeira parte deste trabalho foi abordada a evolução do paradigma do Estado Liberal para o do Estado Social, evidenciando-se a alteração da dogmática contratual, que passou do voluntarismo exacerbado ${ }^{279}$ para a conformação das declarações de vontade às normas de ordem pública, seguindo-se a admissão das cláusulas gerais, que permitiram a permeação de valores éticos e sociais nas relações jurídicas.

O modelo voluntarista do Estado liberal se revelou injusto e permissivo de abuso de posições jurídicas. Com a passagem para o Estado Social, valores sociais e éticos somaram-se ao valor liberdade ${ }^{280}$, e aos poucos essa nova ordem de idéias foi sendo incorporada pelo direito. ${ }^{281}$ Com relação ao ordenamento jurídico brasileiro, desde a Constituição de 1934 os valores decorrentes do Estado social foram privilegiados, muito embora num primeiro momento a consagração tenha sido meramente nominal. Contudo, se inicialmente as transformações sociais foram refletidas no Direito, o inverso também é verdade, pois as previsões constitucionais relativas aos direitos fundamentais

\footnotetext{
${ }^{279}$ No paradigma do Estado Liberal, reconhecia-se à vontade uma força quase absoluta como fonte das obrigações. De acordo com Orlando Gomes, "o voluntarismo clássico atribuía à vontade o papel de fonte exclusiva da criação do Direito, a tal ponto que ignorava a existência anterior do direito objetivo, somente mais tarde se vindo a reconhecer que a vontade individual não passa, como disseram os MAZEAUD, de um comutador que dá passagem a uma corrente cuja fonte se encontra alhures". (GOMES, O. Transformações Gerais do Direito das Obrigações. São Paulo: Revista dos Tribunais, 1967, p. 11).

${ }^{280}$ Franz Wieacker constata que o núcleo do princípio do Estado Social manifesta-se na limitação do conteúdo dos direitos subjetivos, com a responsabilização não apenas da sociedade, mas também do indivíduo, pela existência social e bem-estar dos outros. E prossegue: "Na legislação do moderno direito privado, esta responsabilização encontra a sua expressão mais drástica na protecção do inquilino, na legislação sobre revisão das cláusulas contratuais por via judicial, no recente direito sobre a intervenção dos vizinhos e nos projetos de reforma do direito sobre a responsabilidade por danos. Mas de forma ainda mais eficaz, esta idéia actuou, no contínuo labor da jurisprudência, no sentido da restrição dos direitos do credor sob o ponto de vista do caráter abusivo ou exagerado da prestação, no contínuo alargamento dos deveres de custodia na relação contratual, na dedução de deveres contratuais a partir de situações sociais, na progressiva extensão da responsabilidade delitual e no alargamento dos deveres dos proprietários nas suas relações com os outros particulares. Os sintomas visíveis desta evolução foram constituídos pela desoneração do devedor do dever de prestação em vista da sua situação patrimonial geral na recente jurisprudência sobre a base do negócio". (WIEACKER, F. História do Direito Privado Moderno. Tradução de A.M. Botelho Hespanha. Lisboa: Fundação Calouste Gulbenkian, 1967, p. 624)

${ }^{281}$ Orlando Gomes observa que a transformação no direito das obrigações "corrige situações injustas a que conduziu, quando imperava na órbita política e econômica o liberalismo, dando-lhes conteúdo mais humano, social e ético. Tende, em resumo, para a socialização e a moralização, na conformidade das convicções a esse respeito dominantes” (GOMES, O. Transformações gerais do direito das obrigações. op. cit., p. 2)
} 
impulsionaram a produção legislativa para a proteção das pessoas mais vulneráveis - o que se iniciou com o direito laboral, passando pela Lei do Inquilinato, e, após a Constituição Federal de 1988, em cumprimento de mandamento constitucional, com a proteção do consumidor - dentre muitas outras leis que buscaram implementar os valores do Estado social.

Atualmente, esses novos valores também passaram a ser amplamente aceitos nas relações puramente civis, já que o Código Civil de 2002 recepcionou-os de forma expressa. No Direito das Obrigações, os princípios tradicionais dos contratos (relatividade, força obrigatória e autonomia da vontade) passaram a conviver com os novos princípios da boafé, da função social e do equilíbrio contratual, que encontram seu fundamento nos valores supremos da dignidade da pessoa humana e da solidariedade social. Esses princípios expressam-se nas cláusulas gerais, consagradas expressamente pelo ordenamento jurídico brasileiro, que orientam o comportamento das partes e que servem como pontes para a incidência dos direitos fundamentais reconhecidos pela Constituição Federal nas relações jurídicas de Direito Privado.

Nos tópicos abaixo, serão analisados detidamente estes novos princípios, salientando-se a sua importância na tutela das situações de endividamento excessivo. Observe-se que, por vezes, esses princípios interagem, complementando o significado um do outro e atuando de forma conjunta para conferir o contorno das declarações de vontade e para regular o comportamento das partes e o desenvolvimento do vínculo contratual. 


\section{Seção 1.1 - A boa-fé contratual}

O princípio da boa-fé no Direito das Obrigações atua como um vetor axiológico para orientar tanto a conduta das partes nas relações contratuais, quanto a atuação do juiz na concretização do direito. Em linhas gerais, as funções desempenhadas pela boa-fé são o estabelecimento do verdadeiro sentido e alcance das declarações de vontade, a integração das lacunas legais e contratuais, o alargamento dos deveres contratuais e o repúdio ao abuso das posições jurídicas, o que denota a sua crucial importância como princípio informador das relações contratuais. ${ }^{282}$

De origem bastante remota ${ }^{283}$, a noção de boa-fé serviu aos anseios de moralização e socialização das relações obrigacionais, formulando-se como princípio fundamental imprescindível nos ordenamentos jurídicos contemporâneos. Enquanto padrão de conduta, a boa-fé é considerada em sentido objetivo ${ }^{284}$, sendo o seu significado extraído do

${ }^{282}$ Nesse sentido é a lição de Cláudia Lima Marques: "Efetivamente, o princípio da boa-fé objetiva na formação e na execução das obrigações possui muitas funções na nova teoria contratual: 1) como fonte de novos deveres especiais de conduta durante o vínculo contratual, os chamados deveres anexos, e 2) como causa limitadora do exercício, antes lícito, hoje abusivo, dos direitos subjetivos e 3) na concreção e interpretação dos contratos. A primeira função é uma função criadora (pflichtenbegrundende funktion), seja como fonte de novos deveres (nebenpflichten), deveres de conduta anexos aos deveres de prestação contratual, como o dever de informar, de cuidado e de cooperação; seja como fonte de responsabilidade por ato lícito (Vertrauenshaftung), ao impor riscos profissionais novos e agora indisponíveis por contrato. A segunda função é uma função limitadora (Schranken-bzw. Kontrollfunktion), reduzindo a liberdade de atuação dos parceiros contratuais ao definir algumas condutas e cláusulas como abusivas, seja controlando a transferência dos riscos profissionais e libertando o devedor em face da não razoabilidade de outra conduta (pflichenbefreinde Vertrauensunstände). A terceira é a função interpretadora, pois a melhor linha de interpretação de um contrato ou de uma relação de consumo deve ser a do princípio da boa-fé, o qual permite uma visão total e real do contrato sob exame. Boa-fé é cooperação e respeito, é conduta esperada e leal, tutelada em todas as relações sociais" (MARQUES, C. L. Contratos no Código de Defesa do Consumidor. São Paulo: Revista dos Tribunais, 2006, $5^{\text {a }}$. edição, pág. 215).

${ }^{283}$ Judith Martins-Costa esclarece que a noção de boa-fé provém do Direito Romano, já encontrando registro na Lei das Doze Tábuas (numa de suas acepções, fides sacra, referia-se ao culto da Deusa Fides, como informa Menezes Cordeiro, que apresenta outros dois significados do termo - fides facto e fides ética. Ver no já citado MENEZES CORDEIRO, A. M. R. Da Boa-fé no Direito Civil. cit., pág. 53 a 58). Salienta a autora que a boa-fé no Direito Romano manifestou-se em dois setores jurídicos relacionados ao direito obrigacional: as relações de clientela e as relações contratuais internas e externas (Tratado Roma-Cartago). Nas palavras da autora: "a indicação da presença da fides em dois setores diversos da experiência jurídica romana, a instituição da clientela e a dos contratos, internacionais ou de direito interno, conduz à constatação do nascimento de duas vertentes que fariam riquíssima história: numa delas a fides se apresenta como núcleo das relações internas de uma coletividade, o que Paolo Frezza denomina de relações intrasubjetivas, vale dizer, as relações de clientela; na outra, se aloja numa esfera que, por tratar de relações entre sujeitos pertencentes a coletividades entre si distintas, se pode chamar de relações intersubjetivas (FREZZA, P. Fides Bona. Studi sulla buona fede. Facoltà di Giurisprudenza della Università di Pisa. Milão: Giuffrè, 1975). Em ambas é diversa a sua função. Nas relações intrasubjetivas tem função de autolimitação (fides promessa) e intento protetivo. Já nas relações intersubjetivas a função é a da garantia do respeito à palavras dada (fit quod dicitur)". (MENEZES CORDEIRO, A. M. R. Da Boa-fé no Direito Privado. op. cit., p. 114).

${ }^{284}$ Fernando Noronha distingue a boa-fé crença (subjetiva) da boa-fé lealdade (objetiva), assim resumindo: "mais do que duas concepções da boa-fé, existem duas boas-fés, ambas jurídicas, uma subjetiva, a outra objetiva. A primeira diz respeito a dados internos, fundamentalmente psicológicos, atinentes diretamente ao sujeito, a segunda a elementos externos, a normas de conduta, que determinam como ele deve agir. Num 
ambiente social no qual a declaração de vontade é emitida ou o comportamento é praticado. A condição pessoal das partes envolvidas também é relevante para o estabelecimento do padrão de conduta almejado pela boa-fé. Com efeito, a conduta esperada de um profissional que se relaciona com indivíduos leigos é diferente do padrão exigido entre pessoas iguais (dois profissionais ou dois leigos).

O primeiro registro legal do princípio da boa-fé no ordenamento jurídico brasileiro foi no Código Comercial de 1850, no qual funcionava como critério objetivo de interpretação das declarações de vontade. ${ }^{285}$ O Código de Defesa do Consumidor foi o primeiro diploma legal a prever a boa-fé objetiva como fonte de deveres de conduta, muito embora já se defendesse que o princípio estava implícito no ordenamento jurídico brasileiro. ${ }^{286} \mathrm{O}$ artigo $4^{\circ}$, inciso III do CDC, estabeleceu a boa-fé objetiva como princípio informador da Política Nacional das Relações de Consumo, servindo de base para harmonizar os interesses dos participantes destas relações. Já o artigo 51, inciso IV, previu a boa-fé como cláusula geral na função limitadora da liberdade de contratar, fulminando de nulidade as cláusulas contratuais que lhe forem contrárias. O Código Civil de 2002 ampliou o espectro de atuação do princípio da boa-fé prevendo-o na função interpretativa (CC, art. 113), como parâmetro para a configuração do abuso de direito (CC, art. 187) e como cláusula geral nas relações contratuais, estabelecendo que "os contratantes são obrigados a guardar, assim na conclusão do contrato, como em sua execução, os princípios da probidade e da boa-fé" (CC, art. 422).

$\mathrm{Na}$ função interpretativa (função adjuvandi), a boa-fé atua na obtenção do significado do regulamento contratual, concretizando-se na tutela da confiança legitimamente despertada no destinatário da declaração de vontade. ${ }^{287}$ Para Judith Martins-

caso, está de boa-fé quem ignora a real situação jurídica; no outro, está de boa-fé quem tem motivos para confiar na contraparte. Uma é boa-fé estado, a outra, boa-fé princípio. A distinção interessa-nos, porque a boa-fé contratual é a objetiva - e, aliás, os contratos são o principal campo de aplicação da boa-fé objetiva". (NORONHA, F. O direito dos contratos e seus princípios fundamentais, São Paulo: Saraiva, 1994).

${ }^{285}$ Estatuía o artigo 131 que os contratos deveriam ser interpretados segundo "a inteligência simples e adequada, que for mais conforme a boa fé, e ao verdadeiro espírito e natureza do contrato, deverá sempre prevalecer à rigorosa e restrita significação das palavras".

${ }^{286}$ Nesse sentido, Clóvis do Couto e Silva aduz que "a inexistência, no Código Civil, de artigo semelhante ao $\S 242$ do BGB não impede que o princípio tenha vigência em nosso direito das obrigações" (COUTO e SILVA, C. A obrigação como processo. Rio de Janeiro: Editora FGV, 2007. p. 33).

${ }^{287}$ Como resultado da superação do voluntarismo, abandonou-se a teoria da vontade como fonte criadora do negócio jurídico, reconhecendo-se a sua essência no sentido normal da declaração. Atualmente a teoria da declaração sofreu um abrandamento pela teoria da confiança, que qualifica a declaração emitida considerando a boa-fé do destinatário como parâmetro para aferir tanto a confiança despertada, quanto a sua diligência ao reconhecer a seriedade da promessa feita. Comentando a teoria da confiança, Orlando Gomes aduz: "Havendo divergência entre a vontade interna e a declaração, os contraentes de boa-fé, a respeito dos quais tal vontade foi imperfeitamente manifestada, têm direito a considerar firme a declaração que se podia admitir como vontade efetiva da outra parte, ainda quando esta houver errado de boa-fé ao declarar a própria 
Costa, a interpretação conforme a boa-fé deve preservar a finalidade que as partes pretendiam atingir com o contrato, constituindo-se num "mandamento imposto ao juiz de não permitir que o contrato, como regulação objetiva, dotada de um específico sentido, atinja finalidade oposta ou contrária àquela que, razoavelmente, à vista de seu escopo econômico-social, seria lícito esperar". ${ }^{288}$ Processo diverso ocorre quando a boa-fé é chamada a suprir alguma lacuna do regramento contratual. Aí não há mais função interpretativa, pois o que se tem é a ausência de declaração de vontade a respeito de determinada questão. Na função integrativa (suplendi), na qual a boa-fé funciona como critério objetivo para estabelecer o regramento contratual que melhor se conforme com o padrão de comportamento local, que seria adotado numa contratação análoga. ${ }^{289}$

Como princípio orientador das relações contratuais, sob a forma de cláusula geral, a boa-fé objetiva tem aplicação desde a fase pré-contratual, passando pela fase contratual propriamente dita e prolongando-se durante a fase pós-contratual. ${ }^{290} \mathrm{Na}$ fase précontratual, tutela a confiança das partes que se envolvem numa tratativa ${ }^{291}$, repudiando a ruptura desmotivada ou abusiva das negociações anteriores à celebração do contrato, bem como impondo alguns deveres de lealdade, de informação e de colaboração. ${ }^{292} \mathrm{Na}$ fase contratual, é responsável pelo alargamento do vínculo contratual, impondo uma série de

vontade. Enquanto, pois, tem um dos contratantes razão para acreditar que a declaração corresponde à vontade do outro, há de se considerá-la perfeita, por ter suscitado a legítima confiança em sua veracidade". (GOMES, O. Transformações Gerais no Direito das Obrigações. cit., p. 15)

${ }^{288}$ MENEZES CORDEIRO, A. M. R.. A Boa-fé no Direito Privado. op. cit. p. 274.

${ }^{289}$ De acordo com Emilio Betti, a interpretação desenvolve a coerência lógica do ato, sempre no sentido de esclarecer o conteúdo implícito ou marginal do negócio que não está explícito na fórmula. $\mathrm{O}$ ponto a ser esclarecido decorre do complexo de tudo o quanto foi dito ou feito, sendo inferível ou reconhecível da declaração, valorado segundo o critério de boa-fé, dos usos sociais etc., e são inteligíveis e reconhecíveis pelas partes. A interpretação, portanto, supõe sempre um conteúdo do negócio concreto, seja implícito seja explícito. A integração, diferentemente, pressupõe a ausência total de vontade. Supõe um ponto sobre o qual as partes não dispuseram absolutamente nada. Não está mais em questão a vontade das partes, de maneira que não há integração da fatispécie do negócio, mas somente dos seus efeitos. Lacunosa é a fórmula do negócio, e pela integração dá-se a reconstrução da idéia do negócio, possibilitando a produção de efeitos concretos. (BETTI, E. Interpretazione della legge e degli atti giuridici. Milano: Girffrè, 1971, pág. 408-409). ${ }^{290}$ Esse dinamismo fez com os autores compreendessem o vínculo obrigacional como um processo. Para Clóvis do Couto e Silva “com a expressão obrigação como processo, tenciona-se sublinhar o ser dinâmico da obrigação, as várias fases que surgem no desenvolvimento da relação obrigacional e que entre si se ligam com interdependência" (COUTO e SILVA, C. A obrigação como processo. op. cit. p. 20.). Ainda nesse sentido, Antonio Junqueira de Azevedo: “Sempre digo que o contrato é um 'processo' em que há começo, meio e fim. Temos fases contratuais - fase pré-contratual, contratual propriamente dita e pós-contratual" (Insuficiências, deficiências e desatualização ... cit., p. 150).

${ }^{291}$ Para Antônio Junqueira de Azevedo, a fase pré-contratual “é um campo propício para a regra do comportamento da boa-fé, pois, aí, ainda não há contrato e, apesar disso, já são exigidos aqueles deveres específicos que uma pessoa precisa ter como correção de comportamento em relação a outra" (idem, ibidem). ${ }^{292}$ Em razão da inexistência de obrigação principal esses deveres não podem ser, nesta fase, chamados de acessórios, mas existem enquanto deveres de conduta em razão de uma contratação futura (CASTRO SAMPAIO, L. M. A Boa-fé Objetiva na Relação Contratual. Barueri-SP: Manole, 2004. p. 65). 
deveres de conduta ${ }^{293}$, que têm por objetivo impor um padrão ideal de conduta para assegurar o efetivo exercício da autonomia negocial - o que se consegue por meio dos deveres de informação e de aconselhamento -, bem como evitar que as partes ocasionem danos mútuos e cooperem para a consecução do escopo contratual. ${ }^{294} \mathrm{Na}$ fase póscontratual, vedam-se condutas de um dos contratantes que impeçam o outro de gozar amplamente da prestação que lhe foi conferida, além de imporem-se determinados deveres negativos, como o de sigilo e o de não concorrência, que persistem mesmo após o cumprimento da prestação principal. ${ }^{295}$

Verifica-se, ainda, a incidência do princípio da boa-fé objetiva no caso de inexecução dos contratos, coibindo o abuso de uma posição contratual (não apenas dos direitos decorrentes da prestação principal, mas também de faculdades jurídicas, como é o caso da faculdade de renegociar a dívida), bem como fundamentando a não resolução do pacto em caso de adimplemento substancial e vedando o emprego abusivo de cláusulas resolutivas, multas, formas de cobrança abusivas, dentre outras práticas que denotam o abuso de direito.

Sem desprezar as diversas facetas e as inúmeras possibilidades conferidas pelo princípio da boa-fé objetiva, trataremos a seguir de algumas de suas funções, mais diretamente ligadas à tutela do crédito e das situações de sobreendividamento.

\subsubsection{Imposição de deveres de conduta}

A atual concepção de autonomia negocial exige que, ao lado do regulamento contratual resultante das declarações de vontade das partes, estejam presentes deveres laterais de conduta (também chamados instrumentais, acessórios ou anexos) decorrentes da

\footnotetext{
293 Ensina Fernando Noronha que enquanto os deveres secundários estão ainda ligados à realização da prestação principal, configurando prestações autonomamente exigíveis, os deveres acessórios de conduta, chamado por alguns de laterais, "não se traduzem em prestações específicas, identificáveis com antecipação, para que o credor pudesse exigir o seu cumprimento; eles têm como único fundamento o princípio da boa-fé e, por isso, só são identificáveis em cada caso concreto". (NORONHA, F. O direito dos contratos e seus princípios fundamentais, op. cit., p. 161 e 162).

${ }^{294}$ A boa-fé ainda se concretiza em figuras típicas que retratam o repúdio a condutas contraditórias, como venire contra factum proprium, surrectio, supressio e o tu quoque. A análise dessas figuras típicas foge ao objetivo deste trabalho, razão pela qual se remete a leitura para A.M. da Rocha Menezes Cordeiro, que disserta largamente sobre as hipóteses citadas (MENEZES CORDEIRO, A. M. R. Da Boa-fé no Direito Civil, op. cit., p. 742 a 852).

${ }^{295}$ Clóvis do Couto e Silva salienta que "mesmo adimplindo o dever principal, ainda assim pode a relação jurídica perdurar como fundamento da aquisição (dever de garantia), ou em razão de outro dever secundário independente". (COUTO e SILVA, C. A obrigação como processo. op. cit., p. 20).
} 
boa-fé objetiva enquanto cláusula geral. ${ }^{296} \mathrm{Na}$ lição de Karl Larenz, “de las exigencias de la buena fe derivan para todos los participantes en una relación obligatoria determinados deberes de conducta que hacen referencia a la preparación de la prestación propiamente dicha, a la forma de su ejecución, a la cooperación eventualmente necesaria de ambas partes y a la consideración que según la equidad puede cada parte esperar de la otra en semejante relación". 297

A imposição de deveres acessórios de conduta nas relações contratuais decorre do reconhecimento da complexidade do vínculo obrigacional, o que, de acordo com Menezes Cordeiro, "traduz a idéia de que o vínculo obrigacional abriga, no seu seio, não um simples dever de prestar, simétrico a uma pretensão creditícia, mas antes vários elementos jurídicos dotados de autonomia bastante para, de um conteúdo unitário, fazerem uma realidade composta". ${ }^{298}$ A boa-fé objetiva determina um aumento dos deveres contratuais, além daqueles expressamente convencionados pelas partes, abrindo-se espaço para o que se convencionou chamar de violação positiva do contrato. ${ }^{299}$

Clóvis do Couto e Silva também identificou o fenômeno da relação jurídica como um organismo, numa ordem de cooperação onde "credor e devedor não ocupam mais posições antagônicas, dialéticas e polêmicas", e assim "transformando o status em que se encontravam, tradicionalmente, devedor e credor, abriu-se espaço ao tratamento da relação obrigacional como um todo". ${ }^{300} \mathrm{Na}$ ordem cooperativa e solidária na qual as relações jurídicas estão inseridas, esses deveres não estão a cargo somente do devedor, dirigindo-se também ao credor. ${ }^{301}$

\footnotetext{
${ }^{296}$ Ensina Antonio Junqueira de Azevedo que a boa-fé é um conceito jurídico indeterminado que "quando se refere ao tipo de comportamento exigido - por exemplo, dos contratantes - configura-se em cláusula geral". (JUNQUEIRA DE AZEVEDO, A. Insuficiências, deficiências e desatualização ... op. cit., p. 149).

${ }^{297}$ LARENZ, K.. Derecho de Obligaciones. Tomo I. Versión Española y notas de Jaime Santos Briz. Madrid: Editorial Revista de Derecho Privado, 1958. p. 154.

${ }^{298}$ MENEZES CORDEIRO, A. M. R. Da Boa-fé no Direito Civil. op. cit., p. 586.

299 A partir destas constatações, a doutrina alemã passou a discutir a possibilidade da violação positiva do contrato, nas hipóteses em que, apesar do cumprimento da obrigação principal, tenha ocorrido a violação de deveres acessórios de conduta. Após apresentar as discussões teóricas acerca do tema, Menezes Cordeiro conclui: "Deve considerar-se como integrando hipóteses de violação positiva do contrato, os casos de cumprimento defeituoso da prestação principal, de incumprimento ou impossibilitação de prestações secundarias e de violação de deveres acessórios" (MENEZES CORDEIRO, A. M. R. Da Boa-fé no Direito Civil. op. cit., p. 602). Entendemos que no ordenamento jurídico brasileiro a hipótese de cumprimento defeituoso da prestação principal enquadra-se claramente na hipótese de mora, enquanto descumprimento na forma devida (CC, art. 394). Nesse sentido, Ruy Rosado de Aguiar Jr.: "No Brasil, o conceito de mora absorve as hipóteses de cumprimento imperfeito por defeito quanto à forma e ao lugar da prestação, razão pela qual não sentimos a mesma dificuldade enfrentada na doutrina alemã, que derivou para a teoria da infração contratual positiva" (AGUIAR JR., R. R. Extinção dos Contratos por Incumprimento do Devedor. Rio de Janeiro: AIDE Editora, 2004, p. 126).

${ }^{300}$ COUTO E SILVA, C. V. A obrigação como processo. Rio de Janeiro: Editora FGV, 2007. p. 19.

${ }^{301}$ Como já dizia Clóvis do Couto e Silva: "Endereça-se a todos os partícipes do vínculo e pode, inclusive,
} 
Nos itens abaixo, serão analisados alguns desses deveres, que decorrem do princípio da boa-fé, dentre eles, os de informação, de aconselhamento, de lealdade, de cooperação e de cuidado, todos fundamentais para a tutela das situações de sobreendividamento.

\section{a) Deveres de informação e de aconselhamento}

O dever de informação é a expressão do princípio da transparência nas relações contratuais, impondo às partes o dever de não omitir pontos relevantes acerca do objeto do contrato. Pela definição de Menezes Cordeiro, o dever de esclarecimento obriga as partes a “informarem-se mutuamente de todos os aspectos atinentes ao vínculo, de ocorrências que, com ele, tenham certa relação e, ainda, de todos os efeitos que, da execução contratual, podem advir". 302

Nas relações de consumo há uma presunção de vulnerabilidade do consumidor, fundada, dentre outros aspectos, na assimetria de informações existente entre as partes. $\mathrm{O}$ fornecedor é um profissional do ramo em que atua, tendo elevado conhecimento a respeito da atividade que exerce no mercado. Daí a necessidade de oferecer ao consumidor todas as informações possíveis, para que ele ingresse na relação contratual suficientemente esclarecido, sendo capaz de formar conscientemente a sua vontade. Nas relações de consumo, o padrão de informação exigido é mais elevado do que nas relações entre iguais, não se admitindo o chamado dolus bonus, ${ }^{303}$ que é o engodo utilizado pelo fornecedor para exaltar as qualidades do seu produto.

Por esse motivo, nas relações de consumo o dever de informação tem maior relevância no momento pré-contratual, a fim de possibilitar a escolha consciente do consumidor, inclusive a respeito da opção de não contratar naquele momento, tendo em vista as suas condições pessoais, o que se mostra especialmente relevante em se tratando de uma relação creditícia, já que em muitos casos o tão só cumprimento do dever de informar adequadamente já seria suficiente para evitar diversas situações de endividamento excessivo.

Mas qual seria o conteúdo desse dever de informar capaz de preservar a integridade financeira do consumidor de crédito?

criar deveres para o credor, o qual, tradicionalmente, era apenas considerado titular de direitos". (idem, ibidem. p. 33).

${ }^{302}$ MENEZES CORDEIRO, A. M. R. Da Boa-fé no Direito Civil. op. cit., p. 605.

${ }^{303}$ MARQUES, C. L. Contratos no Código de Defesa do Consumidor. cit. p. 111. 
Nas relações de crédito, o dever de informar consiste nos deveres de esclarecimento a respeito das operações de crédito, bem como no de aconselhamento a respeito das possíveis escolhas entre as diversas modalidades de crédito existente, bem como sobre a eventual inconveniência de tomar um empréstimo, considerando as condições pessoais e financeiras do consumidor.

Com relação ao dever de esclarecimento diz ele respeito às informações necessárias para o consumidor compreender a operação de crédito em si mesma considerada, ou seja, esclarecimento sobre os termos técnicos, os efeitos das taxas de juros conforme o prazo contratual, o significado da cobrança de juros capitalizados, os demais encargos contratuais, dentre outras informações que se mostrem necessárias. Consoante ressalta o jurista italiano Roberto Ruozi, mesmo os consumidores mais evoluídos têm dificuldade de compreender as complexas operações financeiras. ${ }^{304}$ Dessa forma, quanto maior a vulnerabilidade técnica e econômica do consumidor, maior se mostra o dever de informar.

Cláudia Lima Marques destaca a necessidade de proteção da vontade real do consumidor, a fim de evitar as situações de superendividamento:

No direito comparado observa-se que as técnicas legislativas de proteção aos consumidores em matéria de contratos envolvendo crédito visam inicialmente garantir uma nova proteção da vontade dos consumidores, isto é, garantir uma autonomia real da vontade do contratante mais fraco. Uma vontade protegida pelo direito, vontade liberta das pressões e dos desejos impostos pela publicidade e por outros métodos agressivos de venda, uma vez que a concessão do crédito ao consumidor está ligada faticamente a uma série de perigos, vale lembrar os fenômenos atuais de superendividamento, insolvência, abusos contratuais, etc ${ }^{305}$.

Além do dever de esclarecimento, as instituições financeiras têm o dever de aconselhamento a respeito da modalidade de crédito a ser contratada, ou até mesmo sobre a conveniência da contratação, o que necessariamente deverá levar em consideração a condição sócio-econômica do devedor, e os efeitos do contrato na sua economia doméstica, considerando os seus gastos com o mínimo existencial seu e de sua família. Segundo Cláudia Lima Marques o aconselhamento "é um dever mais forte e só existe nas relações entre um profissional, especialista, e um não especialista”. Prossegue a autora esclarecendo que "cumprir ou não o dever de aconselhamento significa fornecer aquelas

\footnotetext{
304 "In proposito è necessario ricordare che ormai neppure i consumatori più evoluti sono in grado di comprendere le complessità e le caratteristiche di tutte le innovazioni finanziarie che sono state prodotte e che si stanno producendo a livello nazionale e internazionale". RUOZI, R. La Tutela Del Consumatore di Servizi Finanziari, a cura di Roberto Ruozi in La tutela del Consumatore di Servizi Finanziari. Milano: E.G.E.A., 1990. p. 13.

${ }^{305}$ MARQUES, C. L. Os contratos de crédito na legislação brasileira de proteção ao consumidor, Revista de Direito do Consumidor, 17, São Paulo, RT, p. 36-56, jan.-mar./1996
} 
informações necessárias para que o consumidor possa escolher entre vários caminhos a seguir". 306

De fato, na concessão de crédito, lida-se de um lado com uma parte tecnicamente vulnerável (um não profissional) e, de outro, com profissionais acostumados com as complexas operações financeiras e com os efeitos que um contrato de crédito pode acarretar no orçamento doméstico do tomador. Esses profissionais têm não apenas o dever de esclarecer os consumidores a respeito dos efeitos do empréstimo considerado isoladamente (explicar a diferença entre um contrato de longo e de curto prazo, com entrada ou sem entrada, e quais os efeitos da capitalização de juros nessas variáveis, etc.), mas também, de analisar a situação financeira do devedor e verificar se ele tem condições de cumprir o contrato. Para quem isso seja possível, é importante que o devedor também cumpra a sua parte no dever de informação, incumbindo-lhe revelar todos os dados a respeito de sua situação financeira, e dos seus gastos diários, para possibilitar ao credor a correta avaliação do risco do crédito e da possibilidade da sua concessão. Note-se, contudo, que por ser o fornecedor a parte profissional, deve ele exigir as informações consideradas indispensáveis para tal avaliação.

Tendo em vista a essencialidade e importância da atividade financeira, nos termos previstos no artigo 192 da Constituição Federal, bem como a potencialidade de causar a ruína financeira do consumidor, tem o fornecedor (instituição financeira) até mesmo o dever de negar a concessão do crédito, caso verifique a ausência de condições financeiras do consumidor de suportar o ônus contratual, ou a impossibilidade prática de compreender os efeitos dos danos da utilização do crédito. Caso não adote esta conduta, estará concedendo o crédito de forma irresponsável, pois estará colaborando para o futuro inadimplemento contratual. ${ }^{307}$ É nesse sentido que o National Credit Act da África do Sul capitula como reckless (irresponsável) a concessão do crédito sem que o credor certifiquese de que o consumidor tem a necessária compreensão dos riscos e dos custos do crédito oferecido, ou sem analisar o histórico de crédito do consumidor, bem como a existência de meios para o cumprimento do contrato (NCA, art. 81-2). Verificando a inadequação da modalidade de crédito solicitada, tem ainda a instituição financeira o dever de indicar uma melhor opção de operações subsidiadas, com taxas de juros mais acessíveis, ainda que seu estabelecimento não disponha dessa modalidade de crédito.

\footnotetext{
${ }^{306}$ MARQUES, C. L. Contratos no Código de Defesa do Consumidor. op. cit., p. 229.

${ }^{307}$ Ver Parte II, Capítulo 2, seção 2.1.
} 
Ainda com relação ao direito à informação, no âmbito contratual, o art. 46 do CDC assegura ao consumidor o direito ao prévio conhecimento do conteúdo do contrato, bem como obriga o fornecedor a redigir as cláusulas contratuais de forma clara, sem dificultar a compreensão do seu sentido e alcance, pena de desobrigar o consumidor ao cumprimento do contrato. Trata-se de norma importante para proporcionar um prazo de reflexão para o consumidor $^{308}$, mas que tem sido silenciosamente violada, tendo em vista que já é prática arraigada na cultura brasileira a falta de clareza e simplicidade das cláusulas padronizadas e pré-dispostas dos contratos de crédito, que em geral são entregues ao consumidor apenas posteriormente à contratação. Ressalte-se que mesmo em relação a outros documentos que dizem respeito ao consumidor, como extratos antigos de conta corrente que não estão mais disponíveis na internet, por vezes, o cliente encontra dificuldades de obtê-los, necessitando lançar mão de medidas judiciais para tanto. ${ }^{309}$

$\mathrm{Na}$ tentativa de reforçar o disposto no artigo 46, com relação aos contratos de adesão, foi introduzido um parágrafo $3^{\circ}$ no artigo 54 do CDC, pela lei 11.785/2008, o qual estabelece que "os contratos de adesão escritos serão redigidos em termos claros e com caracteres ostensivos e legíveis, cujo tamanho da fonte não será inferior ao corpo doze, de modo a facilitar sua compreensão pelo consumidor".

Com relação ao fornecimento de crédito, existe norma específica no CDC que estabelece qual o conteúdo mínimo do dever de informar. Trata-se do artigo 52, que assim dispõe: "No fornecimento de produtos ou serviços que envolva outorga de crédito ou concessão de financiamento ao consumidor, o fornecedor deverá, entre outros requisitos, informá-lo prévia e adequadamente sobre: I - preço do produto ou serviço em moeda corrente nacional; II - montante dos juros de mora e da taxa efetiva anual de juros; III acréscimos legalmente previstos; IV - número e periodicidade das prestações; V - soma total a pagar, com e sem financiamento".

Note-se que a legislação brasileira contém requisitos mínimos que facilmente deveriam ser observados pelas instituições financeiras, mas não era isso que ocorria. $\mathrm{O}$ descumprimento sistemático da norma do art. 52 do CDC fez com que o Banco Central do Brasil editasse a resolução 3.517, em vigor desde março de 2008, que obrigou as instituições financeiras a divulgarem o Custo Efetivo Total (CET) de suas operações, por meio de uma taxa percentual anual. Essa taxa deve englobar todos os encargos e despesas

${ }^{308}$ A técnica do prazo de reflexão é expressamente prevista no direito francês como parte do arsenal de proteção do consumidor de crédito. Sobre o tema consultar: CALAIS-AULOY, J.; STEINMETZ, F. Droit de la consommation. cit. p. 418 a 420.

${ }^{309}$ Ver em: STJ, $3^{\text {a }}$ Turma, Resp n ${ }^{\mathrm{o}} 330.261 /$ SC, Relatora Ministra Nancy Andrighi, DJ 08.04.2002, p. 212. 
das operações (taxas, tarifas, tributos, seguros, etc.), permitindo que o consumidor saiba com maior clareza o que está pagando, facilitando a comparação dos custos entre as instituições financeiras.

Contudo, a divulgação do Custo Efetivo Total (CET) da operação cumpre parcialmente com o dever de informação. É certo que, em razão da diversidade das tarifas bancárias e dos custos adicionais do crédito, era praticamente impossível ao consumidor comparar os produtos oferecidos pelas instituições financeiras, e assim escolher a melhor opção de financiamento do mercado. De acordo com reportagem publicada na Revista do IDEC, saber apenas taxa de juros não basta, já que os custos adicionais podem tornar a operação mais cara, não obstante os juros serem mais baixos, sendo que uma pesquisa realizada pelo instituto apontou uma diferença de CET que chegou a 48,85\% ao final de seis meses. ${ }^{310}$

Mas apenas saber o CET não faz com que o consumidor seja satisfatoriamente informado a respeito dos riscos da operação e das suas conseqüências no orçamento doméstico, muito menos cumpre com o dever de aconselhamento, necessário para afastar o risco do endividamento excessivo. É preciso que o fornecedor de crédito certifique-se de que o consumidor efetivamente compreendeu não apenas as cláusulas contratuais, mas principalmente os efeitos da dívida na sua economia pessoal, em função das características peculiares de cada indivíduo e de sua família, considerando o percentual da renda familiar que já está comprometido com o custeio dos bens essenciais (educação, saúde, alimentação, moradia, transporte, comunicação, etc.) a fim de mensurar qual a parcela do orçamento doméstico que pode ser comprometida com dívidas. Também se devem considerar os motivos que levaram o consumidor a solicitar o empréstimo, sendo circunstâncias favoráveis saber se se trata de uma situação de emergência ou de uma falta de recursos momentânea, que não comprometerão o adimplemento futuro do contrato.

\section{b) Deveres de lealdade e de cooperação}

O dever de lealdade deve ser observado tanto na fase pré-contratual, quanto na de execução do contrato. Durante a fase pré-contratual, o dever de lealdade complementa o

\footnotetext{
${ }^{310}$ Revista do IDEC de abril de 2009, matéria intitulada "Crédito Obscuro". A pesquisa realizada pelo IDEC, divulgada nesta matéria, apurou, ainda, que a maior parte das instituições financeiras vinha descumprindo a obrigação de divulgar o CET. Segundo apurado pela pesquisa, de 10 instituições pesquisadas, apenas uma divulgou espontaneamente o CET, outras quatro divulgaram somente após solicitação do consumidor e as demais alegaram que os cálculos somente seriam apresentados no contrato o que, segundo o IDEC, "eliminaria opções ao consumidor, pois a operação já estaria fechada".
} 
dever de informação e fortalece a tutela da confiança, já que obriga as partes a "absteremse de comportamentos que possam falsear o objectivo do negócio ou desequilibrar o jogo das prestações por elas consignado". 311

Com relação às obrigações do credor, o comportamento leal fundamenta o dever de informação, já tratado anteriormente, além de impor o dever de não atuar de forma a prejudicar o consumidor e de manter a palavra dada (não retirar injustificadamente o crédito prometido), já que o consumidor pode ter assumido compromissos e orientado sua conduta confiando na seriedade da intenção manifestada pelo credor.

$\mathrm{Na}$ fase contratual, a conduta leal impõe a ambas as partes o dever de não frustrar a finalidade do contrato. Ao consumidor incumbe o dever de não agravar a sua situação de endividamento, de forma a impossibilitar o adimplemento de obrigação anteriormente assumida. Ao fornecedor impõe o dever de informar as alterações das circunstâncias de que tiver conhecimento, ainda que potencial, e que sejam capazes de agravar a situação do consumidor e de não contribuir para a alteração de circunstâncias que venham a prejudicar o consumidor.

O dever de cooperação, por sua vez, assemelha-se ao dever de lealdade e, por vezes, com ele se confunde; contudo se refere mais a uma atitude positiva das partes, como expressão da solidariedade nas relações contratuais, no sentido de contribuição mútua para que o contrato cumpra com sua função social e seja extinto pela forma normal do adimplemento.

Apresenta-se aqui também desde a fase pré-contratual, na qual as partes devem cooperar para que a declaração de vontade seja emitida livre de vícios e para que as condições contratuais sejam compatíveis com as condições pessoais do devedor, e assim seja possível o cumprimento do contrato. Nos contratos de crédito, tanto o devedor precisa cooperar para que o credor tenha conhecimento pleno a respeito das suas condições pessoais (patrimônio, renda familiar, quanto do orçamento doméstico pode ser comprometido com dívidas, dentre outras informações relevantes), quanto o credor deve cooperar para a concessão de um empréstimo mais condizente com a condição financeira do devedor. Nesse aspecto, a boa-fé impõe uma alteração de perspectiva: a obtenção das informações a respeito da situação financeira do devedor não deve servir apenas para que o credor avalie as garantias de adimplemento do contrato, como normalmente acontece, mas

${ }^{311}$ MENEZES CORDEIRO, A. M. R. Da Boa-fé no Direito Civil. op. cit., p. 606. 
também para a preservação da incolumidade patrimonial do devedor e para a diminuição do risco do sobreendividamento.

Na fase de execução, o dever de cooperação supõe uma colaboração entre as partes para o bom desenvolvimento do contrato, de acordo com o paradigma da boa-fé objetiva. ${ }^{312}$ Para o cumprimento desse dever é necessário que as partes não obstruam ou dificultem as atuações umas das outras. O consumidor não poderá furtar-se injustificadamente ao cumprimento das prestações, nem a instituição financeira poderá dificultar o pagamento, fazendo restrições quanto à forma, tempo ou local ${ }^{313}$ em que deve ser efetuado.

Com relação à forma de pagamento, se em razão da alteração das circunstâncias tenha se tornado impossível ou extremamente dificultoso o cumprimento do contrato, nos termos inicialmente avençados, surge para o fornecedor um dever de renegociação, a fim de permitir que o consumidor continue cumprindo com o contrato em condições mais adequadas à nova realidade. De acordo com Cláudia Lima Marques, os novos deveres de cooperação “imporiam um esforço de boa-fé para adaptar estes contratos e preservá-los (neue Verhandlungspflichten), a evitar a ruína e o superendividamento dos consumidores de boa-fé". ${ }^{314}$ E prossegue, defendendo a existência de um dever geral de renegociação, com fundamento no dever de cooperação:

Desde a quarta edição de meu livro sobre contratos, destaco que a doutrina européia atual manifesta-se pela necessidade de uma razoável equivalência de prestações, em face do princípio da igualdade no direito privado. Em especial, merece análise a tendência da doutrina alemã atual, que, com base nos deveres de cooperação da boa-fé e na antiga exceção da ruína, está ativamente estudando a existência de um dever geral de renegociação nos contratos de longa duração. ${ }^{315}$

O dever de renegociação, nestas situações de alteração das circunstâncias que impossibilitem ou tornem excessivamente dificultoso o cumprimento do contrato, decorre também do princípio da função social dos contratos, já que, se as condições contratuais não forem adequadas à nova realidade, o contrato será fatalmente descumprido. Nesse contexto, a renegociação manterá vivo o contrato, fazendo com que continue cumprindo a sua função econômica (na medida em que as expectativas econômicas serão mantidas) e social (na medida em que não será imposto um sofrimento desmedido aos direitos

\footnotetext{
${ }^{312}$ MARQUES, C. L. op. cit., p.195.

${ }^{313}$ Art. 329. Ocorrendo motivo grave para que se não efetue o pagamento no lugar determinado, poderá o devedor fazê-lo em outro, sem prejuízo para o credor.

${ }^{314}$ MARQUES, C. L. Sugestões para uma lei sobre o tratamento do superendividamento..., cit. p. 266-267.

${ }^{315}$ MARQUES, C. L. Sugestões para uma lei sobre o tratamento do superendividamento..., cit., p. 267.
} 
fundamentais do consumidor, mantendo-se também as expectativas decorrentes dos valores sociais dos contratos).

Por fim, conforme será adiante explicitado, a negativa de renegociação poderá caracterizar abuso de direito, já que o exercício, além de inútil ao credor, pois sem a renegociação será mais difícil o recebimento do crédito, imporá um sacrifício desmedido ao consumidor, caracterizando-se o exercício desproporcional do direito, sem consideração por situações especiais. Esse tema será retomado no item 2.3.1 desta Parte II.

c) Dever de Cuidado: cobrança de dividas, cadastros de restrição ao crédito e dever de cuidado na concessão do crédito e no desenvolvimento de contratos de longa duração

O dever de cuidado, ou de proteção, consiste na atitude das partes no sentido de evitar danos mútuos pessoais ou patrimoniais. Transportando-se para as relações de crédito, tem-se a obrigação da instituição financeira de zelar pela imagem, pela reputação e pelo patrimônio dos seus depositantes, poupadores ou correntistas. Também os consumidores têm o dever de zelar pela integridade patrimonial da instituição financeira, repudiando-se atitudes dos tomadores de crédito que omitem informações relevantes sobre sua situação financeira e agem de má-fé tomando empréstimos com plena consciência de que não terão capacidade de reembolsá-los - com violação aí da boa-fé subjetiva, já que haverá intenção de causar prejuízo.

É preciso distinguir, contudo, a situação dos consumidores de má-fé, que agem com a intenção de causar prejuízo à instituição financeira para obter vantagem indevida, daqueles consumidores que não foram suficientemente esclarecidos acerca dos riscos do crédito, e que, seduzidos pelo crédito fácil e pelos atrativos publicitários, caíram na "teia" do mercado de consumo, o qual, como já foi analisado anteriormente, tem o endividamento como uma situação desejada e salutar para o seu crescimento. Conforme também já tratado anteriormente, nos Estados Unidos, são os hiperbolic discounters (consumidores/ devedores contumazes) ${ }^{316}$ que trazem os maiores lucros para as empresas de cartão de crédito, pois essas pessoas utilizam constantemente a faculdade de efetuar pagamento mínimo do cartão, de maneira que acabam pagando altos juros para poder se beneficiar desta facilidade. Esses consumidores são, portanto, incentivados a se endividar, e a

\footnotetext{
${ }^{316}$ Ver nota 98.
} 
permanecer endividados. Dessa forma, não é concebível que, diante de uma situação de grave dificuldade financeira, com risco aos direitos fundamentais da pessoa humana, esse mesmo consumidor, cujo comportamento era antes aplaudido, passe a ser rechaçado com a pecha de "caloteiro" ou "mau pagador". Esse indivíduo, portanto, será merecedor da proteção jurídica conferida pelo ordenamento jurídico brasileiro, por intermédio do princípio da boa-fé.

O zelo pela integridade moral do consumidor (imagem, honra e reputação) revelase na proibição de tratamentos vexatórios na cobrança das dívidas, devendo-se evitar atitudes que possam macular a imagem do consumidor de boa-fé perante a sociedade. Nos termos do artigo 42 do CDC, "na cobrança de débitos, o consumidor inadimplente não será exposto a ridículo, nem será submetido a qualquer tipo de constrangimento ou ameaça". Em vista disso, todos os instrumentos de cobrança devem ser moderados, sem referência externa à condição de inadimplente, já que o objetivo da cobrança não é impingir ao consumidor uma punição de cunho moral pelo não pagamento, mas sim, procurar satisfazer o direito do credor de maneira amigável. Caso não seja possível uma solução amigável à pendência, o consumidor tem ciência de que estará sujeito às medidas judiciais, das quais o credor deverá lançar mão.

Vale retomar aqui as premissas estabelecidas na Parte I deste trabalho, na qual ficou esclarecido que o endividamento é uma situação desejada pela atual sociedade de consumo, pois assim os seus principais agentes econômicos (os consumidores) estarão aptos a manter a economia produtiva e dinâmica. No cenário atual, os incentivos ao consumo e ao endividamento multiplicam-se, não sendo lícito ao mercado de crédito, diante de uma eventual dificuldade financeira do consumidor, impor-lhe um sacrifício desmedido, como se ele fosse o único responsável pela sua situação de endividamento. Os credores poderão lançar mão de medidas extrajudiciais para a cobrança das dívidas, desde que o façam com moderação, havendo um limite entre o direito de cobrar e o direito do devedor não ter a sua dignidade violada. Caso os meios moderados não sejam suficientes para a satisfação do crédito, deverão os credores buscar as medidas judiciais cabíveis, de acordo com o devido processo legal, até mesmo porque, em se tratando de uma situação de sobreendividamento, é comum existir mais de um credor, sendo recomendável a intervenção do juiz para a tentativa de composição dos interesses das partes envolvidas ${ }^{317}$ ou para a revisão das condições contratuais nas hipóteses em que isso for admissível,

\footnotetext{
${ }^{317}$ A iniciativa de conciliação nas situações de endividamento excessivo é muito bem-sucedida no projetopiloto desenvolvido no Rio Grande do Sul, conforme já foi enfatizado no item 1.3.2 da Parte I deste trabalho.
} 
inclusive com a imposição do dever de renegociação. Não sendo possível a conciliação, devem ser obedecidas as regras processuais incidentes sobre a cobrança de dívidas, inclusive no que tange à preferência e ao concurso de credores em caso de insolvência. ${ }^{318}$

Com relação aos cadastros de restrição ao crédito (como a SERASA, o SISBACEN, o SPC e similares), essas entidades gestoras desempenham um papel positivo na tutela do sobreendividamento, permitindo aos credores avaliar a real situação financeira do consumidor, e averiguar se há o risco de sobreendividamento. Trata-se, portanto, de importante ferramenta para a prevenção dos riscos do crédito, desde que seja corretamente utilizada pelos credores e pela sociedade. Note-se que não é apenas o risco do crédito para o fornecedor que deve ser avaliado, como normalmente ocorre ${ }^{319}$, mas também deve ser considerado o risco para o consumidor. Nesse sentido, o cadastro será uma ferramenta para o credor cumprir com o seu dever de cuidado e de cooperação na concessão do crédito, evitando-se a concessão um empréstimo que ocasionará a ruína financeira do consumidor. $^{320}$

Por outro lado, o fato do nome do consumidor constar de um cadastro de restrição ao crédito não deve, por si só, ser motivo suficiente para a negativa de um novo empréstimo. ${ }^{321}$ Devem ser averiguados os motivos da inadimplência, as necessidades específicas do consumidor e a possibilidade concreta de pagamento futuro. Pode acontecer da dívida não ter sido paga em razão de uma cláusula abusiva, ou de um defeito do bem

${ }^{318}$ Muito embora já se tenha mencionado a obsolescência do procedimento de insolvência civil previsto no CPC.

319 Os cadastros de proteção ao crédito foram criados para servir ao mercado como instrumento dinamizador das relações de crédito. Como se mencionou na Parte I deste trabalho, a democratização do crédito somente foi possível em razão das novas tecnologias que aprimoraram os cadastros de classificação do risco dos consumidores (credit scoring), eliminando as burocracias na concessão do crédito. Nas palavras de Antônio Carlos Efing: "A dificuldade antes encontrada para se descobrir a saúde e idoneidade financeiras do candidato ao crédito foi facilitada sobremaneira pela instituição dos arquivos de consumo, tomando forma de verdadeiros auxiliares do comércio. Certamente, grande parte do avanço das relações de consumo se deve à agilidade e segurança das concessões creditícias, que só existem em função do implemento dos bancos de dados e cadastros de consumidores" (EFING, A. C. Bancos de Dados e Cadastro de Consumidores. São Paulo: Revista dos Tribunais, 2002, p. 36)

${ }^{320} \mathrm{Na}$ França, o Fichário Nacional de Consumidores, mantido pelo Banco da França, armazena informações a respeito dos incidentes de superendividamento, dos pagamentos e das medidas de recuperação financeira adotadas. Esse fichário faz parte dos mecanismos de prevenção do superendividamento, conforme esclarecem FERRIÈRE e CHATAIN: « la mise en place du Fichier national des incidents de remboursement des crédits aux particuliers, le FICP, constitue un des instruments privilegiés de cette prévention ». (CHATAIN, P. L.; FERRIÈRE, F. Surendettement des Particuliers. Paris : Dalloz, 2006, $3^{\mathrm{a}}$ edição, 10.10, p. 262). Por arrecadar dados oficiais, contendo informações completas a respeito dos procedimentos de recuperação financeira, inclusive dos pagamentos feitos pelos consumidores, esse fichário auxilia na prevenção do superendividamento sem macular a imagem do consumidor.

321 Assim ocorre na França, segundo FERRIÈRE e CHATAIN: "Ce fichier est un outil d'information à destination de la profession bancaire. Il n'est en aucun cas un fichier d' « interdits de crédit ». À cet égard, il diffère fondamentalement, par exemple, du Fichier central des chèques (FCC). Ce dernier fichier, également géré par la Banque de France, recense les personnes ayant fait l'objet d'un incident sur chèque. L'inscription au FCC a pour conséquence une interdiction d'émettre des chèque » (idem, ibidem, p. 275) 
financiado, de maneira que o consumidor poderá apresentar uma justificativa para o não pagamento, sem falar dos casos em que a inscrição é flagrantemente indevida, em razão da cobrança de quantia já paga, e o consumidor encontra dificuldades em retificar o registro. Daí porque a importância das informações serem completas, constando não só dados sobre a dívida em si, mas também sobre eventuais impugnações, ações judiciais discutindo o valor da dívida, justificativas de não pagamento, pedidos de retificações em caso de incorreção dos dados, dentre outras informações relevantes para o exato cumprimento do comando do art. $43, \S 1^{\circ}$ do CDC, pelo qual "os cadastros e dados de consumidores devem ser objetivos, claros, verdadeiros e em linguagem de fácil compreensão”.

Os cadastros existentes no Brasil, contudo, nem sempre são utilizados de forma correta, apresentando-se como instrumentos potencialmente causadores de danos à reputação e à honra dos consumidores. Nessa linha, Cláudio Luiz Bueno de Godoy defende que a atividade de cadastro e armazenamento de informações é potencialmente causadora de danos, de forma que lhe é inerente um risco especial, a fundamentar a responsabilização objetiva dos órgãos responsáveis pela manutenção e fornecimento das informações sobre consumidores. ${ }^{322}$ Para Antônio Herman de Vasconcellos e Benjamin o que preocupa não é somente o interesse isolado e fragmentado de alguns indivíduos desabonados ou maus pagadores, mas sim, “a defesa da coletividade dos bons devedores, que igualmente está à mercê dos abusos praticados pelos bancos de dados". Para o autor, "é a danosidade difusa e não individual que, em última análise, estimula o legislador", acrescentando que "a operação dos bancos de dados, se não exercida dentro de certos limites, se transforma em dano social". ${ }^{323}$ Daí a necessidade de se reconhecer o risco especial desta atividade.

Anote-se que, com a evolução da tecnologia da informação, a forma de coleta de dados tornou-se automatizada, favorecendo o cadastro de informações equivocadas e sem um efetivo controle no ingresso das informações, além do que, devido à burocracia e à falta de regulamentação, tanto as entidades gestoras quanto os fornecedores que enviam as informações não se preocupam em atualizá-las, sendo comum a manutenção de inscrições negativas mesmo após a regularização da situação ou por prazo superior ao previsto em lei, que é de cinco anos. Por outro lado, a facilidade com que as informações são divulgadas e acessadas expõe os direitos de personalidade do consumidor a graves violações, nos casos em que as informações são incompletas, incorretas ou abusivas (utilizada como

${ }^{322}$ GODOY, C. L. B.. Responsabilidade civil pelo risco da atividade. São Paulo: Saraiva, 2009, p. 122.

323 BENJAMIN, A. H. V.. Comentário ao artigo 43 do CDC em: Código Brasileiro de Defesa do Consumidor - comentado pelos autores do anteprojeto. $8^{\mathrm{a}}$ edição. Rio de Janeiro: Forense Universitária, 2005. p. 406. 
instrumento de pressão). De acordo com Antonio Carlos Efing, "a partir do momento em que as condições de transmissibilidade atingem o nível em que ora se encontram, a preocupação se torna maior na medida em que a facilidade de acesso e fornecimento das informações exige controle cada vez mais rígido, sobretudo diante das preocupações de ordem pública decorrentes da atividade em comento". 324

De fato, são freqüentes as inclusões indevidas do nome do consumidor em cadastros de restrição ao crédito. O consumidor incluído indevidamente num cadastro de inadimplentes tem a sua honra e reputação expostas à clara violação, sobretudo se considerado esse amplo acesso e divulgação das informações, tanto que a jurisprudência é pacífica no sentido de que nestes casos dispensa-se a prova específica do dano moral sofrido, que decorre ipso facto da inclusão indevida. ${ }^{325}$

Dessa forma, apesar de se reconhecer o papel positivo que representam os cadastros de consumidores, sendo que o seu caráter público é expresso no diploma protetivo do consumidor, é preciso não olvidar a obrigatoriedade de manutenção de informações corretas, atualizadas e completas, bem como de garantir ao consumidor a possibilidade de contestar e corrigir as informações que se mostrarem abusivas e inexatas. Como destaca Benjamin, com relação a esses cadastros:

São considerados de caráter público para permitir a utilização de certos instrumentos processuais que só têm cabimento contra tais tipos de entidades (mandado de segurança e hábeas data, por exemplo), espantando, de vez, dúvida que porventura viesse a permanecer. A inclusão dos arquivos de consumo no universo restrito das instituições de caráter público não tem por ratio lhes conferir o poder de cadastrar pessoas, manipulando a seu bem querer o nome e reputação dos cidadãos. É exatamente o oposto: por estarem publicizados, cada indivíduo, solitária ou coletivamente, ganha o direito de questioná-los de maneira mais ampla possível, tanto nos procedimentos que utilizam, como no conteúdo do que mantêm. ${ }^{326}$

Em virtude disso, o autor defende que as entidades mantenedoras dos cadastros são responsáveis solidariamente com o fornecedor do qual se originou a informação pelos danos causados aos consumidores em razão da disponibilização de dados incorretos, incompletos ou abusivos. ${ }^{327}$

Como já mencionado acima, também Cláudio Luiz Bueno de Godoy entende pela responsabilização das entidades mentenedoras dos cadastros, destacando que essa

\footnotetext{
${ }^{324}$ EFING, A. C. Bancos de Dados e Cadastro de Consumidores. São Paulo: Revista dos Tribunais, 2002, p. 36.

${ }^{325}$ Ver, por exemplo, STJ, $3^{\text {a }}$ Turma, REsp 768153/SP, Relatora Ministra Nancy Andrighi, DJ 09/10/2006.

${ }^{326}$ BENJAMIN, A. H. V. op. cit., p. 415 e 416.

${ }^{327}$ Idem, ibidem, p. 472 e 473.
} 
responsabilidade é objetiva, em virtude do alto grau de risco especial que ela representa, declarando que "os bancos de dados deixam de se responsabilizar apenas pela falta de comunicação do apontamento, pela inscrição mesmo depois de cinco anos ou por inexatidão que lhes seja diretamente imputável, ou a preposto seu. Respondem, em suma, não pelo defeito, mas pelo risco especial que sua atividade cria". ${ }^{328}$ Daí porque entende ser irrelevante que as informações obtidas por essas entidades sejam provenientes de fontes de domínio público, como os cartórios de protestos ou distribuidores de ações judiciais, já que uma informação negativa obtida individualmente, em relação a um indivíduo determinado, tem potencial lesivo infinitamente inferior em relação às informações divulgadas pelas entidades menatenedoras dos cadastros. ${ }^{329}$ Nas palavras do referido autor:

Impende não olvidar o risco especial que há no cadastramento, muito diferente da mera publicidade que o trâmite de uma ação judicial enseja. É sabido que, a bem do tráfego negocial, os órgãos de proteção ao crédito, mediante convênios, obtêm certidões em forma de relações diárias de todas as ações, em regra executivas ou falenciais, distribuídas. E não se nega que tal ajuizamento e o subseqüente trâmite sejam públicos. Mas uma coisa é a obtenção de certidão individual por parte de algum interessado. Outra muito diversa é a inserção do nome da pessoa em cadastro restritivo de crédito. Evidente que, nesse último caso, os efeitos são muito mais extensos, na direta proporção da maior extensão dos danos potenciais que ocasionalmente ocorram. Aí o risco especial. E se de risco especial se trata, insta diante dele se acautele a entidade de cadastramento, que vai buscar a informação, quando menos cuidando de dar prévio aviso ao consumidor do apontamento que fará e, de toda sorte, pelo cadastramento respondendo. ${ }^{330}$

Não obstante, o entendimento que tem prevalecido na jurisprudência é o de que quem responde é a entidade ou pessoa que deu causa à inclusão do nome (instituição financeira, comerciante, etc.), sendo que os órgãos mantenedores dos bancos de dados somente respondem em caso de descumprimento do dever de notificar previamente o consumidor, nos termos do artigo 43, $\S 2^{\circ}$ do $\mathrm{CDC}^{331}$ (súmula 359 do STJ). ${ }^{332}$ Cabe

${ }^{328}$ GODOY, C. L. B.. Responsabilidade civil pelo risco da atividade. op. cit., p. 124.

${ }^{329}$ A esse respeito cita jurisprudência do Tribunal de Justiça de São Paulo, que entendeu que "irrelevante se mostra a alegação de que a inclusão do nome do apelante se deu em virtude de informação obtida de cartório do distribuidor, com natureza pública e de acesso a todos. O que veda a lei não é a obtenção de dados sobre o consumidor, em órgãos públicos, mas a formação de cadastro, registro ou anotação restritiva de direitos sem que seja previamente cientificado da sua inclusão. Até porque a ciência prévia do consumidor não se destina apenas a permitir a retirada ou suspensão, mas também a verificação da exatidão dos dados" (TJSP, AC 258.472-4/5, 4ª Câm., rel. Des. Maia da Cunha, j. 30-5-2005, JTJ-LEX 295/162, apud, Idem, ibidem, p. 123. ${ }^{330}$ Idem, ibidem, p. 123.

331 RESPONSABILIDADE CIVIL. DANO MORAL. CADASTRO DE PROTEÇÃO AO CRÉDITO. FALTA DE COMUNICAÇÃO. ART. $43, \S 2^{\circ}$, DO CDC. OBRIGAÇÃO DE REPARAR O DANO. - A falta de comunicação prevista no art. $43, \S 2^{\circ}$, do Código de Defesa do Consumidor, gera o dever de reparar o dano extrapatrimonial, independentemente da demonstração, pelo consumidor, da utilidade prática que teria 
ressaltar que a partir do julgamento do recurso representativo 1.061.134/RS, o STJ consolidou entendimento no sentido de que a preexistência de inscrição desabonadora regularmente realizada afasta a responsabilidade por danos morais em razão da ausência de comunicação prévia ao consumidor, resultando na edição da súmula 385 do STJ. Esse entendimento contraria o que vigorava no STJ até maio de $2008,{ }^{333}$ pelo qual a existência de outras inscrições não afastava o dano moral, apenas reduzia o seu montante. ${ }^{334}$

Um outro aspecto a ser abordado é o fato de que os cadastros de restrição ao crédito não podem ser utilizados para impedir o acesso dos consumidores ao Poder Judiciário. Não raros são os casos em que o montante da dívida contém ilegalidades, em razão de cláusulas abusivas ou onerosidade excessiva superveniente, estando presente uma causa de justificação para o não pagamento. Nesses casos, é direito do consumidor buscar a tutela do Poder Judiciário para trazer o relacionamento jurídico à legalidade. E, estando a dívida sendo discutida em juízo, não é de se admitir a inclusão do nome do devedor em cadastro de inadimplentes, ao menos não até que se estabeleça o valor devido nos termos da lei.

\section{Como já decidiu o STJ:}

São conhecidos os efeitos negativos do registro em banco de dados de devedores; daí porque inadequada a utilização desse expediente enquanto pende ação consignatória, declaratória, ou revisional, uma vez que, inobstante a incerteza sobre a obrigação, já estariam sendo obtidos efeitos decorrentes da mora. Isso caracteriza um meio de desencorajar a parte a discutir em juízo eventual abuso contratual. ${ }^{335}$

A exemplo do julgado supra-referido, os Tribunais brasileiros vinham admitindo a suspensão da inscrição do nome devedor nos cadastros de restrição ao crédito sempre que o montante da dívida estivesse sendo discutido em juízo.

Em razão de um certo abuso na utilização da via judicial apenas para evitar a inclusão do nome do devedor nos bancos de dados, o Superior Tribunal de Justiça passou a exigir uma série de requisitos para a suspensão da inscrição, quais sejam: a) que haja ação proposta pelo devedor contestando a existência integral ou parcial do débito; b) que haja

esse aviso. Recurso especial conhecido e provido. (STJ - $4^{\mathrm{a}}$ Turma, REsp 748523/RS, Relator Ministro BARROS MONTEIRO, Data do Julgamento 15/09/2005, Data da Publicação/Fonte DJ 24.10.2005 p. 347)

${ }^{332}$ A respeito da legitimidade passiva da instituição financeira por inscrição indevida, in casu, em razão de abertura de conta corrente com documentos furtados: STJ, $4^{\mathrm{a}}$ Turma, AgRg no REsp 1066684/RS, Relator Ministro Aldir Passarinho Junior, DJ 08/06/2009. Sobre a legitimidade da instituição mantenedora do banco de dados, em caso de falta de notificação a respeito da abertura do cadastro: STJ, $4^{\mathrm{a}}$ Turma, REsp 695902/AM, Relator Ministro Hélio Quaglia Barbosa, DJ 21/05/2007.

${ }^{333}$ A mudança de posicionamento deu-se a partir do julgamento pela $2^{\text {a }}$ Seção do STJ, no recurso especial 1.002.985/RS, Relator Ministro Ari Pargendler, em 14/05/2008, que assim entendeu: "quem já é registrado como mau pagador não pode se sentir moralmente ofendido pela inscrição do seu nome como inadimplente em cadastros de proteção ao crédito".

${ }_{334}$ STJ, 4 a Turma, REsp 612407/RS, Relator Ministro HÉLIO QUAGLIA BARBOSA, DJ 23/04/2007.

${ }^{335}$ STJ, 4 a Turma, REsp 172.854/SC, Relator Ruy Rosado de Aguiar, DJ 08/09/1998. 
efetiva demonstração de que a contestação da cobrança indevida funda-se na aparência do bom direito e em jurisprudência consolidada do Supremo Tribunal Federal ou do Superior Tribunal de Justiça; c) que, sendo a contestação apenas de parte do débito, deposite o valor referente à parte tida por incontroversa, ou preste caução idônea, ao prudente arbítrio do magistrado. ${ }^{336}$ Tal entendimento foi pacificado com o julgamento do recurso representativo $\mathrm{n}^{\mathrm{o}}$ 1.061.530/RS, publicado em 10/03/2009.

Como já dito em outra oportunidade, "apesar da intenção de evitar o abuso da utilização da via jurisdicional, questiona-se se a exigência do depósito da parcela incontroversa não viola o direito dos consumidores, pois em geral esse cálculo exige conhecimentos técnicos, sendo certo que o CDC estabelece a inversão do ônus da prova em favor do consumidor (art. $6^{\circ}$, VIII). Ademais, o descumprimento por parte do consumidor, mesmo em relação ao valor incontroverso, é embaraçado pela presença de ilegalidades nas prestações, sendo muitas vezes a causa da impossibilidade de cumprimento pelo devedor hipossuficiente". 337

Ressalte-se, ainda, a importância de dar ao consumidor a oportunidade para exigir a correção das informações arquivadas a seu respeito, direito que atualmente não tem sido garantido de forma adequada (CDC, art. $\left.43, \S 3^{\circ}\right)$. Com relação a essa questão, o Projeto de Lei $\mathrm{n}^{\circ}$ 836-E de 2003, já aprovado na Câmara dos Deputados, que disciplina o funcionamento de bancos de dados de serviços de restrição ao crédito, contém disposições mais específicas que o CDC, assegurando melhor os direitos dos consumidores. O projeto impõe aos fornecedores o dever de informar aos gestores dos cadastros a regularização das obrigações no prazo de 5 dias (art. 11) $)^{338}$, sem excluir a possibilidade do próprio cadastrado apresentar diretamente ao gestor documento comprobatório da regularização do débito (art. 12). Ademais, prevê garantias de gratuidade e facilidade de acesso aos dados (art. 16) e um procedimento para impugnação das informações (art. 17). Numa primeira análise, o Projeto de Lei peca ao não enfrentar o problema da suspensão da inscrição na pendência de discussão judicial a respeito do débito.

Por fim, o CDC estabelece um limite para a manutenção de informações negativas. Estas não poderão ser mantidas por prazo superior a 5 anos (art. $43, \S 1^{\circ}$ ), sendo que “consumada a prescrição relativa à cobrança de débitos do consumidor, não serão

\footnotetext{
${ }^{336}$ Tal entendimento foi firmado a partir do julgamento do REsp 527618/RS, Relator Ministro CESAR ASFOR ROCHA, pela Segunda Seção, em 22/10/2003.

${ }^{337}$ PALHARES, C. Evolução da proteção do consumidor de crédito bancário no Brasil. Artigo aceito para publicação em obra coletiva organizada pela Fundação Getúlio Vargas, editada Saraiva.

${ }^{338}$ Era comum que esta incumbência fosse deixada a cargo do próprio consumidor, o que dificultava a exclusão do seu nome mesmo após o pagamento.
} 
fornecidas, pelos respectivos Sistemas de Proteção ao Crédito, quaisquer informações que possam impedir ou dificultar novo acesso ao crédito junto aos fornecedores" (art. 43, § $\left.5^{\circ}\right)^{339}$

O dever de cuidado também tem incidência importante na fase do desenvolvimento da relação contratual, sobretudo em se tratando de relações de crédito continuadas, como é o caso do contrato de abertura de crédito em conta corrente, com a utilização de cheque especial, e do cartão de crédito, nos quais o consumidor tem a sua disposição uma determinada quantia de dinheiro para utilização diária.

No contrato de abertura de crédito, o consumidor pode efetuar depósitos mantendo o saldo positivo, ou utilizar o limite do cheque especial, pagando os juros contratuais, que são mais elevados do que aqueles cobrados num empréstimo pessoal - por vezes essa diferença supera $5 \%$ ao mês. A instituição financeira deve observar o comportamento do saldo devedor do cliente e oferecer opções para redução da dívida, como o refinanciamento do saldo devedor a taxas mais favoráveis, como as de um empréstimo pessoal. Deve alertar o consumidor sempre que observar um crescimento desproporcional do saldo devedor, sobretudo naqueles casos em que o crescimento da dívida decorre unicamente da incidência de juros sobre juros. Não se alegue que esse controle não seria possível, pois na situação inversa, em que existem saldos disponíveis em conta corrente, o gerente do banco apressa-se a entrar em contato com o cliente para oferecer uma aplicação. Por fim, não poderá o fornecedor alterar as condições contratuais (aumento do limite, alteração da taxa de juros, dentre outras) sem a prévia anuência do consumidor, devendo ainda alertá-lo a respeito das conseqüências das alterações efetuadas.

Com relação ao cartão de crédito o dever de cuidado deve ser ainda maior. Isso porque esse instrumento de crédito é o mais sedutor existente no mercado, pois reduz a sensação de endividamento e de desperdício de dinheiro, postergando o desembolso efetivo de recursos para uma data futura. A facilidade de utilização e a possibilidade de

339 CÓDIGO DE DEFESA DO CONSUMIDOR - CADASTROS DE PROTEÇ̃̃O AO CRÉDITO RETIRADA DAS INFORMAÇÕES - PRAZO PRESCRICIONAL - ARTIGO 43, PARÁGRAFOS $1^{\circ}$ E $5^{\circ}$ DO CDC. I - Estabeleceu o legislador dois prazos para o arquivamento das informações negativas do consumidor constantes de cadastros de proteção ao crédito ou banco de dados. O primeiro, genérico, disciplinado pelo $\S 1^{\circ}$ do artigo 43 do Código do Consumidor, estabelece o teto máximo de cinco anos para a permanência desses dados, seja qual for o seu conteúdo. $\mathrm{O} \S 5^{\circ}$ desse dispositivo legal, por sua vez, dispõe que, consumada a prescrição da ação de cobrança relativa ao débito que originou a informação, os dados não poderão ser fornecidos. II - Da conjugação desses preceitos normativos, conclui-se que, enquanto for possível ao credor utilizar-se das vias judiciais para obter a satisfação do crédito, respeitado o prazo máximo de cinco anos, é admissível a permanência ou a inscrição da informação nos cadastros de consumidores. Recurso especial provido. (STJ - $3^{\mathrm{a}}$ Turma, REsp 533853/RS, Relator Ministro CASTRO FILHO, Data do Julgamento 20/10/2005, Data da Publicação/Fonte DJ 14.11.2005 p. 308) 
parcelar as compras fazem com que o consumidor seja induzido a gastar mais do que pode. Por outro lado, a possibilidade de efetuar o pagamento mínimo camufla a real gravidade da dívida, que a cada mês cresce em proporção assustadora, já que as taxas de juros são as maiores do mercado (em torno de 10\% ao mês, mais encargos moratórios e comissões). Em poucos meses, a dívida torna-se impagável, com danos irreversíveis para o consumidor. Por este motivo, o dever de cuidado do fornecedor de crédito deve ser mais acentuado, com a imposição da obrigação de informar quanto ao efeito do pagamento mínimo, bem como quanto ao efeito da incidência das altas taxas de juros num determinado período.

Michelle White, dissertando a respeito dos riscos de endividamento em razão da má utilização dos cartões de crédito, propõe a adoção de medidas para desencorajar os consumidores a se endividar e assim evitar as situações de falência pessoal. A autora norteamericana demonstra uma preocupação com os pagamentos mínimos dos cartões de crédito, com as investidas dos credores para encorajar o endividamento (programas de prêmios e estratégias de marketing visando a menores e a estudantes) e com o dever de informação a respeito das conseqüências da dívida na economia pessoal, senão, leia-se:

One possible reform would be to require credit card lenders to raise their minimum monthly payment levels, so that debtors would be required to repay, say, 10 percent of the amount owed each month rather than the current 1 percent. ${ }^{340}$ This change would both reduce the amount of interest that debtors pay and force debtors to reduce their consumption before they accumulate as much debt. Lenders could also be barred from offering rewards programs that encourage additional spending and from marketing to minors and college students. Credit bureaus could also be prohibited from selling information about individual consumers' credit records without their consent, which would reduce or eliminate the practice of lenders mailing out unsolicited card offers.

Truth in lending laws could also be extended to required that consumers receive additional information concerning their credit cards. For example, Senator Christopher Dodd introduced legislation in 2004 that would require credit card lenders to inform consumers each month how long il will take to repay their loans if they pay only the minimum amount. Mann (2006) proposed that payment terminals for credit card transactions be modified so that each time consumers use their credit cards, they would be told whether the purchase will trigger a penalty for exceeding the credit limit and how much interest they will pay if the purchase adds to their credit card. ${ }^{341}$

\footnotetext{
${ }^{340}$ No Brasil, os valores são superiores a $1 \%$, mas fato é que as taxas de juros cobradas dos usuários brasileiros é bem superior do que a norte-americana, de maneira que a exigência de pagamento mínimo deve ser ainda maior do que os $10 \%$ sugeridos pela autora.

${ }^{341}$ WHITE, M. J. Bankruptcy reform and credit cards. cit., p. 175-199.
} 
A sugestão apresentada por White assemelha-se às atuais contrapropagandas existentes nos cigarros ou nas bebidas alcoólicas, o que se justifica na medida em que também o cartão de crédito estimula um vício: o do consumo. O dever de cuidado estaria melhor atendido se, ao efetuar uma compra, em vez de receber um agradecimento, o consumidor fosse alertado sobre os riscos do endividamento excessivo. Tem-se, aí, uma sugestão a ser pensada também para a realidade brasileira.

\subsubsection{Limitação de direitos subjetivos e faculdades jurídicas}

Além da função ampliadora dos deveres contratuais, o princípio da boa-fé tem a função de limitar o exercício dos direitos subjetivos e de faculdades jurídicas (função corrigendi ou de controle). Nesse aspecto, origina-se a proibição às cláusulas abusivas e ao exercício abusivo de direitos, bem como a consideração do adimplemento substancial para evitar a resolução do contrato em prejuízo do consumidor.

\section{a) Proibição das cláusulas abusivas}

O princípio da boa-fé, ao limitar o exercício de direitos subjetivos, quer, por certo, proibir o exercício de direitos que venham a lesar o parceiro contratual. Nesse sentido, não se admite, primeiramente, a subsistência de cláusulas abusivas, que garantam vantagens excessivas para uma das partes em detrimento da outra. Segundo Rubén S. Stiglitz, “é característica definitiva da cláusula abusiva: que importe num desequilíbrio significativo entre os direitos do consumidor e as obrigações e cargas do profissional derivados do contrato em prejuízo do primeiro". ${ }^{342}$

A proibição às cláusulas abusivas ganhou relevância com a multiplicação dos contratos de adesão, pois nessa forma de contratação as cláusulas são predispostas pelo fornecedor, propiciando o estabelecimento de condições que lhe favoreçam e que oneram excessivamente o aderente. Mas os contratos de adesão não são o único terreno para a verificação de cláusulas abusivas, vez que, mesmo quando as cláusulas contratuais são livremente acordadas pelas partes, o fornecedor, abusando da hipossuficiência do consumidor ou da sua premente necessidade, estipula as condições que mais lhe

${ }^{342}$ STIGLITZ, R. S. Contrato de Consumo y Cláusulas Abusivas. Derecho del Consumidor n ${ }^{\circ}$ 8, director Gabriel A. Stiglitz, editorial Juris, página 16. Do original: “es característica definitoria de la cláusula abusiva: que importe un desequilibrio significativo entre los derechos del consumidor y las obligaciones y cargas del profesional derivadas del contrato en prejuicio del primero". 
favoreçam. Contudo, não há que se negar que quando as cláusulas são escritas apenas por uma das partes há um campo fértil para a prática de abusos.

O Código de Defesa do Consumidor estipulou mecanismos que objetivam combater essas cláusulas. No seu artigo 51, caput, o Código elenca de forma não exaustiva quais são as cláusulas consideradas abusivas, estabelecendo a sanção de nulidade de pleno direito. Dentre elas, destacam-se, no âmbito da atividade de concessão de crédito, as cláusulas abusivas que:

1) Subtraiam ao consumidor a opção de reembolso da quantia já paga, nos casos previstos neste código (inciso II): é prática comum nos financiamentos para aquisição de bens de consumo, as chamadas cláusulas de perdimento. Com relação ao compromisso de compra e venda, a jurisprudência recente do STJ autoriza a retenção pelo credor de $25 \%$ do valor pago, reconhecendo a legalidade de uma cláusula de perdimento parcial, a título de indenização. ${ }^{343}$ No âmbito de operações típicas como a alienação fiduciária em garantia, leis específicas (DL 911/69, Lei 4.728/65 e Lei 9.514/97), e o próprio Código Civil ao regular a propriedade fiduciária (CC, 1361 a 1368), exoneram o credor da obrigação de devolver a quantia paga pelo devedor, estabelecendo um procedimento próprio de venda judicial ou extrajudicial do bem financiado para pagamento do saldo devedor, com a devolução ao devedor apenas do valor que sobejar. O maior problema dessas leis é o de que elas não prevêem mecanismos para garantir que o bem seja vendido por um preço justo ou razoável, pois a própria lei dispensa a avaliação prévia;

2) Estabeleçam obrigações consideradas iníquas, abusivas, que coloquem o consumidor em desvantagem exagerada, ou sejam incompatíveis com a boa-fé ou a eqüidade (inciso IV). Estabelece o $\S 1^{\circ}$ do artigo que "presume-se exagerada, entre outros casos, a vontade que: I - ofende os princípios fundamentais do sistema jurídico a que pertence; II - restringe direitos ou obrigações fundamentais inerentes à natureza do contrato, de tal modo a ameaçar seu objeto ou equilíbrio contratual;

\footnotetext{
343 "RECURSO ESPECIAL. COMPRA E VENDA DE IMÓVEL. RESILIÇÃO UNILATERAL PELO DEVEDOR. DIFICULDADES ECONÔMICAS. POSSIBILIDADE. RETENÇÃO DE $25 \%$ DAS PRESTAÇÕES ADIMPLIDAS. PRECEDENTES DESTA CORTE SUPERIOR. RECURSO CONHECIDO E PARCIALMENTE PROVIDO. 1. Resta pacificado, no âmbito da $2^{a}$ Seção desta Corte Superior, a possibilidade de resilição unilateral do compromisso de compra e venda, por iniciativa do devedor, se este não mais reúne condições econômicas para suportar o pagamento das prestações avençadas com a empresa vendedora do imóvel. 2. Ocorrendo a extinção do negócio jurídico, é permitida a retenção de $25 \%$ (vinte e cinco por cento) do valor das prestações pagas, pela alienante, a título de ressarcimento com as despesas administrativas do contrato. 3. Recurso especial conhecido e parcialmente provido". (STJ, 4 Turma, REsp 469484/MG, Relator Ministro HÉLIO QUAGLIA BARBOSA, DJ 17/12/2007 p. 174)
} 
III - se mostra excessivamente onerosa para o consumidor, considerando-se a natureza e conteúdo do contrato, o interesse das partes e outras circunstâncias peculiares ao caso. Daí é possível extrair a abusividade da cláusula que prevê a capitalização de juros (cobrança de juros sobre juros) se, em razão das demais características do contrato (prazo, periodicidade da incidência de juros, percentual elevado da taxa de juros, incidência dos juros sobre outros encargos contratuais, etc.), a prestação tornar-se excessivamente onerosa para o consumidor, em virtude da metodologia empregada para o cálculo dos juros;

3) Imponham representante para concluir ou realizar outro negócio jurídico pelo consumidor (inciso VIII): refere-se à cláusula mandato, pela qual consumidor constituía o banco seu procurador para emitir e aceitar títulos de crédito em seu nome pelo valor da dívida. Essa cláusula era bastante comum até a pacificação da sua ilegalidade pelo STJ, por meio da súmula 60 (“é nula a obrigação cambial assumida por procurador do mutuário vinculado ao mutuante, no exclusivo interesse deste");

4) Autorizem o fornecedor a cancelar o contrato unilateralmente, sem que igual direito seja conferido ao consumidor (inciso XI): essa cláusula tem maior incidência nos contratos de longa duração, como o de abertura de crédito em conta corrente. De acordo com Márcio Mello Casado, “é comum nos contratos bancários, notadamente naqueles de abertura de crédito, na modalidade limite (cheque especial), a cláusula de cancelamento unilateral do pacto quando surgir, por exemplo, alguma restrição cadastral do mutuário, na Serasa, normalmente"; 344

5) Obriguem o consumidor a ressarcir os custos de cobrança de sua obrigação, sem que igual direito the seja conferido contra o fornecedor (inciso XII);

6) Autorizem o fornecedor a modificar unilateralmente o conteúdo ou a qualidade do contrato, após sua celebração (inciso XIII): trata-se de cláusula também comum em contratos de abertura de crédito em conta corrente e de cartão de crédito, nos quais o fornecedor, ao sabor do mercado, aumenta as taxas de juros ou o limite de utilização do cheque especial de forma unilateral, e por vezes sequer avisa o consumidor adequadamente a respeito dessas alterações.

Note-se que a nulidade absoluta (de pleno iuris) adotada pelo Código advém do fato de que as cláusulas abusivas ofendem a ordem pública estabelecida pelo Sistema de

${ }^{344}$ CASADO, M. M.. Proteção do consumidor de crédito bancário e financeiro, $2^{\mathrm{a}}$ edição, São Paulo: RT, 2007, pág. 279. 
Proteção ao Consumidor, o que pode ser extraído do art. $1^{\circ}$ do CDC. Ademais, o artigo 51 do CDC é expresso ao dizer que as cláusulas abusivas nele elencadas "são nulas de pleno direito". Dessa forma, a matéria que diz respeito às condições abusivas não está sujeita à preclusão, podendo ser argüida a qualquer tempo ou grau de jurisdição. De outra parte, o juiz, conhecendo a existência de uma cláusula abusiva, deve declará-la de ofício, ainda que o consumidor não tenha formulado pedido nesse sentido. Tal é a sistemática das nulidades absolutas, que não convalescem, não estão sujeitas a prazo prescricional e devem ser conhecidas pelo juiz, desde que provadas, independentemente da vontade das partes, o que se extrai das normas dos artigos 168, parágrafo único, e 169 do Código Civil.

O conhecimento de ofício das cláusulas abusivas vinha sendo admitido pelos tribunais brasileiros. Recentemente, contudo, o Superior Tribunal de Justiça alterou esse entendimento, com a edição da súmula 381 deste Tribunal, com o seguinte teor: "Nos contratos bancários, é vedado ao julgador conhecer, de ofício, da abusividade das cláusulas". Para melhor compreender o enunciado desta súmula, cabe uma análise dos precedentes que levaram a sua edição. Havia no STJ um dissenso não exatamente a respeito da possibilidade de conhecimento de ofício das cláusulas abusivas pelo juiz, mas, sim, se essa declaração poderia ser feita pelo Tribunal, em grau de recurso, mesmo não tendo sido impugnada a matéria relativa à cláusula abusiva. Assim, enquanto a $4^{\mathrm{a}}$ turma admitia a declaração da nulidade de ofício ${ }^{345}$, a $3^{\text {a }}$ turma entendia que o conhecimento de ofício pelo Tribunal, independente de pedido na apelação do consumidor, encontrava impedimento no art. 515 do CPC (princípio tantum devolutum quantum appellatum). ${ }^{346}$

Note-se que a inadmissibilidade do conhecimento de ofício das cláusulas abusivas decorria de uma questão processual, que dizia respeito ao efeito devolutivo do recurso de apelação (CPC, art. 515), e não exatamente por um fundamento de direito material. De qualquer forma, no julgamento do Recurso Especial 541.153/RS pela Segunda Seção, em

\footnotetext{
345،CIVIL. CONTRATO BANCÁRIO. REVISÃO. DE OFÍCIO. POSSIBILIDADE. 1. O STJ tem preconizado a possibilidade de rever, de ofício, cláusulas contratuais consideradas abusivas, para anulá-las, com base no art. 51, IV do CDC. Nesse sentido: REsp n n $^{\circ} 48155 / \mathrm{SP}$, in DJ de 07/08/2000 e REsp $\mathrm{n}^{\circ}$ 503831/RS, in DJ de 05/06/2003. 2. Agravo regimental improvido". (STJ, 4 a Turma, AgRg no REsp 578715/SC, Relator Ministro FERNANDO GONÇALVES, Data do Julgamento 02/09/2004).

${ }^{346}$ Da ementa: "I - A extensão do pedido devolutivo se mede através da impugnação feita pela parte nas razões do recurso, consoante enuncia o brocardo latino tantum devolutum quantum appellatum. II - A apelação transfere ao conhecimento do tribunal a matéria impugnada, nos limites dessa impugnação, salvo matérias examináveis de ofício pelo juiz. III - Questão não refutada no recurso, que, pela natureza patrimonial do direito, não pode ser decidida de ofício pelo tribunal. IV - Conquanto o CDC seja norma de ordem pública, não pode retroagir para alcançar o contrato que foi celebrado e produziu seus efeitos na vigência da lei anterior, sob pena de afronta ao ato jurídico perfeito". (STJ, 4 ${ }^{\mathrm{a}}$ Turma, Resp 248.155-SP, relatado pelo eminente Ministro Sálvio de Figueiredo Teixeira, DJ 07.08.2000).
} 
08/06/2005, a questão restou pacificada no sentido da impossibilidade do exame de ofício das cláusulas contratuais abusivas, por ofensa ao art. 515 do CPC.

No julgamento dos Embargos de Divergência 702.524/RS, a Ministra Nancy Andrighi propôs a revisão do entendimento, argumentando que a adoção dessa posição representava um conflito dentro do próprio Tribunal, que com relação a outras cláusulas abusivas entendia de forma pacífica pela possibilidade do seu conhecimento de ofício - o que ocorreu com a cláusula de eleição de foro. A revisão proposta não foi acolhida, mantendo-se o entendimento anteriormente adotado pela Segunda Seção.

Recentemente a questão foi novamente objeto de discussão, desta vez no âmbito do recurso especial representativo $\mathrm{n}^{\mathrm{o}}$ 1.061.530/RS, julgado nos termos do art. 543-C do CPC, que resultou na já mencionada súmula 381 do STJ. Contudo, a questão adquiriu nova dimensão, já que a orientação consignada foi a de que "é vedado aos juízes de primeiro $e$ de segundo graus julgar, com fundamento no art. 51 do $\mathrm{CDC}$, sem pedido expresso, a abusividade de cláusulas nos contratos bancários". A questão processual, relativa à incidência do artigo 515 do CPC, perdeu-se, já que mesmo o juiz de primeiro grau não mais poderá conhecer das nulidades absolutas, em flagrante descompasso com o sistema das nulidades expresso no artigo 168, parágrafo único do CC, o qual dispõe, textualmente, que "as nulidades devem ser pronunciadas pelo juiz, quando conhecer do negócio jurídico ou dos seus efeitos e as encontrar provadas, não lhe sendo permitido supri-las, ainda que a requerimento das partes". Contraria também o disposto no artigo 51 do CDC, que estabelece serem "nulas de pleno direito" as cláusulas abusivas. ${ }^{347}$

\footnotetext{
347 Vale transcrever trecho do voto vencido da Ministra Nancy Andrighi, que resume os argumentos contrários ao entendimento adotado pelo STJ: “... No Eresp $n^{\circ} 702.524 / R S$, consignei que a visão restritiva da análise das disposições de ofício, mediante perspectiva puramente processual, estava empurrando a jurisprudência do STJ para um paradoxo, porque em questão similar - decretação de ofício da nulidade da cláusula de eleição de foro -, a solução adotada foi pelo conhecimento de ofício da questão. Diante da antinomia dos julgamentos, por que assumir postura diversa em relação a todas as demais cláusulas abusivas que possam vir a serem declaradas nulas? Ademais, essa proposição, hoje, reafirma-se pela tomada de posição do legislador, que inseriu um parágrafo único no art. 112 do CPC (pela Lei $\mathrm{n}^{\circ} 11.280$ )66), segundo o qual "a nulidade da clausula de eleição de foro, em contrato de adesão, pode ser declarada de ofício pelo juiz, que declinará de competência para o juízo de domicilio do réu". Atenta ao micro-sistema introduzido pelo $\mathrm{CDC}$, vinculado aos demais princípios e normas que orientam o direito pátrio, notadamente do CC02, que é sua fonte de complementação normativa, entendo que não é coerente adotar perante hipóteses idênticas soluções diversas. O CDC é categorizado como norma de ordem pública (art. $1^{\circ}$ ); portanto, todas as suas disposições possuem interesse público que impelem o juiz a atuar de ofício. Além do mais, o CDC adotou a mesma teoria de nulidades que regula os contratos regidos pelo Código Civil, especificando os vícios que são causa de nulidade e que o juiz deve declarar de ofício. A abusividade, por exemplo, é disciplinada como vício de nulidade da cláusula do contrato - art. 51, IV, do CDC. Outro motivo relevante que me levou a fazer esta proposição é o resultado dos julgamentos em favor dos consumidores, na perspectiva da política judiciária. Como explicar ao consumidor, leigo juridicamente, que determinada cláusula, apesar de abusiva, é válida para ele, mas não o é para o seu vizinho, em situação idêntica? O que ocorre é que na ação revisional proposta pelo vizinho houve pedido expresso de declaração de nulidade, ao passo que no seu processo não
} 


\section{Comentando o referido dispositivo do Código de Defesa do Consumidor, Nelson}

Nery Jr. esclarece que o sistema das nulidades do CDC contém peculiaridades em relação ao Código Civil, já que a nulidade de pleno direito nele estabelecida depende de declaração judicial, além do que rompeu com a dicotomia existente no Código Civil entre nulidade absoluta e relativa, pois "o Código só reconhece as nulidades de pleno direito quando enumera as cláusulas abusivas, porque ofendem a ordem pública de proteção $e$ defesa do consumidor, base normativa do Código, como se vê no art. $1^{\circ}$ do CDC". $348 \mathrm{E}$ prossegue:

A nulidade de cláusula abusiva deve ser reconhecida judicialmente, por meio de ação direta (ou reconvenção), de exceção substancial alegada em defesa (contestação), ou, ainda, por ato ex officio do juiz. A sentença que reconhece a nulidade não é declaratória, mas contitutiva negativa [cita Pontes de Miranda, Tratado de Direito Privado, Tomo IV, $\S \S 380$ e 408]. Quanto à subsistência da relação jurídica de consumo contaminada por cláusula abusiva, o efeito da sentença judicial que reconhece a nulidade da cláusula abusiva é ex tunc, pois desde a conclusão do negócio jurídico de consumo já preexistia essa situaçao de invalidade, de sorte que o magistrado somente faz reconhecer essa circunstância fática anterior à propositura da ação.

Sendo matéria de ordem pública (art. $1^{\circ}, \mathrm{CDC}$ ), a nulidade de pleno direito das cláusulas abusivas nos contratos de consumo não é atingida pela preclusão, de modo que pode ser alegada no processo a qualquer tempo e grau de jurisdição, impondo-se ao juiz o dever de pronunciá-la de ofício. Aplicam-se, por extensão, o $\S 3^{\circ}$ do art. 267 , o $\S 4^{\circ}$ do art. 301 e o art. 303 , todos do CPC. ${ }^{349}$

Note-se, portanto, que o conhecimento de ofício das cláusulas abusivas faz parte do sistema de proteção do consumidor adotado pelo Código, sendo corolário da sua base normativa, consistente no caráter de ordem pública das suas normas protetivas (CDC, art. $1^{\circ}$ ). Em virtude disso, entende-se que a súmula 381 do STJ, se interpretada de forma literal,

foi formulado tal pedido, o que impede o juiz de pronunciá-la. Conseqüências graves são geradas por esse tipo de julgamento: a primeira é a equivocada priorização da norma processual (que exige a formulação de pedido expresso) de molde a inviabilizar o conhecimento e a aplicação do direito material (nulificação da cláusula abusiva), exigindo para tanto uma nova movimentação da máquina judiciária com a propositura de outra ação; a segunda é o manifesto descumprimento de regra que disciplina a sanção decorrente da abusividade/nulidade, prevista expressamente no CDC e no ordenamento jurídico complementar (CDC, art. 51 , todos os seus incisos, cumulado com o CC02, parágrafo único, do art. 168, que determina ao juiz pronunciar as nulidades provadas, quando conhecer do negócio jurídico ou de seus efeitos); a terceira é o descrédito no Poder Judiciário, que tem a obrigação constitucional de tratar igualmente os consumidores que se encontram em situações idênticas; a quarta é a frustração de toda a operacionalidade do novo instrumento dos processos repetitivos, pois o não reconhecimento de ofício impõe reiteração de ações e recursos, que o art. 543-C visa impedir, prejudicando a almejada celeridade na entrega da prestação jurisdicional. ..." (Voto vencido da Ministra Nancy Andrighi no Resp 1.061.530/RS, julgado pela $2^{\mathrm{a}}$ Seção do STJ em 22.10.2008).

${ }^{348}$ NERY JR., N. Comentário ao artigo 51 do CDC em: Código Brasileiro de Defesa do Consumidor comentado pelos autores do anteprojeto. $8^{\text {a }}$ edição. Rio de Janeiro: Forense Universitária, 2005. p. 560.

${ }^{349}$ Idem, ibidem, p. 560-561 
mostra-se flagrantemente contra legem. Ademais, não se compreende a razão da discriminação feita aos contratos bancários, já que pela redação da súmula apenas nos contratos bancários é que não será possível o conhecimento das cláusulas abusivas. Assim, impõe-se uma interpretação que leve em consideração os precedentes da referida súmula, bem como a sua conjugação com o sistema de nulidades estabelecido pelo Código de Defesa do Consumidor.

Como já analisado, o entendimento jurisprudencial que orientou a edição da referida súmula repudiava a atuação de alguns Tribunais de Justiça que, em grau de apelação, por vezes sendo o recurso da instituição financeira, conheciam de ofício questões sobre as quais não houve contraditório. Daí porque adere-se ao posicionamento exposto por Nelson Nery Jr., em palestra proferida no Instituto Internacional de Ciências Sociais, em 22 de outubro de 2009, na qual propôs uma releitura da súmula 381 do STJ no sentido de ser possível que o juiz conheça de ofício a cláusula abusiva, desde que a questão tenha sido debatida pelas partes, dando-se oportunidade para o exercício da ampla defesa e do contraditório, sem que nenhuma delas seja surpreendida pela decisão judicial.

\section{b) O problema da capitalização de juros}

Com relação às cláusula abusivas, cabe tratar de uma questão especialmente conturbada em relação aos contratos bancários, que é a possibilidade ou não da cláusula de capitalização de juros em periodicidade inferior a um ano. Essa cláusula é em geral abusiva, pois permite um crescimento exponencial dos juros, tal como se observa do exemplo de Márcio Mello Casado, no qual, em apenas um ano, verificou-se uma diferença de 20 mil reais quando a taxa de juros é calculada de forma capitalizada mensalmente. Observe-se:

Pactuando uma taxa de juros de 5\% a.m. em cláusula de capitalização, demonstrasse ao aderente, devedor de R\$100.000,00 (cem mil reais), que com a capitalização mensal ele teria, ao fim de um ano, um saldo devedor de $\mathrm{R}$ \$ 181.316,68; com capitalização semestral, seria devedor, também ao final de um ano, de R\$ 170.302,22, menos, portanto; e com capitalização anual ele teria um saldo devedor ainda menor, ao fim de um ano: $\mathrm{R} \$ 161.000,00^{350}$

A capitalização de juros em períodos inferiores a um ano é prática proibida expressamente no Brasil desde o Código Comercial de 1850, que assim dispunha no seu artigo art. 253: "É proibido contar juros de juros; esta proibição não compreende a

${ }^{350}$ CASADO, M. M. Proteção do consumidor de crédito bancário e financeiro, 2 a edição, São Paulo: Revista dos Tribunais, 2007, pág. 201 
acumulação de juros vencidos aos saldos liquidados em conta corrente de ano a ano. Depois que em juízo se intenta ação contra o devedor, não pode ter lugar a acumulação de capital e juros". Um século mais tarde, o Decreto 22.626 de 1933, no seu artigo 4º também previu a vedação à capitalização de juros, repetindo a redação do artigo 253 do CCom.

Vale ressaltar, porque adiante será importante para as conclusões acerca da vedação à capitalização de juros, que a legislação brasileira sempre tratou distintamente a questão do limite das taxas de juros e a referente à proibição da cobrança de juros capitalizados: àquela (percentual de taxa de juros), por vezes, foi restringida pelo legislador brasileiro, sendo que atualmente nas operações firmadas no âmbito do sistema financeiro nacional as taxas de juros poderão ser livremente pactuadas; esta (capitalização de juros), por sua vez, sempre foi condenada, mesmo em tempos de influência liberal nas relações jurídicas, entendimento consolidado pela súmula 121 do STF, que assim enunciou: "é vedada a capitalização dos juros, ainda que expressamente convencionada". 351

Contudo, até pouco tempo atrás, existia muita polêmica entre os autores, e alguma confusão na jurisprudência dos Tribunais Estaduais, resultante da impropriedade de identificar a questão da liberação da taxa de juros (que é permitida), com a metodologia de cálculo que contemple capitalização de juros (que era proibida).

Isso se deve ao fato de que quando a jurisprudência consolidou o seu entendimento acerca da liberação da taxa de juros, em razão da interpretação dada pelo STF à Lei 4.595/64 (Lei da Reforma Bancária), que transferiu para a competência do Conselho Monetário Nacional a limitação das taxas de juros nas operações firmadas no âmbito do Sistema Financeiro Nacional ${ }^{352}$, foi editada a súmula 596 do STF, aprovada na seção plenária de 15 de dezembro de 1976, com o seguinte teor: "as disposições do Decreto 22.626/1933 não se aplicam às taxas de juros e aos outros encargos cobrados nas operações realizadas por instituições públicas ou privadas, que integram o sistema financeiro

\footnotetext{
${ }^{351}$ Ver o precedente do STF de 1951, que resultou na edição desta súmula 121, relatado pelo Ministro Orozimbo Nonato, RE 17.785, em que o Supremo entendeu que a proibição da Lei de Usura era norma de ordem pública (ius cogens), não deixando espaço para que as partes pactuassem de forma diversa. $\mathrm{O}$ voto do relator, Ministro Orozimbo Nonato, citou lições de Felício dos Santos, para quem "a lei de 24 de outubro de 1832 só teve por fim facultar às partes a estipulação dos juros que quizessem (SIC); o legislador não tinha em mente permitir o anatocismo condenado pela legislação de todos os povos civilizados". Citou também Lacerda de Almeida, assim arrematando: "o art. $1^{\circ}$ da lei de 24 de outubro de 1832, com facultar às partes o convencionarem livremente a taxa de juros, nem por isso permite o anatocismo, que o Código Comercial, lei posterior, e com maior razão de permiti-lo, proibiu".

${ }_{352}$ Art. $4^{\circ}$ Compete ao Conselho Monetário Nacional, segundo diretrizes estabelecidas pelo Presidente da República: IX - Limitar, sempre que necessário, as taxas de juros, descontos comissões e qualquer outra forma de remuneração de operações e serviços bancários ou financeiros, inclusive os prestados pelo Banco Central da República do Brasil, assegurando taxas favorecidas aos financiamentos que se destinem a promover;
} 
nacional". Note-se que, quando a súmula estabelece que as disposições do Decreto 22.626/1933 (Lei de Usura) não se aplicam às taxas de juros, está a se referir à limitação da taxa de juros, prevista no artigo $1^{\circ}$ do referido Decreto - basta, para isso, verificar os precedentes que levaram à edição da súmula. Contudo, passou a ser alegado que a súmula referia-se a todo e qualquer dispositivo da Lei de Usura, que não seria aplicável às instituições financeiras, incluindo-se, aí, o artigo $4^{\circ}$, que vedava a capitalização de juros.

Contudo, tanto o Supremo Tribunal Federal ${ }^{353}$, quanto anos mais tarde o Superior Tribunal de Justiça ${ }^{354}$, pacificaram entendimento no sentido de que a súmula 596 não guardava relação com a proibição da capitalização de juros, na forma estabelecida pela Lei de Usura, que nesse particular continuava sendo aplicável às instituições financeiras.

Foi esse o entendimento pacífico dos Tribunais brasileiros a respeito do tema até o início do ano 2000. Para tentar burlar essa proibição, as instituições financeiras lançaram mão de manobras jurídicas e artifícios matemáticos para esconder a cobrança de juros capitalizados, sendo as estratégias mais conhecidas a renovação sucessiva dos contratos, com a incorporação periódica de encargos ${ }^{355}$, ou a consolidação do saldo devedor por meio de instrumentos de confissão de dívida ${ }^{356}$, e a utilização da Tabela Price para o cálculo das prestações do contrato, cuja ilegalidade, apesar de tema polêmico ${ }^{357}$, vinha sendo

\footnotetext{
${ }^{353}$ Tal entendimento pode ser observado na seguinte ementa: "É vedada a capitalização de juros, ainda que expressamente convencionada (súmula 121). Dessa proibição não estão excluídas as instituições financeiras, dado que a súmula 596 não guarda relação com o anatocismo. A capitalização semestral de juros, ao invés da anual, só e permitida nas operações regidas por leis especiais que nela expressamente consentem. recurso extraordinário conhecido e provido" (RE 90.341/PA, julgado em 26/02/1980). No mesmo sentido: RE 96.875/RJ, julgado em 16/09/1983 e RE 100.336/PE, julgado em 10/12/1984.

354 “A lei 4.595/64 não afastou a vedação contida no art. $4^{\circ}$ da lei de usura, mostrando-se defeso o anatocismo mesmo nas operações contratadas por entidades financeiras. Apenas nos casos em que lei especifica a autoriza, a capitalização de juros e admissível, condicionada sua exigibilidade, no entanto, ao pactuado e aos balizamentos legais". (STJ, 4a Turma, REsp 23860/PR, Rel. Min. Sálvio de Figueiredo Teixeira, j. 15/06/1993, DJ 02/08/1993). No mesmo sentido: STJ, $4^{\text {a }}$ Turma, REsp 187499, Rel. Min. Aldir Passarinho Junior, DJ 22/05/2000, p. 114.

${ }^{355}$ Esse procedimento enseja a cobrança de juros sobre juros, pois, a cada renovação, havia a incorporação dos encargos da operação anterior para a incidência de novos juros. Entretanto, alegando que havia novação da obrigação, os bancos pretendiam sepultar a discussão acerca das operações anteriores. Os tribunais, entendendo que a obrigação nula não é passível de novação, permitiram a revisão de todo o relacionamento jurídico, desde a sua origem. Nesse sentido, confira o posicionamento do STJ: "Possível a revisão de cláusulas contratuais celebradas antes da novação por instrumento de confissão de dívida, se há uma seqüência na relação negocial e a discussão não se refere, meramente, ao acordo sobre prazos maiores ou menores, descontos, carências, taxas compatíveis e legítimas, limitado ao campo da discricionariedade das partes, mas à verificação da própria legalidade do repactuado, tornando necessária a retroação da análise do acordado desde a origem, para que seja apreciada a legitimidade do procedimento bancário durante o tempo anterior, em que por atos sucessivos foi constituída a dívida novada" (STJ, $4^{\mathrm{a}}$ Turma, Resp 132.565/RS, Relator Ministro Aldir Passarinho, DJ 12.02.2001).

${ }^{356}$ Por meio desse mecanismo, também se pretendeu evitar a discussão a respeito de ilegalidades das operações anteriores, sob alegação de novação. Como resultado do julgamento de questões como esta, o STJ editou a súmula 286, com o seguinte teor: "A renegociação de contrato bancário ou a confissão da dívida não impede a possibilidade de discussão sobre eventuais ilegalidades dos contratos anteriores".

${ }^{357}$ A ocorrência da capitalização de juros no chamado Sistema Francês de Amortização ou Tabela Price é
} 
reconhecida por diversos Tribunais Estaduais ${ }^{358}$, bem como pelo STJ, que, nas poucas ocasiões que se manifestou sobre o mérito da questão, reconheceu a ilegalidade na

tema que ensejou longo capítulo na jurisprudência nacional. Muito embora o entendimento acerca da vedação à capitalização de juros já estar pacificado, as instituições financeiras logravam, por vezes, demonstrar que a metodologia de cálculo pela Tabela Price não contemplava a cobrança de juros capitalizados. Em outros casos, de idêntica base fática, o consumidor é que lograva demonstrar, também abalizado pela perícia judicial, que a Tabela Price fazia incidir juros capitalizados. O argumento no sentido da ocorrência da capitalização é o de que a própria fórmula utilizada para a obtenção das prestações e dos juros enseja o cálculo de juros de forma capitalizada, pois a fórmula contém o fator exponencial, que leva à cobrança de juros compostos. Contudo, alguns peritos judiciais entendiam que juros compostos não ensejariam a cobrança de juros capitalizados. Especialistas em matemática financeira, contudo, ensinam que o conceito de juros compostos significa calcular os juros de forma capitalizada, como se vê em Washington Franco Mathias e José Maria Gomes: "O regime de juros compostos, que tem grande importância financeira por retratar melhor a realidade, o juro gerado pela aplicação será incorporado à mesma passando a participar da geração de juros no período seguinte. Dizemos então que os juros são capitalizados, e como não só o capital inicial rende juros mas estes são devidos também sobre os juros formados anteriormente, temos o nome de juros compostos" (MATHIAS, W. F. e GOMES, J. M. Matemática Financeira - 3. ${ }^{a}$ Edição - São Paulo: Editora Atlas S.A., 2002). Com base nisso, Márcio Mello Casado conclui ser "incontroverso que a metodologia de cálculo denominada método Francês de Amortização ou Tabela Price, acarreta a ilegal capitalização de juros. Até porque a matemática é uma ciência exata, na qual não se admitem diversas explicações para o mesmo fenômeno. Assim, em havendo o elemento $(1+\mathrm{i})^{\mathrm{n}}$ na equação, há a presença de fórmula que prestigia a contagem de juros sobre juros" (In Revista de Direito do Consumidor n ${ }^{\circ}$ 29, São Paulo: Editora Revista dos Tribunais, p. 81-82). A esse respeito também o voto vencido do Ministro Menezes Direito, no recurso especial $n^{\circ}$ 410.775-PR: "Embora bem estruturado o raciocínio do acórdão recorrido no sentido de que sendo a parcela de juros paga mensalmente, não se pode falar na existência de juros capitalizados, não havendo acréscimo de juros ao saldo devedor, porque suficiente o valor da prestação para pagamento das parcelas de amortização e de juros, o fato é que o sistema mesmo de amortização pela Tabela Price parte do conceito de juros compostos, daí decorrendo um plano de amortização em prestações periódicas e sucessivas, considerado o termo vencido. Com isso, a aplicação de juros sobre juros é inerente ao próprio sistema". (STJ, $3^{\mathrm{a}}$ Turma, Recurso Especial n ${ }^{\circ}$ 410.775-PR, Relatora para o acórdão Min. Nancy Andrighi, DJ 10.05.2004, maioria). Para aprofundar a questão consultar: CASADO, M. M. Tabela price: uso no crédito ao consumo. Revista Jurídica. Porto Alegre, v. 46, n 257, p.130-46, março, 1999.

${ }^{358}$ Do Tribunal de Justiça do Rio Grande do Sul: “... 4. Aplicação da Tabela Price. Neste sistema os juros crescem em progressão geométrica e não em progressões aritmética, caracterizando juros sobre juros os anatocismo. É na prestação da Price que estão "disfarçados" os juros compostos, porque não são incluídos e nem abatidos do saldo devedor, mas sim, compõem, os juros compostos, a prestação, em virtude da função exponencial contida na fórmula do Sistema Price. Em tais circunstâncias, o mutuário paga mais juros em cada prestação, em prejuízo da amortização do débito, de modo que o saldo devedor - dado de extrema relevância para o financiado ou mutuário - no sistema da tabela Price não tem qualquer relevância e serve 'apenas' como 'conta de diferença', em prejuízo do mutuário. Assim, no sistema Price, o saldo devedor não é propriamente o saldo devedor 'real', mas se configura tão-somente como simples e mera conta de diferença. Dizer que não se adicionam juros ao saldo devedor, não é o mesmo que dizer que não se cobram juros compostos ou capitalizados. É evidente que, se o mutuário já paga mais em função dos juros compostos incluídos nas parcelas mensais, resulta óbvio que não pode haver adição de juros ao saldo devedor, quer porque o mutuário já pagou juros maiores na parcela, quer porque seria duplo abuso ou duplo anatocismo, o qual restaria induvidosamente configurado se o mutuário, além de já pagar juros sobre juros nas parcelas, tivesse ainda que ver adicionados mais juros ao saldo devedor, sobre o qual seriam calculados novos juros que comporiam as seguintes e sucessivas parcelas, as quais, por sua vez, em face da sistemática da Price, possuem também juros embutidos, que, por evidente, seriam calculados sobre os juros que teriam sido, assim, antes adicionado ao saldo devedor. Seria, portanto, o supra-sumo do abuso ou do anatocismo. Quando se afirma que a Tabela Price não adiciona juros ao saldo, na verdade está-se dizendo, de forma não expressa, mas implícita, que o saldo devedor será mera conta de diferença, porque serão cobrados juros maiores, em progressão geométrica pela função exponencial da Price, acarretando cobrança por taxa superior à contratada, em prejuízo da amortização do saldo devedor, que, de outra forma, seria muito menor. Ora, cobrar juros maiores na prestação, em prejuízo da amortização do saldo devedor, o qual poderia ser menor se a amortização fosse maior, tem o mesmo resultado, do ponto de vista da abusividade, que incluir no saldo devedor juros não cobrados na parcela, formando um novo saldo sobre o qual incidem novos juros. A conclusão é intuitiva: não capitaliza os juros no saldo devedor porque capitaliza na prestação, em função do 
utilização dessa metodologia de cálculo ${ }^{359}$, mas posteriormente passou a decidir que se tratava de matéria de fato, que não poderia ser examinada por aquela corte. ${ }^{360}$

Em função de recomendação do Banco Central ${ }^{361}$, foi editada a Medida Provisória $\mathrm{n}^{\mathrm{o}}$ 1.963-17 de 30 de março do ano 2000 (atual MP 2.170-36), que introduziu a permissão para a cobrança de juros capitalizados no Brasil, em qualquer periodicidade, nas operações realizadas pelas instituições integrantes do Sistema Financeiro Nacional. Essa MP é de constitucionalidade duvidosa, já que, como é sabido, as Medidas Provisórias, editadas pelo Presidente da República com força de lei, devem obedecer aos requisitos de relevância e urgência, exigidos pelo artigo $62 \mathrm{da} \mathrm{CF}$, sendo que uma matéria regulada desde $1850 \mathrm{e}$ pacificada pelos Tribunais, apesar de ser relevante, não apresenta a necessária urgência capaz de dispensar o processo legislativo democrático. Sem falar no fato de que a permissão para os bancos cobrarem juros capitalizados foi introduzida na $17^{\mathrm{a}}$ edição de uma MP que tratava da "administração dos recursos de caixa do Tesouro Nacional", carecendo da necessária pertinência temática exigida pelo art. $7^{\circ}$, inciso II da Lei Complementar $n^{0}$ 95/1998. ${ }^{362}$ Essas e outras questões estão sendo discutidas na Ação

cálculo de taxa sobre taxa, juros sobre juros, ou simplesmente, de maneira mais técnico-matemática: em virtude da função exponencial, que caracteriza progressão geométrica, contida na fórmula da Tabela Price. O custo total do financiamento não é a simples soma das parcelas mensais do prazo do contrato, ou a mera multiplicação do valor da parcela inicial pelo número de parcelas do prazo pactuado. Isto porque, após o pagamento de cada parcela, é como se o credor fizesse a reaplicação ou nova aplicação do saldo devedor em relação ao mutuário, de modo que, quando mais longo for o prazo do contrato, maior é o ganho em juros de juros ou juros capitalizados. Esse efeito só é matematicamente percebido quando apurada a incidência do juro retornado de maneira inversamente proporcional ao prazo transcorrido, sobre cada parcela que representa a fração de devolução no tempo do capital emprestado. Doutrina de José Jorge Meschiatti Nogueira, na obra Tabela Price - Da Prova Documental e Precisa Elucidação do seu Anatocismo, Ed. Servanda, 2002. (...)" (TJRS, Apelação no 70002065662 - $1^{a}$ CÂMARA ESPECIAL CÍVEL, Rel. Des. Adão Sérgio do Nascimento Cassiano, j. 23.10.2002)

359 RECURSO ESPECIAL CONTRATO DE FINANCIAMENTO DE CRÉDITO EDUCATIVO. ATUALIZAÇÃO MONETÁRIA. UTILIZAÇÃO DA TABELA PRICE. IMPOSSIBILIDADE. EXISTÊNCIA DE JUROS CAPITALIZADOS. ANATOCISMO. CARACTERIZAÇÃO DE CONTRATO BANCÁRIO. APLICAÇÃO DO CÓDIGO DE DEFESA DO CONSUMIDOR: ARTIGOS $3^{\circ}, \S 2^{\circ}, 6^{\circ}$, V, e 51, IV, $\S 1^{\circ}$, III. INCIDÊNCIA DE JUROS LEGAIS, NÃO CAPITALIZADOS. 1. O contrato de financiamento de crédito educativo, ajustado entre a Caixa Econômica Federal e o estudante, é de natureza bancária, pelo que recebe a tutela do art. $3^{\circ}, \S 2^{\circ}$, da Lei 8.078, de 1990 (Código de Defesa do Consumidor). 2. É indevida a utilização da Tabela Price na atualização monetária dos contratos de financiamento de crédito educativo, uma vez que, nesse sistema, os juros crescem em progressão geométrica, sobrepondo-se juros sobre juros, caracterizando-se o anatocismo. 3. A aplicação da Tabela Price, nos contratos em referência, encontra vedação na regra disposta nos artigos $6^{\circ}, \mathrm{V}$, e $51, \mathrm{IV}, \S 1^{\circ}$, III, do Código de Defesa do Consumidor, em razão da excessiva onerosidade imposta ao consumidor, no caso, o estudante. 4. Na atualização do contrato de crédito educativo, deve-se aplicar os juros legais, ajustados de forma não capitalizada ou composta. 5. Recurso especial conhecido e provido (STJ - $1^{\text {a }}$ Turma, RESP 572210/RS, Fonte DJ DATA: 07/06/2004 PG: 00166, Relator Min. JOSÉ DELGADO Data da Decisão 06/05/2004, un).

${ }^{360}$ STJ, $2^{\text {a }}$ Seção, REsp. 1070297/PR, Rel. Ministro Luis Felipe Salomão, DJ 18/09/2009, un.

${ }^{361}$ Disponível em: $<$ http://www.bacen.gov.br/?SPREAD>. Acessado em 20 de novembro de 2009.

${ }^{362}$ Ver a respeito CASADO, M. M. Proteção do consumidor de crédito bancário e financeiro, $2^{\mathrm{a}}$ edição, São Paulo: RT, 2007, págs. 203 e segs. 
Direita de Inconstitucionalidade $\mathrm{n}^{0} 2316$, interposta em setembro de 2000, em face do $\operatorname{artigo} 5^{\circ}$ da Medida Provisória 2.170-36, pendente de julgamento perante o STF. ${ }^{363}$

No Superior Tribunal de Justiça, a posição que tem sido adotada é no sentido de admitir a capitalização de juros para os contratos bancários celebrados a partir de 31 de março de $2000 .{ }^{364}$ Contudo, mesmo diante da permissão legal para a cobrança de juros sobre juros, caso seja demonstrado num determinado contrato que esta prática colocou o consumidor em desvantagem exagerada, sendo incompatível com a boa-fé e a eqüidade, é possível defender a nulidade da cláusula com fundamento no art. 51, inciso IV e $\S 1^{\circ}$ do CDC. A verificação da onerosidade excessiva da cláusula de capitalização de juros vai depender do percentual da taxa de juros e do prazo para pagamento, que quanto mais elevados, maior será o ônus sofrido pelo consumidor em função do anatocismo. ${ }^{365}$

\section{c) Vedação ao abuso de direito}

Outra função da boa-fé objetiva é a de servir como critério para a caracterização do exercício inadmissível de posições jurídicas ${ }^{366}$, o que se traduz na limitação ao exercício de direitos subjetivos e de faculdades jurídicas.

A figura do abuso de direito teve sua origem na jurisprudência francesa do período posterior à codificação ${ }^{367}$, referindo-se ao exercício prejudicial do direito de propriedade. O Código Civil Napoleônico, editado no apogeu do liberalismo, não admitia limitações aos direitos subjetivos, não contendo qualquer previsão a respeito da proibição ao abuso de

\footnotetext{
363 Já foram proferidos votos dos Ministros Sydney Sanches, Carlos Velloso, Marco Aurélio e Carlos Brito deferindo a cautelar para suspender a eficácia do dispositivo legal impugnado, e dos Ministros Cármen Lúcia e Menezes Direito indeferindo a medida. O julgamento foi suspenso para retomada do quorum necessário para apreciação da medida.

${ }^{364}$ Ver, por exemplo, STJ, 4 a Turma, o AgRg no Ag 1030809/MS, Relator Ministro HONILDO AMARAL DE MELLO CASTRO Data da Publicação/Fonte DJ 26/10/2009. Com relação aos contratos celebrados anteriormente a 31 de março de 2000, mantém-se a vedação. Nesse sentido: STJ, $4^{\mathrm{a}}$ Turma, AgRg no REsp 677851/PR, Relator Ministro LUIS FELIPE SALOMÃO, DJ 11/05/2009.

${ }^{365}$ Nesse sentido foi o julgamento da Apelação n ${ }^{\circ} 519.909-4 / 2$, pelo Tribunal de Justiça de São Paulo, Relator Maia da Cunha, julgado em 19 de março de 2009.

${ }^{366}$ Menezes Cordeiro abriga sob o título "exercício inadmissível de posições jurídicas” o tratamento da figura genérica do abuso de direito e das figuras típicas de exercícios inadmissíveis, quais sejam, exceptio doli, venire contra factum proprium, suppressio, surrectio, tu quoque e inalegabilidade de nulidades formais (MENEZES CORDEIRO, A. M. R. Da Boa-fé..., op. cit., p. 661 a 852). Trataremos apenas da figura genérica do abuso do direito, que servirá melhor aos objetivos propostos nesse trabalho.

${ }^{367}$ Menezes Cordeiro cita decisões desde 1808, sendo a mais conhecida do caso "Clement Bayard", decidido em 1912 (MENEZES CORDEIRO, A. M. R. Da Boa-fé..., op. cit., p. 671). Este caso foi assim descrito por Heloísa Carpena: "Consta que o proprietário de um terreno vizinho a um campo de pouso de dirigíveis construiu, sem qualquer justificativa, enormes torres no vértice das quais instalou lanças de ferro, colocando em perigo as aeronaves que ali aterrizavam" (O abuso do direito no Código de 2002 - relativização de direitos na ótica civil-constitucional. In TEPEDINO, G. (coord.). A Parte Geral do Novo Código Civil: estudos na perspectiva civil-constitucional. Rio de Janeiro: Renovar, 2003).
} 
direito. $^{368}$ A prática, contudo, evidenciou a necessidade de reprovarem-se condutas de titulares de direito subjetivo (inicialmente do direito de propriedade) cujo exercício visava unicamente ao prejuízo de terceiros. Conforme dizia Planiol, “o direito cessa onde o abuso começa"369, o que mantinha o princípio de não intervenção reinante na época.

Muitas teorias tentam explicar o abuso de direito, sendo que as principais são as concepções subjetivista ou individual, de Georges Ripert ${ }^{370}$, e a finalista ou social, de Louis Josserand. ${ }^{371}$ Para Ripert importa a intenção do titular do direito de prejudicar outrem, tornando-se reprovável por infringir a "regra moral". ${ }^{372} \mathrm{Na}$ concepção de Josserand, para que o ato seja abusivo, "basta que tenha o propósito de realizar objetivos diversos daqueles para os quais o direito subjetivo em questão foi preordenado", caracterizando a contrariedade ao espírito, à finalidade do direito, sem importar a intenção. $^{373}$

Atualmente, entende-se que o exercício do direito é abusivo quando se afasta da finalidade pela qual o ordenamento jurídico lhe reconhece proteção, aproximando-se da concepção finalista de Josserand. O maior problema, como destaca Fernando Noronha, é que nem sempre essa finalidade vem expressa na Lei. "E como a autonomia privada pressupõe ampla margem de discricionariedade, não fica fácil de saber, em especial no âmbito dos contratos (...) até onde vai o direito da pessoa e a partir de que ponto ela passa a agir anômala ou irregularmente". 374

\footnotetext{
368 Menezes Cordeiro assim retrata: "O Código Napoleão não compreende, no seu articulado, qualquer referência ao abuso de direito. Em contrário, não deve considerar-se nem a consagração de certos limites aos direitos subjectivos - incluindo ao direito de propriedade - nem a existência de uma cláusula geral de responsabilidade civil (...) As decisões judiciais que consagraram o abuso do direito não puderam, pois, basear-se em disposições legais. Tão pouco recorreram, porém, a elementos constantes da tradição romanística". (MENEZES CORDEIRO, A. M. R. Da Boa-fé..., op. cit. p. 679-680)

${ }^{369}$ Ripert e Planiol rechaçam a possibilidade do exercício de um direito ser ao mesmo tempo lícito e ilícito. Rejeitam a idéia de que o uso do direito é abusivo, pois quando o abuso ocorre já não há mais direito: "Cette nouvelle doctrine repose tout entière sur un langage insuffisamment étudié ; sa formule, usage abusif des droits, est une logomarchie, car si j'use de mon droit, mon acte est licite, et quand il est illicite, c'est que je dépasse mon droit et que $\mathrm{j}$ 'agis sans droit. Il ne faut donc pas être dupe des mots; le droit cesse où l'abus commence, et il ne peut pas y avoir usage abusif d'un droit quelconque par la raison irréfutable qu'un seul et même acte ne peut pas être à la fois conforme au droit et contraire au droit (RIPERT, G e PLANIOL, M. Traité élémentaire. 11a ed., t. II, $\mathrm{n}^{\mathrm{o}}$ 871. Apud RIPERT, G. La Règle Morale dans les Obligations Civiles. Paris : LGDJ, 1949, pág. 161).

${ }^{370}$ RIPERT, G. La règle morale dans les obligations civiles. Paris : LGDJ, 1949.

${ }^{371}$ JOSSERAND, L. L'esprit de droits et de leur relativité - Théorie dite de l'abus des droits. $2^{\mathrm{a}}$ ed. Paris : Dalloz, 1939.

372 Ripert analisa a questão sob o aspecto moral, citando Savatier: « L'abus du droit nous semble constituer un cas de conflit entre le droit et la morale...». Caracteriza o abuso pelo descumprimento de um dever moral de não causar intencionalmente um prejuízo a terceiros. (RIPERT, G. La règle... op. cit., p. 167).

${ }^{373}$ NORONHA, F. O direito dos contratos e seus principios fundamentais. op. cit., p. 170.

${ }^{374}$ NORONHA, F. O direito dos contratos e seus princípios fundamentais. op. cit., p. 168.
} 
A boa-fé objetiva vem em auxílio do intérprete como um dos critérios para se identificar quando o exercício do direito excede os limites admitidos pela autonomia privada e pelo ordenamento jurídico. O artigo 187 do Código Civil confere o fundamento jurídico para o reconhecimento do abuso do direito, estabelecendo que "também comete ato ilícito ${ }^{375}$ o titular de um direito que, ao exercê-lo, excede manifestamente os limites impostos pelo seu fim econômico ou social, pela boa-fé ou pelos bons costumes". Observese que não apenas a boa-fé, mas também a função econômica e social do direito em questão e os bons costumes são parâmetros de identificação dos limites para o exercício de direitos.

O artigo 187 do Código Civil praticamente repete o disposto no artigo 334 do Código Civil português, razão pela qual tem plena aplicabilidade o ensinamento de Menezes Cordeiro:

Do enunciado, por dedução, retira-se que a boa-fé e os bons costumes impõem, ou podem impor, limites ao exercício dos direitos e que estes têm, ou podem ter, um fim social e económico o qual, por seu turno, limita também, ou pode limitar, o seu exercício. Este último limite é específico - cada direito tem, ou pode ter o seu fim social e económico; os dois primeiros são gerais: a boa-fé e os bons costumes não emergem, na fórmula legal, de cada direito em si. ${ }^{376}$

É de se destacar que o exercício fora dos limites impostos pela boa-fé, pelo fim econômico ou social ou pelos costumes deve exceder manifestamente, melhor dizendo, excessivamente esses limites. Tal como salienta Oliveira Ascensão, "seria muito inconveniente, e mesmo insuportável, que todo o exercício jurídico pudesse ser objeto de um controlo exaustivo, para verificar se haveria abuso ou não". E conclui: "só os casos de exercício manifestamente excessivo, por abusivo, poderão ser atingidos". 377

$\mathrm{Na}$ tentativa de conferir maior concreção à aplicação do abuso de direito, a doutrina elaborou casos típicos, procurando sistematizar as hipóteses de ocorrência do exercício inadmissível de direitos. Com relação ao objeto deste estudo, importa analisar a situação

\footnotetext{
${ }^{375}$ Cabe aqui a ressalva feita por Fernando Noronha: "em rigor, o ato considerado de abuso de direito nem sempre será ilícito, embora seja sempre antijurídico. Apesar da redação de preceitos como o art. 187 do Projeto de Código Civil e o art. 160, I, do Código Civil vigente, nestes casos, ditos de abuso de direito, em rigor nem sempre haverá verdadeira ilicitude, porque esta, se pressupõe a prática de um ato antijurídico, exige ainda que ele seja imputável a alguém, a título de dolo ou culpa; ora, destes dois elementos, antijuridicidade e culpabilidade, só um está sempre presente no abuso de direito: a contrariedade ao direito, isto é, a antijuridicidade (idem, ibidem, p. 170).

${ }^{376}$ MENEZES CORDEIRO, A. M. R. Da Boa-fé... op. cit., p. 679-680.

377 ASCENSÃO, J. O. A desconstrução do abuso do direito. In: DELGADO, M. L.; ALVES, J. F. Questões Controvertidas no Direito das Obrigações e dos Contratos. São Paulo: Editora Método, 2005, p. 40.
} 
do exercício danoso inútil de posição contratual e da desproporção de efeitos práticos (exercícios desequilibrados de direitos). ${ }^{378}$ Segundo Fernando Noronha:

Agrupamos aqui aqueles casos em que há manifesta desproporção entre a vantagem auferida pelo titular do direito e o sacrifício imposto à contraparte, mesmo quando o titular não vise propriamente molestar esta, nem alcançar outra finalidade diversa daquela a que é destinado o seu direito. São casos em que se pode dizer que o titular age sem consideração pela contraparte. ${ }^{379}$

Menezes Cordeiro também trata do exercício danoso inútil e da desproporção dos efeitos práticos como duas hipóteses de exercício inadmissível de posições jurídicas. Explica o autor que a categoria de exercício desequilibrado de direitos é integrada por três sub-hipóteses de comportamentos inadmissíveis, quais sejam: o exercício inútil danoso, a conjunção de situações implicada no brocardo dolo agit qui petit quod statim redditurus est e a desproporcionalidade entre a vantagem auferida pelo titular e o sacrifício imposto pelo exercício a outrem. Assim define cada uma dessas hipóteses:

No exercício inútil danoso, o titular actua no âmbito formal da permissão normativa que constitui o seu direito, em termos de não retirar qualquer benefício pessoal, mas a causar dano considerável a outrem. (...) Dolo agit qui petit quod statim redditurus est traduz uma valoração relativa ao comportamento da pessoa que exige o que, de seguida, terá de restituir. (...) A desproporcionalidade entre a vantagem auferida pelo titular e o sacrifício imposto pelo exercício a outrem constitui, por fim, o mais promissor dos subtipos integrados no exercício em desequilíbrio. Integram-se, aqui, situações como o desencadear de poderes-sanção por faltas insignificantes, a actuação de direitos com lesão intolerável de outras pessoas e o exercício jussubjectivo sem consideração por situações especiais. ${ }^{380}$

A exceção da segunda sub-hipótese apresentada (conduta de quem exige aquilo que em seguida deverá restituir), as outras duas (exercício danoso inútil e desproporção entre a vantagem auferida pelo credor e o sacrifício imposto ao devedor) poderão fornecer soluções bastante úteis para os problemas de endividamento excessivo do consumidor.

Numa relação de consumo que envolva a outorga de crédito, o credor tem o direito de cobrar as prestações da dívida que alcançarem o seu termo e se tornarem exigíveis. Tem também a faculdade de renegociar o débito, caso entenda que desta forma poderá ser mais facilmente reembolsado da quantia emprestada. Efetivamente, essa é uma situação bastante comum na prática bancária: o tomador de crédito que encontra dificuldades em continuar honrando com as prestações devidas procura a instituição financeira que lhe propõe uma renegociação, alongando o prazo de pagamento e, por vezes, alterando a modalidade de

${ }^{378}$ MENEZES CORDEIRO, A. M. R.. Da Boa-fé... op. cit., p. 853-857.

${ }^{379}$ NORONHA, F.. O direito dos contratos e seus princípios fundamentais. op. cit., p. 179.

${ }^{380}$ MENEZES CORDEIRO, A. M. R. Da Boa-fé... op. cit., p. 853-857. 
empréstimo e as taxas de juros (a forma mais comum é a renegociação do saldo devedor em cheque especial por meio de um contrato de empréstimo pessoal). Dependendo da situação da dívida, a instituição financeira, por vezes, propõe um abatimento no valor devido a título de juros, pois verifica que a dívida atingiu um montante de tal forma elevado que será praticamente impossível o pagamento pelo consumidor.

Diante de tudo o que foi dito a respeito do abuso de direito, a pergunta que se faz é a seguinte: a instituição financeira tem, em todos os casos, apenas a faculdade de renegociar a dívida, ou, dependendo da situação concreta, tem o dever de renegociá-la?

Conforme será demonstrado no item 2.3.1, numa situação de sobreendividamento passivo, na qual o consumidor, diante de alterações das circunstâncias pessoais, ficou impossibilitado de continuar honrando com as prestações da dívida na forma como foi inicialmente pactuada, haveria um dever de ambas as partes conjugarem esforços para manter viva a relação contratual e possibilitar a sua extinção pela via normal do adimplemento. A boa-fé objetiva atua aqui tanto por meio do dever de cooperação, quanto para coibir o exercício abusivo de posições jurídicas. Nesse sentido, é possível pensar-se num dever de renegociação a fim de afastar o exercício abusivo de uma faculdade contratual, já que a recusa, além de representar um exercício inútil - pois se as condições contratuais não forem alteradas o credor não receberá o que lhe é devido, não porque o direito negue-lhe, mas porque a realidade fática não permitirá -, representará também um desequilíbrio intolerável entre o direito do credor e o sacrifício imposto ao devedor.

\section{d) Adimplemento substancial do contrato}

A consideração do adimplemento substancial do contrato para evitar a sua resolução é um desdobramento da boa-fé objetiva, na função de limitação ao exercício de direitos subjetivos e de faculdades jurídicas decorrentes da relação contratual. Muitos contratos de financiamento para o consumo, geralmente de adesão, contêm cláusula resolutiva expressa em caso de inadimplemento, como forma de garantia de pagamento ao credor. Em outras vezes, a resolução do contrato decorre de expressa disposição legal, como é o caso dos contratos garantidos por alienação fiduciária, regidos pelo DL 911/69 e pela Lei $4728 / 65$.

Ocorre que em determinadas situações, nas quais o consumidor houver pago a quase totalidade das prestações do financiamento, a sanção da resolução contratual mostra-se injusta e contrária à boa-fé. No caso específico da alienação fiduciária em 
garantia, o credor poderá retomar o bem financiado e vendê-lo a terceiros, sem maiores garantias de que seja pago um preço justo, já que não se exige avaliação prévia, aplicandose o preço da venda no pagamento do crédito e entregando-se ao devedor o saldo, se houver. ${ }^{381}$ Via de regra, o bem é vendido por preço muito inferior ao de mercado, de maneira que o saldo entregue ao devedor é irrisório. O prejuízo é inevitável.

Dessa forma, se ficar caracterizado o adimplemento substancial do contrato, o exercício da faculdade de resolver o contrato deverá ser tida por abusiva, devendo o credor buscar a satisfação do seu crédito pela via normal da execução. Haverá adimplemento substancial sempre que, considerando as prestações adimplidas até o momento do inadimplemento, verificar-se que o contrato alcançou a sua finalidade econômica e social, estando o interesse do credor praticamente satisfeito, de acordo com os ditames da boa-fé objetiva. ${ }^{382}$ De acordo com Anelise Becker, "o adimplemento substancial consiste em um resultado tão próximo do almejado, que não chega a abalar a reciprocidade, o sinalagma das prestações correspectivas. Por isso mantém-se o contrato, concedendo-se ao credor direito a ser ressarcido pelos defeitos da prestação, porque o prejuízo, ainda que secundário, se existe deve ser reparado". 383

Ruy Rosado de Aguiar esclarece que, à luz da boa-fé, o juiz:

Pode rejeitar a aplicação da cláusula resolutiva quando houver o adimplemento substancial, ou quando o inadimplemento é de prestação acessória. Também pode julgar nula a de decaimento (art. 53 do CDC), ou diminuir a perda das prestações pagas, fazendo incidir a cláusula geral do art. 413 do Código Civil, que autoriza o juiz a reduzir a pena pelo descumprimento quando manifestamente excessiva. A cláusula resolutiva expressa, assim como a do termo essencial, quando inseridas em contrato de adesão, somente podem ser aceitas pelo juiz se atenderem a determinados princípios, como o da igualdade (p. ex.: a mesma conseqüência está prevista para o inadimplemento da estipulante?) e o da exigência da gravidade do descumprimento (p. ex.: a falta é suficientemente grave para que se extinga o contrato?. Especial deve ser a cautela quando se tratar de deferir medida judicial

\footnotetext{
${ }^{381}$ DL $911 / 69$, Arts. $2^{\circ}$ e $3^{\circ}$.

382 Ruy Rosado de Aguiar, ao dissertar sobre a definição do inadimplemento, vale-se dos ensinamentos de RAMELLA, para quem "a apuração do incumprimento deve ser feita em subordinação ao princípio da boafé, examinando o juiz se o fato é capaz ou não de deixar insatisfeito o interesse do credor, tendo em conta a interdependência funcional das prestações correspectivas, insistindo em que não se deve observar uma fórmula única para resolver o problema. Indica critérios que têm sido usados para a avaliação da gravidade do incumprimento: resultar a prestação de modo diferente do pactuado; completa diminuição da causa; se previsto o incumprimento, assim como ele ocorreu, não teria sido firmado o contrato; prejuízo da finalidade econômica; violação do interesse do credor". (RAMELLA. La Resolución por Incumplimiento, $2^{\mathrm{a}}$ ed., Editorial Astrea, Buenos Aires, p. 52 apud AGUIAR Jr., R. R.. Extinção dos Contratos por Incumprimento do Devedor. op. cit., p. 138).

383 BECKER, A. A doutrina do adimplemento substancial no direito brasileiro e em perspectiva comparativista. Revista da Faculdade de Direito da Universidade Federal do Rio Grande do Sul. Porto Alegre: Livraria dos Advogados, nº 1, v. 9, nov. 1993, p.62.
} 
que implicar liminarmente a perda da posse, cuja execução significará, na prática, o desfazimento da relação. ${ }^{384}$

O Superior Tribunal de Justiça tem acolhido a tese do adimplemento substancial quando o consumidor tenha deixado de pagar apenas algumas poucas parcelas finais de um longo financiamento, evitando-se, assim, a perda do bem pelo qual pagou pontualmente durante anos. Vale transcrever os fundamentos do voto do Ministro Ruy Rosado de Aguiar no recurso especial $n^{\circ} 272.739 / \mathrm{MG}$, verdadeira doutrina sobre o tema:

A extinção do contrato por inadimplemento do devedor somente se justifica quando a mora causa ao credor dano de tal envergadura que não lhe interessa mais o recebimento da prestação devida, pois a economia do contrato está afetada. Se o que falta é apenas a última prestação de um contrato de financiamento com alienação fiduciária, verifica-se que o contrato foi substancialmente cumprido e deve ser mantido, cabendo ao credor executar o débito. Usar do inadimplemento parcial e de importância reduzida na economia do contrato para resolver o negócio significa ofensa ao princípio do adimplemento substancial, admitido no Direito e consagrado pela Convenção de Viena de 1980, que regula o comércio internacional. No Brasil, impõe-se como uma exigência da boa-fé objetiva, pois não é eticamente defensável que a instituição bancária alegue a mora em relação ao pagamento da última parcela, esqueça o fato de que o valor do débito foi depositado em juízo e estava à sua disposição, para vir lançar mão da forte medida de reintegração liminar na posse do bem e pedir a extinção do contrato. O deferimento de sua pretensão permitiria a retenção dos valores já recebidos e, ainda, obter a posse do veículo, para ser revendido nas condições que todos conhecemos, solução evidentemente danosa ao financiado. ${ }^{385}$

Por fim, a boa-fé atuando em caso de inadimplemento contratual, além de vedar o emprego abusivo de cláusulas resolutivas, serve de parâmetro para a redução, por eqüidade, de cláusulas penais, o que é expressamente admitido pelo art. 413 do CC sempre que houver cumprimento parcial da obrigação ou se o montante da penalidade for manifestamente excessivo, tendo-se em vista a natureza e a finalidade do negócio. $\mathrm{O}$ significado concreto do conceito indeterminado desta norma não é arbitrário. Deve ser obtido com o auxílio da boa-fé objetiva e da função social e econômica que se espera do contrato, e assim obter um resultado concreto que consagre o princípio da justiça contratual.

\footnotetext{
${ }^{384}$ AGUIAR Jr., R. R.. Extinção dos Contratos por Incumprimento do Devedor. op. cit., p. 59.

385 REsp 272739/MG, Relator Ministro RUY ROSADO DE AGUIAR, Órgão Julgador 4a. TURMA, Julgamento 01/03/2001, DJ 02.04.2001.
} 


\section{Seção 1.2 - O equilíbrio contratual}

Sob a égide do liberalismo, a justiça contratual decorria da própria liberdade de manifestação de vontade. Jacques Ghestin recorda a doutrina de Kant, que exalta a vontade como fonte única de todas as obrigações jurídicas e como fonte de justiça, dizendo: “quando alguém decide alguma coisa em relação à outra pessoa, é sempre possível que seja feita alguma injustiça; mas toda injustiça é impossível naquilo que uma pessoa decide para si própria” ${ }^{386}$. Relembra, ainda, a fórmula de Fouillée, pela qual «qui dit contractuel, dit juste $» .{ }^{387}$ Esse conceito de justiça contratual pressupunha uma igualdade entre as partes, que, no entanto, era meramente formal, sendo fonte de mais desigualdades e injustiça. Ghestin desenvolve sua tese afirmando que a força obrigatória dos contratos é justificada pela busca, dentro do ordenamento positivo, daquilo que é útil e justo numa contratação. ${ }^{388}$

Para equilibrar as relações sociais, foi exigido do Estado um papel mais atuante para proporcionar uma melhor distribuição de riquezas e evitar que o contrato fosse um meio para legitimar injustiças. Como destacou Ghestin, a própria visão do contrato foi alterada, de maneira que o Direito passou a tutelar sua força obrigatória apenas na medida em que se mostrasse útil e justo. Os contratos, atualmente, não são apenas instrumentos de circulação de riquezas, fundados no interesse individual. São também instrumentos de promoção dos valores sociais e éticos, consolidados pela sociedade que lhes reconhece força obrigatória.

O princípio do equilíbrio contratual leva à admissão da revisão dos contratos diante de situações de excessiva desproporção, manifestando-se em figuras expressamente previstas tanto pelo Código Civil, quanto pelo Código de Defesa do Consumidor. Quando o desequilíbrio ou desvantagem existir desde a formação do contrato, tem-se configurada a lesão contratual, pondo-se ao Direito a tarefa de estabelecer o sinalagma genético. Se, por outro lado, o desequilíbrio ocorrer durante a execução do contrato, configura-se a

\footnotetext{
${ }^{386}$ Tradução livre. Do original: «Quand quelqu'un décide quelque chose à l'égard d'un autre il est toujours possible qu'il lui fasse quelqu'injustice ; mais toute injustice est impossible dans ce qu'il décide pour luimême ». GHESTIN, J. L'utile et le juste dans les contrats. Recueil Dalloz, Sirey, 1982, Chroniques - I, A-1. ${ }^{387}$ GHESTIN, J. L'utile et le juste dans les contrats. op. cit., p. 1.

${ }^{388}$ Diz o autor: «C'est finalement la recherche, par le droit objectif, de l'utile et du juste, qui justifie la force obligatoire du contrat, et qui du même coup, en fixe les conditions et les limites, autrement dit le régime du contrat, dans son ensemble ». " Dans cette optique le juste et l'utile n'apparaissent plus comme des éléments objectifs, extérieures au contrat, et permettant de le contrôles au nom de l'intérêt général et de la justice contractuelle. Le juste et l'utile sont les fondements mêmes de la force obligatoire du contrat, d'où se déduira l'ensemble de son régime. » E acrescenta : «L'essentiel pour le droit objectif c'est de ne sanctionner que des contrats justes et utiles. Lorsque ces deux impératifs ne concordent pas, il faut, et c'est là le véritable problème législatif du contrat, préciser le domaine qui revient à l'un et à l'autre » (idem, ibidem, p. 3)
} 
onerosidade excessiva superveniente, e o sinalagma a ser restabelecido é o funcional. Nesta seção serão analisadas as situações de desequilíbrio entre as prestações, abrangidas pela lesão e pela onerosidade excessiva superveniente, que merecerão correção à luz do princípio da justiça comutativa. As situações de desigualdade extrema, geradas pela situação de vulnerabilidade de uma das partes, nas quais será necessária a atuação da justiça distributiva, serão abordadas no Capítulo seguinte.

\subsubsection{A lesão contratual}

A figura da lesão existe desde o Direito Romano, referida na Lei Segunda (286 d.c.) e na Lei Oitava (294 d.c.) ${ }^{389}$, que tratava a laesio enormis como a venda do bem imóvel por menos da metade do seu valor, que tornava possível o desfazimento do negócio. Segundo Caio Mário, “os romanistas, em geral, apresentam como fundamento a presunção de que tal venda teria sido realizada por necessidade: quem a fez, vendeu para viver, e é eqüitativo - humanum est - que obtenha a reposição do statu quo ante, porque o comprador estaria conseguindo um enriquecimento causado pela exploração daquela necessidade do co-contratante". ${ }^{390}$ Logo se vê que os requisitos para a configuração da lesão enorme eram objetivos, havendo presunção quanto aos requisitos subjetivos. $\mathrm{Na}$ Idade Média, por influência da moral cristã, surgiu a lesão enormíssima. Considerou-se que se a vantagem numa compra e venda superasse dois terços do valor justo da coisa, a lesão enorme seria insuficiente para restabelecer o statu quo ante. Para atender a essa situação mais grave, a lesão enormíssima considerava o contrato inexistente.

A figura da lesão não se confunde com a usura pecuniária. Márcio Mello Casado expõe que o termo usura, apesar de ter sua origem ligada ao uso de qualquer coisa, foi, posteriormente, ligado apenas ao usus de dinheiro. Tanto é verdade que o Decreto-Lei 22.626/1933, que estabelece limitação da taxa de juros cobrada no mútuo, foi apelidada de Lei da Usura. Assim, constata o autor que "o conceito de usura, no sistema jurídico nacional e português, está ligado à taxa de juros incidente sobre o capital mutuado (usura pecuniária)". Já a lesão "surgiu como forma de rescisão contratual, constituindo-se em

\footnotetext{
${ }^{389}$ Caio Mário da Silva Pereira concluiu que não é possível precisar exatamente a época do surgimento da lesão, apontando como período provável o século sexto, com o imperador Justiniano, por interpolação da Lei Segunda (que é a Constituição Imperial do ano 285), que instituiu a rescindibilidade do negócio lesionário em razão da eqüidade. PEREIRA, C. M. S. Lesão nos Contratos, Editora Forense, $6^{\text {a }}$ edição, p. 22.

${ }^{390}$ PEREIRA, C. M. S. Lesão nos Contratos. op. cit., p.24.
} 
conceito ligado à questão da equidade do pacto". ${ }^{391}$ A lei 1521/51, que trata dos crimes contra a economia popular, refere-se tanto à usura pecuniária (art. $4^{\circ}, a$ ), quanto à lesão $\left(\operatorname{art.} 4^{\circ}, b\right)$. Prossegue o autor concluindo: "vê-se, pois, que o conceito de lesão (ou usura real) está ligado ao lucro patrimonial envolvido no negócio jurídico estabelecido entre as partes, enquanto a noção de usura (ou usura pecuniária), fixa-se no montante de juros incidente sobre a quantia mutuada". ${ }^{392}$

No direito positivo brasileiro, pode-se identificar três espécies de lesão contratual: a) a lesão consumerista; b) a lesão especial, prevista no Código Civil; e c) a lesão usurária ou qualificada, prevista na Lei dos crimes contra a economia popular (Lei 1.521/51).

Antonio Junqueira de Azevedo, antes da edição do Código de Defesa do Consumidor, distinguia três espécies de lesão: a lesão enorme, ou lesão propriamente dita, que é aquela existente desde o direito romano, o qual se referia à venda de imóvel cujo preço fosse inferior à metade do justo, transmudando-se em lesão enormíssima durante a Idade Média, por influência da moral cristã, da qual se expandiu para outros tipos de negócio jurídico e reduziu o patamar de vantagem tolerado (essa não encontra previsão no ordenamento jurídico positivo brasileiro - esteve presente no direito brasileiro précodificado, sendo abolida pelo liberalismo individualista do Código Civil); a lesão usurária, considerada crime contra a economia popular, sendo a prevista em nosso ordenamento pela Lei $1.521 / 51$, com inspiração no $\S 138,2^{\mathrm{a}}$ alínea do BGB; e a lesão especial, atualmente prevista no art. 157 do Código Civil de 2002. Os requisitos para a caracterização dessas espécies de lesão são distintos, nas palavras do ilustre jurista:

Em todos os três, há benefício excessivo de uma das partes, em contrato oneroso, e conseqüente prejuízo da outra, mas: a) para caracterização da lesão propriamente dita, basta haver esse excesso nas vantagens; o defeito é exclusivamente objetivo (...); b) para caracterização da segunda, exige-se também uma situação de necessidade, inexperiência ou leviandade (irreflexão) de uma das partes, com dolo de aproveitamento da outra parte, isto é, com a intenção ou, pelo menos, a consciência de, com o negócio, tirar vantagem da situação; aqui, o caso mergulha na má fé, no ilícito, no crime de usura, praticado pelo contratante autor da lesão; c) finalmente, a lesão especial se limita à mesma exigência de excesso nas vantagens e desvantagens, causada pela situação de necessidade ou inexperiência de uma das partes, ao contratar, mas sem indagar da má fé ou ilicitude do comportamento da outra parte (não se cogita do dolo de aproveitamento). ${ }^{393}$

\footnotetext{
${ }^{391}$ CASADO, M. M. Proteção do Consumidor de Crédito Bancário e Financeiro. $2^{\mathrm{a}}$ edição. São Paulo: Revista dos Tribunais, 2006, p. 99.

392 Idem, ibidem, p. 100.

393 JUNQUEIRA DE AZEVEDO, A. Negócio Jurídico e Declaração Negocial, 1986, tese apresentada para o concurso de Professor Titular de Direito Civil da USP, São Paulo, p. 204 e 205.
} 
O Código de Defesa do Consumidor previu a lesão consumerista, ${ }^{394}$ que exige apenas a desproporção entre as prestações para a sua caracterização, aproximando-se, nesse aspecto, da lesão enorme do direito romano. ${ }^{395}$ Esta espécie de lesão é, portanto, chamada objetiva porque o seu único requisito é aferido em relação ao objeto do contrato, sendo que o requisito de ordem subjetiva é presumido pelo próprio enquadramento da pessoa no conceito de consumidor, reconhecidamente vulnerável pelo sistema protetivo do Código.

A figura da lesão no CDC decorre do disposto nos artigos $6^{\circ}, \mathrm{V}, 39$, V e 51, IV, que de maneiras diversas proíbem a subsistência de condições contratuais que coloquem o consumidor em desvantagem exagerada. Com efeito, o artigo $6^{\circ}, \mathrm{V}$ do $\mathrm{CDC}$ estabelece como direito básico do consumidor a modificação das cláusulas contratuais que estabeleçam prestações desproporcionais; o artigo 39, inciso V, dispõe ser vedado ao fornecedor exigir do consumidor vantagem manifestamente excessiva; e o artigo 51, inciso IV, declara nulas de pleno direito as cláusulas contratuais relativas que estabeleçam obrigações consideradas iníquas, abusivas, que coloquem o consumidor em desvantagem exagerada. Observe-se que nenhum requisito de ordem subjetiva é exigido, pois em verdade a vulnerabilidade do consumidor é presumida pela própria sistemática do Código (art. $4^{\mathrm{o}}$, inciso I). A lesão consumerista leva à nulidade da $(\mathrm{s})$ cláusula $(\mathrm{s})$ que lhe derem causa.

Já no Código Civil a lesão é tratada, no artigo 157, como vício de consentimento, sendo anulável o negócio jurídico em que ela se verificar. Essa espécie de lesão contém requisitos de ordem objetiva (manifesta desproporção entre o valor das prestações) e de ordem subjetiva, pois apesar de não exigir como requisito o dolo de aproveitamento da parte beneficiada (má-fé subjetiva), o dispositivo legal estabelece requisitos quanto à parte prejudicada, quais sejam, a premente necessidade ou a inexperiência, como pode se ver: Ocorre a lesão quando uma pessoa, sob premente necessidade, ou por inexperiência, se obriga a prestação manifestamente desproporcional ao valor da prestação oposta.

A terceira e última espécie de lesão é a usurária, tida como crime contra a economia popular. Nessa espécie de lesão, tem-se tanto o elemento objetivo, que é a obtenção de

\footnotetext{
394 O nome foi sugerido pelo próprio Professor Antônio Junqueira de Azevedo durante as aulas da pósgraduação da Universidade de São Paulo (USP).

395 Existem, entretanto, duas grandes diferenças entre a lesão consumerista e a lesão enorme: a) nesta não há qualquer alusão a requisito subjetivo; naquela o requisito subjetivo é pressuposto e decorre do reconhecimento da vulnerabilidade do consumidor no art. $1^{\circ}$ do CDC; b) esta quantificava a desproporção excessiva (metade, no direito romano, e um terço na idade média), aquela não estabelece nenhum parâmetro a priori.
} 
vantagem exagerada, quanto o elemento subjetivo, esse exigido tanto para a parte prejudicada (que tenha agido por premente necessidade, leviandade ou inexperiência), quanto para a parte beneficiada (dolo de aproveitamento - agir com má-fé subjetiva). Essa espécie de lesão, também chamada de usura real, está expressa no artigo $4^{\circ}$, 'b' da Lei 1.521/51, que prevê, ainda, um critério quantitativo para a apreciação da vantagem exagerada: a obtenção de lucro patrimonial que exceda um quinto do valor corrente ou justo da prestação.

Nas demais espécies de lesão, não há parâmetro objetivo que diga o que é vantagem exagerada, havendo apenas menção ao conceito vago de onerosidade excessiva (Art. 51, $\S 1^{\circ}$, III do CDC) ou aos valores vigentes à época da celebração do negócio (art. $157, \S 1^{\circ}$ do CC). Em virtude disso, a quantificação da onerosidade excessiva tem sido muito discutida na jurisprudência nacional. Especificamente quanto às operações de crédito, muitas já foram as posições tomadas, adotando diferentes parâmetros. Alguns acórdãos prolatados pelo Tribunal de Justiça do Rio Grande do Sul vinham aplicando o limite de $12 \%$ para evitar a onerosidade excessiva. Contudo, este entendimento na verdade burlava a regulamentação do sistema financeiro nacional, a qual não impõe limitação às taxas de juros cobradas pelas instituições financeiras.

Outras decisões aplicaram por analogia o parâmetro da Lei 1.521/51, considerando excessivamente onerosa a prestação que superasse um quinto (ou 20\%) do valor corrente ou justo da prestação. A questão agora é saber qual a base para a incidência do referido de parâmetro de um quinto. Uma primeira possibilidade, já acolhida pela jurisprudência, é considerar o lucro patrimonial obtido pela instituição financeira, e verificar se ele foi excessivamente abusivo, ou seja, se superou o patamar de um quinto (ou 20\%). Pois bem, o lucro obtido nas operações de crédito equivale à diferença entre o valor que o banco paga aos seus aplicadores (taxa de captação) e o valor que o banco cobra dos seus tomadores (taxa cobrada nas operações de crédito), que no jargão financeiro é chamado de spread. No site do Banco Central, a referência ao spread nas operações financeiras é feita em termos de diferença de taxa percentual; contudo, quando a questão é saber se o lucro patrimonial obtido é abusivo, o spread deve ser considerado em valor absoluto. Com base nisso, um precedente do Tribunal de Justiça de São Paulo considerou abusivo o spread que superou $20 \%$ das taxas de capitação da instituição financeira, aplicando subsidiariamente a norma do art. $4^{\mathrm{o}}, b$, da Lei $1.521 / 51{ }^{396}$ Contudo, a jurisprudência nacional não estabeleceu um

${ }^{396} 1^{\mathrm{o}}$ TACSP, $11^{\mathrm{a}}$ Câmara, Ap. 737.410-7. 
percentual de antemão para a quantificação da excessiva onerosidade, preferindo deixar a análise para o caso concreto.

Com relação às operações de crédito, tanto o Superior Tribunal de Justiça, quanto o Supremo Tribuna Federal, já se manifestaram no sentido de admitir o controle judicial da abusividade dos juros praticados pelas instituições financeiras, com fundamento no artigo 51, IV do CDC. Com relação ao STF, esse posicionamento pode ser observado no seguinte trecho do voto condutor do Ministro Eros Grau, no julgamento da ADI $n^{0} 2591$, que decidiu sobre a constitucionalidade da incidência do Código de Defesa do Consumidor às instituições financeiras:

Deveras, a mera e simples comparação entre o montante da chamada taxa SELIC - que, sem nenhuma dúvida, é bastante elevada, se a considerarmos em relação à praticada em outros países - e a soma da efetivamente cobrada no plano de cada negócio individualmente considerado celebrado com os tomadores de crédito evidencia ser indispensável o efetivo controle da composição dessa soma. E não apenas nas hipóteses de relação entre banco, fornecedor de crédito, e cliente, pessoa física, senão também quando se trate de pequena ou média empresa. Pois aqui se instala - e de modo pronunciado - uma relação de dominação, em cujo pólo ativo comparecem os bancos, no pólo passivo, suportando-a, o devedor. Em certos casos, autênticas situações de dependência econômica. O cliente do banco coloca-se sob os efeitos de uma relação de dominação, inclusive a que o abarca quando compelido a depositar em uma instituição financeira suas poupanças. Desejo dizer, com isso, que o Banco Central está vinculado pelo dever-poder de controlar vigorosamente a definição contratual do custo das operações ativas e da remuneração das operações passivas praticadas por instituições financeiras no desempenho da intermediação de dinheiro na economia.

Daí porque tenho como indispensável a coibição de abusos praticados quando instituições financeiras acrescentam à taxa base de juros, a chamada SELIC, taxas adicionais de serviços e outros que tais. Vale dizer: tudo quanto exceda a taxa base de juros, os percentuais que a ela são adicionados e findam por compor o spread bancário, tudo isso pode e deve ser controlado pelo Banco Central e, se o caso, pelo Poder Judiciário (grifamos). Não incide, contudo, sobre esta matéria - repito: definição do custo das operações ativas e da remuneração das operações passivas praticadas por instituições financeiras no desempenho da intermediação de dinheiro na economia - não incide, dizia eu, o micro sistema do Código de Defesa do Consumidor, mas sim o Código Civil. O fato é que tudo quanto exceda o patamar da taxa SELIC é pura relação contratual. Por óbvio, a abusividade e a onerosidade excessiva na composição contratual dessa taxa, além de outras distorções, são passíveis de revisão nos termos dos preceitos aplicáveis do Código Civil -, e, repito ainda, não somente em benefício do cliente pessoa física, mas também em especial das pequenas empresas, em relação às quais a dependência econômica pode estar francamente caracterizada. É necessário não perdermos de vista o poder do oligopólio 
constituído pelas instituições financeiras, capazes de, na multiplicação de moeda circulante em moeda escritural, produzir bem público. O que acima demonstrei, explicando os mecanismos de criação de moeda escritural e como estão constituídos os lucros das instituições financeiras, é impressionante.

O Superior Tribunal de Justiça também entende pela possibilidade do controle do abuso, o que restou pacificado no julgamento do recurso representativo $\mathrm{n}^{0}$ 1.061.530, consoante o voto da Ministra Relatora Nancy Andrighi. Leia-se: ${ }^{397}$

Fixada a premissa de que, salvo situações excepcionais, os juros remuneratórios podem ser livremente pactuados em contratos de empréstimo no âmbito do Sistema Financeiro Nacional, questiona-se a possibilidade de o Poder Judiciário exercer o controle da liberdade de convenção de taxa de juros naquelas situações que são evidentemente abusivas.

A dificuldade do tema, que envolve o controle do preço do dinheiro é enorme. Isso não é, entretanto, suficiente para revogar o art. 39, V, CDC, que veda ao fornecedor, dentre outras práticas abusivas, "exigir do consumidor vantagem manifestamente excessiva", e o art. 51, IV, do mesmo diploma, que torna nulas as cláusulas que “estabeleçam obrigações consideradas iníquas, abusivas, que coloquem o consumidor em desvantagem exagerada, ou sejam incompatíveis com a boa-fé ou a eqüidade".

As premissas básicas de solução foram lançadas no julgamento do REsp 407.097/RS, DJ de 29.09.2003, quando a $2^{\text {a }}$ Seção estava diante da cobrança de taxa de juros de $10,90 \%$ ao mês em contrato de abertura de crédito em conta corrente. Naquela oportunidade, a maioria dos Ministros manifestou o entendimento de que os juros não deveriam ser limitados, salvo em hipóteses excepcionais.

A excepcionalidade pressupunha: (i) aplicação do CDC ao contrato e (ii) taxa que comprovadamente discrepasse, de modo substancial, da média do mercado na praça do empréstimo, salvo se justificada pelo risco da operação (no mesmo sentido, vide REsp 420.111/RS, Segunda Seção, Rel. Min. Pádua Ribeiro, Rel. p. Acórdão Min. Ari Pargendler, DJ de 06.10.2003).

Acompanhando tais precedentes, os Ministros que atualmente compõem esta $2^{\text {a }}$ Seção têm admitido a possibilidade de controle dos juros manifestamente abusivos naqueles contratos que se inserem em uma relação de consumo.

\footnotetext{
397 Eis a orientação vinculante, com os efeitos do art. 543-C: "Portanto, no que diz respeito aos juros remuneratórios, a $2^{\mathrm{a}}$ Seção do STJ consolida o entendimento de que: a) As instituições financeiras não se sujeitam à limitação dos juros remuneratórios que foi estipulada na Lei de Usura (Decreto 22.626/33), como dispõe a Súmula 596STF; b) A estipulação de juros remuneratórios superiores a $12 \%$ ao ano por si só não indica abusividade; c) São inaplicáveis aos juros remuneratórios dos contratos de mútuo bancário as disposições do art. $591 \mathrm{c}$ o art. 406 do CC02; d) É admitida a revisão das taxas de juros remuneratórios em situações excepcionais, desde que caracterizada a relação de consumo e que a abusividade (capaz de colocar o consumidor em desvantagem exagerada - art. $51, \S 1^{\circ}$, do CDC) fique cabalmente demonstrada, ante às peculiaridades do caso concreto". (STJ, 2 ${ }^{\mathrm{a}}$ Seção, Resp 1.061.530/RS, Relatora Min. Nancy Andrighi, julgado em 22/10/2008, publicado DJ 10/03/2009).
} 
O Min. Aldir Passarinho Junior vem considerando "que a pactuação [dos juros] é livre entre as partes, somente se podendo falar em taxa abusiva se constatado oportunamente por prova robusta que outras instituições financeiras, nas mesmas condições, praticariam percentuais muito inferiores” (REsp 915.572RS, Quarta Turma, DJe 10.03.2008).

Por isso, o Ministro Aldir defende que essa abusividade seja demonstrada em "perícia que propicie a comparação com as taxas praticadas por outras instituições financeiras, desde que coincidentes o produto, a praça e a época da firmatura do pacto" (AgRg no REsp 935.231/RJ, Quarta Turma, DJ de 29.10.2007).

No mesmo sentido, o Min. João Otávio de Noronha tem asseverado que "a alteração da taxa de juros pactuada depende da demonstração cabal de sua abusividade em relação à taxa média do mercado" (AgRg no REsp 939.242RS, Quarta Turma, DJe de 14.04.2008).

O Min. Luis Felipe Salomão, por sua vez, afirma que "a abusividade da pactuação dos juros remuneratórios deve ser cabalmente demonstrada em cada caso, com a comprovação do desequilíbrio contratual ou de lucros excessivos, sendo insuficiente o só fato de a estipulação ultrapassar $12 \%$ ao ano ou de haver estabilidade inflacionária no período, o que não ocorreu no caso dos autos (AgRg no REsp 881.383, DJ de 27.08.2008).

Com relação à quantificação da onerosidade excessiva, o STJ não fixou um critério objetivo (um percentual ou uma fração), apenas estabelecendo que a abusividade deve ser aferida a partir da taxa média de mercado, sendo que o "valor corrente ou justo da prestação" é aquele estabelecido pelo próprio mercado. No recurso representativo em exposição, foram mencionadas diversas decisões tomadas pelo STJ que consideraram diferentes critérios de abusividade - taxa que supera o dobro da taxa de mercado, ou em situações ainda piores, em que a taxa atingiu o triplo da taxa de mercado -, sendo que nesses a taxa abusiva deverá ser substituída pela taxa de mercado. Não foi estabelecido nenhum percentual fixo, sendo que desse julgamento originou-se a súmula 382 do STJ, segundo a qual "a estipulação de juros remuneratórios a 12\% ao ano, por si só, não indica abusividade". A análise ficou para o caso concreto, como se vê:

O Min. Massami Uyeda entende ser "firme o entendimento desta augusta Corte no sentido de que, não obstante a inequívoca incidência da lei consumerista nos contratos bancários, a abusividade da pactuação dos juros remuneratórios deve ser cabalmente demonstrada em cada caso, com a comprovação do desequilíbrio contratual ou de lucros excessivos (...)” e, com base nesse argumento e na Súmula 7/STJ, já manteve acórdão que reduziu uma taxa de juros de $45,65 \%$ ao ano, em contrato de alienação fiduciária, para o patamar da taxa média de 37,42\% ao ano (REsp 1.036.857/RS, Terceira Turma, DJe de 05.08.2008). 
O Min. Sidnei Beneti reconheceu que "para o período da inadimplência, permitese o controle judicial dos juros remuneratórios, com base nas regras do Código de Defesa do Consumidor, quando ficar comprovado que o percentual cobrado destoa da taxa média do mercado para a mesma operação financeira”.

Assim, conclui o Min. Beneti que, como "o Acórdão recorrido apurou que a taxa de juros remuneratórios cobrada pela instituição financeira recorrida encontra-se acima do dobro da taxa média do mercado para a modalidade do negócio jurídico efetivado", na inadimplência, os juros deveriam variar "segundo a taxa média do mercado, para a operação de mútuo, apurada pelo Banco Central do Brasil, na forma da Circular da Diretoria $\mathrm{n}^{\circ}$ 2.957, de 28 de dezembro de 1999 (...)” (REsp 977.789/RS, Terceira Turma, DJe de 20.06.2008). Ressalte-se, para fins ilustrativos, que nessa hipótese havia dois contratos de mútuo, um com taxa de $9,9 \%$ ao mês e outro de $8,8 \%$ ao mês.

Aponta-se, ainda, precedente de minha lavra, com o qual manifestaram concordância os Min. Ari Pargendler, Massami Uyeda e Sidnei Beneti, no qual, diante de empréstimo pessoal a juros de $249,85 \%$ ao ano, superiores ao dobro da taxa média apurada pelo Banco Central, ficou estabelecido que "cabalmente demonstrada pelas instâncias ordinárias a abusividade da taxa de juros remuneratórios cobrada, deve ser feita sua redução ao patamar médio praticado pelo mercado para a respectiva modalidade contratual” (Resp 1.036.818, Terceira Turma, DJe de 20.06.2008).

Por sua importância, ainda vale mencionar a posição de alguns Ministros que não mais integram esta $2^{\text {a }}$ Seção:

O Ministro César Asfor Rocha, diante de juros remuneratórios pactuados à taxa de $34,87 \%$ ao mês contra uma taxa média, apurada por perícia, de $14,19 \%$ ao mês, entendeu que, estando "cabalmente comprovada por perícia, nas instâncias ordinárias, que a estipulação da taxa de juros remuneratórios foi aproximadamente $150 \%$ maior que a taxa média praticada no mercado, nula é a cláusula do contrato" (REsp 327.727/SP, Segunda Seção, DJ de 08.03.2004).

O Min. Pádua Ribeiro, por seu turno, constatando cobrança de taxa superior ao triplo da média (380,78\% ao ano contra $67,81 \%$ ao ano), reduziu-a para o "patamar médio praticado pelo mercado para a respectiva modalidade contratual” (REsp 971.853/RS, Quarta Turma, DJ de 24.09.2007).

O Ministro Ari Pargendler consignou que "evidentemente, pode-se, em casos concretos reconhecer a existência de juros abusivos. Por exemplo, no Agravo de Instrumento $\mathrm{n}^{\circ}$ 388.622, MG, tive ocasião de decidir que, 'se o acórdão, confortado por laudo pericial, dá conta de que os juros praticados na espécie excediam em quase $50 \%$ à taxa média de mercado, não há como fugir da conclusão de que são, mesmo, abusivos' (DJ, 10.08.2001). O tema, com certeza, é complexo, porque o risco de cada operação influi na respectiva taxa de juros. Mas o peso desse componente, e de outros, no custo do empréstimo deve, então, caso a caso, ser justificado pela instituição financeira, o juiz saberá decidir as controvérsias a propósito, se respeitar a racionalidade econômica, 
representada pelo mercado" (voto proferido no REsp 271.214RS, Rel. p. Acórdão Min. Menezes Direito, DJ de 04.08.2003; no mesmo sentido, vide REsp 420.111/RS, Segunda Seção, Rel. Min. Pádua Ribeiro, Rel. p. Acórdão Min. Ari Pargendler, DJ de 06.10.2003; REsp 1.061.512, Rel. Min. Ari Pargendler, DJ de 07.08.2008).

Logo, diante desse panorama sobre o posicionamento atual da $2^{\text {a }}$ Seção, conclui-se que é admitida a revisão das taxas de juros em situações excepcionais, desde que haja relação de consumo e que a abusividade (capaz de colocar o consumidor em desvantagem exagerada - art. 51, $\S 1^{\circ}$, do CDC) esteja cabalmente demonstrada.

Necessário tecer, ainda, algumas considerações sobre parâmetros que podem ser utilizados pelo julgador para, diante do caso concreto, perquirir a existência ou não de flagrante abusividade.

Inicialmente, destaque-se que, para este exame, a meta estipulada pelo Conselho Monetário Nacional para a Selic - taxa do Sistema Especial de Liquidação e Custódia - é insatisfatória. Ela apenas indica o menor custo, ou um dos menores custos, para a captação de recursos pelas instituições que compõem o Sistema Financeiro Nacional. Sua adoção como parâmetro de abusividade elimina o spread e não resolve as intrincadas questões inerentes ao preço do empréstimo. Por essas razões, conforme destacado, o STJ em diversos precedentes tem afastado a taxa Selic como parâmetro de limitação de juros.

Descartados índices ou taxas fixos, é razoável que os instrumentos para aferição da abusividade sejam buscados no próprio mercado financeiro.

Assim, a análise da abusividade ganhou muito quando o Banco Central do Brasil passou, em outubro de 1999, a divulgar as taxas médias, ponderadas segundo o volume de crédito concedido, para os juros praticados pelas instituições financeiras nas operações de crédito realizadas com recursos livres (conf. Circular n ${ }^{\circ} 2957$, de 30.12.1999).

As informações divulgadas por aquela autarquia, acessíveis a qualquer pessoa através da rede mundial de computadores (conforme http//www.bcb.gov.br? ?ecoimpom no quadro XLVIII da nota anexa; ou http//www.bcb.gov.br?TXCREDMES, acesso em 06.10.2008), são segregadas de acordo com o tipo de encargo (prefixado, pós-fixado, taxas flutuantes e índices de preços), com a categoria do tomador (pessoas físicas e jurídicas) e com a modalidade de empréstimo realizada ('hot money', desconto de duplicatas, desconto de notas promissórias, capital de giro, conta garantida, financiamento imobiliário, aquisição de bens, 'vendor', cheque especial, crédito pessoal, entre outros).

A taxa média apresenta vantagens porque é calculada segundo as informações prestadas por diversas instituições financeiras e, por isso, representa as forças do mercado. Ademais, traz embutida em si o custo médio das instituições financeiras e seu lucro médio, ou seja, um spread médio. É certo, ainda, que o cálculo da taxa média não é completo, na medida em que não abrange todas as modalidades de concessão de crédito, mas, sem dúvida, presta-se como parâmetro de tendência das taxas de juros. Assim, dentro do universo regulatório atual, a taxa média constitui o melhor parâmetro para a elaboração de um juízo sobre abusividade. 
Como média, não se pode exigir que todos os empréstimos sejam feitos segundo essa taxa. Se isto ocorresse, a taxa média deixaria de ser o que é, para ser um valor fixo. Há, portanto, que se admitir uma faixa razoável para a variação dos juros.

A jurisprudência, conforme registrado anteriormente, tem considerado abusivas taxas superiores a uma vez e meia (voto proferido pelo Min. Ari Pargendler no REsp 271.214/RS, Rel. p. Acórdão Min. Menezes Direito, DJ de 04.08.2003), ao dobro (Resp 1.036.818, Terceira Turma, minha relatoria, DJe de 20.06.2008) ou ao triplo (REsp 971.853/RS, Quarta Turma, Min. Pádua Ribeiro, DJ de 24.09.2007) da média.

Todavia, esta perquirição acerca da abusividade não é estanque, o que impossibilita a adoção de critérios genéricos e universais. A taxa média de mercado, divulgada pelo Banco Central, constitui um valioso referencial, mas cabe somente ao juiz, no exame das peculiaridades do caso concreto, avaliar se os juros contratados foram ou não abusivos. $^{398}$

Entende-se que, muito embora seja possível a utilização da taxa média de mercado como base para a aferição da onerosidade excessiva, a quantificação prevista na Lei 1.521/51 pode ser um parâmetro útil para o preenchimento do conceito de onerosidade excessiva, já que esta lei estabelece um limite acima do qual a obtenção de lucro pode ser tipificada como crime - desde que também seja caracterizado o dolo de aproveitamento. Assim, na esfera cível, mesmo que não haja o dolo de aproveitamento, este parâmetro poderá ser utilizado por analogia, pois se esse é o percentual acima do qual se tem caracterizado um tipo penal, pela mesma ratio iuris não deve ser admitido um lucro que supere um quinto (ou 20\%) do valor justo da prestação nas relações civis. Evidentemente, se a operação envolver um risco efetivamente demonstrado, este deve ser imputado no valor justo da prestação, e não deverá ser considerado para efeito de caracterização da onerosidade excessiva.

\subsubsection{Onerosidade excessiva em razão de fatos supervenientes}

Sempre que a dilação no tempo for elemento do contrato, ou seja, sempre que se tratar de um contrato de execução continuada ou diferida, a alteração das circunstâncias que embasaram a formulação do regulamento contratual poderá entrar em questão. Isso porque as partes estabelecem o vínculo dentro de um determinado contexto econômico e social, ou com fundamento em determinados pressupostos, e, ocorrendo uma alteração das circunstâncias até o momento da execução, o negócio poderá perder a sua função

\footnotetext{
${ }^{398}$ STJ, $2^{\text {a }}$ Seção, Resp 1.061.530/RS, Relatora Min. Nancy Andrighi, julgado em 22/10/2008, publicado DJ $10 / 03 / 2009$.
} 
econômica e social, seja por ter se tornado excessivamente oneroso, seja por ter perdido o seu sentido inicial (casos de frustração do fim), demandando a resolução do vínculo ou a alteração na forma de execução.

A primeira apreciação doutrinária do fenômeno que se tornou largamente conhecida na cultura jurídica foi a do jurista pós-glosador Bartolo de Saxoferrato, que impulsionou o nascimento do conceito da clausula rebus sic stantibus ${ }^{399}$, pela qual o cumprimento do contrato fica condicionado à permanência do estado de fato existente à época da contratação. No período que vai da metade do século XVIII à metade do século XIX, ou seja, durante o apogeu do Estado liberal e o surgimento do Código Civil de Napoleão, a cláusula rebus sic stantibus caiu no esquecimento, pois representava um perigo para os ideais da época de totalidade do ordenamento jurídico e de força obrigatória dos contratos. Após o silêncio dos juristas da iluminação, a clausula rebus sic stantibus ressurgiu em razão de necessidades práticas que se apresentaram (revoluções, crises e guerras), e sofreu diversas reformulações, seguindo duas tradições: a alemã e a francesa.

A doutrina alemã, a respeito da revisão contratual, desenvolveu-se a partir de Windscheid, que em 1850 publicou a sua teoria da pressuposição ${ }^{400}$, segundo a qual quem manifesta a vontade sob uma pressuposição - tal como quem emite uma declaração de vontade condicionada -, quer que o efeito jurídico se produza somente se ocorrer um certo estado de coisas. Se o efeito jurídico subsistir mesmo que não tenha ocorrido a pressuposição, isso não corresponderia ao verdadeiro querer do declarante. Assim, a pressuposição seria uma condição não desenvolvida, que teria como conseqüência a possibilidade de resistência ao cumprimento da obrigação pela parte prejudicada.

A teoria de Windscheid foi retomada por Paul Oertmann, que lançou a teoria da base do negócio em sentido subjetivo, definida pelo autor como sendo "a representação mental de uma das partes no momento da conclusão do negócio jurídico, conhecida em sua

\footnotetext{
399 Para aprofundar o estudo, ver em: MORAES, R. J. Cláusula Rebus sic Stantibus. São Paulo: Saraiva, 2001.

${ }^{400}$ Descreve Menezes Cordeiro que "a pressuposição, de Windscheid, corresponderia, pois, a uma relação de dependência estabelecida, pelo declarante, entre a declaração negocial e certos eventos ou estados de coisas. A sua eficácia emergeria de ser cognoscível pela outra parte. Podendo reportar-se ao desaparecimento futuro de fatos presentes na celebração ou a não concretização, no futuro, de eventos aguardados no desenrolar subseqüente da situação, a pressuposição cobriria, de fato, as hipóteses de alteração das circunstâncias na constância do contrato" (MENEZES CORDEIRO, A. M. R. Da Boa Fé no Direito Civil, op. cit., p. 970971). Para Menezes Cordeiro, a teoria da pressuposição deve ser criticada em dois pontos: primeiro por fundamentar o sistema na vontade humana (se bem que este era o dogma da época) e pela "delimitação periférica pré-operada" (pela representação mental de uma parte passível de ser conhecida pela outra), pois isto "deixa sem resposta todas as hipóteses - e muitas serão - em que a alteração sobreveio em áreas de tal modo inesperadas que, sobre elas, não houve representação alguma de qualquer das partes” (MENEZES CORDEIRO, A. M. R. Da Boa Fé... op. cit., p. 978-980).
} 
totalidade e não rechaçada pela outra parte, ou a comum representação das diversas partes sobre a existência ou aparição de certas circunstâncias, nas quais se embasa a vontade negocial". ${ }^{401}$ Se não existem essas circunstâncias, ou se desaparecem posteriormente, sem se ter assumido o risco do desaparecimento, a parte prejudicada teria o direito de resolver o contrato. $^{402}$

A teoria da base de Oertmann recebeu várias críticas, sendo a principal delas a formulada por Karl Larenz, ${ }^{403}$ que propôs como solução a divisão da base negocial em subjetiva, que se refere aos motivos, devendo ser juridicamente concebida dentro da teoria do erro sobre os motivos; e objetiva que se refere à impossibilidade de realizar o fim do contrato ou à destruição da relação de equivalência entre as prestações, devendo ser regulada de forma diversa, com fundamento na alteração das circunstâncias. ${ }^{404}$ Nos casos de destruição da equivalência, a parte prejudicada poderá resolver o contrato - a menos que a outra parte disponha-se a oferecer aumento da contraprestação -, ou denunciar o contrato de longa duração. ${ }^{405}$ Nos casos de frustração do fim, o credor poderá rechaçar a prestação que se tornou inútil e negar-se a realizar sua contraprestação, desde que indenize os gastos que a outra parte tenha realizado. ${ }^{406}$

Em recente reforma (2002), o Código Civil Alemão (BGB) disciplinou o que já

401 OERTMANN. Geschäftsgrundlage, apud LARENZ, K. Base del Negocio Jurídico y Cumplimiento del Contrato. Madrid: Editorial Revista del Derecho Privado, 1956. p. 7

402 Oertmann procurou esquivar-se das críticas formuladas a Windscheid, argumentando que a base do negócio se diferenciava dos motivos, pois esses são unilaterais, e apenas por coincidência são partilhados pelas partes; já os fundamentos (ou base) do negócio são comuns a ambas as partes, reportando-se ao contrato como um todo. De qualquer forma, era fundamental que houvesse a representação mental, seja de uma das partes, conhecida e não refutada pela outra, ou de ambas as partes, daí porque se trata da base subjetiva do negócio. (OERTMANN. Geschäftsgrundlage, apud, MENEZES CORDEIRO, A. M. R. Da Boa Fé... op. cit., p. 1033).

${ }^{403}$ Larenz formula sua crítica nos seguintes termos: "1) La teoría de Oertmann es muy amplia. Si se aplica integramente, debe admitirse la desaparición de la base del negocio en numerosos casos en los cuales no se ha logrado el propósito de utilización del cliente, que el fabricante o proveedor nunca hizo suyo, aunque le fuera comunicado. Cada parte, sin embargo, debe soportar el riesgo de la frustración de su particular propósito subjetivo; la fórmula de Oertmann no responde a este reparto del riesgo exigido por motivos de seguridad contractual. 2) Pero la teoría de Oertmann es también muy limitada. Se ocupa de lo que las partes se han representado, no de lo que es necesario objetivamente para la consecución de la finalidad contractual común a ambas. Esta cuestión de la finalidad contractual común a ambas. Esta cuestión debe ser examinada en numerosos casos. Son estos casos aquellos que las teorías de Krückmann y Locher tienen preferentemente en cuenta". (LARENZ, K. Base del Negocio Jurídico y Cumplimiento del Contrato, cit., p. 20)

404 “La expresión 'base del negocio' puede ser entendida, y así lo ha sido, en un doble sentido. En primer lugar, como la base 'subjetiva' de la determinación de la voluntad de una o ambas partes, como una representación mental existente al concluir el negocio que ha influído grandemente en la formación de los motivos. En segundo lugar, como la base 'objetiva' del contrato (en cuanto complejo de sentido inteligible), o sea, como el conjunto de circunstancias cuya existencia o persistencia presupone debidamente el contrato sépanlo o no los contratantes -, ya que, de no ser así, no se lograría el fin del contrato, el propósito de las partes contratantes y la subsistencia del contrato no tendría 'sentido, fin u objeto"'. (LARENZ, K. Base del Negocio Jurídico..., op. cit., p. 37)

${ }^{405}$ LARENZ, K. Base del Negocio Jurídico y Cumplimiento del Contrato, cit., p. 38 e 39.

${ }^{406}$ Idem, ibidem, p. 225-226. 
vinha sendo discutido pela doutrina e decidido pela jurisprudência a respeito das conseqüências da impossibilidade na execução da prestação $\left(\S 275^{407}\right)$ e da alteração das circunstâncias $\left(\$ 313^{408}\right)$ e no adimplemento dos contratos. As hipóteses relativas à impossibilidade foram alargadas, admitindo-se não apenas a impossibilidade absoluta ou objetiva, mas também a relativa ou subjetiva (impossibilidade para o devedor). ${ }^{409}$

Menezes Cordeiro alerta para o fato de que o novo $\S 313$ do BGB consagrou a teoria da base do negócio nos seus dois sentidos (base objetiva e base subjetiva), conferindo-lhes tratamento idêntico. De fato, o dispositivo descreve duas figuras de perturbação das circunstâncias: a) alteração subseqüente das circunstâncias (§ 313, I) - esta o que a doutrina chamava de base objetiva; b) carência inicial de circunstâncias basilares $(\S 313, \mathrm{II})$ - o que a doutrina chamava de base subjetiva, e que era tradicionalmente tratada no âmbito da formação da vontade, referente ao erro sobre os motivos. Percebe-se, ainda, pela redação do $n^{0}$ I que não há uma exigência de que a alteração das circunstâncias incida sobre a prestação do negócio. A noção é ampla, e inclui quaisquer circunstâncias que constituíram a base do negócio e que venham a ser alteradas. Uma última observação é que o § 313, III acaba por aproximar os institutos da alteração das circunstâncias com a impossibilidade ao prever a hipótese de que o contrato de qualquer forma "surja inexigível para uma das partes". Segundo Menezes Cordeiro, "o cerne da modificação do contrato é

\footnotetext{
407 Tradução livre do inglês: “§ 275 - Exclusão do dever de prestar. (1) A exigibilidade da prestação é excluída quando o cumprimento for impossível para o devedor ou para qualquer outra pessoa. (2) O devedor pode recusar o cumprimento da prestação sempre que isso requeira despesas e esforços que, levando em consideração o conteúdo da obrigação e o requisito da boa-fé, estejam excessivamente desproporcionais em relação ao interesse do credor. Na determinação de quais esforços podem ser razoavelmente requeridos do devedor, deve ser levado em consideração se ele é responsável pelo obstáculo no cumprimento. (3) $\mathrm{O}$ devedor pode também recusar o cumprimento se tiver que executar a prestação pessoalmente e, quando o seu obstáculo é ponderado em relação ao interesse do credor no cumprimento, este não pode ser razoavelmente exigido do devedor".

408 Tradução livre do inglês: “\$313. (1) Quando, depois da conclusão contratual, as circunstâncias que constituíram a base do contrato se tenham consideravelmente alterado e quando as partes, se tivessem previsto esta alteração, não o tivessem concluído ou o tivessem feito com outro conteúdo, pode ser exigida a adaptação do contrato, e em especial a repartição contratual ou legal do risco, não possa ser exigível a manutenção inalterada do contrato; (2) Também se verifica a alteração das circunstâncias quando representações essenciais que tenham sido base do contrato se revelem falsas; (3) Quando uma modificação do contrato não seja possível ou surja inexigível para uma das partes, pode a parte prejudicada resolver o contrato. Nas obrigações duradouras, em vez do direito de resolução tem lugar o direito de denúncia."

${ }^{409}$ Káren Bertoncello, comentando as lições de Francesco Paolo Traisci sobre as alterações no BGB, expõe que a disciplina das conseqüências da impossibilidade foi modificada "no sentido da ampliação do âmbito de incidência do instituto da Unmöglichkeit, estabelecido no $§ 275$ do BGB", resultando "menor a diferença entre a impossibilidade objetiva e a impossibilidade subjetiva, com que precedentemente era caracterizada a disciplina do adimplemento, de modo que, com a entrada em vigor da reforma, a posição do credor veio a sofrer uma piora". (TRAISCI, F. P. Sopravvenienze contratuali e rinegoziazione nei sistemi di civil e di comon law. Napoli: Edizioni Scientifiche Italiane, 2003, p. 98 apud BERTONCELLO... p. 77-78).
} 
constituído pela exigibilidade, às partes, da alteração encarada, tendo em conta o regime do risco". 410

Na França, devido a forte influência do liberalismo no Direito Civil, as Cortes civis resistiram fortemente à aceitação de uma hipótese em que o contrato poderia deixar de ser cumprido. Tal resistência foi demonstrada nas célebres decisões do Canal de Crappone (1876) e do arrendamento de gado (1921). Contudo, relata Renato José de Moraes que "enquanto as cortes civis francesas, ao menos nominalmente, opõem-se à teoria da imprevisão, a jurisprudência administrativa admite-a a fim de reequilibrar os contratos de concessão de serviço público que se tornaram excessivamente onerosos para as concessionárias" ${ }^{411}$ Foi assim, no âmbito do Direito Administrativo, no qual se reconhecia um papel de destaque para o interesse público, que surgiu a teoria da imprevisão, a qual permitia a revisão do contrato de execução continuada nos casos em que eventos supervenientes, imprevisíveis e extraordinários, tornassem as prestações de uma das partes excessivamente onerosa. No âmbito das relações civis, em razão das Guerras Mundiais e de graves crises financeiras, os casos que demandavam revisão contratual foram solucionados pela superveniência de leis especiais, e até os dias de hoje há resistência em aplicar a teoria da imprevisão no âmbito civil, preferindo-se a solução legislativa, inclusive nos casos de proteção da parte mais fraca. ${ }^{412}$

Seguindo a linha da teoria da imprevisão francesa, o Código Civil italiano de 1942 adotou a teoria da onerosidade excessiva nos artigos 1467 a 1469. O artigo 1467 permite a resolução do contrato bilateral de execução periódica ou diferida se, em razão de eventos extraordinários e imprevisiveis, a prestação de uma das partes tornasse-se excessivamente onerosa. ${ }^{413}$ Já o artigo $1468^{414}$ dispõe sobre os contratos em que há obrigações de uma só das partes, permitindo a redução da prestação ou modificação na forma de execução para

\footnotetext{
${ }^{410}$ MENEZES CORDEIRO, A. M. R. Modernização do Direito Civil, vol. I, Coimbra: Almedina, 2004, p. 115-116.

${ }^{411}$ MORAES, R. J. Cláusula Rebus sic Stantibus. op. cit., p. 76 e 77

412 Por exemplo, Lei Failliot, de 21 de janeiro de 1918 - após $1^{\text {a }}$ Guerra Mundial, e Lei de 22 de abril de 1949 - após a $2^{\mathrm{a}}$ Guerra Mundial.

413 Do original: Art. 1467 Contratto con prestazioni corrispettive. Nei contratti a esecuzione continuata o periodica ovvero a esecuzione differita, se la prestazione di una delle parti è divenuta eccessivamente onerosa per il verificarsi di avvenimenti straordinari e imprevedibili, la parte che deve tale prestazione può domandare la risoluzione del contratto, con gli effetti stabiliti dall'art. 1458 (att. 168). La risoluzione non può essere domandata se la sopravvenuta onerosità rientra nell'alea normale del contratto. La parte contro la quale è domandata la risoluzione può evitarla offrendo di modificare equamente le condizioni del contratto ( 962 , 1623, 1664, 1923).

${ }^{414}$ Do original: Art. 1468 Contratto con obbligazioni di una sola parte. Nell'ipotesi prevista dall'articolo precedente, se si tratta di un contratto nel quale una sola delle parti ha assunto obbligazioni, questa può chiedere una riduzione della sua prestazione ovvero una modificazione nelle modalità di esecuzione, sufficienti per ricondurla ad equità.
} 
conduzir o contrato à equidade. Por fim, o artigo 1469 dispõe sobre a impossibilidade de aplicação dessas regras aos contratos aleatórios.

No Direito brasileiro, até a edição do Código de Defesa do Consumidor, a única possibilidade de revisão contratual conhecida era pela aplicação da teoria da imprevisão, proveniente do direito administrativo francês, sendo ainda comum a referência à cláusula rebus sic stantibus. ${ }^{415}$ Assim como na França, tal teoria tinha maior aplicabilidade nos contratos de direito administrativo, para a manutenção do equilíbrio econômico financeiro das concessões de serviços públicos. Contudo, de forma não sistemática, a teoria também era alegada na esfera cível, mas não teve ampla adesão na jurisprudência.

O Código de Defesa do Consumidor surgiu como diploma protetivo de pessoas presumidamente vulneráveis no mercado de consumo, prevendo a hipótese de revisão do contrato por onerosidade excessiva superveniente, para impedir que o vínculo obrigacional tornasse-se fonte de injustiça e desigualdade. Nesse sentido é que a segunda parte do inciso $\mathrm{V}$ do artigo $6^{\circ}$ estabelece como direito básico do consumidor a revisão das cláusulas contratuais que "estabeleçam prestações desproporcionais em razão de fatos supervenientes que as tornem excessivamente onerosas". Note-se que o diploma consumerista não exige que o fato superveniente seja imprevisível, de forma que a simples ocorrência de fato posterior à contratação que torne a prestação excessivamente onerosa é suficiente para ensejar a revisão contratual. Nesse sentido, leia-se, por exemplo, a lição de Cláudia Lima Marques:

A norma do art. $6^{\circ}$ do CDC avança ao não exigir que o fato superveniente seja imprevisível ou irresistível, apenas exige a quebra da base objetiva do negócio, a quebra de seu equilíbrio intrínseco, a destruição da relação de equivalência entre prestações, o desaparecimento do fim essencial do contrato. Em outras palavras, o elemento autorizador da ação modificadora do Judiciário é o resultado objetivo da engenharia contratual, que agora apresenta a mencionada onerosidade excessiva para o consumidor, resultado de simples fato superveniente, fato que não necessita ser extraordinário, irresistível, fato que podia ser previsto e não foi. ${ }^{416}$

Pelo fato da norma do Código de Defesa do Consumidor não exigir o elemento previsibilidade, que é essencial na teoria da imprevisão, muitos doutrinadores entenderam que o dispositivo legal teria inspiração na teoria alemã da quebra da base objetiva do contrato. Contudo, mesmo para Larenz o elemento previsibilidade era necessário, pois todos os fatos previsíveis fariam parte do risco do negócio, portanto da sua base, sendo que uma alteração desses fatos não poderia ser capaz de romper com a base objetiva do

\footnotetext{
415 JUNQUEIRA DE AZEVEDO, A. Relatório brasileiro sobre revisão contratual... op. cit., p. 189.
}

${ }^{416}$ MARQUES, C. L. Contratos no Código de Defesa do Consumidor, op. cit., p. 916. 
negócio ${ }^{417}$. O CDC é uma legislação que surgiu para resolver um problema de desigualdade próprio de uma sociedade de massas, em que os contratos são padronizados, com cláusulas predispostas pelo fornecedor e que, por isso, favorecem o cometimento de abusos. Além disso, é confessa a intenção do Código de proteger a parte mais fraca na relação de consumo, daí porque se justifica um tratamento diferenciado, situação que não foi considerada pelo jurista alemão. Portanto, o mais correto seria dizer que basta a verificação da onerosidade excessiva para que seja possível a revisão pelo CDC, o qual tem em conta a condição de vulnerabilidade do contratante que visa proteger, e por isso seus requisitos são tanto objetivos quanto subjetivos - já que considera a qualidade da parte para efeito de proteção legal - sem qualquer menção à previsibilidade do fato.

Questão muito decidida pelos Tribunais brasileiros, em que se aplicou o art. $6^{\circ}, \mathrm{V}$ do CDC, foi a relativa aos contratos de arrendamento mercantil com correção vinculada à variação cambial, que em razão da alta do dólar norte-americano em janeiro de 1999 se tornaram excessivamente onerosos para os consumidores. Inicialmente o Superior Tribunal de Justiça reconheceu o direito à revisão pelo consumidor, determinando a substituição da correção pela variação cambial por um índice que melhor refletisse a inflação. ${ }^{418}$ Entretanto, o STJ mudou seu entendimento, passando a determinar a repartição do ônus da valorização cambial entre consumidores e instituições financeiras. Essa decisão, que deixou de aplicar integralmente a norma protetiva do CDC, foi proferida sob o fundamento da eqüidade, ao argumento de que seria muito gravoso ao arrendatário arcar integralmente com o risco contratual. ${ }^{419}$

\footnotetext{
${ }^{417}$ LARENZ, K. Base del Negocio Jurídico y Cumplimiento del Contrato, cit., p. 226.

418 "Revisão de contrato - Arrendamento mercantil (leasing) - Relação de consumo - Indexação em moeda estrangeira (dólar) - Crise cambial de janeiro de 1999 - Plano real. Aplicabilidade do art. 6, inciso V do CDC - Onerosidade excessiva caracterizada. Boa-fé objetiva do consumidor e direito de informação. Necessidade de prova da captação de recurso financeiro proveniente do exterior. O preceito insculpido no inciso $\mathrm{V}$ do artigo $6^{\circ}$ do CDC dispensa a prova do caráter imprevisível do fato superveniente, bastando a demonstração objetiva da excessiva onerosidade advinda para o consumidor. A desvalorização da moeda nacional frente à moeda estrangeira que serviu de parâmetro ao reajuste contratual, por ocasião da crise cambial de janeiro de 1999, apresentou grau expressivo de oscilação, a ponto de caracterizar a onerosidade excessiva que impede o devedor de solver as obrigações pactuadas. A equação econômico-financeira deixa de ser respeitada quando o valor da parcela mensal sofre um reajuste que não é acompanhado pela correspondente valorização do bem da vida no mercado, havendo quebra da paridade contratual, à medida que apenas a instituição financeira está assegurada quanto aos riscos da variação cambial, pela prestação do consumidor indexada em dólar americano. (...)" (STJ, 3 ${ }^{\mathrm{a}}$ T., REsp. no 168661/RJ, rel. Min. Nancy Andrighi, in DJU de 24.09.2001, p. 296).

${ }^{419}$ Leia-se a seguinte ementa: "LEASING. Variação cambial. Fato superveniente. Onerosidade excessiva. Distribuição dos efeitos. A brusca alteração da política cambial do governo, elevando o valor das prestações mensais dos contratos de longa duração, como o leasing, constitui fato superveniente que deve ser ponderado pelo juiz para modificar o contrato e repartir entre os contratantes os efeitos do fato novo. Com isso, nem se mantém a cláusula da variação cambial em sua inteireza, porque seria muito gravoso ao arrendatário, nem se a substitui por outro índice interno de correção, porque oneraria demasiadamente o arrendador que obteve recurso externo, mas se permite a atualização pela variação cambial, cuja diferença é cobrável do
} 
No Código Civil, os artigos 317, 478, 479 e 480 prevêem mecanismos de manutenção do equilíbrio contratual em razão de fatos supervenientes que tornem as prestações excessivamente onerosas, mas neste diploma as hipóteses de revisão ou de resolução estão ligadas à teoria da imprevisão, exigindo-se que esses fatos sejam imprevisíveis e extraordinários. A exceção do primeiro artigo, os demais tiveram clara inspiração no Código Civil italiano, que contém disposições praticamente idênticas nos artigos 1467 e 1468 .

O artigo 478 do Código Civil $^{420}$ estabelece a possibilidade de resolução do contrato quando ocorrer a excessiva onerosidade uma vez verificados os seguintes requisitos: 1) a existência de um lapso temporal entre o momento da conclusão do contrato e da execução da prestação, o que ocorre nos contratos de execução diferida, de trato sucessivo ou de execução continuada; 2) a ocorrência de fatos extraordinários e imprevisíveis; 3) que esses fatos provoquem uma alteração das circunstâncias que torne a prestação excessivamente onerosa para uma das partes, com extrema vantagem para a outra parte, sendo que este último requisito de extrema vantagem é inovação da lei brasileira, considerando o direito comparado, que tende a ser afastado sob pena de tornar inoperante o dispositivo legal. A excessiva onerosidade é aferida no confronto entre prestação e contraprestação, muito embora o artigo não contenha a epígrafe do similar italiano, que se refere expressamente aos "contratos com prestações correspectivas". 421

arrendatário por metade. Não examinados os temas relacionados com a prova de aplicação de recursos oriundos do exterior e com a eventual operação de hedge. Recurso conhecido em parte e parcialmente provido. (STJ - 4 ${ }^{\mathrm{a}}$ Turma, REsp 401021/ES, Relator p/ Acórdão Ministro RUY ROSADO DE AGUIAR, DJ 22.09.2003 p. 331). E também: "Índice de reajuste repartido, a partir de 19.01.99 inclusive, eqüitativamente, pela metade, entre as partes contratantes, mantida a higidez legal da cláusula, decotado, tão somente, o excesso que tornava insuportável ao devedor o adimplemento da obrigação, evitando-se, de outro lado, a total transferência dos ônus ao credor, igualmente prejudicado pelo fato econômico ocorrido e também alheio à sua vontade". (STJ, Segunda Seção, REsp 472594/SP, Relator p/ Acórdão Ministro ALDIR PASSARINHO JUNIOR, DJ 04/08/2003).

${ }^{420}$ Art. 478. Nos contratos de execução continuada ou diferida, se a prestação de uma das partes tornar-se excessivamente onerosa, com extrema vantagem para a outra, em virtude de acontecimentos extraordinários e imprevisíveis, poderá o devedor pedir a resolução do contrato. Os efeitos da sentença que a decretar retroagirão à data da citação.

${ }^{421}$ Questão controvertida é a possibilidade de alargar-se a interpretação deste artigo para permitir a revisão contratual, e não apenas a resolução da avença. Pela letra da lei, somente seria possível a "revisão" do contrato, evitando-se a resolução, se a outra parte oferecer-se para modificar as condições do contrato, nos termos do artigo 479 do Código. Os autores que defendem esta possibilidade fundamentam-na, sobretudo, nos princípios da função social do contrato, da boa-fé objetiva e da conservação dos contratos. Nelson Rosenvald salienta que "o princípio da conservação do negócio jurídico demanda que o ordenamento produza normas hábeis a preservar as relações obrigacionais e apenas em última instância desfazê-las". Ademais, entende que "as cláusulas gerais da função social do contrato e da boa-fé objetiva (arts. 421 e 422 do CC) recepcionam o princípio constitucional da solidariedade (art. $3^{\circ}$, I), indicando a inafastável cooperação nas relações privadas, para que o contrato possa alcançar a finalidade para a qual foi desenhado e não simplesmente resolvido" (ROSENVALD, N. Comentário ao artigo 478. In PELUSO Cezar (coord.), Código Civil Comentado, $3^{\mathrm{a}}$ edição, Barueri: editora Manole, 2009, p. 514 e 515). Essa mesma posição é 
O artigo 317 do Código Civil encontra-se topograficamente no Capítulo do Código Civil relativo ao pagamento, tendo aplicabilidade tanto com relação às dívidas de dinheiro, em que a revisão objetiva a reposição do valor da moeda, quanto às dívidas de valor, caso em que a revisão reporá o valor econômico de troca. ${ }^{422}$ Essa hipótese de revisão tem como requisitos: 1) o lapso temporal entre o momento da conclusão do contrato e da execução da prestação; 2) desproporção manifesta entre o valor da prestação devida e do momento da sua execução; 3) a ocorrência de motivos imprevisíveis. Trata-se de uma hipótese mais restrita, pois a atividade do juiz se limitará a corrigir o valor da prestação, de forma a assegurar o seu valor real.

Por fim, o artigo 480 do Código Civil prevê a possibilidade de revisão por onerosidade excessiva naqueles contratos em que as obrigações couberem a apenas uma das partes, ou seja, nos contratos unilaterais - tais como o mútuo e o comodato. Neste caso, tendo em vista a inexistência de contraprestação, a onerosidade não é aferida no confronto entre prestação e contraprestação. Como afirma Tepedino, "a rigor, não se pode falar aqui em desequilíbrio entre prestações correspectivas - porque tal correspectividade não existe -, mas em um ‘desequilíbrio' entre a obrigação que fora originalmente projetada pelo devedor e a sua configuração no momento em que o respectivo cumprimento se tornou devido". ${ }^{423}$ Observe-se, ainda, que não se trata de um caso de resolução do contrato, pois essa medida só faz sentido quando subsistem obrigações para ambas as partes, mas sim, de revisão da prestação - redução ou modificação da forma de execução - para evitar a onerosidade excessiva.

Dentre os artigos do Código Civil que possibilitam a implementação da justiça contratual, este artigo 480 é bastante promissor, apesar de pouco comentado, pois permite tanto a redução da prestação, quanto a modificação na sua forma de execução, "a fim de evitar a onerosidade excessiva", sem se referir ao desequilíbrio entre as prestações, já que a prestação está a cargo de uma só das partes. Dessa forma, sob a ótica da proteção da parte mais fraca, conforme será analisado na seção 1.4, abre-se a possibilidade de confrontar a prestação com a alteração de circunstâncias relativas à pessoa do devedor, e assim permitir a revisão da forma de execução para evitar a onerosidade excessiva.

encontrada em Tepedino, Barbosa e Moraes (TEPEDINO, G.; BARBOZA, H. H. e MORAES, M. C. B. (coords.), Código Civil Interpretado Conforme a Constituição da República, vol. II, Rio de Janeiro, Renovar, 2006, p. 131). Contudo, para os problemas apresentados nesse trabalho, será preferível a aplicação do art. $6^{\circ}$ do CDC, que abrange um maior número de situações, por não exigir a extraordinariedade e a imprevisibilidade. Daí porque não se enfrentará essa polêmica.

${ }^{422}$ Nesse sentido é a manifestação de Antonio Junqueira de Azevedo, no seu "Relatório brasileiro sobre revisão contratual" (op. cit., p. 187).

${ }^{423}$ TEPEDINO, G.; BARBOZA, H. H. e MORAES, M. C. B. op. cit., p. 134. 


\section{Seção 1.3 - A função social do contrato}

Outra manifestação dos valores sociais no Direito Privado está na consagração do princípio da função social dos contratos pelo Código Civil de 2002, o qual, no seu artigo 421, estabelece que "a liberdade de contratar será exercida em razão e nos limites da função social do contrato". A introdução deste dispositivo reflete a ótica de socialidade e eticidade que orientou a elaboração do novo Código Civil.

A linguagem utilizada reflete a mais fundamental importância da função social dos contratos: trata-se do próprio fundamento de vinculatividade dos atos de autonomia privada. ${ }^{424}$ A vontade das partes, que no liberalismo exercia papel absoluto como fonte das obrigações, foi cedendo lugar a outras fontes decorrentes da ordem jurídica (normas de ordem pública e princípios gerais), o que levou alguns autores a afirmar que "a ordem jurídica é que, em última análise, reconhece a autonomia privada, é ela, pois, que pode impor limites a esta autonomia". 425

Contudo, ao se reconhecer a função social como a própria razão de ser dos contratos, prestigia-se outra vertente doutrinária, segundo a qual o negócio jurídico é fato social $^{426}$, retirando sua força obrigatória do reconhecimento social, ${ }^{427}$ de sua utilidade e da necessidade de tutelar-se a confiança nas relações intersubjetivas, tal como expressa Fernando Noronha:

O interesse primacial da questão do fundamento da vinculatividade do contrato consiste em mostrar que este não obriga propriamente porque tenha sido "querido", porque fundamentalmente se deva dar relevância à vontade livre das partes (liberdade contratual), mas basicamente porque é necessário, do ponto de vista social, tutelar a confiança dos agentes econômicos e, com essa finalidade, do ponto de vista jurídico, garantir segurança

\footnotetext{
424 É essa a abordagem de Fernando Noronha, que analisa a função social como fundamento da vinculatividade do contrato (NORONHA, F. op. cit., p.81 e segs.)

${ }^{425}$ MARQUES, C. L. op. cit. p. 212

${ }^{426}$ Antonio Junqueira de Azevedo, já nas primeiras linhas de sua obra sobre negócio jurídico, esclarece que a essência do negócio jurídico está na sua criação pela sociedade: "O negócio jurídico é uma criação do povo. Ele é, antes de mais nada, um fato social. Não o direito posto, o direito formalmente constituído pelo Estado legislador, que cria o negócio jurídico. Não é ele, também, uma construção teórica, doutrinária, realizada, através de progressiva abstração, por grandes juristas;...” (JUNQUEIRA DE AZEVEDO, A. Negócio Jurídico e Declaração Negocial - noções gerais e formação da declaração negocial. Tese apresentada para o concurso de Professor Titular de Direito Civil da USP, 1986, p. 3)

${ }^{427}$ Emilio Betti foi quem primeiro identificou a essência do negócio jurídico "na autonomia, no autoregulamento de interesses nas relações privadas, como fato social". Esclarece Fernando Noronha que Betti “criticou a própria expressão 'declaração de vontade', por traduzir um individualismo ultrapassado e não revelar a verdadeira natureza do negócio jurídico, que é 'fato social', 'manifestação da autonomia privada na vida de relação' (p. 113), fato este a não ser confundido nem com fato psíquico interno da vontade, nem com fato material da declaração" (BETTI, E. Teoria Geral do Negócio Jurídico, Coimbra ed., 1969, t. 1, p. 85 e segs. apud NORONHA, F. O Direito dos Contratos..., op. cit., p. 89).
} 
ao negócio celebrado. Como fato social, o negócio é instrumento fundamental de produção e distribuição de riqueza. ${ }^{428}$

Essa abordagem também é feita por Jacques Ghestin, para quem a força obrigatória dos contratos está na justiça e na utilidade reconhecidos pela sociedade, que são o próprio fundamento dos contratos, e não apenas mecanismos externos que permitem o controle do seu conteúdo em razão do interesse geral. ${ }^{429}$ Dessa forma, o direito apenas deve tutelar os contratos na medida em que se mostrarem úteis e justos, nas palavras do jurista francês: "o contrato apenas é obrigatório porque é útil e à condição de ser justo, quer dizer, conforme à justiça contratual". 430

Também Luis Renato Ferreira da Silva, ao dissertar sobre a funcionalização dos institutos jurídicos, corrobora com a idéia de que quando o contrato não estiver cumprindo com o seu papel social, dele não se podem extrair pretensões juridicamente tuteláveis, esclarecendo que "ao supor-se que um determinado instituto jurídico esteja funcionalizado, atribui-se a ele uma determinada finalidade a ser cumprida, restando estabelecido pela ordem jurídica que há uma relação de dependência entre o reconhecimento jurídico do instituto e o cumprimento da função". 431

Dessa forma, a determinação legal para que as partes exerçam a liberdade de contratar "em razão e nos limites da função social" significa que o contrato deve estar inserido harmonicamente na ordem social, preservando os valores eleitos pelo ordenamento jurídico como fundamentais para a sociedade. A dificuldade está em que o Código não esclarece o que entende por função social do contrato, nem mesmo quais são os mecanismos para efetivá-la e é nisso que se debatem os autores na atualidade. ${ }^{432}$ É preciso compreender melhor o que é, no contexto social e jurídico brasileiro, essa função social do contrato, para que seja possível identificar até que ponto um ato de autonomia privada será merecedor de tutela jurídica. Quais são os objetivos perseguidos pela sociedade brasileira, e reconhecidos pelo ordenamento jurídico, que constituem o conteúdo desse conceito indeterminado da função social do contrato?

\footnotetext{
${ }^{428}$ NORONHA, F. O Direito dos Contratos e seus Principios Fundamentais, op. cit., p. 82.

${ }^{429}$ «Le juste et l'utile sont les fondements mêmes de la force obligatoire du contrat » (...) «L'essentiel pour le droit objectif c'est de ne sanctionner que des contrats justes et utiles. Lorsque ces deux impératifs ne concordent pas, il faut, et c'est là le véritable problème législatif du contrat, préciser le domaine qui revient à l'un et à l'autre » (GHESTIN, J. L'utile et le juste dans les contrats. Recueil Dalloz, Sirey, 1982, Chroniques $-\mathrm{I}, \mathrm{A}-3)$

${ }^{430}$ Do original : « le contrat n'est obligatoire que parce qu'il est utile et à la condition d'être juste, c'est-àdire conforme à la justice contratuelle» (GHESTIN, J. L'utile et le juste dans les contrats. op. cit., p. 7).

${ }^{431}$ FERREIRA DA SILVA, L. R. A função social do contrato no novo Código Civil e sua conexão com a solidariedade social. In SARLET, I. W. (org.). O novo Código Civil e a Constituição. Porto Alegre: Livraria do Advogado, 2003. p. 134.

${ }^{432}$ FERREIRA DA SILVA, L. R. op. cit., p. 134.
} 
Numa análise eminentemente jurídica, é a própria Constituição Federal que confere os contornos do exercício da autonomia privada, ao eleger como fundamentos da República Federativa do Brasil a dignidade da pessoa humana e os valores sociais do trabalho e da livre iniciativa (art. $1^{\circ}$, incisos III e IV), tendo como objetivo construir uma sociedade livre, justa e solidária (art. $3^{\circ}$, I) e a promoção do bem de todos (art. $3^{\circ}$, IV), sendo que dentre os princípios da ordem econômica estão a busca pela existência digna de todos, segundo os ditames da justiça social (art. 170, caput).

Nesse sentido, conhecida é a lição de Antônio Junqueira de Azevedo, para quem o princípio da função social dos contratos é "preceito destinado a integrar os contratos numa ordem social harmônica”, afirmando, ainda, que:

A idéia de função social do contrato está claramente determinada pela Constituição, ao fixar, como um dos fundamentos da República, o valor social da livre iniciativa (art. $1^{\circ}$, inciso IV); essa disposição impõe, ao jurista, a proibição de ver o contrato como átomo, algo que somente interessa às partes, desvinculado de tudo o mais. O contrato, qualquer contrato, tem importância para toda a sociedade e essa asserção, por força da Constituição, faz parte, hoje, do ordenamento positivo brasileiro - de resto, o art. 170, caput, da Constituição da República, de novo, salienta o valor geral, para a ordem econômica, da livre iniciativa. ${ }^{433}$

Sintetizando essa questão, Cláudio Luiz Bueno de Godoy conclui ser este o contorno primeiro, genérico e básico da função social do contrato: "sua relevância está, antes de tudo, na promoção daqueles objetivos do Estado Social, na eficácia dos valores básicos do ordenamento, repita-se, o que, em nossa Constituição, constitui preceito expresso, a colocar a discussão fora de qualquer contexto que não seja jurídico, que seja puramente ideológico e, por isso, necessariamente parcial". ${ }^{434} \mathrm{E}$, em outra passagem, citando Leonardo Mattietto, salienta que a conformação clássica do contrato cede lugar a um novo modelo voltado aos valores e princípios constitucionais de dignidade e de livre desenvolvimento da personalidade humana.

Extrai-se dos dispositivos constitucionais acima mencionados os valores básicos que servem de norte para a compreensão da função social dos contratos, quais sejam, o da dignidade da pessoa humana e o da solidariedade social, os quais já foram objeto de análise, respectivamente, nos itens 3.2.1 e 3.2.2 da Parte I. Quando a Constituição Federal reconhece o valor social da livre iniciativa, faz transparecer que os contratos, enquanto instrumento de realização da livre iniciativa, não possuem apenas um valor individual,

\footnotetext{
433 JUNQUEIRA DE AZEVEDO, A. Os princípios do atual direito contratual e a desregulamentação do mercado... op. cit., p. 141-142.

${ }^{434}$ GODOY, C. L. B. Função Social do Contrato. São Paulo: Saraiva, 2004. p. 116.
} 
como expressão da liberdade de exercício da autonomia privada, mas também um valor social, decorrente desta necessidade de serem integrados na ordem social, que requer a promoção dos direitos fundamentais e da dignidade humana, bem como o fortalecimento das redes de solidariedade social. Possui, ainda, um valor econômico, que é o de promover as relações de troca - circulação de mercadorias e serviços - e assim proporcionar o desenvolvimento nacional, outro objetivo da República brasileira (CF, art. $3^{\circ}$, II). Analisando dessa forma, logo se vê que o contrato não possui apenas um valor individual, como queriam os teóricos do liberalismo, mas também os valores econômico e social, que juntos fundamentam a sua proteção pela ordem jurídica. Assim, o reconhecimento da força obrigatória do contrato dependerá não apenas da existência formal do vínculo, mas, também, do respeito aos valores fundamentais do ordenamento jurídico, ditados pela dignidade da pessoa humana e pela solidariedade social. ${ }^{435}$

Relembre-se, aqui, a ótica funcional do direito de León Duguit, ${ }^{436}$ para quem o ser humano não pode ser concebido fora dos agrupamentos sociais, pois em seu estado natural é um ser social, sendo não só titular de direitos, mas também sujeito de deveres perante a sociedade. Essa solidariedade social - que na visão de Durkheim é a solidariedade orgânica, estabelecida pela divisão do trabalho e mantida por instituições sociais fortes, inclusive pelo Direito - é indispensável nas sociedades modernas para torná-las mais fortes e desenvolvidas. O indivíduo tem apenas a ilusão de tornar-se cada vez mais independente, quando, na verdade, na medida em que a sociedade evolui e torna-se mais complexa, ele passa cada vez mais a depender dos laços de solidariedade. Dessa forma, a solidariedade social é um princípio cuja importância cresce a cada dia, erigindo-se, ao lado da dignidade humana, como pedra fundamental dos ordenamentos jurídicos modernos. A função social dos contratos carrega consigo esse valor inafastável, sendo a expressão do princípio da solidariedade social no âmbito do direito privado, mais especificamente no direito das obrigações.

Note-se, entretanto, que a função social não significa a permissão para interferências indevidas do Estado na iniciativa privada. ${ }^{437}$ Significa, sim, a incorporação

\footnotetext{
${ }^{435}$ A conceituação de contrato enquanto fusão de três valores (individual, social e econômico) foi defendida por Antonio Junqueira de Azevedo durante as aulas de mestrado na Universidade de São Paulo, no ano de 2007.

436 Já tratada no item 3.2.2 da primeira parte deste trabalho.

${ }^{437}$ Poderia chegar-se a essa conclusão em vista da inspiração do art. 421 do CC no Código Civil italiano, elaborado na época do regime fascista, que considerava a causa dos contratos a função econômico-social típica de cada contrato, abstratamente considerada, conferindo aos particulares a possibilidade de firmarem contratos atípicos apenas se os interesses envolvidos fossem merecedores de tutela (interessi meritevoli - art. 1322), permitindo um controle pelo estado da iniciativa privada.
} 
dos valores decorrentes do Estado social no Direito Privado, reconhecendo-se aos contratos, ao lado do valor individual, um valor social e econômico. Como visto, a própria livre iniciativa é um valor socialmente reconhecido ao contrato, que possui também um valor econômico enquanto instrumento de circulação de riquezas, de maneira que a intervenção do Estado-juiz ${ }^{438}$ deve respeitar também esses limites, ponderando o direito fundamental da autonomia privada com outros direitos fundamentais, individuais e sociais, em jogo numa relação jurídica. ${ }^{439}$

A tutela conferida pelo ordenamento jurídico à liberdade de contratar é, portanto, uma decorrência dos valores sociais e econômicos reconhecidos pela sociedade aos negócios jurídicos. O contrato será merecedor de tutela enquanto estiver cumprindo a sua função social, que será aferida de acordo com os objetivos perseguidos pela sociedade e consagrados pelo ordenamento jurídico, e que tem por fundamento os princípios da dignidade da pessoa humana e da solidariedade social.

Ressalte-se, ademais, a interação da função social dos contratos com os demais princípios sociais dos contratos que, por vezes, atuam em conjunto para complementar o significado um do outro. O princípio da boa-fé objetiva tem uma atuação orientada para a conduta das partes numa relação contratual. Dessa forma, ao analisar-se a função social do contrato numa perspectiva interna ao vínculo, não há como deixar de fora o princípio da boa-fé contratual, que impõe deveres de cooperação, de lealdade e de retidão entre as partes, indispensáveis para que o contrato cumpra com a sua função social. Por vezes, um comportamento contrário à boa-fé poderá comprometer a função social e econômica do contrato, em razão da frustração da confiança da outra parte, ausência de cooperação para permitir o adimplemento ou deficiência no dever de informação e de aconselhamento, dentre outros.

Demais disso, a função econômica e social, juntamente com a boa-fé objetiva, impõe limites à atuação de direitos subjetivos e faculdades jurídicas, nos termos já antes analisados quando se tratou do abuso do direito (seção 1.1.2, c), sendo um dos critérios previstos pelo artigo 187 do Código Civil para caracterizar como abusivo o exercício de um direito. Portanto, assim como a boa-fé objetiva, a função social serve de fundamento

\footnotetext{
${ }^{438}$ Não se está aqui a referir a intervenção direta do Estado na economia, regulada pelo art. 173 da CF.

${ }^{439}$ Deve-se, de fato, buscar o sentido objetivo da funcionalidade exigida nas contratações. Segundo Pablo Rentería: "no enfoque funcional, a tutela do comportamento individual toma por base considerações objetivas, compartilhadas pelo grupo e inscritas na ordem jurídica, o que permite, portanto, que seja feito um controle social, objetivo, dos atos de autonomia" (Considerações acerca do atual debate sobre o princípio da função social do contrato. In: MORAES, M. C. B. (coord.). Princípios do Direito Civil Contemporâneo. Rio de Janeiro - São Pauo: Renovar, 2006, p. 295).
} 
para impedir o exercício inútil e desproporcional de um direito, tal como ocorre quando o credor recusa-se, de maneira injustificada, a renegociar uma dívida, sobretudo nos casos em que o devedor encontra-se em situação de sobreendividamento passivo, tema que será retomado no capítulo seguinte (seção 2.3.1).

Da mesma forma, o princípio do equilíbrio contratual, analisado na seção anterior, contribui para o significado da função social na perspectiva interna, já que situações de extrema desigualdade afrontam a dignidade humana e, dessa forma, afastam o contrato da sua função social. Como visto, a relação contratual não mais serve para atender unicamente aos interesses egoísticos das partes, de forma que o vínculo jurídico só merece ser tutelado pelo direito se estiver de acordo com os valores erigidos pela sociedade e reconhecidos pela ordem jurídica, dentre os quais o da justiça contratual. Orlando Gomes observa que "se orienta modernamente o Direito das Obrigações no sentido de realizar melhor equilíbrio social, imbuídos seus preceitos, não somente da preocupação moral de impedir a exploração do fraco pelo forte, senão, também, de sobrepor o interesse coletivo, em que se inclui a harmonia social, aos interesses individuais de cunho meramente egoístico". ${ }^{440}$

Contudo, o princípio da função social do contrato confere ao princípio da justiça contratual uma abrangência maior, pois permite que sejam consideradas quaisquer circunstâncias que tenham dado ensejo à situação de extrema desigualdade, mesmo aquelas relativas à pessoa do devedor, desde que esta situação represente uma grave violação do núcleo dos direitos fundamentais decorrentes da dignidade humana. Enquanto os mecanismos de equilíbrio contratual, expressamente previstos do Código Civil, requerem a análise do vínculo sob a ótica da justiça comutativa, cujo enfoque é o equilíbrio entre as prestações do contrato, a função social do contrato permite a ampliação do sentido para abranger a justiça distributiva, que considera a qualidade das partes contratantes para conferir uma tutela especial, mais vigorosa, capaz de promover a justiça social através dos contratos.

Cláudio Luiz Bueno de Godoy, ao traçar o conteúdo genérico da função social do contrato, que segundo ele é de promoção da dignidade humana e do solidarismo social, assim conclui:

O solidarismo social ostenta um primeiro contorno, que vale para quaisquer das relações jurídicas, paritárias ou não, de, justamente, preservar uma substancial igualdade entre as pessoas, garantindo que suas contratações sejam justas e, mais, marcadas pelo padrão e exigência de colaboração entre os contratantes, assim socialmente úteis, enquanto

${ }^{440}$ GOMES, O. Transformações gerais do direito das obrigações. cit., p. 1 e 2 
palco de prestígio das escolhas valorativas do sistema. De outra parte, significa também a promoção da justiça distributiva (grifamos), quando fomenta o acesso a bens e serviços, em especial, embora não só, ao se cuidar de relações profissionais e, aí, intrinsecamente desiguais. $^{441}$

O que fazer, então, diante de um contrato que se distancia da sua função social, por gerar uma situação de extrema desigualdade, que represente uma afronta ao princípio da dignidade da pessoa humana no seu núcleo essencial? Se a desproporção for entre as prestações, a solução vem expressa no ordenamento jurídico, que permite a revisão do contrato desde que cumpridos certos requisitos, conforme abordado no tópico anterior. Mas se a desproporção decorrer da alteração de circunstâncias relativas à pessoa do devedor, tornando extremamente dificultoso o cumprimento da prestação, seria possível a intervenção judicial para ajustar a forma de cumprimento do contrato de maneira a permitir que seja cumprida a sua função social?

Esta questão remete a uma polêmica bem conhecida da doutrina civilista alemã, da qual surgiram as primeiras teorias modernas a respeito da possibilidade de revisão contratual, consistente na admissibilidade da doutrina dos limites do sacrifício. Esse tema será retomado detalhadamente no capítulo seguinte (item 2.3.2), mas por ora o importante é salientar que o princípio da função social, integrado pela noção de justiça distributiva, serve para dar uma solução jurídica adequada a esses casos em que o contrato tornou-se excessivamente oneroso, em razão da alteração das condições pessoais da parte mais fraca da relação contratual, de forma a ameaçar o núcleo mínimo da dignidade humana.

É nesse sentido que Antonio Junqueira de Azevedo coloca dentre os seus "grupos de casos", nos quais considera aplicável o princípio da função social dos contratos, a hipótese de contratos que violam o núcleo mínimo da dignidade humana, como se observa no seguinte trecho:

Um segundo grupo de casos - é a segunda hipótese em que o contrato pode ultrapassar os limites da função social - são os contratos que tocam o direito à vida ou aquele mínimo exigido pelo princípio da dignidade humana, especialmente quanto à subsistência. (...) É verdade que essa perspectiva de ineficácia do contrato por quebra da função social normal traz grandes dificuldades para a economia, mas, de novo, no nosso entendimento, devem prevalecer os interesses da pessoa física no seu mínimo de sobrevivência. ${ }^{442}$

${ }^{441}$ GODOY, C. L. B. Função Social do Contrato. cit. p. 129.

442 JUNQUEIRA DE AZEVEDO, A. Relatório brasileiro sobre revisão contratual apresentado para as Jornadas Brasileiras da Associação Henri Capitant. In: Novos Estudos e Pareceres de Direito Privado. São Paulo: Saraiva, 2009. p. 197-198. 
Portanto, o princípio da função social dos contratos, atuando juntamente com o princípio da justiça contratual e da boa-fé objetiva, servindo de ponte para incidência do princípio da solidariedade social e dos direitos fundamentais decorrentes da dignidade da pessoa humana, fundamenta as soluções admitidas pelo ordenamento jurídico brasileiro para o problema do endividamento excessivo em razão de fatos supervenientes relativos à pessoa do devedor, seja por impor limites ao exercício abusivo de posições jurídicas, repudiando a negativa injustificada do credor em renegociar um contrato, cujo cumprimento tornou-se insuportável ao devedor (Parte II, item 2.3.1), seja por fundamentar a alteração da forma de execução do contrato, nos casos de desequilíbrio extremo, em que o núcleo da dignidade humana e dos direitos fundamentais do devedor estejam sendo violados (Parte II, item 2.3.2), e assim permitir que o contrato se aproxime novamente da sua função econômica e social.

Por fim, cumpre destacar que a função social dos contratos, além da eficácia interna ao vínculo, como já visto acima, possui uma eficácia externa, a qual impõe, por um lado, o dever de respeito geral aos vínculos jurídicos, tornando-os oponíveis a terceiros, e, por outro, impede que os contratos produzam efeitos danosos a terceiros e à coletividade. Atualmente está consolidado na doutrina que o princípio da função social do contrato mitigou o princípio contratual clássico da relatividade dos contratos, pelo qual o contrato somente surte efeitos com relação às partes contratantes. A nova realidade contratual faz enxergar um novo alcance dos contratos, que emanam seus efeitos para além das partes envolvidas, atingindo toda a sociedade. ${ }^{443}$

Os contratos de crédito ao consumo são um campo fértil para a exigência do cumprimento da função social nessa vertente externa. E isso não apenas porque a Constituição Federal assim o requer ${ }^{44}$, mas também porque os efeitos sociais de práticas predatórias e abusivas em contratos de crédito ao consumo, destinados à massa de consumidores, são potencialmente causadores de graves problemas sociais e econômicos. A possibilidade de sobreendividamento generalizado da população deve ser uma preocupação constante das autoridades, por estar no centro das mais graves crises econômicas da atualidade, já que retira do principal agente fomentador da economia a capacidade de consumir, e por gerar situações de exclusão social, de escravidão contratual e das mais variadas formas de pressão social, que violam a dignidade humana - daí a

${ }^{443}$ Sobre a eficácia externa da função social do contrato, ou seu conteúdo genérico ultra partes, ver ainda: GODOY, C. L. B. Função Social do Contrato. op. cit., p. 131 a 152.

${ }^{444} \mathrm{CF}$, Art. 192. "O sistema financeiro nacional, estruturado de forma a promover o desenvolvimento equilibrado do País e a servir aos interesses da coletividade...". 
necessidade de fiscalização constante e regulamentação dessa atividade, conforme já referido (Parte I, itens 1.1.3 e 1.2).

Por outro lado, não há dúvida de que os contratos de crédito possuem um relevante valor econômico, pois orientam a economia do país. Como também já se destacou anteriormente, o crédito é o motor propulsor da economia de mercado, importante tanto para o financiamento da produção, quanto para o fomento do consumo, permitindo ao consumidor ter acesso rápido aos bens produzidos e serviços oferecidos. Dessa forma, deve ser exaltada a importância dos instrumentos de crédito, mas não se deve prescindir de um certo grau de equilíbrio, acima do qual, o contrato não estará mais cumprindo com a sua função social, não só na perspectiva interna, como também na perspectiva externa, tal como salientado no parágrafo anterior. A função social exige, portanto, um equilíbrio entre a sustentabilidade do sistema financeiro e a proteção do consumidor.

Daí porque, frise-se, as soluções que serão apresentadas no capítulo seguinte para as situações de endividamento excessivo não devem ser compreendidas de forma generalizada, muito menos ser aplicadas indiscriminadamente para todo e qualquer caso em que o devedor alegue dificuldade financeira para o cumprimento do contrato. Muito embora os contratos de consumo sejam dirigidos à massa de consumidores, contendo cláusulas gerais que se repetem milhares de vezes, o que se deve ter em mente ao realizar a ponderação de interesses é a situação específica de um consumidor individualizado, destacado da massa de consumidores, e considerado enquanto pessoa sujeita a situações excepcionais capazes de alterar a sua condição pessoal que, confrontada com sua história de vida e com sua conduta individualmente considerada (sobretudo para a análise da boafé), poderá ou não ser merecedor de tutela.

Daí a importância de se dar atenção ao caso concreto, a partir do qual deverá ser feita uma análise cuidadosa dos requisitos para a concessão da tutela, além de uma ponderação dos interesses envolvidos à luz dos princípios da boa-fé objetiva, da função social e econômica do contrato e da justiça contratual, para, no confronto entre o direito de crédito (que envolve, aí, a eficácia externa da função social) e os direitos fundamentais do devedor e de sua família (direito à vida, à saúde, à subsistência digna, etc.), chegar-se a uma solução conciliatória e harmônica, repudiando-se tanto o exercício abusivo de posições jurídicas, quanto o abuso da tutela das situações existenciais. 


\section{Seção 1.4 - A proteção à parte mais fraca}

A hipercomplexidade da sociedade pós-moderna polarizou as relações sociais e econômicas, acirrando as diferenças entre as diversas categorias de sujeitos de direito. De um lado, as grandes empresas, conglomerados econômicos e instituições financeiras, nacionais e multinacionais, que se caracterizam como verdadeiros poderes sociais, capazes de influenciar as decisões políticas mais relevantes tomadas pelo Estado e de dirigir o comportamento dos indivíduos. ${ }^{445}$ De outro, as categorias mais vulneráveis ${ }^{446}$, dentre elas os consumidores, que nesse processo acabam sujeitando-se às decisões políticas, econômicas, produtivas e culturais tomadas pelos centros de dominação, tornando-se instrumentos do mercado de consumo. Como reflete Cyril Noblot, é possível fazer uma analogia entre o consumidor, visto como uma força de consumo, e o trabalhador, visto como uma força de trabalho. ${ }^{447}$

Existe atualmente a compreensão de que o Direito deve considerar as diferenças existentes entre os indivíduos a fim de conceder a tutela jurídica adequada. ${ }^{448}$ Como lembra Hondius, a liberdade de contratar não é mais o único paradigma do Direito contratual, ganhando, durante o século XX, a companhia de outros, como o da proteção da parte mais fraca. ${ }^{449}$ É por essa razão que desde a primeira metade do século passado o direito tutela situações especiais, como a dos trabalhadores, passando pela tutela do direito à moradia (Lei do Inquilinato), preocupando-se atualmente com a tutela de diversas

\footnotetext{
445 Essa é a constatação de Cyril Noblot: «ce sont les entreprises de production qui contrôlent les comportements des consommateurs, en même temps qu'elles dirigent et modèlent les attitudes sociales, notamment par les messages publicitaires, L'instrumentalisation de l'homme est liée à la société de consommation; or, un système qui capte à son profit les objectifs sociaux, qui impose ses propres volontés aux consommateurs et qui, par une sorte de dressage économique exercé par les forces productives, conditionne les besoins de l'homme, illustre une forme moderne et peu soupçonnée d'asservissement de l'être humain contre laquelle la dignité humaine se propose de lutter.» (NOBLOT, C. La Qualité du Contractant comme Critère Legal de Protection. Paris: LGDJ, p. 54-55)

${ }^{446}$ A vulnerabilidade é técnica (de informação), econômica e organizacional.

${ }^{447}$ NOBLOT, C.. La Qualité du Contractant comme Critère Legal de Protection. op. cit., p. 55

${ }^{448}$ Esta compreensão teve início com a superação da ideologia liberal, que se contentava com a igualdade formal. Já dizia Josserand na primeira metade do século passado que a condição jurídica do homem não mais é fixada abstratamente, mas em função da sua posição social: «la personne humaine, sujet de droits et d'obligations, n'est plus cet être abstrait que le Code civil, héritier de l'idéologie révolutionnaire, s'était efforcé de dégager, de réaliser sur un type unique, tiré en série, mais c'est l'individu qui exerce un métier, qui accomplit une fonction; à l'homo juridicus, toujours identique à lui-même dans son unité indivisible, viennent se substituer, en nombre grandissant des homines juridici qui sont dotés de status différents, établis en considérations de leurs diverses formes d'activités " (Sur la reconstitution d'un droit de classe, D.H. 1937, chron., p. 2 et La renaissance de la faute lourde sous le signe le la profession, D.H. 1939, chron. P. 29 , spéc. P. 31 apud NOBLOT, C. op. cit., p. 5).

${ }^{449}$ HONDIUS, E.. The protection of the weak party in a harmonized European contract law: a synthesis. Journal of Consumer Policy 27: 245-251, 2004.
} 
categorias carecedoras de proteção especial, como os idosos, as crianças e os consumidores.

Com relação aos consumidores, lembre-se que a forma de contratação também mudou, sendo atualmente caracterizada pelos contratos padronizados, com cláusulas préestabelecidas pelos fornecedores, de forma a melhor atender aos seus interesses, o que favorece o cometimento de abusos. Assim, a qualidade dos sujeitos que se envolvem numa relação contratual de consumo será de extrema importância, tendo em vista a necessidade de conferir um maior equilíbrio (paridade de armas) para minimizar os abusos pela parte mais forte, e assim permitir uma maior liberdade no exercício da autonomia privada. De fato, como ensina o jurista francês Alain Benabent, "a diferença de poder econômico torna frequentemente ilusória a livre negociação: o mais fraco é constrangido a aceitar as condições lhe são impostas, as quais não são necessariamente justas do seu ponto de vista. Assim se expandiu a prática dos contratos de adesão, nos quais uma das partes apenas adere a uma convenção inteiramente preparada pela outra". 450

Cyril Noblot defende que a possibilidade de considerar a qualidade do contratante como critério legal para a sua proteção decorre da influência da justiça distributiva no direito contratual. Para o autor, a justiça comutativa permite apenas manter um equilíbrio entre as prestações de um contrato, sem se preocupar com a qualidade dos sujeitos que participam da relação contratual. A justiça distributiva, por outro lado, não se desinteressa das pessoas envolvidas na relação e permite a atribuição de certas vantagens em razão de uma desigualdade que esteja presente. E completa: "nesta ótica distributiva, em razão desta insuficiência e inadaptação das noções de direito comum, parece ser de boa técnica considerar a qualidade do contratante para lhe conceder uma proteção particular". 451

$\mathrm{Na}$ atual sociedade pós-moderna globalizada, em que o surgimento de grandes grupos de indivíduos social e economicamente vulneráveis ocupa um espaço cada vez maior, como é o caso da massa de consumidores, a noção de justiça distributiva nos contratos vem ganhando força. Relatando o movimento de ascensão e queda da justiça

\footnotetext{
${ }^{450}$ Alain Benabent esclarece que «La différence de puissance économique rend souvent illusoire la libre négociation : le plus faible est contraint d'en passer par les conditions qui lui sont imposées, qui ne sont pas nécessairement juste à son égard. S'est ainsi répandue la pratique des « contrats d'adhésion » dans lesquels une partie ne fait qu'adhérer à une convention entièrement préparée par l'autre.» (Droit Civil - Les Obligations, 3a. édition. Paris: Montchrestien, 1991.p. 12-13, $\mathrm{n}^{\circ}$ 24).

${ }^{451}$ Do original: «dans cette optique distributive, compte tenu de cette insuffisance et de cette inadaptation des notions de droit commun, il semble être cette fois de bonne méthode de considérer la qualité d'un contractant pour lui accorder une protection particulière ». (NOBLOT, C. La Qualité du Contractant comme Critère Legal de Protection. Paris: LGDJ, p. 2).
} 
econômica $^{452}$, MacPherseon constata que vivemos atualmente numa época de revitalização tanto do conceito de "justiça comutativa" (que diz respeito à igualdade nas relações de troca), quanto de "justiça distributiva" (relativa à justa distribuição do bem-estar social), com o Estado assumindo um papel mais intervencionista, impedindo ou distorcendo a distribuição que seria feita pelo mercado. Segundo o autor, "atualmente a distribuição ainda é feita sobretudo através dos mercados mas não pelos mercados". ${ }^{453} \mathrm{E}$ sendo o contrato o principal instrumento de realização das operações econômicas feitas pelo mercado, é correto afirmar que a justiça distributiva também deve ser realizada através dos contratos.

A conseqüência de se considerar a qualidade do contratante em razão da atuação da justiça distributiva é a atribuição de uma tutela jurídica diferenciada, caracterizada por uma maior proteção legal, até mesmo para permitir que a declaração de vontade, que vincula ao cumprimento da obrigação, seja manifestada de forma livre e esclarecida. Como já dito, o exercício da autonomia privada deve ser efetivo, e não meramente formal. Para isso, os princípios contratuais decorrentes do Estado social devem incidir de forma mais intensa, no intuito de proteger a parte mais fraca, trazendo um maior equilíbrio às relações contratuais. Assim, o dever de informação transmuda-se em dever de aconselhamento; o dever de cuidado transmuda-se em dever de proteção; o grau de onerosidade admitido

\footnotetext{
${ }^{452}$ MacPherson define justiça econômica como aquela que "busca submeter as relações econômicas a algum princípio ético inferido do direito natural (ou do direito divino) ou de uma suposta natureza social do homem". Esclarece que quem primeiro desenvolveu essa noção foi Aristóteles (séc. IV a.c), que formulou os conceitos de justiça comutativa e justiça distributiva, que compõem o conceito de justiça econômica. Séculos mais tarde (XII d.c.), o conceito foi retomado por Tomás de Aquino. A queda da justiça econômica ocorreu a partir dos séculos XV e XVI, quando a ordem feudal sucumbiu ao mercantilismo, sendo Thomas Hobbes (1651) o precursor do fim do conceito de justiça econômica ao considerar irrelevantes as reivindicações de justiça comutativa e distributiva, já que para ele "o valor justo é o que foi acertado entre eles [contratantes]" e o mérito individual, para efeito de distribuição das riquezas, somente poderia ser julgado pelo mercado. Hobbes influenciou todos os teóricos do liberalismo, e aos poucos a justiça econômica foi suplantada pela economia de mercado, pois se acreditava que "tudo quanto o mercado livremente competitivo fazia, ou era capaz de fazer, era sempre o melhor possível”. A reação ao pensamento liberal veio com os teóricos socialistas e social-democratas alemães (Programa de Gotha e Marx) na segunda metade do século XIX. No século seguinte, o conceito de justiça econômica revitalizou-se, em razão de uma descrença na viabilidade da economia de mercado livremente competitiva, já que a concentração do capital foi a realidade experimentada. (MACPHERSON, C.B.. Ascensão e queda da justiça econômica. op. cit., p. 15 e ss.).

${ }_{453} \mathrm{O}$ autor constata que os conceitos de justiça distributiva e comutativa ressurgiram primeiramente na prática política das democracias liberais do século XX, tornando-se discurso político freqüente as promessas de melhor distribuição de renda. O Estado foi compelido a intervir por pressão dos movimentos trabalhistas, dos setores do capital organizado e para salvar o próprio sistema. Constatou-se que o mercado era incompetente para promover uma distribuição de renda justa e, por isso, não poderia mais permanecer isento de padrões éticos. Quanto à justiça comutativa, tanto as legislações quanto as sentenças passaram a admitir que os contratos pudessem ser anulados se fossem feitos em desigualdade de condições. A noção de equilíbrio contratual e de justo preço foi retomada mas, de acordo com o autor, não chegou a se tornar uma regra, sendo ainda regida pelas diretrizes do mercado. (MACPHERSON, C.B. op. cit. p. 28 e 32 )
} 
numa relação de consumo é menor, pois presume-se que o consumidor não quis assumir um elevado risco, tal como se poderia supor numa relação entre iguais.

Na nova dogmática contratual a consideração do status das partes é uma tendência internacional, tal como esclarece Guido Alpa, ao comentar as novas fronteiras do direito contratual, esclarecendo que a proteção à parte mais fraca é conferida por algumas diretivas comunitárias, bem como indiretamente pelos princípios do Unidroit sobre interpretação "contra proferentem" (art. 4.6) e sobre a vantagem excessiva (art. 3.10). Ressalta, ainda, as características mais importantes da evolução do direito contratual:

Sans caractère exhaustif, on peut souligner les aspects les plus importants de cette évolution: (i) l'importance du status des parties; (ii) l'importance des tecniques de contrôle intérieur de l'opération économique, par des moyens tels que la cause, l'objet, la forme ; (iii) l'application de critères de «justice contractuelle» par référence aux valeurs de la personne et à l'équité de l'échange ; (iv) l'application de clauses générales (standards) pour le contrôle du comportement des parties pendant les phases de négociation, de conclusion et d'exécution du contrat; (v) l'adaptation du contrat aux circonstances survenues; (vi) la codification sociale de certaines formules contractuelles internationales ; (vii) la confiance de la solution des conflits à des instances extrajudiciaires. ${ }^{454}$

No mesmo sentido, Peter Nygh, comenta que "os Princípios de Direito Comercial Internacional do UNIDROIT, os quais podem ser vistos como reflexo de um consenso internacional, permitem que uma parte repudie um contrato ou um termo que injustificadamente tenha concedido a outra parte uma vantagem excessiva". ${ }^{455}$ Ainda, Hans Micklitz comenta a respeito dos "Principles of European Contract Law - PECL", editados por Ole Lando e Hugh Beale, prevêem expressamente a proteção da parte mais fraca. ${ }^{456}$

E de fato, a doutrina mais recente tem considerado a qualidade do contratante como um novo critério de classificação dos contratos. Cite-se, na doutrina francesa, Philipe

\footnotetext{
454 ALPA G. Les nouvelles frontières du droit des contrats. Revue Internationale de Droit Comparé, $\mathrm{n}^{\circ} 4$, octobre - décembre. 1998, page 1015-1030.

${ }^{455}$ NYGH, P. Autonomy in International Contracts. Oxford: Clarendon Press, 1999, p. 140. Do original: "The UNIDROIT Principles of International Commercial Contrats of 1994 which may be seen as reflecting an international consensus, allow a party to avoid a contract or a term unjustifiably gave the other party an excessive advantage". Na versão em ingles, assim estabelece o artigo 3.10: Gross disparity - (1) A party may avoid the contract or an individual term of it if, at the time of the conclusion of the contract, the contract or term unjustifiably gave the other party an excessive advantage. Regard is to be had, among other factors, to (a) the fact that the other party has taken unfair advantage of the first party's dependence, economic distress or urgent needs, or of its improvidence, ignorance, inexperience or lack of bargaining skill, and (b) the nature and purpose of the contract. (2) Upon the request of the party entitled to avoidance, a court may adapt the contract or term in order to make it accord with reasonable commercial standards of fair dealing. (3) A court may also adapt the contract or term upon the request of the party receiving notice of avoidance, provided that that party informs the other party of its request promptly after receiving such notice and before the other party has reasonably acted in reliance on it. The provisions of Article 3.13(2) apply accordingly.

456 MICKLITZ, H.W. The principles of European Contract Law and the protection of the weaker party. Journal of Consumer Policy, 27: 339-356, 2004.
} 
Malaurie e Lorent Aynes ${ }^{457}$, François Collart Dutilleul et Philippe Delebecque ${ }^{458}$ e Alain Benabent ${ }^{459}$, os quais consideram a dicotomia entre contratos de consumo e contratos empresariais, que envolvem profissionais e não profissionais («professionnels et profanes »). Entre nós, Antônio Junqueira de Azevedo defende uma nova dicotomia entre contratos existenciais e contratos empresariais, como sendo a verdadeira dicotomia contratual do século XXI, "assim como a de contrato paritário/contrato de adesão esteve para o século XX”. Nos contratos existenciais importa a proteção do ser humano, cuja existência não pode ser negligenciada, sendo que os novos princípios contratuais incidem com maior intensidade, para uma maior efetividade do seu propósito. Nas palavras do Professor:

Ela (a boa-fé objetiva), em primeiro lugar, é muito maior entre os contratos que batizamos de "contratos existenciais" (os de consumo, os de trabalho, os de locação residencial, de compras da casa própria e, de uma maneira geral, os que dizem respeito à subsistência da pessoa humana) de que entre os "contratos empresariais". Essa nova dicotomia, que defendemos, "contrato existencial/contrato empresarial”, é, ao nosso ver, a verdadeira dicotomia contratual do século XXI. Por força da renovação dos princípios contratuais e da freqüência de sua concretização, não se pode mais empregar a palavra "contrato" sem consciência dessa nova dicotomia; ela é operacional e está para o século XXI, como a de "contrato paritário/contrato de adesão" esteve para o século $\mathrm{XX}^{460}$

\footnotetext{
${ }^{457}$ Os autores oferecem uma classificação segundo a qualidade dos contratantes, e assim a subdividem em contratos com e sem intiuito personae, e contratos que levam em consideração a qualidade do consumidor. Quanto a esses assim dissertam: «Depuis plus de trente ans, de nobreuses réformes législatives font apparaître une nouvelle classification, qui s'attache à la qualité des contractants, en distinguant les contrats conclu entre les professionnels et les consommateurs des autres contrats, ceux qui sont conclu entre les professionnels ou entre les consommateurs. La notion de consommateur est définie objectivement, par les actes de consommation, c'est-à-dire des contrats qui ne sont pas nécessaires à une activité professionnelle ». (MALAURIE, P. e AYNES, L. Les Obligations, Paris: Defrénois, 2004, p. 189).

${ }^{458}$ Os autores apresentam a qualidade das partes como critério de classificação dos contratos especiais. Sob esse critério, os contratos são divididos entre contratos de consumo (concluídos entre profissionais e consumidores) e contratos empresariais (contrats d'affaire), concluídos entre profissionais. Segundo os autores, em todos os contratos de consumo se colocam problemas similares, em razão do desequilíbrio existente entre as partes. «Les nombreuses mesures qui ne cessent d'être prises par les législateur successifs visent toutes à informer et à protéger le consommateur ». (DUTILLEUL, F. C. e DELEBECQUE, P. Contrats civils et commerciaux, Paris: Dalloz, 1991, p. 23-24, $\mathrm{n}^{\circ} 27$ )

459 « Le droit contemporain est en train d'élaborer une nouvelle classification qui tient non plus au contenu du contrat, mais à la personnalité des contractants, lesquels sont à peu près rangés en deux catégories : professionnels et profanes. Les contrats conclu entre eux par des professionnels, ou par des profanes (ou particuliers) demeurent soumis à un régimes traditionnel. Mais les contrats conclu entre d'une part un professionnel et d'autre part un particulier, qu'on peut appeler des contrats «de consommation», déclenchent la mise en œuvre d'un régime de protection des consommateurs de plus en plus étendu : on parle aujourd'hui d'un « droit de la consommation » ». (BENABENT, A. Droit Civil - Les Obligations, 3a. édition. Paris: Montchrestien, 1991.p. 12, $\mathrm{n}^{\mathrm{O}} 22$ ).

${ }^{460}$ JUNQUEIRA DE AZEVEDO, A. Natureza jurídica do contrato de consórcio..., Revista dos Tribunais $\mathrm{n}^{\circ}$ 832. São Paulo: Editora Revista dos Tribunais, p. 123/124.
} 
O próprio autor, em outra oportunidade, define o que entende por contratos existenciais, distinguindo-os dos empresariais:

Por contrato empresarial há de se entender o contrato entre empresários, pessoas físicas ou jurídicas, ou, ainda, o contrato entre um empresário e um não-empresário que, porém, naquele contrato, visa obter lucro. O contrato existencial, por sua vez, é aquele entre pessoas não-empresárias ou, como é freqüente, em que somente uma parte é nãoempresária, desde que esta naturalmente não pretenda transferir, com intuito de lucro, os efeitos do contrato para terceiros. O critério de distinção é exclusivamente subjetivo, se possível, ou, se não, subjetivo-objetivo. São existenciais, por exemplo, todos os contratos de consumo (o consumidor é o destinatário final das vantagens contratuais ou não visa obter lucro), o contrato de trabalho, o de aquisição da casa própria, o de locação da casa própria, o de conta corrente bancária e assim por diante. ${ }^{461}$

Como se vê, importa o fato de ao menos um dos contratantes não ser comerciante, mas também deve ser considerado o objetivo perseguido pela parte com aquele contrato. Se a finalidade for lucrativa, descaracteriza-se o contrato existencial. Note-se, ainda, que os exemplos oferecidos coincidem com as situações especiais que tem sido objeto de tutela jurídica diferenciada, conforme mencionado linhas atrás.

Cyril Noblot reconhece à pessoa física uma qualidade que por si só fundamenta uma proteção especial. Isso porque a pessoa física, diferentemente da jurídica, merece a proteção da sua própria existência (proteção da personalidade e proteção material da existência), em razão do valor supremo da pessoa humana - como um fim em si mesmo e da sua dignidade que não pode ser prescindida em nome da tutela de outros interesses. Esclarece que as medidas de proteção que favorecem a pessoa física são destinadas a permitir a preservação de sua existência, a qual não se concebe sem um mínimo de bens materiais. Nesse ponto, cita a lei francesa a respeito do tratamento das situações de sobreendividamento que tem a preocupação de garantir a subsistência do indivíduo (« reste à vivre $») .{ }^{462}$ Por tudo isso, conclui:

«Il y a lieu de considérer que la logique contractuelle commutative du droit privé doit céder le pas à une logique personnaliste distributive, car, et la loi du 29 juillet 1998 le

\footnotetext{
${ }^{461}$ JUNQUEIRA DE AZEVEDO, A. J. Relatório brasileiro sobre revisão contratual..., op. cit., p. 186.

${ }^{462} \mathrm{Na}$ França, em razão da forte tradição liberal e da escola da exegese, a admissibilidade na esfera cível da revisão judicial dos contratos sofreu forte resistência, preferindo-se sempre a solução legislativa para a resolução dos problemas decorrentes das situações de onerosidade excessiva - assim ocorreu com a edição da Lei Failliot, de 21 de janeiro de 1918, citada linhas atrás. Contudo, Cyril Noblot desenvolve a tese da necessidade de uma teoria geral dos contratos especiais para que seja possível solucionar questões inéditas, sem previsão em leis especiais. Para isso, diz o autor, « il s'agit d'observer des règles légales substantielles françaises de droit commun et de droit spécial, qui, dans un rapport contractuel, protègent un contractant en fonction de sa qualité, et d'en rechercher l'inspiration idéologique afin d'apprécier la congruence de cette méthode législative originale avec l'objectif poursuivi » (NOBLOT, C. La Qualité du Contractant ... op. cit., p. 7).
} 
confirme, dans la hiérarchie actuelle des valeurs sociales, l'objectif de protection de l'existence de la personne physique se hisse à un rang supérieur à celui qui consiste à faire respecter scrupuleusement la maxime pacta sunt servanda $\gg .{ }^{463}$

Por seu turno, Teresa Negreiros defende que o paradigma da essencialidade, que toma em consideração a utilidade existencial do bem objeto das prestações do contrato utilidade em função da pessoa que dele necessita para realizar interesses existenciais -, deve ser considerado na qualificação dos contratos. Segundo a autora, “...o paradigma da essencialidade proporciona instrumentos e conceitos que permitem tratar os problemas sociais como problemas a serem enfrentados também pelo direito contratual". ${ }^{464} \mathrm{E}$ esclarece:

Embora não conste expressamente dos esquemas classificatórios tradicionais no direito civil, a classificação dos bens em essenciais, úteis e supérfluos e sua utilização como fator de diferenciação dos contratos que tenham por objeto a sua aquisição ou utilização são propostas interpretativas perfeitamente compatíveis com tais esquemas, desde que se lhes imprima uma nova luz: a da primazia das situações existenciais sobre as situações patrimoniais. ${ }^{465}$

Seja qual for a classificação, o importante é conferir uma proteção diferenciada à pessoa humana que se encontre em situação de vulnerabilidade numa determinada contratação. Contudo, a essencialidade do interesse viabilizado pelo contrato, pode conferir um paradigma para reforçar a necessidade de proteção. Isso porque, o princípio da dignidade da pessoa humana e a incidência dos direitos fundamentais nas relações privadas exigem o respeito às condições mínimas de vida ${ }^{466}$ também nas relações contratuais.

Esse princípio de proteção da parte mais fraca, atuando juntamente com os princípios sociais da boa-fé objetiva, do equilíbrio contratual e da função social do contrato, potencializa os seus efeitos, permitindo a efetiva prevenção das situações de endividamento excessivo, pela exigência do dever de proteção e de aconselhamento, bem como conferindo tutela nos casos de desequilíbrio contratual, seja ele congênito (lesão contratual), seja ele em razão da alteração das circunstâncias, ainda que estas digam respeito à alteração da capacidade financeira do devedor, sempre que a tutela se mostrar necessária para a preservação do núcleo dos direitos fundamentais, decorrentes da dignidade da pessoa humana. Dessa última situação nos ocuparemos no capítulo seguinte.

\footnotetext{
${ }^{463}$ NOBLOT, C. La Qualité du Contractant comme Critère Legal de Protection. op. cit., p. 56-57.

${ }^{464}$ NEGREIROS, T. Teoria do Contrato - novos paradigmas. Renovar: Rio de Janeiro, 2006. p. 388

${ }^{465}$ Idem, ibidem, p. 459.

${ }^{466}$ JUNQUEIRA DE AZEVEDO, A. Caracterização jurídica da dignidade da pessoa humana. cit. p. 18.
} 


\section{CAPÍTULO 2 - TUTELA DO CONSUMIDOR EXCESSIVAMENTE ENDIVIDADO}

Ao longo do trabalho, foram estabelecidas algumas premissas que serão fundamentais para as soluções que serão construídas neste Capítulo. Demonstrou-se que o princípio da função social impõe a integração dos contratos numa ordem social harmônica, da qual decorre o respeito aos valores sociais e econômicos eleitos pela Constituição Federal como indispensáveis ${ }^{467}$, sendo eles a própria razão pela qual o ordenamento jurídico reconhece força obrigatória aos contratos. Também o princípio da boa-fé objetiva impõe deveres de conduta, como o de informação, de lealdade e de cuidado, além do que limita o exercício de direitos subjetivos, condenando condutas que tragam prejuízo exagerado ao contratante mais fraco, como a imposição de cláusulas abusivas e o abuso do direito. Por fim, em nome do princípio do equilíbrio contratual, o ordenamento jurídico prevê mecanismos para intervenção judicial nas situações em que uma das partes for excessivamente onerada com o vínculo contratual.

Dessa forma, os princípios da função social do contrato, da boa-fé objetiva e do equilíbrio contratual apresentam-se como pontes para incidência dos princípios da solidariedade social e da dignidade da pessoa humana nas relações privadas.

Nas relações de consumo, os princípios sociais dos contratos são reforçados pelo princípio da proteção da parte mais fraca, que impõe a consideração da qualidade das partes para conferir uma tutela mais adequada, de sorte a tornar efetiva a liberdade de contratar, prejudicada pela forma de contratação massificada, na qual o consumidor encontra-se em situação de constante pressão, o que compromete a livre manifestação do seu consentimento, além do que as cláusulas pré-estabelecidas unilateralmente pelo fornecedor favorecem a prática de abusos. Ademais, o princípio da proteção da parte mais fraca requer a consideração de circunstâncias pessoais do consumidor, no intuito de tornar efetiva a justiça contratual, não apenas no seu aspecto comutativo, mas também no aspecto distributivo.

No capítulo anterior, desenvolveu-se a tutela do consumidor de crédito em geral, a partir dos princípios sociais albergados pelo ordenamento jurídico brasileiro, independentemente de verificar-se em concreto uma situação de endividamento excessivo.

${ }^{467} \mathrm{O}$ contrato, para cumprir com a função social, deve preservar as escolhas axiológicas do ordenamento jurídico, expressas na Constituição Federal (conforme Cláudio Luiz Bueno de Godoy, em palestra proferida no Instituto Internacional de Ciências Sociais, em 22 de outubro de 2009). 
É certo que a incidência das normas anteriormente referidas terá como efeito a prevenção do sobreendividamento, bem como a solução de muitos casos nos quais a onerosidade excessiva do débito decorre de um comportamento ilícito do credor, como a introdução de cláusulas abusivas nos contratos de consumo, ou da verificação de algum evento externo ao crédito, mas de ordem objetiva, que tenha colocado o consumidor em desvantagem exagerada. Contudo, nem todas as situações foram até o momento abrangidas, restando, ainda, os casos em que circunstâncias relativas à pessoa do consumidor, como a vulnerabilidade técnica e econômica, a suscetibilidade às pressões do mercado ou a alteração da sua capacidade financeira, levaram a uma situação de sobreendividamento capaz de ameaçar a sua subsistência.

Um primeiro aspecto que será analisado neste capítulo é a responsabilização do credor por ter efetuado um empréstimo de forma predatória, sem consideração pelas condições pessoais do consumidor que, em razão disso, superendividou-se. Um segundo aspecto refere-se ao sobreendividamento passivo causado pela alteração das circunstâncias subjetivas que tenha tornado o cumprimento das obrigações assumidas extremamente dificultoso, de forma a ameaçar a sua subsistência. Diante disso, questiona-se se existe um dever do credor de renegociar o contrato para permitir o seu cumprimento em condições mais adequadas à nova realidade; mais ainda, seria possível a intervenção judicial para ajustar a forma de cumprimento, de modo a evitar a onerosidade excessiva e permitir que o contrato cumpra a sua função social?

Antes de enfrentar as questões propostas acima, serão estabelecidos os pressupostos para a tutela que se entende cabível, no intuito de orientar a aplicação do direito de acordo com o paradigma do caso concreto. 


\section{Seção 2.1 - Pressupostos para a tutela do consumidor excessivamente endividado}

Dissemos anteriormente que o paradigma jurídico da atualidade requer a atenção ao caso concreto, sendo essa a única forma de dar efetividade aos direitos fundamentais sem agravos à segurança jurídica, sobretudo no que se refere ao tratamento das situações de superendividamento. Para minimizar as incertezas que podem ser criadas em razão da incidência dos princípios da função social, da justiça contratual e da boa-fé objetiva, faz-se necessário o estabelecimento de pressupostos para orientar a atuação do juiz, identificando as situações que efetivamente merecem uma tutela diferenciada.

O paradigma do caso concreto exige que o juiz analise o caso com atenção para todas as circunstâncias que envolvem as partes e a própria relação jurídica, inclusive a situação de vulnerabilidade de uma das partes, as condições econômicas e sociais que possam ter influenciado no necessário esclarecimento e liberdade para o exercício da autonomia privada, a eventual situação de urgência social que a alteração das circunstâncias possa ter causado, com a possibilidade de violação do mínimo existencial e do núcleo da dignidade humana, além de elementos éticos que indiquem um comportamento das partes de acordo com a boa-fé, ou seja, do qual não decorra uma atitude desleal, não cooperativa, ou que de qualquer forma indique o exercício abusivo de direito por quaisquer dos parceiros contratuais.

\subsubsection{Situação de vulnerabilidade do devedor}

De acordo com as premissas desenvolvidas ao longo deste trabalho, estabeleceu-se a necessidade de se tutelar a pessoa física em situação de vulnerabilidade, no seu mínimo existencial, em razão do princípio da dignidade da pessoa humana. Conforme se destacou na seção 1.4 retro, a pessoa física é merecedora de tutela por ser detentora de dignidade inafastável, sobretudo nos contratos ditos existenciais. ${ }^{468}$

Mas não basta a qualidade de pessoa física para a identificação dos sujeitos merecedores da tutela ora proposta: é preciso que se caracterize um estado de vulnerabilidade em razão do desequilíbrio de forças existente na relação jurídica que gerou o superendividamento. $\mathrm{O}$ consumidor pessoa física, enquanto indivíduo sujeito às forças do mercado, que se encontra em situação de hipossuficiência técnica, econômica e

\footnotetext{
${ }^{468}$ Sobre a caracterização do contrato existencial ver item 2.1 retro.
} 
organizacional, tem a sua vulnerabilidade presumida, nos termos do artigo $4^{\circ}$, inciso I do Código de Defesa do Consumidor.

Essa vulnerabilidade decorre da exposição do consumidor às pressões do mercado, reduzindo o seu poder de barganha e retirando-lhe a capacidade de optar por contratos menos onerosos, ou até mesmo a opção de não contratar, muitas vezes por falta de conhecimento específico a respeito das operações financeiras, outras vezes em razão da sua racionalidade limitada, traduzida na incapacidade de previdência e de cálculo dos efeitos de uma operação de crédito no orçamento pessoal e familiar.

Além de ser tecnicamente vulnerável, não dispõe de meios para salvaguardar-se frente aos eventos imprevisíveis da vida, capazes de por em risco a sua subsistência. Já os fornecedores de crédito, em geral grandes instituições financeiras, estão em melhores condições de absorver os riscos dos eventos supervenientes e de redistribuí-los, numa lógica solidarista, desejada pelo ordenamento jurídico brasileiro.

Ademais, é possível identificar certos grupos de indivíduos especialmente vulneráveis que, por expressa disposição constitucional, são merecedores de proteção especial, tais como os idosos ${ }^{469}$, as crianças e os adolescentes ${ }^{470}$. Desses, merecem especial atenção os idosos, tendo em vista as novas modalidades de crédito especialmente criadas para atrair esse tipo de cliente, qual seja, o empréstimo consignado nas aposentadorias pagas pelo INSS. Tendo em vista a facilidade de "captação" desta clientela, muitos idosos entram em sérias dificuldades financeiras, sendo-lhes retirados os meios de sobrevivência, com descontos feitos em desconformidade às normas regulamentares previstas pelo próprio INSS (ver Parte I, seção 2.3).

A tutela especial mostra-se também justificada nos contratos que tem por objeto bens essenciais, segundo o paradigma da essencialidade, abordado na seção 2.1 da Parte II. Assim, contratos que envolvem fornecimento de bens essenciais, como água e luz, bem como contratos de crédito que envolvem aquisição de bens essenciais, como contratos para aquisição da casa própria e financiamento educacional, merecem consideração especial da parte mais fraca na relação.

Em situações como esta, abre-se espaço para a atuação da justiça distributiva, não no sentido prestacional, mas no sentido de promoção da igualdade e do equilíbrio

\footnotetext{
${ }^{469}$ Art. 230. A família, a sociedade e o Estado têm o dever de amparar as pessoas idosas, assegurando sua participação na comunidade, defendendo sua dignidade e bem-estar e garantindo-lhes o direito à vida.

${ }^{470}$ Art. 227. É dever da família, da sociedade e do Estado assegurar à criança e ao adolescente, com absoluta prioridade, o direito à vida, à saúde, à alimentação, à educação, ao lazer, à profissionalização, à cultura, à dignidade, ao respeito, à liberdade e à convivência familiar e comunitária, além de colocá-los a salvo de toda forma de negligência, discriminação, exploração, violência, crueldade e opressão.
} 
contratual. Apesar da justiça comutativa prevalecer nas relações contratuais, garantindo uma equivalência entre as prestações, ou seja, o equilíbrio contratual em sentido objetivo, a justiça distributiva também possui um papel relevante, pois é ela que fundamenta o tratamento mais favorável conferido pelo legislador às categorias de indivíduos mais vulneráveis, merecedores de proteção especial, garantindo, assim, a justiça contratual em sentido mais amplo do que o anterior. ${ }^{471}$

Com a proteção da parte mais fraca, garante-se que a autonomia privada seja efetiva, e não meramente formal. Quando uma das partes é mais vulnerável, em vários sentidos, a possibilidade de o contrato nascer desequilibrado é muito maior. Daí a necessidade do direito resguardar o contratante mais fraco, zelando para que a sua vontade seja manifestada de forma íntegra, bem como conferindo a proteção efetiva aos seus direitos fundamentais, com atenção para sua condição peculiar, de indivíduo sujeito às forças do mercado.

É imprescindível, portanto, que a autonomia privada seja efetiva, e não meramente formal. Quando uma das partes é mais vulnerável, em vários sentidos, a possibilidade do contrato nascer desequilibrado é muito maior. Menezes Cordeiro, a respeito da efetividade da autonomia privada, expõe:

$\mathrm{Se}$, formalmente, ela se contenta com a inexistência de entraves ao seu desenvolvimento, de facto, ela requer a possibilidade de opção efectiva, aquando da celebração. Tal possibilidade pode ser frustrada pela ignorância do contratante, pela sua dependência económica ou outra, por situações de monopólio, pela necessidade impreterível de contratar de imediato ou, simplesmente, por a contraparte se recusar a alterar a proposta ou a contraproposta que tenha formulado. ${ }^{472}$

Portanto, num contrato entre sujeitos que tenham a mesma possibilidade de influir no objeto e nas cláusulas contratuais, presume-se que as partes, no exercício da autonomia negocial, tenham querido um certo grau de desigualdade. Já nos contratos em que há uma relevante fragilidade de uma das partes em relação à outra, seja por não possuir a mesma força para influir no conteúdo do contrato, seja em razão de uma assimetria de informações, ou ainda porque tenha contratado por inexperiência ou necessidade, o grau de desequilíbrio admitido será menor, no intuito de proteger a parte mais fraca e garantir a liberdade efetiva na manifestação de sua vontade.

\footnotetext{
${ }^{471}$ Ghestin também se expressa nesse sentido: «Cette justice distributive joue un certain rôle en matière contractuelle. C'est elle, en particulier, qui peut inciter le législateur à accorder à une catégorie socioprofessionnelle un régime de protection d'ordre public» (GHESTIN, J. L'utile et le juste dans les contrats. op. cit., p .5).

${ }^{472}$ MENEZES CORDEIRO, A. M. R. Da Boa-fé no Direito Civil. op. cit., p. 653.
} 
Reconhece-se, portanto, a necessidade de conferir tutela especial à pessoa física em situação de vulnerabilidade, no intuito de proteger-lhe a efetiva liberdade no exercício da autonomia privada e garantir-lhe a proteção do núcleo dos seus direitos fundamentais, no qual se encontra o mínimo existencial.

\subsubsection{Boa-fé do devedor: ausência de culpa pela alteração das condições pessoais ou pelo agravamento da sua situação financeira}

A exigência da boa-fé do devedor é um dos pontos centrais da tutela do consumidor excessivamente endividado. Não se concebe uma tutela fundada na vulnerabilidade da parte mais fraca que agiu em desacordo com a boa-fé, prevalecendo-se do tratamento especial para auferir vantagem indevida, de forma a causar prejuízo para o credor. Note-se que a boa-fé ora tratada é, no mais das vezes, a subjetiva, ou seja, aquela em que se verifica um comportamento intencional do consumidor que se endivida com a consciência de que não terá a capacidade de cumprir o contrato. Também o comportamento do consumidor que agrava a sua situação financeira após a concessão do crédito, tomando mais empréstimos de forma negligente ou intencional, ou diminuindo propositadamente a sua renda, também deverá ser responsabilizado com o pagamento das sanções contratuais, e não fará jus à proteção especial.

Entretanto, também o comportamento contrário à boa-fé objetiva, que venha a frustrar a confiança despertada no credor com as declarações prestadas na fase précontratual, em decorrência do devedor de colaboração e de lealdade, poderá também afastar a possibilidade de tutela do consumidor. Contudo, nesse caso, é preciso considerar que os deveres decorrentes da boa-fé objetiva são mais intensos para o credor, de forma que incumbe a ele não apenas o dever de lealdade e de informação, mas o dever de aconselhamento, devendo exigir do consumidor as informações relevantes para avaliar a possibilidade de concessão do crédito, tal como já abordado na seção 1.1.1-a, da Parte II. Ressalta Jean Calais-Auloy que a boa-fé do devedor é sempre presumida. São os credores e, na França, as comissões de sobreendividamento, que deverão provar que o devedor agiu de má-fé. ${ }^{473}$ No direito comparado, países que adotaram legislação específica para tratar

\footnotetext{
473 « La bonne foi, ici comme ailleurs, se présume : le débiteur n’a donc pas à prouver qu'il est de bonne foi ; c'est à la commission ou aux créanciers qu'il appartient d'établir que le débiteur est de mauvaise foi. » CALAIS-AULOY, J. e STEINMETZ, F. Droit de la consommation. cit. p. 612. Da jurisprudência francesa: "La bonne foi conformément au droit commun, se présume et il appartient, en conséquence, aux créanciers d' établir la mauvaise foi du débiteur (cass. Civ., 1re, 4 avri 1991, J.C.P. 1991, II, 21702, conclusions FLIPO;
} 
das situações de sobreendividamento salientaram, logo nos dispositivos iniciais, o requisito da boa-fé do devedor. ${ }^{474}$

Ademais, não é apenas o sobreendividado passivo (aquele que excedeu manifestamente a capacidade de pagamento por fatores externos) que é considerado merecedor de tutela. Também aqueles consumidores que foram seduzidos pelo mercado de consumo e que em razão da imprevidência ou da racionalidade limitada acabaram se endividando excessivamente fazem jus ao tratamento do superendividamento. A idéia corrente no direito comparado é a de que o consumidor, também nesses casos, endivida-se de forma inconsciente, sendo que o próprio credor tem uma parcela de culpa por essa situação, por ter concedido o crédito de forma negligente, sem exigir informações sobre a capacidade de pagamento do devedor. Segundo lição de Jean Calais-Auloy:

On pourrait, dans un souci de sévérité pour les débiteurs, considérer comme de mauvaise foi tout débiteur qui s'est surendetté par imprévoyance, légèreté, défaut de réflexion. La procédure du Code de la consommation serait réservée, dans cette conception, aux débiteurs qui se sont conduits en bons pères de famille et dont le surendettement est le résultat de circonstances imprévisibles, par exemple d'un licenciement, d'une maladie ou d'un divorce.

Les commissions et les tribunaux n'ont pas suivi cette conception. Sont de bonne foi, d'après la jurisprudence, non seulement les débiteurs victimes des circonstances, mais encore ceux qui se sont surendettées par imprévoyance, sans l'avoir recherché de manière consciente et réfléchie. On ne peut en effet exiger d'un consommateur les qualités d'un bon père de famille. Seuls sont jugés de mauvaise foi les débiteurs qui ont été conscients de créer ou d'aggraver leur surendettement : eux ne méritent pas le bénéfice de la procédure du Code de la consommation. ${ }^{475}$

Para a caracterização da boa-fé exigida pelo artigo L. 330-1 do Code de la Consommation, a jurisprudência francesa estabeleceu uma série de requisitos. Comentando este dispositivo, J. P. Pizzio ${ }^{476}$ apresenta um resumo do entendimento jurisprudencial francês relativo à configuração da boa-fé :

La bonne foi exigée par l'article L. 331-2 n'est pas celle exigée par l' article L. 332-2 (infra, article L. 333-2) la bonne foi visée au premier article s'appréciait au regard du comportement du débiteur au cours de la période où il s'est endetté, notamment au moment

D., 1991, J., 307, note BOULOC), le juge ne pouvant pas relever d'office la fin de non recevoir tirré de la mauvaise foi du débiteur (avis de la Cour de cassation, 16 décembre 1994, $n^{\circ} 09420028$ P, confirmé par un arrêt, Cass. Civ. Ire, 13 juin 1995, Dalloz Affaires, 1995, p. 15; Rev. Trim. Dr. Com., 1995, p. 653, obs G. PAISANT) ».

${ }^{474}$ Tome-se como exemplo o Code de la Consommation, que no seu art. L 330-1 estabeleceu que "La situation de surendettement des personnes physiques est caractérisée par l'impossibilité manifeste pour le débiteur de bonne foi de faire face à l'ensemble de ses dettes non professionnelles exigibles et à échoir".

${ }^{475}$ CALAIS-AULOY, J.; STEINMETZ, F. op. cit. p. 613.

${ }^{476}$ PIZZIO, J. P. Code de la Consommation Commenté, 2a édition, Paris: Montchrestien, 1996, p. 373. 
de la conclusion de contrats de prêts, la bonne foi visée au second article s'appréciant au regard de son comportement, une fois la procédure ouverte, à l'égard de la Commission à laquelle il ne doit pas dissimuler sa situation réelle pour obtenir le bénéfice de la protection légale (G. PAISANT, Rev. trim. Dr. com., 1991, 447 et 652), cette jurisprudence étant transposable dans le droit actuel qui reprend, dans le nouvel article L.332-2, en y apportant des modifications de pure forme résultant de l'abandon de la dualité de procédure retuene par la loi du 31 décembre 1989, les cas de déchéances du bénéfice de la procédure posés par l'ancien L. 332-2; (...)

L'exigence de bonne foi est satisfaite, dès lors que le débiteur n'a pas commis d'acte deliberé créant ou aggravant son surendettement a pour cause son imprudence ou son imprévoyance (Paris 8 chambre, 10 avril 1991, J.C.P., P., IV, 361), mais la conscience d'un dépassement manifeste de ses capacités de règlement ou le caractère somptuaire des achats effectués notamment sont des élémentes d'appréciation de la mauvaise foi;

Observe-se que os critérios exigidos para a caracterização da boa-fé são tanto de ordem objetiva, quando a jurisprudência refere-se ao comportamento do devedor durante o período em que ele endividou-se, quanto de ordem subjetiva, quando se refere ao fato do consumidor ter cometido atos deliberados que originem ou agravem o seu endividamento, tendo como causa a sua imprudência e imprevisibilidade. Ou seja, o devedor não pode ter agido de forma intencional, com a consciência de que não cumprirá com a obrigação assumida. A subjetividade na apreciação da boa-fé é um fator que tem dificultado a aplicação da lei, mas de acordo com a jurisprudência supracitada, le caractère somptuaire des achats effectués notamment sont des élémentes d'appréciation de la mauvaise foi.

Note-se, portanto, que mesmo o sobreendividado ativo pode ser merecedor de tutela especial, sobretudo se, à luz das circunstâncias, constatar-se que o credor agiu de maneira irresponsável ao conceder o crédito, importando saber se o devedor endividou-se de forma consciente, no intuito de obter vantagem indevida, ou agiu impulsionado pelo excessivo apelo ao consumo e pela oferta irresponsável do crédito, ou ainda, se foi vítima da desinformação, em razão da ausência de transparência das condições contratuais, tornandose incapaz de prever a possibilidade de cumprimento da obrigação assumida. De fato, é preciso abandonar idéia de que a pessoa endivida-se sempre "porque quer", pois, como já se discorreu amplamente, o consumidor sofre pressão do mercado para que se endivide, não sendo correto imputar-lhe culpa em todos os casos. Há casos em que, devido à sedução provocada intencionalmente pelo mercado de consumo, o consumidor endivida-se inconscientemente, não podendo ser a ele imputada má-fé ou conduta maliciosa. 


\subsubsection{Situação de urgência social (força maior social)}

Conforme abordado na seção 3.2.1 da Parte I, a tutela das situações de superendividamento tem como fundamento a proteção do núcleo inafastável da dignidade humana, composto pelas condições materiais mínimas de subsistência, consistentes no direito à educação, à saúde, à vida e à moradia, todos direitos sociais reconhecidos pela Constituição Federal. É esse o núcleo dos direitos fundamentais que não pode ser violado diante de uma situação de endividamento excessivo, e apenas a ameaça a esses "direitos superiores" (para utilizar a terminologia empregada por Larenz) é que poderá fundamentar uma mitigação dos direitos decorrentes da autonomia privada, fundamentando o dever de renegociação, que será tratado a seguir.

Ademais, é preciso recordar as considerações lançadas na seção 1.2.5 da Parte I, na qual restou claro que a redução da atuação do Estado social e a adoção de uma economia de mercado, na qual os entes privados passaram a substituir o estado na prestação dos serviços essenciais, fez aumentar a suscetibilidade dos indivíduos aos chamados "acidentes da vida", que causam o sobreendividamento passivo. Assim, retomando a lição de Macpherson, ressurge o papel da justiça distributiva através dos mercados, sendo necessária a consideração de situações especiais, dos indivíduos vulneráveis às forças dos mercados, para conferir-lhes proteção especial. Essa transferência faz parte da lógica da atual sociedade de consumo, em que algumas entidades que se caracterizam como "poderes sociais" auferem os bônus decorrentes da redução do papel do Estado, devendo, em contrapartida, sujeitar-se a um direito social, que confira especial proteção às partes mais fracas das relações privadas.

Neste conceito de "poder social” certamente estão incluídas as instituições financeiras e as concessionárias de serviços públicos, que além de ser a parte mais forte na relação contratual, firmam contratos que tem por objeto bem essenciais. Fala-se atualmente em "sociedade do crédito", pois os indivíduos recorrem ao sistema financeiro para suprir necessidades básicas, como é o caso do crédito habitacional e o financiamento de bens de consumo essenciais. Mas não só. $\mathrm{O}$ crédito em si tornou-se o principal mecanismo propulsor da economia, sendo que o consumidor tem sido tratado como uma "força produtiva", quase sempre se olvidando que se trata de um indivíduo com necessidades básicas e direitos fundamentais. Como já dito diversas vezes ao longo desse trabalho, se o endividamento é uma situação desejada pela sociedade de consumo, que inflaciona, pela publicidade, a demanda pelos bens e serviços produzidos, incutindo nas mentes falsas 
necessidades e impondo um status societatis pelo que as pessoas consomem, criando falsas ilusões a respeito da possibilidade de obtenção imediata desses mesmos bens, pela promessa de crédito fácil, e se o ordenamento jurídico legitima esse cenário, deve também admitir válvulas de escape, para tutelar a situação dos indivíduos que têm o núcleo dos seus direitos fundamentais ameaçado.

Em virtude disso, surgiu a doutrina da força maior social (social force majeur), pela qual os indivíduos que, neste cenário, incorrerem num acidente da vida não devem ser considerados culpados pelo atraso no cumprimento de uma obrigação. Thomas Wilhelmsson cita a doutrina de Udo Reifner, para quem o devedor que, em virtude de condições sociais relevantes, deixa de cumprir a obrigação, não pode ser considerado culpado, não incorrendo em mora para efeito do $\S 285$ do BGB. Contudo, para que esteja presente essa situação, é preciso que essa causa social relevante, que dificultou sobremaneira o pagamento, não tenha sido ocasionada deliberadamente pelo devedor, nem mesmo que tenha sido por ele prevista no momento de conclusão do contrato, e que o devedor tenha feito o possível para evitar o prejuízo, oferecendo, por exemplo, cumprimento parcial, ou dispondo de seus bens para efetuar o pagamento. ${ }^{477}$

Caracterizada, portanto, uma situação de urgência social, em que o núcleo dos direitos fundamentais do devedor corra risco de ser violado, não lhe deve ser imputada culpa pelo inadimplemento, desde que caracterizada a sua boa-fé, tanto no sentido de não se ter endividado propositadamente, sabendo que não teria condições de pagar, quanto no sentido de não ter causado deliberadamente a situação que provocou a alteração da sua condição pessoal, responsável pelo sobreendividamento passivo.

\footnotetext{
${ }^{477}$ Segundo Thomas Wilhelmsson: "Reifner maintains that in the pertinent cases, where the social conditions of the debtor's obligation to perform become relevant, failure to pay, which is a necessary consequence of the debtor's embarrassment, does not express any special attitude on his part. According to the social interpretation advocated, the failure consists simply of the fact that no income over which the debtor fails to pay in time because of a subsequent need caused by unemployment, short-time work, illness, strike or further drains on his means available for consumption, he should thus not be considered to have rendered himself liable to culpa in the sense intended in sec. 276 of the BGB. This implies that the debtor in such a situation $i s$ not in arreas according to sec. 285 of the BGB and consequently cannot be charged with delay sanctions". Ainda segundo Reifner a aplicação desse entendimento sofre limitaçoes: "If the relevant cause of the payment difficulties is brought about by the debtor, deliberately or through culpa, he should be liable; If the event was foresseable when the contract was entered into, the debtor should be liable similarly; the debtor should do what he can to avert the damage, e.g. by offering part performance, and should in such a way that may be required of him use for payment other property at his disposal". (WILHELMSSON, T. Critical Studies in Private Law. Dordrecht: Kluwer Academic Publishers, 1992, p. 185-186) Com relação ao requisito da imprevisibilidade Thomas Wilhelmsson destaca que não pode ser tomado no sentido de enfraquecer por completo a tutela. Deve-se considerar a efetiva possibilidade do devedor prever o evento. (Idem, ibidem, p. 204).
} 


\section{Seção 2.2 - Responsabilidade pela má concessão do crédito}

Tal como já referido no primeiro capítulo deste trabalho, uma das causas do sobreendividamento é a forma como o crédito vem sendo concedido no mercado de consumo. Juntamente com a chamada "democratização do crédito" surge a prática do “empréstimo predatório", que é o empréstimo efetuado indiscriminadamente à população de baixa renda, que, além de ser mais suscetível às adversidades da vida (desemprego, doença ou morte na família, dentre outras), não tem condições de compreender os efeitos danosos do crédito na economia doméstica. Esta vulnerabilidade técnica, econômica e organizacional é explorada pelos fornecedores, que utilizam estratégias de marketing precisas para atingir esse público menos esclarecido, impondo, na maioria das vezes, condições abusivas, como a incidência de taxas de juros exorbitantes, a pretexto de assegurarem-se contra os riscos dessas operações, efetuadas, em geral, sem garantias e sem a burocracia da análise da situação financeira do devedor.

De fato, no Brasil, são comuns os anúncios publicitários oferecendo crédito "independente de consulta", "basta um talão de cheques", "crédito fácil, sem burocracia" ou mesmo lojas populares ligadas à financeiras parcelando pequenas compras em "24 prestações sem juros", sendo certo que os juros já estão embutidos no valor total da compra, de forma que o consumidor desavisado acaba "caindo" na teia da promessa de crédito fácil. Mesmo as instituições financeiras mais bem conceituadas oferecem o crédito de maneira generalizada e irresponsável, sendo bastante comum o envio de informes publicitários para as casas dos consumidores prometendo facilidades para a aquisição dos mais variados bens de consumo, que vão desde o aparelho de som até a casa própria, nos quais somente é informado o valor da parcela mensal. Em nenhum momento esses "informes" contêm o valor global do crédito, nem mesmo alertam para o fato de que quanto maior for o prazo de pagamento, mais caro custará o bem adquirido, em razão da incidência de altas taxas de juros.

Essas são práticas que denotam a existência de um empréstimo predatório, nos termos definidos na Parte I, item 1.2.4, o qual é caracterizado por: $1^{\circ}$ ) estratégias de marketing que visam atingir pessoas cultural, econômica ou socialmente vulneráveis; $2^{\circ}$ ) presença de condições contratuais abusivas, com o aproveitamento da situação de vulnerabilidade dessas pessoas; $3^{\circ}$ ) comportamento ilícito do fornecedor que falha na explicação dos termos do empréstimo ou prestar informações obscuras, utilização de táticas de alta pressão para forçar um consumidor a continuar o processo de concessão do 
empréstimo mesmo contra a sua vontade, omite explicações sobre condições abusivas (no caso brasileiro, o melhor exemplo é a omissão sobre os efeitos da capitalização de juros), desencoraja os tomadores a buscar opções de menor custo e iniciar empréstimo sem considerar a capacidade do consumidor de cumprir o contrato. ${ }^{478}$

Tudo isso somado ao fato de que a forma de contratação massificada, feita por meio dos contratos de adesão, fez aumentar a vulnerabilidade do consumidor no mercado de consumo, pois as cláusulas são estabelecidas prévia e unilateralmente pelos fornecedores, favorecendo o cometimento de abusos e impossibilitando o consumidor de influenciar no conteúdo do contrato. O exercício da autonomia privada, por parte do consumidor, reduziu-se à mera aceitação das condições existentes no mercado de consumo, sendo certo que, no mercado de crédito, as condições contratuais variam muito pouco entre as instituições financeiras, sendo, em geral, bastante onerosas. Por outro lado, tem-se a constante pressão exercida sobre o consumidor, que é o principal agente da economia de mercado, sendo que as modernas técnicas publicitárias incutem na mente das pessoas falsas necessidades e requerem a renovação constante dos bens adquiridos.

Para amenizar os efeitos dessa nova forma de contratação, o Código de Defesa do Consumidor, reconhecendo a vulnerabilidade do consumidor, impõe uma série de deveres aos fornecedores, tal como o dever de informação, o qual, como já visto, se desdobra nos deveres de esclarecimento e de aconselhamento. Aquele diz respeito ao esclarecimento sobre o sentido e o alcance das disposições contratuais, de forma a que o consumidor possa compreender os termos técnicos, os efeitos das taxas de juros conforme o prazo contratual, o significado da cobrança de juros capitalizados, os demais encargos contratuais, dentre outras informações que se mostrem necessárias. Já o dever de aconselhamento refere-se à orientação a respeito das melhores opções de escolha do consumidor, considerando as diversas modalidades de crédito existente. É dever do fornecedor analisar a condição sócio-econômica do consumidor, a fim de orientar-lhe a respeito da melhor opção de crédito, ou, até mesmo, e principalmente, sobre a inconveniência de realizar um empréstimo, tendo em vista a falta de condições de cumprir o contrato.

O dever de informação nas relações de consumo é mais intenso do lado do fornecedor, que é a parte profissional detentora do conhecimento técnico a respeito dos elementos e efeitos do contrato. Como já discorrido anteriormente, a consideração da

\footnotetext{
${ }^{478}$ Ver em: CARR, J. H. e KOLLURI, L. Predatory Lending: an overview. Fannie Mae Foundation Report, 2001. Disponível em: $<$ http://www.knowledgeplex.org/showdoc.html?id=1325> Acesso em 04 de março de 2010.
} 
qualidade das partes, como decorrência da justiça distributiva, tem como resultado a imposição de uma gama maior de deveres para a parte mais forte, de forma a balancear o equilíbrio da relação e permitir que a parte mais fraca exerça com mais efetividade a sua autonomia privada. Laurence Fin-Langer ressalta que, na verdade, não se trata de suprimir a liberdade da parte mais forte, mas, sim, de assegurar um exercício efetivo da liberdade de contratar por ambas as partes. ${ }^{479}$

Dessa forma, o fornecedor tem o dever de negar a concessão do crédito caso verifique a ausência de condições financeiras do consumidor para suportar o ônus contratual, a desnecessidade do crédito no caso concreto ou mesmo a impossibilidade técnica do consumidor compreender os efeitos danosos da utilização do crédito. O credor que concede crédito, com violação do dever de informação, a uma pessoa que nitidamente não terá condições de reembolsar as quantias emprestadas, quanto mais se o empréstimo não era de fato necessário, tendo sido efetuado por impulso ou cedendo às pressões publicitárias, deve ser responsabilizado. O dever de aconselhamento impõe que o credor analise a situação financeira do consumidor, verificando se ele tem condições de cumprir o contrato sem comprometer o seu mínimo existencial.

Ressalte-se que, sendo a instituição financeira a parte profissional da relação, é ela que deverá solicitar as informações consideradas indispensáveis para tal avaliação, cabendo ao consumidor de boa-fé prestá-las com exatidão, sob pena de não mais fazer jus à tutela protetiva. De uma maneira geral, as informações devem dizer respeito à comprovação da renda e do patrimônio do consumidor, bem como das despesas quotidianas com a sua subsistência digna, tais como as relativas à educação, saúde, alimentação, moradia, vestuário e lazer.

A responsabilização da instituição financeira nesses casos de falha no dever de informação tem sido reconhecida pela literatura de direito comparado. Menezes Cordeiro descreve essa situação, citando a sua acolhida na jurisprudência alemã:

\footnotetext{
${ }^{479}$ Nas palabras do jurista francês: "La doctrine souhaite la recherche d'une véritable liberté effective pour les deux parties contractantes. Il ne s'agit pas de supprimer la liberté du plus fort, mais d'éviter que la liberté du plus faible disparaisse. La formule de Lacordaire semble inspirer ce discours : «Entre le fort et le faible, c'est la liberté qui opprime et c'est la loi qui affranchit». En effet, la réglementation par le droit ne signifie plus atteinte à la liberté, mais au contraire permet un exercice effectif de liberté. (...) Ainsi, les dispositions du droit de la consommation reposent sur le postulat d'une volonté irrationnelle et elles ont pour objet de rétablir une volonté plus rationnelle en imposant des délais de réflexion, des mentions informatives (...) Longtemps la doctrine les analysées comme des atteintes à la liberté contractuelle, aujourd'hui elle semble considérer qu'elles protègent en réalité le consentement et la liberté contractuelle en permettant au consommateur de s'engager en connaissance de cause. Or, la liberté suppose l'entendement et la connaissance. "Pour restaurer une véritable liberté contractuelle, il faut donc donner au contractant faible le pouvoir de dire non » (D. MAZEAUD, Dr. Et Patr., mai 1998, nº 60, p. 8)". (FIN-LANGER, L. L'Équilibre Contractuel. Paris: LGDJ, p. 99-100).
} 
A responsabilidade por questões ligadas às informações prestadas pelo banqueiro domina boa parte do panorama da responsabilidade bancária. A literatura é considerável, obrigando a lidar com os diversos quadros da responsabilidade aquiliana e obrigacional. A responsabilidade bancária concretiza-se, como hipóteses clássicas, perante o banqueiro que atesta factos inexactos (ZGR 1994, 94-112 e BGH 16-Dez-1996), perante a administração de patrimónios, perante o giro bancário, perante os cheques e perante a recomendação de produtos arriscados a clientes inexperientes (OLG Nürnberg 10-fev.-1993, ZBB 1993, 40). ${ }^{480}$

No direito comparado, tem-se, ainda, o exemplo da África do Sul, país que, sofrendo de graves problemas decorrentes da concessão irresponsável de crédito, editou, em 2005, o National Credit Act, o qual impôs aos fornecedores obrigações específicas de diligência, cuidado e informação para evitar as situações de sobreendividamento. Essas obrigações consistem em: (i) certificar-se de que o consumidor tem a necessária compreensão dos riscos e dos custos do crédito oferecido, bem como de seus direitos e obrigações; (ii) analisar o histórico de crédito do consumidor e (iii) verificar a existência de meios para cumprimento do contrato (art. 81, 2 do NCA). Se descumprir estas obrigações, ou se conceder o crédito mesmo que todas as informações obtidas indiquem que o consumidor não compreendeu os riscos, custos ou obrigações do contrato ou que será levado ao sobreendividamento, a concessão do crédito será caracterizada como negligente (art. 80, 1 do NCA), acarretando a responsabilidade do credor, podendo o crédito ser suspenso e até mesmo reestruturado ou extinto, de acordo com o procedimento de reorganização previsto pelo artigo 87 do NCA.

O Código de Defesa do Consumidor brasileiro não contém um dispositivo tão específico quanto o NCA sul-africano, mas, por diversas vezes, refere-se ao dever de informar (artigos $4^{\circ}, 6^{\circ}$, inciso III, $8^{\circ}, 12,31$ ). Em especial o artigo 31 dispõe que "a oferta e apresentação de produtos ou serviços devem assegurar informações corretas, claras, precisas, ostensivas e em língua portuguesa sobre suas características, qualidades, quantidade, composição, preço, garantia, prazos de validade e origem, entre outros dados, bem como sobre os riscos que apresentam à saúde e segurança dos consumidores". Tal como exposto na seção 1.1.1, $a$ da Parte II, o fornecedor de crédito tem não apenas o dever de informar. Mais que isso, ele tem o dever de aconselhar o consumidor a respeito das diversas operações, e até mesmo sobre a oportunidade e conveniência da contratação de um empréstimo, a depender da situação financeira pessoal do consumidor.

${ }^{480}$ CORDEIRO, A. M. Manual de Direito Bancário. Coimbra: Almedina, 1998, p. 365 e 366. 
De acordo com Márcio de Oliveira Puggina, o dever de diligência do banqueiro é mais acentuado do que aquele vigente nas atividades empresariais em geral, em virtude do interesse público peculiar dessa atividade, citando norma do próprio Banco Central que veda às entidades integrantes do Sistema Financeiro Nacional: "realizar operações que não atendam aos critérios de seletividade, garantia, liquidez e diversificação de riscos (MNIBancen 16.7.2.2, b)". 481

Se existe falha no dever de informação, decorrente da boa-fé objetiva, ou negligência por parte do credor, que deixou de exigir as informações necessárias para a concessão do crédito, e vindo esse empréstimo a causar danos ao consumidor, estão presentes os elementos caracterizadores da responsabilidade civil do fornecedor de crédito, sendo que o ato ilícito constitui-se na violação dos deveres anexos à boa-fé, bem como na atuação de forma negligente na fase pré-contratual.

Em resumo, são esses os comportamentos ilícitos do fornecedor que ensejam a sua responsabilização:

- Falha no dever de esclarecimento, que se reflete na ausência de compreensão do consumidor a respeito dos termos técnicos utilizados no contrato, bem como do alcance dos seus efeitos;

- Falha no dever de aconselhamento, consistente na ausência de análise ou desconsideração pelas condições sócio-econômicas do devedor cumprir o contrato;

- Utilização de publicidade abusiva, induzindo o consumidor a efetuar um empréstimo desnecessário, em prejuízo das suas finanças;

- Aproveitamento da inexperiência e da incapacidade do devedor de compreender os efeitos danosos do crédito na sua economia doméstica;

- Inobservância da manutenção do mínimo existencial do devedor na avaliação da renda para efeito de estabelecer os pagamentos mensais da dívida.

Em todos esses casos o serviço de fornecimento de crédito será qualificado como defeituoso, seja em razão da insuficiência e inadequação das informações sobre sua fruição, o que, nos termos do artigo 14 do Código de Defesa do Consumidor, enseja a responsabilização objetiva da instituição financeira, seja em razão da atuação negligente do fornecedor que fornece o crédito de forma predatória, aproveitando-se da inexperiência e da incapacidade do consumidor compreender os efeitos danosos do contrato, utilizando-se da publicidade abusiva, e impondo condições abusivas e usurárias na concessão do crédito.

\footnotetext{
${ }^{481}$ PUGGINA, M. O. Responsabilidade civil do banqueiro pela concessão de crédito. Revista de Direito do Consumidor $n^{\circ}$ 26, abr/jun 1998. São Paulo: Editora Revista dos Tribunais, p. 136-151.
} 
Dessa forma, caracterizado está o dever de indenizar, que segue o regime da responsabilidade pelo fato do serviço, nos termos do artigo 14 do Código de Defesa do Consumidor, verbis:

Art. 14. O fornecedor de serviços responde, independentemente da existência de culpa, pela reparação dos danos causados aos consumidores por defeitos relativos à prestação dos serviços, bem como por informações insuficientes ou inadequadas sobre sua fruição e riscos.

$\S 1^{\circ} \mathrm{O}$ serviço é defeituoso quando não fornece a segurança que o consumidor dele pode esperar, levando-se em consideração as circunstâncias relevantes, entre as quais:

I - o modo de seu fornecimento;

II - o resultado e os riscos que razoavelmente dele se esperam;

III - a época em que foi fornecido.

Excluem essa responsabilidade tanto a inexistência do defeito, o que ocorre se o fornecedor provar que analisou a condição sócio-econômica do consumidor, prestando todas as informações necessárias, quanto a culpa exclusiva do consumidor, o que ocorrerá sempre que este prestar informações incorretas sobre sua condição financeira (CDC, art. $\left.14, \S 3^{\circ}\right)$.

A indenização corresponderá tanto aos prejuízos materiais, quanto aos danos morais. A situação mais corriqueira que enseja a reparação por danos morais é a inclusão do nome do devedor nos cadastros de devedores inadimplentes; contudo, o dano moral pode ter outra origem, como as pressões sofridas pelo devedor no período de inadimplência. Numa situação como esta, o Tribunal de Justiça do Rio de Janeiro já decidiu de maneira favorável ao consumidor, como se vê da ementa:

Apelação cível. Direito civil e do consumidor. Responsabilidade civil. Danos morais. Cliente de banco que, movido por inexperiência, desempregado, de baixa classe social e reduzido poder aquisitivo, faz uso de elevado crédito, inexplicavelmente disponibilizado por banco, em flagrante lesão. Obrigações contraídas se evidenciam desproporcionais ao seu próprio proveito, passando os anos seguintes a celebrar novações e dilapidando o patrimônio da família para fazer frente à obrigação assumida, que alcança três vezes o valor original, em lucro exorbitante para o credor (art.157 do CC). Débitos que eram sempre apresentados de modo a não poderem ser quitados. Negativação do nome do autor no SPC, depois que, contraindo dívidas com outras financeiras para saldar a prestação com o réu, este, debitando os encargos contratuais, faz com que o valor restante se torne insuficiente para o pagamento, quando já havia pago o dobro do montante creditório originariamente contraído. Violação, pelo banco, dos princípios da justiça social (art. 170 da CF), da solidariedade social e da boa-fé, que informam o ordenamento jurídico civil brasileiro. Contrato celebrado com indiscutível lesão ao autor, que, além de inexperiente, não foi informado das condições do crédito. Violação a seus direitos básicos, enquanto 
consumidor, à informação adequada e clara sobre os diferentes produtos e serviços e à educação e divulgação sobre o consumo adequado dos produtos e serviços, asseguradas a liberdade de escolha e a igualdade nas contratações (art.6. do CDC). Abuso de direito da negativação do nome do autor. Sentença condenatória em danos morais, no valor de 50 salários mínimos, equivalente a $\mathrm{R} \$ 12.000,00$, nesta data, que se confirma. Recurso improvido. $^{482}$

Os danos materiais, por sua vez, equivalem, primeiramente, aos juros do próprio contrato devidos ou já pagos pelo consumidor. É preciso, contudo, tratar de forma diferenciada os juros remuneratórios, incidentes no período de normalidade, e os juros moratórios, incidentes no período de inadimplência. Quanto aos juros remuneratórios, em princípio, eles serão integralmente devidos, pois não se pode admitir que o consumidor se beneficie de um empréstimo sem a devida contraprestação, auferindo vantagem indevida. Contudo, podem ocorrer duas situações. Primeiro, é posível que os encargos contratuais sejam abusivos, situação essa que será resolvida pela figura da lesão contratual, com a adequação da taxa de juros à média de mercado, nos moldes já analisados na seção 1.2, item 1.2.1 retro. Ademais, o consumidor pode ter sido levado a contratar um empréstimo absolutamente desnecessário, do qual não auferiu qualquer benefício, movido pela pressão do mercado e pela publicidade abusiva. Neste caso, mesmo os encargos contratuais do período da normalidade constituirão prejuízo para o devedor, de forma que o credor perderá o direito a essas verbas e deverá restituir o que recebeu indevidamente.

Quanto ao período de inadimplência, no qual incidem os juros moratórios, nenhum encargo será devido, pois o ilícito contratual por parte do fornecedor descaracteriza a mora do devedor, que não pode ser considerado culpado pelo inadimplemento do contrato. Com efeito, nos termos do artigo 396 do Código Civil, "não havendo fato ou omissão imputável ao devedor, não incorre este em mora”. O próprio Superior Tribunal de Justiça já admitiu a não incidência de encargos moratórios quando a mora não pode ser imputada ao devedor, devido à existência de encargos ilegais e abusivos embutidos na dívida, que tornem as prestações excessivamente onerosas, de forma a dificultar o adimplemento da obrigação ${ }^{483}$. O entendimento atual do STJ, firmado no recurso representativo $n^{0} 1.061 .530$, relatora Minista Nancy Andrighy, é no sentido de que "o reconhecimento da abusividade nos

\footnotetext{
${ }^{482}$ TJRS, Apelação n ${ }^{\circ}$ 2003.001.02181, Rel. Des. JOSE PIMENTEL MARQUES, julgamento: 25/06/2003

483 "Mora. Culpa do Devedor. Não há mora do devedor quando inexistente culpa sua, elemento exigido pelo artigo 963 do CC para sua caracterização. Inexistindo mora, descabe condenar em juros moratórios e em multa". STJ - $4^{\text {a }}$ Turma Resp no 82.560-SP, rel. Min. RUY ROSADO, DJU 20/05/1996, Seção 1, p. 16.717; "A cobrança de acréscimos indevidos importa na descaracterização da mora, de forma a tornar inadmissível a busca e apreensão do bem (2 $2^{a}$ Seção, EREsp n ${ }^{0}$ 163.884/RS, Rel. p/ acórdão Min. Ruy Rosado de Aguiar, por maioria, DJU de 24.09.2001). Manutenção da improcedência da ação. (...)" (AGRESP 592.635/RS, Rel. Min. ALDIR PASSARINHO JUNIOR, J. 18/03/2004, DJ 10.05.2004 p.00295, un.)
} 
encargos exigidos no período da normalidade contratual (juros remuneratórios e capitalização) descarateriza a mora". No caso de responsabilidade pela má concessão do crédito, apesar de não se tratar necessariamente de cobrança de encargos abusivos, está presente a mesma ratio que levou ao entendimento pacificado no STJ, já que o fornecedor de crédito pratica também ato ilícito. Contudo, o ato ilícito, no caso de empréstimo negligente ou com falta do dever de informação, ocorre na fase pré-contratual, e consolidase na conclusão do contrato. $\mathrm{O}$ vício de origem macula a relação jurídica por completo, tornando-a controvertida por inteiro, daí porque não há que se falar em depósito da quantia incontroversa, nos termos da súmula 380 do STJ e da orientação do recurso representativo $\mathrm{n}^{\mathrm{o}}$ 1.061.530, que exigem o depósito para a descaracterização da mora.

A indenização por danos materiais não se limita, porém, aos encargos contratuais. Qualquer prejuízo material, consistente nos danos emergentes e lucros cessantes, que o consumidor lograr comprovação, demonstrando o nexo causal, poderá resultar no dever de indenização por parte do fornecedor. Sendo o crédito o motor propulsor da sociedade de consumo, o indivíduo que descumpre um contrato de crédito tem seu nome incluído em cadastros de restrição ao crédito, passando a sofrer incontestáveis prejuízos a partir de então. Os danos morais, segundo o entendimento pacífico do STJ, decorrem ipso facto da inclusão do nome do devedor nos cadastros de restrição ao crédito. Contudo, podem advir também danos materiais, como a obstrução à realização de negócios pessoais, a impossibilidade de adquirir um bem essencial, a recusa do recebimento de cartão de crédito ou talão de cheques, dentre outros. 


\section{3 - Tutela do consumidor excessivamente endividado em face da alteração das circunstâncias subjetivas}

Quando a alteração das circunstâncias pessoais do devedor, como a diminuição da renda em razão do desemprego ou ruptura familiar, ou o aumento das despesas em razão de grave enfermidade, dificultar o cumprimento de um contrato de financiamento, criando uma situação de sobreendividamento passivo, essa mudança na situação de fato que afetou a capacidade financeira do devedor poderia fundamentar um dever de renegociação, ou mesmo a adaptação judicial do contrato inadimplido?

Uma vez presentes os requisitos abordados na seção anterior, o consumidor que incorrer em superendividamento ${ }^{484}$ mostrar-se-á merecedor de tutela especial, com incidência mais reforçada dos princípios sociais da boa-fé, da função social dos contratos e da justiça contratual. As soluções possíveis, à luz do ordenamento jurídico brasileiro, serão tratadas a seguir: 1) imposição do dever de renegociação; 2) adaptação do contrato em razão da alteração das circunstâncias; 3) resolução do contrato que se tornou excessivamente oneroso. Ressalte-se, desde já, que não se exige uma ordem sucessiva na adoção dessas soluções, já que, em razão do princípio da inafastabilidae do controle jurisdicional, o devedor não pode ser obrigado a demonstrar o esgotamento da via extrajudicial na tentativa de renegociação para pleitear a tutela juridcional visando a adequação do contrato. Contudo, a tentativa de renegociação reforça a boa-fé do devedor, devendo ser considerada na análise do merecimento da tutela especial.

\subsubsection{Dever de renegociação}

Caracterizada uma situação de sobreendividamento, que tenha tornado extremamente dificultoso o cumprimento do contrato nas condições inicialmente estipuladas, de forma a ameaçar a própria subsistência do devedor, questiona-se se a renegociação do contrato é uma mera faculdade posta à disposição do credor, ou se constitui um dever que lhe é acometido. Entendemos pela segunda opção, pelas razões a seguir expostas.

\footnotetext{
${ }^{484}$ Nesta seção as situações tratadas referem-se ao sobreendividamento passivo, já que se referem à alteração da capacidade financeira do consumidor em razão da alteração de circunstâncias pessoais, independentes da sua vontade, como o desemprego e a doença ou morte na família. Já na seção anterior, inclui-se também o sobreendividamento ativo inconsciente, na qual o consumidor é levado a se endividar pelas pressões do mercado.
} 
No ordenamento jurídico brasileiro, o dever de renegociação encontra guarida tanto no dever de cooperação, decorrente da boa-fé objetiva, quanto na vedação ao exercício abusivo de posições jurídicas, que tem os seus limites delineados pelo mesmo princípio da boa-fé objetiva, pela função econômica e social dos contratos e pelos costumes. ${ }^{485}$ Como será adiante demonstrado, a recusa injustificada do credor em renegociar o contrato, cujo cumprimento tornou-se insuportável, legitima o devedor a faltar o cumprimento, em virtude de uma inexigibilidade temporária da prestação. Nesta situação, não é possível falar em mora do devedor, tendo em vista que o inadimplemento não poderá ser-lhe imputado, já que não terá como causa um comportamento culposo de sua parte, mas sim, a negativa infundada do credor em renegociar o débito.

Inicialmente, é preciso recordar o dever de cooperação, decorrente da boa-fé objetiva, que está presente em todas as contratações. De acordo com Cláudia Lima Marques, os novos deveres de cooperação “imporiam um esforço de boa-fé para adaptar estes contratos e preservá-los (neue Verhandlungspflichten), a evitar a ruína e o superendividamento dos consumidores de boa-fé". ${ }^{486}$ A autora destaca a necessidade de cooperação no sentido de submeter o contrato às alterações necessárias para a manutenção do vínculo e para a realização do objetivo comum, que é a extinção do contrato pela via normal do adimplemento, como se vê:

A doutrina atual germânica considera ínsito no dever de cooperar positivamente o dever de renegociar (Neuverhandlungspflichte) as dívidas do parceiro mais fraco, por exemplo, em caso de quebra da base objetiva do negócio. Cooperar aqui é submeter-se às modificações necessárias à manutenção do vínculo (princípio da manutenção do vínculo do art. $51, \S 2^{\circ}$, do CDC) e à realização do objetivo comum e do contrato. ${ }^{487}$

\footnotetext{
${ }^{485}$ Entendemos não se tratar aqui de um caso de impossibilidade superveniente, à qual a dogmática civilista brasileira reconhece como efeito a resolução do vínculo. Apenas registre-se que, no direito alemão, a questão da impossibilidade superveniente do cumprimento da obrigação ganhou novos contornos a partir da reforma de 2002 de BGB, que positivou a chamada "impossibilidade alargada". Segundo Francesco Paolo Traisci, citado por Karen Bertoncello: De sua parte, a doutrina estabeleceu que a norma não faz mais distinção nem entre a impossibilidade superveniente, e, tampouco, entre a impossibilidade imputável e a não-imputável, chegando, portanto, a julgar relevante cada tipo de Unerfüllbarkeit, significa dizer, de inexeqüibilidade da prestação". "A categoria na qual se encaixam as três hipóteses previstas na norma seria aquela correspondente à noção de Leistungsverweigerung, ou seja, de refutabilidade (rectius de inexigibilidade) da prestação, que pretende assim substituir o conceito de impossibilidade absoluta, objeto do $\S 275$, na sua antiga versão, com aquele de inexigibilidade da mesma prestação, ou seja, de prestação cujo adimplemento poderá ser legitimamente refutada pelo devedor. De fato, o próprio conceito segundo a doutrina seria aquele idôneo a compreender tanto a impossibilidade absoluta quanto outra forma de dificuldade no adimplemento, seja impossibilidade econômica e a Unzumutbarkeit (ou seja, a inexigibilidade). (TRAISCI, F. P. Sopravvenienze contrattuali e rinegoziazione nei sistemi di civil e di common law. Napoli: Edizioni Scientifiche Italiane, 2003. p. 157/158. Apud BERTONCELLO, P. 77, 78).

${ }^{486}$ MARQUES, C. L. Sugestões para uma lei sobre o tratamento do superendividamento..., cit. p. 266-267.

${ }^{487}$ MARQUES, C. L. Contratos no Código de Defesa do Consumidor. cit., p. 236.
} 
Além do dever de cooperação, a renegociação do contrato encontra seu fundamento na vedação ao exercício abusivo de posições jurídicas, que, no direito brasileiro, está prevista no artigo 187 do Código Civil, nos seguintes termos: "Também comete ato ilícito o titular de um direito que, ao exercê-lo, excede manifestamente os limites impostos pelo seu fim econômico ou social, pela boa-fé ou pelos bons costumes".

Primeiramente, tem-se o parâmetro da boa-fé, em seu sentido objetivo, como limite ao exercício de direitos e faculdades jurídicas, que já foi objeto de estudo no item 1.1.2, c, desta Parte II. Diante de uma situação de sobreendividamento, caracterizada pela manifesta impossibilidade de pagamento das dívidas vencidas e a vencer, qualificada pela situação de urgência social, o credor que recusa a renegociação estará agindo com abuso de direito em duas modalidades: a) exercício danoso inútil, pois o exercício meramente formal ou literal do seu direito não lhe trará nenhum benefício, já que a cobrança de um consumidor nessa situação, sem alterar as condições impostas inicialmente, estará fadada ao insucesso, considerando a proteção conferida pelo sistema de impenhorabilidades, ${ }^{488}$ bem como a necessidade da manutenção do mínimo existencial do devedor; b) exercício desproporcional do direito, considerando as vantagens auferidas em comparação com o sacrifício exigido, tendo em vista que a cobrança nessas situações imporá um sacrifício desmedido ao consumidor, que terá ameaçados os seus direitos fundamentais, trazendo pouco ou nenhum benefício ao credor.

Para o credor, a concessão de uma moratória com suspensão dos juros, o recebimento do crédito num maior número de parcelas ou a concessão de desconto no montante equivalente aos juros, não representará grande prejuízo, sobretudo em se tratando de um grande fornecedor como uma instituição financeira que, em geral, compensa o prejuízo de casos isolados de inadimplência com manobras contábeis, cessão do crédito por valor muito inferior a empresas especializadas em cobrança, ou, de qualquer forma, redistribui o "prejuízo" dentre os milhares contratos de financiamento que realiza diariamente.

\footnotetext{
${ }^{488}$ Além do bem de família, protegido pela Lei 8.009/90, tem-se, por exemplo, as impenhorabilidades do artigo 649 do CPC, que dispõe serem absolutamente impenhoráveis: "II - os móveis, pertences e utilidades domésticas que guarnecem a residência do executado, salvo os de elevado valor ou que ultrapassem as necessidades comuns correspondentes a um médio padrão de vida; III - os vestuários, bem como os pertences de uso pessoal do executado, salvo se de elevado valor; IV - os vencimentos, subsídios, soldos, salários, remunerações, proventos de aposentadoria, pensões, pecúlios e montepios; as quantias recebidas por liberalidade de terceiro e destinadas ao sustento do devedor e sua família, os ganhos de trabalhador autônomo e os honorários de profissional liberal, observado o disposto no $\S 3^{\circ}$ deste artigo; V - os livros, as máquinas, as ferramentas, os utensílios, os instrumentos ou outros bens móveis necessários ou úteis ao exercício de qualquer profissão";
} 
De fato, tal como já reconheceu a doutrina norte-americana, o fornecedor de crédito está em melhor posição de calcular (antecipadamente) e redistribuir o "prejuízo", ${ }^{4} 9$ servindo de instrumento de socialização da desgraça de alguns indivíduos, numa idéia que se coaduna com o valor da solidariedade social arraigado na ordem jurídica brasileira. Não é razoável admitir que o credor inclua na taxa de juros um percentual referente ao risco de inadimplência, como de fato o faz, e, quando solicitado a renegociar a dívida de um consumidor em situação de urgência social, simplesmente recuse injustificadamente. E, após recusar a alteração das condições contratuais para a pessoa que de fato necessita, ceda o crédito pela metade do preço para uma empresa especializada em cobrança de dívidas.

Em todos esses casos restará caracterizada uma grande desproporção dos efeitos práticos, que representa violação do artigo 187 do Código Civil. Segundo Menezes Cordeiro, caracteriza-se o abuso do direito nas modalidades de "actuação de direitos com lesão intolerável de outras pessoas" e de "exercício jussubjectivo sem consideração por situações especiais", que assim especifica:

O exercício jussubjetivo sem consideração por situações especiais integra, de algum modo, o desenvolvimento profundo do dispositivo consagrado pelo art. 335 ao conflito de direitos. Nas ordens jurídicas onde falte essa regulação específica, as cláusulas gerais e, em especial, a boa fé, ganham a maior importância para a solução do problema: não é líquida a saída rápida que, no conflito de direitos, vê logo uma violação do direito alheio e não um abuso do direito próprio. No Direito português, soluciona-se a questão a nível de direitos subjectivos. Mas há que ampliá-la: para além dos direitos subjectivos alheios, o titular-exercente deve respeitar, no exercício do direito próprio, outras situações especiais, cuja preterição contrarie o clausulado no art. $334^{\circ}$. Tal como nos casos anteriores, a bitola de decisão é encontrada numa ponderação dos valores em jogo por parte do titular e da pessoa cuja posição é atingida pelo exercício. A materialidade dessa bitola deve, porém, ser procurada noutras latitudes. 490

Segundo o mestre português, na ausência de regulação específica, a cláusula geral da boa-fé ganha importância para a solução dessas situações que exigem uma especial consideração pelo contratante mais forte. Na caracterização do exercício abusivo, importa saber se, na ponderação de valores envolvidos, mostra-se razoável exigir um sacrifício extremo do devedor, considerando o respeito aos seus direitos fundamentais, em razão do exercício formalmente legítimo do direito de crédito. Não se mostrando razoável a

\footnotetext{
489 Ver, por exemplo: NIEMI-KIESILAINEN, J. Consumer Bankruptcy in Comparison: Do We Cure a Market Failure or a Social Problem? Osgoode Hall Law Journal, vol. 37, nº 1 e 2, 1999, p. 473-503.

${ }^{490}$ MENEZES CORDEIRO, A. M.R. Da Boa-fé... op. cit., p. 858.
} 
exigibilidade do crédito, surge o dever de renegociação, devendo a forma de cumprimento da obrigação ser alterada de acordo com o parâmetro da boa-fé objetiva.

Outro critério trazido pelo artigo 187 do CC como limite ao exercício de direitos, fundamentando o dever de renegociação, é o "fim econômico e social do direito". Tal como diversas vezes mencionado ao longo deste trabalho, os direitos existem em função da vida em sociedade. ${ }^{491}$ Ensina Louis Josserand que mesmo no exercício aparentemente individual e egoísta de um direito, o sujeito está a realizar uma prerrogativa social, devendo exercê-lo conforme o espírito da instituição. ${ }^{492}$ Por essa razão, Josserand considera que todo o direito é relativo "em consideração e em função do seu objetivo", e isso vale não somente para as prerrogativas altruísticas, mas também para os direitos mais egoístas como o "direito de propriedade e o direito de um credor exigir de seu devedor, pelos meios legais, o pagamento de seu débito". Esses direitos ditos egoístas são reconhecidos para o bem da própria sociedade, e, “já que cada egoísmo concorre a um objetivo final, é evidente que cada um de nossos direitos subjetivos devem ser orientados e tender em direção a esse objetivo; cada um tem a sua própria missão a preencher, vale dizer, cada um deve se realizar conforme o espírito da instituição; na verdade, numa sociedade organizada, os pretendidos direitos subjetivos são direitos-função; devem permanecer dentro do plano da função para a qual correspondem, caso contrário seu titular comete um desvio, um abuso de direito; o ato abusivo é o ato contrário ao objetivo da instituição, ao seu espírito e a sua finalidade". ${ }^{493}$

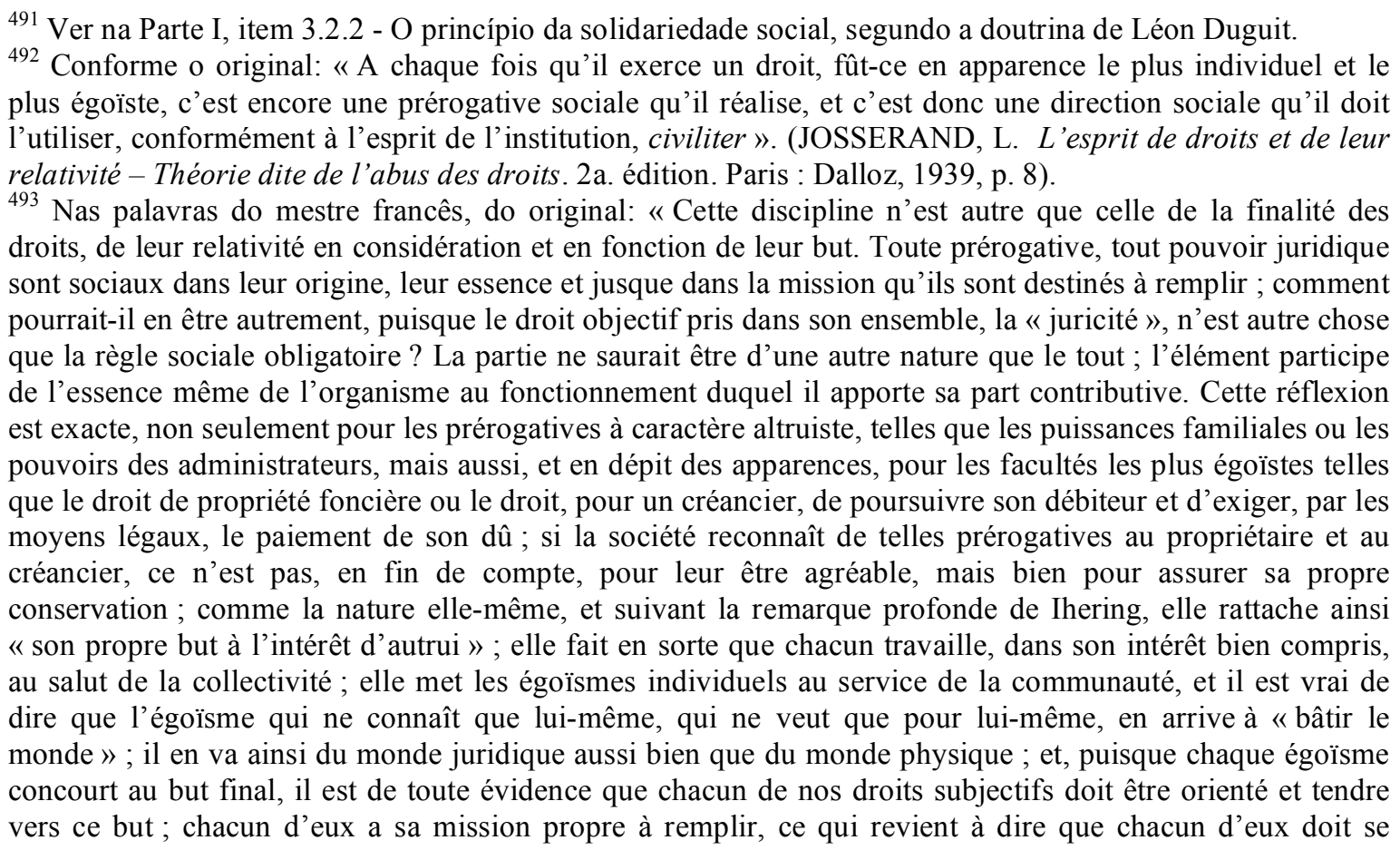


Dessa forma, segundo o autor, o instituto do abuso de direito se desenvolve em duas direções: por um lado alcança domínios até então inexplorados, sendo causa de limitação de direitos - e, em nota, textualmente, o jurista francês menciona o direito do devedor refutar o pagamento, "le droit de ne pas payes ses dettes »; por outro lado, o abuso do direito deixou o seu significado puramente subjetivista, que considerava abusivo apenas o exercício intencional, para adotar um critério mais objetivo, de observância ao espírito da instituição - d'intentionnel qu'il était autrefois, le critère est devenu social. ${ }^{494}$

Tomando por base essas lições, resta claro que a recusa em renegociar um contrato de crédito, para torná-lo exeqüível ao consumidor, trata-se de um exercício abusivo por parte do credor. Primeiro porque impedirá que o contrato se extingua pela via normal do adimplemento, contrariando o "espírito" econômico para o qual a sociedade confere força obrigatória aos contratos, que é o de permitir a circulação de riquezas. Por outro lado, o exercício de direito nesses termos contraria o "espírito" do ordenamento jurídico como um todo, pois desrespeita valores supremos expressamente consagrados pela Constituição Federal, que privilegiam a solidariedade social e a dignidade da pessoa humana, que incidem nas relações privadas por intermédio das cláusulas gerais da boa-fé e da função social do contrato.

Ressalte-se, ademais, que em razão da boa-fé exigida de ambas as partes, é de se reconhecer que o consumidor deverá requerer a renegociação na primeira oportunidade ${ }^{495}$, evitando, se possível, o inadimplemento. Ou seja, uma vez verificado o evento que ensejou a alteração das circunstâncias, o consumidor diligente deverá procurar o seu credor para informar os fatos ocorridos e buscar a renegociação ${ }^{496}$, e, de regra, somente a partir de

réaliser conformément à l'esprit de l'institution ; en réalité, et dans une société organisée, les prétendus droits subjectifs sont des droits-fonction; ils doivent demeurer dans le plan de la fonction à laquelle ils correspondent, sinon leur titulaire commet un détournement, un abus de droit; l'acte abusif est l'acte contraire au but le l'institution, à son esprit et à sa finalité ». (JOSSERAND, L. L'esprit de droits... op. cit., p. 394-395)

${ }^{494}$ Nas palavras de Josserand: «D’une part, en effet, elle s'est propagée jusqu'à des domaines jusque-là inexplorés, elle est venue causer et limiter des droits avec lesquels elle n'avait pas jusqu'à des domaines jusque-là inexplorés, elle est venue causer et limiter des droits avec lesquels elle n'avait pas jusqu'alors pris contact [I - pour un débiteur, ce droit inédit, paradoxal, issu à la fois de la crise économique et de la crise de conscience que nous traversons simultanément : " le droit de ne pas payes ses dettes »!]; d'autre part, elle a changé de signification et de critère : tandis que, pour les juristes romains, l'acte malicieux, il est devenu, dans l'état actuel de notre droit positif, l'acte malicieux, il est devenu, dans l'état actuel de notre droit positif, l'acte antifonctionnel, l'acte contraire à l'esprit d'un droit déterminé ; d'intentionnel qu'il était autrefois, le critère est devenu social, et la théorie y a beaucoup gagné en puissance et en étendue. (JOSSERAND, L. L'esprit de droits... op. cit., p. 8)

${ }^{495}$ AGUIAR JR., R. R. Extinção dos Contratos por Incumprimento do Devedor. cit., p. 160.

496 Francesco Macario, apesar de tratar do caso de resolução por onerosidade excessiva nos contratos bilaterais de longa duração, faz menção à necessidade da proposta ser tempestiva: "Nell'esame del procedimento e quindi delle modalità dell'offerta, deve essere sottolineato il ruolo dell'obbligo di correttezza, che fa capo al generale dovere di cooperazione del debitore e del creditore e che si specifica in 
então é que a tutela será merecida.

Entretanto, mesmo em caso de inércia do consumidor será preciso analisar com cuidado o caso concreto, pois é possível que em razão da vulnerabilidade do sujeito em questão verifique-se um total desconhecimento a respeito da efetiva possibilidade de renegociação, bem como pode haver uma má avaliação da própria situação concreta a respeito dos efeitos da alteração das circunstâncias na economia pessoal, como a daquele consumidor que deixa de pagar algumas prestações, mas confia na sua capacidade de retomar a normalidade contratual. Ademais, o próprio credor pode oferecer obstáculos que impeçam o consumidor de ter acesso aos canais de renegociação. Portanto, apesar de ser valorizado o comportamento diligente do consumidor que procura o seu credor tão logo tenha ciência a respeito da situação de urgência social isso não significa que deverá ser negada a tutela àquele consumidor que se manteve inerte.

Uma vez concluindo-se pela efetiva ocorrência da abusividade no exercício da faculdade de renegociar, qual seria, afinal, a conseqüência jurídica? Estando o abuso do direito previsto como uma modalidade de ato ilícito ( $\mathrm{CC}$, art. 927), teria como conseqüência apenas a indenização, ou poderia gerar efeitos mais amplos?

Segundo Cunha de Sá, parte da doutrina entende que o ato abusivo apenas teria como conseqüência a reparação civil, que seria cabível apenas diante da demonstração do efetivo prejuízo. Dessa forma, se o ato abusivo não ocasionasse prejuízo, apenas poderia ser considerado um "mau uso do direito, que diria exclusivamente respeito à consciência do titular e a ninguém mais". ${ }^{497}$ Contudo, mesmo para os autores que assim pensavam, como o próprio Josserand, acabavam contradizendo-se ao admitir que, por vezes, a reparação civil não seria suficiente..$^{498}$

relazione agli sviluppi del rapporto contrattuale. Un'offerta tardiva, secondo le circostanze e, in particolare, secondo la natura dell'affare, ovvero un'offerta espressa con modalità lesive dell'interesse dell'altra parte a conoscere tempestivamente l'intenzione di mantenere in vita il contratto, non potrà non essere valutata anche alla stregua del principio di buona fede. Ciò può condurre a riconoscere alla parte onerata il diritto al risarcimento del danno e induce a riflettere circa la stessa efficacia dell'offerta, qualora nella controparte sia venuto meno, a causa del comportamento del convenuto, l'interesse alla prosecuzione del rapporto". (MACARIO, F. Adeguamento e rinegoziazione nei contratti a lungo termine. Napoli: Novene Editore, 1996, p. 270)

${ }^{497}$ Cunha de Sá expõe, nesse trecho, a posição de Louis Josserand (CUNHA DE SÁ, F. A. Abuso do Direito. Lisboa, 1973, p. 628).

${ }^{498}$ Como ensina Cunha de Sá: "Não obstante, que esta não seja a correcta visão do problema e aquela a que, em última análise, Josserand vem, embora contraditoriamente, a aderir, é por ele confessado, quando se ocupa ex professor da sanção do acto abusivo. Sendo o caso de abuso verdadeiro e próprio, isto é, conforme já sabemos, na sua construção, de desvio do direito do seu fim social, entende ele como natural que quem quer que seja lesado por tal desvio "possa exigir que o direito seja corrigido, reposto no bom caminho e que possa, com esse fim, pedir ao tribunal que prescreva medidas destinadas a conjurar o retorno de tais desvios". A indenização pecuniária não só se revelaria, sob este aspecto, totalmente ineficaz e insatisfatória para a preservação dos interesses afectados pelo abuso do direito, como tão pouco a obrigação de reparar o dano 
Esclarece Cunha de Sá que tanto o ato abusivo, quanto o ato ilícito, caracterizam-se como "actuação sem direito (...) só que enquanto a ilicitude é, desde logo, directa e frontal violação dos limites formais do direito ou da prerrogativa em causa, já o acto abusivo finge a aparência estrutural desse mesmo direito ou prerrogativa, assim encobrindo a violação da sua intenção normativa". Em outras palavras, enquanto o primeiro se trata de "ultrapassagem dos limites lógico-formais de uma determinada prerrogativa individual", o outro se refere ao "excesso ou desrespeito dos respectivos limites axiológico-materiais". 499 A partir daí, o jurista conclui que a resposta jurídica para o ato abusivo não se resume à mera reparação civil, podendo ser "variável e deve ser determinada, consequentemente, caso por caso". E acrescenta:

Poderá descobrir-se toda uma infinda gama de sanções que, essas sim, impedirão que o titular do direito abusivamente exercido obtenha ou conserve as vantagens que obteve com a prática do acto abusivo e o farão reentrar, em última análise, no exercício legítimo do direito: desde a nulidade, a anulabilidade, a inoponibilidade, ou a rescindibilidade do acto ou negócio jurídico quando seja na sua prática que o abuso se verifique, até ao restabelecimento da verdade ou da realidade dos actos com ele conexionados, aceitando, por exemplo, a sua validade não obstante a falta da forma exigida, concedendo a exceptio doli generalis ou specialis, recusando a acção de anulação ou mantendo em vigor a relação. ${ }^{500}$

Tendo em vista essa amplitude das sanções possíveis, com relação ao dever de renegociação, uma primeira conseqüência que se impõe é a inexigibilidade do crédito, já que, em virtude da "antijuridicidade do ato", segundo Cunha de Sá, "acarreta-lhe como reacção lógica por parte do ordenamento jurídico a recusa da tutela que, não fora tal contraditoriedade, seria adequada ao caso concreto" ${ }^{, 501}$ - se efetivamente houvesse a renegociação, não haveria inadimplemento. Corrobora com essa posição a lição de Josserand, que ao tratar do abuso de direito durante a execução dos contratos, declara: « la convention cesse de faire la loi des parties, dans la mesure où elle choque la conscience moyenne et parce qu'elle est abusive ; ce n'est plus d'un idéal concret et limité à l'espèce que le tribunal se constitue le champion, mais d'un idéal plus vaste et en quelque sorte

assumiria obrigatoriamente tal forma: antes a indenização específica seria a melhor e mais adequada maneira de repor as coisas no estado anterior ao da lesão, fazendo destruir o que foi feito com desprezo do exercício do direito sãmente entendido. Consequentemente, o princípio que dominaria a sanção do abuso do direito seria o da reparação natural, variável evidentemente com o tipo concreto de acto abusivo praticado. (...)" (CUNHA DE SÁ, F. A. Abuso do Direito. cit. p. 629.)

${ }^{499}$ Idem, ibidem, p. 634.

${ }^{500}$ Idem, ibidem, p. 648-649.

${ }^{501}$ Idem, ibidem, p. 625. 
générique : celui d'un équitable commerce juridique $»{ }^{502}$ Some-se a posição de Antonio Junqueira de Azevedo, para quem quando ausente ou desviada a função social, em virtude da violação do núcleo mínimo da dignidade humana, a conseqüência é a ineficácia do contrato, o que confirma as posições assumidas até o momento. ${ }^{503}$

Antunes Varela, reportando-se à doutrina dos limites do sacrifício, corrobora com o posicionamento ora adotado, pois entende que o caso de extrema dificuldade do devedor em cumprir a obrigação não se trata de impossibilidade da prestação, mas sim, de inexigibilidade temporária, em razão da vedação ao abuso do direito, assim afirmando: "quando o exercício do crédito, em face das circunstâncias, exceda manifestamente os limites impostos pela boa fé, o devedor poderá legitimamente faltar ao cumprimento, não por impossibilidade da prestação, mas pelo abuso no exercício do direito do credor" ${ }^{504} \mathrm{E}$ em nota, declara: "Há, além disso, que ter em linha de conta, não como causa de impossibilidade da prestação, mas como fundamento de inexigibilidade (temporária) da obrigação aqueles casos em que à exigência da prestação se oponha a existência de direitos ou deveres de plano superior ao direito de crédito (nomeadamente os direitos fundamentais do devedor)". 505

Dessa forma, nos casos de extremo sacrifício ou custo excessivo da prestação, resta configurada a hipótese de inexigibilidade temporária da prestação, não sendo possível considerar o devedor culpado pelo inadimplemento, desde que os fatos que levaram à inexigibilidade não lhe possam ser imputados. Assim, nos termos do artigo 396 do Código Civil, "não havendo fato ou omissão imputável ao devedor, não incorre este em mora". Tem-se como conseqüência a exoneração do devedor quanto aos danos moratórios, o que, no caso, materializa-se nos encargos contratuais previstos, seja em razão do inadimplemento (juros moratórios), seja em razão da permanência dos valores com o consumidor (comissão de permanência).

É essa também a conclusão de Antunes Varela:

Se a causa da demora no cumprimento fosse devida a culpa do devedor, este responderia pelos danos que a mora trouxe ao credor. Não lhe sendo imputável, não responderá por tais danos; mas não ficará exonerado da obrigação, visto ser temporário ou transitório o obstáculo ao cumprimento. O efeito da impossibilidade temporária será,

\footnotetext{
${ }^{502}$ JOSSERAND, L. L'esprit de droits ..., cit., p. 166-167.

${ }^{503}$ JUNQUEIRA DE AZEVEDO, A. Relatório brasileiro sobre revisão contratual... op. cit., p. 197.

${ }^{504}$ ANTUNES VARELA, J. M. Das Obrigações em Geral. Vol II, op. cit. p. 71.

${ }^{505}$ Tal afirmação consta da nota ${ }^{\circ} 2$, página 70, em ANTUNES VARELA, J. M. Das Obrigações em Geral, vol II, $7^{\text {a }}$ ed., Coimbra: Almedina, 1977.
} 
portanto, o de exonerar o devedor dos danos moratórios, mas só enquanto a impossibilidade perdurar. $^{506}$

Nesse sentido, aliás, já se pronunciou o Superior Tribunal de Justiça, entendendo que "não há mora do devedor quando inexistente culpa sua, elemento exigido pelo artigo 963 do CC para sua caracterização" e "inexistindo mora, descabe condenar em juros moratórios e em multa". ${ }^{507}$ Em diversos julgados o Superior Tribunal de Justiça entendeu que o fato do credor cobrar encargos contratuais em desconformidade com a lei descaracteriza a mora do devedor, sendo que, da reiteração dos julgamentos nesse sentido, foi decidido o recurso representativo $\mathrm{n}^{0}$ 1.061.530, relatora Minista Nancy Andrighy, resultando na seguinte orientação: "O reconhecimento da abusividade nos encargos exigidos no período da normalidade contratual (juros remuneratórios e capitalização) descarateriza a mora". 508

Muito embora não seja aqui o caso de cobrança indevida, a abusividade da recusa na renegociação enquadra-se na mesma ratio do entendimento do STJ na situação descrita acima, pois em ambos verifica-se um comportamento antijurídico por parte do credor, de forma a justificar a posição aqui adotada, pela descaracterização da mora do devedor em caso de exercício abusivo do dever de renegociar o contrato.

Em verdade, a culpa pela inexecução do contrato, nesses casos de recusa injustificada (a renegociar), transfere-se para o credor, que deverá arcar com as conseqüências da sua mora. Assim, poderá ser responsabilizado pelos prejuízos a que a sua mora der causa, o que, para o devedor, constitui-se na própria fluência dos juros moratórios, ou da comissão de permanência, conforme o pactuado no instrumento contratual. De fato, enquanto o credor recusa-se, injustificadamente, a adaptar o contrato às novas circunstâncias, o saldo devedor cresce em função da incidência dos juros. Assim sendo, a indenização consistiria no pagamento dos encargos contratuais, de forma que haverá, em última análise, uma compensação dos danos: os juros devidos pelo devedor compensam-se com a indenização devida pelo credor. A exigência dos juros, em si mesma, caracterizaria um exercício abusivo de direito na forma de "exigir o que em seguida deverá

\footnotetext{
${ }^{506}$ ANTUNES VARELA, J.M. Das Obrigações em Geral. Vol II. op. cit. p. 79-80.

${ }^{507}$ STJ - $4^{\text {a }}$ Turma Resp no 82.560-SP, rel. Min. Ruy Rosado, DJU 20/05/1996.

${ }^{508}$ Em se tratando de ação revisional que tem por objeto a declaração de nulidade de cláusulas aplica-se a súmula 380 do STJ, segundo a qual "a simples propositura da ação de revisão de contrato não inibe a caracterização da mora do autor", sendo necessário, além da verificação da viabilidade da demanda, o depósito da quantia incontroversa, conforme estabelecido no Resp 1.061.530. Esse não é, contudo, o caso ora tratado, muito embora nada impeça que o superendividamento passivo coexista com abusividades praticadas pela instituição financeira. Contudo, isolando-se a alegação abuso de direito por parte do credor, e o reconhecimento do dever de renegociar, percebe-se que o problema é exatamente a falta de disponibilidade do dinheiro, ainda que o credor não tenha cometido qualquer ilegalidade.
} 
se restituir". 509

Contudo, os prejuízos causados ao devedor pela mora do credor podem extrapolar a simples fluência dos juros contratuais. É possível que, em razão da não renegociação do contrato, a manutenção do consumidor na condição de inadimplente ocasione-lhe danos morais, em razão da inclusão do seu nome em cadastros restritivos ao crédito, ou mesmo patrimoniais, por impedir-lhe a realização de negócios pessoais, ou obstar-lhe o acesso às demais instituições financeiras para realização de operações corriqueiras, como a utilização de talões de cheque ou de cartão de crédito, ou mesmo pagamento de contas de consumo. Enfim, o indivíduo inadimplente é excluído do mercado de consumo, o que na sociedade atual significa a exclusão social.

Em suma, o dever de renegociação tem seu fundamento no princípio da boa-fé objetiva que, além de impor o dever de cooperação entre as partes para possibilitar o cumprimento do contrato, apresenta-se como limite ao exercício de posições jurídicas pelas partes, caracterizando como abusivo tanto o exercício danoso inútil, quanto o exercício com lesão intolerável de outras pessoas, sem consideração por situações especiais. Fundamenta-se também no princípio da função econômica e social do contrato, pois a negativa injustificada de renegociação afastará o contrato tanto do seu fim econômico, pois fatalmente será inadimplido, quanto do seu fim social, em razão do desrespeito aos valores constitucionalmente eleitos como fundamentais pela Constituição Federal. Assim sendo, a ordem jurídica não reconhecerá tutela ao direito do credor, tornando-se o crédito inexigível, com a conseqüente suspensão da incidência dos encargos moratórios. Ademais, o credor, em mora, poderá ser responsabilizado pelos danos sofridos pelo devedor, sejam eles de ordem patrimonial ou extrapatrimonial.

Entendemos não ser possível a execução específica do dever de renegociação, com, por exemplo, a cominação de multa diária pelo não cumprimento. Isso porque, muito embora seja em tese possível a execução específica nos casos de exercício abusivo do direito, em razão da atipicidade das sanções admissíveis, no caso da renegociação de uma dívida, os direitos envolvidos carecem da necessária precisão, podendo ser equiparados a uma obrigação ilíquida. Não é possível saber, de antemão, em que termos o contrato deve ser renegociado, de forma que uma ordem judicial nesse sentido seria inócua, vazia de significado prático, e, portanto, inexeqüível. Até que se estabeleçam os termos da renegociação, uma parte sempre poderá alegar que a outra está cometendo abuso no

${ }^{509}$ MENEZES CORDEIRO, A. M. R. Da Boa-fé... op. cit., p. 856. 
exercício das posições jurídicas, de maneira que, não havendo acordo entre as partes, é o juiz que deverá verificar a ocorrência do abuso e decidirá sobre a adaptação do contrato às novas circunstâncias.

Anote-se, por fim, que nesta renegociação a situação do consumidor não pode ser agravada, de maneira que se deve evitar a incidência dos juros da nova operação sobre os juros da operação renegociada. Portanto, não se está aqui a tratar da prática bastante comum utilizada pelas instituições financeiras de consolidar o saldo devedor em instrumentos de confissão de dívidas tão somente para impedir a discussão de ilegalidades cometidas ao longo do relacionamento creditício, alegando novação. Aliás, com relação a essa questão, o STJ editou a súmula 286, esclarecendo que: "a renegociação de contrato bancário ou a confissão da dívida não impede a possibilidade de discussão sobre eventuais ilegalidades dos contratos anteriores". A renegociação da dívida que reflete uma atitude consoante a boa-fé é aquela utilizada como instrumento de cooperação, e não como meio de exclusão do direito do consumidor discutir ilegalidades praticadas ao longo de relacionamento de crédito. São exemplos de renegociação guiada pela boa-fé a concessão de moratória, com a suspensão da incidência dos juros no período de extrema dificuldade para a parte mais fraca; a concessão descontos dos juros incidentes no período de mora (perdão parcial ou total dos encargos contratuais); reparcelamento do saldo devedor, com a exclusão dos juros capitalizados; redução da taxa de juros; extinção da dívida mediante devolução das mercadorias adquiridas por meio dos financiamentos; dentre outras medidas que podem ser aconselháveis diante do caso concreto.

\subsubsection{Adaptação do contrato em razão da alteração das circunstâncias relativas à pessoa do devedor}

Não sendo possível ou não se logrando a renegociação do contrato, seria admissível a intervenção do juiz para adaptar a forma de cumprimento do contrato que, em razão da alteração de circunstâncias exclusivamente relativas à pessoa do devedor, tornou-se excessivamente oneroso?

Há uma grande relutância na doutrina e na jurisprudência em admitir-se uma hipótese semelhante de revisão contratual, pois, como já dizia Larenz, o devedor se furtaria facilmente das suas obrigações e deixaria para o credor todo o risco econômico da 
operação, gerando muita insegurança ao tráfego jurídico ${ }^{510}$. Entretanto, seria exigível um sacrifício extremo do devedor, que represente uma ameaça a sua própria subsistência, em nome da proteção do direito de crédito e da segurança jurídica?

Um caso como esse é bastante delicado, pois envolve o conflito entre dois valores supremos do ordenamento jurídico contemporâneo, de extrema importância na sociedade atual, que são a existência digna, cuja valorização vem se elevando desde o início do século passado, em decorrência do Estado social, e a segurança jurídica, que vem ganhando cada vez mais importância, face às incertezas da sociedade pós-moderna. Contudo, ao contrário do que possa parecer, a discussão a respeito desse tema não é nova. $\mathrm{Na}$ Alemanha, na primeira metade do século passado, já se discutiu a doutrina do limite do sacrificio, pela qual tudo quanto excedesse os limites do sacrifício exigível do obrigado devia ser equiparado, em princípio, à impossibilidade da prestação.

Karl Larenz, ao desenvolver sua teoria do desaparecimento da base do negócio, demonstra uma preocupação em buscar diretrizes concretas e de validade geral para aplicála, no intuito de garantir um mínimo de segurança jurídica. Para o jurista alemão, a decisão por equidade, que leve em consideração todas as circunstâncias individuais dos interessados, deve ser admitida apenas como ultima ratio, "como solución extrema de una situación que de otro modo no podría resolverse". ${ }^{511}$ Para Larenz, as questões da extrema dificuldade financeira e da ruína econômica de uma das partes são circunstâncias alheias ao contrato, que não integram a base do negócio. Contudo, concorda que existem casos em que o devedor deve estar facultado para denegar a sua prestação, em nome de considerações superiores. ${ }^{512}$ Após salientar que a matéria exige critérios rigorosos para a sua aplicação, não sendo suficiente, em princípio, para liberar o devedor, que a obrigação contraída lhe prejudique excessivamente, pondera:

Pero ha de estimarse dicha excepción cuando así lo exijan más altos intereses, especialmente en consideración a la vida o la salud del deudor o de sus familiares o a un deber moral más elevado que el de la prestación. Así, no se puede exigir que actúe el actor de teatro en la tarde fijada si se encuentra enfermo con peligro de su vida, ni a la actriz, cuando su presencia sea necesaria junto al lecho de su hijo, gravemente enfermo. Tampoco es exigible la prestación cuando mediante su cumplimiento perfecto, puede no ser exigible en consideración a una conducta del acreedor contraria a su obligación. Finalmente, existen casos en que por las mismas causas ha de ser exigido al acreedor tener en cuenta la subsistencia económica del deudor por existir una especial relación de lealtad y confianza. Así, no cabe exigir al

\footnotetext{
${ }^{510}$ LARENZ, K. Derecho de Obligaciones. op. cit., p. 152.

${ }^{511}$ LARENZ, K. Base del Negocio Jurídico... op. cit., p. 4.

${ }^{512}$ Idem, ibidem, p. 98-103.
} 
empresario el pago total de la pensión o la renta cuando con ello se ponga en peligro la existencia económica de la empresa. ${ }^{513}$

Dessa forma, não basta uma alegação genérica de excessiva dificuldade econômica no cumprimento da obrigação. Deverá ser demonstrado, no caso concreto, um conflito com “direitos superiores", como os direitos fundamentais do devedor, relativos à vida, à saúde $\mathrm{e}$ à subsistência - que se reportam ao núcleo da dignidade humana -, para fundamentar a intervenção judicial no contrato. $O$ nobre civilista alemão referiu-se, a título exemplificativo, à subsistência econômica de uma empresa; assim, com mais razão ainda, inclui-se nessa hipótese a subsistência da pessoa natural, portadora de dignidade inafastável.

Por sua vez, Emilio Betti analisa, à luz da boa-fé objetiva, do dever de cooperação que dela decorre, e da função econômica e social do contrato, os casos em que o sacrifício econômico do devedor é desproporcional em relação à vantagem do credor, ameaçando a existência econômica do devedor, assim afirmando:

L'obbligazione, invero, si porrebbe in contrasto con la funzione economico-sociale cui à destinata, se dovesse mettere in forse la stessa esistenza economica del debitore e sovvertire la sua integrità patrimoniale. La legge non può ignorare una situazione siffatta: non può ignorarla, perchè coi rapporti di obbligazione si risolve per l'appunto un problema di cooperazione fra consociato e consociato. Quindo, se è una cooperazione che deve essere data dall'uno all'altro, non può onestamente l'uno attendersi e pretendere (“zumuten” secondo l'espressione tedesca) dall'altro il sacrificio della sua esistenza patrimoniale. Qui si presenta ovvio l'allineamento della sopravvenuta eccessiva onerosità con la sopravvenuta impossibilità. (...) Se di cooperazione si tratta, non è onesto, non è umano (perchè antisociale) pretendere dal debitore il sacrificio della esistenza patrimoniale per tener fede al contrato. Ciò sarebbe contrario all'idea della cooperazione nell'interesse del consorciato; ciò sarebbe contrario allo stesso criterio della buona fede contrattuale. Poichè la buona fede ( $§ 5)$ è, sì, essenzialmente fedeltà, impegno di cooperazione nell'interesse altrui per l'adempimiento delle altrui legitime aspettative ... $^{514}$

Betti refere-se também à impossibilidade, entendendo que esta não precisa ser objetiva ou absoluta, podendo referir-se à pessoa do devedor, pois não é dado ao credor pretender que o devedor sacrifique por ele a sua vida ou existência patrimonial, tendo em vista o dever de cooperação, o qual é imanente à exigência da solidariedade social.

Verifica-se na diversidade de posições um ponto em comum: quando se tratar de

${ }^{513}$ LARENZ, K. Derecho de Obligaciones. Tomo I. Versión Española y notas de Jaime Santos Briz. Madrid: Editorial Revista de Derecho Privado, 1958, p. 153.

${ }^{514}$ BETTI, E. Teoria generale delle obbligazioni, I - Prolegomeni: funzione econômico-sociale deu rapporti d'obbligazione. Milano: Giuffrè, 1953, p. 193 e 194. 
um conflito entre os direitos fundamentais do devedor, numa situação de ameaça da sua subsistência, e o direito de crédito, aquele deverá prevalecer, seja em razão da boa-fé objetiva, seja em razão da função econômica e social do contrato, tendo em vista a necessidade de se tutelar o núcleo da dignidade humana nas relações contratuais, com o respeito às condições mínimas de vida. De acordo com Antonio Junqueira de Azevedo:

No campo contratual, o respeito às condições mínimas de vida também tem aplicação. Segundo a teoria alemã dos limites do sacrifício, os contratos não precisam ser cumpridos quando a sua execução leva a gastos excessivos não previstos, o que terá maior razão de ser quando o adimplemento puder dificultar a sobrevivência. ${ }^{515}$

A partir dessas premissas, extrai-se a necessidade de tutelarem-se as situações de endividamento excessivo como corolário da efetivação dos direitos fundamentais derivados do princípio da dignidade humana, já que esta situação pode privar a pessoa dos meios necessários à sobrevivência digna. É com base nesse limite do sacrifício, entendido nesta nova ótica de proteção da parte mais fraca nas relações contratuais, é que deve ser compreendido o conceito de "onerosidade excessiva" dos artigos 480 do Código Civil e $6^{\circ}$, inciso V, do Código de Defesa do Consumidor, de maneira a fundamentar a revisão contratual, ainda que excepcionalmente, por alteração das circunstâncias pessoais, nos casos em que o adimplemento dificultar ou impossibilitar a subsistência ou sobrevivência do devedor. Isso porque o pressuposto do princípio da dignidade da pessoa humana é a intangibilidade da vida humana, que não pode ser descartada em nome da proteção de outros direitos concorrentes. Segundo Junqueira de Azevedo:

O pressuposto de um princípio não é uma conseqüência do princípio; sua exigência é radical. Um princípio jurídico, ao se concretizar, exige sempre um trabalho de modelação para adaptação ao concreto; nesse trabalho, a intensidade da concretização poderá ser maior ou menor. Até mesmo um princípio fundamental, como o da dignidade da pessoa humana, impõe o trabalho de modelação porque, por exemplo, é preciso compatibilizar a dignidade de uma pessoa com a de outra (e, portanto, alguma coisa da dignidade de uma poderá ficar prejudicada pelas exigências da dignidade da outra). Diferentemente, o pressuposto desse princípio fundamental impõe concretização radical; ele logicamente não admite atenuação. Se afastado, nada sobra do princípio da dignidade. E esse princípio, se pudesse ser totalmente eliminado, não seria princípio fundamental. $\mathrm{O}$ preceito da intangibilidade da vida humana, portanto, não admite exceção; é absoluto e está, de resto, confirmado pelo caput do art. $5^{\circ}$ da CR. ${ }^{516}$

Diante de uma situação na qual conflitam a necessidade de cumprimento dos contratos e a impossibilidade de uma das partes honrar a palavra dada sob pena de violação

${ }^{515}$ JUNQUEIRA DE AZEVEDO, A. Caracterização jurídica ... op. cit., pág. 18 e 19

${ }^{516}$ Idem, ibidem, pág. 14. 
de direitos fundamentais, será necessária a ponderação de valores no caso concreto (autonomia privada $v s$ sobrevivência digna). Nesta ponderação, o pressuposto do valor supremo "dignidade humana", que é a intangibilidade da vida humana, não poderá ser mitigado ou parcialmente afastado, devendo-se preservar as condições mínimas de vida. Essas condições, também chamadas de mínimo existencial, constituem o núcleo dos direitos fundamentais que não pode ser violado num confronto com a proteção da autonomia privada e com a força obrigatória dos contratos (pacta sunt servanda).

Como já referido anteriormente, o princípio da função social, potencializado pelo princípio da proteção da parte mais fraca, abre espaço para a atuação da justiça distributiva no âmbito dos contratos, que considera a qualidade das partes para conferir uma proteção especial. Assim, não só o grau de desigualdade admitido será menor, pois não se deve presumir que o consumidor quis assumir um risco elevado, mas também impõe-se a consideração por situações especiais, decorrentes do respeito às condições mínimas de existência e respeito aos valores supremos do ordenamento jurídico, que privilegiam a solidariedade social e a dignidade da pessoa humana.

Ademais, em caso de fato superveniente, que reduza a capacidade econômica do devedor, tornando o cumprimento do contrato extremamente dificultoso, decorre também uma intensificação do dever de cooperação, que impõe, também com fundamento na proteção do mínimo existencial, um dever de renegociação do contrato. Não sendo possível ou não se logrando a renegociação, a necessidade de proteção da parte mais fraca, sobretudo nos contratos existenciais, fundamenta a possibilidade de intervenção judicial para a alteração da forma de execução do contrato, ou mesmo para a redução da prestação, para evitar a onerosidade excessiva, nos termos do artigo 480 do Código Civil, admitindose que circunstâncias pessoais do devedor fundamentem essa revisão.

É esse o entendimento de Antonio Junqueira de Azevedo, que destaca a necessidade de proteção da parte mais fraca nos contratos existenciais:

Digladiam-se, de um lado, os defensores da segurança jurídica, com os olhos voltados ao mundo empresarial, e, de outro, os defensores das pessoas físicas mal aquinhoadas economicamente, despreparadas para atuar num mercado sofisticado. A nosso ver, o direito brasileiro e, talvez, o direito universal, devesse, no séc. XXI, fazer uma distinção essencial, admitindo expressamente uma nova dicotomia contratual. Essa dicotomia seria a de contratos empresariais e de contratos existenciais. Os contratos empresariais teriam um regime de menor interferência judicial; neles, por exemplo, não caberia revisão judicial por questões de onerosidade excessiva subjetiva, - possível, porém, sob a idéia de função social, quando se trata de pessoa humana e contrato existencial. Uma 
entidade jurídica empresarial ineficiente pode - ou até mesmo deve - ser expulsa do mercado, ao contrário da pessoa humana que merece proteção, por não ser “descartável”. (...) A nova dicotomia, própria do século XXI, procura conciliar o funcionamento estável da economia e um desenvolvimento econômico cego ao valor da pessoa humana. Os três níveis do contrato, o econômico, o jurídico e o social devem ser conciliados. ${ }^{517}$

Para o autor, mesmo em se tratando de impossibilidade temporária, será possível a revisão. Em suas palavras: “ainda que seja temporário, havendo desequilíbrio, será possível rever o contrato a fim de saná-lo", pois "as normas do Código Civil (e também as do Código de Defesa do Consumidor) não exigem que a excessiva onerosidade seja permanente". 518

Ressalte-se que essa possibilidade de revisão deve ser compreendida à luz do novo paradigma do caso concreto. É com essa atenção para o caso concreto que as Cortes européias tem decidido questões envolvendo a incidência dos direitos fundamentais nas relações contratuais, liberando o devedor de obrigações excessivamente onerosas assumidas em prejuízo da dignidade humana. Num caso decidido pela Corte Constitucional Alemã, a situação de desequilíbrio no poder de barganha, que contribuiu para a assunção de uma obrigação excessivamente onerosa pela parte mais fraca, foi motivo suficiente para a invalidação do contrato. Neste caso, os direitos fundamentais incidiram por intermédio das cláusulas gerais da boa-fé e dos bons costumes, tal como citado por O. Cherednychenko:

According to the Constitutional Court, in cases where a structural imbalance in the bargaining power has led to a contract which is exceptionally onerous for the weaker party, the private law courts are obliged to intervene on the basis of the general clauses $(\S 138$ (1) and 242 of the Civil Code (Bürgerliche Gesetzbush - BGB) concerning, respectively, good morals and good faith). This obligation is based on the duty to protect the constitutional right to private autonomy in conjunction with the principle of the social state. $^{519}$

${ }^{517}$ JUNQUEIRA DE AZEVEDO, A. Relatório brasileiro sobre revisão contratual... op. cit., p. 185.

${ }^{518}$ Idem, ibidem, p. 192.

${ }^{519}$ CHEREDNYCHENKO, O. Fundamental Rights, Contract Law and the Protection of the Weaker Party. München: Sellier European Law Publishers, 2007, p. 3 e 4. Em outra pubicação o autor assim descreve o caso decidido pela Corte Constitucional Alemã: "In 1993 the Constitutional Court delivered another revolutionary judgment in the famous Bürgschaft case5 where, essentially, the Court invalidated a contract under which the daughter had acted as a surety for her father's debts on the basis of her constitutional right to the free development of one's personality (Article 2[1] of the Basic Law) in conjunction with the principle of the social state (Articles 20[1] and 28[1] of the Basic Law). According to the Court, in cases where a 'structural inequality of bargaining power' has led to a contract which is exceptionally onerous for the weaker party, the private law courts are obliged to protect the constitutional right to private autonomy of this party by intervening within the framework of the general clauses ( $\S 138[1]$ and $\S 242$ of the German Civil Code concerning good morals and good faith, respectively). In the case at hand, a contractual imbalance existed because the bank had failed to sufficiently inform the daughter, who at the time of concluding the 
Antonio Junqueira de Azevedo, mencionando um caso semelhante ao ora citado, entendeu tratar-se de um caso de aplicação do princípio da função social do contrato. Nas palavras do jurista: "É exemplo desta segunda hipótese a questão, atualmente muito debatida na Alemanha, consistente no fato de mulher casada, que, por exemplo, somente recebe salário, assinar como garante (avalista ou fiadora) do marido, grande empresário, e, depois, não ter como responder pelo débito; seria devedora até o final da vida e, ainda, post mortem". 520

Importante salientar que esses casos de conflito entre direitos fundamentais e força obrigatória dos contratos foram discutidos e decididos pelas Cortes Européias antes dos países adotarem as legislações de prevenção e tratamento das situações de sobreendividamento. Na Alemanha, por exemplo, os casos decididos pela Corte Constitucional são anteriores a 1999, quando o Insolvenzordnung foi alterado para prever um procedimento de recuperação financeira também para a pessoa física. Essa herança poderá, portanto, servir como precedente vindo do direito comparado para solucionar casos análogos, envolvendo obrigações excessivamente onerosas em conflito com direitos fundamentais, já que o Brasil encontra-se nessa mesma situação de vácuo jurídico acerca de um tratamento global da recuperação financeira do consumidor.

Também no Brasil questões envolvendo a incidência dos direitos fundamentais nas relações privadas têm sido debatidas nos Tribunais, tal como se verifica nas decisões sobre a possibilidade de corte de serviços essenciais, como energia elétrica e água, diante do inadimplemento do devedor. Apesar do Superior Tribunal de Justiça ter firmado entendimento no sentido da possibilidade do corte $^{521}$, verifica-se que alguns Tribunais Estaduais consideraram valores superiores ligados à dignidade da pessoa humana para impedir a interrupção na prestação desses serviços, tomando-se como exemplo o caso de uma instituição de caridade que abriga menores, inclusive portadores do vírus HIV (AI ${ }^{\circ}$ 4265/2005, TJRJ), de uma anciã de 92 anos de idade, com problemas de saúde (Apelação

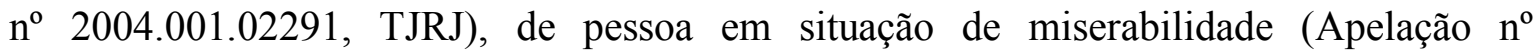

contract was 21 years of age, did not have a high level of education, owned no property and worked as an unskilled employee at a fish factory for a modest salary, about the risk relating to the suretyship, although the risk was relatively high compared to her income". (BVerfG 19 October 1993, BVerfGE 89, 214 (Bürgschaft)). (CHEREDNYCHENKO. O. Fundamental Rights and Contract Law. European Review of Contract Law, Vol. 2, n. 4, pp. 489-505, 2006).

${ }_{520}$ JUNQUEIRA DE AZEVEDO, A. Relatório brasileiro... op. cit., p. 197.

${ }^{521}$ Veja a ementa do acórdão que pacificou a questão: "É lícito à concessionária interromper o fornecimento de energia elétrica, se, após aviso prévio, o consumidor de energia elétrica permanecer inadimplente no pagamento da respectiva conta (L. 8.987/95, Art. $6^{\circ}$, § $3^{\circ}$, II)". (STJ, $1^{a}$ Seção, REsp 363943/MG, Relator Ministro HUMBERTO GOMES DE BARROS, DJ 01/03/2004 p. 119). 
2005.001.33021, TJRJ), ou de pessoas que necessitavam da energia elétrica para manterem-se vivas (AI n $\left.{ }^{\mathrm{o}} 70018098004 \mathrm{e} \mathrm{AI} \mathrm{n}^{\mathrm{o}} 70014119671, \mathrm{TJRS}\right) .{ }^{522}$

Nessas situações, assim como nos casos de endividamento excessivo em que fique ameaçado o núcleo dos direitos fundamentais do consumidor, o princípio da dignidade da pessoa humana é o eixo axiológico em torno do qual deve se desenvolver a tutela, de forma a exigir proteção especial à pessoa física em situação de vulnerabilidade. Esta ótica de proteção da parte mais fraca na relação contratual deve estar sempre presente na busca de soluções para o problema do endividamento excessivo do consumidor, fundamentando a aplicação com maior intensidade dos princípios da boa-fé objetiva, da função social do contrato e da justiça contratual.

Resta saber qual o fundamento específico para a intervenção do juiz nesses casos de alteração das circunstâncias que tenha tornado a prestação excessivamente onerosa para o consumidor, no intuito de readaptar o contrato, para permitir a continuidade no seu cumprimento. $^{523}$

Segundo Francesco Macario, a possibilidade de adequação do contrato é uma característica peculiar de todo e qualquer contrato de longa duração. Aduz que a priori as partes optam por uma gestão de comum acordo do risco contratual, "numa perspectiva de mutualidade e cooperação, que ao mesmo tempo é causa e efeito da cláusula de revisão, de adequação e de renegociação". ${ }^{524}$ A perspectiva de análise do jurista italiano é a dos contratos bilaterais de longa duração firmados entre iguais, nos quais não há uma parte mais fraca, premissa da qual aqui se parte. Portanto, a cautela com a intervenção do juiz na autonomia das partes é naturalmente mais acentuada, de maneira que a revisão, nos termos do artigo 1467 do Codice Civile, apenas é possível diante da oferta do réu na ação de resolução ${ }^{525}$, como, aliás, é a previsão do artigo 478 do Código Civil Brasileiro. Nesse caso, o autor entende que o juiz tem a função de analisar se a contra-proposta foi formulada em termos eqüitativos, podendo interferir com maior liberdade quando esta é

\footnotetext{
${ }^{522}$ Nesses casos, como o STJ não decide questões fáticas (súmula 7 do STJ), as decisões foram mantidas, de maneira que os princípios fundamentais da República foram observados.

523 Segundo Francesco Macario "La finalità dell'azione di modificazione è quella di far proseguire l'esecuzione del contratto e non (o meno non soltanto) quella di sanare lo squilibrio patrimoniale. (284)

${ }^{524}$ MACARIO, F. Adeguamento e rinegoziazione nei contratti a lungo termine. cit., p. 289.

${ }^{525}$ Mesmo diante da proposta de adaptação, o juiz não se exime de verificar a eqüidade da proposta: "Prima di potersi pronunciare sulla proposta di modificazione del contratto, il giudice è chiamato a considerare tutte le circostanze del rapporto relative alla sua esecuzione. In altri termini, la proposizione dell'offerta ex art. $1467,3^{\circ}$ comma, non esime - è fatto salvo, ovviamente, il caso in cui la parte che agisce per la risoluzione rinunzi alla domanda ed aderisca senza riserve all'offerta - dall'esaminare il rapporto, allo scopo di decidere quale modificazione sia equa, nel senso di consentire il successivo svolgimento del rapporto contrattuale (MACARIO, F. Adeguamento e rinegoziazione nei contratti a lungo termine. cit., p. 270)
} 
feita em termo abertos. Nesse caso, "la rinegoziazione, dunque, ove non sia l'effetto dell'accordo originario, che preveda apposite clausole, destinate ad operare durante l'esecuzione del contratto anche indipendentemente dalle sopravvenienze, diventa un effetto legale della fattispecie, un obbligo nascente direttamente dalla legge, nell'ipotesi prevista dall'art. $1467,3^{\circ}$ comma". 526

Cabem, contudo, algumas observações. Primeiramente, como já adiantado, as situações de superendividamento merecedoras de tutela, nos termos ora propostos, são aquelas verificadas em contratos em que uma das partes é vulnerável, ou seja, contratos entre sujeitos desiguais, caracterizados pela assimetria de informações, vulnerabilidade aos acontecimentos externos, fraqueza no poder de barganha e inexperiência de um dos contratantes. Conforme a premissa estabelecida no capítulo anterior (seção 1.4), a tutela do Estado-juiz é protetiva em casos como estes, sendo reconhecida a influência da justiça distributiva nos instrumentos de direito privado. Disso decorre que o grau de desigualdade admitido é menor, pois não se deve supor que o consumidor tenha assumido riscos elevados com a contratação.

Atualmente, a noção de equilíbrio contratual diz respeito a um certo grau de equivalência entre as prestações, exigido de acordo com a qualidade das partes envolvidas e a finalidade do contrato. Essa consideração pela qualidade das partes é resultado da atuação da justiça distributiva no direito contratual ${ }^{527}$, que fundamenta a maior proteção conferida à parte mais fraca para garantir uma efetiva liberdade de contratar. Assim, o grau de equivalência entre as prestações poderá variar de acordo com o grau de liberdade efetivamente verificado numa situação concretamente apresentada. Quanto maior a liberdade, porque as partes encontram-se em pé de igualdade, maior a desproporção admitida no contrato. Segundo Menezes Cordeiro, o Direito não pretende um equilíbrio absoluto, contra a vontade das partes.. Basta ver que admite a figura dos negócios a título gratuito. Mas o desequilíbrio deve ser esclarecido e livremente querido por quem o sofra. $^{528}$

Por outro lado, no mais das vezes, os contratos em questão, nas situações de superendividamento, são de natureza diversa daqueles que sofrem a incidência do artigo 478 do Código Civil: esses são contratos bilaterais de longa duração, nos quais existem prestações para ambas as partes (como um contrato de fornecimento, por exemplo), de

\footnotetext{
${ }^{526}$ MACARIO, F. Adeguamento e rinegoziazione nei contratti a lungo termine. op. cit., p. 296

${ }^{527}$ NOBLOT, C La Qualité du Contractant comme Critère Legal de Protection. Paris: LGDJ, 2002. p. 2.

${ }^{528}$ MENEZES CORDEIRO, A. M.R. Da Boa-fé... op. cit., p. 659.
} 
maneira que a resolução do vínculo reputa-se uma solução eficaz em caso de excessiva onerosidade da prestação para uma das partes. O contrato é resolvido, deixando de surtir os efeitos prejudiciais, a menos que a outra parte ofereça-se para reduzir a prestação, de forma a eliminar a excessiva onerosidade (retomar a álea normal). Quando o superendividamento ocorrer em virtude de um contrato desta natureza (em que subsistam prestações para ambas as partes) a resolução do vínculo poderá ser a solução, tal como será analisado no tópico subseqüente. Contudo, num contrato de empréstimo, no qual apenas subsiste prestação para o consumidor, a resolução mostra-se descabida, já que o seu efeito normal seria a restituição ao status quo ante, com a devolução do dinheiro emprestado: e é exatamente essa a impossibilidade verificada no caso.

Os contratos de empréstimo a juros (mútuo feneratício) são, em verdade, contratos unilaterais onerosos, já que, após o seu aperfeiçoamento, subsistem prestações apenas para uma das partes - no caso, o consumidor. Dessa forma, ainda que a relação fosse entre iguais, incidiria o artigo 480 do Código Civil, e não o artigo 478 do mesmo diploma, o qual dispõe: "Se no contrato as obrigações couberem a apenas uma das partes, poderá ela pleitear que a sua prestação seja reduzida, ou alterado o modo de executá-la, a fim de evitar a onerosidade excessiva". Note-se, portanto, que não há que falar em oferta da contraparte para a revisão, de maneira que não existe esse óbice para a atuação do juiz. Contudo, considerando que se trata de relação de consumo, em que uma das partes é vulnerável, incide o artigo $6^{\circ}$, inciso $\mathrm{V}$, do Código de Defesa do Consumidor, que reconhece ser direito básico do consumidor a revisão das cláusulas contratuais em razão de fatos supervenientes que as tornem excessivamente onerosas.

Nesses termos, é de se admitir a intervenção judicial para adequar o contrato em relação ao qual remanesçam prestações apenas para o consumidor superendividado, sem que isso represente uma violação ilegítima da autonomia privada. ${ }^{529}$ Note-se que essa intervenção fundamenta-se tanto pela recusa injustificada, por parte do credor, de renegociar o contrato, quanto pela presença dos pressupostos apresentados na seção 2.1, quais sejam, a situação de vulnerabilidade num contrato existencial, a boa-fé do devedor e a situação de urgência social, além da posição contratual privilegiada do credor, sobretudo

\footnotetext{
${ }^{529}$ Nesse sentido, Francesco Macario: "La rilevanza degli obblighi di cooperazione fra le parti nella fase dell'esecuzione del contratto consente di risolvere l'apparente antinomia fra l'obbligo di rinegoziare e la libertà di autodeterminazione, poiché la rinegoziazione tende, non a comprimere, bensì a realizzare la volontà delle parti così come si esprime nell'atto di autonomia. L'apparente coercizione della volontà delle parti nell'adoperarsi per ridefinire le condizioni del regolamento di interessi rinviene la giustificazione normativa nel rispetto dell'obbligo di buona fede che, volta a volta, si specifica anche in funzione della natura dell'affare." (MACARIO, F. op. cit., p. 322)
} 
quando este se caracterizar como um poder social. Verificados esses pressupostos, o consumidor deverá tomar a iniciativa da ação (arts. $6^{\circ}, \mathrm{V}$ do CDC e 480, CC), fornecendo os parâmetros para a atuação judicial. Ressalte-se que, em razão do princípio da inafastabilidade do controle jurisdicional (CF, art. $\left.5^{\circ}, \mathrm{XXXV}\right)$, não se pode exigir que o devedor demonstre a tentativa de renegociação do contrato para que seja possível a intervenção judicial. Contudo, uma vez tentada a renegociação, e caracterizada a recusa injustificada por parte do credor nas situações tratadas no tópico anterior, restará fundamentada a possibilidade de intervenção. Ademais, a tentativa de renegociação por parte do devedor demonstrará a sua boa-fé, reforçando a presença do pressuposto apresentado no item 2.1 .2 retro.

A adaptação deve pautar-se pela boa-fé objetiva na sua função integrativa ${ }^{530}$, sendo que o juiz deverá conciliar o menor prejuízo para o credor com a manutenção de um mínimo vital para o devedor, somados à possibilidade de efetivo cumprimento das obrigações assumidas. O artigo 480 do Código Civil poderá servir como parâmetro, já que sugere a alteração da forma de execução da obrigação e a redução da prestação. Com relação a essa última medida, é preciso atentar para o fato de que a prestação principal jamais poderá ser reduzida sem concordância expressa do credor, sob pena de configurar enriquecimento sem causa por parte do devedor. A redução deve limitar-se ao montante dos juros, e apenas na medida do estritamente necessário para permitir a retomada do pagamento das prestações, devendo ser preferidas medidas como o parcelamento do contrato em maior número de prestações, a redução ou suspensão dos juros, lembrando que durante o período da negativa em renegociar não há mora imputável ao devedor.

\subsubsection{Resolução do contrato que se tornou excessivamente oneroso}

Não sendo possível a renegociação, e sendo o caso de contrato de longa duração no qual subsistem obrigações para ambas as partes (por exemplo, financiamentos para aquisição de bens de consumo, ou mesmo da casa própria), outra solução possível é a resolução do vínculo, com a devolução do bem objeto do contrato e a restituição dos valores pagos pelo consumidor.

\footnotetext{
${ }^{530}$ Francesco Macario: "L'attenzione dei giuristi deve essere posta sull'idoneità dei mezzi offerti dell'ordinamento a realizzare quest'obiettivo. Un sicuro punto di partenza è costituito dalla valorizzazione del principio di buona fede - la sua operatività nella dimensione interpretativa, integrativa ovvero esecutiva del contratto non può che condurre al medesimo obiettivo sostanziale -, grazie al quale il regolamento contrattuale espresso dal contratto a lungo termine viene a specificarsi secondo le circostanze" (Idem, ibidem, p. 330).
} 
Os casos de resolução do contrato por onerosidade excessiva superveniente à formação do vínculo são disciplinados pelo artigo 478 do Código Civil, já referido em outras ocasiões neste trabalho, que prevê esta possibilidade para os contratos de execução diferida em caso de ocorrência de fatos extraordinários e imprevisíveis que tornem a prestação excessivamente onerosa para uma das partes, com extrema vantagem para a outra parte. Em se tratando de relação de consumo, tais requisitos devem ser flexibilizados, não se exigindo a previsibilidade e a prova da vantagem para o fornecedor, pois o que se quer é tutelar o consumidor excessivamente onerado pela alteração das circunstâncias, que não poderá permanecer vinculado a um contrato cujo cumprimento represente um sacrifício extremo, pois tal cenário seria contrário à boa-fé e à função social do contrato.

Ressalte-se que, pelos mesmos fundamentos discorridos no tópico anterior, ainda que em razão da alteração de circunstâncias que digam respeito à pessoa do consumidor, deve-se admitir a resolução do contrato, para evitar a onerosidade excessiva, tendo em vista o confronto entre a força obrigatória dos contratos e os direitos fundamentais do devedor.

Segundo Antônio Junqueira de Azevedo, a onerosidade excessiva do contrato gera a sua ineficácia, ensejando a resolução do negócio jurídico. ${ }^{531}$ Com efeito, em razão da alteração superveniente das circunstâncias, o contrato, que era válido e eficaz, afasta-se da sua função social, de forma que não mais será merecedor de tutela jurídica, por impor um sacrifício extremo para a parte mais fraca da relação. Resulta daí a sua ineficácia superveniente, e conseqüente resolução.

O desfazimento do vínculo em situações como esta pode gerar efeitos ex tunc ou ex nunc, a depender da natureza do contrato. Em se tratando de contrato de execução instantânea, mas que foi diferida no tempo pela vontade das partes, a resolução opera efeitos ex tunc, retornando as partes ao status quo ante (ex: contrato de compromisso de compra e venda parcelado). Já em relação aos contratos de execução continuada, que são aqueles cuja própria natureza envolve o elemento temporal (ex: prestação de serviços de segurança), a resolução opera efeitos ex nunc, tendo efeito puramente liberatório. De acordo com o artigo 478, neste caso, os efeitos da sentença retroagirão à data da citação da outra parte.

Segundo Ruy Rosado de Aguiar Júnior:

531 JUNQUEIRA DE AZEVEDO, A. Negócio Jurídico: existência, validade, eficácia. São Paulo: Saraiva, 2002, p. 60-61. 
Os efeitos normais da resolução são ex tunc, com ambas as partes recolocadas na posição existente ao tempo da realização do negócio. Porém, quando se tratar de contratos duradouros, de execução continuada (locação) ou periódica (pagamento de aluguéis), a extinção atinge o contrato apenas na sua duração para o futuro (ex nunc), mantendo-se íntegras as prestações recíprocas já efetivadas. É o que se chama de resilição. ${ }^{532}$

E não poderia ser diferente, pois no caso de contrato de execução diferida tem-se, na verdade, um contrato de execução instantânea, que teve sua execução voluntariamente protraída no tempo, mas que apenas terá seus efeitos consolidados com o cumprimento total das prestações. Assim, por exemplo, no compromisso de compra e venda, o contrato apenas atingirá seus efeitos plenos com o pagamento de todas as prestações pelo comprador e com a conseqüente transferência da propriedade do bem pelo vendedor. Se antes disso for resolvido em razão da onerosidade excessiva, as partes deverão retornar ao status quo anterior, com a devida compensação por perdas e danos, se for o caso. Se assim não fosse, uma das partes estaria auferindo vantagem indevida, privilegiando-se uma situação de enriquecimento sem causa.

Já nos contratos de execução continuada, nos quais os efeitos se consolidam durante a execução, a resolução apenas surtirá efeitos para o futuro, mantendo-se intactas as prestações recíprocas já efetivadas. Tome-se como exemplo um contrato de prestação de serviços de segurança, no qual ambas as partes já cumpriram durante um período as suas prestações recíprocas, mas que posteriormente se tornou excessivamente oneroso. Nesse caso, as prestações já consolidadas não serão desfeitas, e os efeitos da resolução, nos termos do artigo 478 do $\mathrm{CC}$, serão produzidos para o futuro, retroagindo apenas à data da citação, quando a outra parte teve ciência formal do desejo da parte prejudicada de resolver o contrato.

A esse respeito, Nelson Rosenvald ensina que não haveria motivo para a retroação à data do contrato, "tendo em vista a ausência de motivação para que o desfazimento da obrigação alcance as finalidades comuns obtidas na época em que ainda não havia se manifestado a onerosidade excessiva". E acrescenta: “ademais, há o ônus do interessado em promover a demanda resolutória, pois enquanto não o fizer, por mais que evidenciada a situação aflitiva, não será esse período de inércia coberto pelos efeitos retroativos da sentença desconstitutiva". ${ }^{533}$ Note-se, contudo, que tal eficácia apenas faz sentido nos contratos verdadeiramente de execução continuada, cujos efeitos são consolidados ao

\footnotetext{
${ }^{532}$ AGUIAR JR., R. R. Extinção dos Contratos por Incumprimento do Devedor. cit., p. 63-64.

533 ROSENVALD, N. Comentário ao artigo 478. In PELUSO, C. (coord.), Código Civil Comentado, $3^{\mathrm{a}}$ edição, Barueri: editora Manole, 2009, p. 515.
} 
longo do tempo. Nos contratos de execução diferida, como é o caso do compromisso de compra e venda a prazo ou de financiamento para aquisição de bens de consumo, faz-se necessário o retorno das partes ao status quo ante, com a devolução do bem financiado e a devolução do dinheiro ao consumidor.

Quanto à compensação por perdas e danos, segundo Ruy Rosado, “desfeito o contrato por incumprimento imputável ao devedor inadimplente, a indenização decorre da existência de ação ilícita praticada contra o contrato". Todavia, "quando a extinção for efeito da alteração das circunstâncias supervenientes, sem que a contraparte tenha praticado ato pelo qual responda, haverá extinção sem indenização". ${ }^{534}$ Portanto, nos casos em que o devedor não for culpado pela alteração das circunstâncias que causaram o sobreendividamento, ele não ficará, em princípio, obrigado a indenizar perdas e danos.

No Brasil, após alguma divergência, a jurisprudência reconheceu o direito de resolução, pelo consumidor, do contrato de compromisso de compra e venda de imóveis, cujas prestações tenham tornado-se insuportáveis, podendo pleitear a restituição das importâncias pagas, já que, nos termos do artigo 53 do CDC "consideram-se nulas de pleno direito as cláusulas que estabeleçam a perda total das prestações pagas em benefício do credor que, em razão do inadimplemento, pleitear a resolução do contrato e a retomada do produto alienado".

O primeiro precedente do Superior Tribunal de Justiça, favorável ao consumidor, foi assim ementado:

Promessa de compra e venda. Extinção do contrato. Restituição. Art. 53 do CODECON. Ação proposta pelo promissário comprador. 1. Justificado o inadimplemento pela superveniência de fato impeditivo do cumprimento do contrato, com desequilíbrio resultante da desvalorização da moeda, sucessiva aplicação dos planos econômicos e diferentes critérios para atualização dos créditos, pode o devedor pleitear a extinção do contrato. 2. A nulidade de pleno direito da cláusula de decaimento, que prevê a perda da totalidade das prestações pagas pelo promissário comprador em caso de inadimplemento, também se reconhece quando a ação e de iniciativa do comprador. 3. Reconhecimento do direito a restituição de parte do que foi pago. Recurso conhecido e provido em parte. (STJ, 4a turma, resp 109331/SP, relator Ministro Ruy Rosado de Aguiar, data da publicação/fonte dj 31/03/1997 p. 9638).

A pacificação ocorreu após decisão de embargos de divergência pela Segunda Seção do STJ, em acórdão com a seguinte ementa: "O compromissário comprador que deixa de cumprir o contrato em face da insuportabilidade da obrigação assumida tem o

${ }^{534}$ AGUIAR JR., R. R. Extinção dos Contratos por Incumprimento do Devedor. cit., p. 64. 
direito de promover ação a fim de receber a restituição das importâncias pagas. Embargos de divergência conhecidos e recebidos, em parte" ${ }^{\text {} 535}$. Contudo, jurisprudência mais recente determina a retenção de $25 \%$ do valor pago, a título de ressarcimento com as despesas administrativas do contrato, reconhecendo a legalidade de uma cláusula de perdimento parcial, como se vê do precedente do STJ:

RECURSO ESPECIAL. COMPRA E VENDA DE IMÓVEL. RESILIÇÃO UNILATERAL PELO DEVEDOR. DIFICULDADES ECONÔMICAS. POSSIBILIDADE. RETENÇÃO DE $25 \%$ DAS PRESTAÇÕES ADIMPLIDAS. PRECEDENTES DESTA CORTE SUPERIOR. RECURSO CONHECIDO E PARCIALMENTE PROVIDO. 1. Resta pacificado, no âmbito da $2^{\text {a }}$ Seção desta Corte Superior, a possibilidade de resilição unilateral do compromisso de compra e venda, por iniciativa do devedor, se este não mais reúne condições econômicas para suportar o pagamento das prestações avençadas com a empresa vendedora do imóvel. 2. Ocorrendo a extinção do negócio jurídico, é permitida a retenção de $25 \%$ (vinte e cinco por cento) do valor das prestações pagas, pela alienante, a título de ressarcimento com as despesas administrativas do contrato. 3. Recurso especial conhecido e parcialmente provido. (STJ, $4^{\mathrm{a}}$ Turma, REsp 469484/MG, Relator Ministro HÉLIO QUAGLIA BARBOSA, DJ 17/12/2007 p. 174)

Tal como já expressado quando se tratou da cláusula de perdimento, este percentual fixo não é razoável ou proporcional, pois quanto mais o consumidor paga o contrato, maior é a sua penalidade. Assim, aquele consumidor que mesmo com dificuldade, esforçou-se para cumprir o contrato, será punido de forma mais severa do que aquele que diante da primeira dificuldade deixou de pagar o contrato. Ademais, o que a jurisprudência nacional chama de "despesas administrativas do contrato" tem, na verdade, natureza jurídica de ressarcimento por perdas e danos, sendo que estas não seriam devidas pelo devedor que não teve culpa pela resolução do contrato. E, nos casos de sobreendividamento passivo do devedor de boa-fé, como visto, não há culpa que possa ser imputada ao devedor. Melhor seria o estabelecimento de um valor, diante do caso concreto, que efetivamente correspondesse à despesa administrativa, a qual deve ser remunerada por tratar-se de serviço efetivamente prestado pelo credor. Eventual abusividade da retenção poderá ser reconhecida pelo juiz, que poderá reduzir o seu percentual, a exemplo do que ocorre com a cláusula penal, a qual, nos termos do artigo 413 do CC, pode ser reduzida eqüitativamente pelo juiz.

${ }^{535}$ STJ, $2^{\text {a }}$ Seção, EREsp 59870 / SP Relator Ministro BARROS MONTEIRO, DJ 09/12/2002 p. 281 


\section{CONCLUSÃO}

Demonstrou-se ao longo do trabalho que a tendência contemporânea do direito privado é consideração da qualidade das partes para que seja possível conferir uma tutela jurídica adequada. No atual paradigma jurídico, a incorporação dos valores decorrentes do Estado social no direito obrigacional teve como resultado a consagração dos novos princípios contratuais da boa-fé objetiva, do equilíbrio contratual e da função social do contrato, por meio dos quais incidem os direitos fundamentais, decorrentes da dignidade da pessoa humana, nas relações privadas. Tendo em vista a necessidade de consideração das características pessoais dos contratantes, surge o princípio da proteção da parte mais fraca, que requer a incidência mais intensa dos referidos princípios sociais.

Some-se a isso o fato de que o paradigma da globalização, caracterizado pela sociedade de consumo em massa, trouxe duas realidades que interferiram fortemente na estrutura das relações jurídicas contemporâneas. Primeiramente, verificou-se uma alteração na forma de contratação, com a multiplicação dos contratos por adesão, consistentes em instrumentos padronizados com cláusulas pré-estabelecidas pelos fornecedores de produtos e serviços, o que intensificou a posição de vulnerabilidade do consumidor, que além de ser a parte técnica e economicamente mais fraca, ficou sujeito às abusividades praticadas no mercado de consumo. Por outro lado, a economia de mercado, além de disseminar o hábito do consumo desenfreado, criando falsas necessidades e determinando a condição social pela capacidade de ter e de consumir, passou a ter o crédito como seu motor propulsor, já que esse instrumento confere poder aquisitivo imediato para o consumidor, que se tornou o principal agente da economia. Conseqüentemente, além do apelo para o consumo dos bens e serviços produzidos, o consumidor passou a ser assediado para que utilizasse do crédito, sendo certo que o endividamento tornou-se uma situação desejada pelo mercado e incentivada pelos governantes.

Tendo em vista esse cenário, a proteção do consumidor, sobretudo nos contratos de crédito, tornou-se fundamental, seja para proteger a sua manifestação de vontade no momento da formação do contrato, seja para corrigir situações de extrema desigualdade em virtude da alteração das circunstâncias fáticas nos contratos de longa duração. A fim de tornar a liberdade de contratar o mais efetiva possível, impõe-se ao fornecedor - que além de ser economicamente mais forte, é a parte profissional da relação - os deveres de informação, aconselhamento, lealdade e cuidado, decorrentes da boa-fé objetiva. Cominase de nulidade absoluta as cláusulas abusivas, inclusive a que diz respeito à cobrança de 
juros sobre juros, pois permite a obtenção de vantagem exagerada por parte do fornecedor. Também é nulo o contrato que, em virtude da lesão, nasceu excessivamente desequilibrado. Proíbe-se o exercício abusivo de posições jurídicas, seja na modalidade do exercício danoso inútil, seja na desproporção dos efeitos práticos, sem consideração por situações especiais. Considera-se o adimplemento substancial do contrato para evitar a resolução prejudicial ao consumidor, que cumpriu com quase a totalidade do contrato. $\mathrm{Na}$ fase de execução do contrato, impõe-se o dever de cooperação, a fim de permitir que a relação atinja seu termo, cumprindo a sua função social. Ademais, impõe-se a revisão do contrato, diante da quebra do sinalagma funcional.

A tutela acima descrita refere-se às relações de crédito em geral, independentemente da verificação em concreto de uma situação de endividamento excessivo. Contudo, a necessidade de proteção do consumidor de crédito levou diversos países desenvolvidos a ir além, adotando legislações específicas de prevenção e tratamento das situações de sobreendividamento. Verifica-se no direito comparado a existência de dois modelos de tutela, conforme analisado no Capítulo 3 da Parte I: o liberal, que regula a falência do consumidor como instrumento de regulação de mercado, e o social, que encara o endividamento como causa de exclusão social e de violação de direitos fundamentais.

No Brasil, apesar de não existir uma lei que trate de forma global e específica o endividamento excessivo, os mecanismos de direito privado em vigor são aptos a prevenir e a tutelar grande parte das situações. Mesmo os casos de alteração das circunstâncias subjetivas relativas ao consumidor encontram abrigo à luz dos princípios da função social dos contratos e da proteção da parte mais fraca, que permitem a consideração da justiça distributiva no âmbito dos contratos, como decorrência da incidência dos princípios da dignidade da pessoa humana e da solidariedade social. Assim, verificados os pressupostos da vulnerabilidade e da boa-fé do devedor, bem como da situação de urgência social em que o núcleo dos direitos fundamentais decorrentes da dignidade humana corra risco de violação, impõe-se, primeiramente, o dever de renegociação do contrato, que encontra seu fundamento no dever de cooperação e na vedação ao exercício abusivo de posições jurídicas, ou, não sendo possível ou sendo frustrada a renegociação, autoriza-se a intervenção do juiz para adequar a forma de execução do contrato. Ademais, nos casos em que a concessão abusiva - ou predatória - do crédito tenha gerado o sobreendividamento, impõe-se a responsabilização da instituição financeira ou equivalente pela má concessão do crédito. 
Diante da inexistência de legislação específica, a exemplo das estudadas no Capítulo 3 da Parte I, a possibilidade de revisão contratual para adaptar o contrato às condições financeiras do consumidor, que foram alteradas por circunstâncias alheias a sua vontade, fica limitada a situações excepcionais, nas quais se verifique no caso concreto uma violação efetiva ou potencial do núcleo mínimo dos direitos fundamentais, que caracterize uma situação de urgência social. Dessa forma, o ideal seria a adoção de uma legislação específica para a prevenção e tratamento das situações de sobreendividamento. Sendo o Brasil um Estado social e democrático de direito, uma legislação sobre o tema deve seguir o modelo social, tratado na seção 3.1.3, da parte I.

Com efeito, a Constituição da República Federativa do Brasil declara expressamente que os seus fundamentos são a dignidade da pessoa humana (art. $1^{\circ}$, III) e os valores sociais do trabalho e da livre iniciativa (art. $1^{\circ}$, IV); que os seus objetivos são I construir uma sociedade livre, justa e solidária (art. $3^{\circ}, \mathrm{I}$ ), garantir o desenvolvimento nacional (art. $3^{\circ}$, II), erradicar a pobreza e a marginalização e reduzir as desigualdades sociais e regionais (art. $3^{\circ}$, III) e promover o bem de todos, sem preconceitos de origem, raça, sexo, cor, idade e quaisquer outras formas de discriminação (art. $3^{\circ}, \mathrm{IV}$ ); que a sua ordem econômica, que tem por fim assegurar a todos existência digna, conforme os ditames da justiça social (art. 170, caput), deve observar, dentre outros, os princípios da função social da propriedade, da defesa do consumidor e da redução das desigualdades regionais e sociais; além de prever uma série de direitos sociais, tais como a educação, a saúde, o trabalho, a moradia, o lazer, a segurança, a previdência social, a proteção à maternidade e à infância e a assistência aos desamparados (art. $6^{\circ}$ da CF).

Tendo em vista a atual situação do endividamento no país, que apenas recentemente experimentou o fenômeno da democratização do crédito, conforme analisado no capítulo 2 da parte I, urge a edição de uma lei que tutele de forma global a recuperação financeira do consumidor, a exemplo da Lei 11.101/2005, que trata da recuperação judicial e extrajudicial de empresas. Não é razoável relegar à exclusão social o consumidor pessoa física, portador de dignidade inafastável, diante da ocorrência de eventos que alterem a sua capacidade financeira, enquanto as pessoas jurídicas possuem mecanismos legais aptos a proporcionar a sua recuperação.

Feitas essas considerações, cumpre recordar os pressupostos materiais de constitucionalidade de uma lei futura sobre a prevenção e o tratamento das situações de sobreendividamento, num modelo pautado pela necessidade de preservação dos direitos fundamentais do devedor, quais sejam: 1) consideração de atributos éticos das partes, ou 
seja, tanto a boa-fé do consumidor, quanto a retidão no comportamento do credor; 2) necessidade de preservação da dignidade do consumidor, que deve ter meios suficientes para manter uma existência digna; 3) fase extrajudicial para a tentativa de conciliar os interesses das partes, e, caso não seja possível a conciliação, distribuição justa das custas processuais, considerando a capacidade econômica das partes, bem como impondo maior ônus para aqueles que forem considerados culpados pelo endividamento (devedor de má-fé ou credor negligente); 4) elaboração de planos de recuperação financeira que contemplem as mais variadas medidas, tais como a concessão de moratória, reescalonamento da dívida, redução ou exclusão dos juros de mora, devolução de mercadorias com extinção de respectivo débito, dentre outras medidas atípicas capazes de conciliar os interesses dos credores e do consumidor; 5) exigência de conduta ética do consumidor durante o cumprimento do plano de recuperação, inclusive a freqüência em cursos de educação financeira e de elaboração de orçamento familiar; 6) tutela diferenciada para aqueles indivíduos que efetivamente necessitem, a exemplo de que ocorre na França, onde apenas aqueles consumidores de boa-fé que demonstrarem a situação irremediavelmente comprometida é que tem o direito ao perdão das dívidas; 7) não utilização de termos pejorativos, como "falência" ou "insolvência", dando preferência para os termos "recuperação financeira" ou "reorganização de dívidas", em razão do estigma social decorrente da utilização daqueles termos. 


\section{BIBLIOGRAFIA}

\section{Livros}

ADORNO, Theodor W.; HORKHEIMER, Max. Dialética do Esclarecimento: fragmentos filosóficos. Tradução: Guido Antonio de Almeida. Rio de Janeiro: Jorge Zahar Editor, 1985.

AGUIAR JR., Ruy Rosado de. Extinção dos Contratos por Incumprimento do Devedor. Rio de Janeiro: AIDE Editora, 2004.

ALMEIDA, Carlos Ferreira de. Contratos I: conceito, fontes, formação. Coimbra: Livraria Almedina, 2000.

ALMEIDA COSTA, Mario Julio. Direito das Obrigações. $9^{\mathrm{a}}$ ed., Coimbra: Almedina, 2001.

ALPA, Guido. Il diritto dei consumatori. Roma: Laterza, 1995.

AMARAL, Francisco. Direito Civil - Introdução. Rio de Janeiro: Renovar, 2006.

ASCENSÃO, José de Oliveira. A desconstrução do abuso do direito. In: DELGADO, Mário Luiz; ALVES, Jones Figueirêdo. Questões Controvertidas no Direito das Obrigações e dos Contratos. São Paulo: Editora Método, 2005, p. 40.

ASSAF NETO, Alexandre. Matemática Financeira e suas Aplicações. 6. ${ }^{\mathrm{a}}$ ed., São Paulo: Editora Atlas S/A, 2001.

BARCELLOS, Ana Paula de. A eficácia jurídica dos princípios constitucionais: o princípio da dignidade da pessoa humana. Rio de Janeiro: Renovar, 2001.

BAUMAN, Zygmunt. Globalização: as conseqüências humanas. Tradução: Marcus Penchel. Rio de Janeiro: Jorge Zahar Editor, 1999.

. Modernidade e ambivalência. Rio de Janeiro: Jorge Zahar Editor, 1999.

. O mal-estar da pós-modernidade. Rio de Janeiro: Jorge Zahar Editor, 1998.

BEAUBRUN, Marcel. La notion de consommateur de crédit. In: FADLALLAH, Ibrahim (org.). Le droit du crédit au consommateur. Paris: Litec, 1982.

BENABENT, Alain. Droit Civil - Les Obligations. $3^{\text {a }}$ ed. Paris: Montchrestien, 1991.

BENJAMIN, Antônio Herman de Vasconcellos e. Código Brasileiro de Defesa do Consumidor comentado pelos autores do anteprojeto. $8^{\mathrm{a}}$ ed.. Rio de Janeiro: Forense Universitária, 2005.

BERTHIAU, Denis. Le principe d'égalité et le droit civil des contrats. Paris: LGDJ, 1999. BETTI, Emilio. Teoria generale del negozio giuridico. Napoli: Scientifiche Italiane, 1994. 
. Interpretazione della legge e degli atti giuridici. Milano: Girffrè, 1971.

. Teoria generale delle obbligazioni, I - Prolegomeni: funzione econômico-

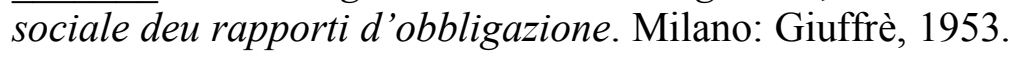

BIANCA, C. Massimo. Diritto civile: il contrato. Milano: Giuffrè, 1987, vol. 3. . Diritto civile: L'Obligazione - IV. Milano: Giuffrè, 1993.

BIHL, Luc. Consommateur réveille-toi. Paris: Syros, 1992. 1994. . La défense de la liberté de la concurrence par les consommateurs. Paris: Dalloz, . Le surendettement: l'apparition d'un fléau social. In: GARDAZ, Michel (dir.). Le surendettement de particuliers. Paris: Anthropos, 1997.

BITTAR, Eduardo C. B. O Direito na Pós-Modernidade. Rio de Janeiro: Forense Universitária, 2005.

BOBBIO, Norberto. A era dos direitos. Tradução de Carlos Nélson Coutinho. $9^{\text {a }}$ ed., Rio de Janeiro: Campus, 1992.

. Direito e Estado no Pensamento de Emanuel Kant. Tradução: Alfredo Fait. São Paulo: Editora Mandarim, 2000.

BONAVIDES, Paulo. Curso de Direito Constitucional. São Paulo: Malheiros Editores, 2008.

2004.

. Do Estado Liberal ao Estado Social. $7^{\mathrm{a}}$ ed., São Paulo: Malheiros Editores,

BOURGOIGNIE, Thierry. Éléments pour une théorie du droit de la consommation. Bruxelles: Story-scientia, 1988.

CALAIS-AUlOY, Jean; STEINMETZ, Frank. Droit de la consommation. $7^{\mathrm{a}}$ ed., Paris: Dalloz, 2003.

CALASSO, Francesco. Il negozio giuridico - lezioni di storia Del diritto italiano. Milano, Giuffrè, 1967.

CANARIS, Claus-Wilhelm. Pensamento sistemático e conceito de sistema na ciência do direito. Tradução de Antonio Menezes Cordeiro. $2^{\mathrm{a}}$ ed., Lisboa: Fundação Calouste Gulbenkian, 1996.

CANOTILHO, José Joaquim Gomes. Direito Constitucional e Teoria da Constituição. Coimbra: Almedina, 1996. 
CAPITANT, Henri. L'endettement - Journées argentines. Tome XLVI - 1995, L.G.D.J, Paris, 1997.

CARPENA, Heloísa. O abuso do direito no Código de 2002 - relativização de direitos na ótica civil-constitucional. In: TEPEDINO, Gustavo (coord.). A Parte Geral do Novo Código Civil: estudos na perspectiva civil-constitucional. Rio de Janeiro: Renovar, 2003.

CAS, Gérard; FERRIER, Didier. Traité de droit de la consommatiom. Paris: PUF, 1986.

CASADO, Márcio Mello. Proteção do consumidor de crédito bancário e financeiro. $2^{\mathrm{a}}$ ed.ição, São Paulo: RT, 2007.

CASTILHO, Ricardo. Justiça Social e Distributiva - desafios para concretizar direitos sociais. São Paulo: Saraiva, 2009.

CASTRO FARIAS, José Fernando de. A Origem do Direito de Solidariedade. Rio de Janeiro: Renovar, 1998.

CASTRO SAMPAIO, Laerte Marrone de. A Boa-fé Objetiva na Relação Contratual. Barueri-SP: Manole, 2004.

CAVALLAZZI, Rosângela Lunardelli; MARQUES, Cláudia Lima (coord.). Direitos do Consumidor Endividado - Superendividamento e crédito. São Paulo: RT, 2006.

CHARDIN, Nicole. Le cotrat de consommation de crédit et l'autonomie de la volonté. Paris: LGDJ, 1988.

CHATAIN, Pierre-Laurent; FERRIÈRE, Frederic. Surendettement des particuliers. Paris: Dalloz, 2000.

CHEREDNYCHENKO, Olha. Fundamental Rights, Contract Law and the Protection of the Weaker Party: A Comparative Analysis of the Constitutionalisation of Contract Law, with Emphasis on Risky Financial Transactions. München: Sellier European Law Publishers, 2007.

COMPARATO, Fábio Konder. A afirmação histórica dos direitos humanos. $2^{\mathrm{a}}$ ed., São Paulo: Saraiva, 2001. $\overline{\text { Letras, } 2006 .}$

Ética: Direito, moral e religião no mundo moderno. São Paulo: Companhia das

CORDEIRO, António Menezes. Manual de Direito Bancário. Coimbra: Almedina, 1998.

COUTO E SILVA, Clóvis V. do. A obrigação como processo. Rio de Janeiro: Editora FGV, 2007.

COUTURIER, Isabelle. La condition de bonne foi pour le règlement des difficultés liées au surendettement des particulier. In: GARDAZ, Michel (dir.). Le surendettement de particuliers. Paris: Anthropos, 1997. 
CROZE, Hervé. Les sanctions de l'inexécution du contrat de crédit. In: FADLALLAH, Ibrahim (org.). Le droit du crédit au consommateurs. Paris: Litec, 1982.

CUNHA DE SÁ, Fernando Augusto. Abuso do Direito. Lisboa, 1973.

DERRUPÉ, Jean. Rapport de Synthese. L'endettement - Travaux de L'Association Henri Capitant-Journées argentines, Tome XLVI, 1995, p. 23.

DUGUIT, Léon. Fundamentos do Direito. São Paulo: Ícone, 2006.

DUPAS, Gilberto. Economia Global e Exclusão Social: pobreza, emprego, estado e o futuro do capitalismo. São Paulo: Paz e Terra, 1999.

DURKHEIM, É. Da Divisão do Trabalho Social. São Paulo: Martins Fontes, 2008.

DUTILlEUL, François Collart; DELEBECQUE, Philippe. Contrats civils et commerciaux,. Paris: Dalloz, 1991.

DWORKIN, Ronald. O Império do Direito. São Paulo: Martins Fontes, 2007.

EFING, Antônio Carlos. Contratos e procedimentos bancários à luz do Código de Defesa do consumidor. São Paulo: RT, 1999.

Tribunais, 2002.

- Bancos de Dados e Cadastro de Consumidores. São Paulo: Revista dos

FADLALLAH, Ibrahim (Org.). Le droit du crédit au consommateur. Paris: Litec, 1982.

FALLETTI, François. La vente à crédit des biens de consommation. Paris: Litec, 1981.

FARIAS, Edílson Pereira de. Colisão de direitos. Porto Alegre: Sergio A. Fabris Editor, 1996.

FARIA, José Eduardo. O direito na economia globalizada. São Paulo: Malheiros Editores, 2005.

FERRIER, Didier. La protection des consommateurs. Paris: Dalloz, 1996.

FERREIRA, Carlos Alberto Goulart. Equilibrio Contratual. In: LOTUFO, Renan (Coord.). Direito Civil Constitucional - Cadernos I. São Paulo: Max Limonad, 1999.

FERREIRA DA SILVA, Luis Renato. Revisão dos contratos: do Código Civil ao Código do Consumidor. Rio de Janeiro: Forense, 2001.

. A função social do contrato no novo Código Civil e sua conexão com a solidariedade social. In: SARLET, Ingo Wolfgang (org.). O novo Código Civil e a Constituição. Porto Alegre: Livraria do Advogado, 2003.

FERRI, Luigi. La autonomia privada. Tradução de Luis Sancho Mendizabal. Madrid: Revista de Derecho Privado, 1969. 
FIN-LANGER, Laurence. L'Équilibre Contractuel. Paris: LGDJ, p. 99-100.

FLÓREZ-VALDÉS, Joaquim Arce y. Los princípios generales del derecho y su formulación constitucional. Madrid: Cuadernos Civitas, 1990.

FONSECA, Antônio Cezar Lima da. Direito Penal do Consumidor. Porto Alegre, Livraria do Advogado, p. 250.

GARDAZ, Michel (Org.). Le surendettement des pariculiers. Paris: Anthropos, 1997.

GJIDARA, Sophie. L'endettement et le droit privé. Paris: LGDJ, 1999.

GODOY, Cláudio Luiz Bueno de. Função Social do Contrato. São Paulo: Saraiva, 2004. . Responsabilidade civil pelo risco da atividade. São Paulo: Saraiva, 2009.

GOMES, Orlando. Contratos. Rio de Janeiro: Forense, 1998.

Tribunais, 1967.

. Transformações gerais do direito das obrigações. São Paulo: Revista dos

GUITARD, Hubert. Le banquier et son client: droits et obligations respectifs. Paris: Delmas, 1988.

HABERMAS, Jürgen. O Discurso Filosófico da Modernidade. Tradução: Luiz Sérgio Repa, Rodnei Nascimento. São Paulo: Martins Fontes, 2002.

HORKHEIMER, Max. Eclipse da Razão. $5^{\text {a }}$ ed., São Paulo: Ed. Centauro, 2003.

HOWELLS, By Geraint G.; WILHELMSSON, Thomas. EC Consumer Law. Ashgate Pub Co, 1997.

JACOBY, Melissa B. Generosity Versus Accessibility: Bankruptcy, Consumer Credit, and Health Care Finance in the US. In: NIEMI-KIESILÄINEN, Johanna; RAMSAY, Iain e WHITFORD, William. Consumer Bankruptcy in Global Perspective. Oxford and Portland, Oregon: Hart Publishing, 2003. p. 281-300.

JOSSERAND, Louis. L'esprit de droits et de leur relativité - Théorie dite de l'abus des droits. $2^{\mathrm{a}}$ éd., Paris: Dalloz, 1939.

JUNQUEIRA DE AZEVEDO, Antonio. Relatório brasileiro sobre revisão contratual apresentado para as Jornadas Brasileiras da Associação Henri Capitant. In: Novos Estudos e Pareceres de Direito Privado. São Paulo: Saraiva, 2009.

. Caracterização jurídica da dignidade da pessoa humana. In: Estudos e Pareceres de Direito Privado. São Paulo: Saraiva, 2004. p. 18.

. Negócio Jurídico: existência, validade, eficácia. São Paulo: Saraiva, 2002. 
- Negócio Jurídico e Declaração Negocial - noções gerais e formação da

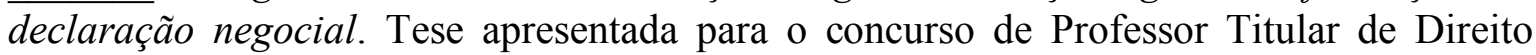
Civil da USP, 1986.

KANT, Immanuel. Fundamentação da metafísica dos costumes. Traduzida do alemão por Paulo Quintela. Lisboa: Edições 70, 2005.

KHAYAT, Danielle. Le droit du surendettement des particuliers. Paris: LGDJ, 1997.

KUHNN, Osmar Leonardo; BAUER, Udibert Reinoldo. Matemática Financeira aplicada e Análise de Investimentos. $2^{\mathrm{a}}$ ed., São Paulo: Atlas, 1996.

LAFER, Celso. A reconstrução dos direitos humanos - um diálogo com o pensamento de Hannah Arendt. São Paulo: Companhia das Letras, 1991.

LAMARQUE, Gilles. L’ exclusion. Paris: PUF, 1995.

LARENZ, Karl. Base Del negocio jurídico y cumplimiento de los contratos. Tradução de Carlos Fernandes Rodriguez. Madrid: Revista de Derecho Privado, 1956.

. Metodologia da Ciência do Direito. Trad. de José Lamego. $3^{\mathrm{a}}$ ed., Lisboa: Fundação Calouste Gulbenkian, 1997. p. 383.

. Derecho de Obligaciones. Tomo I. Versión Española y notas de Jaime Santos Briz. Madrid: Editorial Revista de Derecho Privado, 1958.

. Derecho civil: parte general. Tradução de Miguel Izquierdo y Macías-Picavea. Madrid: EDERSA, 1978.

LEITE, George Salomão. Dos Princípios Constitucionais,. São Paulo: Malheiros Editores, 2003.

L'HEUREUX, Nicole. Droit de la consommation. $4^{\text {a }}$ ed., Quebec: Les Editions Yvon Blais, 1993.

LOPES, José Reinaldo de Lima. Consumer Bankruptcy and Over-indebtedness in Brazil. In: NIEMI-KIESILÄINEN, Johanna; RAMSAY, Iain e WHITFORD, William. Consumer Bankruptcy in Global Perspective. Oxford and Portland, Oregon: Hart Publishing, 2003. p. 85-103.

LORENZETTI, Ricardo Luis; LIMA MARQUES, Cláudia. Contratos de servicios a los consumidores. Buenos Aires: Rubinzal-Culzoni, 2005.

LOTUFO, Renan. Direito civil constitucional - Cadernos I. São Paulo: Max Limonad, 1999.

. Código Civil comentado. São Paulo: Saraiva, 2003, vol. 1.

LYOTARD, Jean-François. A Condição Pós-Moderna. Tradução: José Bragança de Miranda. Lisboa: Gradiva, 2003. 
MACARIO, Francesco. Adeguamento e rinegoziazione nei contratti a lungo termine. Napoli: Novene Editore, 1996.

MACEDO JUNIOR, Ronaldo Porto. Contratos relacionais e defesa do consumidor,. São Paulo: Max Limonad, 1998.

MACPHERSON, C. B.. Ascensão e queda da justiça econômica. Rio de Janeiro: Paz e Terra, 1991.

MALAURIE, Philipe; AYNES, Lorent. Les Obligations. Paris: Defrénois, 2004.

MARCUSE, Herbert. Cultura e Sociedade. Vol. 1. Tradução: Wolfgang Leo Maar, Isabel Maria Loureiro, Robespierre de Oliveira. $2^{a}$ ed.,ição. São Paulo: Paz e Terra, 1997, vol. 1.

MARQUES, Cláudia Lima. "O novo modelo de direito privado brasileiro e os contratos: entre interesses individuais, sociais e direitos fundamentais". In: A nova crise do contrato. São Paulo: Revista dos Tribunais, 2007.

. Sugestões para uma lei sobre o tratamento do superendividamento de pessoas físicas em contratos de crédito ao consumo: proposições com base em pesquisa empírica de 100 casos no Rio Grande do Sul. In: CAVALLAZZI, Rosângela Lunardelli; MARQUES, Cláudia Lima (coord.). Direitos do Consumidor Endividado Superendividamento e crédito. São Paulo: RT, 2006.

.Contratos no Código de Defesa do Consumidor. $5^{\mathrm{a}}$ ed., São Paulo: RT, 1998.

MARQUES, Maria Manuel Leitão; FRADE, Catarina. Searching For an Overindebtedness Regulatory System for Portugal and the European Union. In: NIEMIKIESILÄINEN, Johanna; RAMSAY, Iain e WHITFORD, William. Consumer Bankruptcy in Global Perspective. Oxford and Portland, Oregon: Hart Publishing, 2003.

MARQUES, Maria Manuel Leitão (Coord.); NEVES, Vitor; FRADE, Catarina; et al. $O$ endividamento dos consumidores. Lisboa: Almedina, 2000.

MARTINS-COSTA, Judith. A Boa-fé no Direito Privado. São Paulo: Revista dos Tribunais, 2000.

. Os direitos fundamentais e a opção culturalista do novo Código Civil. In: SARLET, Ingo Wolfgang (org.). Constituição, Direitos Fundamentais e Direito Privado. Porto Alegre: Livraria do Advogado, 2003.

MARTINS DA COSTA, Geraldo de Faria. Superendividamento: a proteção do consumidor de crédito em direito comparado brasileiro e francês. São Paulo: Revista dos Tribunais, 2002.

MAZEAUD, Denis. Rapport français. In: L' endettement - Journées argentines. Paris: LGDJ, 1997. 
MENEZES CORDEIRO, Antônio Manoel da Rocha e. Da boa fé no direito civil. Coimbra: Livraria Almedina, 1984, vol. 1 e 2. . Modernização do Direito Civil,. Coimbra: Almedina, 2004, p. 111, vol I.

MENGONI, Luigi. Spunti per una teoria delle clausole generali. In: Quardeni della Scuola Superione di Studi Universitari e di Perfezionamento. Milano, Giuffre, v. 3, p. 5-18, giug. 1985.

MORAES, Maria Celina Bodin de. O princípio da dignidade humana. In: MORAES, Maria Celina Bodin de (coord.). Princípios do Direito Civil Contemporâneo. Rio de Janeiro: Renovar, 2006.

. O conceito de dignidade humana: substrato axiológico e conteúdo normativo. In: SARLET, Ingo Wolfgang (org.). Constituição, Direitos Fundamentais e Direito Privado. Porto Alegre: Livraria do Advogado, 2003.

MORAES. Renato José de. Cláusula Rebus sic Stantibus. São Paulo: Saraiva, 2001.

MOREIRA ALVES, Jose Carlos. A parte geral do Projeto de Código Civil brasileiro. São Paulo: Saraiva, 1986.

NEGREIROS, Teresa. Teoria do contrato: novos paradigmas. $2^{\mathrm{a}}$ ed., Rio de Janeiro: Renovar, 2006.

NEIERTZ, Véronique. Le Code de la consommation - Édition commentée. Paris: Prat Éditions, 1996.

NERY JR., Nelson. Os princípios gerais do código brasileiro de defesa do consumidor. Revista de Direito do Consumidor, 3, São Paulo: RT, p. 44-77, set.-dez./1992.

- Código Brasileiro de Defesa do Consumidor comentado pelos autores do anteprojeto. $8^{\text {a }}$ ed., Rio de Janeiro: Forense Universitária, 2005.

NIEMI-KIESILÄINEN, Johanna; RAMSAY, Iain e WHITFORD, William. Consumer Bankruptcy in Global Perspective. Oxford and Portland, Oregon: Hart Publishing, 2003.

. Collective or Individual? Constructions of Debtors and Creditors in Consumer Bankruptcy. In: NIEMI-KIESILÄINEN, Johanna; RAMSAY, Iain e WHITFORD, William. Consumer Bankruptcy in Global Perspective. Oxford and Portland, Oregon: Hart Publishing, 2003.

NOBLOT, Cyril. La Qualité du Contractant comme Critère Legal de Protection. Paris: LGDJ, 2002.

NORONHA, Fernando. O direito dos contratados e seus princípios fundamentais (autonomia privada, boa-fé, justiça contratual). São Paulo: Saraiva, 1994.

NYGH, Peter. Autonomy in International Contracts. Oxford: Clarendon Press, 1999. 
PAISANT, Gilles. A reforma do procedimento de Tratamento do Superendividamento pela Lei de 29.07.1998 relativa à luta contra as exclusões. In: CAVALLAZZI, Rosângela Lunardelli; MARQUES, Cláudia Lima (coord.). Direitos do Consumidor Endividado Superendividamento e crédito. São Paulo: RT, 2006.

PASQUALOTTO, Adalberto. Os efeitos obrigacionais da publicidade no código de defesa do consumidor. São Paulo: RT, 1997.

PEREIRA, Caio Mário da Silva. Lesão nos contratos. $6^{\mathrm{a}}$ ed., Rio de Janeiro: Forense, 1994.

PERLINGIERI, Pietro. Perfis do direito civil: introdução ao direito civil constitucional. Tradução de Maria Cristina de Cicco. Rio de Janeiro: Renovar, 1999.

PETIT, Bruno. La formation successive du contrat du crédit. Obra coletiva sob a direção de FADLALLAH, Ibrahim (Org.). Le droit du crédit au consommateur. Paris: Litec, 1982.

PIOVESAN, Flávia. Direitos Humanos e o Direito Constitucional Internacional. São Paulo: Saraiva, 2007.

PIZZIO, Jean-Pierre. Code de la Consommation Commenté,. $2^{\mathrm{a}}$ éd.,ition,. Paris: Montchrestien, 1996.

PONTES DE MIRANDA, Francisco Cavalcanti. Tratado de direito privado. São Paulo: Revista dos Tribunais, 1984, vol. 38.

RAMSAY, Iain. Consumer Credit Society and Consumer Bankruptcy: Reflections on Credit Cards and Bankruptcy in the Informal Economy. In: NIEMI-KIESILÄINEN, Johanna; RAMSAY, Iain e WHITFORD, William. Consumer Bankruptcy in Global Perspective. Oxford and Portland, Oregon: Hart Publishing, 2003, p. 17 a 39.

RAWLS, John. A Theory of Justice. Cambridge, Massachusetts, London, England: The Belknap Press of Harvard University Press.

RAYMOND, Guy. Les contrats de consommation. Aprés de Code de la consommation, grands problèmes choisis (oeuvre collective, direction de J. Calais-Auloy et H. Causse). Paris: Litec, 1995.

REALE, Miguel. O projeto de Código Civil: situação atual e seus problemas fundamentais. São Paulo: Saraiva, 1984.

REIFNER, Udo. 'Thou shalt pay thy debts' - Personal Bankruptcy Law and Inclusive Contract Law. In: NIEMI-KIESILÄINEN, Johanna; RAMSAY, Iain e WHITFORD, William. Consumer Bankruptcy in Global Perspective. Oxford and Portland, Oregon: Hart Publishing, 2003, p. 143 a 166.

RENTERÍA, Pablo. Considerações acerca do atual debate sobre o princípio da função social do contrato. In: MORAES, Maria Celina Bodin de (coord.). Princípios do Direito Civil Contemporâneo. Rio de Janeiro, São Paulo: Renovar, 2006, p. 295. 
RIPERT, Georges. La règle morale dans les obrigations civiles. $4^{\mathrm{a}}$ ed., Paris: LGDJ, 1949.

RIZZARDO, Arnaldo. Contratos de crédito bancário. $3^{\text {a }}$ ed., São Paulo: RT, 1997.

ROSENVALD, Nelson. Comentários aos artigos 478 a 180. In: PELUSO Cezar (coord.), Código Civil Comentado. $3^{\text {a }}$ ed., Barueri: Editora Manole, 2009.

ROUANET, Sérgio Paulo. Mal-estar na Modernidade. $2^{\mathrm{a}}$ ed., São Paulo: Companhia das Letras, 2003.

ROUTIER, Richard. La responsabilité du banquier. Paris: LGDJ, 1997.

RUOZI, Roberto. La Tutela Del Consumatore di Servizi Finanziari, a cura di Roberto Ruozi. In: La tutela del Consumatore di Servizi Finanziari. Milano: E.G.E.A., 1990.

SALLES, Laurent. Le surendettement. Paris: MB Formation, 2004.

SANTOS, Antonio Jeová. Função Social do Contrato. $2^{\text {a }}$ ed., São Paulo: Editora Método, 2004.

SANTOS, Boaventura de Sousa (org.). Reconhecer para Libertar: os caminhos do cosmopolitanismo multicultural. Rio de Janeiro: Civilização Brasileira, 2003.

SARLET, Ingo Wolfgang (org.). Constituição, Direitos Fundamentais e Direito Privado. Porto Alegre: Livraria do Advogado, 2003.

. Dignidade da Pessoa Humana e Direitos Fundamentais na Constituição Federal de 1988. $3^{\mathrm{a}}$ ed., Porto Alegre: Livraria do Advogado, 2004.

. (org.). O novo Código Civil e a Constituição. Porto Alegre: Livraria do Advogado, 2003.

. Algumas notas em torno da relação entre o princípio da dignidade da pessoa $\overline{\text { humana }} \mathrm{e}$ os direitos fundamentais na ordem constitucional brasileira. In: Dos Princípios Constitucionais. São Paulo: Malheiros Editores, 2003.

SARMENTO, Daniel. Direitos Fundamentais e Relações Privadas. Rio de Janeiro: Lúmen Júris, 2004.

SEN, Amartya. Desenvolvimento como liberdade. São Paulo: Companhia das Letras, 2000.

SOBRINHO, José Dutra Vieira. Matemática Financeira. $4^{\mathrm{a}}$ ed., Edição: ACREFI.

STIELTJES, Cláudio. Jürgen Habermas: A Desconstrução de uma Teoria. São Paulo: Germinal Editora, 2001.

STRECK, Lenio Luiz. O Papel da Jurisdição Constitucional na Realização dos Direitos Sociais-Fundamentais. In: SARLET, Ingo Wolfgang (org.). Direitos Fundamentais Sociais: Estudos de Direito Constitucional, Internacional e Comparado. Rio de Janeiro/São Paulo: Renovar, 2003. 
SULLIVAN, Teresa A.; WARREN, Elizabeth; WESTBROOK, Jay Lawrence. As we forgiuve our debtors - bankruptcy and consumer credit in America. New York: Oxford University Press, 1989.

TEPEDINO, Gustavo; BARBOZA, Heloísa Helena; MORAES, Maria Celina Bodin de (coords.),. Código Civil Interpretado Conforme a Constituição da República. Rio de Janeiro, Renovar, 2006, vol. II.

VARELA, João de Matos Antunes. Das obrigações em geral. 10a ed., Coimbra: Almedina, 2000., vol.1.

. Das Obrigações em Geral. $7^{\mathrm{a}}$ ed.,ição. Coimbra: Almedina, 1999, vol II.

VIGNEAU, Vincent; BOURIN, Guillaume. Droit du Surendettement des Particuliers. Paris: Litec, 2007.

WIEACKER, Franz. El principio general de la buena fe. Tradução de José Luis Carro. Madrid: Ed Civitas, 1986.

. História do Direito Privado Moderno. Tradução de A. M. Botelho Hespanha. Lisboa: Fundação Calouste Gulbenkian, 1967.

WILHELMSSON, Thomas. Critical Studies in Private Law. Dordrecht: Kluwer Academic Publishers, 1992.

WINDSCHEID, Bernard. Diritto delle Pandette. Trad. Carlo Fadda e Paolo Emilio Bensa. Torino: Unione Tipografico-Editrice, 1902, vol. I.

XAVIER, José Tadeu Neves. A nova dimensão dos contratos a caminho da pósmodernidade. Tese de doutorado disponível em http://hdl.handle.net/10183/13169.

YAMAMOTO, Kazuhiko. "Rapport Japonais". In: L'endettement, Travaux de L'Association Henri Capitant - Journées argentines, Tome XLVI, 1995. P. p. 160. 


\section{Artigos}

AFANASIEFF, Tarsila Segalla; LHACER, Pricila Maria Villa; NAKANE, Marcio. The Determinants of Bank Interest Spreads in Brazil. Working Paper Series, $\mathrm{n}^{\circ} 46$, Central Bank of Brazil, august, 2002.

ALPA, Guido. Les nouvelles frontières du droit des contrats. Revue Internationale de Droit Comparé, $\mathrm{n}^{\circ}$ 4, octobre-décembre/1998, p.age 1015-1030.

AMARAL JÚNIOR, Alberto do. A boa-fé e o controle das cláusulas contratuais abusivas nas relações de consumo. Revista de Direito do Consumidor, n 2, p. 100-125, mar./1992.

ANCEL, Pascal. Quelques observations sur la structure des sections relatives à l'inexécution des contrats. Revue des Contrats, 01 janvier 2006, nº 1, p. 105.

. Contrat de fait et comportements sociaux typiques. Revue des Contrats, 01 octobre $2004 n^{\circ} 4$, p. 1087.

. Rapport de Synthèse. LPA, 21 mai 1999, n 101, p. 50.

; GOUX, Jean-François. Pouvoirs du juge et contraintes financières - a propos de

l'article 12 de la loi Neiertz. Banque \& Droit, no 17, mai-juin 1991, p. 99-104.

ANGELETOS GM, LAIBSON D, REPETTO D, J. TOBACMAN. The Hyperbolic Consumption Model: Calibration, Simulation and Empirical Evaluation. Journal of Economic Perspectives, 2001, p. 47-68.

ARIDA, Persio; BACHA, Edmar Lisboa; LARA-RESENDE, André. Credit, Interest and Jurisdictional Uncertainty: Conjectures on the Case of Brazil. Work-paper apresentado no seminário Inflation Targeting and Debt: The Case of Brazil.

ARRUDA ALVIM, José Manoel. Cláusulas abusivas e seu controle no direito brasileiro. Revista de Direito do Consumidor, São Paulo, n 20, p. 25-70, out/dez. 1996.

ATHREYA, Kartik. Fresh Start or Head Start? Uniform Bankruptcy Exemptions and Welfare. Research Department of Federal Reserve Bank of Richmond, Working Paper $\mathrm{n}^{\mathrm{o}}$ 03-03R, July 26, 2004.

BANKRUPTCY BASICS. Bankruptcy Judges Divisions. Administrative Office of the Unites States Courts. Disponível em:

http://www.uscourts.gov/bankruptcycourts/bankruptcybasics.html.

Bankruptcy Laws Commission, Report of the Commission on the Bankruptcy Laws of the United States. H. R. Doc. no 93-173 (1973).

BARCELlOS, Ana Paula de. Normatividade dos princípios e o princípio da dignidade da pessoa humana na Constituição de 1988. Revista de Direito Administrativo, $\mathrm{n}^{\circ}$ 221, Renovar, p. 159-188. 
BARROSO, Luís Roberto. Fundamentos teóricos e filosóficos do novo direito constitucional brasileiro. Revista Diálogo Jurídico, ano 1, vol. 1, n ${ }^{0}$ 6. Salvador: CAJ Centro de Atualização Jurídica, set./2001.

BECK, Thorsten; LEVINE, Ross. Legal institutions and financial development. World Bank Policy Research - working paper 3136, 2003.

BÉNABENT, Alain. La question de la bonne foi dans les procédures collectives. Gaz. Pal., 27 févr. 2003, n 58 , p. 37.

BECKER, Anelise. A doutrina do adimplemento substancial no direito brasileiro e em perspectiva comparativista. Revista da Faculdade de Direito da Universidade Federal do Rio Grande do Sul. Porto Alegre: Livraria dos Advogados, nº 1, vol. 9, nov./ 1993, p. 62.

BERTONCELLO, Káren Rick Danilevicz. Superendividamento e dever de renegociação. Dissertação de mestrado. Disponível em: http://hdl.handle.net/10183/13146.

. Bancos de dados e superendividamento do consumidor: cooperação, cuidado e informação. Revista de Direito do Consumidor, São Paulo, vol. 13, n 50, p. 36-57, abr/jun 2004.

; COSTA DE LIMA, Clarissa; DALL'AGNOL, Maria Augusta. Projeto de Mediação em Superendividamento do Consumidor: a experiência nas comarcas do interior e na capital. Multijuris - Primeiro Grau em Ação, ano III, n ${ }^{\circ}$ 5, junho/2008, p. 8-15.

; COSTA DE LIMA, Clarissa. Adesão ao projeto conciliar é legal - CNJ. Projeto-piloto: tratamento das situações de superendividamento do consumidor. Revista de Direito do Consumidor, $\mathrm{n}^{\circ}$ 63, São Paulo, p. 173.

BIHIL, Luc. La loi $\mathrm{n}^{0} 78-23$ du 10 janvier 1978 sur la protection et l'information du consommateur. Juris Classeur Periodique. La semaine juridique édition commerce et industrie, 1978, Doctrine 2909.

BIROUSTE, Jacques. Le point de vue du psychologue. Gaz. Pal, 27 févr. 2003, n 58, p. 6.

BOLTON, Patrick; SCHARFSTEIN, David S. A Theory of Predation Based on Agency Problems in Financial Contracting. The American Economic Review, vol. 80, No. $\mathrm{n}^{0} 1$. Mar./1990, p. 93-106.

BOUTEILLER, Patrice. Les dispositions complétant l'arsenal législatif relatif au traitement $\mathrm{du}$ surendettement apportées par la loi de programmation de cohésion sociale. JurisClasseur. La Semaine Juridique Entreprise et Affaires n 5, 3 Février 2005, 177.

. La publicité du crédit à la consommation. JurisClasseur. La Semaine Juridique

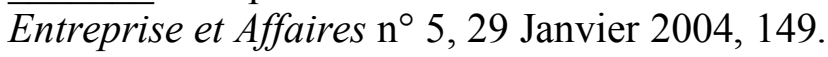

. La mise en oeuvre des nouvelles relations entre les banques et leurs clients. JurisClasseur. La Semaine Juridique Entreprise et Affaires n 9, 27 Février 2003, 312. 
BRUN, Jean-François ; COMBES, Jean-Louis ; MOTELCOMBES, Pascale. Une analyse économique du surendettement des particuliers. $L P A, 21$ mai 1999, ${ }^{\circ} 101$, p. 7.

BURHOUSE, Susan. Evaluating the Consumer Lending Revolution. Federal Deposit Insurance Corporation, September 17, 2003. Disponível em:

$<$ http://www.fdic.gov/bank/analytical/fyi/2003/091703fyi.html $>$. Acessado em: 10 de janeiro de 2009.

CALAIS-AULOY, Jean. L'influence du droit de la consommation sur le droit civil des contrats. Dalloz, RTD Civ., 1994, p. 239.

. L'ordonnance du $1^{\text {er }}$ décembre 1986 et les consommateurs. Recueil Dalloz Sirey, 1987, $20^{\circ}$ cahier, Chronique XXVI, p. 137-141.

Les cinq réformes qui rendraient le crédit moins dangereux pour les consommateurs. Recueil Dalloz Sirey, 1975, 4 cahier, Chronique III, p. 19-22.

. Le crédit à la consommation: suggestion en vue d'une intervention législative assurant la protection efficace du consommateur contre le dangers du prêt lié à la vente. $L a$ semaine juridique edition générale. Jurisprudence, Paris, jurisclasseur, ${ }^{0}{ }^{18.109}, 1975$.

CAMPANA, Marie-Jeanne. L'effacement des dettes. Gaz. Pal., 27 févr. 2003, nº 58, p. 44.

CANARIS, Claus-Wilhelm. A Influência dos Direitos Fundamentais sobre o Direito Privado na Alemanha. In: Revista Brasileira de Direito Comparado, $\mathrm{n}^{\mathrm{o}} 28,1^{\mathrm{o}}$ semestre de 2005, p. 3-29.

CARR, James H.; KOLLURI, Lopa. Predatory Lending: An Overview. Fannie Mae Foundation Report, 2001. Disponível em:

$<$ http://www.knowledgeplex.org/showdoc.html?id=1325 $>$ Acesso em 04 de março de 2010.

CASADO, Marcio Mello. Tabela price: uso no crédito ao consumo. In: em Revista Jurídica. Porto Alegre, vol. 46, n 257, p.130-46, março, 1999.

. Os princípios fundamentais como ponto de partida para uma primeira análise do

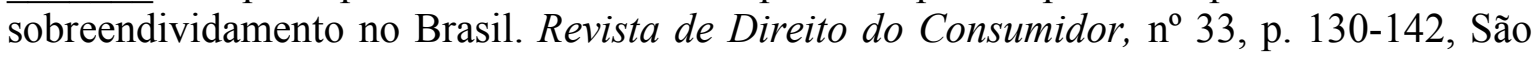
Paulo: RT.

. Sistema financeiro e o código do consumidor. São Paulo: RT, Revista de Direito do Consumidor, $\mathrm{n}^{\mathrm{o}}$ 17, p. 65-84 jan.-mar./1996.

CHATAIN, Pierre-Laurent; FERRIÈRE, Frédéric. Le noveau régime de traitement du surendettement après la loi d'orientation $\mathrm{n}^{0}$ 98-657 du 29 juillet 1998 relative à la lutte contre les exclusions. Recueil Dalloz, 1999, $27^{\circ}$ cahier, chronique., p. 287-294.

; L Le noveau régime de traitement des situations de surendettement des particuliers issu de la loi n ${ }^{\circ}$ 95-125 du 8 février 1995. Recueil Dalloz Sirey, 1996, $6^{\circ}$ cahier, chronique, p. 39-46. 
CHEREDNYCHENKO, Olha. Fundamental Rights and Contract Law. European Review of Contract Law, Vol. 2, n 4, pp. 489-505, 2006.

. EU Fundamental Rights, EC Fundamental Freedoms and Private Law.

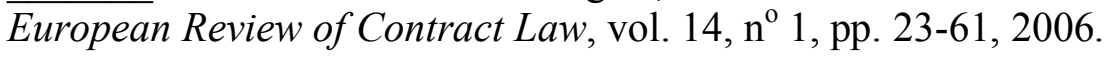

. The Harmonization of Contract Law in Europe by Means of the Horizontal Effect of Fundamental Rights? Erasmus Law Review, vol. 1, n 1, 2007.

COMPARATO, Fábio Konder. Função social da propriedade dos bens de produção. Revista de Direito Mercantil, Industrial, Econômico e Financeiro, vol. 63, p. 71-79, jul/set 1986.

CÔTE, Nathalie. Le nouveau dispositif de traitement du surendettement des particulier. Titre III de la Loi n. 2003-710 du $1^{\mathrm{er}}$ août 2003. La semaine Juridique Edition Générale $\mathrm{n}^{\mathrm{o}}$ 46, 12 Nov. 2003, étude, I, 175.

CREDOT, Francis-J. La prevention du surendettement et la réforme du cautionnement. $L P A, 21$ mai $1999 \mathrm{n}^{\circ} 101$, p. 27.

CROZE, Hervé. Les conditions d'application des nouvelles procédures de traitement des situations de surendettement. JurisClasseur. Procédures n 5, Mai 2004, Etude 7.

; MOUSSA, Tony. Les modifications apportées ar la loi du 29 juillet 1998 relative la lutte contre les exclusions. JurisClasseur. La Semaine Juridique Notariale et Immobilière $\mathrm{n}^{\circ}$ 52, 25 Décembre 1998, p. 1814.

; _. La loi $\mathrm{n}^{\circ}$ 98-46 du 23 janvier 1998 renforçant la protection des personnes surendettées en cas de saisie immobilière. JurisClasseur. La Semaine Juridique Notariale et Immobilière ${ }^{\circ}$ 49, 4 Décembre 1998, p. 1732.

Les modifications apportées à la saisie immobilière par la loi du 29 juillet 1998 relative à la lutte contre les exclusions. JurisClasseur. La Semaine Juridique Edition Générale n ${ }^{\circ}$, 4 Novembre 1998, act.

DE PATOUL, Frédéric. Le consommateur et les services financiers en Belgique. Revue Européenne de droit de la consommation 3/2003, p. 198.

DEVITT, Caitlin. Bankruptcy Reform: Two Years Later. Collections \& Credit Risk, 12.10 (Oct 2007): p. 32. (1663 words).

DICHEV, Ilia D. Is the Risk of Bankruptcy a Systematic Risk? The Journal of Finance, Vol. 53, Issue 3, Page 1131-1147, June 1998.

DICKERSON, A. Mechele. Words that Wound: Defining, Discussing, and Defeating Bankruptcy 'Corruption'. The University of Texas School of Law. Law and Economics Working Paper $n^{\circ}$ 061, october 2005. http://ssrn.com/index.html. 
. Insolvency Principles and the odious debt doctrine: the missing link in the
debate. Law and Contemporary Problems, vol. 70:53-79, 2007. http://law.duke.edu/journals/lcp

. Over-indebtedness, the subprime mortgage crisis and the effect on US Cities. Unpublished work paper.

DOMOWITZ, Ian; SARTAIN, Robert L. Determinants of the Consumer Bankruptcy Decision. The Journal of Finance, vol. 54, Issue 1, Page 403-420, February 1999.

DUBOIS, Philippe. Rapport Introductif. Gaz. Pal., 27 févr. 2003, n 2003, n 58, p. 4.

EDELMAN, Bernard. La dignité de la personne humaine, un concept naouveau. Paris: Recueil Dalloz, 23º caderno, Dalloz, Chronique, p. 185-188, jun. 1997.

EFING, Antônio Carlos. Responsabilidade civil do agente bancário financeiro, segundo as normas do Código de Defesa do Consumidor. Revista de Direito do Consumidor $\mathrm{n}^{0} 18$, São Paulo, RT, p. 105-124, abr.-jun./1996.

EFRAT, Rafael. Global Trends in Personal Bankruptcy. American Bankruptcy Law Journal, vol. 76:81-109, 2002.

ELLIS, Diane. The Effect of Consumer Interest Rate Deregulation on Credit Card Volumes, Cherge-Offs, and the Personal Bankruptcy Rate. Bank Trends - Analysis of Emerging Risks in Banking, n ${ }^{\circ}$ 98-05, march 1998.

ERASLAN, Hülya; LI, Wenli; SARTE, Pierre-Daniel. The Anatomy of U.S. Personal Bankruptcy under Chapter 13. Working paper n 07-05, September 2007.

FALCÃO, Joaquim; SCHUARTZ, Luiz Fernando; e ARGUELHES, Diego Werneck. Jurisdição, Incerteza e Estado de Direito. Revista de Direito Administrativo. Editora Atlas, Set-dez/2006, p. 79-111.

FAN, Wei; WHITE, Michelle J. Personal Bankruptcy and the Level of Entrepreneurial Activity. The Journal of Law and Economics. Volume 46, Issue 2, Page 543-567, Oct 2003.

FAY, Scott; HURST, Erik; WHITE, Michelle J. The Household Bankruptcy Decision. The American Economic Review, vl. 92, nº 3, Jun./2002, p. 706-718.

FERNANDEZ-CORUGEDO, Emilio; MUELLBAUER, John. Consumer credit conditions in the United Kingdom. Disponível em:

www.bankofengland.co.uk/publications/workingpapers/index.htm. Acessado em 5 de novembro de 2009.

FERRIÈRE, Frédéric. L'activité des commissions de surendettement. Gaz. Pal., 27 févr. 2003, n ${ }^{\circ} 58$, p. 12.

FLORES, Philippe. La procédure de rétablissement personnel: un nouveau défi pour le juge de l'exécution. Contrats Concurrence Consommation n ${ }^{\circ} 4$, Avril 2005, étude 4. 
; BIARDEAUD, Gérard. La protection de l'emprunteur: une notion menacée. Recueil Dalloz, 2000, p. 191.

GAVALDA, Christian. L'information et la protection des consommateurs dans le domaine de certaines opérations de crédit. Recueil Dalloz Sirey, 1978, 30 eahier, Chronique XXXVI, p. 189.

GEBHARDT, Hélène. La procédure de rétablissement personnel - Le point de vue du juge de l'exécution. JurisClasseur. Contrats Concurrence Consommation $\mathrm{n}^{\circ} 10$, Octobre 2005, p. 12.

GERANDINE, Natalie. Le creancier, la caution et le debiteur surendetté. LPA, 31 mars $2000, n^{\circ} 65$, p. 5.

GHESTIN, Jacques. L'utile et le juste dans les contrats. Recueil Dalloz Sirey, Paris, 1982, $1^{\text {er }}$ cahier, Chronique I, p. 1.

GOURIO, Alain. Précisions sur l'obligation de mise en garde du banquier dispensateur de crédit à l'égard des emprunteurs non avertis (comm.). JurisClasseur. La Semaine Juridique Edition Générale n 36, 5 Septembre 2007, II 10146.

. Renforcement de l'obligation d'information du banquier prêteur auprès de son client adhérant au contrat d'assurance de groupe (comm.). JurisClasseur, La Semaine Juridique Edition Générale n²2, 30 Mai 2007, II 10098.

. Responsabilité des établissements de crédit envers les emprunteurs et les cautions en matière d'octroi de credits (comm.). JurisClasseur, La Semaine Juridique Edition Générale n 28, 12 Juillet 2006, II 10122.

. Crédit aux particuliers : obligations et responsabilités de l'établissement de credit (comm.). JurisClasseur. La Semaine Juridique Edition Générale n ${ }^{\circ}$ 1, 12 Octobre 2005, II 10140.

. Conditions de la responsabilité du prêteur envers les emprunteurs au titre de l'octroi d'un crédit à des particuliers (comm.). La Semaine Juridique Entreprise et Affaires $\mathrm{n}^{\circ} 22,30$ Mai 2002, p. 852.

GRAVER, Hans Petter. Consumer bankruptcy: A right or a privilege? The role of the courts in establishing moral standards of economic conduct. Journal of Consumer Policy. Dordrecht: 1997. Vol. 20, Iss. 2, pg. 161, 17 pgs.

GROOTE, Bertel. Citizenship and Consumer Insolvency under Belgian Law. Paper apresentado na "Conference on Consumer Law", África do Sul, Cidade do Cabo, abril/2007.

GROSS, David B.; SOULELES, Nicholas S. An Empirical Analysis of Personal Bankruptcy and Delinquency. The Review of Financial Studies, vol. 15, $\mathrm{n}^{\mathrm{o}}$ 1. Spring, 2002, p. 319-347. 
GROSS, Karen. Demonizing Debtors: a response to the Honsberger-Ziegel debate. Osgoode Hall Law Journal, vol 37, ${ }^{\text {os }} 1$ \& 2, p. 263-277, 1999.

GUYON, Yves. Droit du marché et droit commun des obligations - Rapport de synthèse Colloque organisé les 24-25 octobre 1997. RTD Com., 1998, p. 121.

HABERMAS, Jürgen. Paradigms of Law. Cardozo Law Review 17, 771, 1996.

HAMADI, Hakim. Doit-on payer ses dettes familiales? LPA, 29 mars 2006, nº 63, p. 44.

HAURIOU, Maurice. L' ordre social, la justice et le droit. RTD Civ., Paris, $\mathrm{n}^{\mathrm{o}}$ XXVI, $\mathrm{p}$. 795-825,1927.

HIRONAKA, Giselda Maria Fernandes Novaes. A função social do contrato. Revista Jurídica, n 17 , jan.-fev./1987, p.57-73.

HYNES, Richard; POSNER, Eric A. The Law and Economics of Consumer Finance. American Law and Economics Review, vol. 4, n 1, 2002, p. 168-207.

; BERKOWITZ, Jeremy. Bankruptcy Exemptions and the Market for Mortgage Loans. Journal of Law and Economics, vol. XLII, October 1999, p. 809-830.

HONDIUS, Ewould. The Protection of the Waek Party in a Harmonised European Contract Law: A Sythesis. Journal of Consumer Policy, 27: 245-251, 2004.

HUGON, Christine. L'approche théorique de la procédure de rétablissement personnel. JurisClasseur. Contrats Concurrence Consommation $n^{\circ}$ 10, Octobre 2005, p. 10.

JACOBY, Melissa B. Bankruptcy Reform and the Costs of Sickness: Exploring the Intersections. Missouri Law Review, vol. 71, 2006, p. 903-918.

JENSEN, Susan. A legislative history of the bankruptcy abuse prevention act of 2005. American Bankruptcy Law Journal, 79:485, 2005.

JOBARD-BACHELLIER, Marie-Noëlle. L'élaboration d'un régime de surendettement international: emprunts au régime de la «faillite » internationale? Gaz. Pal., 27 févr. 2003, $\mathrm{n}^{\mathrm{o}} 58, \mathrm{p} .27$.

. Surendettement international. Gaz. Pal., Recueil juillet-août 2002, p. 1167.

JOHNSON, Kathleen W. Recent Developments in the Credit Card Market and the Financial Obligations Ratio. 91 Federal Reserve Bulletin, 473, 2005.

JUNQUEIRA DE AZEVEDO, Antonio. O direito pós-moderno e a codificação. Revista de Direito do Consumidor, $\mathrm{n}^{\mathrm{o}} 33$, p. 123-129, jan.-mar./2000.

. A boa-fé na formação dos contratos. Revista de Direito do Consumidor, $\mathrm{n}^{\mathrm{o}} 3$, São Paulo, set./dez. 1992, p. 78-87. 
. Insuficiências, deficiências e desatualização do Projeto de Código Civil na questão da boa-fé objetiva nos contratos. RT, São Paulo, vol. 775, p. 11-17, maio 2000.

Responsabilidade pré-contratual no código de defesa do consumidor: estudo comparativo com a responsabilidade pré-contratual no direito comum. São Paulo: RT, Revista de Direito do Consumidor, n ${ }^{0}$ 18, abr.-jun./1996, p.23-31.

. Natureza Jurídica do contrato de consórcio. Classificação dos atos jurídicos quanto ao número de partes e quanto aos efeitos. Os contratos relacionais. Contratos de duração. Alteração das circunstâncias e onerosidade excessiva. Sinalagma e resolução contratual. Resolução parcial do contrato. Função social do contrato. (parecer). São Paulo. Revista dos Tribunais, vol. 94. $\mathrm{n}^{\mathrm{o}}$ 832, fev./2005, p. 113-137.

. Princípios do novo direito contratual e desregulamentação do mercado.

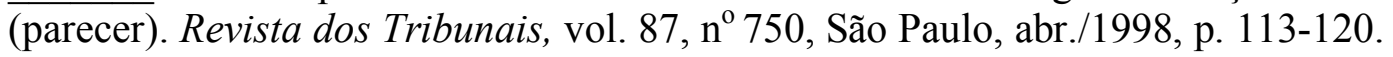

. L'influence du droit français sur le droit brésilien e Influência do Direito Francês sobre o Direito Brasileiro. Revista da Faculdade de Direito da USP, vol. 89, 1998.

KHAYAT, Danielle. Les nouvelles dispositions sur le surendettement des particuliers (Loi $\mathrm{n}^{\circ}$ 95-125 du 8 février 1995 et décret $\mathrm{n}^{\circ}$ 95-660 du 9 mai 1995): une réforme pour rien? Gaz. Pal., 1995, 2e semestre, p. 1374.

; FIORI-KHAYAT, Coralie. Prévention et fichier relactif à l'endettement. $L P A$,

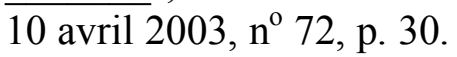

KILBORN, Jason J. The Innovative German Approach to Consumer Debt Relief: Revolutionary Changes in German Law, and Surprising Lessons for the United States. Northwestern Journal of International Law \& Business; Winter 2004; 24, 2; ABI/INFORM Global., p. 257-297.

Behavioral Economics, Overindebtedness \& Comparative Consumer Bankruptcy: Searching For Causes And Evaluating Solutions. Emory Bankruptcy Developments Journal. Atlanta, fall 2005, vol. 22, Iss. 1, pg. 13.

- Continuity, Change and Innovation in Emerging Consumer Bankruptcy

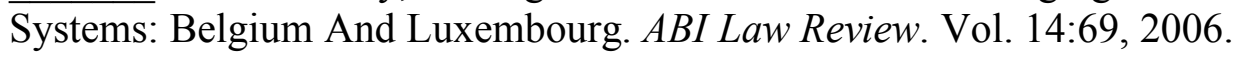

. La responsabilisation de l'economie: what the United States can learn from the new french law on consumer overindebtedness. Michigan Journal of International Law, vol. 26:619, Winter 2005, p. 619-671.

. The Hidden Life of Consumer Bankruptcy Reform: Danger Signs for the New U.S. Law From Unexpected Parallels in the Netherlands.

LAGARDE, Xavier. Le choix des intervenants dans les deux procédures: rôle des créanciers, du juge et du ministère public. Gaz. Pal., 27 févr. 2003, nº 58, p. 33.

LAIBSON, David. Golden Eggs and Hyperbolic Discounting. Quarterly Journal of Economics, May, 1997, p. 443-477. 
; REPETTO A; TOBACMAN J. A Debt Puzzle, NBER Working Paper, 2000.

LAMBERT-WIBER, Sophie. Le principe d'unité du patrimoine a l'epreuve de la responsabilité financière d'une personne mariée sous le régime de la communauté. Repertoire du Notariat Defrénois, 15 nov. 1999, nº 21, p. 1153.

LAURITANO, Mark. Credit Losses Due to Personal Bankruptcy: Some Areas Are More Vulnerable than Others in the Current Regulatory and Economic Environment. The RMA Journal. Philadelphia, Nov 2005, vol. 88, Iss. 3; p. 74, 7 pgs.

LECORRE, Pierre-Michel. Faut-il encore payer ses dettes dans le droit des entreprises en difficulté? $L P A, 29$ mars 2006, $\mathrm{n}^{\circ} 63$, p. 9.

LÉCUYER, Hervé. Le rétablissement personnel et le couple. JurisClasseur. Contrats Concurrence Consommation, $\mathrm{n}^{\circ}$ 10, Octobre 2005, p. 14.

LINDITCH, Florian. Faut-il encore payer ses dettes? L'exemple des collectivités locales. $L P A, 29$ mars $2006, \mathrm{n}^{\mathrm{o}} 63$, p. 3.

LIVSHITS, Igor; MacGEE, James; Tertilt, Michele. Consumer Bankruptcy: A Fresh Start. Federal Reserve Bank of Minneapolis, working paper 617, January 2003.

LÔBO, Paulo Luiz Neto. Contrato e mudança social. Revista dos Tribunais, $\mathrm{n}^{0}$ 722, dez./1995, p. 42.

LOPES, José Reinaldo Lima. Consumidor e sistema financeiro. Revista de Direito do Consumidor, $\mathrm{n}^{0}$ 22, São Paulo: RT, p. 87-101, abr.-jun./1997.

. Crédito ao consumidor e superendividamento - uma problemática geral. Revista de Direito do Consumidor, nº 17, São Paulo: RT, p. 57-64, jan.-mar./1996.

LOTUFO, Renan. Da oportunidade da Codificação Civil e a Constituição., In: Ingo Wolfgang Sarlet (org.), O novo Código Civil e a Constituição, Porto Alegre: Livraria do Advogado, 2003, p. 11-30.

MACEDO JUNIOR, Ronaldo Porto. A globalização e o direito do consumidor. Revista Diálogos e Debates. São Paulo, Escola Paulista da magistratura, vol. 1, set./2000, p. 46-52.

MANN, Ronald J. Bankruptcy reform and the "sweat box" of credit card debt. University of Illinois Law Revew, $\mathrm{n}^{\mathrm{o}}$ 1, 2007, p. 375-403.

MARQUES, Cláudia Lima. Boa-fé nos serviços bancários, financeiros, de crédito e securitários e o Código de Defesa do Consumidor: informação, cooperação e renegociação. São Paulo. Revista de Direito do Consumidor, nº 43, p. 215-257, jul-set./2002.

. Contratos bancários em tempos pós-modernos - primeiras reflexões. Revista de Direito do Consumidor, São Paulo, ${ }^{0}$ 25, jan./mar. 1998, p. 19-38. 
. Os contratos de crédito na legislação brasileira de proteção ao consumidor. Revista de Direito do Consumidor, n 17, São Paulo, RT, jan.-mar./1996, p. 36-56.

. Os contratos de crédito na legislação brasileira de proteção do consumidor.

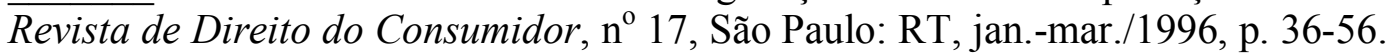

. Novas regras sobre a proteção do consumidor nas relações contratuais. Revista de Direito do Consumidor, $\mathrm{n}^{\mathrm{o}}$ 1, São Paulo: RT, p. 27-53.

MARTINS COSTA, Judith. O direito privado como um sistema em construção: as cláusulas gerais no projeto de Código Civil brasileiro. Revista dos Tribunais $\mathrm{n}^{0}$ 753, p. $25-$ 48, jul./1988.

. Crise e modificação da idéia de contrato no direito brasileiro. Revista de Direito do Consumidor, $\mathrm{n}^{\mathrm{o}} 3$, p. 127.

MARTINS DA COSTA, Geraldo de Faria. Crédito e publicidade: dois fenômenos sócio jurídicos indissociáveis. Revista Jurídica do Ministério Público de Minas Gerais, Belo Horizonte: Gráfica e Editora Perform, vol. 2, p. 101-130, dez./1998.

- A proteção da saúde do consumidor na ordem econômica: direito subjetivo público. Revista de Direito do Consumidor, n 21, São Paulo: RT, jan.-mar./1997, p. 132141.

. Economia solidária de mercado: a ação governamental, os fornecedores e os consumidores na luta contra a exclusão social. AMMP em Notícias, Belo Horizonte: Órgão Oficial da Associação Mineira do Ministério Público, Gráfica e Editora Perform, $n^{0}$ 3. jan.abr./1998.

. O direito do consumidor e a técnica do prazo de reflexão. Revista de Direito do Consumidor, $\mathrm{n}^{\circ}$ 43, São Paulo: RT, p. 259-260,.

MATHIEU-IZORCHE, Marie-Laure. Rapport de synthèse . - La loi sur le rétablissement personnel: questions de situation. JurisClasseur. Contrats Concurrence Consommation, $\mathrm{n}^{\mathrm{o}}$ 10, Octobre 2005, p. 17.

MAZEAUD, Denis. La révision du contrat. $L P A, 30$ juin 2005, $\mathrm{n}^{\mathrm{0}} 129$, p. 4. . Le consommateur de credit immobilier surendetté. $L P A, 29$ juin 1999, n 128, p. 21. - Avant-propos démodé sur le droit du surendettement. Droit \& Patrimoine, $\mathrm{n}^{\mathrm{o}}$ 64, Octobre 1998, p. 50.

MERLE, Werner. Le droit allemand à travers l'Insolvenzordnung. Gaz. Pal., 27 févr. 2003, n ${ }^{\circ} 58$, p. 17.

MICKLITZ, Hans-W. The Principles of European Contract Law and the Protection of the Weaker Party. Journal of Consumer Policy, 27: 339-356, 2004. 
MONACHON DUCHENE, Nicolas. Actualité du redressement judiciaire civil. Gaz. Pal., 7 avril 1994, p. 372.

MORRISON, Edward R. Bankruptcy Decision Making: An Empirical Study of Continuation Bias in Small Business Bankruptcies. The Journal of Law and Economics. Vol. 50, Issue 2, May 2007, p. 381-419.

MUIR WATT, Horatia. Personal insolvency en droit anglais: un autre découpage. Gaz. Pal, 27 févr. 2003, nº 58, p. 21.

NELSON, Jon P. Consumer bankruptcy and chapter choice: State panel evidence. Contemporary Economic Policy. Huntington Beach: Oct 1999. Vol. 17, Iss. 4;, p. 552, 15 pgs.

NEUVILLE, Sébastien. Le traitement planifié du surendettement - Réflexions sur la conciliation et la médiation, l'abdication et la transaction, les matières gracieuse et contentieuse. Dalloz, RTD Com., 2001, p. 31.

NICOLAS, Véronique. Pour l'assuré comme pour l'assureur : Faut-il toujours payer ses dettes? LPA, 29 mars 2006, $\mathrm{n}^{\mathrm{o}}$ 63, p. 33.

NIEMI-KIESILAINEN, Johanna. Changing directions in consumer bankruptcy law and practice in Europe and USA. Journal of Consumer Policy. Dordrecht: 1997. Vol. 20, Iss. $2 ;$,pg. 133, 10 pgs.

. Consumer Bankruptcy in Comparison: Do We Cure a Market Failure or a Social Problem? Osgoode Hall Law Journal, vol. 37, nº 1 e 2, 1999, p. 473-503.

; HENRIKSON, Ann-Sofie. Report on Legal Solutions to Debt Problems in Credit Societies, CDCJ-BU - Bureau of the European Committee on Legal Co-operation, Strasbourg, 11 Oct, 2005. Disponível no link: http://www.coe.int/T/E/ Legal_Affairs/Legal cooperation/Steering_Committees/CDCJ/Documents/2005/CDCJBU\%20 $2005 \% 2011$ EREV.pdf

OLACK. Neil P. Consumer bankruptcy panel: selected hot BAPCPA topics. Emory Bankruptcy Developments Journal. Atlanta: spring 2007. Vol. 23, iss. 2, p. 517.

OLIBONI, Marcella Lopes de Carvalho Pessanha. O superendividamento do consumidor brasileiro e o papel da defensoria pública: criação da comissão de defesa do consumidor superendividado. Revista de Direito do Consumidor, vol. 14, $\mathrm{n}^{0}$ 55, São Paulo, jul.set/2005, p. 168-76.

OSMAN, Filali. Bonne foi et surendettement des particuliers (bilan de deux ans dápplication de la loi Neiertz). Gaz. Pal., 2 avril 1992.

PAISANT, Gilles. Remarques dubitatives sur le projet de loi visant à instaurer une procédire de « rétablissement personnel ». Dalloz, RTDCom., 2003, p. 574.

La réforme de la procédure de traitement du surendettementpar la loi du $1^{\mathrm{er}}$ août 2003 sur la ville et la rénovation urbaine. Dalloz, RTDCom., 2003, p. 671. 
Le traitement du surendettement : l'économie générale de la réforme. $L P A, 21$ mai $1999, n^{\circ} 101$, p. 38.

. Seuls les établissements de crédit sont appelés à supporter la réduction de la fraction des prêts immobiliers restant due après la vente du logement principal du débiteur surendetté. Dalloz. RTD Com., 1999, p. 766.

. La réforme de la procédure de traitement du surendettementpar la loi du 29 juillet 1998 relative à la lutte contre les exclusions. Dalloz, RTD Com., 1998, p. 743.

. La réforme de la procédure de traitement des situations de surendettement par la loi $\mathrm{n}^{\circ}$ 95-125 du 8 février 1995. La Semaine Juridique Edition Générale, n ${ }^{\circ}$, 10 Mai 1995 , I 3844.

. Surendettement. Exigence de la bonne foi. RTD Com.,1991, p. 446.

Redressement judiciaire civil. De la réduction des taux d'intérêts dans le plan de redressement. RTD Com., 1991, p. 655.

. Surendettement. Appréciation des comportements exclusifs de la bonne foi. Dalloz, RTD Com., nº 44, out-dez/1991, p. 652.

PALHARES, Cinara. Ensaio sobre a eficácia dos direitos sociais. Anais do CONPEDI. Disponível em http://www.conpedi.org/manaus/arquivos/anais/salvador/ cinara_palhares.pdf. Acessado em: 20 de outubro de 2009.

PAYAN, Guillaume. Faut-il encore payer ses dettes? Réponse en droit internationale privé communautaire. $L P A, 29$ mars $2006, \mathrm{n}^{\circ} 63$, p. 21.

PÉTEL, Philippe. La procédure de rétablissement personnel et les procédures collectives $\mathrm{du}$ Code de commerce. JurisClasseur. Contrats Concurrence Consommation $\mathrm{n}^{\circ} 10$, Octobre 2005, p. 15.

PIEDELIÈVRE, Stéphane. 37852. Le droit à l'effacement des dettes. Repertoire du Notariat Defrénois, 15 jan 2004, n ${ }^{\circ}$ 1, p. 14.

. 37827. La réforme de certains cautionnements par la loi du $1^{\mathrm{er}}$ août 2003 (loi pour l'initiative économique). Repertoire du Notariat Defrénois, 15 nov. 2003, $\mathrm{n}^{\mathrm{o}} 21$, p. 1371.

PINHEIRO, Armando Castelar. O componente judicial dos spreads bancários. Economia Bancária e Crédito - avaliação de 4 anos do projeto Juros e Spread Bancário. Disponível em: $<$ http://www.bcb.gov.br/?SPREAD $>$. Acessado em 10 de novembro de 2009.

. Judiciário, reforma e economia: a visão dos magistrados. Artigo preparado como parte do projeto de pesquisa "Addressing Judicial Reform in Brazil: Institutions and Constituency Building", realizado pelo Instituto de Estudos Econômicos, Sociais e Políticos de São Paulo (IDESP). 
PUGGINA, Márcio de Oliveira. Responsabilidade civil do banqueiro pela concessão de crédito. Revista de Direito do Consumidor, n² 26, abr.-jun/1998, p. 136-151.

PUYGAUTHIER, Jean-Luc. Le bail et la loi de programmation pour la cohésion sociale. La Semaine Juridique Notariale et Immobilière, $\mathrm{n}^{\circ}$ 15, 15 Avril 2005, 1218.

RACINE, Jean-Baptiste. Faut-il encore payer ses dettes? Le cas du surendettement des particuliers. $L P A, 29$ mars 2006, n ${ }^{\circ} 63$, p. 37.

RAMSAY, Iain. Comparative Consumer Bankruptcy. University of Illinois Law Review, vol. $2007, \mathrm{n}^{\mathrm{o}} 1$, p. 241-274.

. The empirical dimension of consumer bankruptcy: results from a survey of

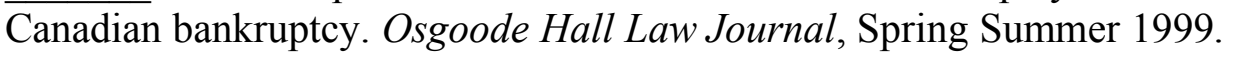

. Models of Consumer Bankruptcy: Implications for Research and Policy. Journal of Consumer Policy, 20: 269-287, 1997.

. Consumer Credit Law, distributive justice and the welfare state. Oxford Journal of Legal Studies, 15: 177-197, 1995.

RAYMOND, Guy. Directive 2008/48/CE relative aux crédits à la consommation Premières approaches. Contrats Concurrence Consommation, $\mathrm{n}^{\circ} 7$, Juillet 2008, étude 9.

. Prohibition des crédits supérieurs à la valeur du bien acheté (Commentaire).

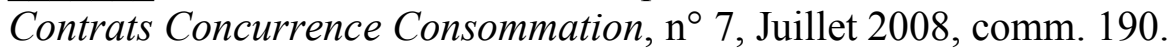

. Notion de situation irrémédiablement compromise (Commentaire). Contrats Concurrence Consommation, $\mathrm{n}^{\circ}$ 1, Janvier 2008, comm. 30.

. Rétablissement personnel et bonne foi (Commentaire). Contrats Concurrence Consommation $\mathrm{n}^{\circ}$ 7, Juillet 2007, comm. 194.

. Responsabilité de l'organisme de crédit (Commentaire). Contrats Concurrence Consommation $\mathrm{n}^{\circ}$ 12, Décembre 2006, comm. 253.

- Obligation de renseigner le consommateur sur les risques du produit (Commentaire). Contrats Concurrence Consommation n ${ }^{\circ}$ 7, Juillet 2005, comm. 142.

REALE, Miguel. Visão geral do projeto de Código Civil. Cidadania e Justiça. Revista da Associação dos Magistrados Brasileiros, vol. 5, n ${ }^{\mathrm{o}}$ 10, p. 61-73, $1^{\mathrm{o}}$ semestre 2001.

REBBOH, Sylvie. La saisie immobilière et le surendettement. Gaz. Pal., Janvier-février 2002, p. 72.

REICH, Norbert. Algumas proposições para a filosofia da proteção do consumidor. Trad. de Débora Gozzo. RT, 728, São Paulo, jun./1996, p. 11-36. 
L' information du consommateur: condition de la transparence du marche. Concurrence et consommation. Direção de Yves Serra e Jean Calais-Auloy. Paris: Dalloz, 1994.

Relatório de Economia Bancária e Crédito, BACEN, 2006, p. 10. Disponível em: $<$ http://www.bacen.gov.br/?SPREAD>. Acessado em 12 de novembro de 2009.

REVEL, Janine. Surendettement et régime matrimonial. Gaz. Pal, 27 févr. 2003, $\mathrm{n}^{\mathrm{o}}$ 58, p. 47.

REVET, Thierry. L'argent et la personne. L'argent et le droit. Archives de Philosophie du Droit. Paris: Sirey, 1997, t. 42, p. 43-54.

REYGROBELLET, Arnaud. La notion de surendettement face à la cessation des paiements. Gaz. Pal, 27 févr. 2003, nº 58, p. 39.

ROCHA, Sílvio Luis Ferreira da. Crédito habitacional como instrumento de acesso à moradia. São Paulo: Revista dos Tribunais, Revista de Direito do Consumidor, $\mathrm{n}^{\mathrm{o}} 36, \mathrm{p}$. 176-184, out.-dez/2000.

ROUTIER, Richard. Le défaut d'information justifiant le non-paiement du banquier. $L P A$, 29 mars 2006, nº 63, p. 15.

SAINT-JAMES, Virginie. Réflexions sur la dignité de l'être humain en tant que concept juridique du droit français. Recueil Dalloz, 1997, p. 61.

SARLET, Ingo Wolfgang. Os Direitos Fundamentais Sociais na Constituição de 1988. Revista de Direito do Consumidor, no 30, p. 97-124.

. O Papel da Jurisdição Constitucional na Realização do Estado Social. Revista da Academia Brasileira de Direito Constitucional - anais do IV Simpósio Nacional de Direito Constitucional, 2003, vol. 3, p. 357-365.

. Direitos Sociais: o problema de sua proteção contra o poder de reforma na

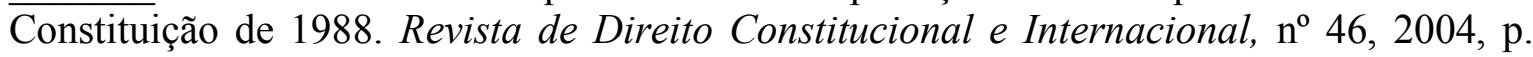
$42-73$.

Direitos Fundamentais Sociais e a Proibição ao Retrocesso: Algumas Notas sobre o Desafio da Sobrevivência dos Direitos Sociais num Contexto de Crise. Revista da Ajuris, ${ }^{\circ}$ 95, setembro de 2004, p. 103-135.

. O Estado Social de Direito, a Proibição de Retrocesso e a Garantia Fundamental da Propriedade. Revista de Direito da Associação dos procuradores do Novo Estado do Rio de Janeiro, 2000, p. 131-150.

. O direito fundamental à moradia na Constituição: algumas anotações a respeito de seu contexto, conteúdo e possível eficácia. Revista de Direito do Consumidor, vol. 12, $\mathrm{n}^{\mathrm{o}} 46$, p.193-244, abr.-jun./2003. 
. Direitos fundamentais e direito privado: algumas considerações em torno da vinculação dos particulares aos direitos fundamentais. Revista de Direito do Consumidor, $\mathrm{n}^{\mathrm{o}} 36$, p. 54-104, out.-dez./2000.

. Contornos do Direito Fundamental à Saúde na Constituição de 1988. In: Revista da Procuradoria-Geral do Estado do Rio Grande do Sul, no 56, vol. 25, 2002, p. 41-74.

SAUPHANOR-BROUILLAUD, Natacha. La notion de surendettement. LPA, 10 avril 2003, n $\mathrm{n}^{\mathrm{T}} 72$, p. 7.

SAUTEL, Oliver. Sur la déchénance en droit prive (contribution à la théorie de la parmanence de la cause). Recueil Dalloz, Paris, Dalloz, $\mathrm{n}^{0}$ 43, Chronique, p. 487-495, dez./1999.

SEILLIER, Bernard. Le contexte de la réforme. $L P A, 21$ mai 1999, $\mathrm{n}^{\mathrm{o}} 101$, p. 3.

SHUMWAY, Tyler. Forecasting Bankruptcy More Accurately: A Simple Hazard Model. The Journal of Business. Volume 74, Issue 1, Jan 2001, p. 101-124.

SINAY-CYTERMANN, Anne. La réforme du surendettement - Les innovations de la loi du 29 juillet 1998 de lutte contre les exclusions. La Semaine Juridique Edition Générale, $\mathrm{n}^{\circ}$ 4, 27 Janvier 1999, I 106.

SILVA, José Afonso da. A dignidade da pessoa humana como valor supremo da democracia. Revista de Direito Administrativo, no 212, Rio de Janeiro: Renovar, p. 89-94.

SOINNE, Bernard. La procédure de rétablissement personnel. Propos "introductif" (Titre III de la loi $\mathrm{n}^{\circ}$ 2003-710 du 1er août 2003 d'orientation et de programmation pour la ville et la rénovation urbaine). JurisClasseur. La Semaine Juridique Edition Générale $n^{\circ} 41,8$ Octobre 2003, act. 475.

1997, no 153 , p. 4.

. «Surendettement » et «Faillite » : unité ou dualité des régimes. $L P A, 22$ déc.

SORTAIS, Jean-Pierre. Le surendettement des particuliers en droit comparé. LPA, 21 mai 1999, nº 101, p. 16.

STEIGER. Eva-Maria; BIGUS, Jochen. When it pays to be honest: how a variable period of good conduct can improve incentives in personal bankrupcy proceedings. European Journal of Law and Economics 22: 233-253, 2006.

. Ex-Ante vs. Ex-Post Efficiency in Personal Bankruptcy Proceedings. School of $\overline{\text { Business }}$ and Economics, Humboldt University at Berlin, April 2005.

STIGLITZ, Rubén S. Contrato de Consumo y Cláusulas Abusivas. Derecho del Consumidor, $\mathrm{n}^{\circ}$ 8, director Gabriel A. Stiglitz, editorial Juris, p. 16.

STÜMER, Bertram Antônio. Bancos de dados e habeas data no código do consumidor. Revista de Direito do Consumidor, n 1, São Paulo: RT, 1992, p. 55-94. 
SUllivAN, A. Charlene; WORDEN, Debra Drecnik. Rehabilitation or Liquidation: Consumer's Choices in Bankruptcy. The Journal of Consumer Affairs, summer 1990; 24, 1; ABI/INFORM global, p. 69-88.

SULLIVAN, Teresa A., WARREN, Elizabeth; WESTBROOK, Jay Lawrence. Consumer bankruptcy in the United States: A study of alleged abuse and of local legal culture. Journal of Consumer Policy. Dordrecht: 1997. Vol. 20, Iss. 2, p. 223, 46 pgs.

TERRÉ, Dominique. Les vertus de l' argent ou la quête du spirituel. L'argent et le droit. Archives de Philosophie du Droit. Paris: Sirey, 1997, t. 42, p. 71-84.

TEUBNER, Gunther. Substantive and reflexive elements in modern law. Law \& Society Review, vol. 17, number 2, 1983, p. 239-285.

TOMASETTI JUNIOR, Alcides. O objetivo de transparência e o regime jurídico dos deveres e riscos de informação nas declarações negociais para consumo. Revista de Direito do Consumidor, $\mathrm{n}^{\circ}$ 4, São Paulo: RT, 1992, p. 52-90.

TOURNIER, Régis. Les incertitudes procédurales après la loi du 1er août 2003 et le décret du 24 février 2005. JurisClasseur. Contrats Concurrence Consommation, $\mathrm{n}^{\circ}$ 10, Octobre 2005, p. 13.

TRUCHET, Didier. L'argent et la liberté. L'argent et le droit. Archives de Philosophie du Droit, Paris: Sirey, 1997, t. 42, p. 55-60.

TRUJILLO, Bernard. Regulating Bankruptcy Abuse: An Empirical Study of Consumer Exemptions Cases. Journal of Empirical Legal Studies, vol. 3, issue 3, nov 2006, p. 561609.

VALLENS, Jean-Luc. L'universalité de la faillite : le droit allemand de l'insolvabilité reconnait les procédures de redressement judiciaire. $L P A, 17$ mars 1999, $\mathrm{n}^{\circ}$ 54, p. 6 .

VATIN, Jean-Luc. Le traitement du surendettement par les commissions départementales. JurisClasseur. Contrats Concurrence Consommation, $\mathrm{n}^{\circ}$ 10, Octobre 2005, p. 11.

. L'activité des commissions de surendettement. LPA, 21 mai 1999, nº 101, p. 21.

VIGNEAU, Vincent. Logement et surendettement. JurisClasseur. Contrats Concurrence Consommation, $\mathrm{n}^{\circ}$ 10, Octobre 2005, p. 16.

VILLEGAS, D. J. 1989. The impact of usury ceilings on consumer credit. Southern Economic Journal, 56, $\mathrm{n}^{\mathrm{o}} 1$.

WAMBIER, Luiz Rodrigues. Os contratos bancários e o código de defesa do consumidor uma nova abordagem. Revista dos Tribunais, ${ }^{0}$ 742, ago./1977, p. 57-66.

WHITE, Michelle J. Abuse or Protection: Economics of Bankruptcy Reform Under BAPCPA. American Law \& Economics Association Annual Meetings, Chicago, April 7 2006. 
. Why Don't More Households File for Bankruptcy? The Journal of Law, Economics \& Organization. Vol. 14, nº 2, p. 205-231.

. Why it pays to file for bankruptcy: A critical look at the incentives under U.S.

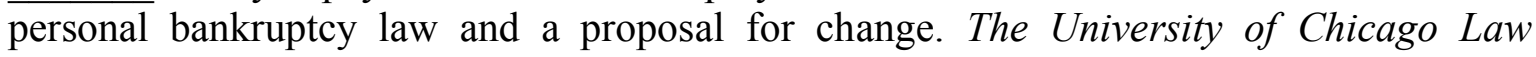
Review. Chicago: Summer 1998. Vol. 65, Iss. 3, p. 685, 48 pgs.

. Contract Breach and Contract Discharge Due to Impossibility: A Unified Theory. Journal of Legal Studies, 1988.

. Bankruptcy reform and credit cards. Journal of Economic Perspectives, vol. 21,

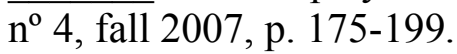

WHITFORD, William C. Changing definitions of fresh start in U.S. bankruptcy law. Journal of Consumer Policy. Dordrecht: 1997. Vol. 20, Iss. 2, p. 179, 20 pgs.

WILHELMSSON, Thomas. Social 'Force Majeure': A new concept in Nordic consumer law. Journal of Consumer Policy, 13: 1-14, 1990.

WILHELMSSON, Thomas. Control of Unfair Contract Terms and Social Values: EC and Nordic Approaches. Journal of Consumer Policy, 16: 435-453, 1993.

. Social Force Majeure - A New Concept in Nordic Consumer Law. Journal of Consumer Policy, 13: 1-14, 1990, p. 1-14.

ZABOROWSKI, Christoph; ZWEIFEL, Peter. Getting Out of Debt: Garnishment of Wage in Whose Interest? European Journal of Law and Economics, Dordrecht: Nov 1999, vol. 8, Iss. 3, p. 207.

ZIEGEL, J. S. Canadian perspectives on the challenges of consumer bankruptcies. Journal of Consumer Policy, 20: 199-221, 1996. 